DANMARKS GEOLOGISKE UNDERSØGELSE

II. Række. Nr. 104

Geological Survey of Denmark. II. Series. No. 104

\title{
Lower Jurassic biostratigraphy and ostracods of the Danish Embayment
}

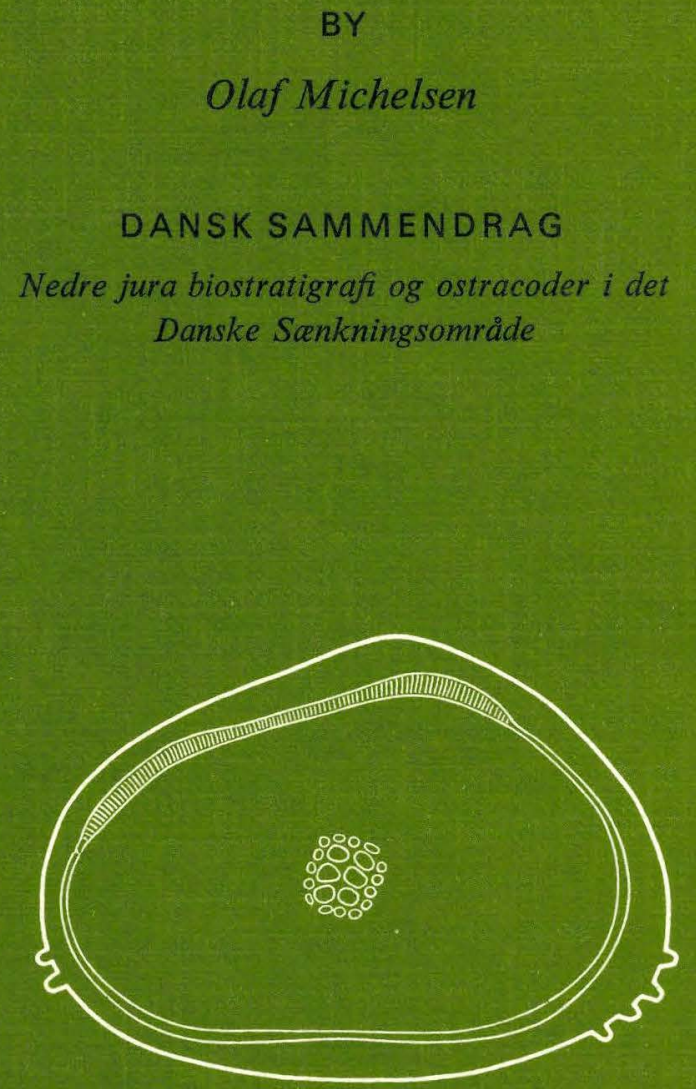


Danmarks Geologiske Undersøgelse. II. Række. Nr. 104

Geological Survey of Denmark. II. Series. No. 104

Lower Jurassic biostratigraphy and ostracods of the Danish Embayment

By

Olaf Michelsen

Dansk sammendrag:

Nedre jura biostratigrafi og ostracoder

i det Danske Sænkningsområde

I kommission hos C. A. Reitzels Forlag

København 1975 
D. G. U. II. rk. nr. 104

er sat med Linotype Times

og er trykt i 1000 eksemplarer

hos Andelsbogtrykkeriet i Odense.

Klichéerne er fremstillet af

Tutein \& Koch og fototavlerne af

F. Hendriksen's Eftf.

Bogen er trykt på ekstraglittet $250-41,120 \mathrm{~g}$

og fototavlerne på Top-Cote 106, $120 \mathrm{~g}$

fra a/s De forenede Papirfabrikker.

ISBN 8742106427

With 42 plates

Date of publication: 1975-09-25 


\section{Contents}

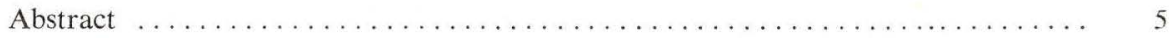

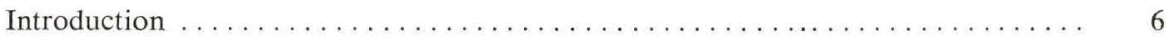

Lower Jurassic deposits within the Danish Embayment ............. 6

Previous descriptions of Lower Jurassic ostracod faunas . . . . . . . . . . . . 9

Purpose and scope of the present investigation ................. 10

Materials and methods .................................... 12

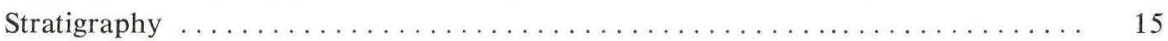

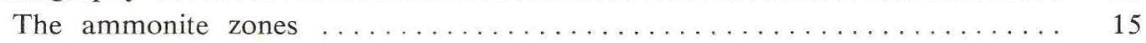

Description of the ostracod zones ......................... 18

Methods ......................................... 19

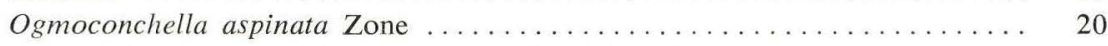

Cristacythere betzi - Cristacythere crassireticulata Zone ............ 26

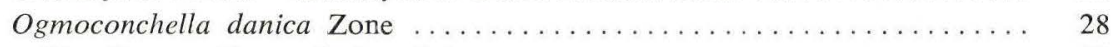

The Progonoidea reticulata Subzone ...................... 28

The Gramannella apostolescui - Kinkelinella (Klinglerella) foveolata

Subzone ................................... 34

Ogmoconchella adenticulata - Nanacythere (Nanacythere) simplex Zone .. 38

Description of the sections (borings) ...................... 43

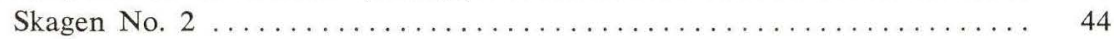

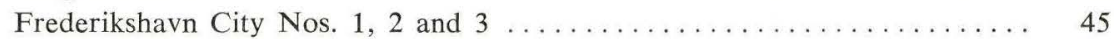

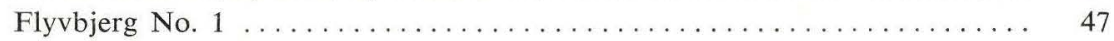

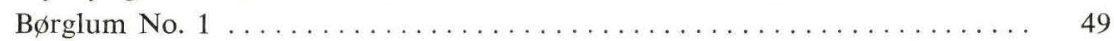

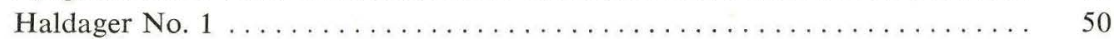

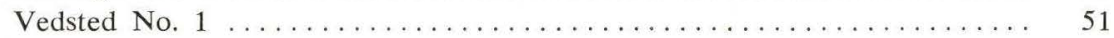

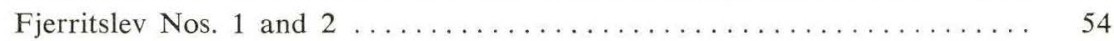

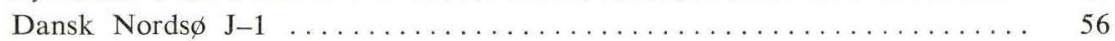

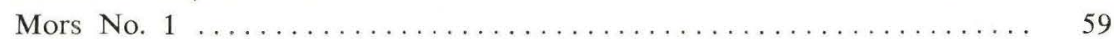

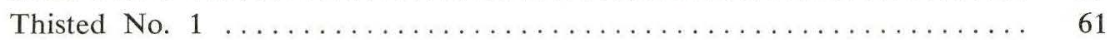

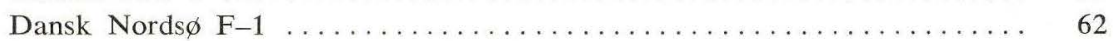

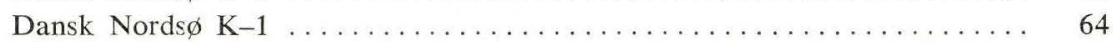

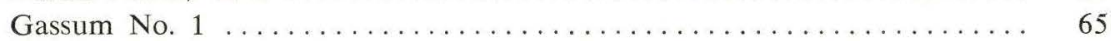

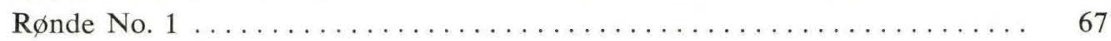

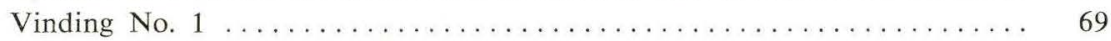

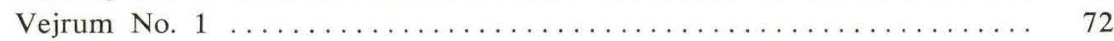

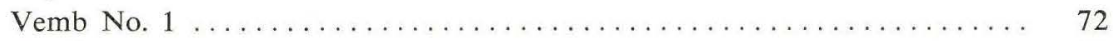

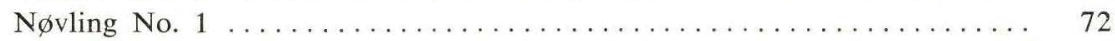

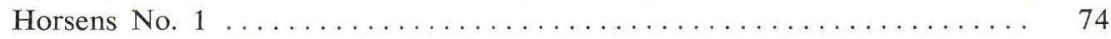

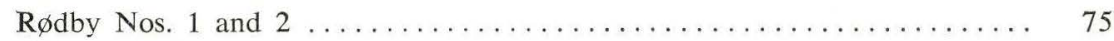

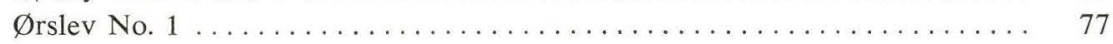




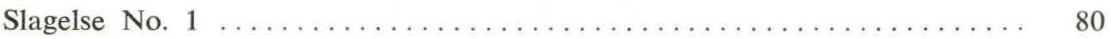

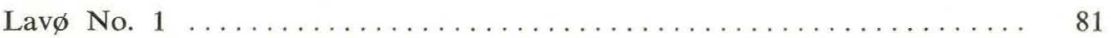

$\emptyset$ resund Nos. 2, 3, 8, 9, 10, 11, 12, 14 and $15 \ldots \ldots \ldots \ldots \ldots \ldots \ldots \ldots$

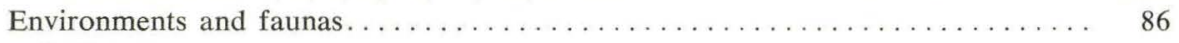

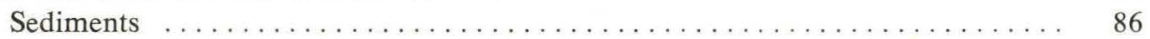

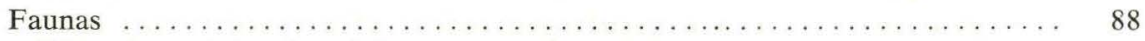

Diversity and density of the ostracod fauna ................ 89

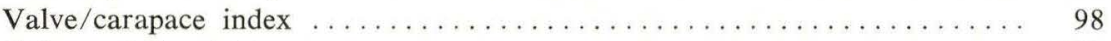

Colour of the shells ............................... 101

Shell morphology ................................ 102

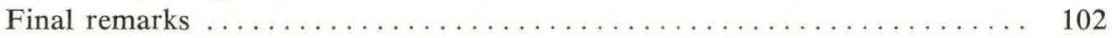

Stratigraphical and environmental conclusions ................. 103

Comparisons of ostracod faunas from Northwest Europe ............. 110

Evolutionary trends of Ogmoconcha and Ogmoconchella ............ 115

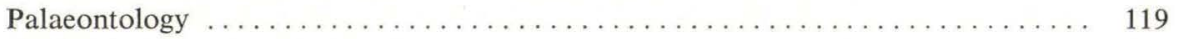

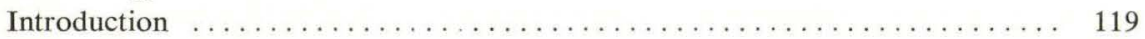

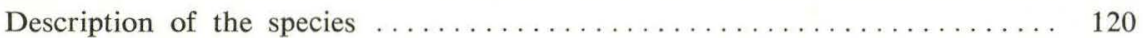

Acknowledgements . . . . . . . . . . . . . . . . . . . . . . . . . 267

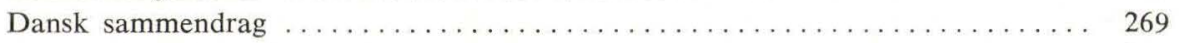

Index of species, subgenera and genera . . . . . . . . . . . . . . . . 277

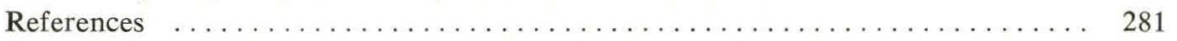

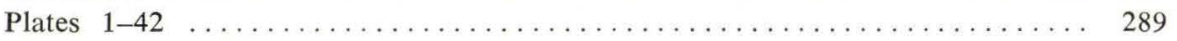




\section{Abstract}

The Lower Jurassic sequence and ostracods from 36 borings within the Danish Embayment are analysed and described.

Hettangian, Sinemurian and Pliensbachian are demonstrated on the basis of extensive ostracod faunas, whilst only weak indications of Aalenian have been found.

The following ostracod zones are defined as a basis for a biostratigraphical subdivision of the Lower Jurassic series in the Danish Embayment:

The Ogmoconchella adenticulata - Nanacythere (Nanacythere) simplex Zone (Upper Pliensbachian).

The Ogmoconchella danica Zone (Upper Sinemurian and Lower Pliensbachian).

The Gramannella apostolescui - Kinkelinella (Klinglerella) foveolata Subzone (Lower Pliensbachian).

The Progonoidea reticulata Subzone (lowest Upper Sinemurian, Lias Beta-1a).

The Cristacythere betzi - C. crassireticulata Zone (upper Lower Sinemurian).

The Ogmoconchella aspinata Zone (Hettangian and lower Lower Sinemurian).

The chronostratigraphical subdivision of the Lower Jurassic sequence in the Danish Embayment is presented, based upon the ostracod faunas described here and upon previous investigations of sediments, foraminifera and megafossils.

The conditions prevailing in the basin are discussed, with descriptions of the sedimentary and faunal developments, and an evaluation of the relationships with other parts of the Northwest European area.

124 ostracod species are described; 23 are described as new, whilst 30 species which cannot be referred to any known species are described with open nomenclature owing to limited or badly preserved material. The remaining 71 species have all been described previously and are more or less well-known. The 124 species fall into 27 genera or subgenera, of which 2 genera (Pseudomacrocypris and Cristacythere) and 1 subgenus (Nanacythere (Goniocythere)) are established as new.

A subdivision is made of the described Lower Jurassic "Procytheridea". The genus Klinglerella Anderson, 1964 is placed as a subgenus under Kinkelinella Martin, 1960. Pleurifera Gramann, 1962 and Progonoidea Gramann, 1962 are regarded as independent genera placed together with Kinkelinella and the new genus Cristacythere.

The family Healdiidae is regarded as being represented by only three genera in the Lower Jurassic: Ogmoconcha, Ogmoconchella and Pseudohealdia. The Ontogenetic development of the muscle scar area in Ogmoconchella is shown to be a development from a simple muscle scar of the Pseudohealdia-type to a typical Ogmoconchella-scar. 


\section{Introduction}

\section{Lower Jurassic deposits within the Danish Embayment}

Less than a half century ago nothing was known about the Lower Jurassic deposits in Denmark outside the island of Bornholm. With the exploration work, firstly of the Danish American Prospecting Company and later of the Dansk Undergrunds Consortium, several wells were drilled through the Mesozoic and into the Palaeozoic formations. Today 27 deep test borings and 9 shallow ones show more or less complete sections of the Lower Jurassic deposits (cf. text-fig. 1).

An important result of the exploration activity is the knowledge gained of the sedimentary sequences and the basinal conditions. The area is structurally divided by the Ringkøbing-Fyn High, with the North German basin to the south and the Danish Embayment to the north. The Danish Embayment is bounded by the Fennoscandian Border Zone to the northeast. It joins the Polish Basin to the southeast and extends into the NorwegianDanish Basin to the northwest (Sorgenfrei, 1969b). A nearly complete Mesozoic series, and a less continuous Palaeozoic series, is found in the basin (cf. Sorgenfrei \& Buch, 1964, Christensen, 1971c and Michelsen, 1971b). The Lower Jurassic deposits are limited to the Danish Embayment. They are connected to the Polish and German deposits to the southeast and probably to the English deposits to the northwest, since the Danish deposits clearly extend out under the North Sea.

The Lower Jurassic sections exposed by the drilling activity have been described in some detail. The occurrence of marine Lower Jurassic sediments within the Danish Embayment is mentioned for the first time by Nørvang (1946) in a description of a boring situated in Northern Jylland near the village Vejrum. In Gregersen \& Sorgenfrei (1951) the latter author presents the section from the Gassum No. 1 boring and a stratigraphical subdivision of the section, based on analyses of the megafossils by Hans Frebold. The presence of Lias Alpha-Beta in the Vinding No. 1 boring is also mentioned. Nørvang (1957) presents a thorough examination of the Liassic foraminiferal faunas and an outline of the lithology in the sections from nine borings, of which Gassum No. 1 is the most important. The chronostratigraphical subdivision given in his paper builds mainly on anal- 


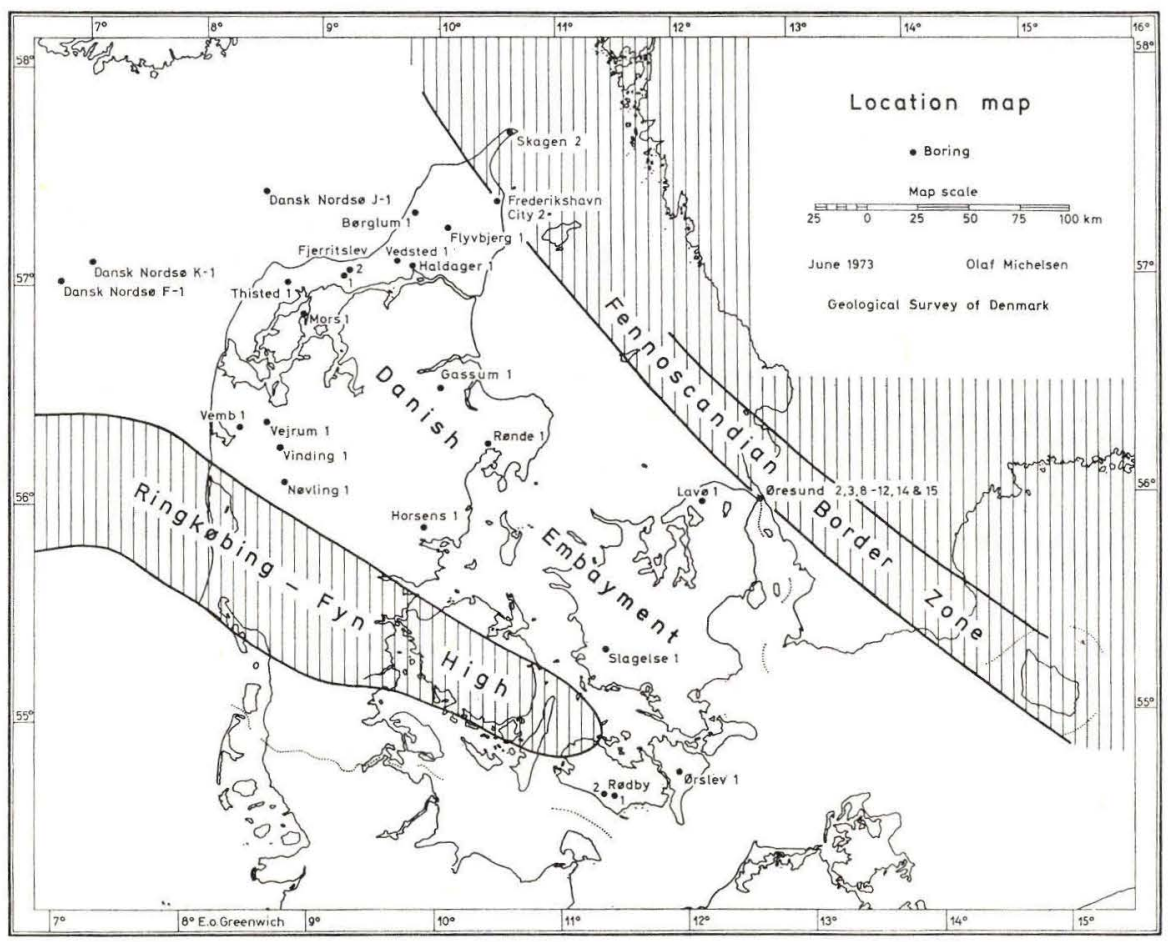

Text-fig. 1.

yses of the megafossils by Peter H. Baadsgaard and Hans Frebold. A short description of the formations in the Lav $\varnothing$ No. 1 boring is given by Dinesen (1960), and in Slagelse No. 1 by Larsen \& Buch (1960). Sorgenfrei (1963) describes the sedimentary development within the basin and characterizes the Liassic sedimentation as a clayey facies with traces of a sandy marginal facies in northernmost Jylland. The thickness and the character of the lithology in the Lower Jurassic deposits is presented in his map, plate II, fig. 2 .

All borings drilled by the Danish American Prospecting Company are published in the important paper by Sorgenfrei \& Buch (1964). The paper comprises a lithological description and a chronostratigraphical subdivision of the sections. The stratigraphical subdivision of the Lower Jurassic is based on microfossils as well as megafossils, whereas the upper and lower boundaries of this series are mainly determined by means of lithological evidence and lithological correlations.

An outline of the sedimentary development is given by Larsen (1964). He counts the sandy Rhaetic and the clayey Liassic deposits as the 1st 
cycle, succeeded by the sandy Dogger and the clayey Malm deposits as the 2nd cycle. These features of the basin are worked out in detail in his important paper (Larsen, 1966), in which he defines a lithostratigraphical subdivision of the formations. The Fjerritslev Formation is the most important of these in connection with the subject of the present paper. The formation is defined as a marine, dark coloured claystone deposit mainly of Lower Jurassic age. However, in Northern Jylland the uppermost part of the formation is regarded as Middle Jurassic according to the chronostratigraphical subdivision given by Sorgenfrei \& Buch (1964). This age determination of the Fjerritslev Formation seems questionable and will be discussed below. Above the Fjerritslev Formation deposits dominated by sandstone and siltstone are found, and these are defined by Larsen (1966) as the Haldager Formation. Below the Fjerritslev Formation in Northern and Central Jylland deltaic deposits occur, defined as the Gassum Formation, and according to the chronostratigraphical determination given by Sorgenfrei \& Buch (1964), this is of Rhaetic age. The coincidence of the upper boundary of this formation and the Triassic-Jurassic boundary will be discussed below. The Fjerritslev Formation is underlain by the marine, Rhaetic Vinding Formation in the southwestern part of the basin, and by the deltaic Ullerslev Formation in the southern part. The Vinding Formation is also supposed to be present in the Slagelse boring, and Larsen (1966) considers it likely that a belt including the localities Vinding and Slagelse was covered by the sea from the start of Rhaetic times and that in Lower Jurassic times a transgression from this region affected adjacent parts of the basin.

Another important paper is the report by Larsen et al. (1968, written but not published in 1964) concerning shallow borings drilled in the northernmost Øresund, on two lines between Helsingør and Hälsingborg. These borings are drilled through the Quaternary deposits into Mesozoic, mainly Jurassic, sediments. The lithology of the Lower Jurassic deposits, which are of special interest here, is described by Gunnar Larsen. The biostratigraphical conditions are described on the basis of the ostracod fauna by Ole Bruun Christensen (1968a), and on the basis of the foraminifera by Inger Bang (1968). Some of the sections overlap each other and there are stratigraphical gaps between other sections, so the series cannot be combined into a continuous profile. Gunnar Larsen (1968) describes and defines the formations within the area with reference to lithological units known from Southwest Sweden. The stratigraphical subdivision worked out by Ole Bruun Christensen and Inger Bang is concordant in its main features with the division presented in the present paper, but they have difficulty in defining the Lias Alpha-Beta and Lias Beta-Gamma boundaries.

Sorgenfrei (1969a and 1969b) shows the lithological facies of the Lower 
Jurassic section in different parts of the North European sedimentary basin on maps, and discusses the possible connections between the areas.

Bertelsen \& Michelsen (1970) revise the stratigraphical subdivision of the Lower Jurassic in the Rødby No. 1 boring, inasmuch as the whole section is referred to Hettangian and possibly to the lower part of Lower Sinemurian. The Triassic-Jurassic boundary is determined both by ostracods and megaspores. Later on, the facies and stratigraphy of the same section, together with other sections of the same stratigraphical age, are elucidated and discussed on the basis of the ostracod fauna and the holothurian fauna (Michelsen, 1973b). In Michelsen (1971a and 1973a) the Lower Jurassic sections of Rønde No. 1 and Nøvling No. 1 are subdivided stratigraphically on the basis of the ostracod faunas. Bang (1971 and 1973) describes the same sections, referring to the foraminiferal faunas. Rasmussen (1972) briefly describes the entire sections of the onshore deep borings drilled by Dansk Undergrunds Consortium in the period 1965-1968, and includes a chronostratigraphical subdivision.

The present paper deals with all the borings containing Lower Jurassic sections. Except for three borings (Dansk Nords $\varnothing$ F-1, J-1 and K-1), all of them have been published in the papers mentioned above.

\section{Previous descriptions of Lower Jurassic ostracod faunas}

As the stratigraphical discussion in the present paper is mainly based on ostracod species and faunas, their morphological definition, and their stratigraphical and geographical range, it is desirable to review the most important literature dealing with the ostracod faunas of the northern and western European basins.

In England, Liassic ostracod faunas have been described rather early. Jones (1872) describes, without any figures, four species from "Infralias" of Yorkshire. Later on, he mentions additional species from Rhaetic and Liassic sections and gives small drawings, which today have little value for identifying the species (Jones, 1894). The same view must be taken of the species described by Blake (1876). Recently Lord (1971) has made valuable revisions of some of the species. As the basis for their stratigraphical occurrence he refers to ammonite zones; otherwise, there is only minor information regarding biostratigraphical correlation (cf. Lord, 1972a, and unpublished ostracod-lists in the "Eleventh Micropalaeontological Colloquium, England 1969").

In Germany, studies on the ostracod species have been more intensive, but descriptions of the entire fauna including the range of each of the 
species occur only rarely. An outline of the stratigraphical range of certain important species is given by Klingler (1962), who defines the stratigraphical subdivision on the basis of the ammonite zones. Herrig (1969 a and 1969b) describes the fauna from parts of the Domerian (determined by ammonites) in northeast Germany, but the total stratigraphical range of each species is not given. Dreyer (1965) has examined the ostracod faunas from Lower Jurassic sections, comprising the Hettangian to the Lower Domerian, in southwest Brandenburg. Unfortunately the sedimentary sequence is not developed as a continuously marine series. The description of the uppermost Lower Jurassic ostracod faunas from East Germany (Stoermer \& Wienholz, 1965), together with Herrig (1969a and 1969b) and Dreyer (1965), make an excellent basis for a biostratigraphical correlation with the eastern part of Germany.

From southwestern Germany Drexler (1958) describes thoroughly the ostracod and foraminiferal faunas from sections which are referred to Lias Alpha on the basis of ammonites. The stratigraphical range of most of the ostracod species is covered within the sections. Klingler \& Neuweiler (1959) describe several "Procytheridea"-species and their stratigraphical range in relation to ammonite zones, but they do not treat the total faunas.

Several other papers dealing with Lower Jurassic ostracods from Germany are palaeontological works, but they often include information concerning the stratigraphical range of the species.

From the French literature only a few papers will be emphasized. The detailed palaeontological works are not relevant here because of the relatively large faunal dissimilarity from the North European faunas. Apostolescu (1959) and Donze (1966 and 1967) briefly describe species with their stratigraphical range in relation to the ammonite zones. Oertli (1963) shows a qualitative outline of the faunas from each stage or substage. The extensive paper of Viaud (1963) has unfortunately never been published. It consists of a thorough description of the species and faunas from the whole of France, and is the only paper in Northwest Europe which includes a quantitative analysis of ostracod faunas from the entire Lower Jurassic section. It has been very useful in preparing the present paper. Several of the reports in "Colloque sur le Lias francais, 1961" contain an outline of stratigraphical relationships useful for correlation work.

\section{Purpose and scope of the present investigation}

Hitherto the knowledge of the Lower Jurassic deposits in Denmark has been based mainly upon the lithology. The investigation described in the present paper must be seen in the light of this fact and in the light of 
the fragmentary knowledge of the Lower Jurassic ostracod faunas in Northwest Europe.

The primary purpose has been to describe all of the species recorded from the sedimentary sequence and to present a complete outline of the faunas and of the development within them. The Lower Jurassic deposits in the Danish Embayment are situated below a thick sedimentary sequence, so all studies must be carried out on rather small bore samples, most often on cuttings samples. Analysis of cuttings samples is only possible on the basis of a detailed knowledge of the morphological variation of the species and of the faunal relationships. Half of the species described in the present paper have been described previously, but only a few of them have been mentioned from many localities. Therefore, the purpose has been to enlarge the knowledge of the morphological variation, and of course to describe the unknown species. Furthermore, it has been considered important to describe the ontogenetic development, since a large part of a fauna may often be composed of larvae. For evaluation of the stratigraphical conditions of sections represented by cuttings samples, in particular, it is very important to know the larval stages of the species.

The description of the Lower Jurassic has been rather one-sided in the present paper, since the lithology has previously been treated and is only briefly referred to here. The megafossils of these faunas are analysed in unpublished reports, referred to in the present paper. The foraminiferal faunas from some of the borings have been described by Nørvang (1957), and they have also been studied in recent times by Inger Bang (cf. Bang 1968). Megaspores have been described by Bertelsen (1970) and the holothurian faunas by Michelsen (1973b). The purpose has therefore been to describe the ostracod faunas in relation to the lithology and to make a subdivision of the sections based on all known data. Importance has been placed upon defining ostracod zones which are useful in the Danish Embayment and in adjacent parts of the North European basinal area. Finally an attempt has been made to elucidate the principal features of the facies and the environmental conditions. 


\section{Materials and Methods}

The materials used for the present investigation consist of reports on the lithology and on certain groups of fossils, electrical logs, core samples and cuttings samples.

As the main purpose has been to describe the ostracod faunas and to make a biostratigraphical subdivision of the sedimentary sequence, no comprehensive studies on the sediments have been carried out. The electrical logs and the lithological description given below are in the contracted form published by Sorgenfrei \& Buch (1964). The reports on the megafossils are referred to in relation to each section as in Nørvang (1957). It has not been my intention to check this information and only in relation to the section in Rødby No. 1 has it been necessary to work out a new lithological subdivision (Michelsen, 1973b).

The core samples are regarded as the most important type of rock sample. They are defined at a fixed level in the sedimentary sequence; thus the fauna recorded can be referred with certainty to that level and related rather precisely to lithological features visible in the core and on the electrical logs. The ostracod zones and the ostracod species are described on the basis of core samples; only very few species have been described from cuttings samples. Nearly all of the core samples, approximately 300 in number, have been selected by colleagues for a co-ordinated investigation, but a few new core samples are added by the present author. This is done partly to replace older material, e.g. in the Horsens No. 1 boring, and partly as supplement to, and control for, the older samples, e.g. in the Øresund borings. The samples consist of 100-200 grammes of sediment, which after drying has been disintegrated by means of petrol and boiling water. The rock samples have only rarely been crushed. After disintegration the samples were washed on a sieve with $0.1 \mathrm{~mm}$ apertures. The ostracods have been picked out from the whole fraction larger than $0.1 \mathrm{~mm}$. Nearly all core samples are treated quantitatively and the composition of the ostracod faunas is expressed as relative percentages in tables 1-13.

As a supplement to the quantitatively treated core samples, a large number of preparations made during the drilling have also been used. The technique used for these preparations has been rather variable, so that none 
of them are quantitative. Some of the preparations, e.g. from the Gassum No. 1 boring, represent an accumulation of material from a larger sedimentary section, usually a $4^{\prime}$ to $7^{\prime}$ thick series of a core. These samples are taken continuously within each of the cores, and they should therefore show the whole fauna present in the sedimentary sequence very well. These preparations, taken from the cores, are excellent as a qualitative supplement for the description of the stratigraphical range of the species, and for showing the composition of the fauna. The small, quantitatively treated samples may comprise faunas from differing environmental conditions, and may therefore be misleading for an evaluation of the biostratigraphical conditions.

A large number of cuttings samples have been used for the present investigation, especially from the new borings drilled by Dansk Undergrunds Consortium. The cuttings samples have been treated in the same way as the core samples, but they are not counted as quantitative samples. During the drilling work the samples are numbered by depth figures, which when calculated with the factor "lag time" may give an approximately true estimate of the level of the sediments included in the samples (cf. Rasmussen, 1971, p. 24 and Dinesen, 1971, p. 34). They include rock materials from beds above the calculated depth, since the cuttings samples are brought from the bottom of the borehole to the ground surface by the circulating mud. During the drilling there is always a possibility of cavings from any of the layers between the level of sampling and the bottom of the casing. It is important when analysing cuttings samples to remember both the difficulty of determining the exact depth and the possibility of the admixture of rock materials from different layers. Therefore the occurrence of a species must be counted from the uppermost appearance and not from the lowermost; ostracod zones recognized in cuttings samples may be indicated by their upper boundary only. The depth figures based on cuttings samples may possibly be too high and the determined boundaries may be located higher in the sedimentary sequence.

The specimens figured on plates 1-41 were photographed either under a light microscope or under a scanning electron microscope of type Cambridge Stereoscan Mk. IIa (Inst. Hist. Geol. Palaeont., University of Copenhagen) or Jeol JSM-S1 (Geological Survey of Denmark). Some of the figures taken under the light microscope were illuminated by a Sunpak RV, which on shells with a smooth external surface, e.g. the Ogmoconchellaspecies, may show a ring-shaped figure of light with a dark swelling rim close to this. Specimens of reticulate forms were stained green or violet before photography. The figures on plates 1-2, 5-7, 9-10, 13-15, 17, 19-21, 23, 25, 29, 31-32, 36, and 39-41 were taken under a scanning 
electron microscope, whereas the remaining figures were taken under a light microscope. The two methods of figuring the specimens are used together, as they are regarded as supplementary methods. By means of the light microscope it is possible to show the outline and shape of the carapace or the valve in well-defined positions: in dorsal view, in lateral view, and in anterior or posterior view. When the scanning electron microscope is used, the proportions between the length, height and breadth of the shell may be figured erroneously. The scanning electron microscope is used mainly to figure details of the shell: sculpture, hinge and muscle scars.

All preparations and figured specimens, including the holotypes, are stored in the type collection of the Department of Subsurface Geology at the Geological Survey of Denmark.

In addition to the present investigation the author has had the opportunity to study French type material as well as faunas from the French Lower Jurassic sections during a visit to H. J. Oertli (Pau). Furthermore, I an very grateful for receipt of French type material from H. J. Oertli, and English type material from A. Lord. Material collected in England by my colleagues A. Buch and I. Bang has kindly been placed at my disposal, as has material collected in Sweden and Bornholm by E. Stenestad, O. Bruun Christensen and F. Bertelsen. Paratypes of the species described by Klingler \& Neuweiler (1959) were kindly sent by "Gewerkschaften Brigitta und Elwerath Betriebsführungsgesellschaft $\mathrm{mbH}$ " (Hannover). During a visit to H. Malz (Frankfurt a.M.) he kindly helped me in studying type material and also lent me material for comparative studies. This availability of study material from other parts of the Northwest European basins has formed a good basis for carrying out an evaluation of the ostracod faunas. 


\section{Stratigraphy}

A chronostratigraphical subdivision of the Lower Jurassic section within the Danish Embayment can not be based on a direct correlation of the ostracod zones because a quantitative treatment of the ostracod faunas from all of the type localities of the stages has not yet been published. Furthermore all the type areas are located outside the North German Basin. The ostracod faunas in basinal areas, where the type localities are located, seem to differ so much from the faunas in the North German Basin and the Danish Embayment, that a comparison of the faunas has generally little value.

On the other hand the ammonite zones are usually regarded as a reliable basis for chronostratigraphical subdivision, at least within Northern and Western Europe. The stratigraphical range of the ostracod species and faunas described from Germany are usually referred to the ammonite zones, so it is possible to make an indirect correlation and a stratigraphical determination of the Lower Jurassic section within the Danish Embayment. The present paper primarily contains a local subdivision, worked out on the basis of the ostracod faunas. This subdivision is secondarily correlated with the biostratigraphical units in the standard division on the deposits in the adjacent areas. Of course, it is necessary to have additional localities in order to check the correspondence between the different kinds of zones, e.g. the ammonite zones and the ostracod zones. If the localities are reasonably situated in relation to the sedimentary basin there must be a good basis for a chronostratigraphical subdivision. It is therefore important that the stratigraphical range designated to a species includes exact information about biozones or lithozones as well as about the stage.

\section{The ammonite zones}

In the present paper ostracod zones are established which can be followed into the North German Basin, at least. From information on the occurrence of megafossils inside and outside the Danish Embayment it seems likely that these zones coincide with the ammonite zones. The ammonite zones are therefore the real basis for the subdivision described below. The subdivision 
of the Lower Jurassic used is in agreement with that recommended in "Colloque du Jurassique, Luxembourg 1962":

\author{
Aalenian: top Zone of Graphoceras concavum \\ base Zone of Leioceras opalinum \\ Toarcian: top Zone of Pleydellia aalensis \\ base Zone of Dactylioceras tenuicostatum \\ Pliensbachian: \\ Upper Pliensbachian: \\ top Zone of Pleuroceras spinatum \\ base Zone of Amaltheus margaritatus \\ Lower Pliensbachian: \\ top Zone of Prodactylioceras davoei \\ base Zone of Uptonia jamesoni \\ Sinemurian: \\ Upper Sinemurian (Lotharingian): \\ top Zone of Echioceras raricostatum \\ base Zone of Caenisites turneri \\ Lower Sinemurian (Sinemurian s.str.): \\ top Zone of Arnioceras semicostatum \\ base Zone of Arietites bucklandi \\ Hettangian: top Zone of Schlotheimia angulata \\ base Zone of Psiloceras planorbis
}

Different index fossils are used in the different parts of the sedimentary basins, especially for some of the subzones; thus it is necessary briefly to outline the ammonite zones and the index fossils used. Furthermore, the subdivision of the Lower Jurassic in Germany is often indicated by Greek letters. A comparison of the different kinds of terminology used is therefore necessary.

Hettangian. Of the three zones used by Dean, Donovan \& Howarth (1961)

Schlotheimia angulata Zone

Alsatites liasicus Zone

Psiloceras planorbis Zone

only the upper and lower ones are used in Germany and the middle zone is divided between them (Hoffmann, 1960 and 1962). The upper subzone of the $A$. liasicus Zone (the $A$. laqueus Subzone) is included under the $S$. angulata Zone, whereas the lower subzone is supposed to correspond to the $P$. hagenowi Zone and is counted under the P. planorbis Zone.

Hettangian corresponds to Lias Alpha-1 and 2, since Alpha-1 comprises 
the $P$. planorbis Zone and the $A$. liasicus Zone, and Alpha-2 the $S$. angulata Zone sensu Dean, Donovan \& Howarth, 1961 (cf. Hoffmann, 1960).

Lower Sinemurian (Sinemurian s.str.). This substage includes two ammonite zones

Arnioceras semicostatum Zone

Arietites bucklandi Zone

and corresponds to Lias Alpha-3.

Upper Sinemurian (Lotharingian). Of the four zones

Echioceras raricostatum Zone

Oxynoticeras oxynotum Zone

Asteroceras obtusum Zone

Caenisites turneri Zone

the $C$. turneri Zone corresponds to Lias Beta-1a, the A. obtusum Zone to Lias Beta-1b, while the two upper zones correspond to Beta-2 and Beta-3 respectively (Hoffmann, 1960).

Lower Pliensbachian. The substage is subdivided by three ammonite zones.

Prodactylioceras davoei Zone

Tragophylloceras ibex Zone

Uptonia jamesoni Zone

of which the uppermost one corresponds to Lias Gamma-3. The boundary between Gamma-1 and 2 is placed between the lower two subzones of the T. ibex Zone, between the P. brevispina and P. taylori Subzones (see also Geyer, 1964 and Hoffmann, 1960).

Upper Pliensbachian comprises two ammonite zones

Pleuroceras spinatum Zone

Amaltheus margaritatus Zone

According to Hoffmann (1960), the lower zone, the A. margaritatus Zone, corresponds to Lias Delta-1 and 2, and the upper zone to Delta-3 and 4. The subdivision of Lias Delta in relation to Upper Pliensbachian is variable, as other authors (e.g. Hoffmann, 1949 and Klingler, 1962) distinguish an upper and a lower part, Lias Delta-1 and 2, and each one may be subdivided into "a" and "b". When correlating by means of ostracod species marked with a stratigraphical range of the last mentioned type, there have been difficulties in deciding which of the ammonite zones to refer to.

Toarcian. As no ostracod faunas have been found in the Danish Embayment corresponding to faunas recorded from this stage elsewhere in Northwest Europe, reference will be confined to the remarks on p. 16.

Aalenian. This stage is here included under the Lower Jurassic in agreement with "Colloque du Jurassique, Luxembourg 1962" (see also p. 16). Ostracod faunas recorded from this section in the Danish Embayment are 
so poor and rare, that there seems to be no reason to discuss the subdivision in details.

The boundary between Lower and Upper Sinemurian is questionable and is defined in different ways by different authors. A short outline of the problems must be given to clarify the subdivision used in the present paper.

The Sinemurian sedimentary series is reduced in the type area and comprises phosphatized fossils. The lower boundary of the Lotharingian substage is by definition placed at the base of a poorly fossiliferous series of a marl with phosphatic concretions in the lowermost part. Near the base are found the species $P$. planicosta and $M$. birchi which are used as index fossils for the $A$. obtusum Zone and the $C$. turneri Zone respectively (cf. Dean, Donovan \& Howarth, 1961 and Hoffmann, 1962 and Spath, 1942).

In Southwest Germany the upper part of the Lotharingian substage is well-defined, whereas the lower part, corresponding to the C. turneri Zone, is more questionably determined. According to Hoffmann (1964) the species $C$. turneri is not recorded with certainty, whereas $M$. birchi is known from the upper part of the "Arietenbank", and $P$. capricornoides from a higher level in the series. The upper part of "Arietenbank" must therefore be included under the lowermost Lotharingian (Hoffmann, 1964).

In most of Northwest Germany there is a hiatus between the P. planicosta Subzone and the A. semicostatum Zone. However, a ca. $10 \mathrm{~m}$ thick series in the "Herforder Liasmulde" must, based on the occurrence of the species $M$. birchi and $P$. capricornoides, be referred to the $C$. turneri Zone (Hoffmann, 1964).

Corresponding to the reduced or missing deposition in the lowermost Upper Sinemurian, divergent species and faunas are developed in the different parts of the basin. The $C$. turneri Zone may generally be subdivided into two subzones (Dean, Donovan \& Howarth, 1961), but in Germany it only comprises one subzone, the $P$. capricornoides Subzone (Hoffmann, 1964). The A. obtusum Zone, too, is anomalously defined in Germany where it comprises two subzones of which the $P$. planicosta Subzone is important for the subdivision of the Danish Lower Jurassic as outlined below.

\section{Description of the ostracod zones}

As mentioned above, the main purpose of the present investigation has been to describe the ostracod species and faunas. During the examination of the faunas these have clearly stood out as well-defined units, which have shown 
themselves to be a good and constant basis for a subdivision of the sedimentary sequences. Four zones and two subzones are formally named and a possible further subdivision into subzones is described (cf. pl. 42):

The Ogmoconchella adenticulata - Nanacythere (Nanacythere) simplex Zone includes at least two subzones. It is correlated with the Upper Pliensbachian.

The Ogmoconchella danica Zone includes three subzones, of which the uppermost is named the Gramannella apostolescui - Kinkelinella (Klinglerella) foveolata Subzone and the lowermost the Progonoidea reticulata Subzone. The uppermost subzone is correlated with the Lower Pliensbachian, and the underlying part of the zone with the Upper Sinemurian.

The Cristacythere betzi $-C$. crassireticulata Zone is correlated with the uppermost Lower Sinemurian.

The Ogmoconchella aspinata Zone includes two subzones. It is correlated with the Hettangian and the lower part of the Lower Sinemurian.

The ostracod zones are described as assemblage zones, though some of them may be range zones or concurrent range zones within the Danish Embayment. However, as the ranges of all the species are not totally known in other parts of the Northwest European basins the correlation is more surely made on the basis of assemblages.

\section{Methods}

The zones are defined exclusively on the basis of quantitatively treated core samples, whereas the description is also based on qualitatively treated samples. In counting the specimens from each sample the number of specimens has been recorded as number of individuals. Each carapace was naturally counted as one individual; of the valves counted, the largest number of left or right valves gives the number of individuals. The larger fragments were counted such that none of the fragments counted must be a portion of an individual counted before. Minor fragments of a characteristic species, but of a species not counted in the above-mentioned way, have been counted as one individual if it has been impossible to state with certainty the presence of more individuals. The species presented in tables 1-13 were counted as individuals in the manner outlined and comprise the total number of specimens identifiable as species. Fragments which could 
not be assigned to a known species have been referred to a genus if possible and were counted as outlined above. This last-named figure is given separately and is included under the figure for the total number of individuals in the sample.

The method of counting described above results in a "minimum figure" and may of course be wrong. However, a more satisfactory and objective method of counting has not yet been suggested. None of the species dealt with in the present investigation seems to be more markedly destined to break down than any others. Of course, if the methods used in the laboratory for disintegration of the samples are too violent the number of fragments will increase, and it will possibly increase more rapidly for large, thin-shelled forms than for smaller ones. However, in the author's experience this source of error is not marked. The relative number of each of the species is considered to be accurate, or at least not far from the truth. The total number is possibly too low in certain cases, but the difference will be minor and the only really important figure is the relative number of each of the species.

Besides the quantitatively analysed samples, several other core samples have been treated qualitatively with the purpose of obtaining a solid basis for determination of the range of the species and of the zones. The diagrams of the Gassum, Rønde and Øresund borings comprise both quantitative and qualitative data (cf. text-figs. 15, 16, and 21).

The main purpose of the analysis has been to characterize the faunas by the dominant forms and to create a background for an estimate of the special differences between the faunas based on the dominating and associated forms. The quantitative analysis mainly has the characterizing function, whereas the qualitative analysis describes the composition of the fauna as precisely as possible.

As mentioned above, the zones are assemblage zones, which according to the "Code of stratigraphic nomenclature, 1961" are defined as "a body of the strata characterized by a certain assemblage of fossils without regard to their ranges". Conditions of analyses of the materials as outlined above are necessary for using this definition.

\section{Ogmoconchella aspinata Zone}

The zone is defined in the Rødby No. 1 boring as the section 1588'-1858' and it is characterized by Ogmoconchella aspinata (Drexler, 1958) and by the following accessory species (cf. Michelsen, 1970, p. 15): 
Kinkelinella (Klinglerella) medioreticulata (Michelsen, 1970)

Nanacythere (Goniocythere) elegans (Drexler, 1958)

Pseudomacrocypris subtriangularis n.sp.

Polycope minor n. sp.

Paradoxostoma? pusillum n. sp.

Stenestroemia? roedbyensis Michelsen, 1970

Nanacythere? sp. 4061 (Michelsen, 1970)

Nanacythere (Goniocythere) circumcostata n. sp.

Cristacythere sp. 4081 (Michelsen, 1970)

Examination of all sections comprising this zone within the Danish Embayment has excluded S.? roedbyensis, N.? sp. 4061 and C. sp. 4081 as characteristic species though they are never recorded from series outside the zone. Ogmoconcha hagenowi Drexler, 1958 and Nanacythere (Goniocythere) paracostata $\mathrm{n}$. sp. must on the other hand be emphasized as important accessory species.

The $O$. aspinata Zone is furthermore recognized in the Gassum No. 1, Horsens No. 1, Vedsted No. 1 and Vinding No. 1 borings.

The section in Gassum is fairly well represented by cores (cf. text-fig. 15). The fauna is dominated by $O$. aspinata $(50-90 \%)$ and shows a development parallel to that of the Rødby section (cf. table 3). The zone may be subdivided in two subzones:

1) A lower subzone with a fauna consisting of a few species only. The fauna is dominated by $O$. aspinata, $P$. subtriangularis and $K$. (K.) medioreticulata and characterized by a very scarce occurrence of the subgenus Nanacythere (Goniocythere) n. subgen.

2) An upper subzone with a fauna richer both in the number of species and specimens. It is characterized by a frequent occurrence of the subgenus $N$. (Goniocythere) and by the species $P$. minor and $O$. hagenowi. The three species mentioned as occurring in the lower subzone are less dominating in the upper subzone.

The general features of the faunal development and the distinct bipartition of the zone may form the basis for a correlation between Gassum and Rødby (see text-fig. 15 and Bertelsen \& Michelsen, 1970, pl. XVII). It is assumed that the uppermost interval of the zone recorded in Gassum is not present in Rødby. The ostracod fauna in the upper part of the latter section comprises fewer species than the fauna in the Gassum section, and no ostracods are recorded from the uppermost part of the Rødby section referred to the Lower Sinemurian (cf. Bertelsen \& Michelsen, 1970). 


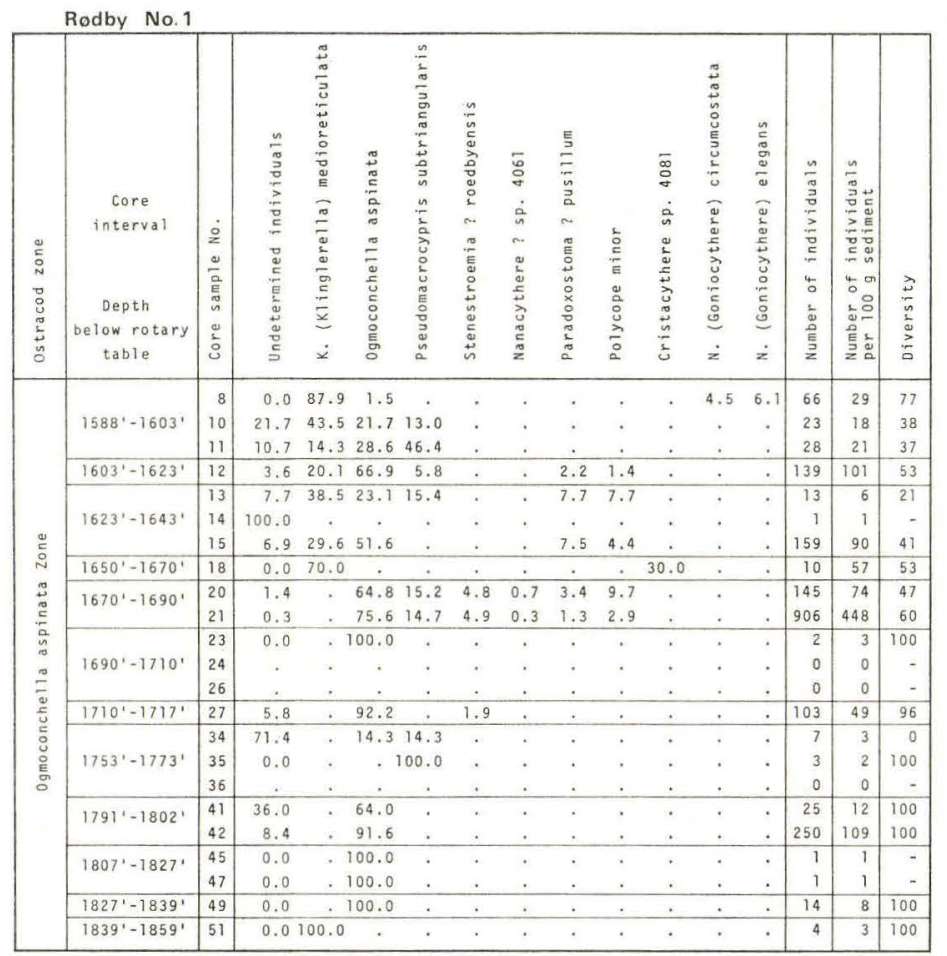

Table 1. The $O$. aspinata Zone in the Rødby section. Composition of the ostracod fauna expressed as relative percentages.

Furthermore it must be mentioned that the Gassum section is thicker than the Rødby section.

In the Horsens No. 1 boring the $O$. aspinata Zone is recorded from only one core (cf. text-fig. 19). The recovered fauna corresponds to that from the upper subzone in Gassum No. 1 (table 2). This is supported by the fact that the $O$. aspinata fauna is not found in the cuttings samples above the core, and by the fact that the $O$. danica Zone ( $P$. reticulata Subzone, p. 29) occurs in the cuttings samples ca. $45 \mathrm{~m}$ above the core.

In the Vedsted No. 1 boring, too, the zone is represented in one core only (text-fig. 7). The fauna is not rich in species, so it is assumed to correlate with a lower level than the Horsens core (table 4). The cuttings samples do not yield any additional information.

Two cores from the Vinding No. 1 boring show well-preserved rich faunas belonging to the $O$. aspinata Zone. The upper one of the two cores must evidently be placed in the upper subzone on the basis of the faunal composition (cf. table 2). This is supported by the ascertainment of the 


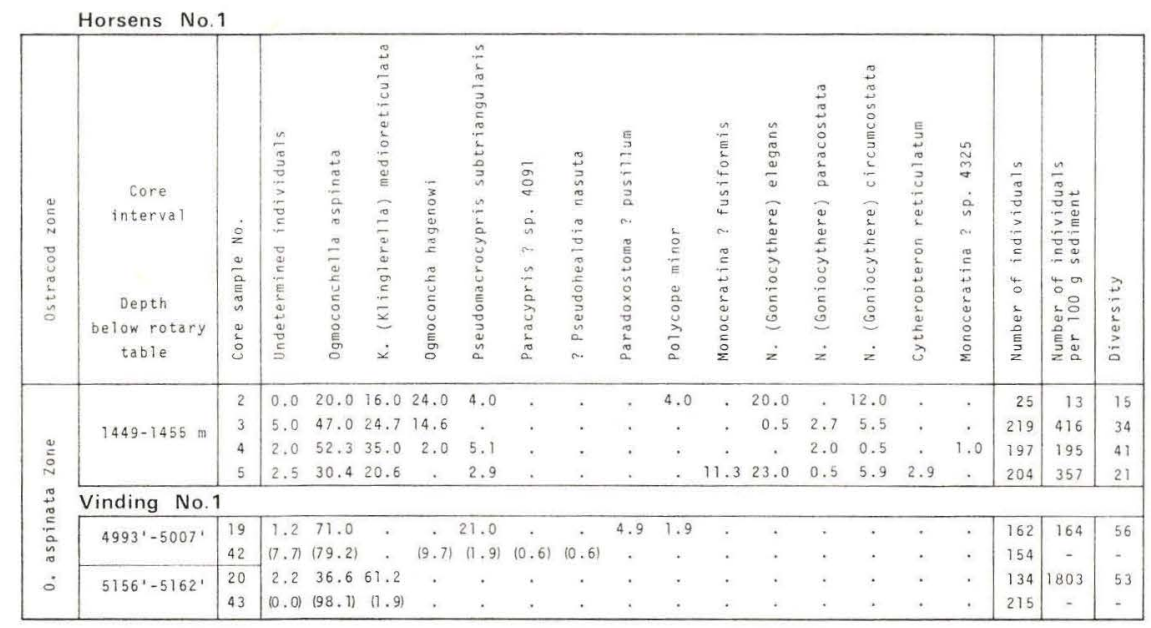

Table 2. The $O$. aspinata Zone in the Horsens section and the Vinding section. Composition of the ostracod fauna expressed as relative percentages.

below-mentioned $C$. betzi $-C$. crassireticulata Zone and the $P$. reticulata Subzone immediately above the core (cf. text-fig. 17). The fauna of the lower core includes only two species and may probably be referred to the lower subzone of the $O$. aspinata Zone.

In both the Fjerritslev No. 2 and Flyvbjerg No. 1 borings, a core has been taken within the section, which by means of the fauna from the cuttings samples is proved to belong to the $O$. aspinata Zone (text-figs. 9 and 4). However, none of the cores have yielded a fauna characteristic for this zone. From the core of Fjerritslev No. 2 only one specimen is recorded of Paradoxostoma? pusillum, a species also occurring in sediments overlying the $O$. aspinata Zone (table 8). The fauna from the core of Flyvbjerg No. 1 is very rich in individuals, but dominated by only one species: Cristacythere costata n. sp. This fauna is unique both in the Danish Embayment and in the other North European Lower Jurassic deposits whose faunas are known from the literature. That this unique fauna is contemporary with the $O$. aspinata fauna is indicated by the occurrence of the megaspore assemblage characterized by Nathorstisporites hopliticus (personal communication from Finn Bertelsen; see also Bertelsen \& Michelsen, 1970). A cuttings sample, ca. $26 \mathrm{~m}$ above the core, contains the ostracod species $O$. aspinata, so it seems reasonable to correlate the sedimentary sequence including the level of the cuttings sample and of the core with the $O$. aspinata Zone. 


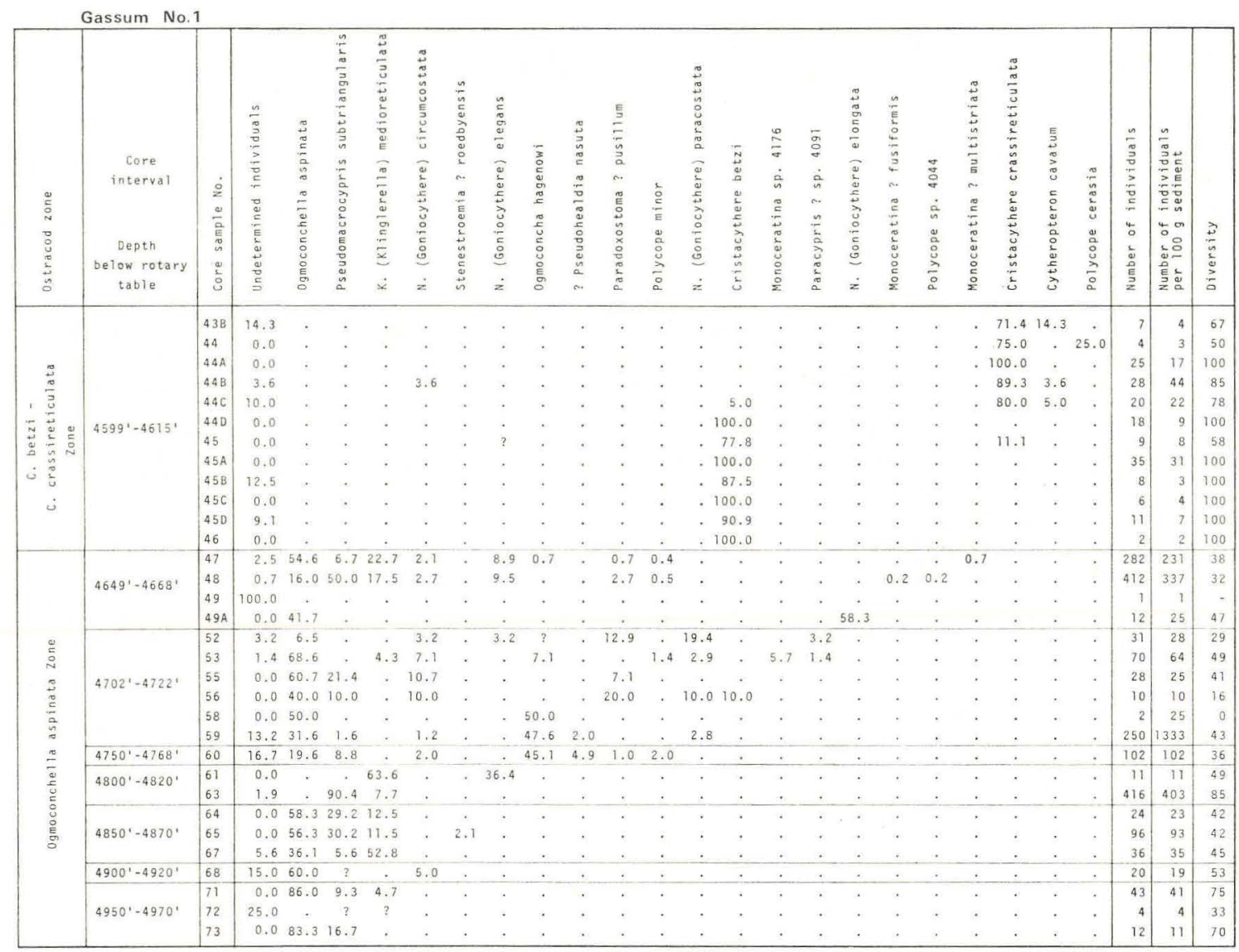

Table 3. The $O$. aspinata Zone and the C. betzi - C. crassireticulata Zone in the Gassum section. Composition of the ostracod fauna expressed as relative percentages.

The $O$. aspinata Zone within the Danish Embayment is a rather uniform zone with a relatively homogeneous fauna, which gradually develops from a fauna of a few species to a fauna rich in species.

The most important species in the lowest part of the Lower Jurassic of Northwest Germany are Ogmoconchella aspinata, Kinkelinella (Klinglerella) medioreticulata and Ogmoconcha hagenowi (cf. Klingler, 1962). From South Germany Drexler (1958) describes a fauna characterized by $O$. aspinata, O. hagenowi, Nanacythere (Goniocythere) elegans, and Monoceratina? fusiformis.

Lord (1971) describes a few species selected from a fauna of the same age, comprising $O$. aspinata, $O$. hagenowi, and $K$. (K.) medioreticulata.

The affinities to faunas known from France are not pronounced, but 


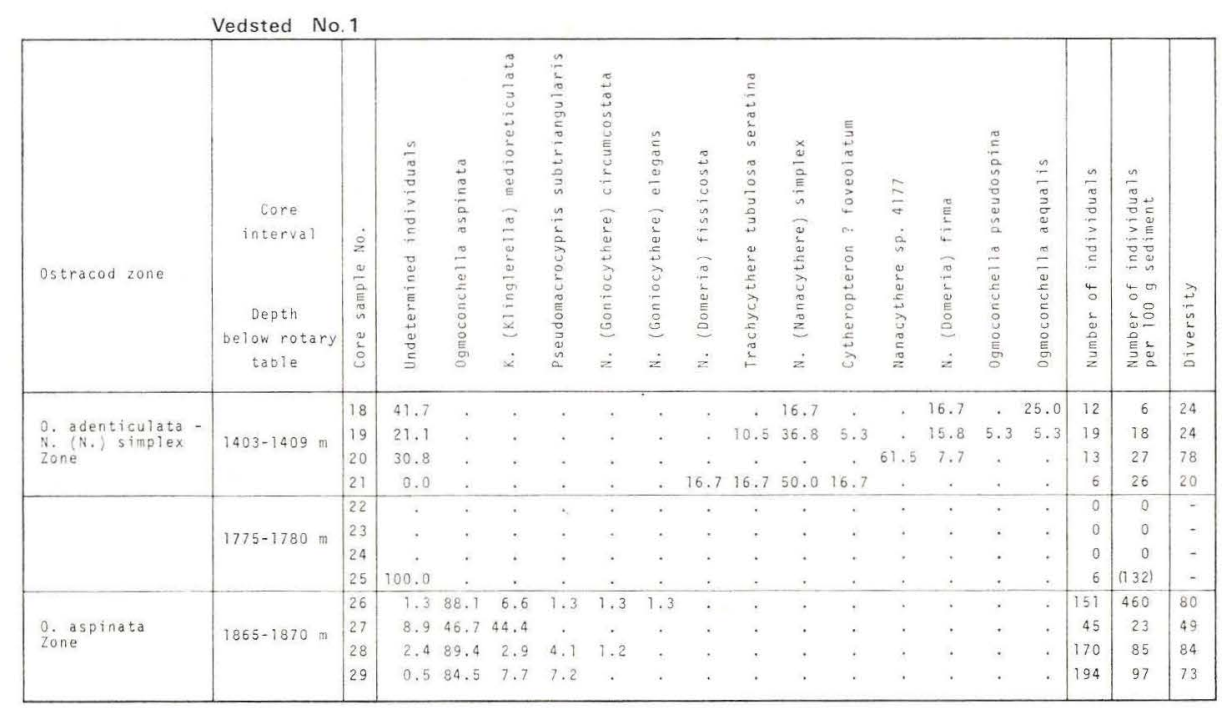

Table 4. The $O$. aspinata Zone and the $O$. adenticulata $-N$. (N.) simplex Zone in the Vedsted section. Composition of the ostracod fauna expressed as relative percentages.

there are two important species in common: $O$. aspinata and $K$. (K.) medioreticulata. If the fauna dealt with here is compared with those described by Oertli (1963) and Viaud (1963) the common character is appreciably small.

Therefore a useful correlation must be made primarily with the German deposits. A description of the fauna, including all elements, has only been made in South Germany (Drexler, 1958), where the ostracod fauna from the "Psilonoten-Schichten", "Angulaten-Schichten" and "Arieten-Schichten" is described. $O$. aspinata is recorded from the entire section except from the upper part of the "Arieten-Schichten". O. hagenowi occurs throughout the section, whereas N. (G.) elegans is found in the "Angulaten-Schichten" and in the lower part of the "Arieten-Schichten" only. The fauna in general is poor in species in the "Psilonoten-Schichten" and rich in the lower part of "Arieten-Schichten", which is a faunal development corresponding to that known from Gassum No. 1 and Rødby No. 1.

Hans Frebold has analysed the megafossils recorded from the Gassum section (see p. 65). He finds Psiloceras sp. in the core 4950'-4970', Schlotheimia angulata in the cores 4800'-4820' and 4850'-4870', and Oxytoma sinemuriensis in the core $4649^{\prime}-4668^{\prime}$. These data and the abovementioned possibility of unambiguous correlation with the German deposits by means of the ostracod fauna indicate a concordant stratigraphical determination. The lower subzone of the $O$. aspinata Zone may be referred 
to Hettangian and the upper one to Lower Sinemurian. The boundary between Hettangian and Lower Sinemurian in Gassum No. 1 may be placed between the cores $4750^{\prime}-4768^{\prime}$ and $4800^{\prime}-4820^{\prime}$ (cf. text-fig. 15). From the range of the $O$. aspinata fauna in South Germany it may be assumed that the upper subzone can be referred only to a part of the Lower Sinemurian (see Drexler, 1958, fig. 3). However, according to Hoffmann (1964) an upper part of the "Arieten-Schichten" (Lias Alpha-3 sensu Drexler, 1958) must be referred to the Upper Sinemurian (see p. 18). The ostracod faunas succeeding the $O$. aspinata fauna, and the occurrence of megafossils in the corresponding sedimentary sequence in the Danish Embayment, support the assumption that the $O$. aspinata Zone must be correlated with the Hettangian and the lower part of the Lower Sinemurian.

The Hettangian fauna is entirely dominated by $O$. aspinata, $K .(K$. medioreticulata and $P$. subtriangularis. In the uppermost part the subgenus $N$. (Goniocythere) is associated with the species $N$. (G.) circumcostata and $N$. (G.) elegans, of which the last-named is an important species within the $S$. angulata Zone in South Germany. The Lower Sinemurian fauna is more rich in species and differs from the underlying fauna in the occurrence of the species P.? pusillum, P. minor and the subgenus $N$. (Goniocythere). The last-named subgenus is a prominent and important group in the Lower Sinemurian $O$. aspinata assemblage.

\section{Cristacythere betzi - Cristacythere crassireticulata Zone}

The zone is defined in the Gassum No. 1 boring as the sedimentary sequence in the core 4599'-4615' (see text-fig. 15). It is characterized by Cristacythere betzi (Klingler \& Neuweiler, 1959) in the lower part and by Cristacythere crassireticulata n. sp. in the upper part (cf. tables 3 and 5). As accessory species which also occur in the $O$. aspinata Zone are to be mentioned:

Polycope minor n. sp.

Nanacythere (Goniocythere) circumcostata n. sp.

Pseudomacrocypris subtriangularis $\mathrm{n} . \mathrm{sp}$.

Furthermore two species must be mentioned which are introduced in this zone, but which also occur in the overlying $O$. danica Zone:

Cytheropteron? cavatum $\mathrm{n} . \mathrm{sp}$.

Acrocythere gassumensis n. sp. 


\begin{tabular}{|c|c|c|c|c|c|c|c|c|c|c|c|c|c|c|c|c|c|c|c|c|}
\hline \multicolumn{21}{|c|}{ Oresund No. 10} \\
\hline Ostracod zone & $\begin{array}{l}\text { Core } \\
\text { interval } \\
\text { Depth } \\
\text { below rotary } \\
\text { table }\end{array}$ & 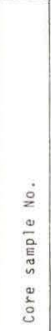 & 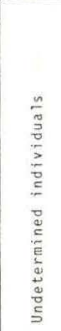 & 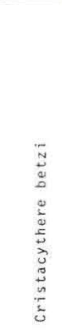 & 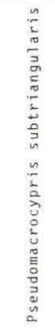 & 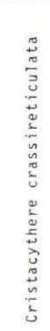 & 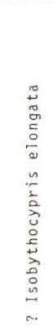 & 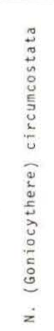 & 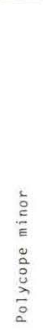 & 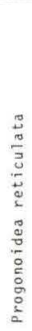 & 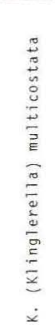 & 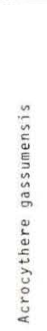 & $\begin{array}{l}\bar{a} \\
0 \\
\circ \\
\dot{0} \\
\vdots \\
- \\
\vdots \\
\vdots \\
\vdots \\
\vdots \\
0 \\
0 \\
\vdots \\
\vdots \\
0\end{array}$ & 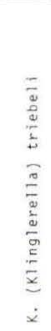 & 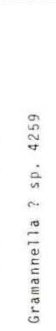 & 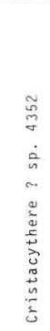 & 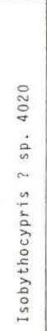 & 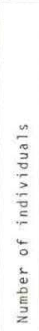 & 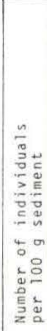 & 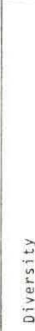 \\
\hline \multirow{6}{*}{$\begin{array}{l}\text { 0. danica } \\
\text { zone }\end{array}$} & $51.50-52.80 \mathrm{~m}$ & 1168 & 100.0 & . & . & . & . & . & . & . & . & . & . & . & . & . & . & 1 & 1 & - \\
\hline & $56.10-57.30 \mathrm{~m}$ & 1175 & 100.0 & . & . & . & . & . & . & . & . & . & . & . & . & . & . & 1 & 1 & - \\
\hline & $60.00-61.45 \mathrm{~m}$ & 1180 & 53.8 & . & . & . & . & . & . & . & . & 3.8 & . & 7.7 & 15.4 & 15.4 & 3.8 & 26 & 18 & 20 \\
\hline & $61.45-62.80 \mathrm{~m}$ & 1182 & 50.0 & $?$ & . & . & . & . & . & . & . & . & . & 25.0 & 12.5 & . & . & 8 & 16 & 17 \\
\hline & $64.25-65.50 \mathrm{~m}$ & 1186 & 100.0 & . & . & . & . & . & . & . & . & . & . & . & . & . & . & 1 & 1 & - \\
\hline & \multicolumn{20}{|l|}{ Oresund No. 9} \\
\hline P. reticulata & $35.00-35.85 \mathrm{~m}$ & 1051 & 22.2 & . & 14.8 & . & . & 11.1 & . & $?$ & 25.9 & 3.7 & 3.7 & . & . & . & . & 27 & 85 & 19 \\
\hline \multirow{12}{*}{ 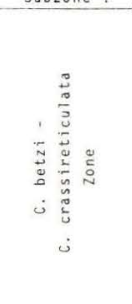 } & $36.80-38.10 \mathrm{~m}$ & 1055 & 13.3 & . & . & . & 80.0 & . & 6.7 & . & . & . & . & . & . & . & . & 15 & 9 & 85 \\
\hline & $36.80-38.10 \mathrm{~m}$ & 1057 & . & . & . & . & . & . & . & . & . & , & . & . & . & . & . & 0 & 0 & - \\
\hline & $39.60-40.76 \mathrm{~m}$ & 1060 & 0.0 & . & 83.3 & 16.7 & . & . & . & . & . & . & . & . & . & . & . & 6 & 5 & 67 \\
\hline & $44.75-46.00 \mathrm{~m}$ & 1067 & 33.3 & . & . & . & . & 66.7 & . & . & . & . & . & . & . & . & . & 9 & 10 & 100 \\
\hline & $46.00-47.50 \mathrm{~m}$ & 1071 & 0.0 & . & .1 & 100.0 & . & . & . & . & . & . & . & . & . & . & . & 1 & 12 & - \\
\hline & $47.50-50.00 \mathrm{~m}$ & 1075 & 66.7 & 33.3 & . & . & . & . & . & . & . & . & . & . & . & . & . & 3 & 6 & - \\
\hline & $47.50-50.00 \mathrm{~m}$ & 1076 & 14.5 & 3.2 & . & . & 82.3 & . & . & . & . & . & . & . & . & . & . & 62 & 28 & 93 \\
\hline & $50.60-53.35 \mathrm{~m}$ & 1080 & . & . & . & . & . & . & . & . & . & . & . & . & . & . & . & 0 & 0 & - \\
\hline & \multicolumn{20}{|l|}{ Oresund No. 8} \\
\hline & $26.00-27.25 \mathrm{~m}$ & 922 & 62.5 & . & 33.3 & 4.2 & . & . & . & . & . & . & , & . & . & . & . & 24 & 9 & 78 \\
\hline & $32.20-33.65 \mathrm{~m}$ & 938 & 0.0 & 38.9 & 61.1 & . & & . & . & . & . & . & . & . & . & . & . & 18 & 14 & 50 \\
\hline & $38.90-40.30 \mathrm{~m}$ & 951 & 0.0 & 100.0 & . & . & . & . & & . & . & . & & . & . & . & . & 6 & 39 & 100 \\
\hline
\end{tabular}

Table 5. The C. betzi - C. crassireticulata Zone and the $O$. danica Zone in three $\emptyset$ resund sections. Composition of the ostracod fauna expressed as relative percentages.

The present zone is furthermore recorded from the Øresund Nos. 8, 9 and 14 borings. The same relative occurrence of the two index fossils is found both in the Gassum section and in the Øresund sections. The fauna in Gassum is poor in the number of species. Of the accessory species mentioned above, only $N$. (G.) circumcostata and $C$. ? cavatum are found. The faunas in the Øresund sections are richer in the number of species and, to a certain extent, also in the number of specimens. The differences between the faunal composition in the two regions may be due to different environmental conditions (cf. p. 91).

All species mentioned, except for C. betzi (Klingler \& Neuweiler, 1959), are described in the present paper as new species. As seen in text-fig. 2 the fauna comprises more species, but none of these have a stratigraphical range sufficiently well-defined for stratigraphical correlations.

C. betzi is only known from German deposits and it there has the stratigraphical range: upper part of Lower Sinemurian to lower part of Upper Sinemurian. 
No megafossils are recorded from the sedimentary sequence of the $C$. betzi - C. crassireticulata Zone within the Danish Embayment. The only useful stratigraphical indication is the fact that the overlying $P$. reticulata Subzone must be referred to the lowermost Upper Sinemurian (Lias Beta-1a, the $P$. capricornoides Subzone). The inference, that the section with the $C$. betzi - C. crassireticulata Zone must be referred to the uppermost part of Lower Sinemurian, does not conflict with the stratigraphical range of $C$. betzi. This stratigraphical evaluation of the zone is furthermore supported by the assumption that the $O$. aspinata Zone does not correlate with the uppermost part of Lower Sinemurian.

\section{Ogmoconchella danica Zone}

The zone is defined in the Gassum No. 1 boring as the sedimentary series embraced by the core interval $4265^{\prime}-4570^{\prime}$. The faunas are characterized and often dominated by

Ogmoconchella danica n. sp.

"Ogmoconchella mouhersensis" (Apostolescu, 1959)

$O$. danica may also occur above the zone, so the upper boundary of the $O$. danica Zone is defined by the uppermost occurrence of species characteristic for the $G$. apostolescui $-K$. (K.) foveolata Subzone: Kinkelinella (Klinglerella) foveolata n. sp., Gramannella apostolescui (Gramann,1962), G. laevigata n. sp., and Monoceratina amlingstadtensis Triebel \& Bartenstein, 1938 (cf. p. 34).

The character of the fauna changes within the zone; the association of species may yield the basis for a more detailed stratification than described below; the number of species and of specimens varies considerably. The zone is here subdivided into three subzones, and the zone will be described in these three parts.

Of the three subzones, only the lower and the upper ones are formally named. The fauna is described below and the stratigraphical conditions within each of the subzones are outlined.

The $O$. danica Zone is furthermore recorded from the Børglum No. 1, Fjerritslev No. 2, Frederikshavn City No. 2, Øresund Nos. 9, 10, 11, 12, 14 and 15 borings.

The Progonoidea reticulata Subzone embraces the lowermost part of the $O$. danica Zone. It is defined in the Gassum No. 1 boring as the core interval $4550^{\prime}-4570^{\prime}$ (see text-fig. 15). The fauna is characterized and dominated by 
Ogmoconchella danica n. sp.

Progonoidea reticulata (Klingler \& Neuweiler, 1959)

It comprises the following important accessory species:

Kinkelinella (Klinglerella) laqueata (Klingler \& Neuweiler, 1959)

Kinkelinella (Klinglerella) triebeli (Klingler \& Neuweiler, 1959)

Polycope minor n. sp.

Cytheropteron? cavatum n. sp.

Acrocythere gassumensis n. sp.

Acrocythere rectangula $\mathrm{n}$. sp.

Isobythocypris spp.

The $P$. reticulata Subzone is furthermore recorded from the Fjerritslev No. 2, Øresund Nos. 9, 10 and 14 borings (text-figs. 9 and 21).

Neither the upper nor the lower boundary can be located in the Gassum section as the subzone comprises the entire sedimentary series present in the core 4550'-4570' (table 7). The sedimentary sequence in Gassum is preferred as the type section, however, since the recorded fauna is wellpreserved, and also because the faunal succession found in the core below, the core in question, and the core above shows biostratigraphical conditions known from North Germany.

The section from Øresund No. 9 comprises only the lowermost part of the subzone, whereas the entire subzone is present in Øresund No. 14 (tables 5 and 6). In the section from the latter boring the lower boundary of the subzone is located between the core 69.95-70.60 m, containing Cristacythere crassireticulata n. sp. and the core $67.70-69.15 \mathrm{~m}$, containing $P$. reticulata. The upper boundary of the subzone, which is supposed to be determined by the uppermost occurrence of $P$. reticulata, is less distinct in Øresund No. 14. In this boring the boundary is placed between the core $39.20-40.40 \mathrm{~m}$, containing a differing form of $P$. reticulata, and the core 34.55-35.80 m, with the species Kinkelinella (Klinglerella) multicostata (Klingler \& Neuweiler, 1959) and $K$. (Klinglerella) bipartita (Klingler \& Neuweiler, 1959). The two latter species are characteristic elements lowermost in the overlying subzone, but they may also occur in the present subzone. The upper boundary of the $P$. reticulata Subzone in Øresund No. 10 is based on the uppermost occurrence of typical forms of the index fossil.

One core, 2000-2004 m, from Fjerritslev No. 2 contains a fauna belonging to this subzone. The composition of the fauna is typical (cf. table 8 and text-fig. 9). 


\begin{tabular}{|c|c|c|c|c|c|c|c|c|c|c|c|c|c|c|c|c|c|c|c|c|c|c|c|c|}
\hline \multicolumn{25}{|c|}{ Oresund No.11 } \\
\hline \multicolumn{2}{|c|}{$\begin{array}{c}\text { Ostracod } \\
\text { zone }\end{array}$} & $\begin{array}{l}\text { Core } \\
\text { interval } \\
\text { Depth } \\
\text { below rotary } \\
\text { table }\end{array}$ & 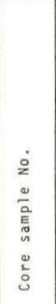 & 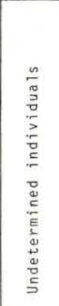 & $\begin{array}{l}0 \\
0 \\
0 \\
3 \\
0 \\
0 \\
0 \\
0 \\
0 \\
0 \\
0 \\
0 \\
0 \\
0 \\
0 \\
0 \\
0 \\
\vdots \\
0\end{array}$ & 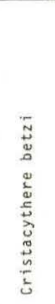 & 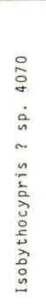 & 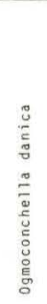 & 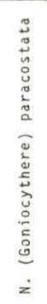 & 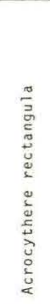 & 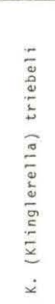 & 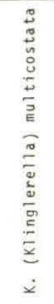 & 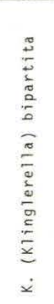 & 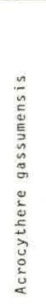 & 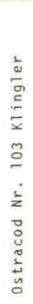 & 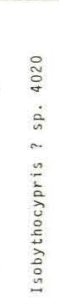 & 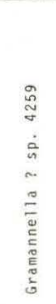 & 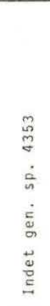 & 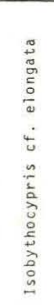 & 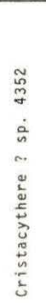 & 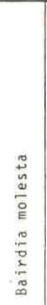 & 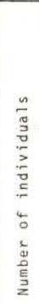 & 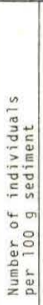 & $\begin{array}{l}\frac{\hat{t}}{n} \\
\frac{n}{\omega} \\
\frac{\Delta}{a}\end{array}$ \\
\hline \multirow{20}{*}{ 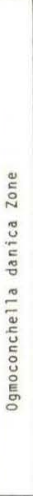 } & \multirow{21}{*}{ 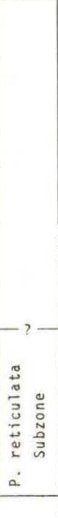 } & $66.40-69.40 \mathrm{~m}$ & 1292 & 100.0 & . & . & . & . & . & . & . & . & . & . & . & . & . & . & . & . & . & 4 & 5 & - \\
\hline & & $72.10-75.00 \mathrm{~m}$ & 1308 & 100.0 & . & . & . & . & . & . & . & . & . & . & . & . & . & . & . & . & . & 10 & 9 & - \\
\hline & & $76.25-79.15 \mathrm{~m}$ & 1318 & . & . & . & . & . & & . & . & . & . & . & . & . & . & . & . & . & . & 0 & 0 & - \\
\hline & & $82.15-85.05 \mathrm{~m}$ & 1328 & . & . & . & . & . & . & . & . & . & . & . & . & . & . & . & . & . & . & 0 & 0 & - \\
\hline & & $102.95-105.55 \mathrm{~m}$ & 1360 & 20.0 & . & . & . & . & . & . & . & . & 80.0 & . & . & . & . & . & . & . & . & 5 & 5 & 100 \\
\hline & & $108.20-110.45 \mathrm{~m}$ & 1365 & 42.9 & . & . & . & 2.9 & . & . & . & . & 22.9 & . & . & . & 11.4 & 8.6 & . & 2.9 & 8.6 & 35 & 16 & 21 \\
\hline & & $108.20-110.45 \mathrm{~m}$ & 1367 & 37.5 & . & . & . & . & . & . & 25.0 & . & & . & . & . & . & 37.5 & . & . &. & 8 & 7 & 40 \\
\hline & & $110.45-113.35 \mathrm{~m}$ & 1369 & 28.6 & . & . & . & . & . & . & . & . & 28.6 & . & . & . & 14.3 & 14.3 & 14.3 & . & . & 7 & 3 & 10 \\
\hline & & $113.35-115.80 \mathrm{~m}$ & 1374 & 0.0 & . & . & . & . & . & . & . & . & . & . & . & 100.0 & . & . & . & . & . & 3 & 3 & 100 \\
\hline & & \multicolumn{23}{|l|}{ Oresund No.14 } \\
\hline & & $29.60-30.40 \mathrm{~m}$ & 1678 & . & . & . & . & . & . & . & . & . & . & . & . & . & . & . & . & . & . & 0 & 0 & - \\
\hline & & $31.35-31.75 \mathrm{~m}$ & 1681 & . & . & . & . & . & - & . & . & . & . & . & & . & . & . & . & . & . & 0 & 0 & - \\
\hline & & $34.55-35.80 \mathrm{~m}$ & 1691 & 9.1 & . & . & . & 53.5 & . & 11.1 & 1.0 & 21.2 & 2.0 & 1.0 & $?$ & . & . & . & . & . & . & 99 & 33 & 41 \\
\hline & & $39.20-40.40 \mathrm{~m}$ & 1702 & 0.0 & $?$ & . & . & . & . & . & . & . & 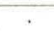 & . & . & . & . & . & . & . & . & 1 & (1) & - \\
\hline & & $44.30-45.70 \mathrm{~m}$ & 1720 & 0.0 & . & . & . & . & . & $\cdot 1$ & 100.0 & . & . & . & & . & . & & . & . & . & 7 & 5 & 100 \\
\hline & & $46.65-47.45 \mathrm{~m}$ & 1727 & 25.0 & . & . & . & . & 50.0 & 25.0 & . & . & . & . & . & . & . & . & . & . & . & 4 & 2 & 33 \\
\hline & & $47.45-48.80 \mathrm{~m}$ & 1730 & . & . & . & . & . & . & . & . & . & . & . & . & . & . & . & . & . & . & 0 & 0 & - \\
\hline & & $52.25-53.70 \mathrm{~m}$ & 1747 & 20.0 & . & 80.0 & . & . & . & . & . & . & . & . & . & . & . & . & . & . & . & 5 & 8 & 100 \\
\hline & & $57.40-58.60 \mathrm{~m}$ & 1761 & 4.0 & . & 4.0 & 4.0 & 88.0 & . & . & . & . & . & . & . & . & . & . & . & . & . & 25 & 39 & 84 \\
\hline & & $67.70-69.15 \mathrm{~m}$ & 1795 & 16.7 & 83.3 & . & . & . & . & . & . & . & . & . & . & . & . & . & . & . & . & 6 & 20 & 100 \\
\hline & & $71.90-73.30 \mathrm{~m}$ & 1806 &. & . & . & . & . & . & . & . & . & . & . & . & . & . & . & . & . & . & 0 & 0 & - \\
\hline
\end{tabular}

Table 6. The $O$. danica Zone in two Øresund sections. Composition of the ostracod fauna expressed as relative percentages.

For an evaluation of the affinities of the fauna and a possible stratigraphical correlation of the zone only four species can be emphasized. In Germany $P$. reticulata is restricted to the $P$. capricornoides Subzone, whereas the species $K$. (Klinglerella) laqueata and $K$. (K.) multicostata occur for the first time in the overlying $P$. planicosta Subzone. $K$. (K.) triebeli is known from each of the mentioned ammonite subzones (Klingler \& Neuweiler, 1959).

The other species occurring in the $P$. reticulata Subzone are mainly new species described in the present paper. They are important accessory species for the local correlation within the Danish Embayment.

The simultaneous occurrence of the species P. reticulata, K. (K.) multicostata and $K$. (K.) laqueata can not be directly correlated with any known ostracod assemblage. Within the Danish Embayment $K$. (K.) multicostata has only been recorded from one sample, belonging to the subzone in Øresund No. 9; and $K$. (K.) laqueata only from the Gassum section. It may therefore be supposed that the occurrence of the two species together with $P$. reticulata, not previously recorded, indicates an earlier appearance of these two species. On the other hand, it may be due to a local ecological 


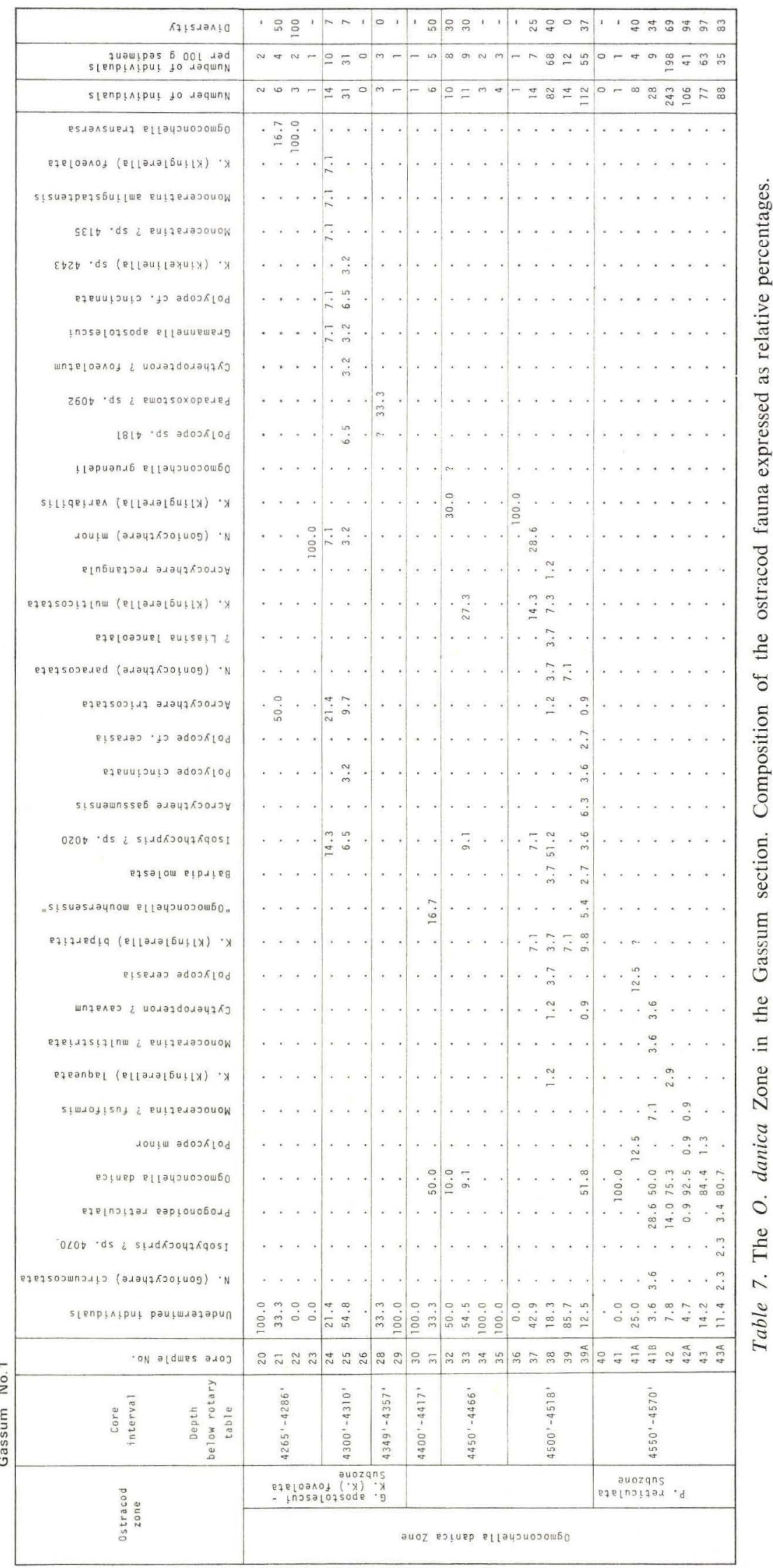




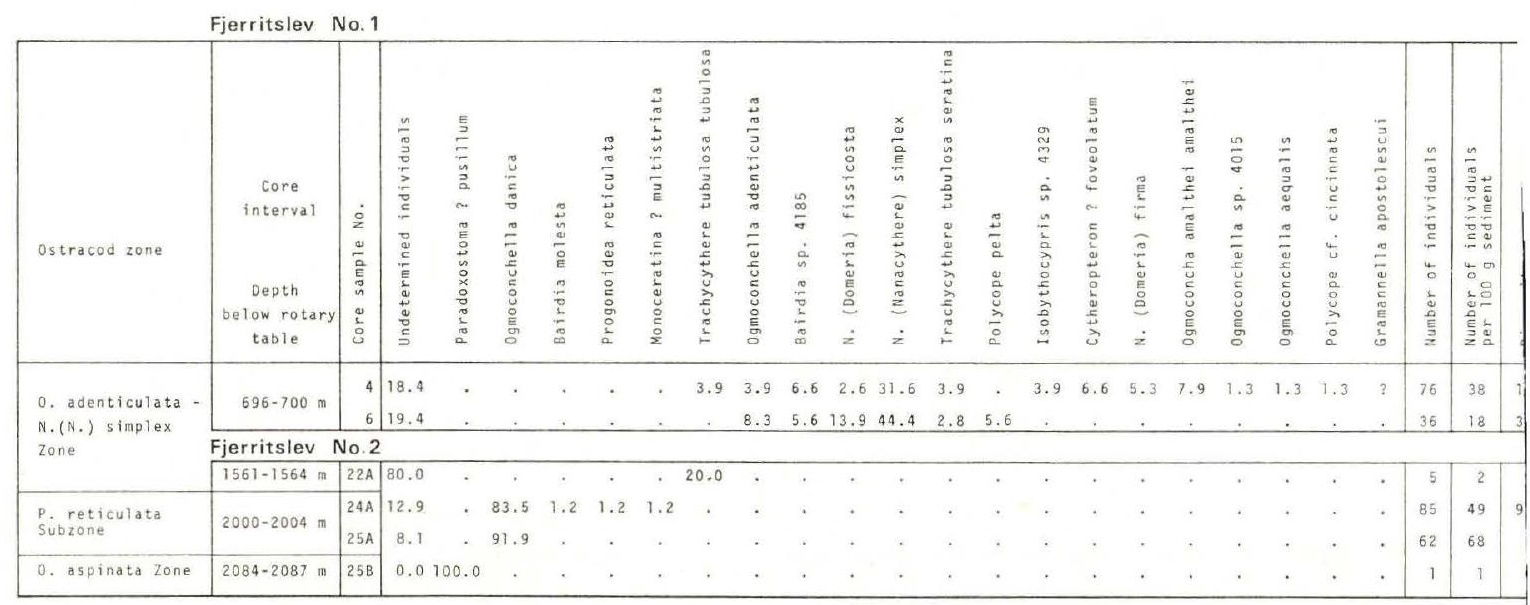

Table 8. The $O$. aspinata Zone, the $P$. reticulata Subzone and the $O$. adenticulata $-N$. (N.) simplex Zone in the two Fjerritslev sections. Composition of the ostracod fauna expressed as relative percentages.

condition. The co-occurrence of $P$. reticulata and $K$. (K.) triebeli is wellknown from the P. capricornoides Subzone in Germany. As the first-named ostracod species has never been found outside this ammonite subzone, the $P$. reticulata Subzone is considered to correlate with the lowermost Upper Sinemurian, with Lias Beta-1a. This determination is supported by the fact that $P$. planicosta is found just above the subzone in Gassum, in the core $4500^{\prime}-4518^{\prime}$, and by the general development of the ostracod fauna in the Gassum section.

The middle subzone of the $O$. danica Zone is only found complete in the Gassum section. It is recorded from the cores $4500^{\prime}-4518^{\prime}, 4450^{\prime}-4466^{\prime}$ and $4400^{\prime}-4417^{\prime}$. The fauna is characterized by the species:

Ogmoconchella danica n. sp.

"Ogmoconchella mouhersensis" (Apostolescu, 1959)

The following of the accessory species must be emphasized as important for the stratigraphical correlation:

Kinkelinella (Klinglerella) glabellata (Klingler \& Neuweiler, 1959)

Kinkelinella (Klinglerella) multicostata (Klingler \& Neuweiler, 1959)

Kinkelinella (Klinglerella) triebeli (Klingler \& Neuweiler, 1959)

Kinkelinella (Klinglerella) sulcata (Klingler \& Neuweiler, 1959)

Kinkelinella (Klinglerella) variabilis (Klingler \& Neuweiler, 1959) 
Kinkelinella (Klinglerella) bipartita (Klingler \& Neuweiler, 1959)

Acrocythere gassumensis n. sp.

Acrocythere oeresundensis n. sp.

The middle subzone of the $O$. danica Zone is furthermore present in the Øresund Nos. 10, 11, 12, 14 and 15 borings.

The lowermost core, $4500^{\prime}-4518^{\prime}$, in the Gassum section contains a fauna characterized by $K$. (K.) glabellata, $K$. (K.) multicostata, $K$. (K.) triebeli and $K$. (K.) variabilis. Only parts of this assemblage are recorded from the sequence overlaying the $P$. reticulata Subzone in Øresund Nos. 10, 11 and 14, but correlation with the core mentioned from Gassum cannot be doubted (see tables 5-7 and text-figs. 15 and 21). The species found associated in the core taken in Gassum are known from and are characteristic for the fauna in the P. planicosta Subzone in Germany (cf. Klingler \& Neuweiler, 1959); thus this part of the middle subzone is considered to correlate with the lower part of Upper Sinemurian, with Lias Beta-1b. This determination is supported by the occurrence of the index fossil $P$. planicosta in the Gassum core 4500'-4518' (cf. Nørvang, 1957).

The middle core, 4450'-4466', in the Gassum section contains an ostracod fauna poorer in species than the underlying one. The fauna is characterized by the species $K$. (K.) sulcata, $K$. (K.) multicostata and $K$. (K.) variabilis, which is a typical association of species in the faunas known from the O. oxynotum Zone in Germany (cf. Klingler \& Neuweiler, 1959). Corresponding ostracod faunas have not been recorded from any other core sections within the Danish Embayment. The middle, variegated part of the Pankarp Formation is supposed to correspond to the present interval of the middle subzone. A stratigraphical determination of the mentioned section in Gassum No. 1 may be made solely by means of the ostracod fauna, which indicates a determination to the middle of Upper Sinemurian, to Lias Beta-2.

The upper core, 4400'-4417', in the Gassum section contains an impoverished fauna, which contains only the species $O$. danica, "O. mouhersensis" and $K$. $(K$.$) variabilis. These together with a few other species are$ found in the Øresund Nos. 12 and 15 borings in the beds just below the $G$. apostolescui - K. (K.) foveolata Subzone, described below. In the Øresund sections the boundary between the middle subzone and the upper one of the $O$. danica Zone is placed between the occurrence of $K$. $(K$.) variabilis and Gramannella apostolescui (Gramann, 1962). The stratigraphical determination of this uppermost part of the middle subzone in the $O$. danica Zone can hardly be made with certainty on the basis of the ostracod fauna. This uppermost part of the middle subzone is assumed to cor- 
respond to the uppermost Upper Sinemurian, since $K$. $(K$.) variabilis has never been found above the E. raricostatum Zone and since, in this ammonite zone, it has not been found associated with any of the species mentioned as characteristic for the underlying parts of the middle subzone. This tentative correlation is supported by the more certain biostratigraphical indications which are the basis for the correlation of the overlying $G$. apostolescui - K. (K.) foveolata Subzone with the Lower Pliensbachian. The Sinemurian-Pliensbachian boundary in the Danish Embayment is considered to be placed between the middle and the upper subzone of the $O$. danica Zone, e.g. between the occurrence of $K$. (K.) variabilis below the boundary and G. apostolescui above it. Progonoidea acuticostata (Klingler \& Neuweiler, 1959) is used as a substitute for $K$. (K.) variabilis in series where the latter not is found.

The Gramannella apostolescui - Kinkelinella (Klinglerella) foveolata Sub. zone, which is the upper one of the three subzones embraced by the

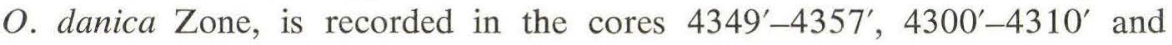
$4265^{\prime}-4286^{\prime}$ from the Gassum section. As the fauna is very well-developed and well-preserved in the Øresund No. 12 boring, the assemblage is defined in this latter boring, and the lower boundary of the subzone is placed $15-20 \mathrm{~cm}$ below the top of the core $63.40-66.05 \mathrm{~m}$.

The fauna is characterized and dominated by the following species:

Kinkelinella (Klinglerella) foveolata $\mathrm{n} . \mathrm{sp}$.

Gramannella apostolescui (Gramann, 1962)

Gramannella laevigata $\mathrm{n}$. sp.

Ogmoconchella danica n. sp.

"Ogmoconchella mouhersensis" (Apostolescu, 1959)

Pleurifera harpa (Klingler \& Neuweiler, 1959)

Nanacythere (Goniocythere) minor n. sp.

Except for G. apostolescui, P. harpa and "O. mouhersensis", all of these species are new and described in the present paper. Their occurrence has shown itself to be important for correlation within the Danish Embayment, where they are a common and constant part of the assemblage (cf. table 9).

As more rare, but useful for an evaluation of the stratigraphical subdivision, the following species must be emphasized:

Monoceratina amlingstadtensis Triebel \& Bartenstein, 1938

Nanacythere? bachi (Gramann, 1962) 
Trachycythere horrida Triebel \& Klingler, 1959

Isobythocypris unispinata Apostolescu, 1959

These four species together with $P$. harpa and $G$. apostolescui are known from other parts of the Northwest European basins.

Finally some species must be mentioned which are a pronounced part of the fauna, but which are less important for an accurate stratigraphical determination of the sedimentary sequences:

Ogmoconcha amalthei amalthei (Quenstedt, 1858)

Ogmoconchella transversa (Gründel, 1970)

Ogmoconchella bispinosa (Gründel, 1964)

Gramannella cf. tatei (Gramann, 1962)

Acrocythere tricostata n. sp.

This subzone is recorded from the Børglum No. 1, Frederikshavn City No. 2, Gassum No. 1, and Øresund Nos. 12 and 15 borings.

In the Øresund sections the lower boundary is well-defined (cf. p. 34), whereas the upper boundary is not present. In each of the borings Børglum No. 1 and Frederikshavn City No. 2 the subzone is represented in one core (text-figs. 5 and 3). The core from Børglum No. 1 contains a rich fauna characteristic for the subzone (cf. table 10).

The three cores from Gassum No. 1 show a varying content of ostracods (see text-fig. 15 and table 7). The poor fauna in the lowermost core, $4349^{\prime}-4357^{\prime}$, comprises $P$. harpa, which is the oldest record of this species in the section (see text-fig. 15). A corresponding occurrence of the species is observed in the Øresund sections. The middle core, 4300'$4310^{\prime}$, contains a typical fauna for the subzone, whereas the uppermost core, 4265'-4286', includes a poor fauna in which the only important species is $M$. amlingstadtensis (see text-fig. 15). As none of the remaining species recorded from this last-named core indicate relationship of the assemblage to the overlying zone, it has been decided to include the core under the $G$. apostolescui $-K$. (K.) foveolata Subzone.

It is not possible to point out any fauna outside the Danish Embayment to which the $G$. apostolescui - K. (K.) foveolata fauna shows affinities. The reason is that no fauna which corresponds in its entirety has been described, but only selected species and genera. From France descriptions are known of faunas from the entire Lower Jurassic sequence (Viaud, 1963), but the composition of these differs so much from the fauna in question that there are few species in common. 


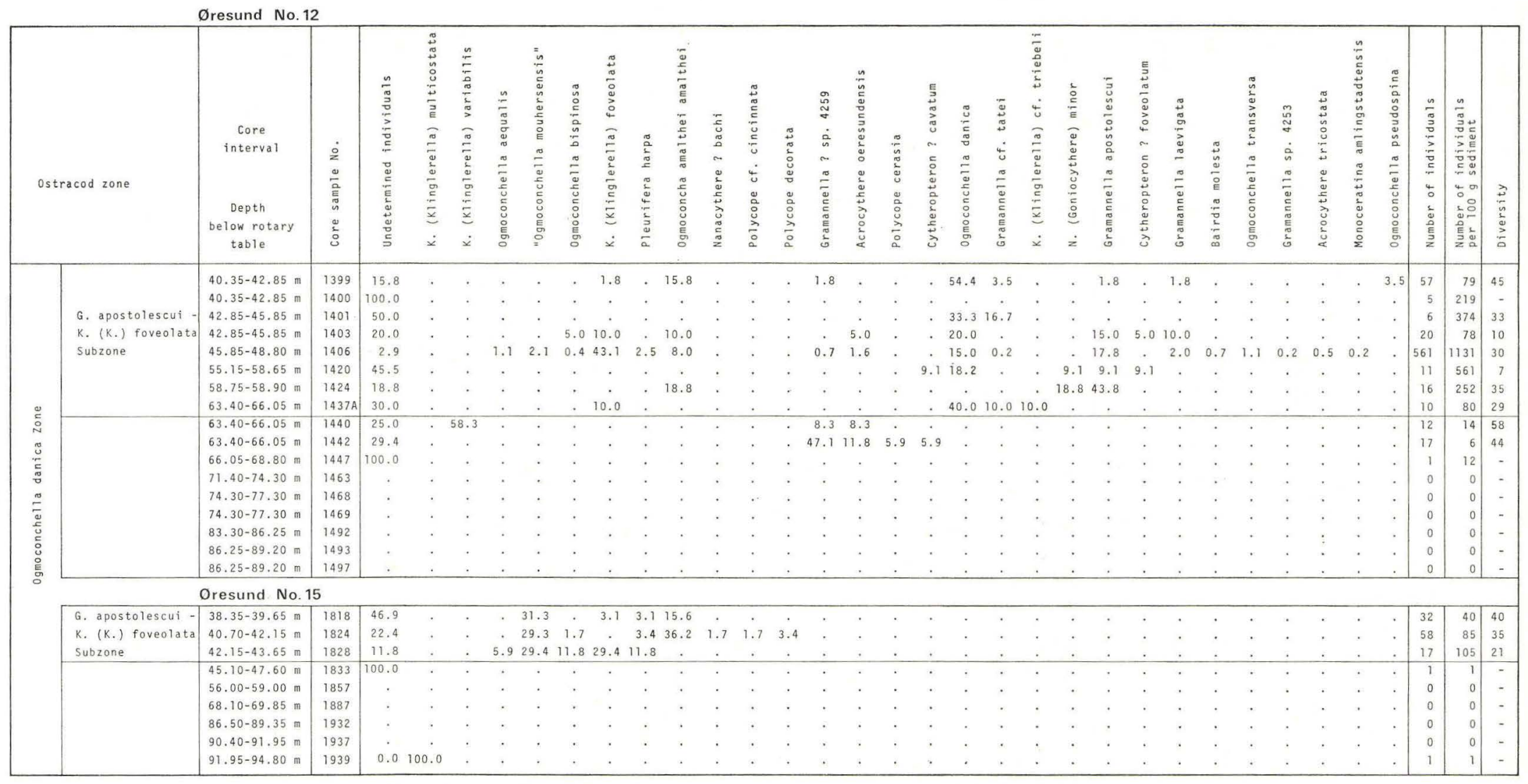

Table 9. The $O$. danica Zone in two Øresund sections. Composition of the ostracod fauna expressed as relative percentages. 


\begin{tabular}{|c|c|c|c|c|c|c|c|c|c|c|c|c|c|c|c|c|c|c|c|c|c|c|c|c|c|c|}
\hline & rglum No & & & & & & & & & & & & & & & & & & & & & & & & & \\
\hline \multirow[t]{2}{*}{ Ostracod zone } & $\begin{array}{c}\text { Core } \\
\text { interval } \\
\text { Depth } \\
\text { below rotary } \\
\text { table }\end{array}$ & 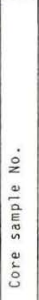 & 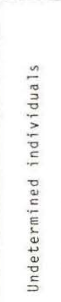 & $\begin{array}{l}\frac{0}{n} \\
\stackrel{5}{0} \\
\stackrel{E}{E} \\
\frac{0}{0} \\
\vdots \\
0 \\
0\end{array}$ & 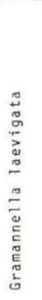 & 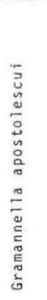 & 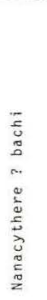 & 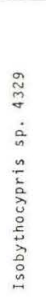 & 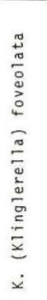 & 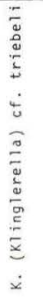 & 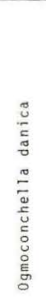 & 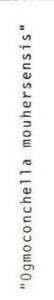 & 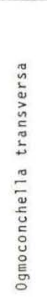 & 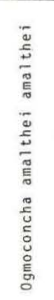 & 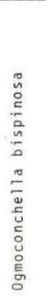 & 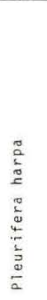 & 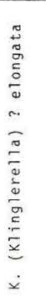 & 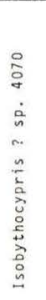 & $\begin{array}{l}\frac{\bar{\sigma}}{\sigma} \\
\dot{\vdots} \\
\vdots \\
\vdots \\
\vdots \\
\vdots \\
\vdots\end{array}$ & 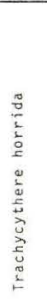 & $\begin{array}{l}0 \\
\vdots \\
u \\
0 \\
0 \\
\vdots \\
0 \\
\vdots \\
0 \\
0 \\
0 \\
0 \\
0 \\
0 \\
0 \\
0 \\
0 \\
E \\
0 \\
0\end{array}$ & 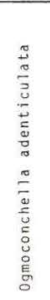 & 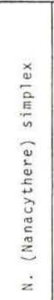 & 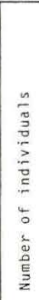 & 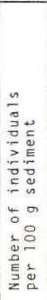 & $\begin{array}{l}\frac{2}{n} \\
\frac{\Delta}{0} \\
\frac{a}{0}\end{array}$ \\
\hline & $3874^{\prime}-3884^{\prime}$ & 12 & . & . & . & . & . & . & . & . & . & . & . & . & . & . & . & . & . & . & . & . & . & 0 & 0 & - \\
\hline $\begin{array}{l}\text { adenticulata - } \\
\text { (N.) simplex zone }\end{array}$ & $4095^{\prime}-4105^{\prime}$ & 13 & 22.2 & $\cdot$ & • & . & · & . & - & · & . & . & . & 11.1 & . & . & . & . & . & . & 14.8 & 11.1 & 40.7 & 27 & 16 & 32 \\
\hline \multirow{5}{*}{$\begin{array}{l}\text { apostolescui - } \\
\text { ( } k \text {.) foveolata } \\
\text { ubzone }\end{array}$} & $4294^{\prime}-4314^{\prime}$ & 14 & 14.9 & 0.8 & . & 1.8 & 5.7 & 1.8 & 4.6 & . & 20.3 & 21.3 & 1.3 & 21.3 & 0.3 & 0.8 & 3.9 & 0.8 & 0.3 & 0.3 & . & . & . & 389 & 266 & 19 \\
\hline & & $15 \mathrm{~A}$ & 17.7 & 0.9 & 0.9 & 0.9 & 0.9 & 0.9 & 4.4 & 2.7 & 4.4 & 50.4 & 1.8 & 14.2 & . & . & . & . & . & . & . & . & . & 113 & 140 & 41 \\
\hline & & 16 & $\cdot$ & . & . & . & . & . & . & . & . & . & . & . & . & . & . & . & . & . & . & . & . & 0 & 0 & - \\
\hline & $4494^{\prime}-4513^{\prime}$ & 17 & . & . & . & . & . & . & . & . & . & . & . & . & . & . & . & . & . & . & . & . & . & 0 & 0 & - \\
\hline & & 18 & 100.0 & . & . & . & . & . & . & . & . & . & . & . & . & . & . & . & . & . & . & . & . & 3 & 3 & - \\
\hline
\end{tabular}

Table 10. The G. apostolescui - K. (K.) foveolata Subzone and the O. adenticulata - N. (N.) simplex Zone in the Børglum section. Composition of the ostracod fauna expressed as relative percentages.

The stratigraphical range of $G$. apostolescui embraces the interval about the Lower-Upper Pliensbachian boundary (Lord, 1972a). The co-occurrence of this species with $M$. amlingstadtensis, $N$. ? bachi and $T$. horrida restricts the possibilities for a stratigraphical determination to the Lower Pliensbachian. The occurrence of $P$. harpa and I. unispinata does not conflict with a correlation with the Lower Pliensbachian as these species are known from this substage and from the underlying Upper Sinemurian. The three species $O$. amalthei amalthei, $O$. bispinosa and $O$. transversa have a larger stratigraphical range including Lower Pliensbachian. The argument for the stratigraphical determination of the $G$. apostolescui $-K$. (K.) foveolata Subzone may be weakened to some extent because the species $M$. amlingstadtensis, $N$. .? bachi and $T$. horrida are hitherto only known from a few localities, so further investigation may possibly show a larger stratigraphical range. The varying range of $P$. harpa and G. apostolescui in different parts of the Northwest European basin is also important (cf. Lord, 1972a, Viaud, 1963 and Klingler \& Neuweiler, 1959).

Another aspect of the stratigraphical problem is that $P$. harpa and Kinkelinella (Klinglerella) variabilis in Germany are found together in the E. raricostatum Zone, whereas they in the Danish Embayment have never been recorded together. $K$. (K.) variabilis is here found in series underlying beds with a fauna including P. harpa, G. apostolescui, N.? bachi and M. amlingstadtensis. It is therefore resolved to place the Sinemurian-Pliensbachian boundary at the change in the ostracod fauna, and to refer the sedimentary series belonging to the $G$. apostolescui $-K$. (K.) foveolata 
Subzone to Lower Pliensbachian. The upper boundary of the subzone is not present in the Øresund sections; in the Gassum section it is weakly marked, as mentioned above. The uppermost core, 4265'-4286', in the Gassum section contains a rather poor fauna referrable to this subzone, and as Upper Pliensbachian biostratigraphical indications are recorded from the overlying core, the Lower-Upper Pliensbachian boundary is placed above the core $4265^{\prime}-4286^{\prime}$. The stratigraphical correlation of the $G$. apostolescui $-K$. $(K$.) foveolata Subzone with Lower Pliensbachian is supported by the occurrence of $A$. capricornus in the core $4300^{\prime}-4310^{\prime}$ in the Gassum section (cf. Nørvang, 1957).

The stratigraphical subdivision of the sedimentary sequence corresponding to the $O$. danica Zone can be outlined briefly as follows:

1) The lowermost subzone, the $P$. reticulata Subzone, is based on the ostracod fauna and on the faunal succession in the Gassum section referred to lowermost Upper Sinemurian, to Lias Beta-1a.

2) The middle subzone is based on the ostracod faunas referred to the overlying part of Upper Sinemurian, to Lias Beta-1b, Beta-2 and Beta-3. The lowermost part of the middle subzone can with certainty be referred to Lias Beta-1b on the basis of the ostracod fauna and the occurrence of $P$. planicosta.

3) The uppermost subzone, the $G$. apostolescui $-K$. (K.) foveolata Subzone, is based on the ostracod fauna referred to Lower Pliensbachian. The determination is supported by the occurrence of $A$. capricornus in the middle of the subzone.

\section{Ogmoconchella adenticulata - Nanacythere (Nanacythere) simplex Zone}

The zone is defined in the Gassum No. 1 boring as the sedimentary series represented in the core interval 3967'-4230' (cf. text-fig. 15 and table 11). The fauna is characterized by the species:

Ogmoconchella adenticulata (Pietrzenuk, 1961)

Nanacythere (Nanacythere) simplex Herrig, 1969

The most important accessory species are:

Ogmoconcha amalthei amalthei (Quenstedt, 1858)

Ogmoconcha contractula Triebel, 1941

Ogmoconchella pseudospina (Herrig, 1969)

Ogmoconchella transversa (Gründel, 1970) 
Ogmoconchella bispinosa (Gründel, 1964)

Ogmoconchella aequalis (Herrig, 1969)

Nanacythere (Domeria) firma Herrig, 1969

Nanacythere (Domeria) fissicosta Herrig, 1969

Trachycythere tubulosa tubulosa Triebel \& Klingler, 1959

Trachycythere tubulosa seratina Triebel \& Klingler, 1959

The zone is furthermore recorded from the Børglum No. 1, Fjerritslev Nos. 1 and 2, Flyvbjerg No. 1, Frederikshavn City No. 2, Haldager No. 1, Vedsted No. 1, and Øresund No. 3 borings.

In the Gassum section the zone can be divided into two subzones. This section is the only one which has the two subzones represented in the cores. A formal subdivision into subzones, therefore, does not seem reasonable, but the recognition of a corresponding subdivision in sections represented by cuttings samples justifies an outline and description of the two subzones.

The lower subzone is recorded from the cores 4222'-4230', 4184'-4194' and $4143^{\prime}-4150^{\prime}$ in the Gassum section. The fauna is characterized by the two index fossils $O$. adenticulata and $N$. (N.) simplex and by the following accessory species:

Ogmoconchella gruendeli Malz, 1971

Ogmoconchella transversa (Gründel, 1970)

Acrocythere tricostata n. sp.

The last-named species is new and is described in the present paper. It has proved to be an important species for stratigraphical correlation within the Danish Embayment. The other four species are all known from Germany, but there they have been described from restricted stratigraphical levels only. In the Danish Embayment the two index fossils are restricted to, and common in, the entire $O$. adenticulata $-N$. (N.) simplex Zone, whereas the three other species occur in, and are characteristic of, the lower subzone and the upper part of the underlying $O$. danica Zone. $O$. transversa is known in Germany from the upper part of the Lower Pliensbachian and the lower part of the Upper Pliensbachian, whereas $O$. gruendeli is known from the lower part of the Upper Pliensbachian only. The two index fossils, $O$. adenticulata and $N$. (N.) simplex, have so far only been described from beds referred to uppermost Upper Pliensbachian. A tentative correlation with the lower part of the Upper Pliensbachian is supported by the occurrence of the ammonite species A. margaritatus in the three cores mentioned and in the overlying core $4080^{\prime}-4092^{\prime}$ in the Gassum section. 


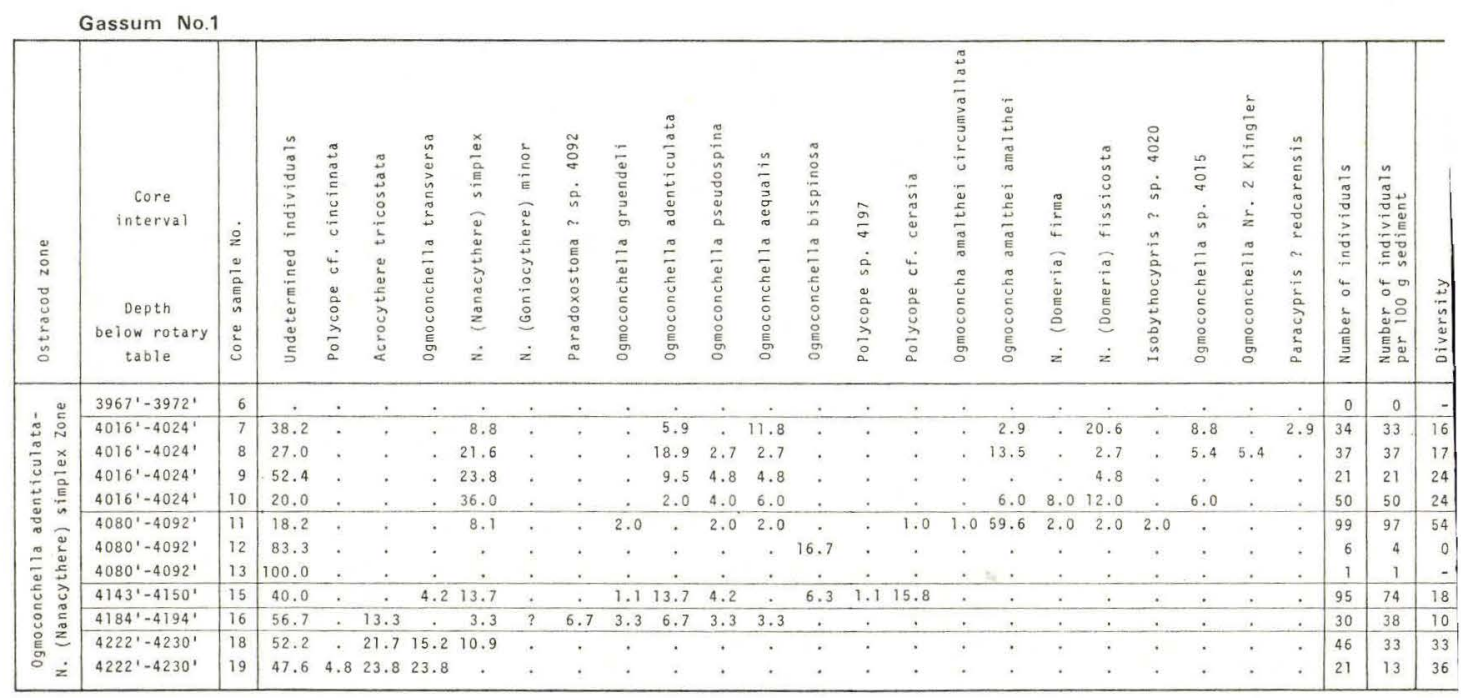

Table 11. The $O$. adenticulata - N. (N.) simplex Zone in the Gassum section. Composition of the ostracod fauna expressed as relative percentages.

The upper subzone is recorded from the cores 4080'-4092', 4016'-4024' and $3967^{\prime}-3972^{\prime}$ in the Gassum section. The fauna is characterized by the two index fossils $O$. adenticulata and $N$. (N.) simplex, and the following accessory species are the most important ones:

Nanacythere (Domeria) firma Herrig, 1969

Nanacythere (Domeria) fissicosta Herrig, 1969

Trachycythere tubulosa tubulosa Triebel \& Klingler, 1959

Cytheropteron? foveolatum n. sp. (not in the Gassum section)

The upper subzone is furthermore present in the Børglum No. 1, Fjerritslev Nos. 1 and 2, Haldager No. 1, Vedsted No. 1 and Øresund No. 3 borings.

In Germany T. tubulosa tubulosa is only known from the lower part of the Upper Pliensbachian; N. (D.) fissicosta from the entire substage; and $N$. (D.) firma from the upper part of the substage. The ostracod fauna can therefore only indicate a correlation with Upper Pliensbachian. In the Gassum section it is obvious that a correlation must be made with the upper part of the substage; but as it is the only locality containing a lower subzone in a section represented by cores, the stratigraphical indication is weak. However, the occurrence of the ammonite species $A$. margaritatus in the lowermost core, $4080^{\prime}-4092^{\prime}$, in the section, and of P. spinatum in 


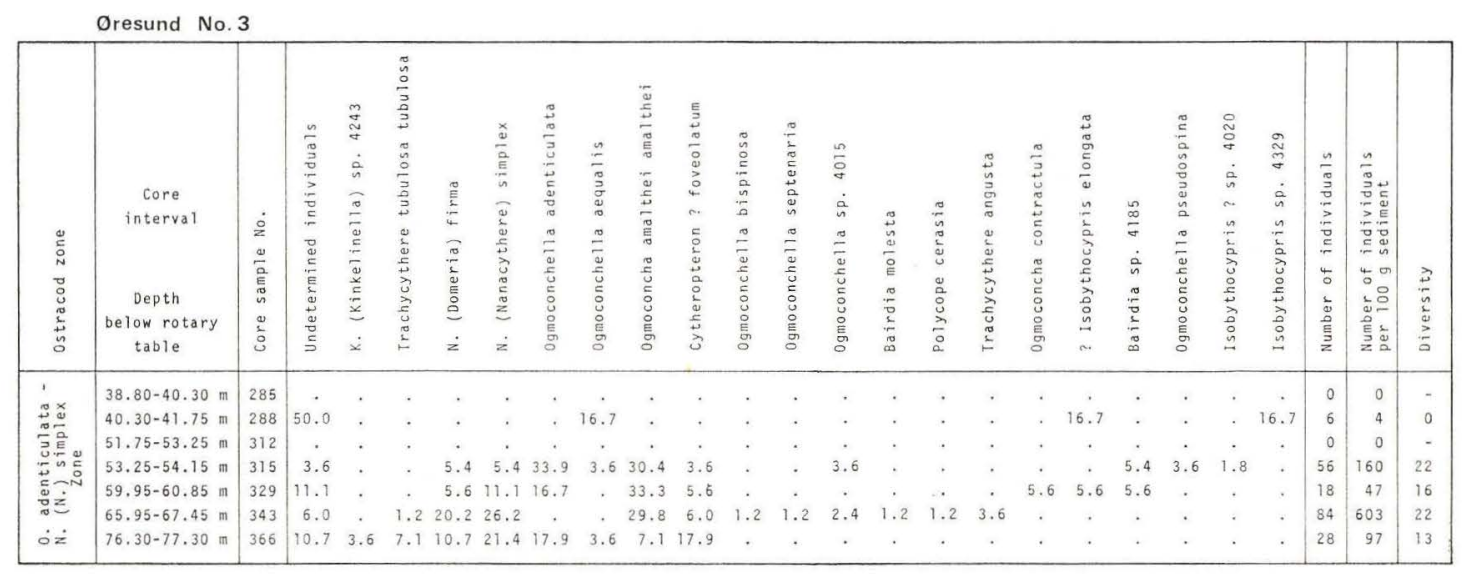

Table 12. The O. adenticulata $-N$. (N.) simplex Zone in an Øresund section. Composition of the ostracod fauna expressed as relative percentages.

the overlying core, $4016^{\prime}-4024^{\prime}$, is the basis for considering that the zone in Gassum must embrace both of the ammonite zones in the Upper Pliensbachian, and for regarding the two subzones of the $O$. adenticulata $-N$. (N.) simplex Zone as nearly corresponding to the two ammonite zones. The biostratigraphical conditions based on the cuttings samples in the sections where the cored interval only comprises the upper subzone make it obvious that a bipartition of the ostracod zone is reasonable.

Investigations of the sedimentary sequences represented by cuttings samples, especially from the Rønde No. 1 and Dansk Nords $\varnothing$ J-1 borings, support this bipartition. The Rønde section furthermore indicates an uppermost biostratigraphical unit which is not present in Gassum (cf. text-fig. 16). Unfortunately the two sections cannot be correlated precisely by means of the lithology since only an undifferentiated Gamma Ray log has been measured in Gassum (text-fig. 15). The fauna recorded from the uppermost part of the Rønde section is unusually poor in species, whereas the rich fauna characteristic of the upper subzone in Gassum is found in the middle of the $O$. adenticulata - N. (N.) simplex Zone in Rønde. When this is taken together with the fact that the mentioned ostracod zone is thicker in Rønde than in Gasum, a possible uppermost, third subzone may be supposed to occur. However, until more sections represented by cores are examined, the $O$. adenticulata $-N$. (N.) simplex Zone cannot be stated to be composed of three subzones.

The stratigraphical evidence of the faunas recorded from Flyvbjerg No. 1 and Frederikshavn City No. 2 differs from and conflicts with the outlined bipartition of the zone. The fauna from the core in Flyvbjerg includes 
Haldager No.1

\begin{tabular}{|c|c|c|c|c|c|c|c|c|c|c|c|c|c|c|c|c|c|c|c|c|c|c|c|c|c|c|c|c|c|c|c|}
\hline 0stracod zone & $\begin{array}{c}\text { Core } \\
\text { interval } \\
\\
\text { Depth } \\
\text { below rotary } \\
\text { table }\end{array}$ & 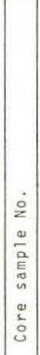 & 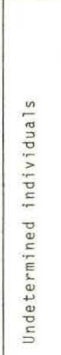 & 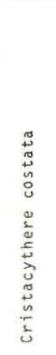 & 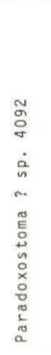 & 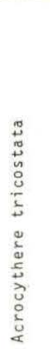 & 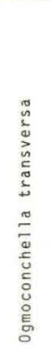 & 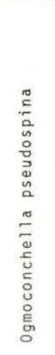 & 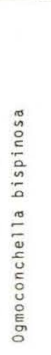 & 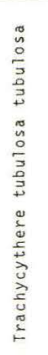 & 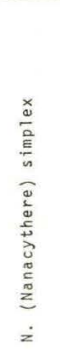 & 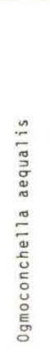 & 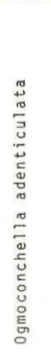 & 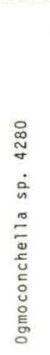 & 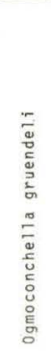 & 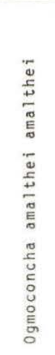 & 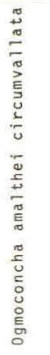 & 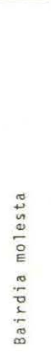 & 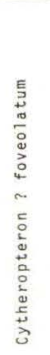 & 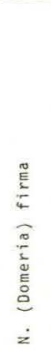 & $\begin{array}{l}\infty \\
\stackrel{\infty}{\sigma} \\
\dot{0} \\
i \\
\frac{\infty}{0} \\
\frac{2}{\sigma} \\
\infty\end{array}$ & $\begin{array}{l}\frac{0}{\vdots} \\
\vdots \\
\vdots \\
\vdots \\
\vdots \\
\vdots \\
\vdots \\
\vdots \\
\vdots \\
\vdots\end{array}$ & 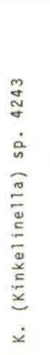 & 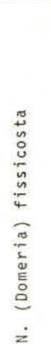 & 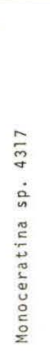 & 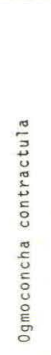 & 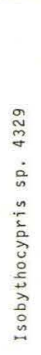 & $\begin{array}{l}\bar{\infty} \\
\stackrel{+}{\sigma} \\
\vdots \\
\vdots \\
\vdots \\
\vdots \\
0 \\
0 \\
0 \\
0\end{array}$ & 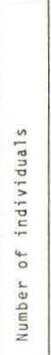 & 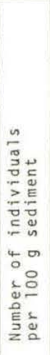 & $\begin{array}{l}\frac{3}{3} \\
\vdots \\
\vdots \\
\vdots \\
2 \\
0\end{array}$ \\
\hline \multirow{7}{*}{$\begin{array}{l}\text { O. adenticulata } \\
\text { N. (N.) simplex } \\
\text { Zone }\end{array}$} & \multirow{3}{*}{$4980^{\prime}-5000^{\prime}$} & 62 & 29.0 & . & . & . & . & . & 6.5 & . & 6.5 & . & . & . & . & 25.8 & . & . & 3.2 & 9.7 & . & . & . & . & . & 3.2 & $?$ & $?$ & 31 & 32 & 17 \\
\hline & & 63 & . & & . & . & & . & . & . & . & . & . & . & . & . & . & . & $\cdot$ & & . & . & . & . & . & . & . & . & 0 & 0 & - \\
\hline & & 64 & 26.7 & . & . & . & & & . & . & 40.0 & . & . & . & . & 33.3 & . & . & . & . & . & . & . & . & . & . & . & . & 15 & 18 & 45 \\
\hline & \multicolumn{31}{|c|}{ Flyvbjerg No.1 } \\
\hline & \multirow{3}{*}{$1190-1194 \mathrm{~m}$} & 18 & 18.8 & . & . & . & . & 3.4 & 0.7 & 0.7 & 11.5 & 7.4 & . & 4.1 & 10.8 & 34.5 & 0.7 & . & 1.4 & 4.1 & 0.7 & . & . & 0.7 & 0.7 & . & . & . & 148 & 74 & 23 \\
\hline & & 19 & 6.6 & . & . & . & . & 2.0 & . & 0.7 & 8.6 & 13.9 & 5.6 & 1.0 & 5.3 & 51.5 & 1.3 & 0.3 & 0.3 & 2.0 & 0.3 & 0.3 & 0.3 & . & . & . & . & . & 303 & 152 & 34 \\
\hline & & 21 & 22.6 & . & 1.6 & 9.7 & 29.0 & 22.6 & 4.8 & 4.8 & 4.8 & . & . & . & . & . & . & . & . &. & . & . & . & . & . & . & . & . & 62 & 31 & 24 \\
\hline $\begin{array}{l}\text { O. aspinata } \\
\text { Zone }\end{array}$ & $1396-1402 \mathrm{~m}$ & 27 & 1.0 & 99.0 & . & . & . & . & . & . & . & . & . & . & . & - & . & . & . & . & . & . & . & . & . & . & . & . & 193 & 97 & 100 \\
\hline
\end{tabular}

Table 13. The O. adenticulata - N. (N.) simplex Zone in the Haldager section and the Flyvbjerg section. Composition of the ostracod fauna expressed as relative percentages. 
species from both of the subzones in Gassum (table 13). The fauna of the core in Frederikshavn City No. 2 comprises only four species, among others T. tubulosa tubulosa and Trachycythere angusta Herrig, 1969, and must according to the outlined bipartition be referred to the upper of the two subzones. The core just below comprises the $G$. apostolescui $-K$. (K.) foveolata Subzone, and thus the occurrence of the lower subzone of the $O$. adenticulata $-N$. (N.) simplex Zone is ruled out. An erroneous evaluation of the stratigraphical conditions with the zone could be a possible explanation. However, it seems most likely that in both Frederikshavn City No. 2 and Flyvbjerg No. 1 the series is reduced. When the electrical logs of the two sections are compared with those of Vedsted No. 1 and Fjerritslev No. 2, it is obvious that the series is reduced in Frederikshavn City No. 2, at least, so it is possible that parts of the sequence are missing or eroded (cf. text-figs. 3, 4, 7 and 9; and pl. 42).

The precise stratigraphical determination of the $O$. adenticulata $-N$. (N.) simplex Zone is not evident, but on the basis of the biostratigraphical indications in general and of the indications in each of the bored sections which include the zone, it must be concluded that the zone correlates with the Upper Pliensbachian, and probably with the entire substage. The two index fossils have never been found outside the substage, and none of the other species have a range which excludes a correlation with the Upper Pliensbachian. It must furthermore be concluded that the zone can be subdivided into two subzones, of which the lower one corresponds to parts of the A. margaritatus Zone and the upper one to the uppermost part of this ammonite zone and to the overlying $P$. spinatum Zone.

\section{Description of the sections (borings)}

The present investigation deals with 36 sections bored through or into the Lower Jurassic series. Each of the sections will be described below. The lithology and the lithostratigraphical subdivision are as far as possible given according to Sorgenfrei \& Buch (1964) and Larsen (1966). The hitherto known chronostratigraphical subdivision is referred from the first-named paper and from Nørvang (1957). As a supplement to the description of the main part of the sections, a drawing is presented including a short outline of the lithology, the lithostratigraphy, the ostracod zones and the chronostratigraphical subdivision worked out in the present paper. The locations of the core samples are also marked relative to the depth and to the lithology. Only three figures include details of the recorded ostracod fauna: 
The figures for Gassum No. 1, Rønde No. 1 and the Øresund borings. Details of the faunas from all quantitatively treated core samples are presented in tables $1-13$.

The depth figures indicate depth below rotary table or below kelly bushing. The depth figures printed in italics indicate depth below ground or below M.S.L., for onshore and offshore borings respectively.

\section{The Skagen No. 2 boring}

The boring is described by Sorgenfrei \& Buch (1964) and Larsen (1966).

According to these two papers the following lithological and lithostratigraphical description can be given:

Haldager Formation, 406-473 m: Sand, silt and clay, grey to dark grey; with thin coal beds.

Fjerritslev Formation, 473-553 m: 473-547 m: Clay, greenish grey to grey with subordinate beds of sand and clay-ironstone. 547-553 m: Clay and silt with limestone.

Gassum Formation, 553-564 m: Clay and silt, greenish grey, with lignite.

The entire Fjerritslev Formation is represented by cores, except for a small interval.

The interval $473-547 \mathrm{~m}$ is referred to Middle? Lias, and the interval 547-553 $\mathrm{m}$ to Lias Alpha-3, based on the occurrence of $O$. sinemuriensis (see Sorgenfrei \& Buch, 1964).

From only one of the cores, 1750'-1760', have determinable ostracods been recorded: Ogmoconchella aequalis, "O. mouhersensis" and $O$. danica. The simultaneous occurrence of these three species indicates that the sedimentary series belongs to the upper part of the $O$. danica Zone.

On the basis of the biostratigraphical conditions the interval $1750^{\prime}-1760^{\prime}$ can be referred to Lower Pliensbachian, and the interval 1794'-1814' $(547-553 \mathrm{~m})$ to Lower Sinemurian. O. sinemuriensis has been recorded from the latter interval (see Sorgenfrei \& Buch, 1964).

The upper and the lower boundaries of the Lower Jurassic, respectively $473 \mathrm{~m}$ and $553 \mathrm{~m}$, are here given according to the previous determination. 


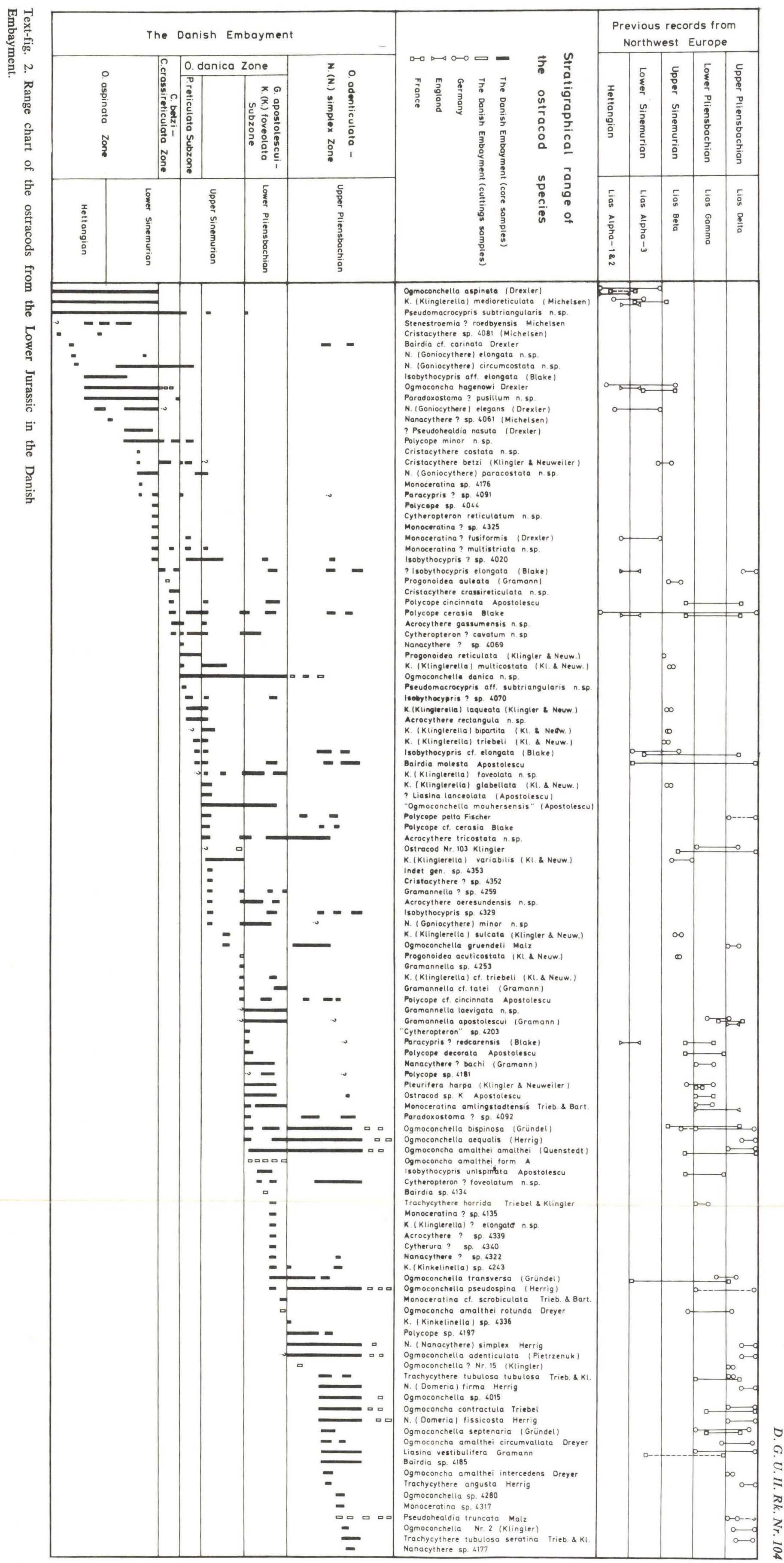


The Frederikshavn City Nos. 1, 2 and 3 borings

All three borings are described by Nørvang (1957) and Sorgenfrei \& Buch (1964), and the first one by Larsen (1966).

The sedimentary sequence in Frederikshavn City No. 1 can be described lithologically and lithostratigraphically according to Larsen (1966):

Haldager Formation, 646-756 m: Sand, silty clay and claystone, greenish grey to greyish black.

Fjerritslev Formation, 756-903 m: 756-810 m: Claystone, silty, light green to greenish grey; with siderite. 810-903 m: Claystone, silty, greenish grey and greyish black; sand, fine-grained, brownish grey.

Gassum Formation, 903-980 m: Sand, whitish grey, with subordinate beds of greyish black clay.

According to previous stratigraphical determinations the Triassic-Jurassic boundary is placed at the depth $903 \mathrm{~m}$, and the Lower-Middle Jurassic boundary at $756 \mathrm{~m}$.

The sedimentary sequences of the two other borings, Frederikshavn City Nos. 2 and 3, are nearly identical with the series described above (cf. Sorgenfrei \& Buch, 1964; and text-fig. 3).

The interval $2560^{\prime}-2905^{\prime}$ in Frederikshavn City No. 2 is referred to Upper Lias Alpha - Middle Lias Gamma on the basis of Peter Baadsgaard's analyses of the megafossils (cf. Nørvang, 1957). Nørvang (1957) has referred the interval $2720^{\prime}-2777^{\prime}$ in Frederikshavn City No. 1 to "Lias Delta or uppermost part of Lias Gamma" and the interval $2787^{\prime}-2837^{\prime}$ to Lias Gamma on the basis of the foraminiferal faunas.

The investigation of the ostracod fauna has mainly given poor results.

In Frederikshavn City No. 1 the only ostracod species, Ogmoconcha contractula, is recorded from the core $2710^{\prime}-2720^{\prime}$, which indicates the occurrence of the $O$. adenticulata $-N$. (N.) simplex Zone.

The best ostracod faunas are recorded from Frederikshavn City No. 2. The core $2560^{\prime}-2568^{\prime}$ contains a fauna belonging to the O. adenticulata $N$. (N.) simplex Zone. As the fauna comprises the species Ogmoconchella adenticulata, Trachycythere angusta and T. tubulosa tubulosa it is supposed that only the upper part of the zone is present. The cores $2568^{\prime}-2588^{\prime}$ and $2785^{\prime}-2805^{\prime}$ contain a fauna belonging to the $G$. apostolescui $-K$. (K.) foveolata Subzone, including "Ogmoconchella mouhersensis", Ogmoconcha amalthei amalthei and the two index fossils. As mentioned on p. 43 it must be assumed that the series in this boring have been reduced, as the 


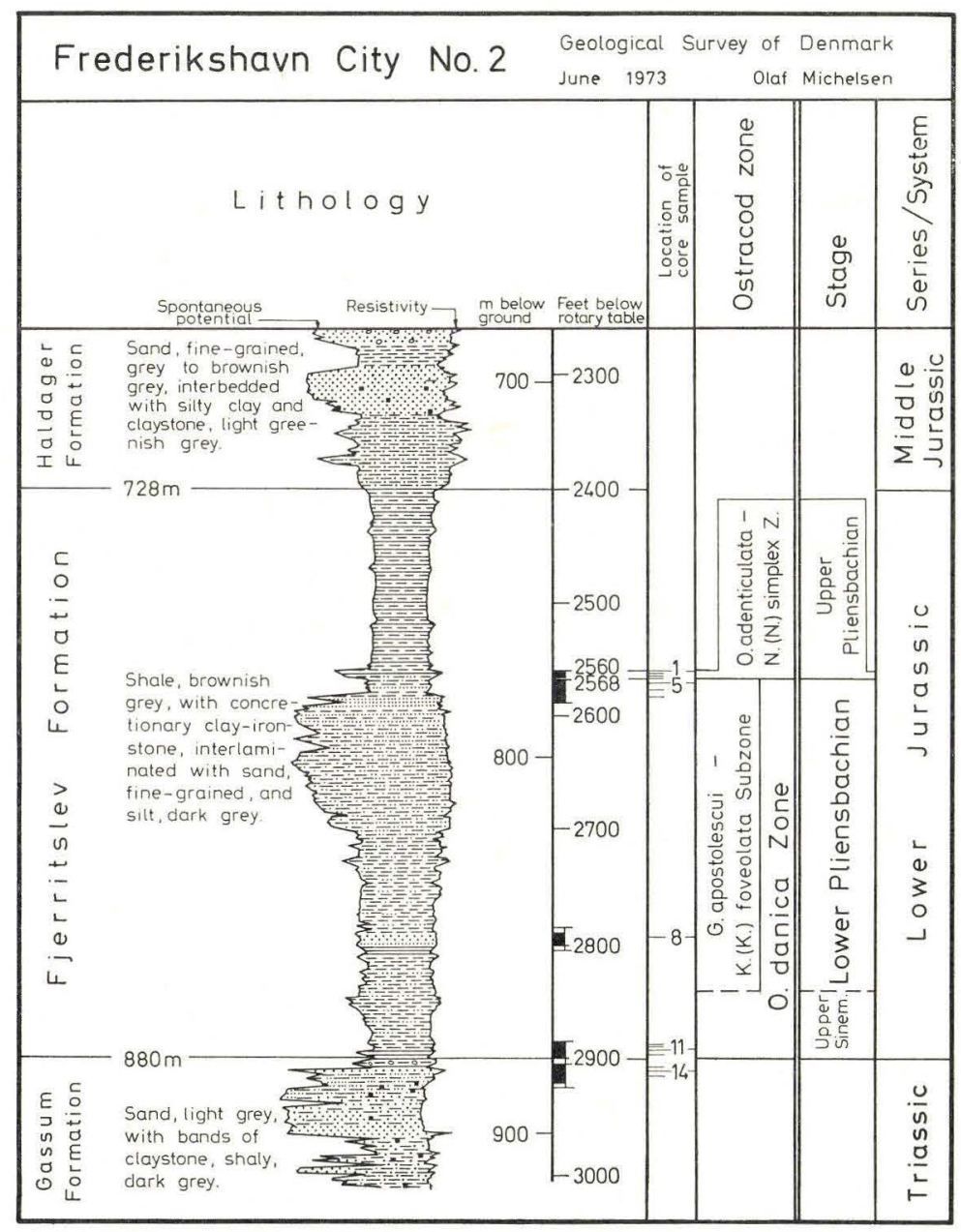

Text-fig. 3 .

lower part of the $O$. adenticulata $-N$. (N.) simplex Zone is missing. From the core 2885'-2905' one fragment of Progonoidea acuticostata is recorded, which indicates a stratigraphical level immediately below the $G$. apostolescui $-K$. (K.) foveolata Subzone.

The sedimentary sequence of Frederikshavn City No. 3 is only represented by cuttings samples, and the ostracod fauna is sparse. However, the recorded species show with certainty the occurrence of the upper part of the $O$. danica Zone up to a depth of $2625^{\prime}$.

The sedimentary sequences which in all three borings have yielded ostracod faunas belong to the same biostratigraphical level: The $O$. adenticulata $-N$. (N.) simplex Zone and the upper part of the $O$. danica Zone. 
In all three borings these faunas are recorded from that part of the section which is lithologically characterized by a distinct rise of the Resistivity curve and by corresponding oscillations on the Gamma Ray and the Spontaneous Potential curves (cf. text-fig. 3; and Larsen, 1966, pl. III). The three borings are situated so close to each other and have such similar lithological developments that it seems reasonable to let Frederikshavn City No. 2 represent all of them.

The stratigraphical subdivision of the Lower Jurassic series based on the above-mentioned features may be outlined as follows:

1) Lowest in the series occurs a thin zone which can be correlated with the uppermost Upper Sinemurian.

2) The overlying series can with certainty be referred to the Lower Pliensbachian and the Upper Pliensbachian.

3) The uppermost part of the Lower Jurassic series cannot be determined from the present material.

The stratigraphical subdivision is not in accordance with that given by Peter Baadsgaard. However, the megafossil faunas do not include index fossils (cf. Nørvang, 1957). On the other hand the present subdivision is concordant with that based on the foraminiferal faunas in the section in Frederikshavn City No. 1 (cf. Nørvang, 1957).

\section{The Flyvbjerg No. 1 boring}

The boring is described by Sorgenfrei \& Buch (1964) and Larsen (1966).

The lithology and the lithostratigraphy of the sedimentary sequence is according to Larsen (1966):

Haldager Formation, 950-1060 m: Sand and sandstone, greenish white, with silt and shale, greenish grey.

Fjerritslev Formation, 1060-1306 m: 1060-1149 m: Shale, green to greenish grey. 1149-1306 m: Shale, light greenish grey, and sand, greyish white.

Gassum Formation, 1306-1480 m: Sand, greenish white, sandstone, brownish white, and shale, dark grey.

The above-mentioned authors place the boundary between Lower Jurassic and Middle Jurassic at the depth $1094 \mathrm{~m}$, so the uppermost part of the Fjerritslev Formation together with the Haldager Formation is included under Middle Jurassic. The Triassic-Jurassic boundary corresponds to the boundary between the Gassum Formation and the Fjerritslev Formation. 
The Lower Jurassic series is represented by four cores (cf. text-fig. 4), of which only two, 1190-1194 m and 1396-1402 m, contain an ostracod fauna of stratigraphical importance (table 13). Little information has been recorded from the cuttings samples.

The upper one of the two cores, 1190-1194 m, contains an ostracod fauna rich in species and in specimens, representing the $O$. adenticulata $N$. (N.) simplex Zone. Besides the two index fossils, the important species Trachycythere tubulosa tubulosa, Nanacythere (Domeria) fissicosta and $N$. (D.) firma are found, which indicates that the fauna represents the upper part of the zone and that the sedimentary sequence must be referred to Upper Pliensbachian (see p. 43).

The lower one of the two cores, 1396-1402 m, contains an ostracod fauna rich in specimens, but poor in species. Cristacythere costata is the absolutely dominating species in the fauna (cf. table 13). A stratigraphical evaluation cannot be based on this fauna with certainty, as the recorded species is not known outside this locality. It belongs to the European "Procytheridea"-group and may therefore indicate Lower Jurassic (see also Christensen, 1973b). However, this ostracod group appears earlier, since two species of the genus Klinglerella are described from the Rhaetic in England (Anderson, 1964). An analysis of the megaspore content of the mentioned core has shown the occurrence of the Nathorstisporites hopliticus Assemblage without admixture of older assemblage-elements (Finn Bertelsen, personal communication). The sediments in the core must therefore be referred to Lower Jurassic, to Lias Alpha (cf. Bertelsen \& Michelsen, 1970). The ostracod species Ogmoconchella aspinata is recorded from cuttings samples both below and above the core, so the interval below $1367 \mathrm{~m}$ is referred to the $O$. aspinata Zone. The lower boundary of this zone, which is assumed to correspond to the Triassic-Jurassic boundary, is placed at $1483 \mathrm{~m}(1480 \mathrm{~m})$ on the basis of a change in the lithology. The megaspores from the core situated immediately below this boundary belong to the Trileites pinguis Assemblage, and thus this latter sedimentary sequence must be referred to Triassic (Finn Bertelsen, personal communication). In fact, the entire Gassum Formation in this locality belongs to Lower Jurassic.

Indications are found in two cuttings samples of the occurrence of the $O$. danica Zone between the $O$. adenticulata $-N$. (N.) simplex Zone and the $O$. aspinata Zone, whereas representatives of the $C$. betzi $-C$. crassireticulata $Z$ one are not found.

The remaining and upper part of the Fjerritslev Formation, 1063-1190 m, does not contain ostracods. The greenish shale in the interval 1060-1149 m is known from the Frederikshavn City Nos. 1-3 borings, and the characteristic oscillation on the Resistivity and the Spontaneous Potential curves 
at the base of this series is also found in these borings. The uppermost part of the greenish shale, 1060-1094 m, has earlier been referred to Middle Jurassic (cf. Sorgenfrei \& Buch, 1964 and Larsen, 1966). In the present paper the stratigraphical determination is left open because of a weak indication of Lower Jurassic found in corresponding beds in the Haldager No. 1 and Vedsted No. 1 borings. This problem is discussed in general on p. 109.

\section{The Borglum No. 1 boring}

The boring is described by Nørvang (1957), Sorgenfrei \& Buch (1964) and Larsen (1966).

According to Larsen (1966) the lithology and the lithostratigraphy of the sedimentary sequence is as follows:

Haldager Formation, 1009-1128 m: Sandstone, with subordinate beds of grey claystone.

Fjerritslev Formation, 1128-1368 m: 1128-1234 m: Claystone, with subordinate beds of sand. 1234-1368 m: Claystone, with subordinate beds of sand and clay-ironstone.

Gassum Formation, 1368-1524 (total depth) m: Alternating sandstone, shale and claystone, dark grey to greyish black.

Sorgenfrei \& Buch (1964) and Larsen (1966) locate the boundary between Lower Jurassic and Middle Jurassic at the depth $1182 \mathrm{~m}$ (3890'). Nørvang (1957) finds a poor foraminiferal fauna of agglutinating species in the core $3874^{\prime}-3884^{\prime}$ and in the cuttings samples up to $3825^{\prime}$, which in his opinion makes it probable that these beds must be referred to Lias. He regards the lithological break at $3770^{\prime}$ as being the top of Lias. Regardless whether one or the other of these two mentioned depths is chosen, an uppermost part of the Fjerritslev Formation is referred to Middle Jurassic. The Triassic-Jurassic boundary is placed at the top of the Gassum Formation, at $1368 \mathrm{~m}$.

The Lower Jurassic series is represented by four cores, of which only two have contributed ostracod faunas.

The upper core, $4095^{\prime}-4105^{\prime}$, contains a characteristic but poor fauna, belonging to the $O$. adenticulata $-N$. (N.) simplex Zone. The fauna, which comprises the two index fossils and Trachycythere tubulosa seratina, among others, is regarded as belonging to the upper part of the zone, and is the basis for correlating the section with the uppermost Upper Pliensbachian. 
The lower core, 4294'-4314', shows a fauna rich in species and in specimens, belonging to the $G$. apostolescui $-K$. (K.) foveolata Subzone, so the section must be correlated with Lower Pliensbachian (cf. table 10).

The cuttings samples contain a considerable number of ostracods, which assist in the location of the zonal boundaries. The samples between the two mentioned cores contain species belonging to the $O$. adenticulata $-N$. (N.) simplex Zone. The boundary between the two zones is therefore placed at the top of the lower core, at 4294'. The upper boundary of the O. adenticulata - N. (N.) simplex Zone is placed at 4060' on the basis of the uppermost occurrence of Ogmoconchella aequalis. The G. apostolescui - K. (K.) foveolata Subzone is supposed to comprise the entire Lower Jurassic series below the lower core, since no biostratigraphical indications of the occurrence of older zones is recorded.

Biostratigraphical indications supporting the location of the lower and the upper boundary of the Lower Jurassic are not found in this boring. The Triassic-Jurassic boundary has previously been placed at the top of the Gassum Formation. This boundary is also used in the present paper (textfig. 5), but it must be emphasized that the Gassum Formation in the neighbouring boring, Flyvbjerg No. 1, is included under Lower Jurassic (cf. p. 48, and pl. 42). A further discussion of the chronostratigraphical relationships is found on p. 104. The Upper Pliensbachian ostracod fauna is the youngest Lower Jurassic fauna recorded. The weak indication of Aalenian fauna in the Haldager No. 1 and Vedsted No. 1 borings together with the possibility of stratigraphical determinations based on lithological correlations make it probable that the boundary between Lower and Middle Jurassic has previously been placed too low (see p. 109). For these reasons the stratigraphical determination of the interval, $1128-1182 \mathrm{~m}$, is left open (cf. text-fig. 5).

\section{The Haldager No. 1 boring}

The boring is described by Nørvang (1957), Sorgenfrei \& Buch (1964) and Larsen (1966).

The lithology and the lithostratigraphy are here given according to Larsen (1966):

Haldager Formation, 1078-1403 m: Sandstone, with subordinate beds of clay and shale.

Fjerritslev Formation, 1403-1521 (total depth) m: Shale, grey to greenish grey, with some beds of fine-grained sandstone, argillaceous, greyish brown. 
According to the above-mentioned authors the boundary between Lower Jurassic and Middle Jurassic is coincident with the boundary between the two formations.

The Lower Jurassic series is represented by two cores, of which only the lower one, 4980'-5000', contains ostracods. The fauna is not rich in specimens, but comprises species characteristic of the $O$. adenticulata $-N$. (N.) simplex Zone (cf. table 13). The occurrence of Nanacythere (Domeria) firma suggests that the upper part of the zone is represented and that the section must be referred to the uppermost Upper Pliensbachian.

The cuttings samples contain no ostracods, and for that matter, very few other fossils.

The core 4501'-4508', which is situated within the lower part of the Haldager Formation, contains a numerous, but fragmentary, ostracod fauna. Only a few specimens have the shell preserved, and they can probably be referred to the subgenus $K$. (Kinkelinella). The main part of the fauna is represented by pyrite-casts. These have been determined as Pseudomacrocypris subaequabilis, but a few indeterminable specimens may possibly belong to the genus Monoceratina. The fauna can form the basis for a correlation with Aalenian or Bajocian. The heavy dominance (87-98\%) of the species $P$. subaequabilis shows some affinities with the fauna of the Øresund No. 2 boring (cf. text-fig. 21). However, the more important species from the Øresund fauna are missing in the Haldager fauna, so a certain stratigraphical determination of the section cannot be given.

The boundary between Lower and Middle Jurassic is here placed with uncertainty at 4501', since the ostracod fauna found in the core 4501'$4508^{\prime}$ makes it probable that the boundary should be placed within the Haldager Formation. A revision of the stratigraphy can possibly be made with greater certainty on the basis of the spores.

\section{The Vedsted No. 1 boring}

The boring is described by Sorgenfrei \& Buch (1964), Larsen (1966), and in parts by Michelsen (1973b).

The lithology given below is in accordance with the original description and with Sorgenfrei \& Buch (1964); the lithostratigraphy is in agreement with Larsen (1966):

Haldager Formation, 1120-1220 m: Sandstone, grey and yellowish brown. Fjerritslev Formation, 1220-1899 m: 1220-1376 m: Claystone, greenish 
grey and dark grey. 1376-1899 m: Shale, grey to dark grey, occasionally with fine-grained sand, with siderite locally.

Gassum Formation, 1899-2065 (total depth) m: Siltstone and sandstone, white, with thin beds of grey shale and coal.

According to Sorgenfrei \& Buch (1964) and Larsen (1966) the boundary between the Gassum Formation and the Fjerritslev Formation is coincident with the Triassic-Jurassic boundary. The boundary between Lower Jurassic and Middle Jurassic is placed within the Fjerritslev Formation, at the depth $1376 \mathrm{~m}$.

The Lower Jurassic series is represented by three cores, of which the middle one, 1775-1780 m, only contains indeterminable fragments of an Ogmoconchella-species (see text-fig. 7).

The upper core, 1403-1409 m, contains an ostracod fauna rich in specimens and characteristic of the $O$. adenticulata - N. (N.) simplex Zone. (cf. table 4). On the basis of the occurrence of the species Trachycythere tubulosa seratina, Nanacythere (Domeria) fissicosta and N. (D.) firma, the sediments in the core can be referred to the upper part of the zone and correlated with the uppermost Upper Pliensbachian.

The lower core, 1865-1870 m, contains a fauna rich in specimens and belonging to the $O$. aspinata Zone (cf. table 4). The fauna is dominated by the index-fossil and is characterized by Nanacythere (Goniocythere) circumcostata and $N$. (G.) elegans, so it is assumed to belong to the upper part of the zone. The section is therefore correlated with Lower Sinemurian.

The cuttings samples make only modest contributions to an elucidation of the faunal successions in this boring. No ostracods are found above the upper core mentioned, whereas the fauna of the $O$. adenticulata $-N$. (N.) simplex Zone is recovered in the samples from below this core. The first change in the fauna is observed at $1530 \mathrm{~m}$ with the introduction of the species Ogmoconchella danica and "O. mouhersensis". Two other important species, Ogmoconchella aspinata and Kinkelinella (Klinglerella) medioreticulata are found as representatives of the $O$. aspinata Zone below $1845 \mathrm{~m}$. From these sparse data the interval $1530-1845 \mathrm{~m}$ may be referred to the $O$. danica Zone, and the section below $1845 \mathrm{~m}$ to the $O$. aspinata Zone. The occurrence of the $G$. apostolescui $-K$. (K.) foveolata Subzone is indicated by the species Kinkelinella (Klinglerella) foveolata and $K$. (K.) cf. triebeli, which are found within the interval between the two depths men- 
tioned. On the other hand no indications are found of the presence of the lower part of the $O$. danica Zone nor of the presence of the $C$. betzi $-C$. crassireticulata Zone.

Based on these data the interval 1403-1530 m can be referred to Upper Pliensbachian. The occurrence of Lower Pliensbachian can also be demonstrated. The occurrence of the species Nanacythere (Goniocythere) circumcostata and $N$. (G.) elegans in the $O$. aspinata Zone shows that at least the core section 1865-1870 m must be correlated with Lower Sinemurian. No biostratigraphical indications of Upper Sinemurian are found, but as this substage is proved in the neighbouring boring, Fjerritslev No. 2 (cf. text-fig. 9), it is also assumed to be present in Vedsted No. 1. The boundary between Lower and Upper Sinemurian cannot be identified in the latter boring, but the Lower Sinemurian must comprise at least the section below the depth $1845 \mathrm{~m}$.

The Triassic-Jurassic boundary is here placed in accordance with the earlier determination given by the authors mentioned above. The occurrence of the $O$. aspinata Zone in relation to the lithology shows a good correlation with the section of Flyvbjerg No. 1 (cf. text-figs. 4 and 7), but the subdivision into formations in Flyvbjerg does not correspond with the present correlation. This is probably due to the fact that the Vedsted section is influenced to a higher degree by claystone and shale in the $O$. aspinata Zone. For an evaluation of the chronostratigraphy the relative location of the two sections within the basin must be considered. The Vedsted section is located more centrally in the basin than the Flyvbjerg section, which probably explains the differences found in the sediments from the $O$. aspinata Zone within the two sections (see pl. 42). It must be reasonable to retain the Triassic-Jurassic boundary at the top of the Gassum Formation in Vedsted, but to place the boundary within or below this formation in Flyvbjerg, as far as is indicated by the biostratigraphical conditions and supported by the relative location within the basin (see also p. 105).

As mentioned for other borings located in this part of the basin, there is some uncertainty concerning the boundary between Lower Jurassic and Middle Jurassic. The uppermost part of the Fjerritslev Formation in this boring has earlier been referred to Middle Jurassic. The greenish claystone in this part of the formation seems to be barren of fossils, but from the uppermost core in the formation, $1227-1230.7 \mathrm{~m}$, an ostracod fauna of pyrite-casts is recorded. The dominating and only determinable species is Pseudomacrocypris subaequabilis, so the fauna resembles that from the lower part of the Haldager Formation in the Haldager No. 1 boring (see p. 51), and it may show affinities with the fauna of the Øresund No. 2 bor- 
ing (text-fig. 21). A species probably belonging to the genus Camptocythere has been found in the cuttings samples from the upper part of the Fjerritslev Formation by O. Bruun Christensen (personal communication). The occurrence of this species (which may be due to cavings) can support a possible correlation to the Øresund No. 2 section and a possible stratigraphical determination to Aalenian. However, the biostratigraphical data do not indicate the exact stratigraphical level, so a final stratigraphical determination of the interval $1220-1376 \mathrm{~m}$ has not been made. It is here referred with uncertainty to Lower Jurassic.

\section{The Fjerritslev Nos. 1 and 2 borings}

The borings are described by Sorgenfrei \& Buch (1964) and Larsen (1966).

Fjerritslev No. 2 comprises the entire Lower Jurassic series, whereas Fjerritslev No. 1 does not penetrate this. The lithology and the lithostratigraphy given below are in accordance with Larsen (1966).

\section{Fjerritslev No. 1}

Haldager Formation, 543-588 m: Sandstone and claystone, brownish grey.

Fjerritslev Formation, 588-915 (total depth) m: Claystone, shale and siltstone, dark grey.

\section{Fjerritslev No. 2}

Haldager Formation, 1260-1320 m: Sandstone, whitish grey, with clay beds.

Fjerritslev Formation, 1320-2300 m: 1320-1539 m: Shale, dark grey, with beds of sandstone, fine-grained, whitish grey, glauconitic. 1539-2300 m: Shale, grey, dark grey and greenish grey, with siderite and in lower part beds of white sandstone.

2300-2326 m: Alternating thin beds of shale, dark grey, silty, and sandstone, white, slightly glauconitic, with coal pieces.

In Fjerritslev No. 1 the Lower-Middle Jurassic boundary is placed within the Fjerritslev Formation, at the depth 647 m (cf. Sorgenfrei \& Buch 1964).

In Fjerritslev No. 2 the Triassic-Jurassic boundary is placed at the depth $2300 \mathrm{~m}$, and the Lower-Middle Jurassic boundary is placed at the depth 1539 m, within the Fjerritslev Formation (cf. Sorgenfrei \& Buch, 1964). 
The Lower Jurassic series of the Fjerritslev No. 1 boring is only represented by one core, 696-700 m (cf. text-fig. 8). The fauna is rich in species and belongs to the $O$. adenticulata - N. (N.) simplex Zone (table 8). On the basis of the two index fossils and the species Nanacythere (Domeria) firma, N. (D.) fissicosta, Trachycythere tubulosa tubulosa and $T$. tubulosa seratina the fauna can be referred to the upper part of the zone, and the sedimentary sequence represented by the core can be correlated with the uppermost Upper Pliensbachian. The overlying cuttings samples, up to the depth $684 \mathrm{~m}$, contain the species Ogmoconchella adenticulata and $O$. aequalis, so the section between this depth and the core must belong to the zone mentioned. The cuttings samples below the core are dominated by Ogmoconcha-species, but at $829 \mathrm{~m}$ the important species, Ogmoconchella danica, "O. mouhersensis" and Kinkelinella (Klinglerella) foveolata appear, so the section below $829 \mathrm{~m}$ must belong to the $O$. danica Zone. The occurrence of $K$. (K.) foveolata indicates that the section 829-918 in can be correlated with Lower Pliensbachian. There is no indication of the presence of Upper Sinemurian.

The Lower Jurassic series of the Fjerritslev No. 2 boring is represented by four cores, from three of which ostracods are recorded (cf. text-fig. 9). The upper core, 1561-1564 m, contains only three species: T. tubulosa tubulosa, Nanacythere? sp. 4322 and Ostracod K Apostolescu, which is a fauna belonging to the $O$. adenticulata $-N$. (N.) simplex Zone. The core 2000-2004 m contains a more abundant fauna comprising Ogmoconchella danica and Progonoidea reticulata. This fauna is characteristic of the $P$. reticulata Subzone (see table 8). The core 2084-2087 $\mathrm{m}$ has only yielded one species, Paradoxostoma? pusillum, which is known from the $O$. aspinata Zone and the $C$. betzi $-C$. crassireticulata Zone. The content of ostracods in the cuttings samples is rather sparse, but it is sufficient, together with the faunas of the cores, to make the basis for a stratigraphical subdivision of the sedimentary sequence. No ostracods are found above the uppermost core, but species known both from the $O$. adenticulata $-N$. (N.) simplex Zone and from the uppermost part of the $O$. danica Zone are found below it. Ogmoconchella danica and "O. mouhersensis" are found at the depth $1793 \mathrm{~m}$, so the boundary between these two zones may be placed at this depth. The $O$. danica Zone comprises the core with the $P$. reticulata Subzone. Below this core at $2040 \mathrm{~m}$ typical representatives of the $O$. aspinata Zone are found: Ogmoconchella aspinata, Kinkelinella (Klinglerella) medioreticulata, Ogmoconcha hagenowi and Pseudomacrocypris subtriangularis. The boundary between Lower Sinemurian and Upper Sinemurian cannot be placed exactly as the $C$. betzi $-C$. crassireticulata Zone is not indicated. On text-fig. 9 this boundary is tentatively given at the top of 
the $O$. aspinata Zone. It is probably too low in the section, but the correct level can hardly be far from this as the $C$. betzi $-C$. crassireticulata Zone is usually thin. The lower part of the section, 2040-2303 m, is therefore correlated with Hettangian and Lower Sinemurian; the section 1793-2040 m with Upper Sinemurian and Lower Pliensbachian; and finally 1561-1793 m with Upper Pliensbachian.

The lower boundary of the Lower Jurassic is as mentioned not penetrated in Fjerritslev No. 1. In Fjerritslev No. 2 the location of this boundary is based on the lithology because of missing biostratigraphical indications. The upper boundary of the Lower Jurassic is more problematic, as discussed for other borings from this part of the basin and on p. 109. In Fjerritslev No. 1 it seems reasonable to the present author to place this boundary at the top of the Fjerritslev Formation if the section is correlated with Haldager No. 1 by means of the electrical logs and the biostratigraphical data. In Fjerritslev No. 2 the upper part of the Fjerritslev Formation is extensive and resembles the corresponding part of the formation in Vedsted No. 1 (cf. text-fig. 7). In the latter boring and in Haldager No. 1 an ostracod fauna is registered near the upper boundary of the Fjerritslev Formation which possibly indicates Aalenian or Bajocian. Based on a correlation with the Vedsted section the upper part of the Fjerritslev Formation in Fjerritslev No. 2 is stratigraphically determined as Lower or Middle Jurassic. Finally it must be mentioned that O. Bruun Christensen has found a few specimens referable to the genus Camptocythere in cuttings samples from this interval (personal communication).

\section{The Dansk Nords $\phi J-1$ boring}

The boring is located in the northern part of the Danish North Sea area, ca. $30 \mathrm{~km}$ north of Hanstholm in North Jylland. The coordinates of the position are $57^{\circ} 25^{\prime} 57^{\prime \prime}$ North and $08^{\circ} 33^{\prime} 06^{\prime \prime}$ East. The boring was drilled in the period 23rd Dec., 1969 to 14th Jan., 1970 by the Dansk Undergrunds Consortium company.

The part of the section dealt with in the present paper is represented by cuttings samples taken every $20^{\prime}$ or $10^{\prime}$.

The shortened lithological description and the lithostratigraphical subdivision given below and on text-fig. 10 are based on an unpublished report by Finn Bertelsen, F. Nyhuus Kristoffersen, F. Lyngsie Jacobsen and Olaf Michelsen:

Haldager Formation, 1054-1122 m: Light grey siltstone with subordinate beds of dark grey claystone. 


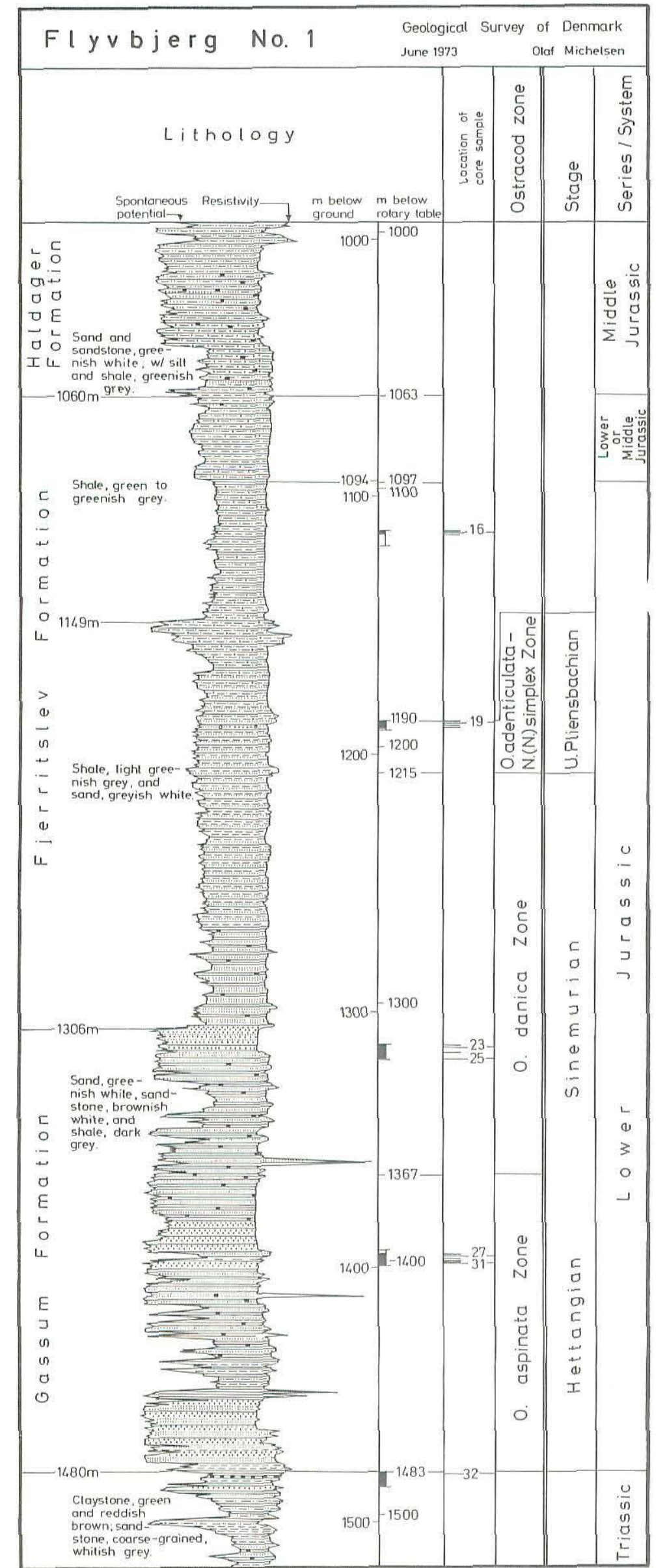

Text-fig. 4.

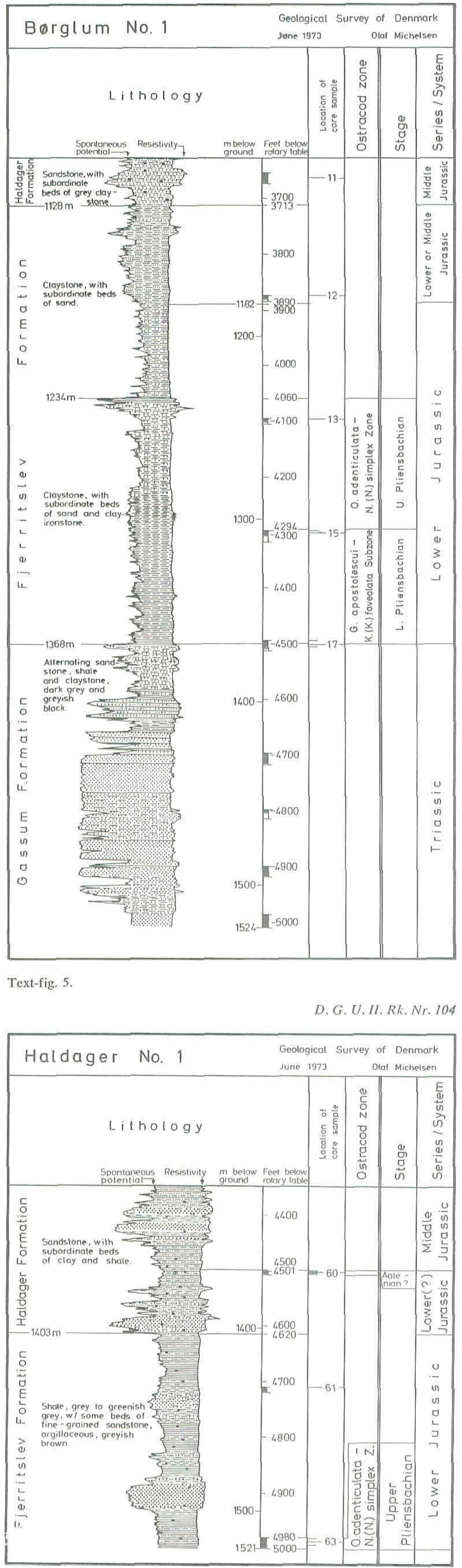

Text-fig. 6.

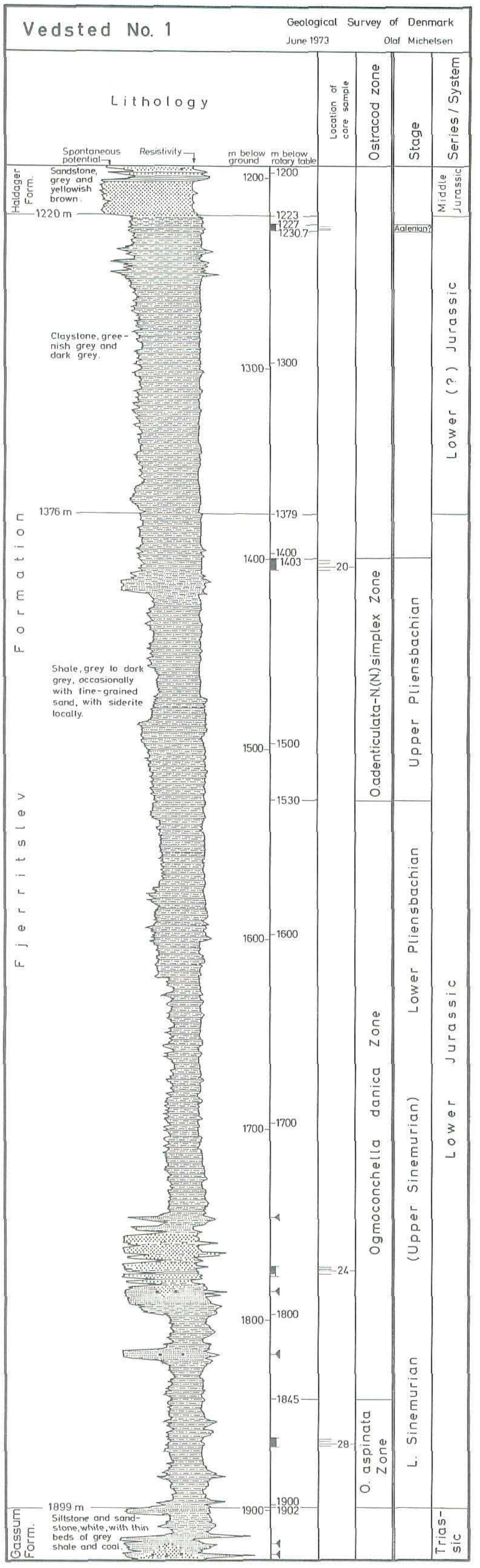

Text-fig. 7. 


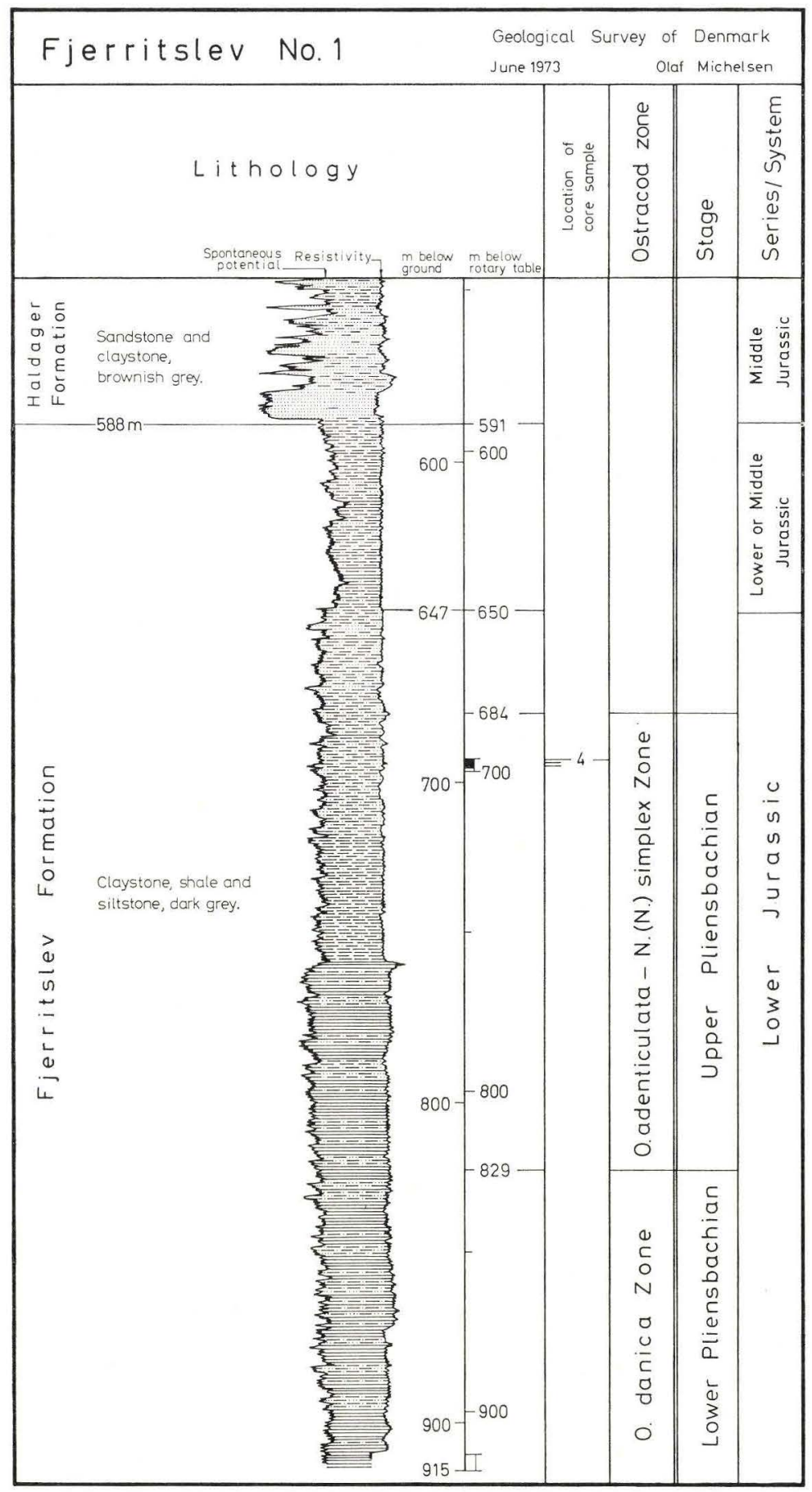

Text-fig. 8 .

D.G.U. II. rk. nr. 104 
Fjerritslev Formation, 1122-1697 m: 1122-1157 m: Grey and silty claystone. 1157-1697 m: Claystone with changing contents of silt. The claystone is grey in the upper part, but darker in colour and shaly in the lower part. Pyrite and pyritized megafossils are common. In the sample intervals 4900' $-5000^{\prime}$ and $5250^{\prime}-5290^{\prime}$ beds of siltstone are a prominent feature.

Gassum Formation, below 1697 m: Sandstone with angular to subangular grains, interbedded by clayey siltstone and by smaller layers of claystone.

The stratigraphical subdivision presented below is based solely on the ostracod faunas.

The $O$. adenticulata - N. (N.) simplex Zone is represented in the interval $3920^{\prime}-4420^{\prime}$ by a fauna rich in species and specimens. The composition and the development of the fauna within the zone resembles that known from the Rønde and Gassum sections (see text-figs. 16 and 15). The interval must therefore comprise the entire zone and correspond to the entire Upper Pliensbachian.

The $O$. danica Zone is represented in the interval 4420'-5110' and a relatively abundant fauna is found in the upper part of the interval, where the occurrence of the G. apostolescui - K. (K.) foveolata Subzone can be demonstrated. The upper boundary of the zone is based on the uppermost occurrence of Polycope decorata, Polycope sp. 4181 and Kinkelinella (Klinglerella) cf. triebeli (which are the latest representatives of the subzone in this section). The subzone is furthermore indicated by Kinkelinella (Klinglerella) foveolata and Nanacythere? bachi. The other index fossil, Gramannella apostolescui, is only found in one sample from a deeper level of the section (probably due to cavings). The lower boundary of the subzone can not be placed with certainty from the present material, which is possibly due to a very poor fauna found in the middle and lower parts of the $O$. danica Zone. The samples from the lower part of the zone are mainly dominated by cavings, so a subdivision is not possible. However, the $P$. reticulata Subzone must be present as the index fossil is found in samples from the deeper part of the underlying $O$. aspinata Zone.

The interval $5110^{\prime}-5690^{\prime}$ is included under the $O$. aspinata Zone. The ostracod content of the samples is small; only in the lower part of the interval is an abundant and typical $O$. aspinata Assemblage recorded. The upper boundary of the zone is determined from a few poorly determinable specimens of the index fossil. As the samples do not contain other stratigraphical indications, and as the corresponding intervals in the Mors No. 1 and Fjerritslev No. 2 borings (text-figs. 11 and 9) are characterized by poor faunas, the interval of the present boring is considered to be included under the $O$. aspinata Zone. 
The above-described section, 4420'-5690', can be stratigraphically determined as Hettangian, Sinemurian and Lower Pliensbachian without pointing out the boundaries between the stages (see text-fig. 10).

The lower boundary of the Lower Jurassic series is placed at $1697 \mathrm{~m}$ $\left(5690^{\prime}\right)$ on the basis of the lithology. In the underlying sequence, 5690'6519', no fossils are found which are usable for a stratigraphical determination. By correlation with borings in North Jylland, e.g. Fjerritslev No. 2 , it seems natural to locate the Triassic-Jurassic boundary at the depth $1697 \mathrm{~m}$. The upper boundary of the Lower Jurassic series cannot be established on the basis of biostratigraphical conditions in this section. In accordance with the description of borings from North Jylland the uppermost, non-fossiliferous section of the Fjerritslev Formation, 1122-1157 m, is referred to Lower or Middle Jurassic, and the Haldager Formation to Middle Jurassic. The section 1157-1697 $\mathrm{m}$ is referred to Lower Jurassic on the basis of the ostracod faunas.

\section{The Mors No. 1 boring}

The boring is briefly described and stratigraphically subdivided by Rasmussen (1972).

It was drilled in the period 13th Dec., 1966 to 21st Sept., 1967 in the northeastern part of the island of Mors by the Dansk Undergrunds Consortium company. The coordinates of the position are $56^{\circ} 54^{\prime} 00^{\prime \prime}$ North and $08^{\circ} 53^{\prime} 05^{\prime \prime}$ East.

The part of the section dealt with in the present paper is represented by cuttings samples taken every $10^{\prime}$.

The shortened lithological description and lithostratigraphical subdivision below and on text-fig. 11 are based on the original descriptions worked out by T. Juul Hansen and F. Nyhuus Kristoffersen:

Haldager Formation, above $2148 \mathrm{~m}$ : Alternating claystone and sandstone.

Fjerritslev Formation, 2148-2713 m: Dark grey to dark brownish grey claystone, with subordinate beds of siltstone.

Gassum Formation, below 2713 m: Alternating claystone and siltstone, with lignite and minor beds of limestone.

The lithological description and the lithostratigraphical subdivision of the section may be correlated directly with the section of Fjerritslev No. 2. The upper part of the Fjerritslev Formation, dominated by claystone, and the characteristic change to the silty claystone in the middle of the formation, 
distinctly marked on the electrical logs, are easily recognizable features in both of the sections mentioned (cf. text-figs. 9 and 11). Taken together with the biostratigraphical subdivision outlined below, the correlation with Fjerritslev No. 2 is very conspicuous.

The sedimentary sequence represented by the samples is generally poor in fossils, and the ostracods are often badly preserved.

The uppermost occurrence of Lower Jurassic ostracods is found at 7580'. The interval $7580^{\prime}-8090^{\prime}$ is covered by the $O$. adenticulata $-N$. (N.) simplex Zone. The fauna is relatively poor, but includes both of the index fossils. A subdivision of the zone is not possible. However, on the basis of the ostracods it is assumed that the interval must be correlated with the entire Upper Pliensbachian.

The interval 8090'-8540' comprises the $O$. danica Zone. The index fossil is recorded for the first time at 8170', but the upper boundary is based on the uppermost occurrence of Ogmoconchella transversa. This species is characteristic both for the lower part of the overlying zone and the upper part of the present zone, but it seems in this part of the basin to be most common in the latter. The fauna of the $O$. danica Zone in this section is characterized by Kinkelinella (Klinglerella) foveolata and Pleurifera harpa, both of which are recorded below 8220'. They indicate the presence of the G. apostolescui - K. (K.) foveolata Subzone. The upper boundary of the Lower Pliensbachian is placed at 8090' on the basis of the ostracod fauna, but the lower boundary cannot be established. However, it must be emphasized that the occurrence of Kinkelinella (Klinglerella) laqueata, $K$. (K.) triebeli and $K$. $(K$.) multicostata deeper in the sequence make it probable that the lower part of the $O$. danica Zone comprises at least parts of the Upper Sinemurian.

The top of the C. betzi - C. crassireticulata Zone is placed at 8540' on the basis of the first-named index fossil, but the lower boundary of the zone cannot be established. The series is extremely poor in ostracods and the representatives of the underlying $O$. aspinata Zone are first recorded at $8890^{\prime}$. This low ostracod content is a characteristic feature for this part of the Lower Jurassic series in the northern part of the basin, so the thickness of the $C$. betzi $-C$. crassireticulata Zone is probably given as too large on text-fig. 11. On the basis of the faunas, however, the interval 8540'8960 ' can be correlated with Hettangian and Lower Sinemurian.

Due to the missing biostratigraphical indications, the Triassic-Jurassic boundary is placed at $2713 \mathrm{~m}\left(8960^{\prime}\right)$ on the basis of the lithology. The uppermost Triassic ostracods are recorded at the depth 9620'. The boundary between Lower and Middle Jurassic is determined lithologically by correla- 

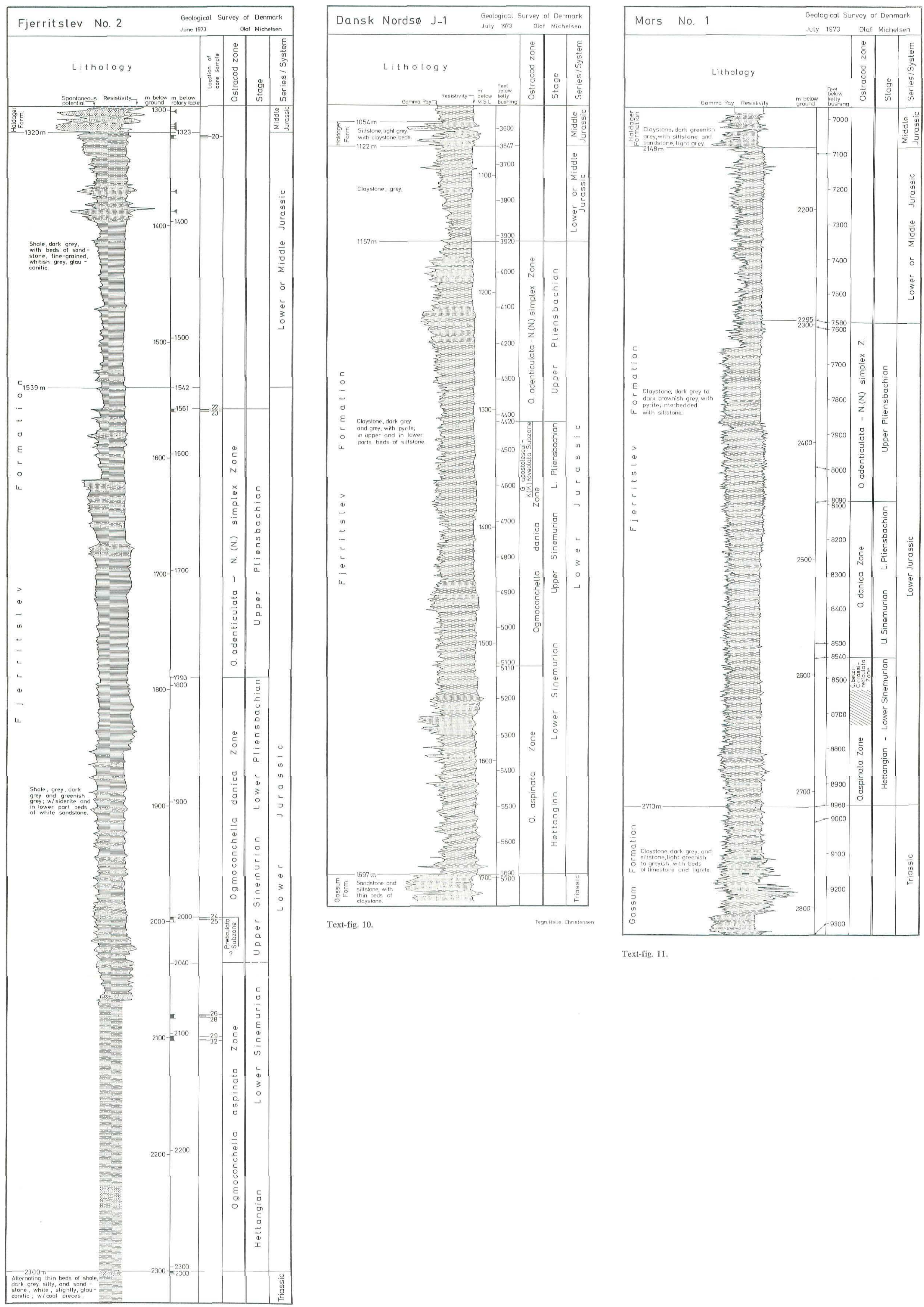

Text-fig. 11. 
tion with the Fjerritslev No. 2 boring, so that the Haldager Formation is referred to Middle Jurassic, the part of the Fjerritslev Formation containing ostracod faunas, 2295-2713 m, is referred to Lower Jurassic, and the upper part of the Fjerritslev Formation, 2148-2295 m, to Lower or Middle Jurassic.

\section{The Thisted No. 1 boring}

The boring is briefly described and stratigraphically subdivided by Rasmussen (1972).

It was drilled in the period 1st Oct. to 11 th Oct., 1967 ca. $2 \mathrm{~km}$ west of Nors (Northwest Jylland) by the Dansk Undergrunds Consortium company. The coordinates of the position are $57^{\circ} 01^{\prime} 26^{\prime \prime}$ North and $08^{\circ} 39^{\prime}$ $10^{\prime \prime}$ East.

The part of the section dealt with in the present paper is represented by cuttings samples taken every $20^{\prime}$ or $30^{\prime}$.

The shortened lithological description and lithostratigraphical subdivision below and on text-fig. 12 are based on the original description worked out by Svend E. Henriksen:

Haldager Formation, above 629 m: Siltstone, with intercalations of clay.

Fjerritslev Formation, 629-735 m: Dark grey claystone, which in the upper part is shaly; with pyrite.

Gassum Formation, below 735 m: Siltstone and sand.

This series is easily subdivided into formations, partly from the description of the lithology and partly from the electrical logs.

Uppermost in the Lower Jurassic series, in the interval $2145^{\prime}-2210^{\prime}$, oniy the species Ogmoconchella danica and Progonoidea reticulata are found, so the interval is referred to the lowermost $O$. danica Zone, to the $P$. reticulata Subzone, and it is correlated with the lowermost Upper Sinemurian (Lias Beta-1a).

The determination of the interval $2210^{\prime}-2235^{\prime}$ to the $C$. betzi $-C$. crassireticulata Zone is based on one specimen of the first-named index fossil; thus the location and the thickness of the zone must be taken with caution. The zone is tentatively located in this section because the index fossil is found between the sections of the over- and underlying zones. The boundary between Lower and Upper Sinemurian may be placed at the depth $2210^{\prime}$.

The $O$. aspinata Zone, $2235^{\prime}-2470^{\prime}$, is represented by a rich fauna. The 
absence of the subgenus Nanacythere (Goniocythere) in the lowest part of the zone indicates a stratigraphical relationship with the Hettangian, whereas the rich fauna uppermost in the zone, including the mentioned subgenus, is the basis for correlation with the Lower Sinemurian.

The Triassic-Jurassic boundary is placed at $2470^{\prime}(735 \mathrm{~m})$ on the basis of the lithology. The uppermost occurrence of Triassic ostracods is found at $2830^{\prime}$. The upper boundary of the Lower Jurassic is nearly coincident with the upper occurrence of Lower Jurassic ostracods and is placed at the top of the Fjerritslev Formation.

\section{The Dansk Nords $\phi$ F-1 boring}

The boring is located in the northern part of the Danish North Sea area. The coordinates of the position are $57^{\circ} 02^{\prime} 02^{\prime \prime}$ North and $06^{\circ} 53^{\prime} 46^{\prime \prime}$ East. It was drilled in the period 5th Oct. to 18th Oct., 1968 by the Dansk Undergrunds Consortium company.

The part of the section dealt with in the present paper is represented by cuttings samples taken every $20^{\prime}$ and $30^{\prime}$, rarely every $10^{\prime}$. A few side wall samples were also taken (see text-fig. 13).

The shortened lithological description and lithostratigraphical subdivision below and on text-fig. 13 are based on an unpublished report by Erik Stenestad:

Haldager Formation, above $1761 \mathrm{~m}$ : Light coloured sandstone, with subordinate beds of dark grey claystone.

Fjerritslev Formation, 1761-2042 m: A uniform series of grey to dark grey claystone (shale), with thin layers of siltstone and with pyrite and clayironstone concretions.

Gassum Formation, below 2042 m: Greyish and reddish siltstone, with subordinate beds of dark grey claystone.

The uniform development of the Fjerritslev Formation, without any marked features on the electrical curves, cannot be correlated with the sections known from northern Jylland, whereas it resembles the section from Nøvling No. 1, situated to the south in the basin (see text-figs. 13 and 18).

The ostracod faunas from the Fjerritslev Formation are relatively rich and form a good basis for the stratigraphical subdivision.

The section 5920'-6050' contains the uppermost occurrence of Lower Jurassic ostracods. The fauna is very poor in species and in specimens, and it mainly comprises species known from both the $O$. adenticulata $-N$. $(N$.) 
simplex Zone and the $G$. apostolescui - K. (K.) foveolata Subzone. The finding of Ogmoconcha contractula within the section, 5920'-6050', and of Ogmoconchella adenticulata, in samples below it (probably due to cavings), indicates the presence of the $O$. adenticulata - N. (N.) simplex Zone, so the interval $5920^{\prime}-6050^{\prime}$ is correlated with the Upper Pliensbachian.

The $O$. danica Zone is considered to include the interval $6050^{\prime}-6610^{\prime}$. The upper part, the interval $6050^{\prime}-6260^{\prime}$, is referred to the G. apostolescui - K. (K.) foveolata Subzone on the basis of the occurrence of the species Nanacythere? bachi, Kinkelinella (Klinglerella) foveolata, Acrocythere oeresundensis and "Ogmoconchella mouhersensis". The species Ogmoconchella danica and Pleurifera harpa occur for the first time near the bottom of the subzone; Gramannella apostolescui is found immediately below the lower boundary of the subzone. The remaining and underlying part of the O. danica Zone, 6260'-6610', contains a relatively poor fauna, which can not form a basis for a more detailed subdivision. The boundary towards the $G$. apostolescui $-K$. $(K$.) foveolata Subzone is determined on the basis of the first appearance of Progonoidea acuticostata. The P. reticulata Subzone cannot be demonstrated with certainty, but the occurrence of Nanacythere (Goniocythere) circumcostata above the underlying $C$. betzi $-C$. crassireticulata Zone indicates the presence of this subzone. This evaluation is furthermore supported by the occurrence of Kinkelinella (Klinglerella) multicostata a little above the uppermost appearance of $N$. (G.) circumcostata. It is therefore natural to refer the interval $6260^{\prime}-6610^{\prime}$ to Upper Sinemurian and to assume that the entire substage is present. The interval $6050^{\prime}-6260^{\prime}$ can with certainty be referred to Lower Pliensbachian.

The interval 6610'-6680' comprises the C. betzi - C. crassireticulata Zone, represented by the first-named index fossil only.

The $O$. aspinata Zone is present in the interval $6680^{\prime}-6820^{\prime}$ and the fauna includes the index fossil and Kinkelinella (Klinglerella) medioreticulata and Nanacythere (Goniocythere) elegans as the most important species. The zone is thin and the occurrence of the latter species refers the zone to the Lower Sinemurian; thus the Hettangian is assumed not to be present within the interval. On the basis of the presence of the two latter zones the interval $6610^{\prime}-6820^{\prime}$ is referred to the Lower Sinemurian.

The upper boundary of the Lower Jurassic is here placed on the basis

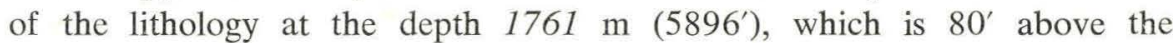
uppermost occurrence of the Lower Jurassic ostracods. The light grey siltstone above $1761 \mathrm{~m}\left(5896^{\prime}\right)$ is referred to Middle Jurassic by correlation with borings in North Jylland. The lower boundary of the Lower Jurassic is also established from the lithology, and it is placed at the depth $2042 \mathrm{~m}$ 
$\left(6820^{\prime}\right)$. The samples down to $7920^{\prime}$ have been studied without recording any Triassic ostracods, but the sediments below the Lower Jurassic boundary are interpreted to belong to the Gassum Formation.

\section{The Dansk Nords $\phi K-1$ boring}

The boring is located in the northern part of the Danish North Sea area, ca. $87 \mathrm{~km}$ west of Hanstholm, in North Jylland. The coordinates of the position are $57^{\circ} 07^{\prime} 48^{\prime \prime}$ North and $07^{\circ} 09^{\prime} 43^{\prime \prime}$ East. It was drilled in the period 21st Jan. to 7th Feb., 1970 by the Dansk Undergrunds Consortium company.

The section dealt with in the present paper is represented by cuttings samples taken every $30^{\prime}$, rarely every $20^{\prime}$.

The lithological description and the lithostratigraphical subdivision given below and on the text-fig. 14 are based on an unpublished report by Finn Bertelsen, F. Nyhuus Kristoffersen, F. Lyngsie Jacobsen and Olaf Michelsen:

Haldager Formation, 1371-1392 m: Sand of angular and subangular quartz grains, and siltstone with lignite and iron oxides. Lowest in the interval a few feet thick bed of dark grey claystone occurs.

Fjerritslev Formation, 1392-1948 m: Claystone or shale, more or less silty, dark grey, with subordinate beds of siltstone. In the interval 5450'$5460^{\prime}$ glauconitic siltstone and sandstone occur.

Gassum Formation, below 1948 m: Sandstone with gravel, with a coal bed at 6660 '.

The Fjerritslev Formation is rather uniformly developed, and the electrical logs do not show any of the characteristic features known from borings in North Jylland (see also Dansk Nordsø F-1, p. 62).

The stratigraphical subdivision is based solely on the ostracod faunas, which in certain intervals are rich.

The interval 4700'-5000' contains a fauna belonging to the $O$. adenticulata - N. (N.) simplex Zone. The dominating species are Ogmoconcha amalthei amalthei and Ogmoconchella adenticulata, whereas the Nanacythere-species are not recorded. The interval may be correlated with Upper Pliensbachian without differentiation into subzones.

The $O$. danica Zone, which is considered to comprise the interval $5000^{\prime}-$ $5900^{\prime}$, is in general poor in species and in specimens. The uppermost 200 


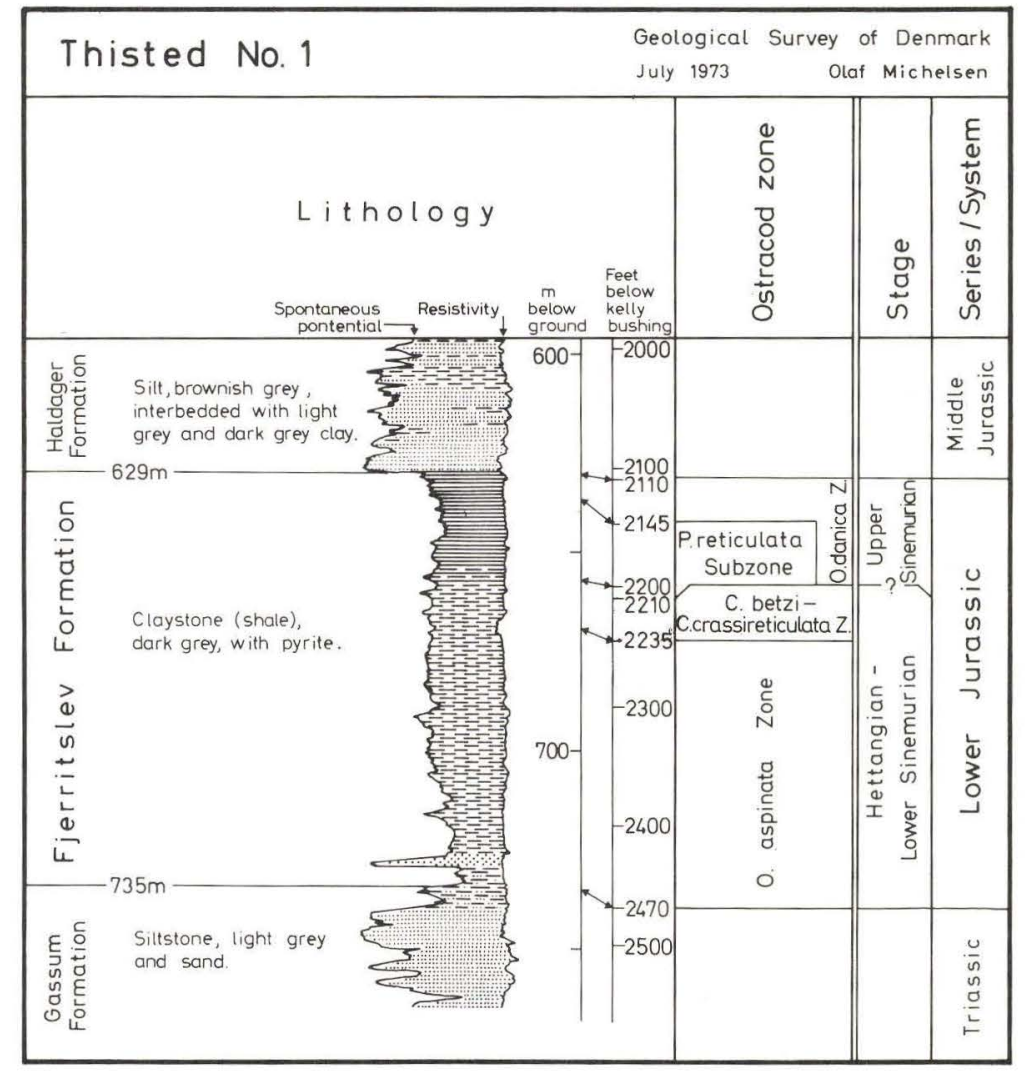

Text-fig. 12.

D. G. U. II. Rk. Nr. 104

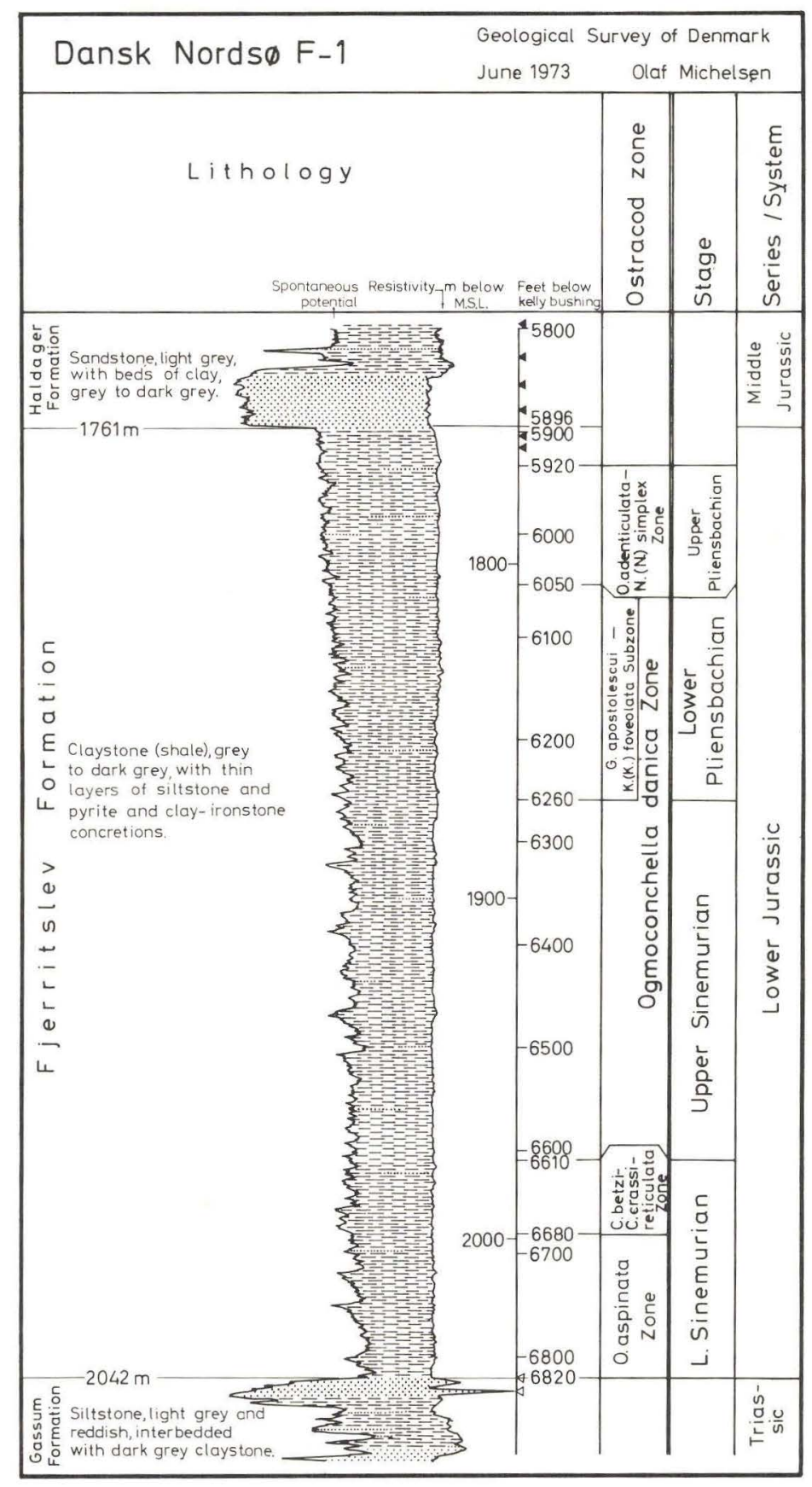

Dansk Nordso K-1 Geological Survey of Denmark

Dansk Nords $\emptyset$ K-1 June 1973 Olat Michelsen

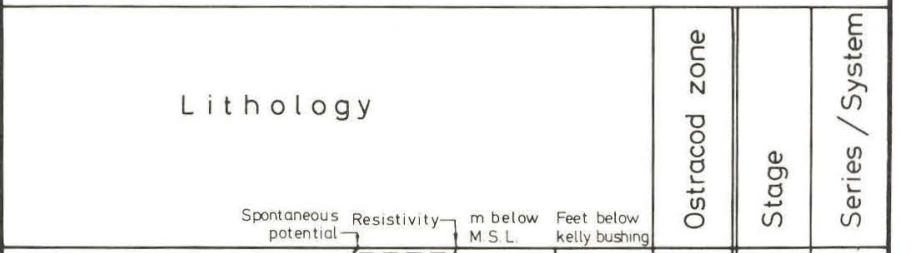
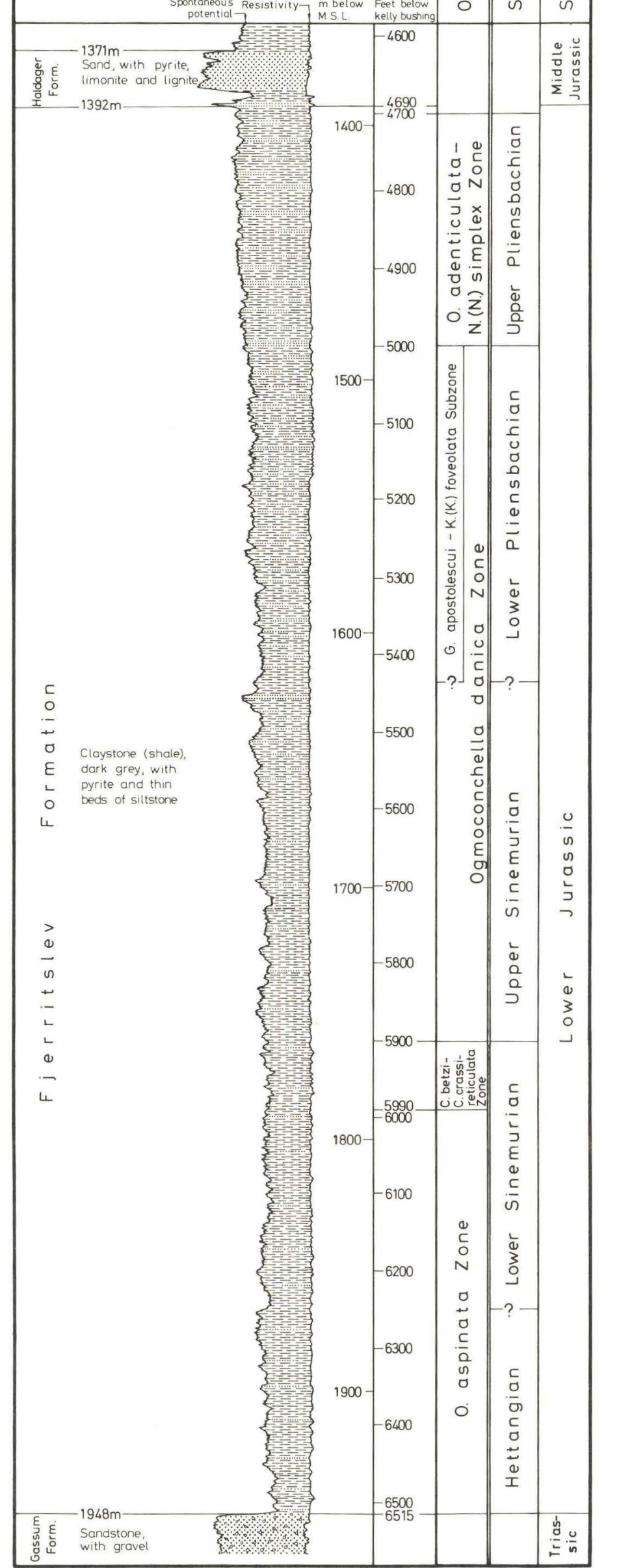

Text-fig. 14. 
feet of the zone contain a rather good fauna characteristic of the G. apostolescui - K. (K.) foveolata Subzone. In the neighbouring boring, Dansk Nords $\varnothing$ F-1, the lower boundary of this subzone is based on the species Progonoidea acuticostata. In the present boring this species is found together with Kinkelinella (Klinglerella) laqueata at 5510', in the section with the fauna poor in specimens, so it seems obvious that $P$. acuticostata occurs here as a caving. The lower boundary of the $G$. apostolescui $-K$. (K.) foveolata Subzone is therefore probably placed too low in the present section (see text-fig. 14). The interval $5000^{\prime}-5900^{\prime}$ may in its entirety be correlated with Upper Sinemurian and Lower Pliensbachian.

The interval 5900'-5990' contains very few ostracods, among others Cristacythere betzi, and it is assumed to belong to the C. betzi - C. crassireticulata Zone. As none of the species recorded from the samples immediately above 5900' are stratigraphically significant, the boundary between Lower and Upper Sinemurian must be taken with caution.

The $O$. aspinata Zone comprises the interval 5990'-6515', and the rich fauna is characterized and dominated by the index fossil and by Ogmoconcha hagenowi. The boundary between Hettangian and Lower Sinemurian is determined with some uncertainty from the occurrence of Nanacythere (Goniocythere) elegans, N. (G.) paracostata and $N$. (G.) circumcostata (cf. text-fig. 14).

The uppermost occurrence of Lower Jurassic ostracods is found immediately below the Haldager Formation so the upper boundary of the Lower Jurassic is with confidence placed at $1392 \mathrm{~m}\left(4690^{\prime}\right)$. The Haldager Formation is determined, by correlation with the borings in North Jylland, to Middle Jurassic. The lower boundary of Lower Jurassic is determined from the lithology and placed at $1948 \mathrm{~m}$ (6515'). The beds below this depth are referred to Triassic and the sediments are interpreted as belonging to the Gassum Formation. The samples down to the depth $7490^{\prime}$ have been analysed without recording any Triassic ostracods.

\section{The Gassum No. 1 boring}

The boring is described by Gregersen \& Sorgenfrei (1951), Nørvang (1957), Sorgenfrei \& Buch (1964), and Larsen (1966); the lowermost interval of the Lower Jurassic series is described by Michelsen (1973b).

The description of the lithology and the lithostratigraphical subdivision given below are in accordance with Sorgenfrei \& Buch (1964) and Larsen (1966) respectively: 
Børglum Formation, $1186-1198 \mathrm{~m}$ : Shale and sandy shale, dark grey to bluish grey.

Fjerritslev Formation, 1198-1513 m: 1198-1303 m: Lias Delta. Shale, dark grey, with clay-ironstone concretions. 1303-1361 m: Lias Gamma. Shale, dark grey, with grey shaly sandstone in the lower part. 1361-1407 in: Lias Beta. Shale, dark greenish grey, with clay-ironstone concretions. 1407-$1513 \mathrm{~m}$ : Lias Alpha. Shale, dark grey, locally with thin beds of grey sandstone.

Gassum Formation, 1513-1642 m: Sand and sandstone, light grey, interbedded with dark grey shale.

The stratigraphical subdivision of the Fjerritslev Formation presented here is based upon Hans Frebold's examination of the megafossils and is used by Sorgenfrei \& Buch (1964) and Larsen (1966). In his subdivision of the Lower Jurassic series Nørvang (1957) places the Lias Beta-Gamma boundary 10 to $15 \mathrm{~m}$ higher in the section, between the cores $4400^{\prime}-4417^{\prime}$ and $4450-4466^{\prime}$ (see text-fig. 15 ).

The Lower Jurassic section is represented by several cores, of which nearly all contain ostracod faunas rich in species and in specimens (text-fig. 15 and tables $3,7,11)$. As only very little material has been recorded from the cuttings samples, the boundaries between zones and stages will not be given with depth figures, but as located between two cores.

All information concerning the species occurring, their range and dominance within the cores are given in text-fig. 15 and in tables 3, 7, 11, so only the stratigraphical subdivision based on the ostracod assemblages and on the megafossils will be outlined below.

Upper Pliensbachian corresponds to the $O$. adenticulata $-N$. (N.) simplex Zone, defined as the core interval 3967'-4230'. The finding of A. margaritatus in the core $4080^{\prime}-4092^{\prime}$ and the underlying cores, and of $P$. spinatum in the core 4016'-4024' determines these intervals as Upper Pliensbachian. The section may therefore be subdivided into the two ammonite zones: the $A$. margaritatus Zone and the $P$. spinatum Zone. The ostracod fauna, too, shows a subdivision at the same level in the section, so the $O$. adenticulata $-N$. (N.) simplex Zone is composed of two subzones which correspond stratigraphically to the two ammonite zones (cf. p. 39).

Upper Sinemurian and Lower Pliensbachian corresponds to the $O$. danica Zone, defined as the core interval $4265^{\prime}-4570^{\prime}$. The stratigraphical determination is based on the ostracod faunas and is supported by the occurrence of $P$. planicosta in the core $4500^{\prime}-4518^{\prime}$ and of $A$. capricornus in the core $4300^{\prime}-4310^{\prime}$. On the basis of the ostracod faunas the Upper Sinemurian 
may possibly be subdivided parallel to the ammonite zones used in North Germany, whereas the Lower Pliensbachian remains undifferentiated (cf. p. 28).

Hettangian and Lower Sinemurian, based on the $O$. aspinata Zone and the C. betzi - C. crassireticulata Zone, constitute the core interval 4599'$4970^{\prime}$. The finding of Psiloceras $s p$. in the core $4950^{\prime}-4970^{\prime}$ and of $S$. angulata in the cores $4800^{\prime}-4820^{\prime}$ and $4850^{\prime}-4870^{\prime}$ refer these parts of the section to Hettangian. The sequence in the core $4649^{\prime}-4668^{\prime}$ is referred to Lower Sinemurian from the occurrence of $O$. sinemuriensis $(O$. inaequivalvis). On the basis of the ostracod fauna the Hettangian-Lower Sinemurian boundary is placed between $4768^{\prime}$ and $4800^{\prime}$, and the Lower-Upper Sinemurian boundary between the depth $4570^{\prime}$ and $4599^{\prime}$ (cf. pp. 26 and 28).

The present subdivision of the Lower Jurassic series differs from that given in Sorgenfrei \& Buch (1964), but it conflicts with the stratigraphical data recovered by means of megafossil analyses only in the question concerning the Lower-Upper Pliensbachian boundary. The first Amaltheids are found together with A. capricornus in the core $4300^{\prime}-4310^{\prime}$, so the upper boundary of Lias Gamma is placed about the depth 4300' by Hans Frebold (cf. Nørvang, 1957). The ostracod fauna in the overlying core, 4265'$4286^{\prime}$, is poor in specimens and does not contain any certain indication of Lias Delta, but only indications of Lias Gamma are recorded (cf. p. 38). It is therefore assumed that this core must be included under the older substage, Lower Pliensbachian (Lias Gamma). The different evaluation of the stratigraphical level may be due to the poor ostracod fauna found in the core $4265^{\prime}-4286^{\prime}$. On the other hand, it must be emphasized that none of the two ostracod species, Polycope cincinnata and Monoceratina amlingstadtensis, have been found in Upper Pliensbachian in France or Germany. This argument may be rather weak, as the two species mentioned have only been recorded rarely, and future investigations may elucidate the problem more thoroughly.

The former determination of the lower and upper boundaries of the Lower Jurassic, at $1198 \mathrm{~m}$ and $1513 \mathrm{~m}$, are well-founded and are used here.

\section{The Ronde No. 1 boring}

This boring is thoroughly described in Rasmussen et al. (1971). The faunas and the lithology in the Lower Jurassic and the overlying and underlying series, are described by Bang (1971), Christensen (1971a and 1971b) and Michelsen (1971a). The detailed diagram in text-fig. 16 is shown here because this boring comprises the most comprehensive Lower Jurassic series in this part of the Danish Embayment. 
The description of the lithology and the lithostratigraphical subdivision given below are in accordance with Rasmussen et al. (1971):

? Haldager Formation, 2133-2188 m: Claystone, brown to brownish grey, alternating with siltstone, with lignite and plant remains.

Fjerritslev Formation, 2188-2607 m: 2188-2249 m: Claystone, light grey and greenish grey. 2249-2448 m: Shale, dark grey to dark brownish grey, with clay-ironstone. $2448-2607 \mathrm{~m}$ : Shale as above, and with intercalations of light siltstone.

Gassum Formation, 2607-2743 m: Siltstone, light grey and grey, interbedded by claystone, dark grey and reddish brown.

According to the above-mentioned authors the Triassic-Jurassic boundary is coincident with the lower limit of the Fjerritslev Formation; and the Lower-Middle Jurassic boundary must be placed within the lower part of the Haldager Formation.

The entire Lower Jurassic series is represented by cuttings samples taken every $10^{\prime}$ and $15^{\prime}$.

Nearly all the cuttings samples contain rather good ostracod faunas useful for the stratigraphical subdivision.

Sample $7195^{\prime}-7210^{\prime}$ contains one larval shell of the species Kinkelinella (Kinkelinella) oblonga, which indicates the presence of Aalenian. Neither the underlying part of the Haldager Formation nor the greenish claystone in the Fjerritslev Formation has yielded other ostracods or foraminifera. In the samples 7330'-7345' and 8140'-8165' Finn Bertelsen (personal communication) has found a few specimens of the megaspore Erlansonisporites excavatus Marcinkiewicz, 1962 (cf. Michelsen, 1971a). In Poland and East Germany this species is known from Lias Epsilon-Zeta (Rusbült \& Petzka, 1964). The upper part of the Fjerritslev Formation and the lowest part of the Haldager Formation may therefore be correlated with the Upper Lias.

The uppermost occurrence of Ogmoconcha-species is found at 7390' and the interval $7390^{\prime}-7885^{\prime}$ is constituted by the $O$. adenticulata $-N$. (N.) simplex Zone. As mentioned on p. 41, the zone in the present section may be subdivided into three parts. The uppermost part is characterized by a poor fauna in which the two most important species are Ogmoconchella adenticulata and Nanacythere (Domeria) fissicosta. A fauna of this character is not known in the Gassum section, and as the zone is thicker in the present boring, it seems possible that this upper part of the zone is not present in the Gassum section. The middle part of the zone in Rønde No. 1 is characterized by Nanacythere (Nanacythere) simplex, N. (Domeria) firma and $N$. (D.) fissicosta and resembles the upper subzone in Gas- 


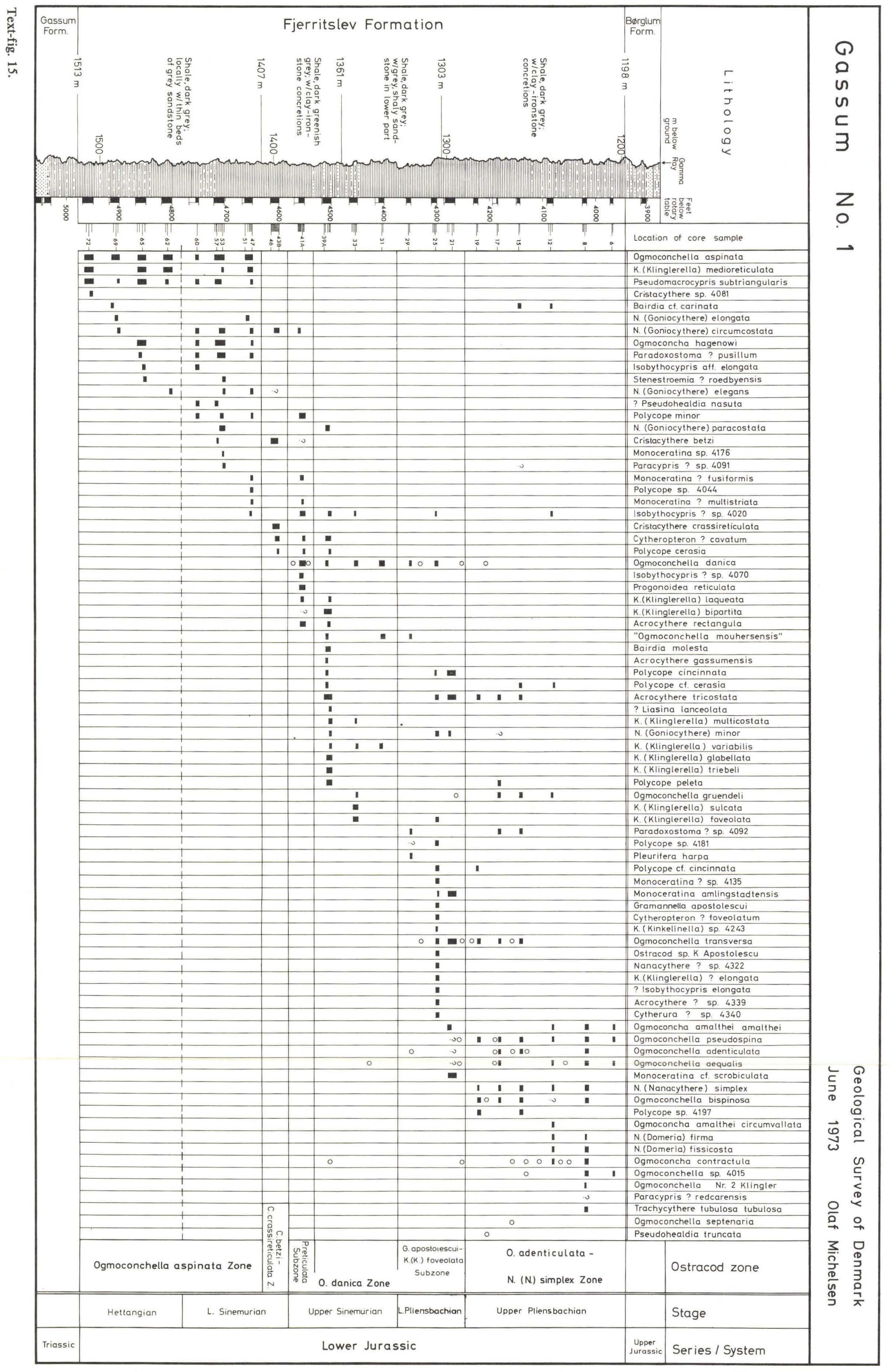


D. G. U. II. Rk. Nr. 104

\section{Rønde No.1}

Geological Survey of Denmark

une 1973 Olaf Michelsen

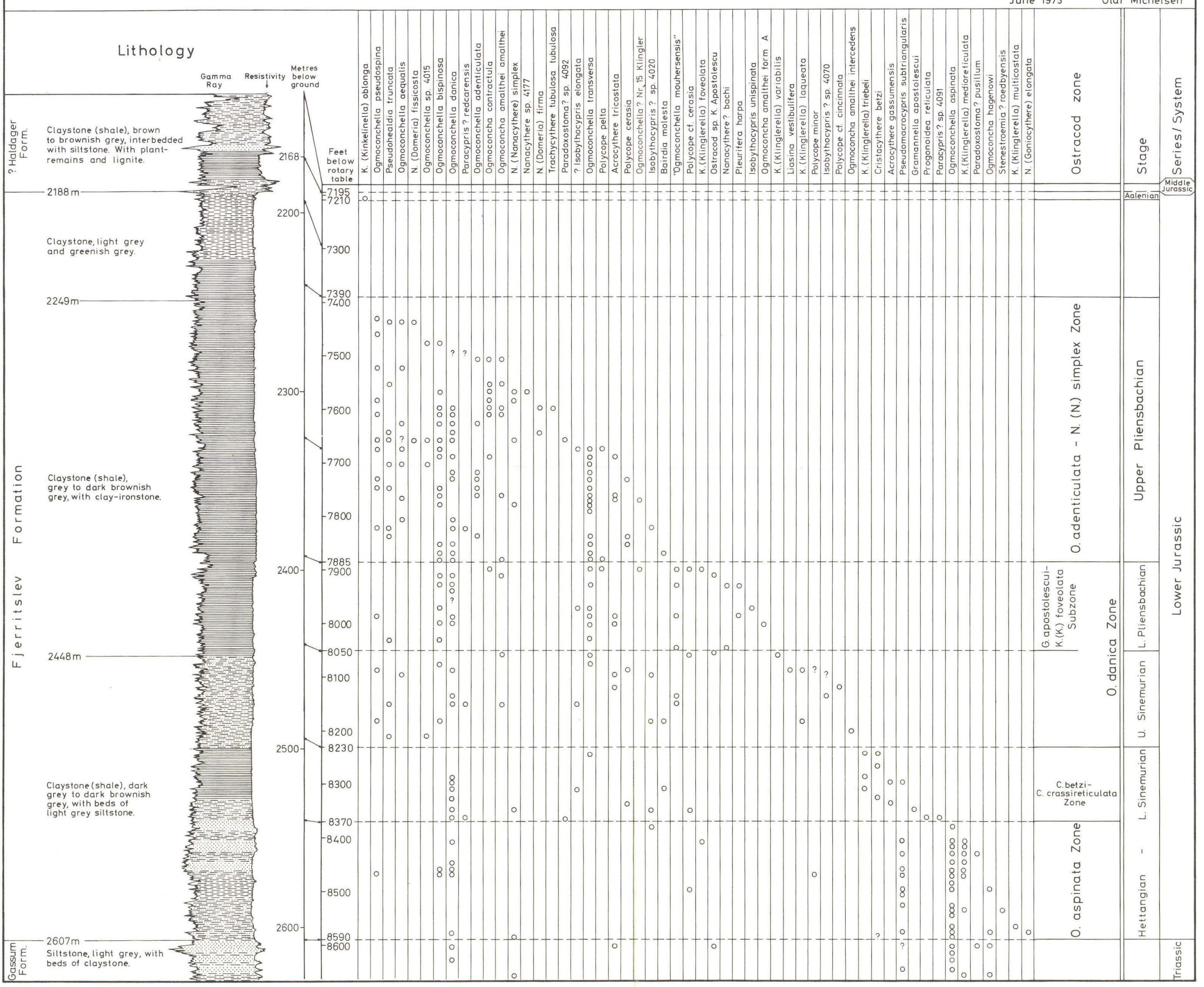

Text-fig. 16. 
sum. The lower part of the zone in Rønde No. 1 is also typical and resembles the lower subzone with the occurrence of Ogmoconchella transversa and Acrocythere tricostata.

The interval $7885^{\prime}-8230^{\prime}$ contains a scattered but characteristic fauna belonging to the $O$. danica Zone. The uppermost boundary of the zone is placed at the uppermost occurrence of Kinkelinella (Klinglerella) foveolata and "Ogmoconchella mouhersensis". The upper boundary may possibly be placed too low in the section as the species Ogmoconchella danica is found above the boundary. $O$. danica also occurs above this boundary in the Gassum section, so it is assumed that it is its occurrence together with the two other species which is a certain basis for the boundary. The fauna in the upper part of the $O$. danica Zone, in the interval $7885^{\prime}-8050^{\prime}$, permits the determination of the $G$. apostolescui $-K$. (K.) foveolata Subzone and the correlation of this interval with the Lower Pliensbachian. The lower part of the $O$. danica Zone, $8050^{\prime}-8230^{\prime}$, can be correlated with the Upper Sinemurian. The occurrence of Kinkelinella (Klinglerella) variabilis indicates a possible occurrence of the uppermost Upper Sinemurian; and the occurrence of the species $K$. (Klinglerella) laqueata and $K$. (K.) triebeli may indicate the occurrence of the lower part of the substage (Lias Beta-1). The finding of Progonoidea reticulata in samples from a deeper level is interpreted as due to cavings, but shows that the $P$. reticulata Subzone must be present.

The interval $8230^{\prime}-8370^{\prime}$ contains a poor fauna characterized by Cristacythere betzi. The interval is referred to the $C$. betzi $-C$. crassireticulata Zone and correlated with the uppermost Lower Sinemurian.

The lower part of the Lower Jurassic series, 8370'-8590', is included under the $O$. aspinata Zone, but the boundary between Hettangian and Lower Sinemurian cannot be established on the basis of the present material.

The Triassic-Jurassic boundary is placed at $2607 \mathrm{~m}$ on the basis of the lithology. The Lower-Middle Jurassic boundary is referred to the top of

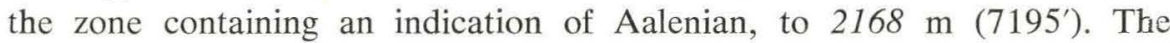
sample $7195^{\prime}-7210^{\prime}$ represents a thin zone of claystone and, in the author's opinion, shows an intercalation of the Fjerritslev Formation in the Haldager Formation (cf. Michelsen 1971a). Stratigraphically the lowest part of the Haldager Formation and the underlying greenish claystone is supposed to correspond to the Toarcian and Aalenian.

\section{The Vinding No. 1 boring}

The boring is described by Nørvang (1957), Sorgenfrei \& Buch (1964), Larsen (1966) and in parts by Michelsen (1973b). 
The description of the lithology and the lithostratigraphical subdivision given below and on text-fig. 17 are in accordance with Larsen (1966):

Fjerritslev Formation, 1367-1580 m: 1367-1453 m: Claystone, sandy, greyish brown. 1453-1580 m: Shale, bluish grey to dark grey, with clayironstone concretions.

Vinding Formation, 1580-1720 m: Claystone, dark grey, with subordinate beds of fine sand, light grey.

The uppermost part of the Fjerritslev Formation, 1367-1453 m, is questionably referred to Middle Jurassic, whereas the lower part, 1453-1580 m, is determined as Lower Jurassic. The Vinding Formation is based on fossils determined as Rhaetic (cf. Sorgenfrei \& Buch, 1964 and Larsen, 1966).

The Lower Jurassic series is represented by three cores, of which the lower two contain ostracod faunas (cf. text-fig. 17 and table 2).

The upper of the two cores, 4993'-5007', contains an ostracod fauna relatively rich in species and belonging to the $O$. aspinata Zone. The fauna is characterized by Ogmoconchella aspinata, Pseudomacrocypris subtriangularis and Ogmoconcha hagenowi. The fauna of the lower core, 5156'$5162^{\prime}$, belongs to the same zone, but comprises only the first-named species and Kinkelinella (Klinglerella) medioreticulata. The relationship between the two faunas relative to their location in the sedimentary sequence corresponds to the known features of the $O$. aspinata Zone in Gassum and R $\varnothing$ dby, and it indicates a Hettangian age for the lower and a Lower Sinemurian age for the upper core.

The sedimentary sequence above these two cores may be stratigraphically subdivided by means of the cuttings samples. The interval $4805^{\prime}-4840^{\prime}$ contains a fauna characterized by Ogmoconchella danica and Kinkelinella (Klinglerella) bipartita, which refer the interval to the $O$. danica Zone. The $P$. reticulata Subzone comprises the interval, 4840'-4890', and the fauna is characterized by Ogmoconchella danica and Progonoidea reticulata. The section $4805^{\prime}-4890^{\prime}$ must be correlated with the Upper Sinemurian. The biostratigraphical determination of the interval $4890^{\prime}-4993^{\prime}$ on the other hand is less certain as only three samples contain ostracods. Cristacythere betzi is found immediately below the upper boundary of the interval, so at least the upper part of the interval must be referred to the $C$. betzi $-C$. crassireticulata Zone and correlated with the Lower Sinemurian. The lowest interval, 4993'-5200', must on the basis of the fauna of the two cores and one cuttings sample be referred to the $O$. aspinata Zone and correlated with the Lower Sinemurian and the Hettangian.

The stratigraphical subdivision is supported by the megafossil analysis of 


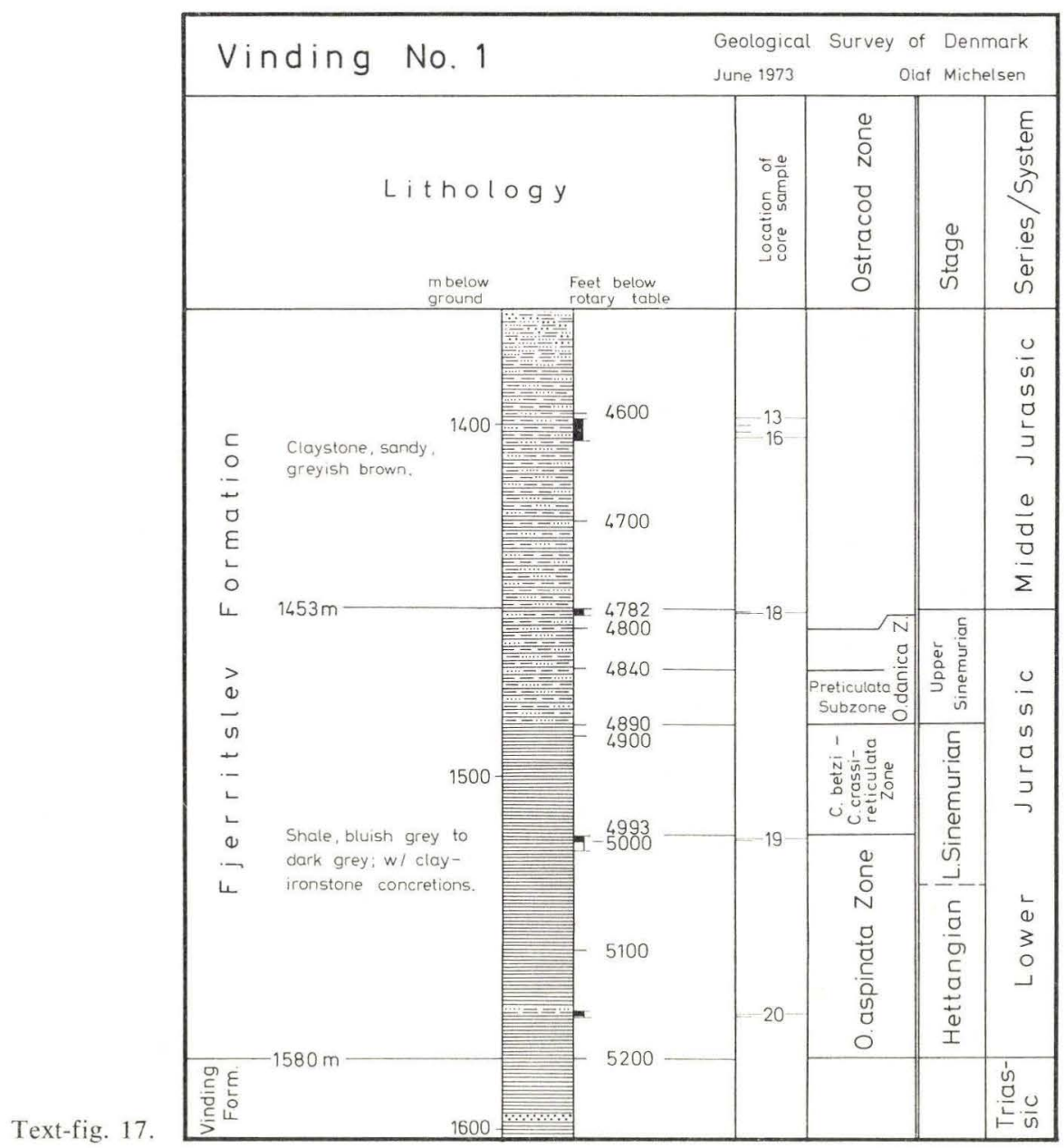

Hans Frebold (cf. Nørvang, 1957). In core $4782^{\prime}-4788^{\prime}$ the index fossil $P$. planicosta occurs with some doubt about the identification and in the core 4993'-5007' Arietites sp. occurs; S. angulata is found in a sample of unknown depth.

There is thus a well-founded basis for correlating the series $4782^{\prime}-4890^{\prime}$ with the Upper Sinemurian, and 4890'-5200' with the Lower Sinemurian and Hettangian. The boundary between Hettangian and Sinemurian is assumed to be located between the two cores: 4993'-5007' and 5156'-5162'.

Nothing can be added regarding the determination of the upper boundary of the Lower Jurassic $(1453 \mathrm{~m})$ on the basis of the present material. The Triassic-Jurassic boundary, at $1580 \mathrm{~m}\left(5200^{\prime}\right)$, is based partly on the 
lithology and partly on the finding of A. contorta in the core $5353^{\prime}-5360^{\prime}$ (determined by Hans Frebold).

\section{The Vejrum No. 1 and Vemb No. 1 borings}

Cuttings samples and core samples from the neighbouring Vejrum No. 1 and Vemb No. 1 borings have been examined. The recorded faunas are generally sparse, but a broad evaluation of the biostratigraphical conditions is possible. The sedimentary sequences containing ostracod faunas are referrable to the same zones as in Vinding No. 1. The section of Vemb No. 1 must undoubtedly be referred to the $O$. danica Zone and the $O$. aspinata Zone, whereas only the latter zone is proved with certainty in the Vejrum section.

\section{The N $\phi$ vling No. 1 boring}

The boring is described by Rasmussen et al. (1973). The faunas and the lithology of the Lower Jurassic series and of the underlying and overlying sections are treated by Bang (1973), Christensen (1973a and 1973b) and Michelsen (1973a).

The description of the lithology and the lithostratigraphical subdivision given below are in accordance with the above-mentioned authors:

Børglum Formation, 1486-1502 m: Claystone, partly silty, greyish black, with pyrite.

Fjerritslev Formation, 1502-1840 m: Claystone, greyish black, with pyrite and clay-ironstone concretions, and with intercalations of siltstone in the upper and the lower parts.

Vinding Formation, 1840-1989 m: Claystone, reddish brown, greyish brown and grey, interbedded by siltstone and limestone.

The entire Fjerritslev Formation is correlated with the Lower Jurassic (Michelsen, 1973a); the Vinding Formation with the Rhaetic and the Keuper, and the Børglum Formation with the Upper Jurassic (Christensen, 1973a and 1973b).

The Lower Jurassic series is represented solely by cuttings samples taken every $15^{\prime}, 20^{\prime}$ and $30^{\prime}$. Except for the uppermost 20 feet the entire series contains an abundant and well-preserved ostracod fauna.

The interval $5010^{\prime}-5120^{\prime}$ is correlated with the lower part of the Upper Pliensbachian, corresponding to the A. margaritatus Zone. The recorded 


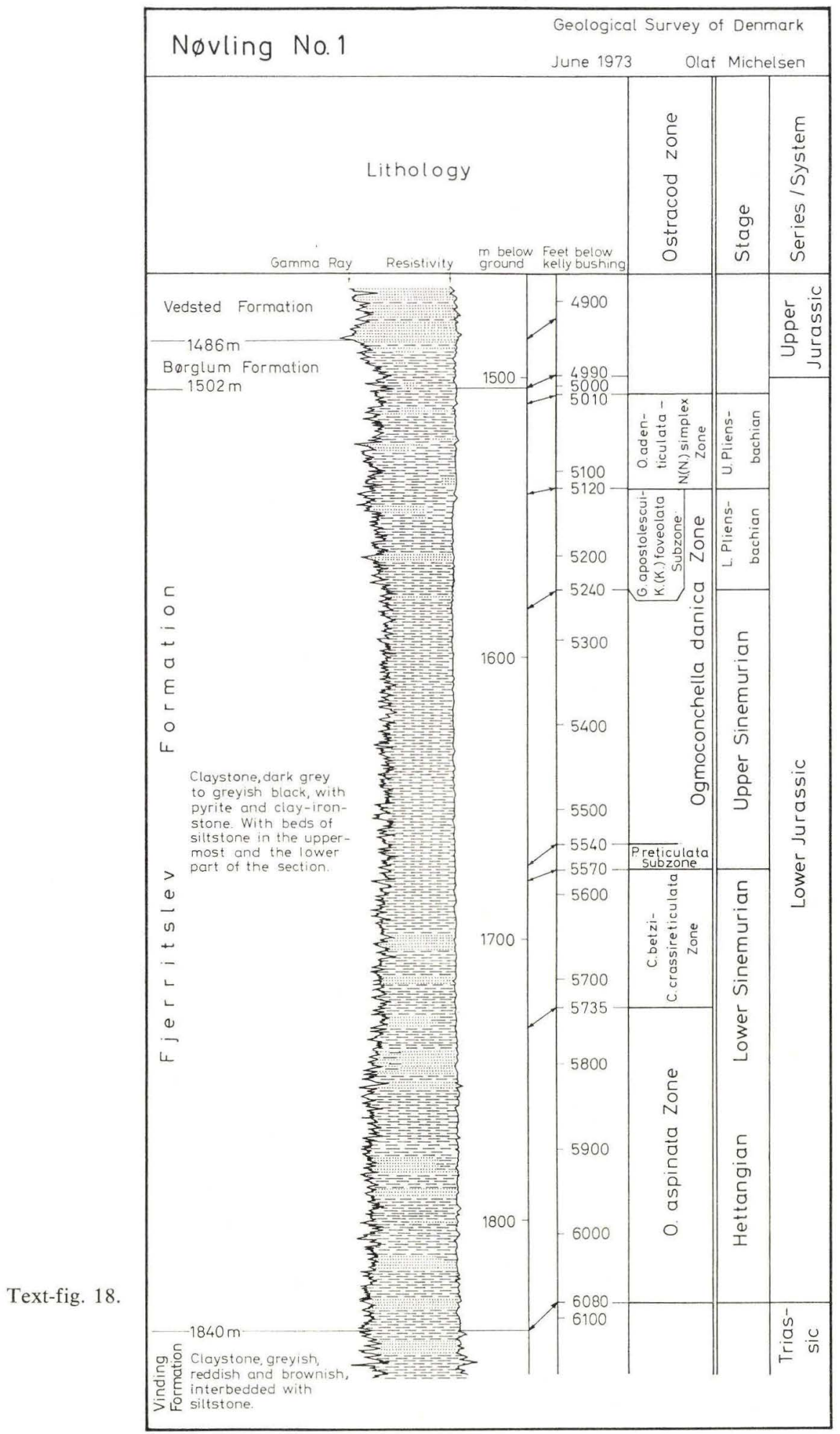


ostracod fauna belongs to the $O$. adenticulata $-N$. ( $N$.) simplex Zone and is characterized by the species Ogmoconchella transversa, Acrocythere tricostata and Nanacythere (Nanacythere) simplex.

The interval $5120^{\prime}-5570^{\prime}$ is referred to the $O$. danica Zone, and the upper boundary is based on the occurrence of Monoceratina amlingstadtensis. From the occurrence of the index fossils the interval $5120^{\prime}-5240^{\prime}$ is separated as the $G$. apostolescui - K. (K.) foveolata Subzone and correlated with the Lower Pliensbachian. The underlying parts of the $O$. danica Zone are correlated with the Upper Sinemurian; the lower boundary of the G. apostolescui - K. (K.) foveolata Subzone, at 5240', is based on the uppermost occurrence of the species Kinkelinella (Klinglerella) variabilis and $K$. (K.) multicostata. The lowermost $30^{\prime}$ of the $O$. danica Zone is embraced by the $P$. reticulata Subzone, which is correlated with Lias Beta-1a.

The uppermost part of the Lower Sinemurian includes the C. betzi $-C$. crassireticulata Zone in the interval 5570'-5735' of the Nøvling section. The fauna is relatively poor and is only characterized by the first-named index fossil.

The interval 5735'-6080' contains a fauna rich in specimens and belonging to the $O$. aspinata Zone. The Hettangian-Sinemurian boundary cannot be located, but the presence of Lower Sinemurian can be established from the ostracod fauna.

Both the upper and lower boundaries of the Lower Jurassic, at $1502 \mathrm{~m}$ and $1840 \mathrm{~m}$ respectively, are here given according to previous determinations (Michelsen, 1973a).

\section{The Horsens No. 1 boring}

The boring is described by Sorgenfrei \& Buch (1964) and Larsen (1966).

The description of the lithology and the lithostratigraphy given below are in accordance with the above-mentioned authors:

? Haldager Formation, 1220-1294 m: Sandstone and siltstone, pale greenish, glauconitic.

Fjerritslev Formation, 1294-1569 m: 1294-1309 m: Sandstone and siltstone, pale greenish, glauconitic. 1309-1569 m: Shale, dark grey and greyish black, with dark brown beds; at the base with dark grey sandstone and siltstone.

Gassum Formation, 1569-1603 m: Sandstone and siltstone, alternating with greyish black shale; lignite seams.

The Triassic-Jurassic boundary is placed at the top of the Gassum For- 


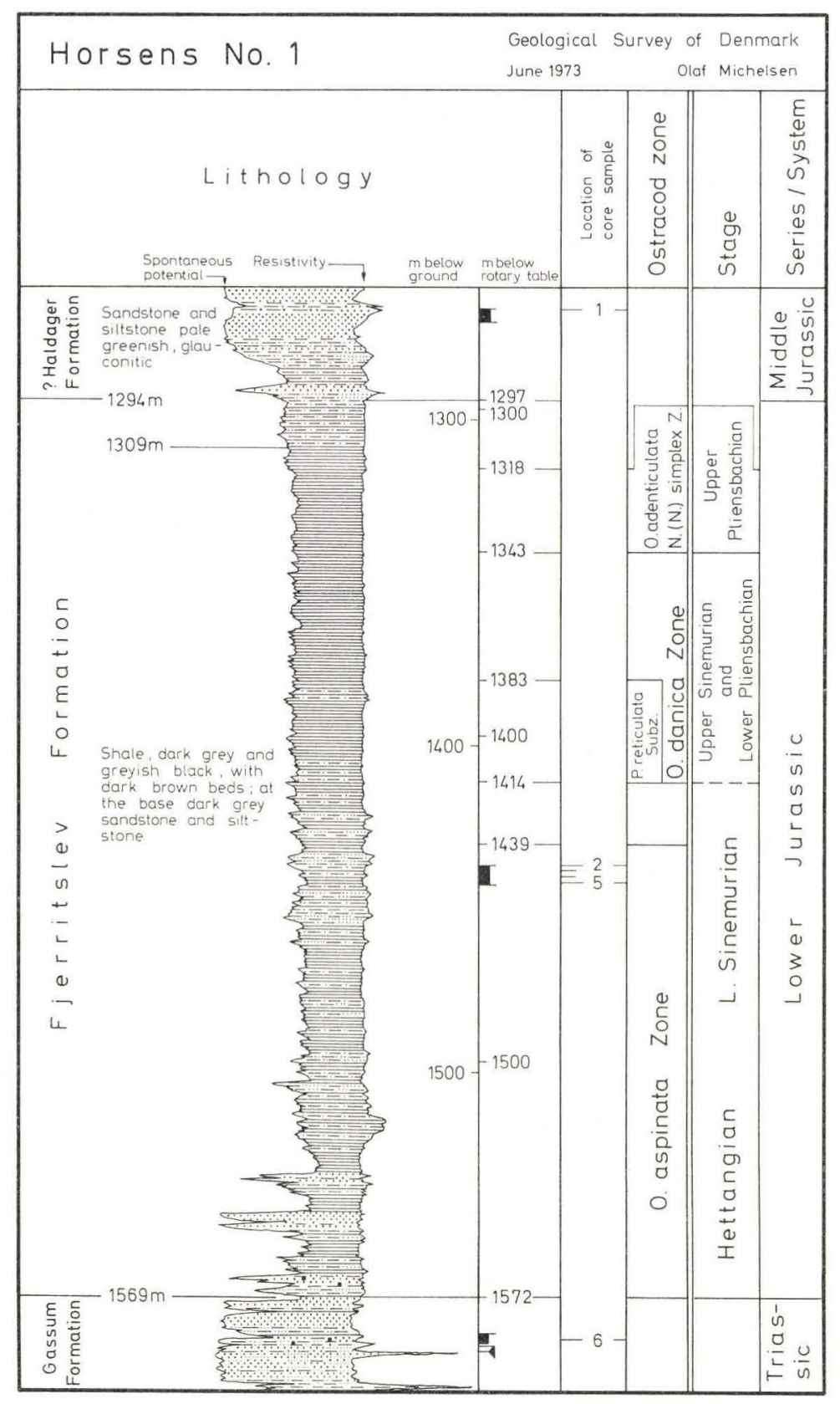

Text-fig. 19. 
mation, at $1569 \mathrm{~m}$; whereas the boundary between the Lower and Middle Jurassic is located within the Fjerritslev Formation, at the mentioned lithological break at 1309 m (cf. Sorgenfrei \& Buch, 1964).

The Lower Jurassic series is only represented by one core, 1449-1455 m (cf. text-fig. 19). The abundant ostracod fauna recorded from the core belongs to the $O$. aspinata Zone and is the basis for correlating the interval with the Lower Sinemurian (cf. table 2).

The cuttings samples contain abundant ostracod faunas, which can be used as basis for a stratigraphical subdivision of the sedimentary sequence. The highest occurrence of Lower Jurassic ostracods is found at $1318 \mathrm{~m}$. The fauna recorded from the interval $1318-1343 \mathrm{~m}$ is rather poor in species, but belongs to the $O$. adenticulata $-N$. (N.) simplex Zone. It is characterized by the species Ogmoconcha amalthei amalthei, O. contractula and Ogmoconchella sp. 4015, so the interval is assumed to correlate with the Upper Pliensbachian.

The interval 1343-1414 $\mathrm{m}$ includes the $O$. danica Zone and is correlated with the Upper Sinemurian and questionably with the Lower Pliensbachian. Whether the $G$. apostolescui $-K$. (K.) foveolata Subzone is present or not can not be stated with certainty; the only representative of the subzone is the species Kinkelinella (Klinglerella) foveolata, found in a sample deeper in the section. The occurrence of the $P$. reticulata Subzone is, on the other hand, based on the index fossil recorded below the depth $1383 \mathrm{~m}$.

The first representatives of the $O$. aspinata Zone are found below $1439 \mathrm{~m}$. Above this depth occurs the species Ogmoconcha hagenowi, which elsewhere in the Danish Embayment is known from both the O. aspinata Zone and the $C$. betzi $-C$. crassireticulata Zone; hence it is assumed that the boundary between the Lower and Upper Sinemurian must be placed at $1414 \mathrm{~m}$.

The Triassic-Jurassic boundary, at $1569 \mathrm{~m}$, is determined from the lithology. The boundary between the Lower and Middle Jurassic was formerly located at $1309 \mathrm{~m}$. There are no biostratigraphical indications around that depth, so it is decided to determine the boundary by lithological correlation with the Rønde section. The boundary is therefore tentatively located at the depth $1294 \mathrm{~m}$.

\section{The Rфdby Nos. 1 and 2 borings}

Both of the borings are described by Sorgenfrei \& Buch (1964), whereas Nørvang (1957) and Larsen (1966) describe only the Rødby No. 1 boring. A revision of the stratigraphical subdivision of the Lower Jurassic series in the last-named boring is given by Bertelsen \& Michelsen (1970), who refer 
the entire section to the Hettangian and the Lower Sinemurian on the basis of the megaspore and ostracod assemblages. Michelsen (1973b) revises the lithological subdivision. The section is divided into an upper and a lower marine part, and a middle part dominated by delta-deposits, which is a subdivision corresponding also to the features of the environmental conditions indicated by the ostracod and the holothurian faunas.

Larsen (1966) includes the entire Lower Jurassic series under the Fjerritslev Formation, which seems questionable to the present author. Only smaller parts of the upper and lower marine intervals are typical for this formation, whilst at least the middle deltaic series shows greater resemblance to the Ullerslev Formation. The lowermost part of the Lower Jurassic series in the neighbouring $\emptyset$ rslev No. 1 boring also shows features resembling the Ullerslev Formation. It seems therefore questionable whether the Fjerritslev Formation occurs in this part of the Danish Embayment at all. The Lower Jurassic series is clearly present, but the sedimentary sequence differs so much from that of North Jylland, that at most only small parts can be included under the Fjerritslev Formation, whilst the other parts must be referred to the Ullerslev Formation or possibly to a new formation.

On the basis of the analysis of the ostracod faunas it is concluded that the section from Rødby No. 1 must be correlated with the Hettangian and the lower part of the Lower Sinemurian (cf. table 1). The boundary between the two stages is supposed to be placed within or at the top of the deltaic deposits. On account of the differences in the facies a direct comparison between Rødby and Gassum is difficult. The upper marine series in Rødby is characterized by the subgenus $N$. (Goniocythere), which is common and typical for that part of the $O$. aspinata Zone in Gassum which includes beds with $O$. sinemuriensis. It is therefore reasonable to conclude that this part of the series in Rødby No. 1 must be correlated with the Lower Sinemurian, whereas the lower marine series and possibly also the deltaic series are referrable to the Hettangian.

\section{The Ørslev No. 1 boring}

The boring is briefly described and the section is stratigraphically subdivided by Michelsen (1971b) and Rasmussen (1972).

The boring is located east of Nyk $\phi$ bing on the island of Falster. The coordinates of the position are $54^{\circ} 46^{\prime} 55^{\prime \prime}$ North and $11^{\circ} 59^{\prime} 02^{\prime \prime}$ East. It was drilled in the period 31st Oct., 1967 to 9th Jan., 1968 by the Dansk Undergrunds Consortium company.

The Lower Jurassic series and the sections above and below are described 
lithologically and subdivided lithostratigraphically on the basis of the original description worked out by Thomas Eriksen and Arne Dinesen.

The? Fjerritslev Formation, 451-619 m, is described in two intervals. The upper one, 451-519 m, consists of dark grey claystone with intercalations of siltstone; the lower one, 519-619 m, of grey and brownish grey siltstone with plant remains and lignite. Above the formation is found reddish brown marl, and below is found greenish grey claystone with lignite.

(In spite of the lithological break at $519 \mathrm{~m}$ which seems to be marked on the Schlumberger logs, the lithological features are not indicated correctly on these logs (cf. text-fig. 20). The source of error is thought to be that the casing is placed with the casing shoe at $516 \mathrm{~m}$. The section of the curve measured through the casing is considered to be weakened relatively to that part measured below it.)

The lithostratigraphical subdivision is questionable. Only the uppermost sedimentary sequence, 451-519 m, may be typical for the Fjerritslev Formation, whereas the lower one, which probably is a deltaic deposition, rather resembles the Ullerslev Formation. The entire Lower Jurassic series is provisionally referred to the Fjerritslev Formation because the corresponding section in the neighbouring Rødby No. 1 boring has earlier been referred to that formation (cf. Larsen, 1966). As mentioned under the Rødby Nos. 1 and 2 borings, the lithostratigraphical subdivision there is not in accordance with the definition of the Fjerritslev Formation, and parts of the Lower Jurassic series are supposed to belong to the Ullerslev Formation or to a new formation.

The marlstone overlying the ? Fjerritslev Formation in Ørslev can be classified with the Rødby Formation. The beds below $619 \mathrm{~m}$ are assumed to belong to the Ullerslev Formation.

The Lower Jurassic series is represented by cuttings samples taken every $30^{\prime}$, rarely every $10^{\prime}$ and $20^{\prime}$.

The occurrence of Progonoidea reticulata and Kinkelinella (Klinglerella) laqueata in the sample $1510^{\prime}-1540^{\prime}$ demonstrates the presence of the $P$. reticulata Subzone, but the finding of Kinkelinella (Klinglerella) foveolata and $K$. (K.) triebeli in samples from a deeper level indicates that younger parts of the $O$. danica Zone are also present in the section.

The samples just below $1540^{\prime}$ comprise faunas poor in species. The interval $1570^{\prime}-1600^{\prime}$ is taken to belong to the $C$. betzi $-C$. crassireticulata Zone, as the first-named index fossil is found in the sample. Therefore the Lower-Upper Sinemurian boundary is placed at $1570^{\prime}$, and the intervai $1510^{\prime}-1570^{\prime}$ is referred to the Upper Sinemurian. 


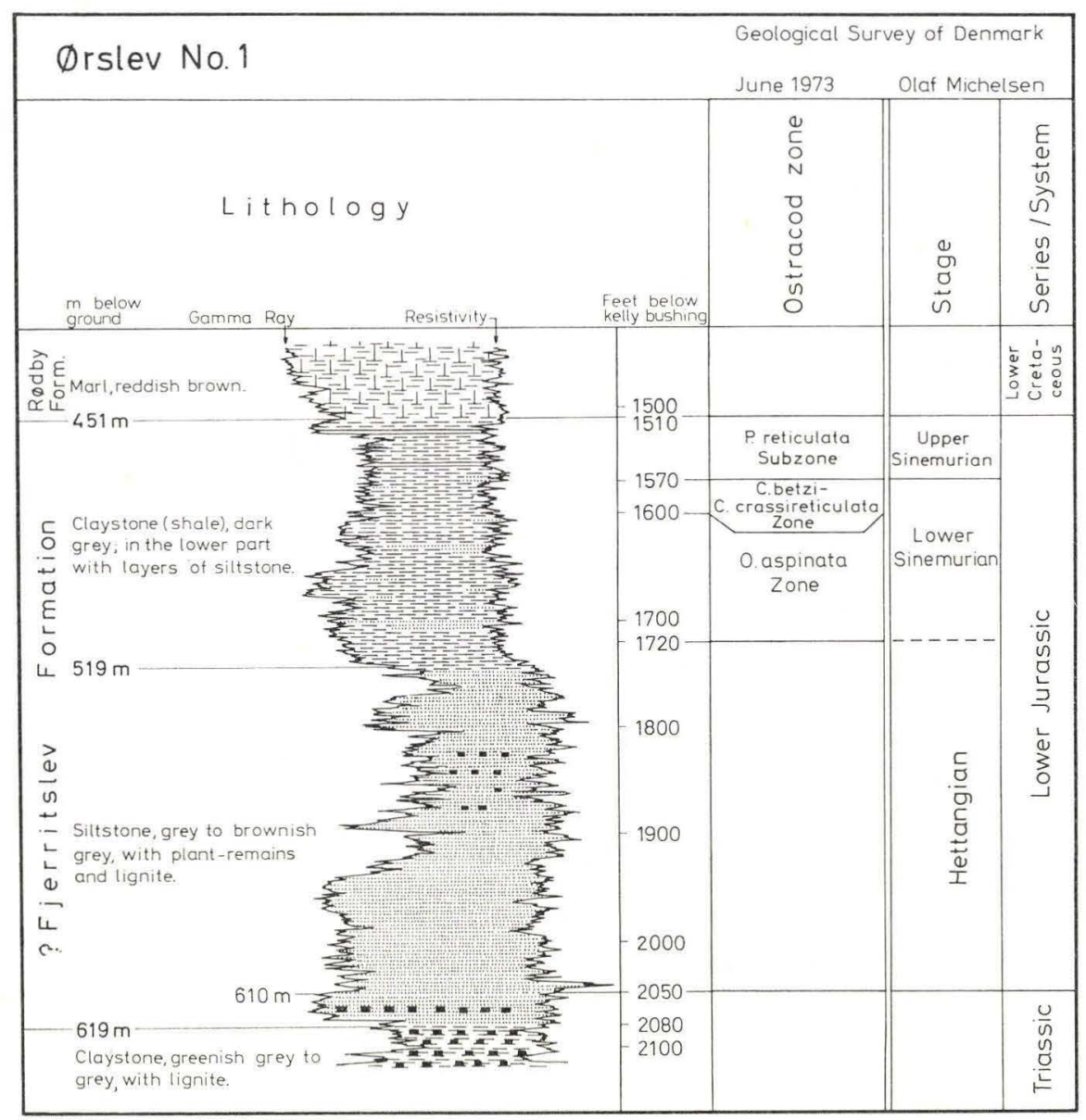

Text-fig. 20.

The interval $1600^{\prime}-1720^{\prime}$ contains a fauna relatively rich in species and belonging to the upper part of the $O$. aspinata Zone, the part which is correlated with the Lower Sinemurian.

Neither ostracods nor foraminifera are recorded from the remaining lower part of the ? Fjerritslev Formation, 1720'-2050', which is supposed to be of deltaic origin. Finn Bertelsen (unpublished report) has analysed the megaspores from this and the underlying section. In agreement with his subdivision of the Rødby section (cf. Bertelsen, 1970) he places the TriassicJurassic boundary at 2050', near the bottom of the siltstone series in $\varnothing_{\text {i- }}$ slev. Concordant with the stratigraphical determination based on the ostracod 
faunas and the megaspore assemblages in the Rødby section the interval $1720^{\prime}-2050^{\prime}$ in Ørslev No. 1 is referred to Hettangian.

Both the upper and the lower boundary of the Lower Jurassic in Ørslev No. 1 are well-documented. The lower boundary is proved by means of the megaspore assemblages and correlated with the Rødby section; the upper boundary is based on the ostracod fauna and on lithological correlation with the Rødby section.

\section{The Slagelse No. 1 boring}

The boring is described by Larsen \& Buch (1960) and Sorgenfrei \& Buch (1964).

The Lower Jurassic series is described as:

971-997 m: Claystone, bluish grey.

997-1022 m: Claystone, dark grey.

1022-1169 m: Claystone, dark grey, with beds of siltstone.

Above these series is found greyish green claystone referred to the Lower Cretaceous; and below is found grey and greenish grey claystone referred to the Rhaetic.

The examined cuttings samples contain only few ostracods, and the faunas are only found in the intervals $987-1042 \mathrm{~m}$ and $1142-1152 \mathrm{~m}$.

The recorded ostracod faunas represent three zones. The $O$. aspinata Zone, represented by the index fossil and Ogmoconcha hagenowi, is found in the lower of the two intervals. In the upper one the $C$. betzi $-C$. crassireticulata Zone is represented by Cristacythere betzi, and the $P$. reticulata Subzone by the index fossil and the species Ogmoconchella danica and Kinkelinella (Klinglerella) triebeli. The boundary between the two latter zones can be established at $1012 \mathrm{~m}$, whereas the $O$. aspinata Zone can not be delimited.

On the basis of the ostracod faunas the Lower Jurassic section can be subdivided so the beds below $1012 \mathrm{~m}$ are correlated with the Hettangian and the Lower Sinemurian, and the interval 987-1012 m with the Upper Sinemurian. The uppermost part of the Lower Jurassic series is not dated by biostratigraphical indications. It may possibly belong to Upper Sinemurian as Kinkelinella (Klinglerella) bipartita is found in samples from the $P$. reticulata Subzone. $K$. (K.) bipartita usually occurs in beds overlying the mentioned subzone, and its occurrence in the sample is therefore assumed to be due to caving. 


\section{The Lav $\phi$ No. I boring}

The boring is described by Dinesen (1960), Sorgenfrei \& Buch (1964) and Larsen (1966).

Below sandstone and claystone from the Lower Cretaceous, greenish grey claystone from the Lower Jurassic is found in the interval $2069-2290 \mathrm{~m}$. The Rhaetic (?) deposits below $2290 \mathrm{~m}$ consist of greenish grey, brownish grey and greyish black claystone.

The samples from three cores and from the cuttings samples have been examined, but the content of ostracods is very sparse. (A diagram showing the lithology and the location of the cores in the section is given by Larsen, 1966, pl. XVI.)

Only two species have been determined: Ogmoconchella danica in the cuttings sample 2207-2210 m and Cristacythere betzi in the cuttings sample $2298-2301 \mathrm{~m}$. These are only very poor biostratigraphical indications, but as both of the species are index fossils it is probable that the $O$. danica Zone and the $C$. betzi $-C$. crassireticulata Zone are present in the section. A stratigraphical subdivision cannot be given.

The Øresund Nos. 2, 3, 8, 9, 10,11, 12, 14 and 15 borings

A shortened description of these borings, which is presented by Larsen (1966), is based on an originally unpublished report which was published two years later (Larsen et al. 1968). In the report, Gunnar Larsen describes the sediments and the geological features in the area; Ole Bruun Christensen works out the stratigraphical subdivision of the Pre-Quaternary deposits on the basis of the ostracods, Inger Bang bases the subdivision of the same deposits on the foraminifera, and Arne Buch treats the Quaternary foraminiferal faunas.

The lithology of the Øresund sections is so complicated, in comparison with the lithology in the remaining parts of the Danish Embayment, that it is outside the scope of the present paper to describe it in detail; the reader is referred to the above-mentioned report and the very short description given on text-fig. 21. The outline of the stratigraphy given below will only contain an outline of the characteristics of the formations.

The Hälsingborg Formation is drilled into by the borings No. 13, 18 and 19. They are not indicated on text-fig. 21 , as no ostracods have as yet been found in the beds. On the basis of the characters of the sediments and their location relative to the fossiliferous beds of other borings, the Hälsing- 
borg Formation is referred to the Hettangian in accordance with Troedsson (1951).

The Döshult Formation, penetrated by the borings Nos. 8 and 9, is composed of fine-grained to coarse-grained sandstone with smaller intercalations of claystone. The development of the lithology and the facies within the formation is characterized by Larsen (1968) as deltaic to littoral. Larsen describes the upper boundary of the formation as sharp, but intercalations of a greyish black claystone, like the claystone lowermost in the overlying Pankarp Formation, are common within the uppermost part of the present Formation. Larsen (1968) places the upper boundary of the Döshult Formation in boring No. 8 at $25.3 \mathrm{~m}$ and in boring No. 9 at $45.4 \mathrm{~m}$. Within this formation ostracod faunas are only found in boring No. 8. The fauna belongs to the C. betzi $-C$. crassireticulata Zone, which is correlated with the Lower Sinemurian (text-fig. 21 and table 5).

In his description of the Pankarp Clays Bölau (1959) mentions an underlying "Übergangsschichten" with a dark grey colour. In this bed the ammonite M. cf. birchi is found so the bed is referred to the C. turneri Zone, which in the present paper is included under the Upper Sinemurian. This transitional bed is supposed to correspond to the lowermost dark grey claystone series in the Pankarp Formation sensu Larsen, 1968. However, this is included by Norling (1972) under the Döshult Formation, so that this formation includes the Lower-Upper Sinemurian boundary. As the definition of the boundary between the Döshult Formation and the Pankarp Formation given by Larsen (1968) is followed in the present paper, the chronostratigraphical boundary mentioned is located within the Pankarp Formation (and within the dark grey claystone).

The Pankarp Formation defined in the Øresund sections is tri-partite. Lowest is found dark grey to greyish black claystone, in the middle reddish to brownish claystone and in the upper part greenish grey claystone. The uppermost part of the formation is not completely covered by the borings, as there is a stratigraphical gap between boring No. 11 and No. 15 (cf. Larsen et al. 1968), but the uppermost part is thought to consist of alternating claystone, siltstone and sandstone of greenish and reddish colour with a few layers of coal. The formation is present in the borings Nos. 8, 9, 14, 10, 11 and 15. With the exception of a small part of the uppermost section (beds with coal) the entire formation is marine (Larsen et al. 1968).

The fossil content is generally limited to the greyish black series lowest 
in the formation. Two ostracod zones are present. A thin zone lowest in boring No. 14 contains the $C$. betzi - C. crassireticulata Zone, which is also present lowest in the Pankarp Formation in the borings Nos. 8 and 9 and in the uppermost part of the Döshult Formation in boring No. 8. The fauna is relatively abundant and is characterized by both the index fossils (cf. table 5). In the middle of the greyish black sequence is found the $P$. reticulata Subzone, which is the lowest part of the $O$. danica Zone. The remaining parts of the formation belong to overlying parts of the $O$. danica Zone. Except for a single occurrence of Kinkelinella (Klinglerella) multicostata in the otherwise non-fossiliferous series of boring No. 15 , ostracods are only found in a thin sequence just above the $P$. reticulata Subzone.

Stratigraphically the sedimentary sequence is therefore subdivided so that the lowermost part of the greyish black series in the Pankarp Formation together with the uppermost Döshult Formation is correlated with the Lower Sinemurian, whereas the remaining parts of the Pankarp Formation must be correlated with the Upper Sinemurian. The $P$. reticulata Subzone is correlated with Lias Beta-1a. The overlying part of the greyish black claystone is referred to Lias Beta-1b on the basis of the occurrence of Kinkelinella (Klinglerella) triebeli, $K$. (K.) multicostata and $K$. (K.) bipartita. The occurrence of $K$. (K.) multicostata high in the formation in boring No. 15 indicates the presence of Lias Beta-1b or 2, but the relative position of this occurrence in the sedimentary sequence makes a determination as Lias Beta-2 the most probable.

This interpretation of the stratigraphical conditions is in accordance with the biostratigraphical indications found by Reyment (1959 and 1969) and Norling (1972). The latter author placed the Lower-Upper Sinemurian boundary between the Döshult Formation and the Pankarp Formation. This was done because Norling referred the $C$. turneri Zone to the Lower Sinemurian and because the boundary between the two formations was placed above the dark grey series, "Übergangsschichten" sensu Bölau, 1959. In the present paper the $C$. turneri Zone is referred to Upper Sinemurian (cf. p. 16), and the dark grey claystone, which is supposed to correspond to the "Übergangsschichten", is placed lowermost in the Pankarp Formation (see above). The occurrence of the $P$. reticulata Subzone is in accordance with the indication of the $C$. turneri Zone within the "Übergangsschichten". The stratigraphical indication of Lias Beta-1b (= the P. planicosta Subzone) above the $P$. reticulata Subzone in the Øresund sections also agrees with the results described by Reyment (1969). Finally it must be emphasized that the Lower-Upper Sinemurian boundary in the Øresund sections must be placed near the bottom of the Pankarp Formation (sensu Larsen, 1968). 
The Kattlösa Formation, which is present in the borings Nos. 12 and 15, consists of marine, greyish and greenish sandstone and siltstone with subordinate beds of claystone. The lower boundary is placed at $76 \mathrm{~m}$ in boring No. 15 (cf. Larsen, 1968). The upper boundary of the formation is not present in the borings, as there is a stratigraphical gap between the borings Nos. 12 and 3. The boring No. 12 includes only the Kattlösa Formation.

Only the upper part of the available part of the formation contains microfossils. The ostracod fauna belongs to the uppermost part of the $O$. danica Zone, including the G. apostolescui - K. (K.) foveolata Subzone (cf. table 9). The beds just below the subzone mentioned contain a poor fauna, characterized by Kinkelinella (Klinglerella) variabilis and indicating the presence of the uppermost Upper Sinemurian, Lias Beta-3. The G. apostolescui $-K$. (K.) foveolata Subzone, which is defined in the boring No. 12 , is represented by a fauna rich in species and in specimens. This change in the fauna, from the assemblage with $K$. $(K$.) variabilis to that with Gramannella apostolescui, is not coincident with a lithological change and is therefore not thought to be a change based on facies. The subzone mentioned is correlated with the Lower Pliensbachian (cf. p. 34). The boundary between Sinemurian and Pliensbachian has earlier been stated to be located within the Kattlösa Formation (cf. Troedsson, 1951 and Larsen et al. 1968). In the present paper it is exactly located in the Øresund series, by means of the ostracod faunas (cf. text-fig. 21).

The Rydebäck Beds, as they are defined by Norling (1972), are represented in the borings Nos. 2 and 3. The deposits are only partially present since the series in the two borings are 32 and $36 \mathrm{~m}$ thick, and since there is thought to be an $85 \mathrm{~m}$ thick series between the two borings and a $50 \mathrm{~m}$ thick series below (cf. Larsen, 1968). The deposits in boring No. 3 are greyish silt of marine origin; in boring No. 2 the lower part consists of alternating greenish grey sand, silt and clay without marine indications, but the upper part of marine grey to black clay and silt. This latter part has been referred by Larsen (1968) to the Vilhelmsfält Formation, whereas Norling (1972) correlates it with the Rydebäck Beds in the Rydebäck-Fortuna No. 4 boring.

The beds in the Øresund No. 3 boring are highly fossiliferous and the ostracod fauna is rich in species and in specimens (cf. table 12). This fauna belongs to the $O$. adenticulata - N. (N.) simplex Zone, and from the occurrence of the species Trachycythere tubulosa tubulosa, Nanacythere (Domeria) fissicosta and $N$. (D.) firma the sedimentary sequence of the boring is correlated with the upper part of the Upper Pliensbachian, probably with the $P$. spinatum Zone.

As mentioned above, the lower part of boring No. 2 does not contain 


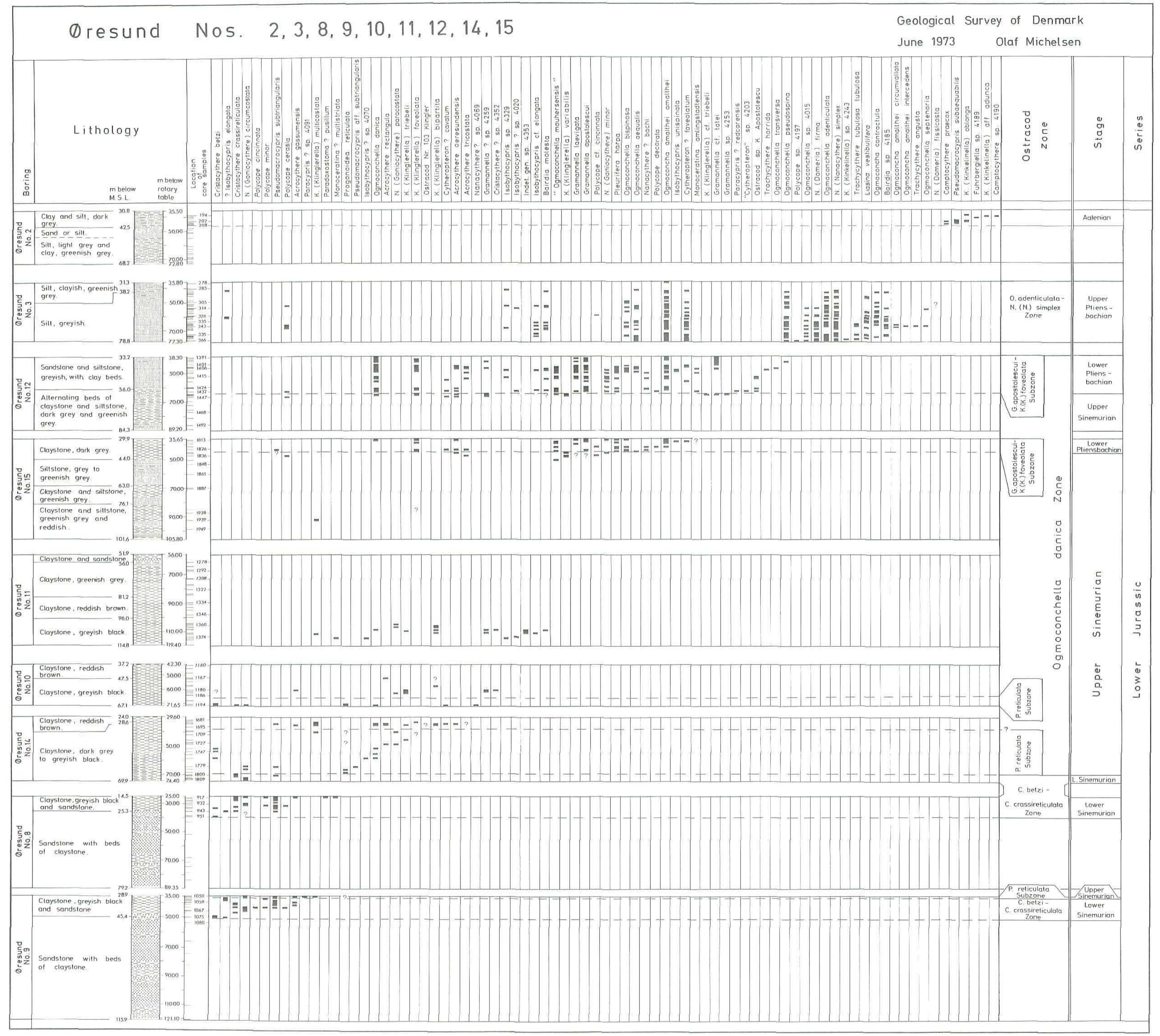

Text-fig. 21. 
marine fossils. The upper part comprises a poor and badly preserved ostracod fauna, which is of little stratigraphical significance. The occurrence of Kinkelinella (Kinkelinella) oblonga together with Pseudomacrocypris subaequabilis and Camptocythere praecox is the basis for correlating the section with the Aalenian. This stratigraphical determination is supported by the occurrence of the foraminifera species Citharina clathrata $(=C$. infraopalina in Bang, 1968). Norling finds this species in the upper part of the Rydebäck Beds and the lowest part of the Eriksdal Beds. Tralau \& Artursson (1972) have analyzed the pollen and spore floras of the section and determined the age as Bajocian/Bathonian. They emphasized four species of which one is only locally known. Other species are restricted to Lower Jurassic, whereas the main part of the species mentioned have a range comprising at least Lower and Middle Jurassic. A correlation with Aalenian on the basis of the foraminiferal and the ostracod faunas is therefore considered as the most reasonable until further investigations can be done. The lower, non-fossiliferous part of the series in boring No. 2 may presumably be referred to the Toarcian or the Aalenian. 


\section{Environments and faunas}

\section{Sediments}

The Lower Jurassic sedimentary sequence in the main part of the Danish Embayment is rather uniform and shows only small variations. The deposits are dominated by dark grey claystone or shale with a relatively high content of pyrite. A characteristic feature is the extensive transgression which has covered the entire basin. It began in the regional zone including Vinding, Slagelse (?) and Rødby (see Larsen, 1966 and Michelsen, 1970); it covered the main parts of the basin in the Hettangian, and in the Lower Sinemurian it reached the northeastern and eastern border zone including Skagen and Øresund.

In a few localities, e. g. Flyvbjerg, the sediments from the Hettangian are dominated by sand and silt containing lignite. They were deposited in an environment with a high energy level and possibly not under continuously marine conditions. The Lower Jurassic sedimentary sequence elsewhere in Jylland is dominated by dark grey shale or claystone deposited under continuously marine conditions. The energy level was low, and the high content of pyrite is considered to indicate reducing conditions in or above the seabottom. The increased content of silt in the Pliensbachian sequence, indicated by the electrical logs from the sections in North Jylland (cf. p. 107 and pl. 42) may have been caused by a change in the erosion level of the rivers leading to an increased transportation of more coarse-grained sediments. The overlying, uppermost part of the Fjerritslev Formation is totally dominated by clay which is not known to contain fossils. The facies of this sequence is questionable. Occasional microfossils in the cuttings samples may possibly come from this sequence, and may then indicate a marine environment with conditions unfavourable for the benthonic fauna, corresponding to the conditions known from the "Posidonienschiefer". The predominantly greenish colour of the sediments may also direct attention to the predominantly limnic "Grüne Series" in northern Germany (cf. Stoermer \& Wienholz, 1965). The facies cannot be determined on the basis of the present material, however, but it must be stated that the series seems to be totally or nearly non-fossiliferous and that in the present author's opinion, it can probably be correlated with the German "Posidonienschiefer". 
The analyses of the mineral content show only very small variations throughout the Lower Jurassic series (cf. Larsen, 1966). His diagram including the Gassum section (Larsen, 1966, pl. XII) may be regarded as typical for that part of the basin. As it is the section best represented by cores, it will be used below together with the features of the ostracod fauna to describe the environmental conditions. Here it must be emphasized that only very small variations in the curves of the mineral content are seen. The carbonate content curve is uniform, showing figures always below $20 \%$, and rareiy increasing above $10 \%$. The composition of the "light fraction" is totally dominated by the component "other aggregates", which is characterized as a very fine-grained, brownish substance with inclusions of quartz of silt-size, pyrite, and fragments of plant material. The groundmass consists of clay material. These fine-grained materials may have been strongly affected by weathering. Other important components of the "light fraction" are quartz and feldspar and plant-remains, which only occur in small amounts and in restricted intervals of the section. Of the components in the "heavy fraction" may be mentioned pyrite, which is found in small amounts only, and often together with or a little higher in the section than the three last-named components of the "light fraction". The minor variation in the mineral composition is difficult to use for an evaluation of the environmental conditions, but when considered together with the faunas some trends of the development can be described.

The scattered information which can be gathered from the more northerly borings in Jylland show mainly the same trends, except that in some places quartz and feldspar are more prominent components, and that pyrite may be more dominant in the uppermost, greenish part of the Fjerritslev Formation.

The section of the Rødby No. 1 boring is treated separately in Michelsen (1973b) and will only be commented on below, together with the basinal development in the Hettangian and the Lower Sinemurian.

In the Øresund area the development of sediments is more varied and shows changes in the facies. The Hälsingborg Formation is a predominantly non-marine, presumably estuarine deposit with sparsely occurring marine horizons (Larsen, 1966). The overlying Döshult Formation was deposited under marine conditions and contains rich marine faunas in the upper part. Both of the mentioned formations consist mainly of coarse-grained materials and must have been formed in an environment with a high energy level. The overlying Pankarp Formation consists mainly of claystone and clearly represents a change in the environmental conditions. Except for a few subordinate, coal-bearing bands in the uppermost part, the formation seems to be of marine origin (Larsen, 1966). The very fine-grained marine sediments indicate an environment with a low energy level and with restricted 
oxygenation and water circulation (cf. Larsen, 1968). The dark grey and greyish black colour in the lowest part of the formation is supposed to be due to a considerable content of pyrite and organic material. The overlying reddish beds have been studied by Bölau (1954), who states that the red colour was created under oxidizing conditions preserved by rapid sedimentation in a reducing environment. The greenish colour in the series above is supposed to be due to slower sedimentation of the same kind of sediments in an environment with the same conditions (Larsen, 1968). Except for the non-marine conditions in the upper part of the Pankarp Formation the environmental conditions seem to have been unchanged, marine and reducing, but the amount and character of material carried to the basin must have changed. The Kattlösa Formation is dominated by sandstone and siltstone with subordinate beds of claystone with greyish colour. The fossil content shows that the beds are of marine origin, and the changing sandstone and claystone layers indicate an environment with changing energy level. The Rydebäck Beds consist of silt and sand with smaller intercalations of clay. The part of the formation, which is present in Øresund No. 3, is of marine origin, whereas only the uppermost part in $\emptyset$ resund No. 2 can with certainty be determined as marine. These beds are known as a corresponding sedimentary sequence in South Sweden, but here there is a scattered occurrence of variegated deposits and conglomerates. Changes in the environmental conditions are evident, and breaks in the sedimentation must be supposed.

\section{Faunas}

In connection with the examination of the ostracod faunas, the content of other fossils (foraminifera, molluscans, echinoderms and vertebrates) has been registered, but not quantitatively treated. The occurrence and character of these groups have only occasionally been mentioned in the present paper, because the sole purpose has been to describe the ostracod species and the biostratigraphical subdivision based on the ostracod faunas.

Below will be outlined the features of the ostracod faunas. An evaluation of the environmental conditions and the factors affecting the faunas and species will be based on the faunistic features and trends of sedimentation. For this purpose the quantitatively treated samples are used. The variation in the calculated indices has been so considerable, even within short distances, that only the general trends are outlined.

It must be emphasized that the main part of the core samples used are the same as used by Larsen (1966), and that they are here indicated with the same sample number as in his paper. 


\section{Diversity and density of the ostracod fauna}

A quantitative treatment of the faunas is necessary primarily for stratigraphical determination, but also for an evaluation of the environmental conditions. In tables $1-13$ is given the composition of the ostracod faunas expressed as relative percentages, and the total number of individuals is presented. The number of individuals per $100 \mathrm{~g}$ sediment is calculated, and the diversity index is also included in the tables. When only few individuals have been found in the samples, both the percentage composition and the number of individuals per $100 \mathrm{~g}$ sediment will of course be of a dubious character, but in order to present a uniform picture the small figures have also been calculated.

The diversity formula used is the same as in Michelsen (1973b)

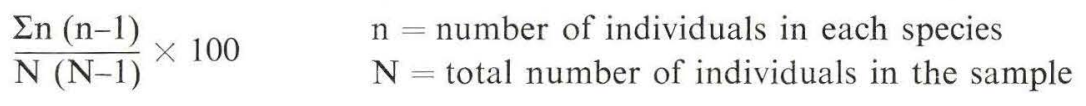

which was introduced by Simpson, 1949 (cf. Pokorný, 1971). The formula is often used in its reverse form, but since in Michelsen (1973b) it has been applied as shown above the calculations in the present study have been carried out in the same way. Used in this way a large index will express low diversity and a small index high diversity of the fauna.

With the purpose of evaluating the environmental conditions different kinds of diversity indices have often been used. Besides the index of Simpson, different other formulae comprising the ratio between the number of species and the total number of individuals, and the Fischer's $\alpha$-index are used by several authors. These indices have recently been discussed by Murray (1968) and Surlyk (1972). The formula of Simpson is used in the present paper since it stresses the relative abundance of species and excludes species represented by only one individual. Furthermore, it seems reasonable to apply a formula usually used by colleagues studying the same group of fossils or faunas from the same stratigraphical level. The disadvantages of the different kinds of diversity indices are emphasized by Surlyk (1972). Among others, he mentions the effect of the sample size. This factor affects most strongly the values calculated by the ratio between number of species and number of individuals. Some effect of this can also be seen in using Simpson's formula, but it seems to the present author to be a rather small one (cf. Murray, 1968, table 6). A more direct measure of the fauna is the number of species. This figure is possibly the most usable if the size of the sample is not too small, as the new species found by increasing the size of the fauna will be the rare species. Besides the diversity index the number of species of the faunas dealt with in the present 
paper can be read from the tables 1-13. Plotted as a curve the number of species has shown to conform the curve of the individuals/100 g sediment in the Gassum section.

The diversity index, as it is used in the present paper, is regarded as a supplement to the number of individuals/100 g sediment and the number of species. In evaluating the environmental factors affecting the faunas both of the mentioned figures are taken in consideration. It must be emphasized, that the exact size of the diversity index can not be used, neither in the individual samples nor in general in the section. The relative size of the index and the general trend of changes up through a section are the features which are considered to be valuable in evaluating the environmental conditions.

Pokorný (1971) calculated the diversity indices of Upper Cretaceous faunal successions and tried to find connections between the size of the indices and the environmental conditions. It was thought that a large hydrodynamic activity in the basin and increased amount of material transported by the rivers should yield more favourable conditions and therefore a larger faunal diversity. Pokorný examined sections situated marginally and centrally in the basin and got opposite figures from the two parts. He concluded that trends in the development of the indices also depend on the bathymetrical conditions.

The observations on the diversity within the Danish Embayment are very scattered. The few cores drilled yield only sparse possibilities for quantitative evaluation of the fauna. The Gassum section is the only one whose cores represent the Lower Jurassic series as a whole, though not with a continuous series of cores. In text-fig. 22 the diversity indices are plotted together with the calculated figures of the number of individuals per $100 \mathrm{~g}$ sediment relative to the section of Gassum No. 1 (see also tables 3, 7 and 11). In cores represented by several calculations of the index it is seen that the size of the index may vary rather much within small vertical distances, so for the cores represented by only one calculation, this must be treated with caution. However, the trend of the development in the size of this index may be used.

In the $O$. aspinata Zone there is an increasing faunal diversity and an increasing number of individuals present in the fauna. We know that, during the corresponding period, the transgression progressed from the south and the southwest, and reached the northeastern border zone of the basin in the uppermost part of the zone or in the overlying $C$. betzi $-C$. crassireticulata Zone (cf. pp. 8, 104). Within the present interval in Gassum there is only very little correspondence found in the mineral content (see Larsen 1966, pl. XII). In the "light fraction" the proportion of the quartz-feld- 
spar group increases generally. The amount of pyrite is variable, but it is relatively high. The curve of the quartz/feldspar ratio is parallel to the curve of the diversity index, and it indicates a decrease in the quartz content. The only other section represented by a continuous core series in the $O$. aspinata Zone is found in Rødby No. 1, where a corresponding development in the fauna is found. However, the middle part of that section differs slightly because of a different facies, which is dominated by deltaic deposits (Michelsen, 1973b).

The development in the diversity of the ostracod fauna in Gassum may be due either to development in the environmental conditions or solely to evolution dependent on time. The corresponding development of the faunas in Gassum and Rødby, in spite of the different environmental conditions, indicates that evolution dependent on time is the main factor affecting the faunal features within the present zone. The similarity to the development of the fauna in South Germany also supports this assumption (cf. Drexler, 1958). On the other hand, the relative size of the fauna seems to be affected by the environmental conditions, as the figures for the number of individuals per $100 \mathrm{~g}$ sediment are quite different in the Gassum and R $\varnothing$ dby sections. The largest number of ostracods in the Rødby section is found within the deltaic series in interbedded sediments indicating an environment with a low energy level. The diversity of the fauna also seems to be affected in these beds (Michelsen 1973b, text-fig. 2). It is assumed that the food supply has been rather high in such an environment, and that the food supply has also been increasing under the transgressive phase represented in the Gassum section.

The C. betzi-C. crassireticulata Zone, which is the oldest one represented in the Øresund area, shows quite different faunal features. The diversity index is high, both in the Gassum section and in the Øresund sections. The fauna found in the Øresund sections is a little richer in species, but does not differ considerably from the fauna in the Gassum section (cf. tables 3 and 5). The number of individuals found is low in both localities. The mineral content is different in the two sections, as the sediments in the Øresund section contain a considerable amount of the quartzfeldspar group which is absent in the Gassum section. Small amounts of pyrite occur at both localities. The sediments in the Øresund area furthermore contain some plant-remains indicating a more marginal position. The level of energy in the environment must be regarded as relatively low, also in the Øresund area where the sedimentary sequence succeeds the sandy sediments of the Döshult Formation. Whether the change in the environmental conditions, relative to those in the $O$. aspinata Zone and indicated by both the fauna and the sediments, is due to an alteration in the trans- 


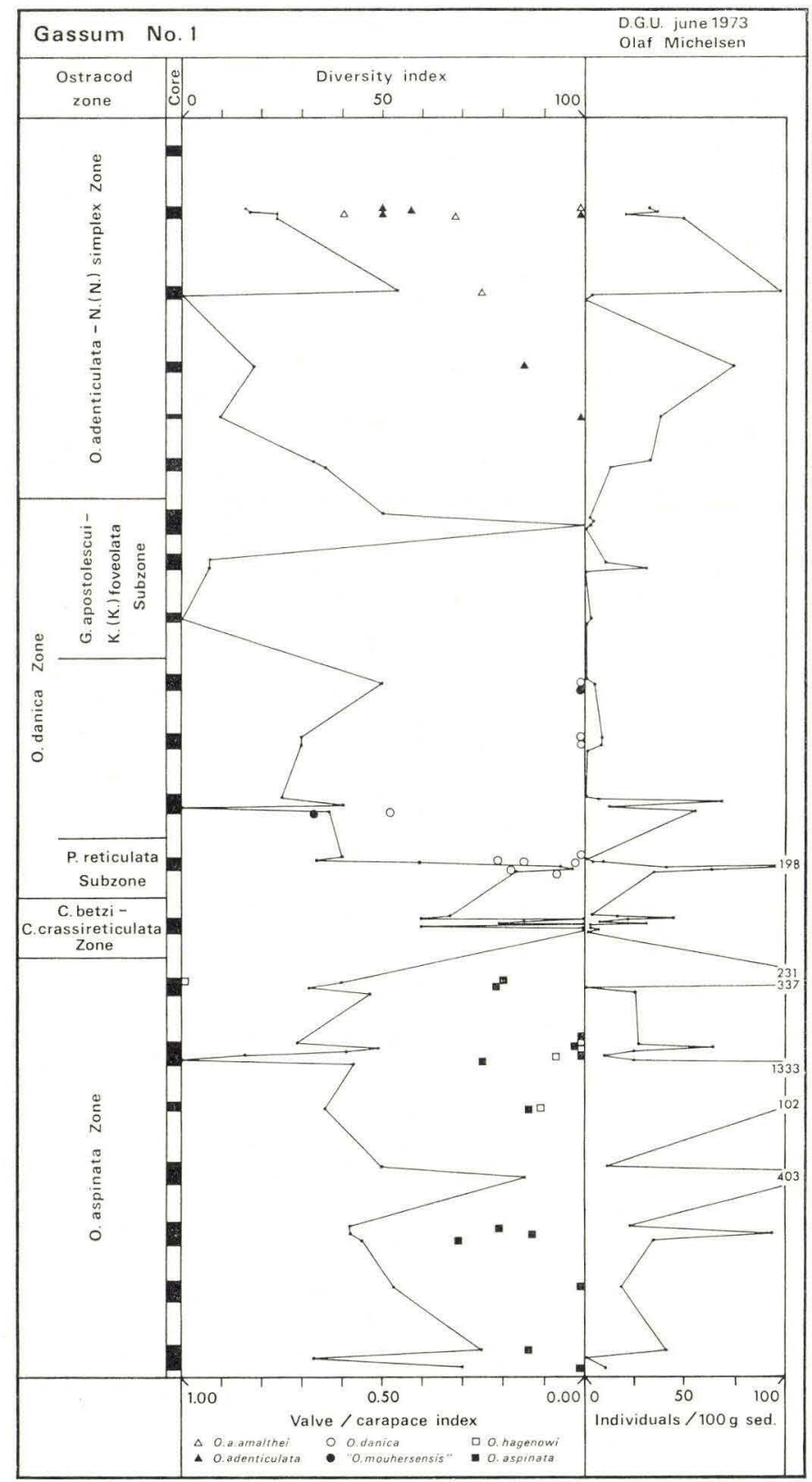

Text-fig. 22. Diagram for the Gassum No. 1 boring showing the faunal diversity $\left(\frac{\Sigma \mathrm{n}(\mathrm{n}-1)}{\mathrm{N}(\mathrm{N}-1)} \times 100\right)$, the number of specimens per $100 \mathrm{~g}$ sediment, and the valve/carapace index for the species Ogmoconchella adenticulata, Ogmoconcha amalthei amalthei, Ogmoconchella danica, "O. mouhersensis", $O$. aspinata, and Ogmoconcha hagenowi. 
gressive process or in the climate alone can not be stated. The sedimentological indication of an environment with restricted water circulation and a decrease in the amount of coarse material transported by the rivers is evident. The occurrence of the index fossil Cristacythere betzi between the $O$. aspinata Zone and the $P$. reticulata Subzone is natural compared with the biostratigraphical conditions known from Germany. Therefore the sudden change in the diversity and density of the fauna must be explained by environmental factors and not by a time-dependent development. A stagnation in the transgressive process succeeded by a decrease in the food supply is a possible explanation.

The $O$. danica Zone comprises such varying relationships in the faunas that it will be treated according to the biostratigraphical tripartite division outlined above. The figures for the fauna in the P. reticulata Subzone show considerable variation, but generally compare with those in the $C$. betzi $-C$. crassireticulata Zone (cf. text-fig. 22). There is a tendency to a greater faunal diversity both in the Gassum section and the Øresund area (cf. tables 5-7). The mineral content in the sediments from Gassum is very close to that of the zone below, and there is a greater similarity in the lithology of the Gassum section and the Øresund sections in the present zone (cf. Larsen, 1966, pls. XII and XVII). It must therefore be assumed that the environmental conditions are very similar to those mentioned above for the $C$. betzi - C. crassireticulata Zone.

In the middle subzone of the $O$. danica Zone there is an evident difference between the two areas. In the Øresund area only the lower and uppermost parts are fossiliferous, whereas the reddish and greenish series in the Pankarp Formation is non-fossiliferous. This latter sedimentary sequence is supposed to be built up under marine conditions, but in an environment with restricted water circulation (Larsen, 1968). The rate of sedimentation is assumed to be high in the reddish series and low in the greenish one (see p. 88). Except for an abundant fauna in the lowest part of this middle subzone in the Gassum section, the faunas found there are rather poor in species and especially in individuals. As far as this middle subzone of the $O$. danica Zone is known from the cuttings samples it is a general feature that the fauna is very poor and that the recorded specimens are badly preserved.

A striking feature of the Gassum section is that the interval correlated with the $P$. planicosta Subzone is rich in individuals and that the faunal diversity is rather high compared with the overlying interval. The mineral content shows a variation corresponding to the curves on text-fig. 22. The proportions of the quartz-feldspar group and of pyrite are relatively high and the quartz/feldspar ratio is low lowermost in this middle subzone. There 
thus seems to be a correspondence between the mineral content and the features of the fauna lowermost in the middle subzone resembling that demonstrated in the $O$. aspinata Zone. If the model outlined for the environmental conditions in the latter zone is valid, a progressive transgression and a high food supply must be assumed just above the $P$. reticulata Subzone, succeeded by stagnation in hydrodynamic activity upwards approaching the $G$. apostolescui $-K$. (K.) foveolata Subzone.

The variegated sequence in the Pankarp Formation is considered to have been deposited at a high rate of sedimentation and in a reducing environment. The sediments are non-fossiliferous. The corresponding series in the Gassum section, the upper part of the middle subzone of the $O$. danica Zone, contains very poor ostracod faunas. The content of the quartz-feldspar group in the sediments is small. The factors of importance may be the reducing conditions, the high sedimentation rate and the low energy level. The faunas recorded from sections with a considerable thickness are generally poor (cf. p. 96 and text-fig. 23).

The uppermost subzone of the $O$. danica Zone, the G. apostolescui $K$. (K.) foveolata Subzone, shows conditions quite different from those mentioned for the beds just below. The diversity of the faunas and the number of individuals per $100 \mathrm{~g}$ sediment is higher (cf. text-fig. 22). In the Øresund area the faunal diversity has increased markedly and the number of individuals is extremely high (cf. table 9). The mineral content of the sediments in Gassum is characterized by a relatively large proportion of the quartz-feldspar group in the "light fraction". In the Øresund area the proportion of this group is considerable, and pyrite is markedly common in the lowest part of the subzone. In both areas the quartz/feldspar ratio seems to increase (cf. Larsen, 1966, pls. XII and XVII). This subzone is known in core samples from North Jylland (Børglum No. 1) where both the litho-facies and the bio-facies resemble those of the Øresund area (cf. table 10). It is obvious that the environmental conditions have changed at the transition to this subzone. More coarse-grained materials are transported into the basin, and the decrease of pyrite upwards within the zone in both the Gassum and Øresund sections indicate an increase in the water circulation. These features are assumed to represent a transgression. The most extensive marine beds in Bornholm have been referred to Lower Pliensbachian (Malling, 1914 and 1920, and Rosenkrantz, 1939). Though the transgression in the Bornholm area may possibly be due to local tectonic activity, it is remarkable that it is contemporaneous with the change in the environmental conditions in other parts of the basin. It therefore seems most likely to the present author that a transgressive phase has influenced the environment in the entire basin. 
There are only a few notable features to emphasize concerning the conditions in the $O$. adenticulata - N. (N.) simplex Zone. The number of individuals per $100 \mathrm{~g}$ sediment generally increases upwards in the zone. In the Øresund section, which is referred to the upper part of the zone, this figure is also rather high. The faunal diversity is also rather high in all the sections comprising the zone (cf. tables 8 and 10-13). The sediments are generally more fine-grained than in the subzone below, but do not show any other remarkable features. The relatively small proportion of pyrite in the sediments may indicate the continuation of an environment with a relatively good water circulation. However, it is remarkable that the shells found in this zone, especially in the upper part of the zone in Gassum, are usually brownish and that the shell-surface is more or less covered by small crystals of pyrite (see p. 101). This kind of pyritization is assumed to have taken place shortly after death, when the shells were buried by sediment in an environment with reducing conditions (cf. Herrig, 1969a and Oertli, 1971).

The number of observations and the number of quantitative calculations on the faunas is relatively small compared with the time interval and the thickness of the sedimentary sequence in question. However, some general features and trends can be seen in the development of the faunas. An increase in the diversity of the fauna and in the number of individuals is characteristic in certain sections, both in the marginal and the more central part of the basin. Combined with the development of sedimentation and evidence of transgressive processes it is likely that this development of faunal conditions was affected by the transgressive process and the consequent increase in the food supply. The increase in the diversity of the fauna and in the number of individuals within the $O$. aspinata Zone and the $G$. apostolescui $-K$. $(K$.) foveolata Subzone is contemporaneous with known transgressions in parts of the Danish Embayment. The change in the faunal conditions in the beds just above the $P$. reticulata Subzone does not have any counterpart in known regression-transgression oscillations. The only evidence is the change in the mineral content which is similar to that demonstrated in the G. apostolescui $-K$. (K.) foveolata Subzons. The opposite trend in the faunal conditions shown for the $C$. betzi $-C$. crassireticulata Zone, and partly for the P. reticulata Subzone, is contemporaneous with the oldest ostracod faunas recorded from the Øresund area, but not with the very beginning of the transgression, since marine fossils are abundant in the Döshult Formation below. The faunal conditions are contemporaneous with lithological evidence of a decrease in the hydrodynamic activity. 
It must therefore be concluded that an increase in the diversity of the fauna and in the relative number of individuals was affected mainly by an increase in hydrodynamic activity succeeded by an increase in food supply, which is probably due to a transgression or to the climate, or both. It must be borne in mind that the present material is somewhat sparse, so the model outlined here should only be regarded as indicating the trend which can be seen in the environmental conditions within the Danish Embayment. Though the present model differs from that given by Pokorný (1971) it is hoped that it supplements the examination of the most important factors in question. Finally, it is likely that Gassum and Øresund are situated within one bathymetrical zone according to Pokorný.

In addition to the studies on the diversity of the faunas, an attempt has been made to count the number of new species introduced and to figure this in cumulative curves for some of the sections (cf. text-fig. 23). As most of the information comes from qualitatively treated cuttings samples it has been necessary to count the number of species in reverse, e.g. from the upper part of the sections downwards. However, the main trends of the faunas will still be marked in such a way that the sharpest bends on the curves represent considerable changes in the fauna. This is seen in the curve for the Gassum section (cf. text-figs. 15 and 23).

The curves in the text-fig. 23 clearly show changes in the faunas in the upper part of the $O$. aspinata Zone, in the middle part of the $O$. danica Zone and in the G. apostolescui - K. (K.) foveolata Subzone. A weak inflection is seen in the $O$. adenticulata $-N$. (N.) simplex Zone. These changes in the faunas are contemporaneous with the changes in the faunas demonstrated by the quantitative methods described above. The reason for using this qualitative method is that most of the samples originating from deep test borings will usually be cuttings samples. It is therefore necessary to work out a usable method for demonstrating changes in the environmental conditions in qualitative material. It is presented here to support the trends shown in the relatively sparse quantitative material.

Another feature of the environmental conditions shown by the cumulative curves (text-fig. 23) is the difference between different parts of the basin. The area around Rønde, Gassum and Nøvling indicates conditions favourable for the benthonic fauna, whereas the conditions in the Mors locality have been less favourable. If the faunal conditions in Nøvling and Mors are compared, considerable differences are obvious. Though the sample interval in Mors is $10^{\prime}$ and in Nøvling 30', the number of species introduced in the Nøvling section is appreciably larger than that in the Mors section. The knowledge of the faunas in the neighbouring boring, Fjerritslev No. 1, 


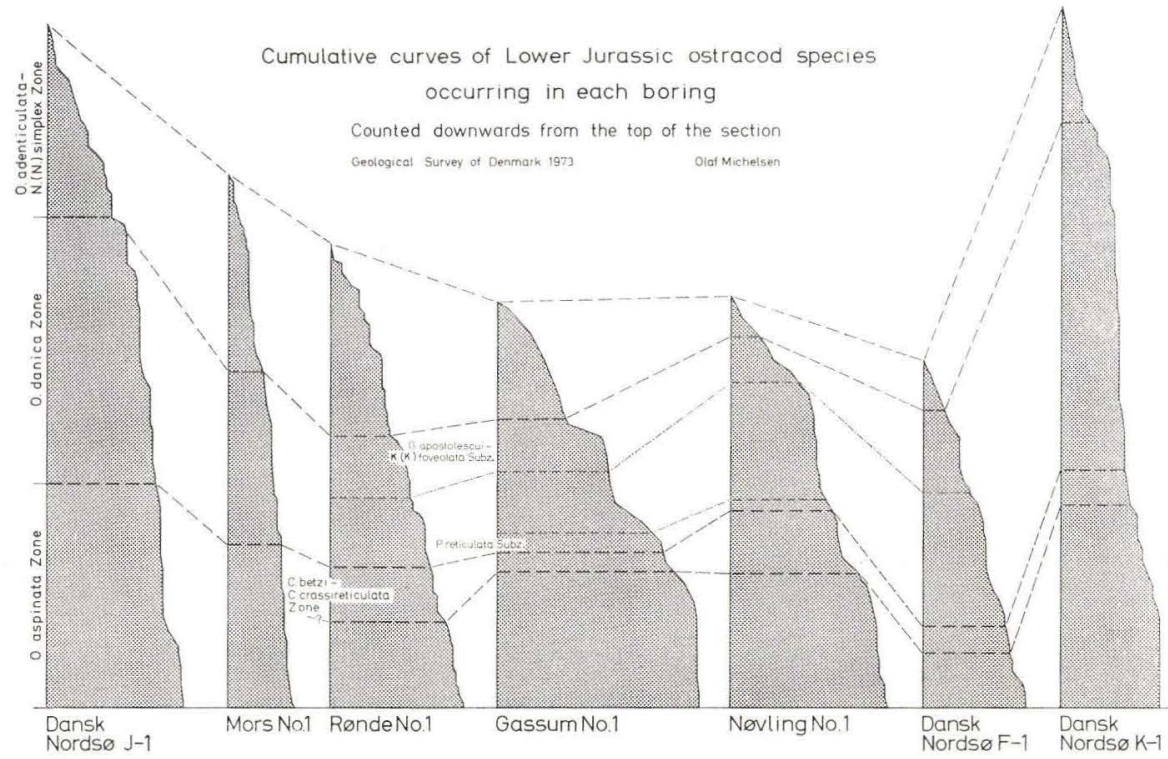

Text-fig. 23.

supports this indication of the regional difference. The borings in the North Sea show the same features. Dansk Nords $\varnothing$ J-1 resembles Mors No. 1, whereas Dansk Nords $\varnothing \mathrm{F}-1$ and $\mathrm{K}-1$ more are like Rønde No. 1. Even Dansk Nords $\varnothing \mathrm{K}-1$, which is represented by an extensive sedimentary sequence and which may resemble Dansk Nords $\emptyset \mathrm{J}-1$ in some ways, shows the characteristic increase in the number of species uppermost in the O.danica Zone and in the $O$. aspinata Zone known from Rønde No. 1 and $N \emptyset v-$ ling No. 1. There is a striking difference between the central part of the basin and the more marginal part. The influence of the bathymetrical conditions may also be demonstrated on a small scale by the closely located borings Dansk Nords $\varnothing \mathrm{F}-1$ and $\mathrm{K}-1$ (see text-fig. 23). The number of species recorded compared with the thickness of the sedimentary sequences is larger in the former boring than in the latter one.

In the faunas known from the cores from the older borings further north in Jylland there seems to be the same tendency of more abundant faunas than in the Fjerritslev-Mors area. The faunas from the G. apostolescui - K. (K.) foveolata Subzone (Børglum No. 1) and from the O. adenticulata - N. (N.) simplex Zone (Flyvbjerg No. 1) are abundant in the same way as those from the Øresund sections (cf. tables 9, 10, 12 and 13).

The sizes of the faunas indicate differing environmental conditions in the central part of the basin, around the localities Mors and Fjerritslev. Ac- 
cording to Larsen (1966) these localities are situated in a tectonically determined zone of subsidence, which ran along the length of the basin from the Fjerritslev area over the Øresund to Bornholm. Though the borings are located on local structures, as illustrated by the differences in the thickness of the sections in Fjerritslev Nos. 1 and 2, there are indisputable differences in the environmental conditions as indicated by the cumulative curves on text-fig. 23. The primary controlling factor is assumed to be the bathymetric conditions. The high sedimentation rate, which is a prerequisite for the extensive sedimentary series in Mors No. 1, Fjerritslev No. 2, Dansk Nords $\varnothing$ $\mathrm{J}-1$ and $\mathrm{K}-1$ may also have been an important factor.

\section{Valve/carapace index}

The ratio between intact carapaces and single valves has been shown to be useful for the interpretation of the environmental conditions (cf. Kilenyi, 1969 and 1971, Oertli, 1971 and Michelsen, 1973b). A relatively large proportion of single valves is considered to be due to post-mortem transportation, and an increase in the valve/carapace ratio has been demonstrated to correspond to the character of the sediments. The disarticulation is furthermore stated to be an individual characteristic of each species (Kilenyi, 1971 and Michelsen, 1973b). In the Lower Jurassic faunas it has been demonstrated that Ogmoconchella aspinata is affected by the disarticulating factor, whereas Kinkelinella (Klinglerella) medioreticulata is usually found as single valves and Pseudomacrocypris subtriangularis as closed carapaces (Michelsen, 1973b).

Another factor considered to affect the degree of disarticulation is the rate of sedimentation. Oertli (1971) found the importance of this factor confirmed by investigations of the Aptian faunas in the Paris Basin and by Pokornýs studies in the Cretaceous sedimentary basin in Bohemia. The theory is furthermore supported by the post-mortem development of ostracod shells observed in an aquarium. The present investigations do not confirm this theory unequivocally (see below, and Michelsen, 1973b).

Finally it must be mentioned that preparation of samples may modify the ratio between valves and carapaces.

For calculation of this proportion, the formula presented in Michelsen (1973b) is used:

\section{$\frac{\text { valve }}{\text { valve }+ \text { carapace }}$}

This formula gives the ratio between the numbers of individuals found as single valves and the total number of individuals of the species in question. 
As earlier investigations have shown that Ogmoconchella aspinata shows a degree of disarticulation useful for describing environmental features, species of the genera Ogmoconcha and Ogmoconchella have been chosen for the studies of the entire Lower Jurassic section. The figures of the ratio given below are from the quantitatively treated samples (cf. tables 1-13).

The O. adenticulata - N. (N.) simplex Zone:

\begin{tabular}{lrcc}
\hline Boring & Sample No. & O.a.amalthei & O. adenticulata \\
\hline Børglum 1 & 13 & 0.33 & 0.67 \\
Fjerritslev 1 & 4 & 1.00 & 0.67 \\
- & 6 &. & 1.00 \\
Flyvbjerg 1 & 18 & 0.76 &. \\
- & 19 & 0.76 & 0.88 \\
Gassum 1 & 7 & 0.00 & 0.50 \\
- & 8 & 0.60 & 0.43 \\
- & 9 &. & 0.50 \\
- & 10 & 0.33 & 0.00 \\
- & 11 & 0.25 &. \\
- & 15 &. & 0.15 \\
- & 16 &. & 0.00 \\
Haldager 1 & 62 & 0.38 &. \\
- & 64 & 0.00 &. \\
Øresund 3 & 315 & 0.65 & 0.63 \\
- & 329 & 0.83 &. \\
- & 343 & 0.84 & 0.60 \\
\hline
\end{tabular}

The G. apostolescui-K. (K.) foveolata Subzone:

\begin{tabular}{|c|c|c|c|c|}
\hline Boring & Sample No. & O. a. amalthei & O. danica & "O. mouhersensis" \\
\hline Børglum 1 & 14 & 0.14 & 0.20 & 0.22 \\
\hline - & $15 \mathrm{~A}$ & 0.38 & 0.40 & 0.28 \\
\hline Øresund 12 & 1399 & 0.44 & 0.71 & . \\
\hline - & 1401 & . & 1.00 & . \\
\hline - & 1403 & 1.00 & 1.00 & . \\
\hline- & 1406 & 0.89 & 0.86 & 0.75 \\
\hline - & 1420 & . & 1.00 & . \\
\hline- & 1424 & 0.33 & . & . \\
\hline - & $1437 \mathrm{~A}$ & . & 0.76 & . \\
\hline Øresund 15 & 1818 & 0.40 & . & 0.30 \\
\hline- & 1824 & 0.10 & . & 0.41 \\
\hline- & 1828 & . & . & 1.00 \\
\hline
\end{tabular}


The O. danica Zone (excl. the G. apostolescui - K. (K.) foveolata Subz.):

\begin{tabular}{|c|c|c|c|}
\hline Boring & Sample No. & O. danica & "O. mouhersensis" \\
\hline Fjerritslev 2 & $24 \mathrm{~A}$ & 0.00 & . \\
\hline - & $25 \mathrm{~B}$ & 0.04 & . \\
\hline Gassum 1 & 31 & 0.00 & 0.00 \\
\hline- & 32 & 0.00 & . \\
\hline- & 33 & 0.00 & . \\
\hline - & $39 \mathrm{~A}$ & 0.48 & 0.67 \\
\hline - & 41 & 0.00 & . \\
\hline - & $41 \mathrm{~B}$ & 0.21 & . \\
\hline - & 42 & 0.15 & . \\
\hline - & $42 \mathrm{~A}$ & 0.02 & . \\
\hline - & 43 & 0.18 & . \\
\hline - & $43 \mathrm{~A}$ & 0.07 & . \\
\hline Øresund 11 & 1365 & 0.00 & . \\
\hline Øresund 14 & 1691 & 0.17 & . \\
\hline- & 1761 & 0.05 & . \\
\hline
\end{tabular}

The O. aspinata Zone:

\begin{tabular}{lcc}
\hline Boring & Sample No. & O. hagenowi \\
\hline Gassum 1 & 47 & 1.00 \\
- & 53 & 0.00 \\
- & 58 & 0.00 \\
- & 59 & 0.07 \\
- & 60 & 0.11 \\
Horsens 1 & 2 & 0.00 \\
- & 3 & 0.06 \\
- & 4 & 0.00 \\
\hline
\end{tabular}

(The figures of the ratio for Ogmoconchella aspinata can be found in Michelsen, 1973b, and those calculated from the entire Gassum section are plotted in text-fig. 22).

The features of the $O$. aspinata Zone have been described earlier (Michelsen, 1973b), and the calculations for Ogmoconcha hagenowi given above fit with that description. The valve/carapace ratio is generally a little lower than in the $O$. adenticulata $-N$. (N.) simplex Zone, whereas the differences in the mineral content are inconsiderable. In the Gassum section the higher relative proportion of the quartz-feldspar group in the $O$. aspinata Zone must be noticed. Concerning the differences in facies between Gassum and Rødby reference must be made to Michelsen (1973b). 
The majority of individuals in the $G$. apostolescui $-K$. (K.) foveolata Subzone are found to be disarticulated. Unfortunately nearly all the data available in this subzone comes from the Øresund area. In comparison with the sediments above and below it must be emphasized that the grainsize is relatively large in this subzone. Furthermore it is assumed that the thickness of the sequence in the Øresund area is the same as or greater than in other parts of the basin.

The general feature of the underlying parts of the $O$. danica Zone is the predominance of closed carapaces; the corresponding sediments are very fine-grained. The three samples from Gassum, sample Nos. 31, 32 and 33, are from a sequence which is considered contemporaneous with the reddish and greenish series of the Pankarp Formation.

The relative proportion of individuals occurring as single valves is rather high in the $O$. adenticulata - N. (N.) simplex Zone, and higher in North Jylland and the Øresund area than in the Gassum section. This feature agrees with the mineral content, as the proportion of the quartz-feldspar group is higher and the grain-size is larger in the two first-named areas than in the latter one (cf. Larsen, 1966). The thickness of the sedimentary series corresponding to this zone is found to be larger in North Jylland than in the Gassum section.

As a general trend of the ratio between individuals represented by single valves and the total number of individuals, it must be emphasized that a relatively high proportion of valves occurs in more coarse-grained sediments, but the variation in the ratio cannot be correlated with the variation in the thickness of the sedimentary sequences. It must therefore be assumed that the factor affecting disarticulation is the effect of currents in the environment of sedimentation.

\section{Colour of the shells}

The colour of the shells may be an important feature in describing the environmental conditions in the upper parts of the bottom, where the individuals are buried, or in the life environment (cf. Oertli, 1971).

The majority of the series studied is characterized by the occurrence of white and opaque or translucent shells, and only two horizons show brown shells. In the upper part of the $O$. adenticulata $-N$. (N.) simplex Zone in the Gassum section, and in all other sections where the zone is represented by cores, the ostracod shells are brown and on the shell-surface are seen diminutive crystals of pyrite. This feature is also found in the fossiliferous beds within the deltaic series in the Rødby section (sample Nos. 20 and 21). This kind of pyritization is assumed to have taken place 
shortly after death when the shell was buried in an environment with reducing conditions (Herrig, 1969a and Oertli, 1971). This indication of reducing conditions within the sediments fits with the general trend of the deltaic series in the Rødby section (cf. Michelsen, 1973b). The contrast between the translucent to white shells in the Kattlösa Formation and the brownish shells in the Rydebäck Beds as they are known from the Øresund borings indicates more quiet conditions in the latter series, which agrees with the differences in the environmental conditions shown by the faunal diversity and by the valve/carapace ratio.

The ostracod shells from the $C$. betzi $-C$. crassireticulata Zone in Gassum are very often black probably owing to the occurrence of pyritecasts within the carapaces, whereas the same zone in the Øresund area contains mainly white and opaque shells. This feature combined with the larger faunal diversity in the Øresund area than in Gassum may indicate more reducing conditions in the life environment at the latter locality. Scattered levels of the overlying $O$. danica Zone show the same feature in Gassum, and also to some degree in the Øresund area. The development of sedimentation in the latter area also indicates an environment with decreasing water circulation passing from the $C$. betzi $-C$. crassireticulata Zone into the $O$. danica Zone. In recent deposits, black coloured ostracod shells are found in fine-grained sediments with a high content of organic materials, laid down in an environment with unfavorable conditions for benthonic ostracods (Kilenyi, 1969).

\section{Shell morphology}

A few observations on shell morphology must be added for elucidation of the environmental conditions. The species Cristacythere betzi, which in the Gassum section is often black due to a pyrite-cast, is here found to be of a size equal to or a little smaller than the holotype and those individuals found in the Øresund area. Furthermore, the specimens recorded from the Øresund area may have stronger reticulation (cf. pl. 11, figs. 164-166). These differences may indicate more strongly reducing and quiet conditions in the life environment at Gassum than in Øresund during the $C$. betzi $-C$. crassireticulata Zone.

\section{Final remarks}

The main trends in the development of the sedimentation and of the environmental conditions are shown to have affected the ostracod fauna. The composition and size of faunas are a result of evolution/extinction, the en- 
vironmental conditions and data failure. The last-named factor may be important and should be taken into consideration when some of the cuttings samples are used. The core samples taken as a check for the treatment of the older core samples have shown that the influence of this factor is small. The evolutionary trends are evident, but after these factors have been taken into account, it is possible to recognize certain features of the environmental conditions. The sedimentational development and changes in the progress of the transgression are reflected, and the bathymetrical conditions in different parts of the basin are also found to have been important for the faunas recorded.

The question as to whether the faunas found are primary or transported has not been discussed above. As none of the shells are worn and as in nearly all samples the ratio between numbers of adults and larvae (large and small shells) is equal, it is assumed that they cannot have been transported far, but of course only a few samples, e.g. Nos. 20 and 21 in $\mathrm{R} \emptyset \mathrm{dby}$ No. 1, comprise a definite indigenous population.

The diversity of the fauna and the number of individuals are found to be affected positively by transgressions, and the factor in question is thought to be the increase in material transported into the basin and in the food supply (cf. Neale, 1971). Environments with reducing conditions are only found to have influenced the fauna at one level, the C. betzi - C. crassireticulata Zone, whereas the reducing conditions indicated by an abundance, of pyrite, partly in sediments and partly on the surface of the shells, do not seem to impoverish the faunas, e.g. the $O$. adenticulata $-N$. (N.) simplex Zone and in a certain part of the $O$. aspinata Zone. The latter kind of reducing conditions was possibly limited to the sediments in which the shells were buried.

\section{Stratigraphical and environmental conclusions}

An attempt will now be made to combine the various data concerning the faunas, biostratigraphical conditions, and lithology, and to describe the development of the lithological, stratigraphical and environmental conditions within the Danish Embayment. The facies map (text-fig. 24) is given as an aid; it is based on the maps compiled by Sorgenfrei (1963, pl. II, fig. 2) and by Larsen (1966, fig. 46). The columns on the present map represent the faunal development in each of the borings dealt with. Each division in the columns represents one ostracod zone or subzone, and the horizontal scale expresses the number of ostracod species found in the zones or subzones. The vertical scale is independent of the thickness of the sedimentary sequence, which is given by the number below the column. The figures of 
the number of species based on core samples are indicated by a " $\mathrm{C}$ "; the remaining figures represent cuttings samples. Another possible source of error when interpreting the map is that the thickness of the zones varies, so the number of species presented may not all be directly comparable. In spite of these defects the map shows the general development of the faunas rather clearly, and supports an interpretation of the environmental development.

A regional zone along the Ringk øbing-Fyn High, including the localties Vinding, Slagelse (?) and Rødby, is considered to have been covered by the sea from the beginning of the Lower Jurassic (cf. pp. 8 and 105). The $O$. aspinata Zone, which is correlated with Hettangian and parts of the Lower Sinemurian, is extensive in these localities. The transgression is considered to come from this regional zone over the adjacent parts of the basin. It has not been possible to prove a gradual transgression as demonstrated in Northeast Germany (Meinhold et al. 1960). In the central parts of the basin, in the area including Gassum, Rønde, Fjerritslev, Mors and the Dansk Nords $\emptyset$ borings, the $O$. aspinata Zone is thick and contains a typical fauna throughout; it is assumed to correspond to the main part of the Hettangian and Lower Sinemurian. Along the northeastern and eastern border of the basin the zone is not recorded, but in the Øresund area fossiliferous beds in the Döshult Formation indicate the presence of the transgression and Lower Sinemurian deposits in Skagen No. 2 have been proved to be marine. In the centre of the basin the development of the environmental conditions seems to have been rather uniform. To the north in Flyvbjerg a unique ostracod fauna is recorded from sandy beds which are referred to the Gassum Formation. Agglutinating forms dominate in the foraminiferal fauna, which thus differs strongly from the faunas usual for the zone sequence. Varying facies differing from the typical basinal facies are also found to the south in the basin. In the middle of the R $\varnothing$ dby section are found deltaic deposits, which may be contemporaneous with the deflection of the diversity curve in the middle of the Gassum section (cf. text-fig. 22). In Ørslev No. 1 only the uppermost part of the $O$. aspinata Zone is present, and the underlying deltaic series is assumed to correspond to the Hettangian. Several oscillations have occurred during the transgression. Some of them are also indicated by the agglutinating foraminifera found in the Lower Coal Bearing Series on the island of Bornholm (cf. Gry, 1969 and Sellwood, 1972). The most extensive oscillation has been demonstrated in the south of the basin at the localities Rødby and Ørslev. Some of the oscillations may be local and due to syn-sedimentary tectonic activities, but the main features of the transgression are supposed to correspond to the widespread transgression in the Hettangian and Lower Sinemurian (cf. Hallam, 1961 and 1964). 


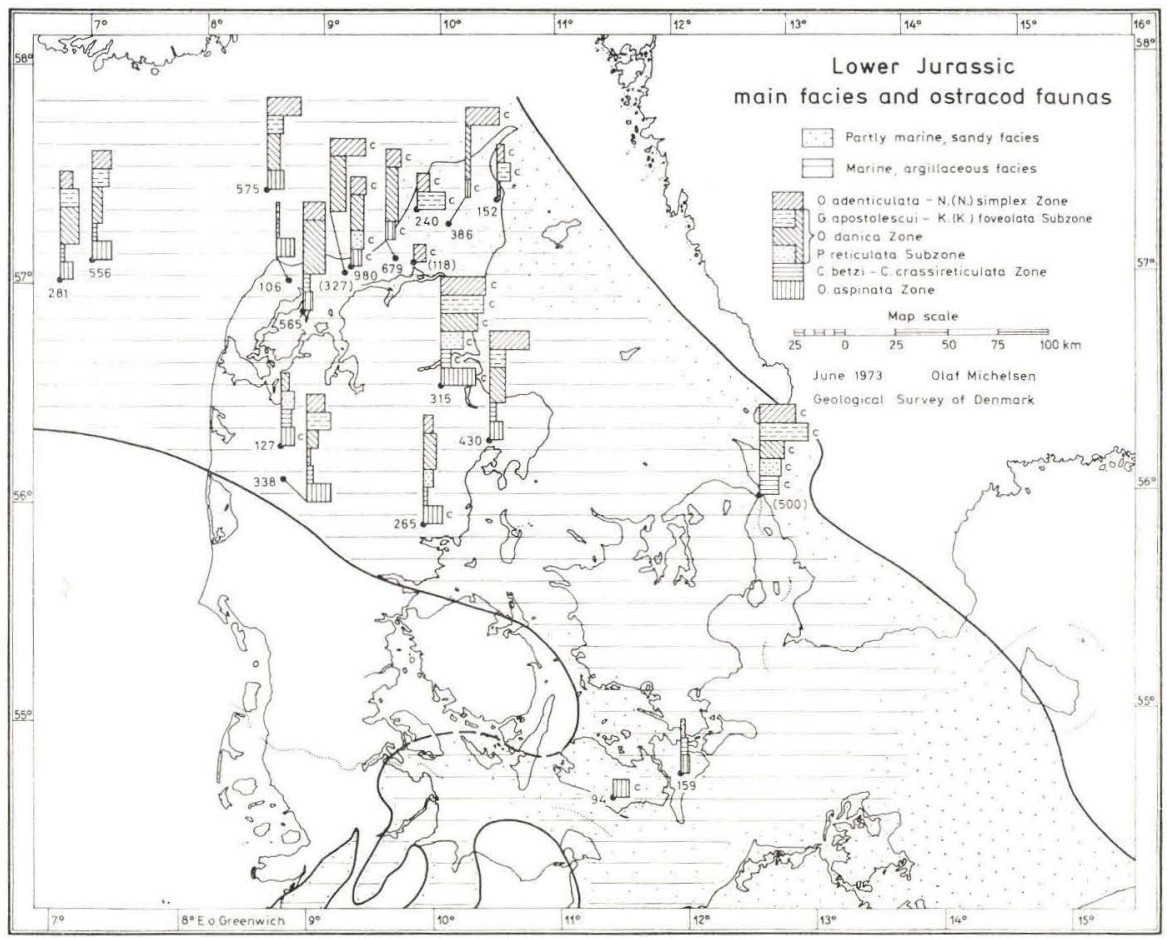

Text-fig. 24. Facies map of the Lower Jurassic in the Danish Embayment. For each of the borings the relative number of species in the ostracod zones is figured by the abscissa in the column and the thickness of the Lower Jurassic series is given immediately below (in metres).

The lower boundary of the Lower Jurassic can be located in a few sections by means of the biostratigraphical conditions. Fossiliferous Triassic beds are known underlying the marine Jurassic sequence in $\mathrm{R} \varnothing \mathrm{dby}$ and in Vinding (Michelsen, 1970 and Sorgenfrei \& Buch, 1964). In Gassum the closely located cores may make a good basis for an evaluation of the stratigraphical conditions, even though the uppermost of the beds referred to Triassic are non-fossiliferous. In all other sections the boundary is based on the lithological trends. The predominantly sandy Gassum Formation is counted as Triassic whereas the clayey Fjerritslev Formation is referred to Lower Jurassic. Only if cores are taken near the boundary, as in Gassum, it is possible to base this determination upon the occurrence of Lower Jurassic fossils. The fact that Lower Jurassic fossils are found within the Gassum Formation in the most northerly part of Jylland, at Flyvbjerg, makes it clear that this lithostratigraphical boundary cannot always be used. If the 
lithological and biostratigraphical evidence recorded from Flyvbjerg No. 1, Børglum No. 1 and Vedsted No. 1 is examined, it seems likely that in Børglum, too, the lower boundary of the Lower Jurassic can be placed within or below the Gassum Formation (cf. pl. 42). It has been proved that the Gassum Formation in the north of Jylland must be correlated with the Hettangian and parts of the Sinemurian, and that the mainly deltaic facies represented in this formation is contemporaneous with the deltaic facies in Southwest Sweden and with the marine facies in the central and southern part of the basin.

The $C$. betzi - C. crassireticulata Zone represents a striking change in the fauna which must indicate quite different environmental conditions. With the exception of the most northeasterly region, the zone is recorded from the entire basin. The sediments are uniformly fine-grained and clayey, but in the Øresund area they are more coarse-grained in the lowest part of the zone. It is correlated with the upper part of the Lower Sinemurian. The decrease in faunal diversity and the evidence of reducing conditions in the biotope here in the uppermost Lower Sinemurian can not be correlated with any evidence of change in sea level or in other factors. As the fauna was contemporaneous with the beginning of the deposition of the clayey Pankarp Formation in Southwest Sweden, and as the environmental conditions during the deposition of this formation seem to have been unfavourable for the benthonic fauna, both here and in other parts of the basin, certain factors associated with a stagnation of the transgressive process must have been important.

The $O$. danica Zone, which is correlated with the Upper Sinemurian and the Lower Pliensbachian, is characterized by abundant faunas in certain sections. The zone is tri-partite; the uppermost and lowermost subzones are formally named the $G$. apostolescui $-K$. (K.) foveolata Subzone and the $P$. reticulata Subzone respectively. The $P$. reticulata Subzone is correlated with the $P$. capricornoides Subzone of the lowermost in Upper Sinemurian, whereas the middle subzone is correlated with the remaining overlying part of the Upper Sinemurian. The G. apostolescui $-K$. (K.) foveolata Subzone is correlated with Lower Pliensbachian. In the central parts of the basin, around Gassum and Fjerritslev, the entire $O$. danica Zone is found. In the southwestern part, at Vinding, only the lower part of the zone is found, corresponding to Lias Beta-1, which is the youngest recorded Lower Jurassic deposit. In the south of the basin too, at Ørslev and Slagelse, only the lower part of the zone is present. Northernmost in the basin, at Frederikshavn, only the upper part of the zone, corresponding to the uppermost Upper Sinemurian and the Lower Pliensbachian, has been recorded. In the Øresund area the entire zone seems to be present as far as can be ascertained 
from the discontinuous sedimentary sequences present in the Øresund borings. The Danish Embayment seems to have been "tilted" during this period, as the depositions ceased in the southwestern and southern parts of the basin in the lower part of the $O$. danica Zone, and the marine deposits began in the northeastern part of the basin in the middle of the zone. However, it is known that marine Lower Sinemurian intercalations occur in the Skagen section. Moreover, the missing part of the Lower Jurassic in the southern and southeastern parts of the basin may have been eroded.

The fauna and sediments in the $P$. reticulata Subzone indicate environmental conditions corresponding to those in the underlying $C$. betzi $-C$. crassireticulata Zone. A change in the conditions is indicated in the beds just above the $P$. reticulata Subzone, in beds correlated with the $P$. planicosta Subzone. The number of species and of specimens in the ostracod fauna increases markedly coincident with an increase in the amount of quartz-feldspar and of pyrite. In the main, the sediments are uniformly clayey, so the change in the fauna is supposed to be due to minor increases in hydrodynamic activity. The ostracod fauna of the remaining overlying part of the middle subzone in the $O$. danica Zone is impoverished and the sediments are more fine-grained. The environmental conditions were unfavourable for the benthonic fauna. In the Øresund area the corresponding beds appear to be unfossiliferous, and non-marine conditions are indicated by the occurrence of coal beds in the upper part of Upper Sinemurian. Just below the Sinemurian-Pliensbachian boundary, at a level corresponding to the first record of the ostracod fauna in Frederikshavn, there is a change in the environmental conditions in the Øresund area. An ostracod fauna belonging to the uppermost Upper Sinemurian appears in the Øresund area and is succeeded by a rich and well-preserved fauna belonging to the G. apostolescui - K. (K.) foveolata Subzone. The trends in the fauna and in the corresponding sediments in the Øresund area and also more centrally in the basin, at Gassum, indicate an environment with good water circulation and increased transporting activity in the rivers. The extensive marine beds on Bornholm show a transgression which is dated as beginning in the $U$. jamesoni Zone. This transgression is here considered to have influenced the conditions in the entire basin and it may possibly be associated with the widespread Lower Pliensbachian transgression known from several parts of Northwest Europe (cf. Hallam, 1961 and 1964). The increasing diversity of the fauna in the G. apostolescui $-K$. $(K$.) foveolata Subzone and the coarsegrained sediments in the Kattlösa Formation must be associated with the transgression. Larsen (1966, fig. 13) shows a possible correlation between borings in North Jylland, based on deflections on the electrical logs. According to the present author's opinion, the line he draws must be constructed 
in another way. The correlation in his drawing between Frederikshavn City No. 1, Fjerritslev No. 2 and Vedsted No. 1 marks deflections locatcd around the Lower-Upper Pliensbachian boundary as this is interpreted in the present paper (cf. text-figs. 3, 7 and 9), whereas the deflections used by Larsen in Haldager No. 1, Børglum No. 1 and Flyvbjerg No. 1 correspond in the present author's opinion to the uppermost part of the deflection in Frederikshavn and the overlying, sharp deflections in Fjerritslev and Vedsted. Both in Flyvbjerg and in Børglum underlying deflections can be seen which correspond to the deflection used by Larsen in Vedsted No. 1 (cf. text-figs. 4-5). If the line of correlation is divided into two, the lower one will connect deflections spanning a rather thick sedimentary sequence, within which is located the Lower-Upper Pliensbachian boundary (cf. p!. 42). The change in the sediments indicated by this latter deflection is then considered to correspond to the Lower Pliensbachian transgression. The Lower Pliensbachian fauna in Børglum No. 1 resembles the corresponding fauna in the $\varnothing$ resund sections so much, that identical environmental conditions are assumed to have occurred in both of these areas (cf. text-fig. 24).

The $O$. adenticulata - N. (N.) simplex Zone is characterized by an abundant fauna; it is correlated with Upper Pliensbachian. Although the overlying beds are non-fossiliferous, e. g. in Rønde No. 1, the zone is assumed to correlate with the entire substage. In the Gassum section, which possibly does not include the uppermost part of the zone, the ammonite species $A$. margaritatus and $P$. spinatum are found within this ostracod zone. The sedimentary section corresponding to the zone covers the main part of the basin, but along the southern and the southwestern border the zone is not present. To the north, at Frederikshavn, the succession of the ostracod faunas indicates that the sedimentary sequence is reduced. It is supposed that the lower part of the present zone is absent in that part of the basin. The biostratigraphical conditions show so high a degree of similarity with those known from Germany that open connections for migration of the species must be considered even though the zone is not recorded further south in the Danish Embayment than the Øresund area. However, the discovery of T. $t u$ bulosa tubulosa (cf. pl. 25, figs. 386-387) in clayey deposits on the island of Bornholm may indicate biostratigraphical conditions comparable with those further north, in Øresund. Also the finding of Pleuroceras sp. on Bornholm shows the occurrence of Upper Pliensbachian (Reyment, 1959 and 1972). The environmental conditions in the basin seem to have been favourable for the ostracod fauna throughout the $O$. adenticulata $-N$. (N.) simplex Zone. The pyritization of the shell surfaces may indicate slightly increased reducing conditions towards the upper boundary of the zone. 
The youngest ostracod fauna belonging to the Lower Jurassic is found in the Øresund area, where a rather poor fauna indicating an Aalenian age is recorded from the upper part of the Rydebäck Beds. In the lowest part of the Haldager Formation in Rønde a poor indication of a fauna of the same age is also found. The faunas recorded from the uppermost Fjerritslev Formation and the lowermost Haldager Formation in respectively Vedsted No. 1 and Haldager No. 1 are impoverished and not stratigraphically significant. However, the similarities in certain features makes it possible that they correspond to the fauna in the Rydebäck Beds. On the basis of these indications the upper boundary of Lower Jurassic is placed low in the Haldager Formation in Rønde, and it is thought to be situated at a corresponding level relative to the lithology in the sections in North Jylland. If this stratigraphical determination is correct, the non-fossiliferous series of greenish clay and claystone in the upper part of the Fjerritslev Formation will be included under the Lower Jurassic, tentatively correlated with Toarcian-Aalenian. In Southwest Sweden the part of the Rydebäck Beds referred to Toarcian-Aalenian contains only a sparse foraminiferal fauna (Norling, 1972). Among the ostracods found here Norling mentions Aphelocythere kuhni Triebel \& Klingler, which is known from the uppermost Lias and the lowermost Dogger (Alpha and Beta). Furthermore, ammonite species indicating the D. tenuicostatum Zone are found (Bölau, 1959). However, a lithological correlation between the greenish, non-fossiliferous clay in North Jylland and the often variegated clayey and silty deposits in Southwest Sweden is not possible. The suggested stratigraphical position of the uppermost part of the Fjerritslev Formation is therefore based solely on the weak biostratigraphical evidence mentioned above. The sedimentary development in other parts of Northwest Europe shows trends parallel with the development in the Fjerritslev Formation. In Germany the Pliensbachian deposits are overlain by the "Posidonienschiefer" and the "Grüne Serie", which represent environmental conditions very unfavourable for benthonic faunas. However, rather abundant faunas are recorded from the upper part of the "Posidonienschiefer", Upper Toarcian, and Aalenian (cf. Stoermer \& Wienholz, 1965). The character of the faunas changes suddenly above the Pliensbachian, and Middle Jurassic faunal features predominate in the Toarcian-Aalenian.

Here, it is suggested that the non-fossiliferous greenish claystone in the upper part of the Fjerritslev Formation should be included in the Lower Jurassic. The upper boundary of the Lower Jurassic can not yet finally be determined, but the poor biostratigraphical evidence outlined suggests that the boundary may be placed at the bottom of the overlying Haldager Formation, at least in certain regions. To the south and southwest in the Danish 
Embayment the boundary is more easily located, as there is often a hiatus, as in Gassum and Rødby (cf. pl. 42).

\section{Comparisons of ostracod faunas from Northwest Europe}

The composition of the ostracod faunas within the Danish Embayment has been given above in connection with the description of the ostracod zones. In order to elucidate the background for the established biostratigraphy and the possibilities for correlation between different parts of the Northwest European region, the faunal development as known from Germany, England and France will be described. This description is also important as a supplement to the study of the connections between the Northwest European basinal areas.

The Danish Embayment. The faunal conditions are outlined in connection with the description of the ostracod zones; they are figured in text-fig. 2.

In the $O$. aspinata Zone the genera Ogmoconchella and Ogmoconcha are represented by $O$. aspinata and $O$. hagenowi. The European "Procytheridea" are present with the species Kinkelinella (Klinglerella) medioreticulata and Cristacythere costata. Another important group is the subgenus Nanacythere (Goniocythere). Of the described species belonging to this subgenus only $N$. (G.) elegans has previously been found elsewhere in Northwest Europe.

Of the species occurring in the $C$. betzi $-C$. crassireticulata Zone the most important is Cristacythere betzi. It dominates this zone; one specimen is known from the underlying $O$. aspinata Zone, and a few specimens have been recorded from the overlying $P$. reticulata Subzone. Another important species is $O$. hagenowi, whose uppermost occurrence in the Danish Lower Jurassic series is found within the present zone.

The dominant and most important species occurring in the lower and middle subzones of the $O$. danica Zone belong to the European "Procytheridea". Several of the species are known from other parts of the Northwest European basins: Progonoidea reticulata, Kinkelinella (Klinglerella) multicostata, K. (K.) laqueata, K. (K.) bipartita, K. (K.) triebeli, K. (K.) glabellata, $K .(K$.$) foveolata and K$. (K.) variabilis. The genus Ogmoconchella is represented by the species $O$. danica and " $O$. mouhersensis", which are also common in the uppermost subzone of the $O$. danica Zone. In this last-named subzone also occur several important and well-known species: Gramannella apostolescui, Pleurifera harpa, Ogmoconchella aequa- 
lis, O. bispinosa, O. transversa, O. pseudospina and Ogmoconcha amalthei amalthei.

The last-named Ogmoconchella- and Ogmoconcha-species all occur frequently in the $O$. adenticulata - N. (N.) simplex Zone, whereas Ogmoconchella adenticulata, $O$. septenaria and Ogmoconcha contractula are restricted to and characteristic of this zone. An important genus in this ostracod zone is Nanacythere which is represented by the following species: Nanacythere (Nanacythere) simplex, N. (Domeria) firma and N. (D.) fissicosta. Finally, the genus Trachycythere, with the species T. angusta, T. tubulosa tubulosa and $T$. tubulosa seratina, must be emphasized as important for the evaluation of faunal communications.

Germany. The ostracod faunas recorded from the North German Basin are relatively well-known, though they are described from restricted areas and from selected stratigraphical levels. Some of the species are described separately from the faunas (see p. 9).

As far as the faunas are known they show a high degree of similarity to the faunas described from the Danish Embayment. All the species mentioned above as characteristic of the Danish Lower Jurassic are known from the German deposits. The composition of the faunas and the relative stratigraphical range of the species corresponds to that demonstrated for the species within the Danish Embayment. The chronostratigraphical subdivision of the Danish Lower Jurassic deposits is therefore also created on the basis of this correspondence and on the basis of the occurrence of megafossils. The biostratigraphical subdivision defined in the present paper should also be useful within the North German Basin.

Some features of the faunal communities and of the migration of species may possibly be established from the known data. The biostratigraphical conditions in the Danish and North German basins during the Hettangian and Sinemurian are very similar in relation to the established chronostratigraphy based on the megafossils. The biostratigraphy outlined in the present paper is based on successions of faunas and species, and not on the absolute range of the species; furthermore it is supported by the known stratigraphical data based on the megafossils. No circular reasoning will be involved, therefore, when the faunas are compared in relation to the stratigraphical subdivision worked out in the present paper. It will be a substantiation of the stratigraphical relations and of the basis of stratigraphical correlations.

The $O$. aspinata assemblage recorded both in Denmark and in Germany is so similar in composition in both of the areas (p. 25) that good connections between the basins, even with South Germany, must be assumed.

The occurrence and succession of the European "Procytheridea"-species in Denmark and North Germany also correspond during the main part of 
the Sinemurian (pp. 28-34), so there must have been open connections between the basins. However, there may be differences in the composition of the faunas in the $C$. betzi $-C$. crassireticulata Zone since the succession of the "Procytheridea"-species below, in and above this zone differs slightly from the succession known from North Germany. The succession of the species in the overlying part of the Sinemurian is similar in the two areas and indicates close relationship between the two regions.

The German Lower Pliensbachian fauna has not been published in its entirety. The important species Gramannella apostolescui, Pleurifera harpa, Monoceratina amlingstadtensis, Nanacythere? bachi and Trachycythere horrida are all described separately from the faunas (cf. Klingler \& Neuweiler, 1959, Gramann, 1962, Triebel \& Klingler, 1959, and Triebel \& Bartenstein, 1938).

The Upper Pliensbachian faunas are described from parts of the substage (cf. Herrig, 1969a and 1969b and Dreyer, 1965). The composition of these faunas corresponds to that described for parts of the $O$. adenticulata $-N$. (N.) simplex Zone. The relative range of the species can not be compared directly, partly because the faunas described from Northeast Germany are from parts of the Upper Pliensbachian and partly because the entire $O$. adenticulata - N. (N.) simplex Zone is only known from one section in the Danish Embayment (p. 38). The important Trachycythere-species are also described separately from their faunas in Germany (cf. Triebel \& Klingler, 1959).

England. The knowledge of the faunas in England is based on Lord (1971), the lists in the "Eleventh Micropalaeontological Colloquium, England 1969", and on an examination of a few samples carried out by the present author.

Of the Hettangian and Lower Sinemurian faunas Lord (1971) describes the following species: Polycope cerasia, Cytherella drexlerae, $C$. concentrica, Cytherelloidea circumscripta, C. pulchella, Bairdia aff. B. molesta, B. cf. B. carinata, B. tatei, Bairdiacypris? sartriensis, Paracypris cf. P. ? semidisca, Klinglerella moorei, K. (K.) medioreticulata (cf. p. 183), K.? translucens, "Cythere" terquemiana, Ogmoconchella aspinata (cf. p. 238), and Ogmoconcha hagenowi. A fossil list presented in the "Eleventh Micropalaeontological Colloquium, England 1969" includes the following species in addition to the above-mentioned: Ektyphocythere? luxuriosa, Lophodentina bicostata, Monoceratina frentzeni and Paracypris cf. redcarensis. From the same locality, the Portland Cement Works, Rugby, the author has examined two samples. One sample from the ? S. angulata Zone contains the following species in common with the $O$. aspinata assemblage: Ogmoconcha hagenowi, Ogmoconchella aspinata, Kinkelinella (Klinglerella) medioreticulata, Isoby- 
thocypris aff. elongata, Nanacythere (Goniocythere) elegans. The other sample, which is from the $A$. bucklandi Zone, contains $O$. hagenowi, $O$. aspinata, N. (G.) circumcostata, N. (G.) paracostata, Paradoxostoma? pusillum and Polycope minor. The Hettangian and the Lower Sinemurian ostracod faunas in England include many species in common with the $O$. aspinata, N. (G.) circumcostata, N. (G.) paracostata, Paradoxostoma? pusilmainly expressed in the occurrence of the genera Cytherella and Cytherelloidea, which are not found in the Danish Embayment.

The Lower Pliensbachian fauna is only partly known. In the "Eleventh Micropalaeontological Colloquium, England 1969" the following species are mentioned: Liasina lanceolata and Polycope cerasia.

The Upper Pliensbachian fauna, too, is only poorly known. In the above-mentioned paper are mentioned Polycope pumicosa $(=P$. cerasia, see p. 258), and $P$. suborbicularis. The present author has examined samples from the A. margaritatus Zone in the Kirton Cement Works and has found the following species which are known from the $O$. adenticulata $-N$. (N.) simplex assemblage: Ogmoconchella adenticulata, O. pseudospina, Ogmoconcha amalthei amalthei and? Nanacythere (Nanacythere) simplex. In samples from the $P$. spinatum Zone only a few specimens and species were found and none of them are known from the Danish Embayment. These sparse data can not be used for a comparison. However, they have proved that the two index fossils used in the present paper also occur in the English deposits, but their relative representation is not known.

As a general feature it must be emphasized that the Hettangian and Lower Sinemurian ostracod faunas in England and in Denmark have many species in common. Another characteristic feature seems to be that the faunas in England are richer in species and that the genera Cytherella and $C y$ therelloidea are commonly represented.

France. Comprehensive lists of the Lower Jurassic ostracod species recorded from the French deposits are found in Apostolescu (1959), Oertli (1963), Viaud (1963) and Donze (1966 and 1967). From these it is seen that the similarity of the faunal composition in the Danish Embayment and the French basin is restricted.

Of the important European "Procytheridea"-group only Kinkelinella (Klinglerella) medioreticulata, Pleurifera harpa and Gramannella apostolescui are found. These species all have nearly the same stratigraphical range in France as they are thought to have in the Danish Embayment. A few other species described by Viaud (1963), e. g. Procytheridea aff. triebeli and P. aff. multicostata, may be closely related to the German species.

Some species of the genera Polycope, Isobythocypris, Paracypris and Liasina are common to France and Denmark. Though these species may 
be important for the evaluation of the stratigraphy they are so rare that they are of less significance for evaluation of the communities.

The very common and important group Ogmoconcha and Ogmoconchella includes several species which occur in both of the basinal areas. The species Ogmoconchella aspinata and Ogmoconcha hagenowi are both recorded from the Lower Sinemurian, the first-named also from the Hettangian and the latter species from the lowermost Upper Sinemurian. The species $O g$ moconchella transversa, O. mouhersensis and Ogmoconcha amalthei are all recorded from the Sinemurian and some of them also from the Pliensbachian. In France Ogmoconcha contractula is only found in the Pliensbachian. The general trend of the faunal development in the French basin is that the species of the Ogmoconcha and Ogmoconchella-group are initiated earlier in the section and that they have a larger stratigraphical range than in the Danish Embayment and in the North German Basin.

A striking feature of the faunal composition in France is the occurrence of Cytherella-species and Cytherelloidea-species. These two groups have not been recorded from the deposits in the Danish Embayment, and they have not yet been described from the North German deposits.

Summary. Two aspects must be emphasized on the basis of this outline of the faunas in the different parts of the Northwest European region: 1) generally it is possible to estimate the degree of faunal communication, and 2) some features characteristic of the distribution of certain genera can be emphasized.

In general, the correspondence between the Danish and North German ostracod faunas is high. The Hettangian faunas and the older Lower Sinemurian faunas are very similar in the two areas. The faunal developments in the Upper Sinemurian and the Upper Pliensbachian are also considered to correspond closely. An evaluation of the degree of similarity in the Lower Pliensbachian can not be given.

As far as is known, the Hettangian and Lower Sinemurian faunas in England seem to correspond only partly with the Danish faunas, whereas the English Upper Pliensbachian fauna differs quite considerably from the Danish one.

The French faunas all differ entirely from the Danish ones. The degree of agreement in the Upper Pliensbachian may be due to the dominance of Ogmoconcha and Ogmoconchella, which are mainly represented by the same species in the whole of Northwest Europe.

The connections between the Danish and the North German basinal areas are considered to have been good in the main part of the Lower Jurassic. However, there may have been a less good connection in that part of the Lower Sinemurian corresponding to the $C$. betzi $-C$. crassireticulata Zone. 
The possible connections with the English area can hardly be determined on the basis of the present material, whilst the possibilities for communication with the French basin seem in general to have been rare. Only the Ogmoconcha - Ogmoconchella-group is common to both, whereas the important European "Procytheridea"-group develops quite different species in the French basin. A characteristic feature of the ostracod faunas from the deposits in France and England is the occurrence of Cytherella and Cytherelloidea which do not occur in the North German and the Danish basin areas.

It is characteristic of the Lower Jurassic faunas from the whole of Northwest Europe that they contain the genera Ogmoconcha and Ogmoconchella represented by the same species at the same levels. Except for the genus Polycope it is the only group represented by the same species. Since the species of the two genera occur everywhere in faunas of varying composition their presence must be explained as being a result of their way of life or their mobility. The great locomotory ability postulated by A. Lord (in Catt et al. 1971) may possibly be an explanation of the wide dispersal of the Ogmoconcha- and the Ogmoconchella-species.

\section{Evolutionary trends of Ogmoconcha and Ogmoconchella}

The family Healdidae is represented by the genera Ogmoconcha, Ogmoconchella and Pseudohealdia in the Danish Lower Jurassic deposits and in the Northwest European basins as a whole. The genus Healdia is considered to be a pre-Lower Jurassic genus. The genera Ogmoconcha and Ogmoconchella are known from the Triassic section in Middle and West Europe and in U.S.S.R. (cf. Anderson, 1964, Gramm, 1970, Kozur, 1970, Kristan-Tollmann, 1971, and Urlichs, 1972). The group developed in the Lower Jurassic to become a dominant and characteristic part of the ostracod fauna. In the Hettangian and Sinemurian a few species of both genera occur, which often dominate the faunas with more than $50 \%$ of all known specimens. In the Pliensbachian the number of species increased rapidly and the faunas may be totally dominated by these groups. At the transition to the Toarcian they suddenly disappear (Fischer, 1961a), only in a few localities is "Hungarella" registered a little above the base of the Toarcian (Plumhoff, 1967). The present author has observed a few specimens of Ogmoconchella in a sample taken in the lower part of the D. tenuicostatum Zone in Roxby Ironstone Quarry, Lincolnshire in England.

The general feature of the faunal development is that the genera Ogmoconcha and Ogmoconchella developed to become a dominant and characteristic group in the Lower Jurassic and disappeared at the beginning of the 
Toarcian. Viaud (1963) compiled his observations on these groups in a diagram illustrating the evolution of the most important species. The majority of the species included in his diagram belong to Ogmoconcha which in French deposits seems to comprise several species in the Pliensbachian. Below an attempt will be made to describe the evolutionary trends as they can be interpreted on the basis of the present material, supported by the published data from other parts of the North European basin. The main features are presented in text-fig. 25.

Ogmoconcha. The oldest Lower Jurassic species recorded in Europe is $O$. hagenowi which appears in the Hettangian and continues into the Lower Sinemurian (see also p. 231). In France it is also recorded from the Upper Sinemurian. The next species appearing in the core samples is $O$. amalthei amalthei, which is common both in the Lower and Upper Pliensbachian. There is thus an interval of time with no Ogmoconcha-species. In France, too, there is a break in the succession of Ogmoconcha-species (cf. Viaud, 1963). Ogmoconcha amalthei form A, described in the present paper, may possibly form a connection. Unfortunately, this form is only recorded from cuttings samples so its stratigraphical range can not be established, but it is assumed to occur lowest in or below the section with the Pliensbachian Ogmoconcha-species. The external morphology of the carapace also suggests a possible transition between $O$. hagenowi and $O$. amalthei amalthei. In lateral view, $O$. amalthei form $A$ has an outline very like that of $O$. hagenowi, but in dorsal view the lateral concavities typical of $O$. amalthei amalthei and $O$. contractula are seen (cf. pl. 27, figs. 409-413).

In the Pliensbachian (mainly in the Upper Pliensbachian) occur a large number of species or subspecies of the genus Ogmoconcha. The variation in external morphology is limited and mostly represents minor variations on the outline of $O$. amalthei amalthei. In the French deposits a larger number of species or subspecies seem to occur (cf. Viaud, 1963); the German deposits resemble the Danish ones. Both in the French and the German basins the general pattern of variation corresponds to that demonstrated for the Danish Embayment.

Ogmoconchella. The oldest Lower Jurassic species of this genus is $O$. aspinata. It is known elsewhere in Europe from the entire Hettangian and Lower Sinemurian, but in the Danish Embayment it is not thought to occur in the upper Lower Sinemurian. The external morphology of this species is characteristic and rather constant. However, in the uppermost part of the $O$. aspinata Zone in the Gassum section some larvae with a more rounded outline in lateral view are observed together with typical adults; they resemble the species $O$. danica to some degree. Generally the outline of the 


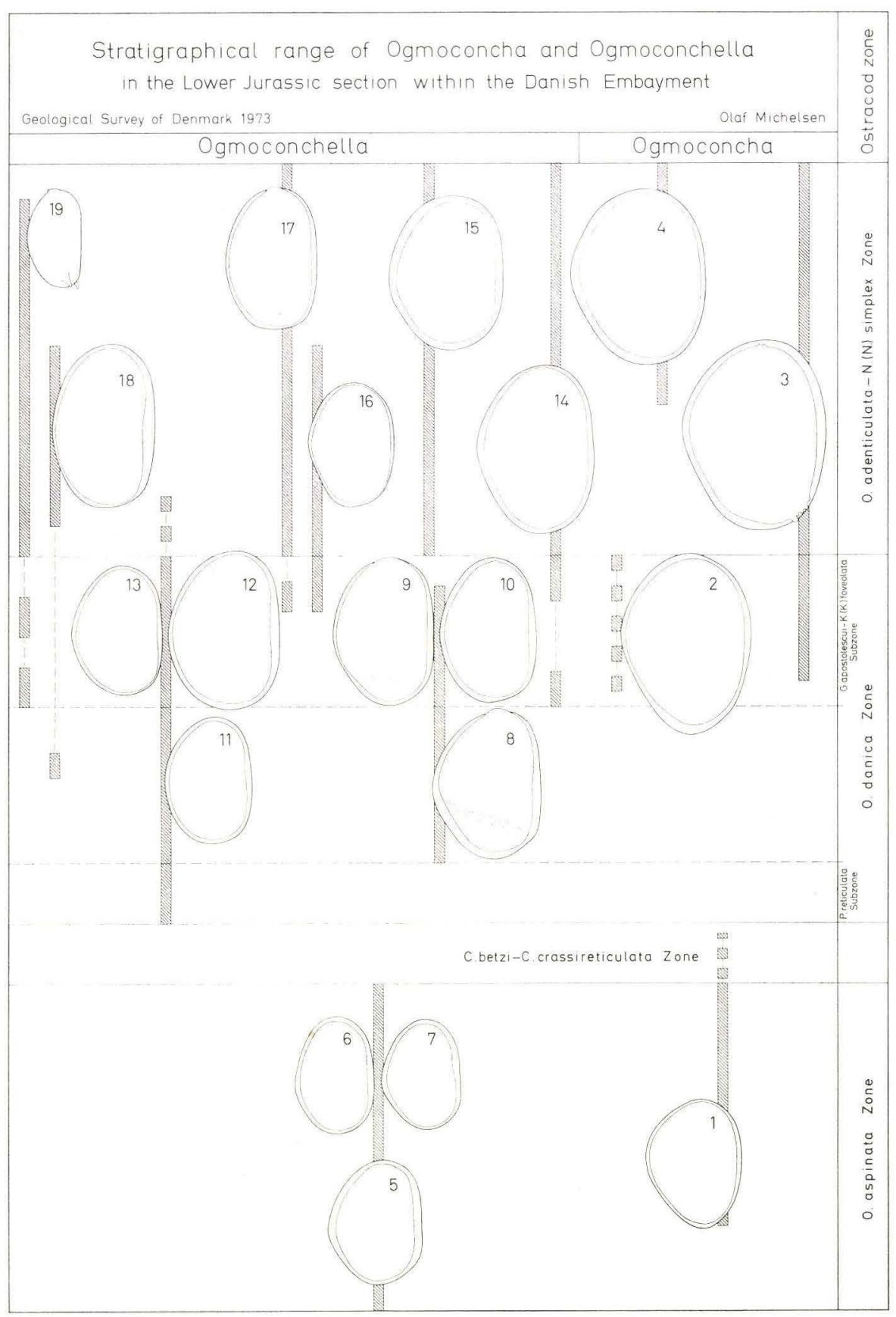

Text-fig. 25. Stratigraphical range of important Ogmoconcha- and Ogmoconchellaspecies within the Danish Embayment. 1: O. hagenowi. - 2: O. amalthei form A. 3: O. amalthei amalthei. - 4: O. contractula. - 5: 0. aspinata. - 6 \& 7: Larvae of O. aspinata. - 8 \& 9: "O. mouhersensis". - 10: Transitional form between "O. mouhersensis" and $O$. adenticulata. - $11 \& 12: 0$. danica. - 13: Transitional form between O. danica and $O$. propinqua. - 14: O. aequalis. - 15: O. adenticulata. - 16: $O$. transversa. - 17: O. pseudospina. - 18: O. gruendeli. - 19: O. bispinosa, larva. 
adults in lateral view resembles the species "O. mouhersensis". Evolutionary trends can not be followed continuously within the Danish Embayment, because the $C$. betzi $-C$. crassireticulata assemblage does not contain Ogmoconchella-species.

In the $O$. danica Zone two species occur: $O$. danica and " $O$. mouhersensis". The first-named species is represented in the uppermost part of the zone (Lower Pliensbachian) by relatively large specimens (cf. text-fig. 43) which may show affinities with the German species $O$. propinqua Malz, 1971. A few specimens of a transitional type are recorded from the Gassum No. 1 boring (cf. pl. 31, figs. 451-452). O. propinqua occurs in the German Upper Pliensbachian. Two other species which are morphologically closely related to $O$. danica and $O$. propinqua are $O$. gruendeli and $O$. pseudospina. O. gruendeli is known both in Germany and in Denmark from the lower part of Upper Pliensbachian, but in the Danish Embayment it is also recorded from the Upper Sinemurian. O. pseudospina is known both in Germany and in Denmark from both the Lower and the Upper Pliensbachian. Thus these species have a concurrent range in the Pliensbachian. In the author's opinion an evolutionary succession can be followed from $O$. aspinata through $O$. danica into the group of species including $O$. propinqua, $O$. gruendeli and $O$. pseudospina.

The species "O. mouhersensis" is not well-defined, and in the present paper it is regarded as a morphospecies characterized by a subvertical swelling on the posteromedian external surface. The specimens recorded from the lower part of the $O$. danica Zone, the part referred to the Upper Sinemurian, have the characteristic features. The specimens recorded from the G. apostolescui $-K$. (K.) foveolata Subzone have a weaker swelling, and the carapace is relatively longer. Some specimens found in cuttings samples in the Danish North Sea borings are more elongated and the swelling is only feeble. These last-named specimens may be regarded as transitional forms to the species $O$. adenticulata, which can be more elongated than indicated by the holotype. A third species considered to belong to this evolutionary line is $O$. aequalis. It is more symmetrical, with the largest height near the middle of the shell. Within the range of variation of the external morphology this species contains forms which have been mistaken for $O$. adenticulata (cf. Dreyer, 1965, pl. VI, fig. 5). Finally it should be mentioned that $O$. transversa is also supposed to belong to this morphogroup on the basis of its characteristic outlines in lateral view. The species $O$. aspinata, "O. mouhersensis", $O$. adenticulata and $O$. aequalis have such similar outlines in lateral view that they are here considered to be connected in the same evolutionary succession. 


\section{Palaeontology}

\section{Introduction}

The main purpose of the present investigation has been to describe all ostracod species recorded from the Danish Lower Jurassic deposits. They have been described in order to indicate their morphological variation and their application in a biostratigraphical subdivision of the Lower Jurassic sequence. The given description is composed of:

1. List of synonyms. No attempt has been made to make this list complete. It comprises mainly those descriptions of the species in question which accord with the present material and which include details sufficient for identification.

2. Material. The number of carapaces, left valves and right valves given are those on which the description and the identification are based. These shells will most often be from the quantitatively treated core material, but when such material has not been available, shells from cuttings samples have been used.

3. Diagnosis. The original diagnosis of previously known species is given, and in certain cases an emended diagnosis is added. For all new species erected in the present paper a new diagnosis is presented.

4. Description. A detailed description is only given for the new species, for species given with open nomenclature and for previously known species where the previous description is not sufficiently extensive or does not include all the details visible in the present material. For all other previously known species reference is made to the description which in the author's opinion includes the best details of the shell-morphology.

5. Measurements and statistics. For species represented by large numbers of well-preserved shells, measurements of the length and height have been carried out. Calculations of the mean $(\bar{x})$, the standard deviation (s), the coefficient of variation (v) are made where the material has been sufficient. The number of shells on which the calculations are based is marked N. The observed range of a parameter is marked O.R. The purpose of these calculations has been to describe the species in question more exactly.

6. Remarks. Under this heading are included remarks concerning the 
variation of the investigated material, and its state of preservation.

The affinities with other species are discussed together with previous determinations of the species in question and closely related species.

7. Distribution. The stratigraphical range of the species within the Danish Embayment is given (see also text-fig. 2).

The known stratigraphical range in other parts of the Northwest European basins and the geographical range of the species are mentioned.

8. Plates 1-40. All species recorded from the Danish Lower Jurassic series are figured by photographs taken with a light microscope and/or a scanning electron microscope (see p. 13).

A thorough and detailed description is only given for the new species erected in the present paper, for species of which the former description does not include all the details observed in the present material, and for species in which the present material consists of a large number of wellpreserved shells. In the author's opinion a description of a species only represented by very few specimens is not useful, since the specimens may represent a skew sample of the morphological variation. In the present paper comments on the main features of the recorded specimens of such species are made under the heading "Remarks". Furthermore, the scanning electron microscope technique is so objective in figuring the shell morphology that it serves better than verbal description for describing the features of the shell.

The classification given in Moore (ed.), 1961 is followed. Of the different taxa mentioned below, the species is regarded as the most important in connection with the present investigation. In certain cases it has been necessary to deal with the genera, too, as defects in certain groups have been obvious.

Description of the species

Order Podocopida Müller, 1894

Suborder Podocopina Sars, 1866

Superfamily Bairdiacea Sars, 1888

Family Bairdiidae Sars, 1888

Genus Bairdia McCoy, 1844

Type species. Bairdia curta McCoy, 1844.

Original diagnosis. "Shell elongated, fusiform, suddenly tapering at both 
ends; a very short proportion of the valve overlaps the abdominal margin" (McCoy, 1844, p. 164).

Stratigraphical range. Ordovician - Recent.

Bairdia molesta Apostolescu, 1959

Pl. 1, figs. 1-2.

1959: Bairdia molesta Apostolescu, p. 806, pl. II, fig. 31.

Material. 21 carapaces, 3 left valves, and 12 right valves in core samples from the Børglum No. 1, Fjerritslev No. 2, Flyvbjerg No. 1, Gassum No. 1, Øresund Nos. 3 and 12 borings.

Original diagnosis. "Espèce caractérisée par la forme générale de sa carapace et par un sillon longeant le bord antérieur et une partie du bord postérieur. Surface des valves lisse" (Apostolescu, 1959, p. 806).

Description. The dorsal margin between the distinct cardinal angles is slightly convex. Behind the posterior cardinal angle the margin is slightly concave; pronouncedly concave on the right valve. In front of the anterior cardinal angle the margin is feebly convex and passes evenly into the wellrounded and nearly symmetrical anterior margin. The posterior margin is acuminate or sharply rounded. Below the extended point the margin is convex and passes into the straight ventral margin, which has a feeble concavity anteromedianly (especially on the right valve). Along the anterior margin and the posteroventral margin a narrow zone is laterally compressed into flanges. The lateral face is evenly inflated. The left valve is larger than the right one and overlaps it considerably along the dorsal margin and the central part of the ventral margin.

The present valves are filled with sediment so the internal features can not be observed. However, uncovered sections of the hinge indicate the usual Bairdia-type.

The external surface is smooth.

The larvae mainly conform to this description, but the posterior end is shorter and the margin in front of the anterior cardinal angle is straight to slightly concave.

Remarks. The present specimens are identical with the species described by Apostolescu (1959), and have been compared with type material deposited with H. J. Oertli (Pau, France).

The species published by Lord (1971, p. 649) as Bairdia aff. B. molesta Apostolescu, 1959 is distinguished by Lord from B. molesta by "a slightly more rounded aspect". The present material does not show any variation which can include the form published by Lord. However, Viaud (1963, pl. $\mathrm{V}$, figs. 140-145) shows a variation of $B$. molesta including it. 
Distribution. Denmark: The $O$. danica Zone to the $O$. adenticulata $-N$. (N.) simplex Zone; Upper Sinemurian to Upper Pliensbachian.

France: The $A$. bucklandi Zone to the $P$. davoei Zone; Lower Sinemurian to Lower Pliensbachian (Apostolescu, 1959). The A. margaritatus Zone to the $P$. spinatum Zone; Upper Pliensbachian (Viaud, 1963).

Bairdia cf. carinata Drexler, 1958

Pl. 1, fig. 3.

cf. 1958: Bairdia carinata Drexler, p. 512, pl. 22, figs. 2 a-c.

Material. 2 carapaces in a cuttings sample from the Nøvling No. 1 boring.

Remarks. The present specimens differ from $B$. carinata by being a little less extended posteriorly. In dorsal view they are suboval with the largest breadth at mid-length, whilst $B$. carinata is drop-shaped with the largest breadth anteriorly.

Distribution. Denmark: The $O$. aspinata Zone and the O. adenticulata $N$. (N.) simplex Zone; Hettangian and Upper Pliensbachian.

Bairdia sp. 4134

Pl. 1, fig. 4.

Material. 1 carapace in a cuttings sample from the Nøvling No. 1 boring.

Remarks. The specimen is characterized by a pitted external surface and by an oblique anterior margin, extended dorsally and ornamented by fine spines.

In the outline of the carapace and in the ornamentation of the anterior margin this specimen resembles Bairdia clio Bizon (1960, p. 204). However, the external surface of $B$. clio is covered by numerous pustules connected in a fine reticulation. Furthermore, the present carapace is half the size of $B$. clio.

A final description of the relationship to $B$. clio must be based on more specimens.

Distribution. Denmark: The G. apostolescui - K. (K.) foveolata Subzone; Lower Pliensbachian.

Bairdia sp. 4185

P1. 1, figs. 5-8.

1968a: Bairdia sp. 811 Christensen, pl. 23, fig. 65. 
Material. 4 carapaces, 7 left valves, and 10 right valves in core samples from the Fjerritslev No. 1 and $\varnothing$ resund No. 3 borings. - Numerous fragments are recorded from the Flyvbjerg No. 1 boring.

Description. The dorsal margin between the distinct cardinal angles is straight on the right valve and feebly convex on the left one. This margin and the ventral margin converge only slightly towards the posterior end. The posterior margin is acuminate with the extended point a third of the height above the ventral margin. The margin between this point and the posterior cardinal angle is formed as an elongate $\mathrm{S}$. The posteroventral margin is concave, passing evenly into the nearly straight ventral margin, which has a distinct concavity anteromedianly. The anterior margin is symmetrical and broadly rounded. Between the anterior margin and the anterior cardinal angle the margin is concave. Zones along the anterior and posteroventral margins are laterally compressed, forming flanges. The lateral face is evenly vaulted. The left valve is larger than the right one; it overlaps the right valve along the dorsal margin and along the central part of the ventral one.

The hinge is a simple ridge-groove system between the cardinal angles. The contact-margin of the right valve is slightly raised terminally. On the left valve there is a corresponding contact-groove anteriorly.

The duplicature is rather broad. Anteriorly there is a long and narrow vestibule, posteriorly a short and narrow one. The radial pore canals are very thin, straight and numerous. They are simple, but a few of them are proximately so closely spaced that they may possibly be connected.

The muscle scars form a rosette of four suboval spots (see pl. 1, fig. 8).

Remarks. Bairdia sp. 4185 resembles $B$. molesta. It is a little more elongated than the latter species, and posteriorly its ventral and dorsal margins do not converge so pronouncedly. Bairdia sp. 4185 may possibly be a variant of $B$. molesta as considerable variation has been observed within one assemblage of this genus (Sylvester-Bradley, 1948a, pp. 197-198). Unfortunately none of the present assemblages are large enough for studying morphological variation.

Bairdia sp. 4185 is relatively longer than Bairdia fullonica Jones \& Sherborn (1888, p. 253) and without a punctate external surface.

The poorly described Bairdia hilda Jones (1884, p. 771) seems to have the dorsal and ventral margins converging more pronouncedly posteriorly.

Statistical analysis may be the only satisfactory method of distinguishing species which are so close to each other and diagnosed on the morphology alone (cf. Sylvester-Bradley, 1950, p. 199).

Distribution. Denmark: The $O$. adenticulata - N. (N.) simplex Zone; Upper Pliensbachian. 
Type species. Isobythocypris unispinata Apostolescu, 1959.

Original diagnosis. "Un genre de Bairdiidae caractérisé par se carapace subréniforme et par sa charnière. Dans la valve droite, le système de fermeture consiste en deux proéminences de forme elliptique; dans la valve gauche, un sillon étroit et lisse, terminé à chaque extrémité par un alvéole" (Apostolescu, 1959, p. 807).

Stratigraphical range. Lower Jurassic.

? Isobythocypris elongata (Blake, 1876)

Pl. 1, figs. 10-11; pl. 3, figs. 31-32.

? 1876: Bairdia elongata Blake, p. 431, pl. XVII, fig. 5.

1968a: Pontocyprella elongata (Blake) - Christensen, pl. 23, fig. 1.

1969b: Isobythocypris cf. elongata (Blake) - Herrig, p. 1076, text-fig. 3; pl. II, figs. 1a-e.

Material. 133 carapaces in core samples from the Øresund Nos. 3, 8, and 9 borings.

Original diagnosis. "Carapace large, long, like a narrow bean; ends nearly alike, sharply curved; ventral side slightly concave, dorsal side greatly convex, not compressed" (Blake, 1876, p. 431).

Description. See Herrig, 1969b, p. 1076.

Remarks. Herrig (1969b) named his species Isobythocypris cf. elongata (Blake) as the figure and description given by Blake (1876, p. 431) do not include sufficient detail. The specimens are here referred to the species of Blake, with reservations, as a comparison with the original type material has not been made.

In the present author's opinion the specimen drawn by Christensen (1968a, pl. 23, fig. 29: Pontocyprella cf. P. elongata) may also be referred to ? I. elongata.

Isobythocypris? sp. Dreyer (1965, pl. VI, fig. 7) differs only slightly from the present species. The posterior end is not pronouncedly extended ventrally, but this part of the carapace seems deformed.

The forms referred to Blake's species by Apostolescu (1959), Drexler (1958) and Viaud (1963) differ in having more pronouncedly convex dorsal margins and stronger convergence between the dorsal margin and the ventral margin posteriorly (see also p. 126).

Distribution. Denmark: The $C$. betzi - C. crassireticulata Zone, the G. apostolescui - K. (K.) foveolata Subzone and the O. adenticulata N. (N.) simplex Zone; Lower Sinemurian and Lower to Upper Pliensbachian. 
England: The $S$. angulata Zone and the A. bucklandi Zone; Lias Alpha-2 and 3 (Blake, 1876).

Northeast Germany: Lias Delta-2 (Herrig, 1969b).

Isobythocypris aff. elongata (Blake, 1876)

Pl. 2, fig. 12; pl. 3, figs. 33-36.

aff. 1876: Bairdia elongata Blake, p. 431, pl. XVII, fig. 5.

Material. 16 carapaces and 1 right valve in a core sample from the Gassum No. 1 boring.

Description. The dorsal margin is convex with a bend at mid-length (at the position of the greatest height of the carapace). The ventral margin is straight, however, with a concavity just anterior of mid-length on the right valve. The anterior margin is broadly rounded, slightly extended dorsally. The posterior margin is more narrowly rounded to acuminate, with the point of extension a third of the height above the ventral margin. The outline in dorsal view is elongated oval, with tapered ends and with the greatest breadth posteriorly. The left valve is larger than the right one.

The hinge seems to be the usual type for the genus Isobythocypris.

The duplicature is broad especially at the anterior end. The vestibules at both ends have a depth corresponding to between one third and a quarter of the breadth of the duplicature, and they are connected along the ventral margin.

The muscle scar area could not be observed clearly.

The external surface is smooth.

Remarks. There is some morphological variation within the present material: Some specimens are elongated and slender, whilst others are relatively higher and have a more convex dorsal margin. In all other respects, e.g. the relationships between the two valves and the details of the outline, they are identical.

I. aff. elongata differs from ? I. elongata by having a more convex dorsal margin and a more even transition between the dorsal margin and the posterior one. The point of maximum extension on the latter margin is also situated relatively high.

I. cf. elongata is higher and has a shorter posterior end than I. aff. elongata.

Isobythocypris? sp. 4070 is also higher and has a more rounded outline in lateral view than $I$. aff. elongata. Furthermore, on the right valve of $I$.? $s p .4070$ there is a weak concavity above the point of maximum extension on the posterior margin. 
The four species mentioned above are rather close to each other. The morphological variation of $I$. aff. elongata makes it clear that a subdivision into species must be based on statistical analysis of more abundant material.

Distribution. Denmark: The $O$. aspinata Zone; Hettangian and Lower Sinemurian.

Isobythocypris cf. elongata (Blake, 1876)

Pl. 1, fig. 9; pl. 3, figs. 29-30.

cf. 1876: Bairdia elongata Blake, p. 431, pl. XVII, fig. 5.

pars. 1958: Bythocypris cf. elongata (Tate \& Blake) - Drexler, p. 515, pl. 23, figs. 1c-f; pl. 26, figs. 7-9; (non pl. 23, figs. 1a-b; pl. 27, figs. 1-2).

1959: ? Isobythocypris elongata (Tate \& Blake) - Apostolescu, p. 808, pl. II, figs. 24-25.

1968a: Bairdia sp. 805 Christensen, pl. 23, fig. 64.

Material. 11 carapaces, 2 left valves, and 1 right valve in core samples from the Fjerritslev No. 2, Øresund Nos. 3, and 12 borings.

Description. See Drexler, 1958, p. 515.

Remarks. Isobythocypris cf. elongata is characterized by: A convex dorsal margin; in the right valve it is nearly straight anteriorly. The posterior margin is acuminate with the extended point a quarter of the height above the ventral margin. The anterior margin is convex, oblique, narrowly rounded and extended dorsally. The hinge is of the Isobythocypris-type. One well-preserved right valve (pl. 1, fig. 9) shows a narrow vestibule anteriorly, but none posteriorly. However, a left valve filled with sediment seems to have a posterior vestibule.

On account of the hinge characters the present species must be placed in the genus Isobythocypris (see also Apostolescu, 1959).

The specimens figured by Apostolescu (1959), Drexler (1958, pars) and Viaud (1963, pl. VII, figs. 192-193) are identical with the present specimens. This form differs from the specimen drawn by Blake (1876, pl. XVII, fig. 5 = Bairdia elongata; see p. 124) in having a more pronouncedly convex dorsal margin. Furthermore, the dorsal and ventral margins are distinctly convergent anteriorly.

The specimens figured by Drexler (1958, pl. 23, figs. 1a-b; pl. 27, figs. 1-2) are more slender, having a slightly convex dorsal margin only; so they may be identical with ? I. elongata. The specimens figured by Viaud (1963, pl. VII, figs. 195-196) may possibly be referred to the same species.

The taxonomical relationships of the present form cannot be established until Blake's species have been redescribed.

Distribution. Denmark: The O. danica Zone, Upper Sinemurian (Lias 
Beta-1); and the $O$. adenticulata - N. (N.) simplex Zone, Upper Pliensbachian.

Southern Germany: Upper part of Lias Alpha-3 to Lias Beta, "obere Arieten Schichten" to planicosta Subzone (Drexler, 1958).

France: The A. semicostatum Zone to the A. margaritatus Zone; Lower Sinemurian to Upper Pliensbachian (Viaud, 1963).

Isobythocypris unispinata Apostolescu, 1959

Pl. 2, fig. 13 .

1959: Isobythocypris unispinata Apostolescu, p. 807, pl. II, figs. 26-28.

Material. 3 carapaces, 1 left valve, and 1 right valve in core samples from the Øresund Nos. 12 and 15 borings.

Original diagnosis. "La carapace de cette espèce a les caractères du genre Isobythocypris n.g. La valve droite comporte à la base de l'extrémité postérieure une épine généralement bien développée.

Surface des valves lisse" (Apostolescu, 1959, p. 808).

Remarks. Isobythocypris unispinata differs from ? I. elongata in having a fine thin spine posteroventrally on the right valve. The carapace outlines of these two species are nearly identical.

The single carapace recorded from the Øresund No. 15 boring has the spine region covered by sediment and is only doubtfully referred to $I$. unispinata.

Distribution. Denmark: The $G$. apostolescui - K. (K.) foveolata Subzone; Lower Pliensbachian.

France: The E. raricostatum Zone to the $P$. davoei Zone; Lotharingian and Pliensbachian (Apostolescu, 1959, see also Viaud, 1963).

Isobythocypris? sp. 4020

P1. 2, figs. 14-16.

Material. 78 carapaces and stone-casts, and 1 right valve in core samples from the Gassum No. 1, Øresund Nos. 3, 11, and 12 borings.

Description. The dorsal margin is pronouncedly convex, most strongly arched posteromedianly, and slightly concave anteriorly. The ventral margin is slightly concave at mid-length, but convex at both ends. The posterior margin is acuminate and extended ventrally; dorsally to this sharp bend the margin is feebly concave. The anterior margin is convex, oblique, and extended at the dorsal margin. It passes into the dorsal and ventral margins with rather sharp bends. The lateral surface is evenly inflated. The left valve 
is larger than the right, strongly overlapping the latter along the dorsal and the ventral margins.

The internal features are unknown.

The external surface is smooth.

Remarks. Most of the specimens are broken or deformed. Deformation of areas at the concavities on the margins is very common. For this reason an evaluation of the morphological variation is difficult to give, and it is not clear whether this group of specimens represents more than one species. Some specimens seem to be shorter and to have a less pointed posterior end. As characteristic features the pronounced convex dorsal margin and the oblique anterior margin must be emphasized. Better preserved material is necessary for a description of the species on the basis of the total material found. The above description is based mainly on a few rather wellpreserved specimens.

As the internal features are unknown the form is only tentatively referred to the genus Isobythocypris.

Distribution. Denmark: The $O$. aspinata Zone, the $O$. danica Zone and the O. adenticulata - N. (N.) simplex Zone; Lower Sinemurian to Upper Pliensbachian.

Isobythocypris? sp. 4070

Pl. 2, fig. 20; pl. 3, figs. 37-38.

1968a: Bythocypris sp. 872 Christensen, pl. 23, fig. 18.

Material. 7 carapaces in core samples from the Børglum No. 1, Gassum No. 1, Øresund Nos. 11 and 14 borings.

Description. The outline is suboval in lateral view, with the greatest height posteromedianly. The dorsal margin is evenly convex and has slightly marked cardinal angles. The ventral margin is straight, with a concavity at midlength in the right valve. The anterior margin is symmetrically and broadly rounded. The posterior margin is moderately acuminate with the maximum extension lying one third of the height above the ventral margin. The ventral section of the posterior margin is rounded, the dorsal section on the left valve slightly convex and on the right valve slightly concave.

The internal features have not been observed; however, the muscle scars seem to be of the Isobythocypris-type as far as they have been observed externally on one carapace.

The external surface is smooth.

Remarks. The present species, of which only a few more or less wellpreserved specimens are found, resembles $I$. cf. elongata, but it has a lateral view outline distinctly unlike that of $I$. cf. elongata (cf. pl. 3, fig. 38), and 
thus it may be an independent species. However, one specimen (pl. 2, fig. 20) has a more rounded posterodorsal margin and may be a transitional type. A final definition of the species can not be given on the basis of these very few specimens.

Because of the resemblance to $I$. cf. elongata the present species has provisionally been referred to the genus Isobythocypris.

Isobythocypris? sp. 4070 may possibly be identical with Pontocyprella cavata Donze, 1967. It resembles the latter species in the general outline in lateral view, but it seems to be relatively shorter and to have a more elongated anterior end. A final determination of the present species can only be made from more abundant material.

Distribution. Denmark: The $O$. danica Zone; Upper Sinemurian to Lower Pliensbachian.

Isobythocypris sp. 4329

Pl. 2, figs. 17-19.

Material. 24 carapaces, 1 left valve, and 2 right valves from the Børglum No. 1, Fjerritslev No. 1, Haldager No. 1, Øresund Nos. 3, 11, and 12 borings.

Remarks. All the specimens are small and are probably larvae. The only two valves with uncovered internal features are larvae.

This group of specimens is characterized as follows: the dorsal margin is pronouncedly convex, often with a marked bend at mid-length and another one posteriorly. Between the posterior bend and the ventral margin the posterior margin is steep and only slightly convex. The ventral margin is straight. The hinge on the two right valves, mentioned above, is of the Isobythocypris-type.

The above-mentioned specimens are probably larvae of more than one species. As a few specimens are found together per sample, with no clear connection with other representatives of the genus, they are here left under open nomenclature, to complete the picture of the occurrence of Isobythocypris in the Lower Jurassic section in the Danish Embayment.

Distribution. Denmark: The $O$. danica Zone to the $O$, adenticulata $-N$. (N.) simplex Zone; Upper Sinemurian to Upper Pliensbachian.

Family Macrocyprididae Müller, 1912

Genus Pseudomacrocypris n.gen.

Derivation of the name. From Pseudos $=$ false, falsehood + macrocypris.

Type species. Pseudomacrocypris subtriangularis n.sp.

Diagnosis. A genus resembling Macrocypris in the outline of the carapace, 
with a smooth external surface, and with the right valve larger than the left one.

The hinge consists of three elements: In the left valve the posterior elongate terminal ridge is markedly dentate and the anterior one only slightly dentate. The median element is a groove emphasized by a dorsal ridge; it passes between this ridge and the dentate ridges. In the right valve a corresponding crenulate, median ridge and terminal grooves are seen. The terminal grooves are covered by roof-like extensions of the margin.

Rather deep vestibules may occur. The muscle scars consist of a rosette of 5-6 spots.

Remarks. Pseudomacrocypris n.gen. differs from Macrocypris Brady, 1867 in having a more simple hinge: tripartite and not quinquepartite as in the latter genus. The muscle scar area is also simpler in Pseudomacrocypris, since it consists of a rosette of 5-6 spots only. Unfortunately, frontal and dorsal spots are not yet known in this new genus. In all other respects the two genera are alike.

The pre-Tertiary Macrocypris-species are generally found as carapaces, and they are often rather badly preserved. Thus the internal features are rarely described. Of Pseudomacrocypris subtriangularis 1154 specimens are found, of which only 73 are valves. Only very few valves are sufficiently well-preserved for studying the internal features by scanning electron microscope and light microscope. The hinge can be described with certainty, as above. The duplicature is crushed in all valves, but it seems to have been rather broad, covering a deep vestibule. The muscle scars are not clearly visible in this species, but in Pseudomacrocypris aff. subtriangularis they can be observed as a rosette of 6 (?) spots. Pyrite-casts of Pseudomacrocypris subaequabilis show five spots in the rosette. The radial pore canals are not observed in the present material.

Of all the pre-Tertiary Macrocypris-species included in Ellis \& Messina (1940 ff.) the internal features are described in only one (Macrocypris parva Kaye, 1965). M. parva has a large number of fine, rather wavy radial pore canals. The duplicature is broad and the vestibules large. The muscle scars consist of five spots grouped in a rosette (see also pl. 41, figs. 579579). The hinge is as described for Pseudomacrocypris subtriangularis n.sp. $M$. parva and $P$. subtriangularis must be regarded as congeneric but differ from the genus Macrocypris Brady, 1867, emended by Sylvester-Bradley, 1948b (type species: Cythere minna Baird, 1850).

The following species are included in the genus Pseudomacrocypris:

Pseudomacrocypris subtriangularis $\mathrm{n} . \mathrm{sp}$.

(= Macrocypris No. 4023 Michelsen, 1970) 
Pseudomacrocypris aff. subtriangularis n.sp.

(= Macrocypris? sp. 863 Christensen, 1968a)

Macrocypris parva Kaye, 1965

Pseudomacrocypris subaequabilis n.sp.

Probably several other Mesozoic Macrocypris-species may be referred to this genus.

Stratigraphical range. Lower Jurassic to Lower Cretaceous.

Pseudomacrocypris subaequabilis n.sp.

Pl. 2, fig. 21; pl. 4, fig. 39.

1963: Macrocypris (Macrocypris) ? aequabilis Oertli - Plumhoff, p. 18, pl. 1, figs. 4-8 (non Macrocypris aequabilis Oertli, 1959).

1968a: M. (Macrocypris) ? aequabilis Oertli - Christensen, pl. 23, fig. 69 (non Macrocypris aequabilis Oertli, 1959).

Derivation of the name. From $s u b=$ slightly (under) + aequabilis, referring to the resemblance to Macrocypris aequabilis Oertli, 1959.

Holotype. A carapace; D.G.U. catalogue No. 1972-OM-97; pl. 4, fig. 39.

Type locality. The Øresund No. 2 boring.

Type stratum. Sample No, 205. Rydebäck Beds. Dark grey clay and silt. Aalenian (?).

Material. 16 carapaces (11 as pyrite-casts) in core samples from the Øresund No. 2 boring. - More than 200 pyrite-casts are recorded from the Haldager No. 1 and Vedsted No. 1 borings.

Diagnosis. A species of the genus Pseudomacrocypris with a rounded dorsal margin and a broadly rounded anterior margin. The acuminate posterior margin has the maximum extension one third of the height above the ventral margin. The greatest height is at the anterior third.

Description. The carapace is elongated oviform to drop-shaped, with a rounded dorsal margin. The cardinal angles are feeble, so the entire dorsal margin between the two ends is a flat arch more rounded anteriorly than posteriorly. The ventral margin is nearly straight and passes evenly into the anterior and posterior margins. The anterior margin is broadly rounded, slightly extended ventrally. The posterior margin is narrowly rounded to acuminate, with the maximum extension situated one third of the height above the ventral margin. The greatest height is one third of the length from the anterior end. In dorsal view the outline is drop-shaped with the greatest breadth one third or a quarter of the length from the anterior end. The right valve is larger than the left one, strongly overlapping the latter along the ventral margin. 
The internal features can not be studied in the present material, apart from the muscle scars observed on pyrite-casts. They consist of five spots arranged in a rosette.

The external surface is smooth.

Sexual dimorphism was not observed.

Measurements (in $\mathrm{mm}$ ). Only two specimens from the Øresund No. 2 boring are measurable:

\begin{tabular}{lcc}
\hline & Length & Height \\
\hline Sample No. 205, holotype & 0.41 & 0.20 \\
Sample No. 206 & 0.36 & 0.18 \\
\hline
\end{tabular}

Remarks. Though the material is sparse and badly preserved the establishment of a new species is well-founded. The present specimens are regarded as identical with those published by Plumhoff 1963 as Macrocypris (Macrocypris) ? aequabilis Oertli, 1959, even if the latter are a little more slender (type material deposited with $\mathrm{H}$. Malz (Frankfurt) has been studied). Plumhoff's specimens are also characterized by a rounded outline in lateral view. The cardinal angles are feeble. The anterior margin is broadly rounded and only slightly extended ventrally. The maximum extension of the posterior margin lies one third of the height above the ventral margin.

Macrocypris aequabilis Oertli (1959, p. 24) has a more narrowly rounded anterior margin and has the maximum extension of the posterior margin near the ventral margin. The cardinal angles are also more marked. Furthermore, the greatest height is only a little anterior to mid-length. The margin anterior to this point is rather long and only slightly convex, whilst in $P$. subaequabilis it is short and rounded.

Distribution. Denmark: Upper part of the Rydebäck Beds; Aalenian (?).

Northern Germany: Aalenian and Bajocian (Plumhoff, 1963).

Pseudomacrocypris subtriangularis n.sp.

Pl. 2, figs. 22-28; pl. 4, figs. 40-41, 44-45.

1968a: Paracypris? sp. 854 Christensen, pl. 23, fig. 2.

1968a: Macrocypris ? sp. 855 Christensen, pl. 23, fig. 4.

1970: Macrocypris No. 4023 Michelsen, p. 33, pl. XII, figs. 1a-b; text-fig. 2.

Derivation of the name. From triangulus = triangular, referring to the subtriangular outline in lateral view.

Holotype. A right valve; D.G.U. catalogue No. 1969-OM-4; pl. 2, figs. 22, 26-28; pl. 4, figs. 40-41. 
Type locality. The Rødby No. 1 boring.

Type stratum. Sample No. 21. Dark grey to grey clay. Hettangian.

Material. 1081 carapaces, 45 left valves, and 28 right valves in core samples from the Gassum No. 1, Horsens No. 1, Rødby No. 1, Vedsted No. 1, Vinding No. 1, Øresund Nos. 8, 9, 14 and 15 borings.

Diagnosis. A species of the genus Pseudomacrocypris with the straight ventral margin and the dorsal margin slightly converging posteriorly. Cardinal angles are weakly marked. The anterior margin is well-rounded, the posterior one acuminate; both of the margins are extended ventrally so the greatest length is below the centre of the valve.

In the left valve hinge the terminal ridges are dentate; in the right valve the median ridge is crenulate.

Description. The carapace is subtriangular in lateral view, with the greatest height at the anterior cardinal angle. In dorsal view it is discus-shaped, with the greatest breadth posterior to the mid-point. In posterior view it is oval.

The right valve is larger than the left one. The dorsal margin between the weakly marked cardinal angles is straight. The dorsal and the nearly straight ventral margin converge posteriorly. The anterior margin is well-rounded, but most sharply curved ventrally. The posterior margin is acuminate with slightly convex dorsal and ventral parts. The lateral surfaces are evenly inflated. The larvae have a more pronouncedly angular outline. In dorsal view they have a more pointed posterior end, the greatest breadth anteromedianly.

The hinge is tripartite, in the left valve with elongated terminal ridges of which the posterior one is pronouncedly dentate and the anterior one only slightly so. The median element is a groove, emphasized by a dorsal ridge, passing between this ridge and the terminal ridges. In the right valve the median element is a crenulate ridge; the terminal grooves (sockets) are overhung by roof-like extensions of the margin.

The duplicature is crushed in all of the valves, but it seems to have been rather broad with deep vestibules. The muscle scars can not be clearly observed, but seem to show a rosette of few spots.

The external surface is smooth.

Sexual dimorphism was not observed.

Measurements (in $\mathrm{mm}$ ). As only rather few specimens are measurable, only those in sample No. 21 of Rødby No. 1 are measured (see Michelsen, 1970, text-fig. 2).

Remarks. The interpretation of the hinge given by Michelsen (1970, p. 34) is erroneous. The description of the hinge, given above, is based on studies by means of the scanning electron microscope. It shows clearly that this species cannot be referred to the genus Macrocypris, but that it is still close to this genus. 
The two specimens figured by Christensen, 1968a (Paracypris ? sp. 854 and Macrocypris? sp. 855) are identical with the present species. Concerning further affinities see Michelsen (1970, pp. 34-35).

Distribution. Denmark. The $O$. aspinaia Zone (frequent), the $C$. betzi $C$. crassireticulata Zone and the $O$. danica Zone (rare); Hettangian to lowermost Lower Pliensbachian.

Pseudomacrocypris aff. subtriangularis n.sp.

Pl. 4, figs. 42-43.

1968a: Macrocypris? sp. 863 Christensen, pl. 23, fig. 24.

Material. 1 carapace in a core sample from the Øresund No. 14 boring.

Remarks. This specimen differs from P. subtriangularis n.sp. only in being shorter. It is mainly the section behind the posterior cardinal angle which is "shortened". The lateral surfaces seem to be a little more inflated.

The muscle scars, which can be observed externally, consist of 6(?) spots in a rosette.

Distribution. Denmark: The $P$. reticulata Subzone; Upper Sinemurian, Lias Beta-1a.

Superfamily Cypridacea Baird, 1845

Family Paracyprididae Sars, 1923

Genus Paracypris Sars, 1866

Type species. Paracypris polita Sars, 1866.

Original diagnosis. See Sars, 1866, p. 11.

Paracypris? redcarensis (Blake, 1876)

Pl. 4, figs. 48-49.

1876: Bairdia redcarensis Blake, p. 431, pl. XVII, fig. 4.

1959: ? Paracypris redcarensis (Tate \& Blake) - Apostolescu, p. 806, pl. II, fig. 32.

1968a: Paracypris sp. 878 Christensen, pl. 23, fig. 33.

Material. 11 carapaces in a core sample from the Øresund No. 12 boring, and 1 pyrite-cast from the Gassum No. 1 boring.

Original diagnosis. "Carapace more than half as broad as long, not very inflated, uniformly convex on the dorsal side, nearly straight, or with a very open sigmoid curve on the ventral side" (Blake, 1876, p. 431).

Description. A small carapace with a straight to concave dorsal margin; distinct cardinal angles. The ventral margin is straight with a feeble concavity posteromedianly. The anterior margin is broadly rounded, extended ventrally. The posterior end is acuminate near the ventral margin; the margin dorsal 
to this point is evenly convex. The greatest height is at the anterior cardinal angle. In dorsal view the carapace is an elongated oval with both ends acuminate and with the greatest breadth near the anterior cardinal angle. The left valve is larger than the right, overlapping the latter along the dorsal and ventral margins.

The internal features are unknown.

Remarks. P.? redcarensis has never been clearly defined as all material found (including the present) is rather badly preserved, with internal features which can not be studied. However, the present specimens agree with those figured by Apostolescu (1959, pl. 11, fig. 32) and Viaud (1963, pl. V, fig. 135).

Distribution. Denmark: The G. apostolescui - K. (K.) foveolata Subzone and the $O$. adenticulata - N. (N.) simplex Zone (?); Lower Pliensbachian and Upper Pliensbachian (?).

England: The $S$. angulata Zone and the A. bucklandi Zone; Lias Alpha (Blake, 1876).

France: The $E$. raricostatum Zone to the $T$. ibex Zone; Lotharingian to Pliensbachian (Apostolescu, 1959 and Viaud, 1963). According to Oertli \& Grosdidier (1961) also in Lower Toarcian.

Paracypris? sp. 4091

Pl. 4, figs. 46-47.

Material. 4 carapaces in core samples from the Gassum No. 1, Vinding No. 1, and Øresund No. 9 borings.

Remarks. None of the four specimens are intact. They are characterized by a long carapace with an elongated and pointed posterior end. The left valve overlaps the right one along the dorsal and ventral margins.

Paracypris ? sp. 4091 is possibly identical with Macrocypris mucronata Conti (1954, p. 227). The only difference seems to be that Paracypris ? sp. 4091 has the left valve larger than the right one. It differs from Paracypris ? sp. 402 Viaud (1963, pl. V, figs. 133-134) in having a shorter anterior end and a narrower posterior end.

Distribution. Denmark: The $O$. aspinata Zone, the $P$. reticulata Subzone and the $O$. adenticulata - N. (N.) simplex Zone (?); Lower Sinemurian, Upper Sinemurian (Lias Beta-1a) and Upper Pliensbachian (?).

Family Pontocyprididae Müller, 1894

Genus Liasina Gramann, 1963

Type species. Liasina vestibulifera Gramann, 1963.

Original diagnosis. "Gehäuse klein, spindelförmig. Linke Klappe deutlich 
grösser als die rechte, jedoch diese nur terminal und ventral vollständig umgreifend. Vorderende breiter gerundet als das Hinterende. Dorsalrand leicht eingesenkt, fast gerade. Dorsale Umrisslinie und Ventralrand mehr oder weniger konvex. Klappen stark gewölbt, glatt. Schloss einfach: In der linken Klappe eine an beiden Enden etwas verbreiterte Furche zur Aufnahme einer von Saum der rechten Klappe gebildeten Schlossleiste. Innenlamelle sehr breit. An den Enden je ein Vestibulum, das vordere taschenförmig; Porenkanäle unverzweigt. Das Zentral-Muskelfeld besteht aus einer Gruppe von 5 annähernd rosettenförmig angeordneten Muskelnarben, entsprechend den Verhältnissen bei den Pontocyprididae" (Gramann, 1963, p. 66).

Stratigraphical range. Lower Jurassic (Lower and Middle Lias).

Liasina vestibulifera Gramann, 1963

P1. 4, figs. 51-52.

1963: Liasina vestibulifera Gramann, p. 67, pl. 3, figs. 1-3.

1968a: Liasina vestibulifera Gramann - Christensen, pl. 23, fig. 62.

Material. 9 carapaces, 6 left valves, and 4 right valves in core samples from the Øresund No. 3 boring.

Original diagnosis. "Eine spindelförmige Liasina mit gut gerundetem, annähernd ovalem Umriss und einem relativ kurzen Hinterende. Klappen nur wenig länger als das Doppelte der Höhe. Innenlamelle am Hinterende schmal. Das vordere Vestibulum gross, taschenförmig, seitlich stark eingezogen" (Gramann, 1963, p. 67).

Description. See Gramann, 1963, p. 67.

Remarks. Bythocypris? sp. 10 Viaud (1963, pl. VII, figs. 187-188) is in the present author's opinion probably identical with Liasina vestibulifera.

Distribution. Denmark: The O. adenticulata - N. (N.) simplex Zone; Upper Pliensbachian.

North Germany: The $U$. jamesoni Zone to the $P$. spinatum Zone; Lias Gamma-1a to Delta-4 (Gramann, 1963).

France: Bythocypris ? sp. 10 is recorded from the A. semicostatum Zone to the P. davoei Zone; Sinemurian to Pliensbachian (Viaud, 1963).

? Liasina lanceolata (Apostolescu, 1959)

Pl. 4, fig. 50 .

? 1959: ? Krausella lanceolata Apostolescu, p. 815, pl. IV, fig. 77.

? 1963: Liasina lanceolata (Apostolescu) - Gramann, p. 68, pl. 3, figs. 4-5.

Material. 3 carapaces in a core sample from the Gassum No. 1 boring.

Original diagnosis. "Carapace lancéolée assez lourde. Surface des valves lisse ou très faiblement ponctuée (Apostolescu, 1959, p. 816). 
Remarks. Gramann (1963, p. 69) includes in his diagnosis: "Dorsalrand kurz, Hinterrand lang ausgezogen" and "Innenlamelle auch am Hinterende breit, mit einem deutlichen Vestibulum."

The three specimens found in the Danish material are deformed and can not be referred with certainty to $L$. lanceolata.

Distribution. Denmark: The $O$. danica Zone; Upper Sinemurian.

North Germany: The $U$. jamesoni Zone to the T. ibex Zone; Lias Gamma (Gramann, 1963).

France: The E. raricostatum Zone to the P. spinatum Zone, Upper Lotharingian to Domerian (Viaud, 1963); and lowest in the D. tenuicostatum Zone, Lower Toarcian (Bizon \& Oertli, 1961).

Superfamily Cytheracea Baird, 1850

Family Cytheridae Baird, 1850

Genus Camptocythere Triebel, 1950

Type species. Camptocythere praecox Triebel, 1950.

Original diagnosis. "Eine Gattung mit dem Narbenfeld der Cytheridae und folgenden Besonderheiten: Rechte Klappe dorsal mit einer Aufwölbung, die den geraden, nach hinten geneigten Schlossrand der linken Klappe überragt. Ventral greift die linke Klappe über die rechte, so dass in der Endansicht die beiden Klappen gegeneinander verschoben erscheinen. Vordere Randzone mit einfachen, weit gestellten Porekanälen. Schloss links ohne Zähne, rechts mit zwei flach dreieckigen, unvollkommen gekerbten Zähnen” (Triebel, 1950a, p. 198).

Stratigraphical range. Toarcian - Aalenian - Bajocian.

Camptocythere praecox Triebel, 1950

Pl. 5, fig. 56.

1950a: Camptocythere praecox Triebel, p. 199, pl. 1, figs. 1-10; pl. 2, figs. 11-12.

1962: Camptocythere praecox Triebel - Klingler, p. 113, pl. 14, fig. 56.

1962: Camptocythere praecox Triebel - Brand \& Fahrion, p. 137, pl. 20, fig. 11.

1963: Camptocythere praecox Triebel - Plumhoff, p. 42, pl. 8, figs. 125-126.

1965: Camptocythere praecox Triebel - Stoermer \& Wienholz, pl. V, fig. 45a; pl. VI, figs. $45 \mathrm{~b}-49$.

1968a: Camptocythere praecox Triebel - Christensen, pl. 23, fig. 68.

Material. 1 left valve and 2 right valves in core samples from the Øresund No. 2 boring.

Original diagnosis. "Eine Art mit den Merkmalen der Gattung Camptocythere und folgenden Besonderheiten: Gehäuse mittelgross, mit kleinen, 
wenig auffälligen Grübchen bedeckt. Seiten in Rückenansicht gewölbt, Vorderende mit deutlichem Kiel" (Triebel, 1950a, p. 200).

Description. See Triebel, 1950a, p. 200.

Distribution. Denmark: The Rydebäck Beds; (?) Aalenian.

North Germany: The Upper Toarcian to the Lower Aalenian (Triebel, 1950a and Plumhoff, 1963); and, in the northeastern part only, in the $P$. aalensis Zone, uppermost Toarcian (Stoermer \& Wienholz, 1965).

Camptocythere sp. 4190

Pl. 5, fig. 57.

Material. 1 carapace and 1 left valve in a core sample from the Øresund No. 2 boring.

Remarks. Both specimens are broken and badly preserved. They seem to be close to Camptocythere parvula Plumhoff (1963, p. 45), but differ from this in the nearly smooth external surface and the more widely spaced normal pore canals.

Distribution. Denmark: The Rydebäck Beds; (?) Aalenian.

Family Bythocytheridae Sars, 1926

Genus Monoceratina Roth, 1928 s.l.

Type species. Monoceratina ventrale Roth, 1928.

Diagnosis. See Triebel \& Bartenstein, 1938, p. 504.

Remarks. The genus Monoceratina is here used as a group without generic rank for a number of species (or morphospecies) belonging to the family Bythocytheridae. Among others, Gründel \& Kozur (1971) have tried to solve the taxonomical problems of the group of species referred to this genus during the last fifty years. However, it has not been possible for the present author to refer all of the below-mentioned species with certainty to different genera. Furthermore, as these species only occur occasionally and as they are of minor importance in a stratigraphical sense, they are included informally under the genus-name Monoceratina.

Stratigraphical range. Devonian - Recent.

Monoceratina amlingstadtensis Triebel \& Bartenstein, 1938

Pl. 5, fig. 69.

1938: Monoceratina amlingstadtensis Triebel \& Bartenstein, p. 512, pl. 3, fig. 12.

Material. 3 carapaces and 1 left valve in core samples from the Gassum No. 1 and Øresund No. 12 borings; - and 1 carapace in a cuttings sample from the Nøvling No. 1 boring. 
Original diagnosis. "Eine Art der Gattung Monoceratina mit kleinem, spitzem Seiten-Stachel, netz-förmiger Zeichnung der Oberfläche und LängsRippchen" (Triebel \& Bartenstein, 1938, p. 513).

Description. See Triebel \& Bartenstein, 1938, p. 513.

Remarks. Type material deposited with H. Malz (Frankfurt) has been studied. The only difference observed is that the paratypes, which originate from South Germany, are more thin-shelled than the present specimens. However, specimens from North Germany (also deposited with H. Malz) agree with the present specimens.

Distribution. Denmark: the $G$. apostolescui - K. (K.) foveolata Subzone, Lower Pliensbachian.

Germany: Lias Gamma-1 and 2 (Triebel \& Bartenstein, 1938).

France: Carixian and Lower Domerian (Donze, 1967).

Monoceratina? fusiformis (Drexler, 1958)

Pl. 4, figs. 53-55; pl. 5, figs. 58-60.

1958: Paradoxostoma? fusiformis Drexler, p. 526, pl. 24, figs. 7 a-d.

Material. 26 carapaces, 1 left valve, and 1 right valve in core samples from the Gassum No. 1 and Horsens No. 1 borings.

Original diagnosis. "Eine Art, die mit Vorbehalt zur Gattung Paradoxostoma gestellt wird, mit den folgenden Besonderheiten: das glatte $G$ zeigt in Dorsalansicht in der Mitte die grösste Breite, LKI und RKI sind am Vorder- und Hinterende schwach eingekerbt" (Drexler, 1958, p. 526).

Description. See Drexler, 1958, p. 526.

Remarks. The present material may be subdivided into two "groups": The specimens from Horsens No. 1 are $0.38-0.39 \mathrm{~mm}$ long, whilst the maximum length of specimens from Gassum No. 1 and from Nøvling No. 1 are $0.42 \mathrm{~mm}$. As the outlines are identical, both of these groups are referred to the same species.

The hinge seems to be of the type usual for Monoceratina. The external surface of a well-preserved specimen from Nøvling No. 1 (see pl. 5, figs. 58-59) shows a few widely spaced weak ribs on the middle and anterior parts of the shell.

As the inner margin and the line of concrescence coincide (see also Drexler, 1958, p. 526) this species cannot be referred to the genus Paradoxostoma Fischer, 1855. Because of the missing alate extension and sulcus this species cannot belong to the genus Monoceratina, but it cannot be referred with certainty to any other genus, so as mentioned above, it is preliminarily referred to the genus Monoceratina (cf. p. 138).

Together with Monoceratina? multistriata and M.? sp. 4135 the present 
species may constitute a new genus, probably belonging to the tribus Protojonesiini Gründel \& Kozur, 1971.

Distribution. Denmark: The $O$. aspinata, Lower Sinemurian; and the $P$. reticulata Subzone; Upper Sinemurian (Lias Beta-1a).

Southern Germany: Lias Alpha-2 and lower part of Alpha-3 (Drexler, 1958).

Monoceratina? multistriata n.sp.

Pl. 5, figs. 62-63; pl. 8, figs. 105-106.

Derivation of the name. From multus $=$ many + striatus $=$ striated; referring to the characteristic sculpture.

Holotype. A carapace. D.G.U. catalogue No. 1973-OM-9; pl. 8, figs. 105-106.

Type locality. The Nøvling No. 1 boring.

Type stratum. Cuttings sample $5930^{\prime}-5960^{\prime}$. Dark grey to greyish black claystone, interbedded with siltstone. The $O$. aspinata Zone, Hettangian or Lower Sinemurian.

Material. 3 carapaces, 1 left valve, and 2 right valves in core samples from the Fjerritslev No. 2, Gassum No. 1, and Øresund No. 11 borings.

Diagnosis. The carapace is elongated, drop-shaped in lateral view. The anterior margin is symmetrically rounded; the posterior margin is acuminate, with the maximum extension dorsally. There are no alate extensions or median sulcus.

The sculpture consists of numerous, fine, closely-spaced ribs which conform to the dorsal and ventral margins.

Description. The carapace is drop-shaped with an acuminate posterior end and a symmetrical, rounded anterior margin. The dorsal margin is slightly convex; the ventral margin convex. The lateral surfaces are inflated and have a sculpture of very fine, longitudinal ribs, which are closely spaced and converge posteriorly, conforming to the ventral and dorsal margins.

The internal features are poorly known. The duplicature at the anterior end seems to be rather broad. The anterior section of the hinge on the right valve is a straight (and smooth ?) groove.

Measurements. Holotype (1973-OM-9): Length $0.58 \mathrm{~mm}$ and height $0.23 \mathrm{~mm}$.

Remarks. Monoceratina? multistriata n.sp. differs from Monoceratina striata Triebel \& Bartenstein (1938, p. 514) in having a sculpture of more numerous ribs, which conform to the ventral and dorsal margins, and by having a more slender and drop-shaped outline. 
In the shape of the carapace, M.? multistriata resembles Monoceratina? sp. 4135 which, however, has a sculpture of rather few and strong ribs.

Though M.? multistriata has neither a median sulcus nor alate extensions it is preliminarily referred to the genus Monoceratina (cf. p. 138). It probably belongs to a new genus together with $M$. ? fusiformis (see p. 139).

Distribution. Denmark: The $O$. aspinata Zone to the $O$. danica Zone; Lower to Upper Sinemurian.

Monoceratina cf. scrobiculata Triebel \& Bartenstein, 1938

Pl. 5, figs. 65-66.

cf. 1938: Monoceratina scrobiculata Triebel \& Bartenstein, p. 508, figs. 5-6.

Material. 1 carapace in a core sample from the Gassum No. 1 boring.

Remarks. The specimen is broken and fragmentary: half of the left valve is missing; the anterior margin is fragmentary, and the dorsal extension of the posterior margin is broken.

This specimen is characterized by a sculpture of longitudinal, parallel, and sharp ribs with distinct cross-ribs between them, forming squares. The longitudinal ribs continue as finer ribs on the marginal flange. There is a broad, median sulcus, but no alate extensions. Anterodorsally, close to the dorsal margin, there is a smooth hemispherical spot, - resembling an eye spot (cf. pl. 5, fig. 66).

This form differs from $M$. scrobiculata in the more regular sculpture and the absence of alate extensions.

Gründel \& Kozur (1971) referred Monoceratina scrobiculata to the subgenus Bythoceratina (Praebythoceratina) Gründel \& Kozur, 1971, but owing to the above-mentioned difference between the present species and M. scrobiculata the latter cannot be referred with certainty to the same subgenus. The present form shows affinities to the genus Saxellacythere Gründel \& Kozur, 1971, but differs in having a median sulcus. Therefore it is here placed informally under the genus-name Monoceratina (see p. 138).

Distribution. Denmark: The $G$. apostolescui - K. (K.) foveolata Subzone; Lower Pliensbachian.

Monoceratina? sp. 4135

Pl. 5, fig. 61.

Material. 1 fragment in a core sample from the Gassum No. 1 boring; and 1 carapace in a cuttings sample from the Nøvling No. 1 boring.

Remarks. Monoceratina? sp. 4135 resembles $M$. striata Triebel \& Bar- 
tenstein (1938, p. 514), but its dorsal margin is slightly convex and the number of ribs is less than on $M$. striata.

Monoceratina? sp. 4135 has no alate extension and no median sulcus, so it cannot belong to the genus Monoceratina. As mentioned under the description of $M$. ? fusiformis it must probably belong to a new genus (see p. 139). It is here placed informally under the genus-name Monoceratina (see p. 138).

Distribution. Denmark: The G. apostolescui - K. (K.) foveolata Subzone; Lower Pliensbachian.

Monoceratina sp. 4176

P1. 5, fig. 68.

Material. 3 carapaces and 1 left valve in a core sample from the Gassum No. 1 boring.

Remarks. The four specimens are more or less fragmentary. They are characterized by a sculpture of ribs and very fine intercostal pits. The ribs are irregular, partly with a longitudinal direction as the dominating one. The posteroventral part of the lateral surface is inflated with an alate extension which ends in a strong "spine". A feeble sulcus is present.

This appears to be a new species, which has some affinities with Monoceratina cf. striata Triebel \& Bartenstein, 1938, sensu Drexler (1958, p. 522).

Distribution. Denmark: The $O$. aspinata Zone; Lower Sinemurian.

Monoceratina sp. 4317

P1. 5, fig. 67.

Material. 1 carapace in a core sample from the Flyvbjerg No. 1 boring.

Measurements. Length $0.27 \mathrm{~mm}$ and height $0.14 \mathrm{~mm}$.

Remarks. This very small specimen, which is possibly a larva, does not resemble any known species.

The external surface is ornamented by numerous small pits. Near the posterior part of the dorsal margin there is a short, longitudinal elevation (a rib ?). The alate extension is strong and rather short. Along the anterior margin there is an elevated marginal rim.

Distribution. Denmark: The $O$. adenticulata - N. (N.) simplex Zone; Upper Pliensbachian.

Monoceratina? sp. 4325

Pl. 5, fig. 64. 
Material. 2 carapaces in a core sample from the Horsens No. 1 boring.

Remarks. Monoceratina? sp. 4325 differs from Monoceratina ungulina Triebel \& Bartenstein (1938, p. 508) mainly in having a sculpture of very fine pits. Furthermore the carapace is relatively higher.

Gründel \& Kozur (1971) referred M. ungulina to the genus Patellacythere Gründel \& Kozur, 1971, from which the present species differs since it does not have a median sulcus. It is close to Saxellacythere Gründel \& Kozur, 1971 which, however, has an eye spot. M. ? sp. 4325 is only referred preliminarily to the genus Monoceratina (see p. 138).

Distribution. Denmark: The O. aspinata Zone; Lower Sinemurian.

Family Cytheruridae Müller, 1894

Genus Cytheropteron Sars, 1866

Type species. Cythere latissima Norman, 1865.

Diagnosis and description. See Sars (1866, p. 79) and Alexander (1933, pp. 187-190).

Remarks. None of the below-mentioned species can with certainty be referred to the genus Cytheropteron.

Cytheropteron reticulatum n.sp., of which the internal features are only partly known, may possibly belong to the subgenus Cytheropteron (Cytheropteron). Cytheropteron? foveolatum n.sp. and Cytheropteron? cavatum n.sp. have outlines and carapace-shape resembling the subgenus Cytheropteron (Eocytheropteron) Alexander (1933, p. 195), but the hinge structure resembles that of Cytheropteron (Cytheropteron). The genus Metacytheropteron Oertli (1957, p. 664) has minor alate extensions only, as have the present species. It differs from these species in the triangular outline of the carapace and in the sculpture, which is dominated by longitudinal ribs.

A species very close to C. ? foveolatum, C. ? diversum Herrig (1969b, p. 1090), is described as having smooth hinge elements. Dentation of the terminal hinge elements on the right valve has been observed in $C$. ? foveolatum. A left valve of $C$. ? cavatum has a crenulate median element. It should be mentioned that specimens of both species appear to be partly corroded.

The three species (C.? diversum, C.? foveolatum, C.? cavatum) seem to be transitional forms between the two first-named subgenera, and may possibly form the basis for a new subgenus.

Herrig (1969b, p. 1091) describes some of the radial pore canals as bipartite. Such radial pore canals are described in a few species (e.g. Cytheropteron (Cytheropteron) confusum Hornibrook, 1952). Several other species have straight and simple radial pore canals (e.g. Cytheropteron (Cytheropteron) acutangulum Hornibrook, 1952 and C. alatum Sars, 1866). 
The radial pore canals must be regarded as a very important character on the generic level, as is the hinge structure. A revision of the whole group, reviewing such characters as hinge structure, muscle scars, radial pore canals, and possibly occurrence of the alate extension, is desirable.

Establishment of a new subgenus, including $C$.? diversum, C. ? foveolatum and C.? cavatum, would not be reasonable before such a revision. For this reason all the species present in the Danish Lower Jurassic have provisionally been referred to the genus Cytheropteron only.

Stratigraphical range. Lower Jurassic - Recent.

Cytheropteron? cavatum n.sp.

Pl. 6, figs. 70-71.

1968a: Cytheropteron sp. 869 Christensen, pl. 23, fig. 25.

Derivation of the name. From cavus = cavity, referring to the sculpture, which consists of numerous cavities or pits.

Holotype. A carapace. D.G.U. catalogue No. 1973-OM-62, pl. 6, fig. 70 .

Type locality. The Gassum No. 1 boring.

Type stratum. Sample No. 38. Dark greenish grey shale. The $O$. danica Zone; Upper Sinemurian.

Material. 3 carapaces, 5 left valves, and 4 right valves in core samples from the Fjerritslev No. 2, Gassum No. 1, Øresund Nos. 10, 12, 14 and 15 borings.

Diagnosis. A Cytheropteron-like species without alate extensions, but with the hinge usual for the genus.

The sculpture consists of numerous fine pits of equal size over the entire lateral surface, partly arranged in longitudinal rows, and with a few feeble, longitudinal ribs between.

Description. The outline in lateral view is suboval, tapering posteriorly with a caudal extension above the mid-line. The ventral margin is straight with a concavity anteromedianly. The anterior margin is broadly rounded, extended ventrally. The dorsal margin is convex, but slightly concave posteriorly. The lateral surface is strongly inflated in the posteroventral region, but without an alate extension. Dorsally in the middle of the lateral surface there is a feeble concavity (sulcus). A zone along the anterior, posterior, and posteroventral margins is laterally compressed (forming flanges).

The hinge of the left valve is tripartite with a long crenulate ridge and small terminal sockets located in bulges in the margin.

The muscle scars form a vertical row of four spots, which seem to be elongated. 
The sculpture consists of fine to very fine pits of uniform size over the entire lateral surface. They are partly arranged in longitudinal rows; the rows are distinct along the ventral margin. Between the pits there are a few feeble, longitudinal ribs. On the posteroventral marginal area the ribs are the only sculpture found.

Remarks. All specimens found are larvae, - except for one carapace(?). Therefore the marginal zone is not known. Of the valves, only one left valve is sufficiently well-preserved to allow study of the hinge and the muscle scars.

In shape of the carapace this species resembles Cytheropteron? foveolatum n.sp., but it has a different sculpture.

This species is questionably referred to the genus Cytheropteron as the internal features are only partly known (see also p. 143).

Distribution. Denmark: The $C$. betzi $-C$. crassireticulata Zone to the $G$. apostolescui - K. (K.) foveolata Subzone; Lower Sinemurian to Lower Pliensbachian.

Cytheropteron? foveolatum n.sp.

Pl. 6, figs. 72-78; pl. 8, figs. 107-111.

1968a: Cytheropteron? sp. 814 Christensen, pl. 23, fig. 53.

1968a: Cytheropteron? sp. 809 Christensen, pl. 23, fig. 61.

Derivation of the name. From foveolae $=$ pits, a characteristic feature of the sculpture.

Holotype. A right valve. D.G.U. catalogue No. 1973-OM-12; pl. 8, figs. 107-109.

Type locality. The Fjerritslev No. 1 boring.

Type stratum. Sample No. 4. Dark grey claystone, shale and siltstone. The $O$. adenticulata $-N$. (N.) simplex Zone; Upper Pliensbachian.

Material. 17 carapaces, 38 left valves, and 41 right valves in core samples from the Fjerritslev No. 1, Flyvbjerg No. 1, Gassum No. 1, Haldager No. 1, and Øresund No. 3 borings.

Diagnosis. A Cytheropteron-like species without alate extensions, but with a hinge usual for the genus. Anteriorly and posteriorly there are narrow vestibules.

The sculpture consists of pits, large in the centre and small near the margins. At the anterior margin there are a few irregular radial ribs (or wrinkles).

Description. The outline in lateral view is suboval with a caudal extension at the posterior end, and with greatest height anteromedianly. In dorsal view it is elongated oval with nearly straight lateral surfaces and distinct

10 D.G.U. II. rk. nr. 104 
marginal flanges; the greatest breadth occurs posteromedianly. In posterior view it is oval to subtriangular.

The dorsal margin is slightly convex. The ventral margin is nearly straight with a weak concavity posteromedianly. The anterior margin is rounded, extended ventrally. The posterior margin is narrowly arched with a caudal extension. In the right valve there is a distinct concavity on the dorsal side of this caudal extension. Along the anterior margin there is a flange which is broadest anteroventrally. Along the posterior and the posteroventral margin there is a rather broad zone which is laterally compressed without forming a flange. Along this zone the valve is only moderately inflated, whilst the remaining part of the lateral surface is strongly inflated (especially ventrally, but without an alate extension). The left valve is larger than the right one and overlaps it along the anterior and posterior margins. Along the dorsal margin the left valve is overlapped.

The hinge is tripartite; the right valve has dentate terminal ridges. The median element is a narrow groove emphasized by a strong dorsal ridge. In the left valve the terminal sockets are formed by bulges of the margin.

The duplicature is broad; the inner margin and line of concrescence coincide except for part of the anterior end and the posteroventral end, where narrow vestibules occur. The radial pore canals can not be clearly observed.

The muscle scar area consists of a vertical row of four elongate spots and two spots (?) in front of these.

The sculpture consists of pits, - rather large in the centre of the lateral surface and small in the marginal areas. The laterally compressed parts ("flanges") are also ornamented with minor pits. Along the ventral margin the pits are arranged in three to four rows. Opposite the area of the muscle scars there are one to three vertical rows of rather large pits. Radial to the anterior margin there are a few short and irregular ribs (or wrinkles).

Sexual dimorphism was not observed.

Remarks. The radial pore canals seem to be rather numerous, but can not be clearly observed.

The present species resembles Cytheropteron? diversum Herrig (1969b, p. 1090). The latter has a sculpture of rather large pits arranged in rows radially from the centre to the margins. Its anterior and posterior marginal areas are smooth, and the area along the ventral margin has three ribs. The differences in the hinges of the two species may be due to corrosion in $C$. ? diversum.

On a few specimens the sculpture is coarser, resembling that of Cytheropteron? diversum Herrig, 1969, but in nearly all of the present specimens the pits are small and irregularly arranged.

These two species are very close to each other and must be congeneric. 
They are only doubtfully referred to the genus Cytheropteron as the occurrence of the posterior vestibule should exclude them from that genus. The missing alate extension and the occurrence of raised terminal dental areas in the right valve place these species as transitional forms between the subgenera $C$. (Cytheropteron) and $C$. (Eocytheropteron), - see also p. 143).

Distribution. Denmark: The G. apostolescui - K. (K.) foveolata Subzone and the $O$. adenticulata - N. (N.) simplex Zone; Lower and Upper Pliensbachian.

Cytheropteron reticulatum n.sp.

Pl. 6, figs. 79-82.

Derivation of the name. From reticulum = network, referring to the characteristic sculpture.

Holotype. A carapace. D.G.U. catalogue No. 1973-OM-69; pl. 6, figs. 79-80.

Type locality. The Horsens No. 1 boring.

Type stratum. Sample No. 5. Dark grey and greyish black shale. The $O$. aspinata Zone; Lower Sinemurian.

Material. 5 carapaces, 1 left valve, and 1 right valve in a core sample from the Horsens No. 1 boring.

Diagnosis. A small species of the genus Cytheropteron characterized by distinct, longitudinal ribs which conform to the ventral and dorsal margins and are supported by numerous cross-ribs. In the centre of the lateral surface the reticulation is open and rather irregular.

Description. The carapace is small and has a long, straight to slightly convex dorsal margin. Posteriorly the margin ends at the distinctly extended posterior end. Below this point the margin is convex, passing into a short and nearly straight ventral margin. The anterior margin is broadly rounded and slightly extended ventrally. The lateral surface is inflated with a strong alate extension, which overhangs the ventral margin. There is no spine. A feeble sulcus is found anteromedianly. There is a narrow compressed zone along the anterior margin and another along the posteroventral one.

The internal features are only poorly known: The duplicature at the posterior end is broad. The muscle scar area contains a vertical, arched row of four elongated spots. The hinge in one right valve is observed as a long groove and a posterior ridge.

The sculpture consists of longitudinal ribs which conform to the ventral and dorsal margins, and also to the ventral edge of the alate extension. Between the ribs there are numerous finer cross-ribs. The reticulation is 
fine and dense near the margins, but open and strong in the centre of the lateral surface. The pattern is rather irregular in the centre.

Measurements. Holotype: Length $0.31 \mathrm{~mm}$ and height $0.17 \mathrm{~mm}$.

Remarks. Because of the characteristic sculpture, C. reticulatum can not be confused with any known species. C.? diversum, C.? foveolatum and C. ? cavatum do not have strong sharp ribs.

C. reticulatum seems to have a hinge like those of $C$. ? diversum and C.? foveolatum. Based on this hinge type and the alate extension this species may possibly be referred to the subgenus Cytheropteron (Cytheropteron). It has provisionally been referred to the genus Cytheropteron as the internal features are only partly known.

Distribution. Denmark: The $O$. aspinata Zone; Lower Sinemurian.

"Cytheropteron"sp. 4203

Pl. 6, fig. 84 .

1968a: Cytheropteron sp. 888 Christensen, pl. 23, fig. 28.

Material. 1 right valve in a core sample from the Øresund No. 12 boring.

Remarks. The specimen is tentatively referred to the Cytheropteron-group.

The external surface is covered by a reticulation of distinct ribs. A rather strong alate extension occurs. The internal features are not clearly visible due to covering by sediment, but the duplicature of the anterior end seems rather broad.

Distribution. Denmark: The G. apostolescui - K. (K.) foveolata Subzone; Lower Pliensbachian.

Genus Cytherura Sars, 1866

Type species. Cythere gibba Müller, 1785.

Original diagnosis. See Sars, 1866, p. 69.

Stratigraphical range. Lower Jurassic (?), Cretaceous to Recent.

Cytherura? sp. 4340

Pl. 6, fig. 87.

Material. 1 right valve in a core sample from the Gassum No. 1 boring.

Remarks. The hinge is nearly straight with a long median groove and terminal dental elevations, of which the anterior one is short and rounded and the posterior one elongated (smooth?). The duplicature is broad. A narrow vestibule occurs anteriorly.

The specimen is referred to the genus Cytherura with reservations since 
it does not clearly have the generic characters and since this genus has not yet been found in the Lower Jurassic.

Distribution. Denmark: The G. apostolescui - K. (K.) foveolata Subzone; Lower Pliensbachian.

Family Limnocytheridae Klie, 1938

Genus Stenestroemia Christensen, 1968

Original diagnosis. See Christensen, 1968b, p. 39.

Stratigraphical range. Jurassic.

Stenestroemia? roedbyensis Michelsen, 1970

Pl. 7, figs. 88-89; pl. 8, fig. 112.

1970: Stenestroemia ? roedbyensis Michelsen, p. 35, pl. XI, figs. 1-3; text-figs. 3-4.

Material. 5 carapaces, 45 left valves, and 46 right valves in core samples from the Gassum No. 1 and Rødby No. 1 borings.

Original diagnosis. "A species with hinge and muscle scar like in the genus Stenestroemia. The posterior end of the carapace is strongly developed and has its largest width posterodorsally. The radial pore canals seem to be narrow and closely spaced" (Michelsen, 1970, p. 35).

Description. See Michelsen, 1970, p. 35.

Remarks. Stenestroemia ? roedbyensis is described from Rødby No. 1 where it is common in two samples. Since then only few specimens have been found in other localities (Gassum No. 1: 2, Nøvling No. 1: 1, and Rønde No. 1: 1 specimen).

The systematic problem is still unsolved. S. ? roedbyensis should probably be referred to a new genus, but it is desirable to have more species in order to establish a new genus.

Distribution. Denmark: The O. aspinata Zone; Hettangian and Lower Sinemurian.

Family Paradoxostomatidae Brady \& Norman, 1889

Genus Paradoxostoma Fischer, 1855

Type species. Paradoxostoma dispar Fischer, 1855.

Original diagnosis. See Fischer, 1855, p. 654.

Stratigraphical range. Lower Jurassic ?, Cretaceous ?, Eocene-Recent.

Paradoxostoma? pusillum n.sp.

Pl. 7, figs. 90-95; pl. 8, figs. 113-114. 
1968a: Paradoxostoma? sp. P. ? fusiformis Drexler - Christensen, pl. 23, fig. 8.

1970: Paradoxostoma ? cf. P. ? fusiformis Drexler - Michelsen, p. 37, pl. XII, figs. 2a-b.

Derivation of the name. From pusillus = small or diminutive, referring to the size of this species.

Holotype. A carapace. D.G.U. catalogue No. 1973-OM-78. Pl. 7, figs. 90-91.

Type locality. The Øresund No. 8 boring.

Type stratum. Sample No. 917. Greyish black claystone, and sandstone. The $C$. betzi $-C$. crassireticulata Zone; Lower Sinemurian.

Material. 47 carapaces and 37 valves in core samples from the Fjerritslev No. 2, Gassum No. 1, Rødby No. 1, Vinding No. 1, and Øresund No. 8 borings.

Diagnosis. A small species, suboval in lateral view with ends equal in height; the anterior one is rounded and the posterior one obliquely truncated. Fusiform in dorsal view. Right valve larger than left valve.

Vestibule rather deep.

Description. The carapace is suboval in lateral view, with the greatest height medianly. It is fusiform in dorsal view, with the greatest breadth medianly.

The dorsal margin is convex, more strongly so in the left valve. The ventral margin is straight to convex, with a faint concavity anteromedianly. The anterior margin is broadly rounded, most narrowly arched dorsally. The posterior margin is slightly convex, oblique and with the narrowly rounded dorsal part extended. Both ends are equally high. The lateral surface is evenly vaulted, most strongly in the region between the centre and the ventral margin and only slightly so near the ends. The right valve is larger than the left one, but the latter overlaps the former along the middle two thirds of the dorsal margin.

The hinge appears to be lophodont. The dorsal margin of the right valve is overlapped by the left valve, whilst the overlap is reversed in the short terminal parts.

The muscle scar area contains a vertical row of three or four elongate spots.

The duplicature is broad, especially anteriorly. The vestibules of both ends are deep, connected along the ventral margin. Radial pore canals were not observed.

The external surface is smooth.

Sexual dimorphism was not observed.

Remarks. This little species is apparently thin-shelled and is often found 
broken or deformed. Of the 37 valves recorded from Rødby No. 1, only very few are so well-preserved that internal features can be studied. The other valves, as well as a large proportion of the carapaces from that borehole, are squashed. The very characteristic outline in lateral view makes a good basis for including all the above-mentioned specimens in the species.

Paradoxostoma? pusillum n.sp. has been placed close to Paradoxostoma ? fusiformis Drexler (= Monoceratina? fusiformis (Drexler), see p. 139 in the present paper) by Christensen (1968a) and Michelsen (1970). Studies of specimens from other boreholes (than Rødby No. 1) have clearly shown that the present species cannot be confused with the species of Drexler. $P$. pusillum is smaller, both ends of the carapace are of equal height and the posterior end is not pointed. Michelsen (1970, p. 37) supposed that only larvae were found in Rødby No. 1; however, new discoveries have established that those specimens must be adults since two valves with welldeveloped duplicatures have been recorded.

The present species is referred to the genus Paradoxostoma with reservations as the internal characters are only partly known.

Distribution. Denmark: The O. aspinata Zone and the C. betzi - C. crassireticulata Zone; Hettangian and Lower Sinemurian.

Paradoxostoma? sp. 4092

Pl. 7, fig. 96; pl. 8, figs. 115-116.

Material. 7 carapaces in core samples from the Gassum No. 1 boring.

Description. The outline in lateral view is elongate-oval, with the greatest height posteromedianly. The dorsal margin is convex; the anterior one symmetrically rounded, the posterior one oblique, extended dorsally; the ventral margin is nearly straight, but with a feeble concavity anteromedianly. In dorsal view the carapace is fusiform with the greatest breadth posteromedianly. The two valves are of nearly equal size, but the right valve overlaps the left one along the dorsal margin.

The internal features are unknown.

The external surface is smooth.

Remarks. This species differs from $P$. ? pusillum in being longer and in having the greatest height posteromedianly.

It is questionably classified within the genus Paradoxostoma on the basis of some morphological points of resemblance to $P$. ? pusillum.

Distribution. Denmark: The G. apostolescui $-K$. $(K$.) foveolata Subzone and the $O$. adenticulata $-N$. (N.) simplex Zone; Lower and Upper Pliensbachian. 
Family Progonocytheridae Sylvester-Bradley, 1948

Subfamily Progonocytherinae Sylvester-Bradley, 1948

Genus Fuhrbergiella Brand \& Malz, 1962

Type species. Fuhrbergiella gigantea Brand \& Malz, 1962.

Original diagnosis. See Brand \& Malz, 1962, p. 2.

Stratigraphical range. Aalenian - Bajocian.

Fuhrbergiella sp. 4189

P1. 9, fig. 125 .

Material. 1 left valve in a core sample from the Øresund No. 2 boring.

Remarks. This specimen, which is broken and rather badly preserved, has a sculpture and valve outline resembling $F$. (Praefuhrbergiella) sauzei Brand \& Malz (1962, p. 22) and F. (Praefuhrbergiella)? favosa Plumhoff (1963, p. 26). Because of the state of preservation it is left under open nomenclature.

Distribution. Denmark: The Rydebäck Beds; (?) Aalenian.

Subfamily Protocytherinae Lyubimova, 1955

Genus Acrocythere Neale, 1960

Type species. Orthonotacythere hauteriviana Bartenstein, 1956.

Original diagnosis. "A subgenus of Orthonotacythere with hinge and internal features as in Orthonotacythere, sensu stricto, but differing in shape and ornament. The posterior end of the shell ends in a blunt point which lies on or about the level of the mid-line and not markedly dorsally as in Orthonotacythere, sensu stricto. Ornament is dominantly costate or reticulate, tubercles being absent or much reduced" (Neale, 1960, p. 213).

Remarks. Neale (1960) established Acrocythere as a subgenus of Orthonotacythere Alexander, 1933 which is referred to the subfamily Loxoconchinae Sars, 1925. Plumhoff (1963, p. 20) gave Acrocythere the taxonomic rank of genus and placed it in the subfamily Progonocytherinae Sylvester-Bradley, 1948. As the hinge is merodont, Acrocythere is placed in the subfamily Protocytherinae in the present paper.

The species referred to the genus Acrocythere in the present paper constitute a heterogeneous group of species, all of which differ more or less from the type species. The species are divided into three groups: the oeresundensis-group, the rectangula-group, and the tricostata-group.

The oeresundensis-group comprises the species $A$. gassumensis n.sp. and A. oeresundensis n.sp., which differ from the type species in being smaller, 
in having the entire external surface covered by a reticulation of ribs forming a hexagonal pattern, and in the occurrence of the strong elevations (ridges and knots) between the lateral and ventral surfaces and ventrally to the posterior and anterior cardinal angles. This group may probably belong to a new genus.

The rectangula-group comprises the species $A$, rectangula n.sp. only. It differs from the type species in being subrectangular in lateral view without an acuminate posterior margin, in being smaller, and in the sculpture. This species may probably also belong to a new genus.

The tricostata-group comprises the species A. tricostata and A. ? sp. 4339. These species are more closely related to the genus Acrocythere than the species of the other two groups, but they differ in being smaller and in having a more weakly developed sculpture. However, they are here considered as belonging to the genus.

Stratigraphical range. Lower Jurassic to Lower Cretaceous.

The oeresundensis-group

Acrocythere gassumensis n.sp.

Pl. 7, figs. 97-100; pl. 8, figs. 117-119.

1968a: Monoceratina sp. 653 Christensen, pl. 23, fig. 7.

Derivation of the name. From the name of the type locality.

Holotype. A carapace. D.G.U. catalogue No. 1973-OM-15; pl. 8, figs. 117-119.

Type locality. The Gassum No. 1 boring.

Type stratum. Sample No. 39A. Dark greenish grey shale. The $O$. danica Zone; Upper Sinemurian.

Material. 9 carapaces, 3 left valves, and 7 right valves in core samples from the Gassum No. 1, Øresund Nos. 8, 9 and 14 borings.

Diagnosis. An Acrocythere-like species characterized by a sculpture with a strong broad rib and knots, and with a distinct reticulation. Ventrally on the lateral surface there is a longitudinal rib with terminal elevations. Ventrally to the eye spot a strongly elevated area occurs. Near the posterior cardinal angle there are two distinct knots. The entire lateral surface, including ribs and knots, is covered by a reticulation of sharp and rather strong ribs forming a hexagonal pattern.

Description. Subrectangular outline in lateral view, with the greatest height at the anterior cardinal angle. Suboval in dorsal view, with marked marginal flanges, and with the greatest breadth in the posterior third. In posterior view suboval, with the greatest breadth ventrally. 
The dorsal margin of the left valve is straight, and on the right valve slightly convex. The cardinal angles are distinct. The ventral margin is nearly straight and the anterior margin is broadly rounded, slightly extended ventrally. The posterior margin is shorter and terminates in an obtuse angle; the dorsal section of this margin is straight to concave. The left valve is larger than the right one, overlapping the latter posteriorly and ventrally, whilst the right valve overlaps the left one along the dorsal margin. The marginal flanges are distinct. The lateral surface is strongly inflated, especially ventrally and posteriorly. Medianly and up to the dorsal margin there is a feeble concavity, which is emphasized by the strong ribs. Eye spot distinct.

The hinge is apparently merodont, the right valve with dentate terminal ridges separated by a narrow (and finely crenulate?) groove.

The muscle scars and the duplicature were not clearly observed.

The sculpture is characterized by strong ribs and knots, and by a distinct reticulation. Ventrally there is a longitudinal rib with strong terminal elevations. The posterior end may form a spine-like extension. Close below the eye spot there is a strong knot. Ventrally and anteroventrally to the posterior cardinal angle there are two strong knots, of which the posterior one may be only weakly developed. The entire external surface, including the rib and knots, is covered by a reticulation of sharp, rather strong ribs forming a hexagonal pattern. Along the ventral margin the reticulation tends to be in rows of hexagons. On the marginal flanges there are radial ribs.

Most of the small larvae found in the Øresund borings have less strong ribs and knots.

Sexual dimorphism was not observed.

Remarks. Acrocythere gassumensis resembles A. oeresundensis n.sp., but the former is relatively shorter and has a more rectangular outline in lateral view. The strong ventral rib does not bend anteriorly and continue to the eye spot as it does in $A$. oeresundensis. Furthermore, A. gassumensis has two knots near the posterior cardinal angle, whereas $A$. oeresundensis has one elongated knot.

"Cythere" terquemiana Jones, 1872 (cf. Lord, 1971, p. 657) is possibly close to $A$. gassumensis n.sp., but has a different sculpture with more numerous and irregular "knots". More detailed studies of the former, and comparison of the two species are necessary to elucidate their relationships.

In spite of the fact that the internal features have not been completely elucidated, A. gassumensis is referred to the genus Acrocythere, on the basis of the close relationship to $A$. oeresundensis (see also p. 152).

Distribution. Denmark: The $C$. betzi $-C$. crassireticulata Zone and the lower part of the $O$. danica Zone; Lower and Upper Sinemurian. 
Acrocythere oeresundensis n.sp.

Pl. 7, figs. 101-104; pl. 8, figs. 120-124.

1968a: Cytheropteron sp. 848 Christensen, pl. 23, fig. 38.

Derivation of the name. From the name of the type locality.

Holotype. A right valve. D.G.U. catalogue No. 1973-OM-10; pl. 8, figs. 120-122.

Type locality. The $\emptyset$ resund No. 12 boring.

Type stratum. Sample No. 1406. Greyish sandstone and siltstone. The $G$. apostolescui - K. (K.) foveolata Zone; Lower Pliensbachian.

Material. 5 carapaces, 33 left valves, and 45 right valves in core samples from the Øresund Nos. 12 and 15 borings.

Diagnosis. A small species with an outline resembling the genus Acrocythere and characterized by a sculpture with a strong longitudinal ridge in the ventral part of the lateral surface. Anteriorly this ridge bends $\left(90^{\circ}\right)$ dorsally to the eye spot. Below the posterior cardinal angle there is a strong, very short rib (or knot). The entire external surface (also the strong ribs) is covered by a strong reticulation of ribs forming a hexagonal pattern.

Description. Subrectangular in lateral view with the greatest height at the anterior cardinal angle. Oval to subrectangular in dorsal view, with greatest breadth posteriorly.

The dorsal margin is straight to slightly convex in the right valve and concave in the left. The ventral margin is slightly concave. The anterior margin is broadly rounded, slightly extended ventrally. The posterior margin is acuminate with the sharp angular termination at the mid-height. In the right valve the dorsal part of this margin is concave; otherwise it is nearly straight. The left valve is larger than the right valve, but is overlapped by the latter along the dorsal margin. The lateral surface is most strongly inflated ventrally and has a weak concavity in the middle up to the dorsal margin. This shape is emphasized by the strong ribs mentioned below. The eye spot is small, but distinct. The marginal flanges at both ends are rather broad. The larvae do not differ markedly from this description.

The hinge is merodont, with dentate terminal ridges in the right valve; the posterior ridge is rather long. The median-element is a long, straight, finely crenulate groove. The muscle scars form a vertical row of four spots. The duplicature is broad. The inner margin and the line of concrescence coincide, (at the anterior end in some specimens there is a frosted zone which may indicate the occurrence of a narrow vestibule). The radial pore canals are straight and simple, 6-7 anteriorly and 3-4 posteriorly. 
The sculpture consists of a very strong, longitudinal rib which is situated on the border between the lateral and ventral surfaces. Posteriorly the rib is high and forms an alate extension. Anteriorly it bends $\left(90^{\circ}\right)$ dorsally and ends at the eye spot. Below the posterior cardinal angle there is a very short rib (or a knot). The entire external surface (also the ribs) is covered by a distinct hexagonal reticulation. On the marginal flanges there are a few rather widely spaced, radial ribs.

Measurements (in $\mathrm{mm}$ ). Only few specimens are measurable. The measurements of the specimens from sample No. 1406 of the Øresund No. 12 boring are given below:

\begin{tabular}{lcc}
\hline & Length & Height \\
\hline Carapace, adult & 0.40 & 0.19 \\
Left valve, adult & 0.39 & 0.19 \\
Left valve, adult & 0.39 & 0.20 \\
Right valve, adult & 0.37 & 0.17 \\
Right valve, adult & 0.39 & 0.19 \\
Left valve, larva & 0.34 & 0.17 \\
\hline
\end{tabular}

Remarks. The merodont hinge, the eye spot and the shape of the carapace with the reticulate and costate sculpture are the grounds for referring this species to the genus Acrocythere. The occurrence of a vestibulum is doubtfully inferred from an irregular frosted zone along the inner margin. The radial pore canals pass into this zone, but it has not been possible to observe the proximal end of these canals. The frosted zone, which has also been observed in a few specimens of Acrocythere tricostata n.sp., may be due to corrosion.

The larvae of the present species are the same size as adult $A$. tricostata n.sp., but differ from it in lacking the median rib. A. oeresundensis n.sp. resembles $A$. aff. pumila Plumhoff (1963, p. 21), but the latter has a more open reticulation and a diagonal, median rib.

Concerning the relationship with $A$. gassumensis see the remarks under that species (pp. 152 and 154).

Distribution. Denmark: The middle subzone and the G. apostolescui $K$. (K.) foveolata Subzone of the $O$. danica Zone; Upper Sinemurian and Lower Pliensbachian.

The rectangula-group

Acrocythere rectangula n.sp. 
Pl. 9. figs. 126-130; pl. 11, figs. 154-156.

1968a: Lophocythere sp. 865 Christensen, pl. 23, fig. 20.

Derivation of the name. From rectus = right and angulus $=$ angle, referring to the outline of the carapace.

Holotype. A carapace. D.G.U. catalogue No. 1972-OM-93; pl. 11, figs. 154-156.

Type locality. The Øresund No. 14 boring.

Type stratum. Sample No. 1691. Dark grey to greyish black claystone. The $O$. danica Zone; Upper Sinemurian.

Material. 6 carapaces, 6 left valves, and 7 right valves in core samples from the Gassum No. 1, Øresund Nos. 10 and 14 borings.

Diagnosis. A small species with a rectangular or subrectangular outline in lateral view.

The sculpture consists of rather high, sharp ribs forming a pattern of polygons. The polygons are placed in two rows, longitudinally on the lateral surface. Anterodorsally the pattern is irregular.

Description. The outline in lateral view is subrectangular with the greatest height at the anterior cardinal angle. The outline in dorsal view is subrectangular to elongate-oval with the marginal flanges a little extended, and with the greatest breadth posteromedianly. In posterior view it is subtriangular with the greatest breadth ventrally.

The dorsal margin in the right valve is straight or slightly convex; in the left valve it is slightly concave. The cardinal angles are distinct. The ventral margin is nearly straight, with a concavity anteromedianly. The anterior margin is broadly rounded and slightly extended ventrally. The posterior margin in the left valve is broadly rounded, but in the right valve it is more pointed and has a dorsal concavity. The lateral surface is most strongly inflated ventrally and posteriorly. Behind the anterior cardinal angle it is concave. Along the ventral margin it is also concave. The marginal flanges (especially the anterior one) are narrow. The eye spot is distinct.

The hinge in the right valve consists of terminal dental areas (with 5-6 teeth in the posterior one and 5(?) in the anterior one), and a narrow and finely crenulate, median groove. The hinge in the left valve consists of corresponding notched sockets separated by a bar.

The inner margin and the line of concrescence coincide. The marginal area is moderately broad. Radial pore canals seem to be simple and straight, 6-7 anteriorly and 3-4 posteriorly.

The muscle scars form an arched, vertical row of four spots.

The sculpture consists of rather high, sharp ribs forming a pattern of elongated polygons. The polygons are arranged in two horizontal rows with 
the longest side of the polygons at right angles to this direction. Anteriorly and anterodorsally the pattern is more irregular with oblique ribs. The intercostal areas are ornamented with small pits. Along the ventral margin there are two or three fine longitudinal ribs. The marginal flanges are smooth.

The inferred males are more elongated and have a more angular outline in lateral view than the females.

Measurements (in $\mathrm{mm}$ ).

\begin{tabular}{lccc}
\hline & & Length & Height \\
\hline Holotype, carapace, female, 1972-OM-93 & $:$ & 0.37 & 0.18 \\
Paratype, carapace, male, 1973-OM-93 & $:$ & 0.39 & 0.18 \\
Paratype, right valve, female, 1973-OM-92: & 0.38 & 0.18 \\
Paratype, left valve, male, 1973-OM-91 & $:$ & 0.41 & 0.19 \\
Paratype, left valve, female, 1973-OM-90 & $:$ & 0.38 & 0.19 \\
\hline
\end{tabular}

Remarks. Though the present material is small and not all of the internal characters are completely elucidated, Acrocythere rectangula is clearly a new species which cannot be confused with any known species. The sculpture of $A$. rectangula is in some degree like that of Cristacythere crassireticulata n.sp., so larvae of this species may show some affinities with $A$. rectangula. However, the sculpture of $C$. crassireticulata is denser and the ribs form smaller polygons, which are not elongated. Concerning the relationship to the genus Acrocythere see p. 152.

Distribution. Denmark: The lowest part of the $O$. danica Zone, Upper Sinemurian.

The tricostata-group

Acrocythere tricostata n.sp.

Pl. 9, figs. 131-142; pl. 11, figs. 157-158. Text-fig. 26.

Derivation of the name. Tres $=$ three + costa $=$ rib; referring to the three longitudinal ribs.

Holotype. A carapace. D.G.U. catalogue No. 1973-OM-95; pl. 9, figs. 132-133.

Type locality. The Gassum No. 1 boring.

Type stratum. Sample No. 16. Dark grey shale. The O. adenticulata $N$. (N.) simplex Zone; Upper Pliensbachian.

Material. 23 carapaces, 8 left valves, and 7 right valves in core samples from the Flyvbjerg No. 1, Gassum No. 1, and Øresund No. 12 borings. A 
few badly preserved specimens are found in the Øresund Nos. 12, 14 and 15 borings.

Diagnosis. A small species of the genus Acrocythere characterized by three distinct longitudinal ribs, of which the median and dorsal ones are simple and nearly straight. The ventral rib is double and closely spaced posteriorly, widely spaced and more indistinct anteriorly. The intercostal areas have a polygonal pattern of low ribs.

The dorsal and ventral margins only converge slightly posteriorly.

Description. The carapace is subrectangular in lateral view, with the greatest height at the anterior cardinal angle. In dorsal view the outline is oval, with extended marginal flanges, and with the greatest breadth posteriorly. In posterior view it is subtriangular, with the greatest breadth ventrally.

The dorsal margin of the left valve is straight, whilst that of the right valve is slightly convex. Of the cardinal angles the anterior one is the most distinct. The anterior margin is broadly rounded and very slightly extended ventrally. The posterior margin is acuminate with a concavity dorsally in the right valve, and is extended dorsally to the median line in both valves. The ventral margin is nearly straight. The dorsal margin and the ventral one only converge slightly posteriorly. The left valve is slightly larger than the right one, but is overlapped by the latter along the dorsal margin. Eye spot distinct. The posteroventral part of the lateral surface is strongly inflated (with a weak alate extension).

The hinge is merodont with short, terminal, dentate grooves connected by a long, crenulate ridge in the left valve. The muscle scars form a vertical row of four small spots. The duplicature is broad; the inner margin and the line of concrescence coincide. The radial pore canals are straight and simple, 6 anteriorly and 3 posteriorly.

The sculpture is characterized by three longitudinal ribs: one along the dorsal margin, one median rib which posteriorly is dorsal and anteriorly is ventral to the median line, and one ventral double rib which is closely spaced posteriorly and more widely spaced and indistinct anteriorly. The intercostal areas are covered by low ribs forming a pattern of small polygons. The broad posterior flange may be smooth or have a few radial ribs, the more narrow anterior flange has few radial ribs.

The characters of the larvae are close to this description, but the outline in lateral view is more triangular.

Sexual dimorphism was not observed with certainty.

Measurements (in $\mathrm{mm}$ ). Only very few specimens are measurable. The measurements from two samples of Gassum No. 1 are given in text-fig. 26.

Remarks. Acrocythere tricostata n.sp. is identical with the species named Nanacythere sp. 4007 by Michelsen (1971a) and Acrocythere sp. 4007 


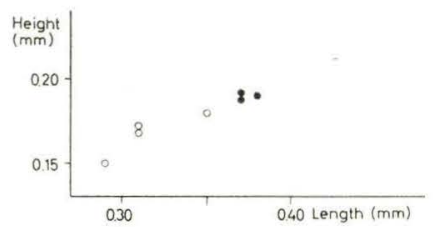

Text-fig. 26. Scattergram showing relations between numbers, lengths and heights for carapaces of Acrocythere tricostata n. sp. Sample No. 18 (circles) and sample No. 19 (black spots) from the Gassum No. 1 boring.

by Michelsen (1973a). Lophocythere? sp. 866 Christensen (1968a, pl. 23, fig. 26) is assumed to be identical with the present species.

A. tricostata can not be mistaken for any known species.

Distribution. Denmark: Rare in the middle subzone of the $O$. danica Zone, common in the $G$. apostolescui $-K$. (K.) foveolata Subzone and in the lower part of the $O$. adenticulata $-N$. (N.) simplex Zone; Upper Sinemurian, Lower and Upper Pliensbachian.

Acrocythere? sp. 4339

Pl. 6, fig. 86 .

Material. 1 left valve in a core sample from the Gassum No. 1 boring.

Remarks. The hinge is straight with a long, crenulate (?) median ridge and terminal sockets, of which the anterior one is very short and the posterior one is elongated. The duplicature is broad; the line of concrescence and the inner margin coincide.

The specimen is referred with uncertainty to the genus Acrocythere as it differs in sculpture and size from the type species, and since the internal characters are poorly known only.

Distribution. Denmark: The G. apostolescui - K. (K.) foveolata Subzone; Lower Pliensbachian.

\section{Liassic "Procytheridea"}

The genus Procytheridea was described by Peterson (1954) from the North American Rierdon Formation and Sundance Formation (Callovian).

In 1959 Klingler \& Neuweiler described fifteen Liassic species referring them to Procytheridea. Apostolescu (1959) included eight species in this genus. Since then several Liassic species have been ascribed to the genus by: Bizon, 1960, Donze, 1966 and 1967, Dreyer, 1965, Fischer, 1963, Gramann, 1962, Michelsen, 1970, Plumhoff, 1963, and Stoermer \& Wienholz, 1965. 
None of these Liassic species are congeneric with the type species, Procytheridea exempla Peterson, 1954. The internal characters (hinge, muscle scars, marginal zone) are the same, with the possible exception of the radial pore canals which were not observed by Peterson. Howe (in Moore, 1961) describes the number of canals as few in Procytheridea, without giving any references. However, the external features and shape of the carapace in the European Liassic species and in Procytheridea exempla are quite different. The marginal flanges of the latter are narrow and reticulate, whilst the Liassic species have broad and smooth flanges. The sculpture of Procytheridea is rather strong and dense, a feature which is only found in a few Liassic species.

In 1960 Martin described an Upper Liassic genus, Kinkelinella, which in the shape of the carapace is typically Liassic, but which differs from both the Liassic "Procytheridea" and from Procytheridea s.str. in having a smooth median hinge-element. However, in 1962 Gramann described Kinkelinella with an antimerodont hinge, and placed it together with Progonoidea and Pleurifera as a subgenus belonging to Procytheridea. Anderson (1964) described the genus Klinglerella with the Lower Liassic Procytheridea glabellata Klingler \& Neuweiler, 1959 as type species.

Other authors have discussed the problems concerning the European "Procytheridea". Lord (1972b) gives a thorough and detailed examination of the problems as they have been treated in the literature. He concluded that the genus Procytheridea does not occur in the Lias and may not even be present in Europe. Further he mentioned that the "species assigned to the genus belong to Kinkelinella, Klinglerella, Micropneumatocythere, Pleurifera, Progonoidea, Gramannella, (?) Gloughtonella and several other undescribed genera".

One of the characters in question is the median hinge element. In the most of the species dealt with it has been described as (weakly) crenulate or dentate. It seems to be a feature difficult to observe and describe exactly. This character has not been totally elucidated even by studying the present material by means of the scanning electron microscope. In the present study the median hinge element has been shown to be finely crenulate, at least in well-preserved specimens; it seems to be smooth only in species belonging to Cristacythere n.gen.

Kinkelinella may possibly differ from Klinglerella in having a smooth middle hinge element, but Gramann (1962) described it as crenulate. Subsequently, other species with an antimerodont hinge have been referred to the genus (cf. Malz 1966).

The taxonomical problems have not been solved completely, but it is assumed by the present author that only a few species have a smooth 
middle hinge element (the Cristacythere-species), whilst all others have a crenulate one. A classification of the species in question must therefore be based on other features. The great differences in the external morphology of the shells are obvious. A combination of the shape of the shell, the sculpture, the features of the marginal zone and of the hinge is here proposed as the basis for a classification. On the basis of the Danish material and the data known from the literature (especially the German material) the species dealt with in the present paper are referred to five closely related genera and subgenera:

1. Klinglerella is placed as a subgenus under Kinkelinella since these two groups are considered to differ only in minor features of the sculpture. (The Middle Jurassic genus Ektyphocythere Bate, 1963 is by Malz (1966) regarded as a junior synonym of Kinkelinella. If this assumption is correct the differences between the oldest Klinglerella-species and the youngest Kinkelinella-species will probably be too large to permit inclusion of both of them under the same genus).

2. Progonoidea and Pleurifera are here regarded as independent genera.

3. One new genus is established: Cristacythere.

Genus Cristacythere n.gen.

Derivation of the name. From crista $=$ crest, + cythere.

Type species. Cristacythere costata n.sp.

Diagnosis. A genus of the family Progonocytheridae characterized by an elongated subrectangular to subtriangular carapace, which is not pronouncedly inflated. The hinge is merodont (with a smooth median element). The adductor muscle scars form a vertical row of 4 elongate-oval scars, with 2 suboval scars anteriorly. The inner margin and the line of concrescence coincide. The radial pore canals are simple and straight, 6-8 anteriorly and 4-5 posteriorly.

The sculpture consists of strong and broad ribs, which may be more or less longitudinal or form a network-pattern. The intercostal areas may be smooth or with fine cross-ribs.

Remarks. The present genus includes Procytheridea betzi Klingler \& Neuweiler, 1959, Cristacythere costata n.sp. and C. crassireticulata n.sp. Characteristic for these three species is the elongated subrectangular outline in lateral view, with distinct cardinal angles. $P$. betzi is more triangular than the other two and has the posterior end more pointed, but is close to C. crassireticulata in being elongated and having strong and broad ribs. The hinge of $P$. betzi is described by Klingler \& Neuweiler (1959, p. 376) as having 
a weakly crenulate middle section. In the present material no specimens with a crenulate middle section are found; this is also true for the other two species.

Cristacythere differs from all other genera mentioned within the European "Procytheridea"-group (cf. p. 162). P. betzi may show some degree of a triangular sculpture-pattern, but the ribs are much stronger and fewer than in Klinglerella; the carapace is pronouncedly elongated and more subrectangular, too. The outlines of $C$. costata and $C$. crassireticulata in lateral view are a little like that of $P$. harpa, but the carapace of the former is more rounded and the sculpture is quite different. Cristacythere thus shows some affinities with Klinglerella and Pleurifera, but cannot be confused with these.

Sexual dimorphism occurs, probably also in some of the larval stages.

Stratigraphical range. Lower Jurassic (Hettangian to Upper Sinemurian).

Cristacythere betzi (Klingler \& Neuweiler, 1959)

P1. 10, figs. 143-147; pl. 11, figs. 159-171. Text-fig. 27.

1959: Procytheridea betzi Klingler \& Neuweiler, p. 374, pl. 13, figs. 1-5, 9.

1962: Procytheridea betzi Klingler \& Neuweiler - Klingler, p. 80, pl. 12, fig. 5.

1965: Procytheridea betzi Klingler \& Neuweiler - Dreyer, p. 503, pl. V, figs. 1a-d.

1968a: Procytheridea betzi Klingler \& Neuweiler - Christensen, pl. 23, fig. 13.

Material. 59 carapaces, 26 left valves, and 35 right valves in core samples from the Gassum No. 1, Øresund Nos. 8, 9, 10, and 14 borings.

Original diagnosis. "Eine Art der Gattung Procytheridea mit einer sehr leicht erkannbaren Längsrippenskulptur. Zwischen den rundlichen Rippen sind durch feine Leistchen vergitterte, breite und schmälere Täler vorhanden. Der Vorderrand ist in der unteren Hälfte stärker gerundet, der Dorsalrand lang und fast gerade sowie schwach nach hinten abfallend, der Hinterrand etwas unter der Mittellinie des Gehäuses eng gerundet und die Ventralnaht durch die gebauchten Ventralflächen in Seitenansicht verdeckt" (Klingler \& Neuweiler, 1959, p. 374).

Description. The shell is elongated subtriangular in lateral view with the greatest height at the anterior cardinal angle. The dorsal margin is straight to slightly convex. The cardinal angles are weakly marked. The anterior margin is rounded and slightly extended in the ventral part. The posterior end is more acute, with a concave dorsal part in the right valve. The ventral margin is straight with a small concavity in front of the mid-point. The right valve is smaller than the left one. In dorsal view the carapace is oval, with the greatest breadth posterior of mid-length, with strong marginal flanges at both ends. 
The hinge is straight. In the left valve it consists of two elongated and notched sockets separated by a bar, which is emphasized by a dorsal groove. The hinge of the right valve consists of corresponding terminal dental areas (with seven teeth in the posterior one and six in the anterior one), separated by a smooth groove.

The inner margin and the line of concrescence coincide. The duplicature is broad. The radial pore canals are simple and nearly straight. There are eight pore canals in the anterior margin and four in the posterior. The muscle scar is only observed as a vertical row of spots (pl. 10, fig. 147).

The sculpture is characterized by rather strong longitudinal ribs in the ventral half of the valve. Over to the muscle scars the ribs are interrupted and slightly wavy. In the dorsal part of the valve the ribs converge towards the middle of the dorsal margin. The area between the ribs is ornamented by very fine and small cross-ribs. The reticulation does not extend onto the flanges; a narrow zone along the dorsal margin is also smooth.

Sexual dimorphism was only tentatively recognised.

Measurements and statistics (in $\mathrm{mm}$ ). The specimens of Øresund No. 8, sample No. 951 and Gassum No. 1, samples Nos. 45A, 45C, and 45D have been measured (cf. text-fig. 27). In the table below the measurements of the left valves of the inferred females (adults) from Gassum No. 1, sample No. $45 \mathrm{~A}$ are shown:

\begin{tabular}{lccccc}
\hline & $\overline{\mathrm{x}}$ & $\mathrm{s}$ & $\mathrm{v}$ & $\mathrm{O} . \mathrm{R}$. & $\mathrm{N}$ \\
\hline Length & 0.564 & 0.008 & 1.42 & $0.55-0.57$ & 8 \\
Height & 0.294 & 0.009 & 3.06 & $0.28-0.31$ & 8 \\
\hline
\end{tabular}

These specimens are a little smaller than the one figured by Klingler \& Neuweiler (1959, pl. 13, fig. 1). However, the specimens from Gassum No. 1, sample No. 45C are larger (cf. text-fig. 27).

Only two valves found are thought to be males: one left valve (length $0.68 \mathrm{~mm}$, height $0.32 \mathrm{~mm}$ ) and one right valve (length $0.67 \mathrm{~mm}$, height $0.30 \mathrm{~mm}$ ).

Remarks. As mentioned above, the most specimens are smaller than the specimens described by Klingler \& Neuweiler (1959). In all other details the specimens studied agree with the holotype.

Two valves are thought to be males (cf. pl. 11, figs. 168-171). They were found in the cuttings sample $1700^{\prime}-1720^{\prime}$ from the $\emptyset$ rslev No. 1 boring. They differ in lacking the fine sculpture between the ribs.

Distribution. Denmark: Rare in the upper part of the O. aspinata Zone 


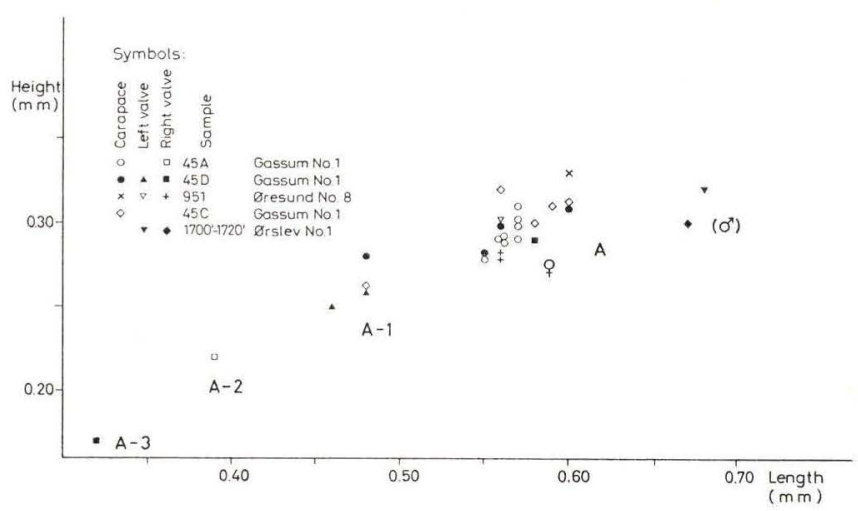

Text-fig. 27. Scattergram showing relations between numbers, lengths and heights for Cristacythere betzi (Klingler \& Neuweiler, 1959).

and in the lower part of the $O$. danica Zone, common in the $C$. betzi $-C$. crassireticulata Zone; Lower to Upper Sinemurian.

Northwest Germany: Lias Alpha-3 and lower part of Beta (Klingler \& Neuweiler, 1959 and Klingler, 1962).

Northeast Germany: The P. capricornoides Subzone; Lias Beta-1a (Dreyer, 1965).

Cristacythere costata $\mathrm{n} . \mathrm{sp}$.

Pl. 10, figs. $148-151$; pl. 12, figs. 172-178. Text-figs. 28-29.

Derivation of the name. Costa $=$ rib, referring to the strong rib ventrally on the lateral surface.

Holotype. A left valve, female. D.G.U. catalogue No. 1972-OM-31; pl. 12, figs. $172-174$.

Type locality. The Flyvbjerg No. 1 boring.

Type stratum. Sample No. 27. Alternating sand, sandstone and shale. The $O$. aspinata Zone; ? Lower Sinemurian.

Material. 196 carapaces, 40 left valves, and 38 right valves in core samples from the Flyvbjerg No. 1 boring.

Diagnosis. A species of the genus Cristacythere. The outline is elongated in lateral view, subquadrate (males) to subtriangular (females). The sculpture is dominated by longitudinal ribs, which in the mediodorsal part of the valve converge towards the dorsal margin. The border between the ventral and lateral surfaces is emphasized by a strong elevated rib. The intercostal areas are smooth or with a few fine cross-ribs.

Description. In lateral view the outline of the males is elongated and 
subquadrate, and the outline of the females is subtriangular; both of them have the greatest height near the anterior end. In the larvae the greatest height is closer to the middle of the valve. In dorsal view the outline is oval with the greatest breadth posterior to the mid-point of the carapace in females, at the mid-point in the males. In posterior view the outline is oval with a distinct concavity ventrally, and with the greatest breadth at the mid-point.

The dorsal margin of the left valve is slightly concave, with a distinct posterior cardinal angle. In the right valve it is slightly convex and the cardinal angles are distinct. The anterior margin is rounded and extended ventrally. The posterior margin is rounded, but in the right valve straight to slightly concave dorsally. The ventral margin is straight to slightly concave. The left valve is larger than the right and overlaps it, particularly along the dorsal margin. The males are more elongated and have a very distinct posterior cardinal angle in the right valve.

The hinge is straight. In the left valve it consists of two elongated and notched sockets separated by a heavy (smooth) bar, which is emphasized by a broad, dorsal groove. In the right valve it consists of corresponding terminal dental areas (with five teeth anteriorly and four to five posteriorly), separated by a rather narrow (smooth) groove.

The inner margin and the line of concrescence nearly coincide. There are six-seven radial pore canals anteriorly and four-five posteriorly. The muscle scars were observed as a vertical row of four elongated spots with two additional ones in front of these.

The sculpture of the lateral surfaces consists of rather strong longitudinal ribs, but on the dorsal part of the valve the ribs converge towards the middle of the dorsal margin. The area ventral to the anterior cardinal angle has small, irregular ribs. The intercostal areas are smooth or with fine cross-ribs. The ventral surface has fine ribs parallel to the margin. The border between the ventral and lateral surfaces is emphasized by a strong rib, which is rather heavy in the posterior part. The flanges and a zone along the dorsal margin are smooth.

Sexual dimorphism is considered to occur both in the adult and the last larval stage (A-1).

Measurements and statistics (in $\mathrm{mm}$ ). Specimens from the core sample No. 27 (Flyvbjerg No. 1) have been measured when possible (see text-fig. 29). On this scattergram a tendency can be seen for the points to concentrate in four areas, combined two and two. An examination of the outline of the carapace and the duplicature has made possible a division into larvae (the open circles and triangles) and adults (the black circles and triangles). Within both these groups there is a clear (sexual) dimorphism. The males of both groups are elongated with evenly curved lateral surfaces, whilst 

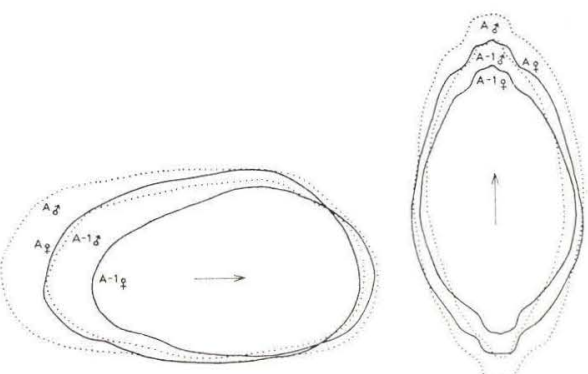

Text-fig. 28. Cristacythere costata n.sp. Outlines in lateral view and in dorsal view of carapaces of adults (A) and larvae (A-1). Inferred females are drawn with full lines and males with dotted lines. Sample No. 27 from the Flyvbjerg No. 1 boring.

the females are shorter and have the greatest breadth posterior to the midpoint (cf. text-fig. 28).

The statistical calculations for the left valve of the adults are shown below:

\begin{tabular}{|c|c|c|c|c|}
\hline & $\overline{\mathrm{x}}$ & s & $\mathrm{v}$ & O.R. \\
\hline \multicolumn{5}{|c|}{ Females $(\mathrm{N}=38)$} \\
\hline Length & 0.458 & 0.019 & 4.15 & $0.42-0.51$ \\
\hline Height & 0.270 & 0.010 & 3.70 & $0.25-0.29$ \\
\hline \multicolumn{5}{|c|}{ Males $(\mathrm{N}=13)$} \\
\hline Length & 0.537 & 0.016 & 2.98 & $0.51-0.56$ \\
\hline Height & 0.278 & 0.010 & 3.60 & $0.26-0.29$ \\
\hline
\end{tabular}

The growth factor between the two instars is calculated as:

\begin{tabular}{lcc}
\hline & $\mathrm{A} / \mathrm{A}-1$ (females) & $\mathrm{A} / \mathrm{A}-1$ (males) \\
\hline Length & 1.18 & 1.20 \\
Height & 1.17 & 1.14 \\
\hline
\end{tabular}

The calculated growth factors emphasize the above-mentioned differences between the females and the males. The occurrence of females and males and their relative growth rate is known from other Liassic "Procytheridea": Kinkelinella (Klinglerella) foveolata and $K$. (K.) medioreticulata. Cristacythere costata differs from these species in having a low growth factor; in the two species mentioned it is calculated to about 1.26.

Remarks. C. costata differs from all known species by its elongated out- 


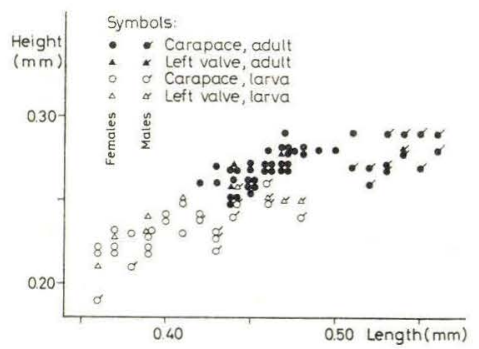

Text-fig. 29. Scattergram showing relations between numbers, lengths and heights for Cristacythere costata n.sp. Sample No. 27 from the Flyvbjerg No. 1 boring.

line, the longitudinal ribs, and the heavy rib at the border between the lateral and ventral surfaces. It may possibly be the same as Procytheridea? sp. 38 Viaud 1963, pl. XIV, fig. 414, which is found in the French Hettangian, and which has not been examined.

For comparison with Cristacythere sp. 4081 (Michelsen, 1970) see below.

Distribution. Denmark: The O. aspinata Zone; (?) Lower Sinemurian.

Cristacythere sp. 4081 (Michelsen, 1970)

1970: Procytheridea sp. (4081) Michelsen, p. 42, pl. XIII, figs. 3 a-c.

Material. 1 carapace, 1 left valve, and 2 right valves in a core sample from the Rødby No. 1 boring.

Remarks. These specimens are very like Cristacythere costata. The valves differ from the latter mainly in lacking the heavy rib at the border between the ventral and lateral surfaces. The carapace has this rib, but in the intercostal areas it has more and stronger cross-ribs than $C$. costata. The carapace is bigger than that of $C$. costata. The studied material is too small for complete certainty, but the present author believes C. sp. 4081 to be identical with $C$. costata or at least to be very close to this species.

Distribution. Denmark: The O. aspinata Zone; Hettangian.

Cristacythere crassireticulata n.sp.

Pl. 10, fig. 153; pl. 12, figs. 179-185.

1968a: Procytheridea sp. 856 b Christensen, pl. 23, fig. 5.

1968a: Lophocythere? sp. 654 Christensen, pl. 23, fig. 3.

Derivation of the name. Crassitudo $=$ thickening, reticulum $=$ network.

Holotype. A carapace. D.G.U. catalogue No. 1972-OM-22; pl. 12, figs. 183-185. 
Type locality. The Gassum No. 1 boring.

Type stratum. Sample No. 44A. Dark greenish grey shale. The C. betziC. crassireticulata Zone; Lower Sinemurian.

Material. 33 carapaces, 64 left valves, and 84 right valves in core samples from the Gassum No. 1 and Øresund Nos. 8, 9, and 10 borings.

Diagnosis. A species of the genus Cristacythere with an elongate-oval outline. The sculpture of the lateral surfaces consists of strong ribs forming a polygonal pattern. Longitudinal ribs occur along the ventral margin. One or two oblique ribs run from the anterior margin towards the dorsal margin.

Description. In lateral view the outline is elongated oval, tapering posteriorly, and with the greatest height at the anterior cardinal angle. In dorsal view the outline is elongated oval, with the greatest breadth posteriorly, and with rather strong marginal flanges at both ends. In posterior view the outline is subtriangular with the greatest breadth ventrally.

The dorsal margin is nearly straight, slightly concave near the obtuse cardinal angles. The anterior margin is rounded, but straight in the dorsal part. The ventral margin is straight with a concavity anterior to the mid-point. The posterior margin is rounded and extended ventrally; in the right valve it is slightly concave dorsally. The area around the anterior cardinal angle is slightly swollen. The outline of the larvae is more subtriangular. The inferred males are more elongated and relatively higher posteriorly.

The hinge is straight. In the left valve it consists of elongated, notched sockets separated by a smooth bar, which is emphasized by a dorsal groove. In the right valve it consists of corresponding terminal dental areas, with seven teeth in the posterior one and five (?) in the anterior one.

The inner margin and the line of concrescence coincide. The duplicature is broad. Radial pore canals were not observed. The muscle scar area seems to consist of a vertical and slightly arched row of spots.

The sculpture of the lateral surfaces consists of strong ribs forming a polygonal pattern. In the middle of some of the polygons there is a very short rib. From the anterior margin one or two ribs run towards the mid-point of the dorsal margin. There are longitudinal ribs along the ventral margin. A zone along the dorsal margin is smooth. The flanges are also smooth; however, the anterior flange sometimes has an irregular pattern. There is a slight variation in the sculpture on the lateral surfaces, e. g. on some specimens there can be a pronounced longitudinal feature. Apparently the two valves can differ from each other, the one having a typical polygonal pattern, and the other having less pronounced vertical ribs and stronger longitudinal ribs.

Sexual dimorphism is thought to occur; the inferred males appear to be more elongated.

Measurements (in $\mathrm{mm}$ ). Most of the specimens mentioned above are more 


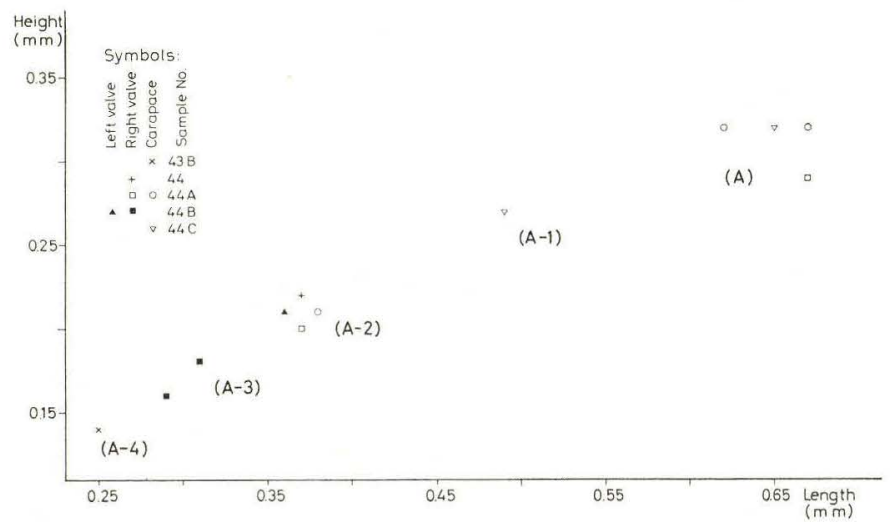

Text-fig. 30. Scattergram showing relations between numbers, lengths and heights for Cristacythere crassireticulata n.sp. The Gassum No. 1 boring.

or less broken. The measurable specimens in the samples from the Gassum No. 1 boring are figured together in text-fig. 30 to give an idea of the relative dimensions within this species. The measurable specimens from the Øresund No. 8 and No. 10 borings are larvae (cf. Christensen, 1968a, pl. 23, fig. 5).

Remarks. C. crassireticulata is identical with Procytheridea sp. $856 \mathrm{~b}$ and Lophocythere? sp. 654 Christensen, 1968a. The differences between the two forms, as figured by Christensen, are mostly due to the differences between the right valve and the left valve. The state of preservation also produces some differences; Lophocythere? sp. 654 is figured from sample No. 917 of Øresund No. 8 and Procytheridea sp. $856 b$ from sample No. 937 of the same boring.

In the outline of the carapace C. crassireticulata resembles C. betzi (Klingler \& Neuweiler, 1959), but differs in the character of the reticulation.

The sculpture of $C$. crassireticulata shows some resemblance to that of Progonoidea reticulata (Klingler \& Neuweiler, 1959). Larval reticulation in these two species is very much alike, but they have quite different shell outlines.

Distribution. Denmark: The C. betzi $-C$. crassireticulata Zone, Lower Sinemurian; lowermost in the $P$. reticulata Subzone, Lias Beta-1a.

Cristacythere? sp. 4352

Pl. 10, fig. 152.

Material. 1 carapace, 4 left valves, and 3 right valves in core samples from the Øresund Nos. 10 and 11 borings.

Description. The valve is elongated, subtriangular in lateral view, with the 
greatest height at the anterior cardinal angle. The dorsal margin is straight and the cardinal angles rather distinct. The ventral margin is concave, passing with slight bends into the posterior and anterior margins. The latter margin is broadly rounded and extended ventrally, whilst the posterior margin is narrowly rounded to acuminate. There are broad flanges at both ends. The lateral surface is strongly inflated ventrally and posteriorly. From the area behind the anterior cardinal angle and obliquely forward there is a distinct concavity. In front of this the lateral surface has a characteristic inflation and overlaps the dorsal margin. The ventral margin is only slightly overlapped.

The hinge is merodont, with two elongated and notched terminal sockets and a finely crenulate median ridge in the left valve. The hinge of the right valve has corresponding terminal dental areas and a median groove emphasized by a dorsal ridge.

The muscle scars appear to form a subvertical row of four scars.

The duplicature is not known.

The sculpture is characterized by sharp, rather high ribs. On the lateral surface there are three longitudinal ribs; the ventral one is parallel to the ventral margin whilst the dorsal one is diagonal (running posterodorsally to the anteroventrally). Posteriorly the ventral and dorsal ribs are connected by a vertical rib. Posterior to the above-mentioned concavity of the lateral surface there is a fourth rib, which bends dorsally and continues parallel to the dorsal margin as far as the posterior cardinal angle. The triangular area between this rib and the above-mentioned diagonal rib is ornamented with broad, irregular rib-like structures. A fifth rib occurs in front of the concavity of the lateral surface. Along the ventral margin there are three or four irregular longitudinal, fine ribs. The intercostal areas are ornamented with fine cross-ribs. The flanges are smooth.

Remarks. All specimens found are larvae, and only one of these is an entire valve.

Cristacythere? sp. 4352 resembles larvae of $C$. betzi, but differs from the latter in having fewer ribs in the sculpture and in having a vertical rib connecting the posterior ends of two longitudinal ribs. The inflation of the lateral surface in front of the posterior cardinal angle is also a feature which is feebly developed or not found at all in C. betzi.

As only larvae are recorded, and as the median hinge element is considered to be finely crenulate, this species is only tentatively referred to the genus Cristacythere.

Distribution. Denmark: The middle subzone of the $O$. danica Zone; Upper Sinemurian. 
Type species. Procytheridea? apostolescui Gramann, 1962.

Original diagnosis. "Shape sub-rectangular, anterior margin broadly but asymmetrically rounded, posterior short and acuminate. Left valve larger than right. Ornament reticulate, often strongly so. Hinge antimerodont. Marginal pore canals simple, curved, $8-10$ anteriorly, 2 or 3 posteriorly. Adductor muscle scars arranged in sub-vertical row of 4 rounded scars with round antennal scar anteriorly. Sexual dimorphism evident, with inferred males more elongate than females" (Lord, 1972a, p. 192).

Stratigraphical range. Lower Jurassic (Middle Lias).

Gramannella apostolescui (Gramann, 1962)

Pl. 12, figs. 186-189; pl. 13, figs. 190-197. Text-fig. 31.

1962: Procytheridea ? apostulescui Gramann, p. 193, pl. 3, figs. 4-6.

1968a: Procytheridea? aff. P. ? apostulescui Gramann - Christensen, pl. 23, fig. 41. 1972a: Gramannella apostolescui (Gramann) - Lord, p. 193, pl. 39, figs. 14-23.

Material. 30 carapaces, 120 left valves, and 125 right valves in core samples from the Gassum No. 1, Børglum No. 1, Øresund Nos. 12 and 15 borings. - One fragment from the Fjerritslev No. 1 boring is with some doubt referred to this species.

Original diagnosis. "Annähernd mandelförmige Ostracoden mit nur einigen Merkmalen der Gattung Procytheridea, einer kräftigen Netzskulptur und einem nicht vorgezogenen Vorderrand" (Gramann, 1962, p. 193).

Description. The shell is elongated oval with the greatest height at the anterior cardinal angle. The dorsal margin is nearly straight. The anterior cardinal angle is well defined, the posterior one more weakly marked. The anterior end is well-rounded with the ventral part extended. The posterior end is more acute, with a concave dorsal part in the right valve. The ventral margin is concave anterior to the mid-point. The right valve is a little smaller than the left one. In dorsal view the carapace is elongated with nearly straight, parallel sides. The greatest breadth is found a little posterior to the mid-point. Both ends are rather sharply cut off; at the posterior end the margin is slightly extended. In anterior view the carapace is subtriangular with the greatest breadth located ventrally. The area just behind the anterior cardinal angle is depressed, most distinctly in the males.

The hinge is straight and rather weak. The hinge of the left valve consists of two elongated and notched sockets separated by a narrow bar. Grooves are situated dorsally and ventrally to this bar. The hinge of the right valve has corresponding terminal dental areas with seven teeth in each. They are separated by a finely crenulate groove. 
The inner margin and the line of concrescence nearly coincide. Anteroventrally there is a very narrow vestibule. The radial pore canals are simple, straight or weakly curved; 7-8 anteriorly and 3-4 posteriorly.

The muscle scar pattern consists of a vertical row with four spots and at least two more anterior spots. Of the four spots the middle two are elongated and the other two are circular.

The surface sculpture is a pattern of rather strong ribs surrounding polygonal hollows. The area at the anterior cardinal angle as well as a narrow marginal zone (anteriorly, dorsally and posteriorly) is smooth. The ventral marginal zone has fine longitudinal ribs.

Sexual dimorphism occurs with more elongated males characterized by a rounded posterior end. The outline of the carapace in the larvae corresponds to the description above, but the posterior end is more pointed.

Measurements and statistics (in $\mathrm{mm}$ ). The specimens are usually broken; thus only one sample (Øresund No. 12, sample No. 1406) is available for measurements. In other samples only few specimens are intact. The measurements and the statistical calculations of the adults from Øresund No. 12, sample No. 1406 are listed below (see also text-fig. 31):

\begin{tabular}{|c|c|c|c|c|}
\hline & $\overline{\mathrm{x}}$ & s & $\mathrm{v}$ & O.R. \\
\hline \multicolumn{5}{|c|}{ Males, left valves $(\mathrm{N}=6)$} \\
\hline Length & 0.460 & 0.026 & 5.65 & $0.40-0.50$ \\
\hline Height & 0.213 & 0.010 & 4.69 & $0.20-0.22$ \\
\hline \multicolumn{5}{|c|}{ Males, right valves $(\mathrm{N}=6)$} \\
\hline Length & 0.435 & 0.008 & 1.84 & $0.42-0.44$ \\
\hline Height & 0.197 & 0.010 & 5.08 & $0.18-0.21$ \\
\hline \multicolumn{5}{|c|}{ Females, left valves $(\mathrm{N}=31)$} \\
\hline Length & 0.388 & 0.017 & 4.38 & $0.36-0.44$ \\
\hline Height & 0.196 & 0.011 & 5.61 & $0.18-0.22$ \\
\hline \multicolumn{5}{|c|}{ Females, right valves $(\mathrm{N}=22)$} \\
\hline Length & 0.382 & 0.017 & 4.45 & $0.35-0.42$ \\
\hline Height & 0.192 & 0.011 & 5.73 & $0.18-0.22$ \\
\hline
\end{tabular}

Remarks. The present specimens belong without doubt to Gramannella apostolescui (Gramann, 1962). They differ slightly from the German specimens in having a less pointed posterior end; the males, in particular, have a more rounded posterior end. The dorsal and ventral margins are less tapered posteriorly than in the German specimens.

The species shows a rather large variation of the outline in lateral view between the Danish specimens (which have the most rounded posterior end) and the English specimens (which have the most pointed posterior end). 


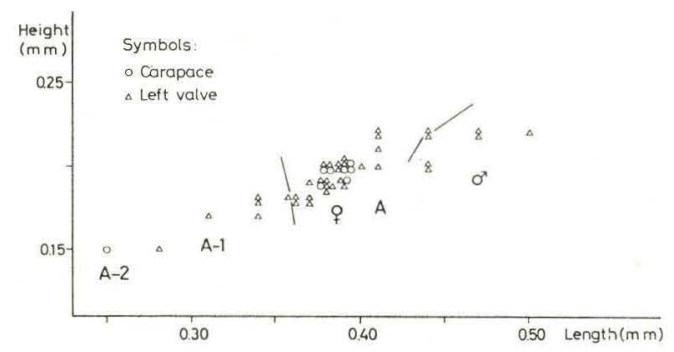

Text-fig. 31. Scattergram showing relations between numbers, lengths and heights for Gramannella apostolescui (Gramann, 1962). Sample No. 1406 from the Øresund No. 12 boring.

There is also a large variation in the shell size:

Length of German females: $\quad 0.40-0.41 \mathrm{~mm}$ (Gramann, 1962, p. 194).

Length of Danish females: $\quad 0.36-0.44 \mathrm{~mm}$.

Length of English females: $0.58 \mathrm{~mm}$ (Lord, 1972a, p. 193).

Length of German males: $\quad 0.45-0.46 \mathrm{~mm}$ (Gramann, 1962, p. 194).

Length of Danish males: $\quad 0.40-0.50 \mathrm{~mm}$.

Length of English males: $\quad 0.61-0.69$ mm (Lord, 1972a, p. 193).

Furthermore, the Danish specimens differ from the English specimens in having 7-8 (not 8-10) marginal pore canals anteriorly and 3-4 (not 2-3) posteriorly, and in having a very narrow vestibule anteroventrally. The marginal zone of the German specimens is not described.

Considering the rather large variation within this species it may be reasonable to subdivide it into subspecies. To the present author the English specimens seem to differ rather greatly from the German and Danish specimens in the character of the posterior end and in the size of the shell.

Finally it must be emphasized that the English specimens are described from deposits referred to the $A$. margaritatus Zone, the German specimens from the T. ibex Zone, and the Danish specimens from the Lower Pliensbachian. The latter specimens may be of the same age or a little older than the German specimens.

Concerning the spelling of the name of this species see Lord, 1972a.

Cousin \& Apostolescu (1961, fig. 3) present a drawing of a species (? Procytheridea $D$ ) which has an outline resembling that figured by Lord (1972a). However, the area at the anterior cardinal angle does not seem to be smooth as in G. apostolescui. A certain identification of ? Procytheridea D can only be made by studies on the French material.

Distribution. Denmark: The G. apostolescui - K. (K.) foveolata Subzone, Lower Pliensbachian; and possibly the $O$. adenticulata $-N$. (N.) simplex 
Zone, Upper Pliensbachian. (Uppermost Upper Sinemurian?, questionably determined.)

Germany: The $B$. centaurus Subzone (the T. ibex Zone) to the A. stokesi Subzone (the $A$. margaritatus Zone); Lias Gamma-2 to Delta-1 (Gramann, 1962).

England: The A. margaritatus Zone; Upper Pliensbachian (Lord, 1972a).

France: The $P$. davoei Zone to the $P$. spinatum Zone; uppermost Lower Pliensbachian and Upper Pliensbachian (Lord, 1972a).

Gramannella laevigata n.sp.

Pl. 13, figs. 198-200, 203; pl. 16, figs. 235-238.

1968a: Procytheridea? sp. 895 Christensen, pl. 23, fig. 49.

1968a: Ostracod sp. 884 Christensen, pl. 23, fig. 39.

Derivation of the name. From laevis $=$ smooth, referring to the smooth external surface.

Holotype. A left valve. D.G.U. catalogue No. 1972-OM-16, pl. 16, fig. 235.

Type locality. The Øresund No. 12 boring.

Type stratum. Sample No. 1393. Greyish sandstone and siltstone, with clay beds. The G. apostolescui $-K$. (K.) foveolata Subzone; Lower Pliensbachian.

Material. 3 carapaces, 20 left valves, and 27 right valves in core samples from the Børglum No. 1 and Øresund Nos. 12 and 15 borings.

Diagnosis. A species of the genus Gramannella characterized by a smooth external surface. The outline and shape of the valves resemble the type species: G. apostolescui.

Description. The carapace is elongated oval to subtriangular in lateral view with the greatest height at the anterior cardinal angle. The dorsal margin is straight, the cardinal angles broadly obtuse. The anterior margin is rounded, slightly extended ventrally. The ventral margin is straight, but with a little concavity anterior to the mid-point. The posterior end is low, rounded to acute, extended ventrally. The carapace is elongated oval in dorsal view with the greatest breadth posterior to the mid-point. The surface of the valve is evenly vaulted with a slight concavity at the extended part of the posterior margin. The outline of the larvae corresponds with this description, but it is subtriangular in lateral view.

The hinge is straight. The hinge of the left valve consists of elongated and notched sockets separated by a bar. The hinge of the right valve has corresponding terminal dental areas separated by a finely crenulate groove.

The duplicature is rather narrow. The inner margin and the line of con- 
crescence coincide (?). The muscle scar area consists of an arched vertical row of four spots and at least one more anterior spot. The two spots in the middle of the row are elongated and the ventral spot is circular.

The external surface is smooth. The very distinct normal pores are the only decoration.

Remarks. Of the present specimens only one, a left valve, is an adult. However, the smooth external surface makes confusion with other species impossible.

The shape and outline of the valves resemble those of $G$. apostolescui and $G$. tatei, both of which have a reticulate external surface. G. laevigata occurs in the samples together with $G$. apostolescui, so it can not be a stratigraphical or geographical variety of the latter species.

Distribution. Denmark: The G. apostolescui - K. (K.) foveolata Subzone; Lower Pliensbachian. (Uppermost Upper Sinemurian?, questionably determined.)

Gramannella cf. tatei (Gramann, 1962)

Pl. 13, figs. 201-202; pl. 14, figs. 204-205.

cf. 1962: Procytheridea ? tatei Gramann, p. 192, pl. 3, figs. 1-3.

Materials. 3 left valves and 6 right valves in core samples from the Øresund No. 12 boring.

Remarks. Almost all the valves found are more or less broken. The sculpture consists of strong, broadly-rounded ribs forming an irregular pattern. In the intercostal areas pits are found, which are probably connected with the pore canals visible on the internal side of the valve. The duplicature is rather broad, broader than the zone of concrescence.

The present specimens differ from Gramannella tatei (Gramann, 1962) in the broad duplicature, the rounded posterior end, and the straight dorsal margin. Because of the badly preserved and scarce material it is not possible to refer these specimens to any known species with certainty.

Procytheridea? tatei Gramann, 1962 is referred to the genus Gramannella Lord, 1972 by Lord (1972a, p. 192).

Distribution. Denmark: The uppermost part of the middle subzone of the $O$. danica Zone and in the $G$. apostolescui - K. (K.) foveolata Subzone; uppermost Upper Sinemurian and Lower Pliensbachian.

Gramannella sp. 4253

Pl. 16, figs. 239-241.

Material. 3 left valves in core samples from the Øresund No. 12 boring. 
Remarks. The present specimens cannot be referred to any known species with certainty. They have some affinity with Procytheridea? tatei Gramann (1962, p. 192, pl. 3, figs. 1-3).

They differ from $P$.? tatei mainly in the outline, particularly with the broadly rounded posterior end. The present valves seem to be of males, but Gramann (1962) neither describes nor figures the left valve of the male. Furthermore the ribs of the sculpture are very low and indistinct, and the intercostal pits are numerous.

Distribution. Denmark: The uppermost part of the middle subzone of the $O$. danica Zone; Upper Sinemurian.

Gramannella? sp. 4259

P1. 14, figs. 206-209.

Material. 3 carapaces, 11 left valves, and 15 right valves in core samples from the Øresund Nos. 10, 11, and 12 borings.

Description. The shell is elongated oval to subtriangular in lateral view, with the greatest height at the anterior cardinal angle. The dorsal margin is straight in the right valve and feebly concave in the left one. The anterior cardinal angle is rather distinct, the posterior one only slightly marked. The anterior margin is well-rounded and is extended ventrally. The posterior margin is narrowly rounded in the left valve. In the right valve it is more acuminate and has a straight to concave dorsal part. The ventral margin is straight with a weak concavity anterior to the mid-point. The lateral surface is inflated, overhanging the ventral margin posteriorly. Along the posterior margin there is a distinct and narrow flange. Along the anterior margin there is a thickened zone, but not a distinct flange.

The hinge is merodont; in the right valve with terminal dental areas and a long crenulate median groove which is emphasized by a dorsal ridge; in the left valve the hinge consists of corresponding terminal sockets and a median ridge.

The muscle scars form an arched, vertical row of four elongated scars.

The duplicature is moderately broad at the anterior end. The inner margin and the line of concrescence coincide. There are 7 simple straight marginal pore canals anteriorly. (The marginal zone of the posterior end has not been clearly observed).

The sculpture consists of more or less irregular, broad and low ribs, and cf several intercostal pits. The main impression of the reticulation is a longitudinal "striation". Along the ventral margin this striation is distinct. Small areas at the anterior cardinal angle and the posterior marginal flange are smooth. 
Remarks. The above description is based mainly on larval specimens as only two adults have been found. The description is based on specimens recorded from the Øresund No. 12 boring. The specimens from Øresund Nos. 10 and 11 are small larvae which have a shape and outline as described, but a sculpture with weaker ribs and more distinct pits, partly arranged in longitudinal rows.

Gramannella? sp. 4259 may have a sculpture nearly similar to that of Procytheridea? tatei Gramann, 1962 (= Gramannella tatei), but it differs in having a distinct, posterior marginal flange and a thickened anterior margin.

Gramannella? sp. 4259 is referred to the genus Gramannella with reservations, since the marginal pore canals are straight and only 7 in number anteriorly. The occurrence of a posterior marginal flange and a thickened anterior margin may exclude this species from the genus.

Distribution. Denmark: The middle subzone and the G. apostolescui $K$. (K.) foveolata Subzone of the $O$. danica Zone; Upper Sinemurian to Lower Pliensbachian.

Genus Kinkelinella Martin, 1960

Type species. Kinkelinella tenuicostata Martin, 1960.

Original diagnosis. "Eine Gattung der Familie Cytheridae mit folgenden Merkmalen: Gehäuse mittelgross, ventral aufgebläht, ohne Flügelansätze und Augenknoten. Schloss merodont, mit zwei deutlichen kerbzähnen bei der kleineren rechten Klappe. Dazwischen eine gleichmässige Furche, ohne Einkerbungen. Linke Klappe mit ungekerbter Leiste zwischen den Zahngruben. Vorderrand mit 8 bis 10 einfachen, unverzweigten randständigen Porenkanälen. Verschmolzene Zone mittelbreit; Innenrand und Verwachsungslinie fallen zusammen" (Martin, 1960).

Remarks. The genus Kinkelinella is here considered to comprise two subgenera: K. (Kinkelinella) Martin, 1960 and K. (Klinglerella) Anderson, 1964. The two genera are so close in all features that they may be treated together (see pp. 161-162).

Subgenus Kinkelinella (Kinkelinella) Martin, 1960

Remarks. In the present paper the following species are referred to this subgenus: Procytheridea adunca Plumhoff, 1963, P. oblonga Plumhoff, 1963, and K. (Kinkelinella) spp. 4243 and 4336.

The present subgenus differs from the subgenus $K$. (Klinglerella) in its sculpture, which consists of strong ribs forming a triangular pattern. The 
intercostal cross-ribs are rather strong. The outlines of the carapace are more rounded and inflated (especially in dorsal view).

Stratigraphical range. Lower Jurassic (Middle Lias (?) and Upper Lias) and Middle Jurassic.

Kinkelinella (Kinkelinella) aff. adunca (Plumhoff, 1963)

P1. 16, fig. 248.

aff. 1963: Procytheridea adunca Plumhoff, p. 30, pl. 4, figs. 64-65.

1968a: Procytheridea aff. P. adunca Fischer - Christensen, pl. 23, fig. 71.

Material. 1 left valve in a core sample from the Øresund No. 2 boring.

Diagnosis (of $K$. (K.) adunca). "Eine Kinkelinella-Art mit gebläht walnussartigem Umriss in Dorsalansicht; Hinterende in Seitenansicht eng gerundet, stumpf. Seitenflächen ventralwärts von umriss-parallelen Rippen überzogen; Rippen- bzw. Netzmuster in der Mitte und zum Dorsalrand hin \pm unregelmässig verlaufend (und nicht nach einem ineinandergeschachtelten Giebel-Muster angeordnet wie bei K. fischeri)" (Malz, 1966, p. 387).

Remarks. This single valve is the same as figured by Christensen (1968a, pl. 23, fig. 71).

The specimen differs from K. (K.) adunca (Plumhoff, 1963) in being larger: length $0.86 \mathrm{~mm}$; length of Plumhoff's specimens $0.66-0.75 \mathrm{~mm}$. Furthermore, the sculpture of the present specimen is definitely triangular, whereas $K$. (K.) adunca has the ribs at the posterior end curved from the ventral towards the dorsal margin.

Concerning the problem about Procytheridea adunca Plumhoff, 1963, and $P$. adunca Fischer, 1963 (= Kinkelinella fischeri Malz, 1966) see the discussion in Malz (1966).

Distribution. Denmark: The Rydebäck Beds; (?) Aalenian.

Kinkelinella (Kinkelinella) oblonga (Plumhoff, 1963)

P1. 15, fig. 228.

1963: Procytheridea oblonga Plumhoff, p. 31, pl. 4, figs. 71-72; pl. 5, figs. 73-74.

1968a: Procytheridea oblonga Plumhoff - Christensen, pl. 23, fig. 70.

Material. 1 carapace, 1 left valve, and 2 right valves in core samples from the Øresund No. 2 boring.

Original diagnosis. "Eine Art der Gattung Procytheridea mit folgenden Besonderheiten: G gross, in Seitenansicht \pm lang-dreieckig-oval. Hinterrand stumpf gewinkelt, Oberabschnitt abgeschrägt, Unterabschnitt eng gerundet. Breite laterale Vertikalfurche von der Gehäusemitte, die dicht unter der 
Längs-Mittellinie ansetzt. Maschenskulptur geringen Reliefs ohne Rippenbildung. Stark ausgeprägter Sexualdimorphismus" (Plumhoff, 1963, p. 31).

Description. See Plumhoff, 1963, p. 31.

Remarks. Only the carapace is well-preserved (cf. pl. 15, fig. 228).

The reticulation is distinct in the middle of the lateral surfaces; fainter in the anterior marginal zone. The carapace, as well as the more or less fragmentary valves must be referred to Procytheridea oblonga Plumhoff, 1963 and not to the subspecies P. oblonga levis Stoermer (1965, p. 551), since the latter is characterized in having a smooth or very weakly reticulate external surface.

Distribution. Denmark: Rydebäck Beds; ? Aalenian.

Germany: The L. sinon Subzone and the S. staufensis Subzone; Upper Aalenian (Plumhoff, 1963).

Kinkelinella (Kinkelinella) sp. 4243

Pl. 15, fig. 229.

Material. 1 left valve and 1 right valve in core samples from the Flyvbjerg No 1 and Øresund No. 3 borings.

Remarks. These valves are elongated, subtriangular in lateral outline. The sculpture consists of rather fine, longitudinal ribs, with numerous pits in the intercostal areas.

This form differs from $K$. (Klinglerella) multicostata in being more elongated and in having the anterior margin extended ventrally. The ribs are finer and more closely situated.

Distribution. Denmark: The G. apostolescui - K. (K.) foveolata Subzone and the $O$. adenticulata - N. (N.) simplex Zone; Lower and Upper Pliensbachian.

Kinkelinella (Kinkelinella) sp. 4336

Pl. 15, fig. 230.

Material. 1 carapace in a core sample from the Frederikshavn City No. 2 boring.

Remarks. This specimen is characterized by a sculpture of low rounded ribs forming polygons. Ventrally the polygons are arranged in longitudinal rows; centrally they are undirected; dorsally, posteriorly, and anteriorly the surface is nearly smooth. Dorsally on the lateral surface there is a concavity anterior to the mid-point. 
The present species resembles $K$. (Kinkelinella) adunca, but differs from this in the weaker, closely spaced reticulation. $K$. (Kinkelinella) oblonga has a more distinct reticulation in the marginal zones.

$K$. (Kinkelinella) $s p$. 4336, of which only one carapace is known, seems to be a new species which is closely related to $K$. (K.) oblonga.

Distribution. Denmark: The $O$. adenticulata - N. (N.) simplex Zone; Upper Pliensbachian.

Subgenus Kinkelinella (Klinglerella) Anderson, 1964

Type species. Procytheridea glabellata Klingler \& Neuweiler, 1959.

Original diagnosis. "Triangular-ovate carapace. Surface reticulate with longitudinal elements of reticulum usually dominant in median area. A wide arcuate flange anteriorly, triangular-arcuate posteriorly. Inner lamella broad.

Articulation consists in right valve of a row of from six to eight subcuboidal teeth anteriorly and posteriorly separated by a row of fine transverse grooves which lie in the groove between the hinge flange and the hinge list. In the left valve the corresponding sockets are separated by a narrow bar bearing fine transverse ribs or denticles. Adductor muscle scars form a vertical median row of four closely adjacent scars with two dissociated scars to the anterior" (Anderson, 1964, p. 141).

Remarks. The species referred to this subgenus in the present paper vary in the sculpture. The subgenus is therefore considered to comprise two groups: the glabellata-group and the bipartita-group.

The glabellata-group is characterized by a sculpture with longitudinal ribs and fine intercostal cross-ribs and pits. The pattern of the sculpture tends towards the triangular form which is characteristic of the subgenus Kinkelinella (Kinkelinella), but in the present subgenus the longitudinal ribs are the most prominent and the marginal areas are more or less smooth. Furthermore, the ribs are stronger in $K$. (Kinkelinella).

The bipartita-group is characterized by an asymmetrical sculpture, composed of two parts: anterior and posterior. The ribs on the anterior part are arched in different figures, whilst on the posterior part they are often longitudinal. The intercostal areas are ornamented by pits and fine crossribs. Ventrally there are longitudinal ribs. Along the other margins there may be a smooth zone.

In the present paper the following species described by Klingler \& Neuweiler (1959) are referred to the glabellata-group: Procytheridea glabellata, P. multicostata, P. sulcata, and P. triebeli, and Procytheridea medioreticulata Michelsen, 1970.

To the bipartita-group are referred Procytheridea bipartita, P. laqueata, 
P. variabilis (all described by Klingler \& Neuweiler, 1959), and K. (Klinglerella) foveolata $\mathrm{n} . \mathrm{sp}$.

K. (Klinglerella) ? elongata n.sp. is tentatively referred to the subgenus without reference to any of the two groups.

The two groups of species are here referred to the subgenus $K$. (Klinglerella) since all species comprise the characters included in the diagnosis. The separation into groups is made since the species of the bipartitagroup have a sculpture clearly differing from that of the type species: P. glabellata Klingler \& Neuweiler, 1959.

Sexual dimorphism was observed, and probably also occurs in the larvae (A-1 and A-2). The growth factor is calculated as 1.26 (see $K$. $(K$.) foveolata n. sp.).

Stratigraphical range. Upper Triassic (?), Lower Jurassic (Lower and Middle Lias).

The glabellata-group

Kinkelinella (Klinglerella) glabellata (Klingler \& Neuweiler, 1959)

Pl. 14, fig. 210.

1959: Procytheridea glabellata Klingler \& Neuweiler, p. 379, pl. 14, figs. 22 and 26-32. 1962: Procytheridea glabellata Klingler \& Neuweiler - Klingler, p. 83, pl. 12, fig. 10.

Material. 1 carapace and 1 right valve in a core sample from the Gassum No. 1 boring.

Original diagnosis. "Eine längliche und schmale sowie niedrige Art der Gattung Procytheridea mit einer sehr charakteristischen Oberflächenskulptur, die im vorderen Drittel meist eine fast glatte, sehr schwach netzskulptierte Schalenauftreibung mit wenigen groben, etwas länglichen Vertiefungen aufweist. Dahinter schliesst sich eine der Procytheridea multicostata ähnelnde, gebogene Längsrippenskulptur mit feinen Quersepten an. Die Abstände zwischen den Rippen verbreitern sich in der Schalenmitte etwas und kommen zum Hinterende wieder einander näher" (Klingler \& Neuweiler, 1959, p. 379).

Description. See Klingler \& Neuweiler, 1959, p. 379.

Remarks. This species can not be mistaken for any of the other "Procytheridea"-species described by Klingler \& Neuweiler (1959), but it resembles $K$. (Klinglerella) medioreticulata (Michelsen, 1970). Both species are characterized by a weak reticulation which makes up a triangular pattern. The marginal zones (except for the ventral one) are more or less smooth. K. (K.) medioreticulata usually has a weaker sculpture and broader 
smooth marginal zones. However, the main difference between the two species is found in the outline and shape of the shell. $K$. (K.) glabellata has a less pointed posterior end and the dorsal margin of the right valve has a characteristic concavity anterior to the posterior cardinal angle. The dorsal margin of the left valve has a concavity behind the anterior cardinal angle. The dorsal margins of $K$. (K.) medioreticulata are shorter and slightly convex, and there is a smaller concavity in front of the posterior cardinal angle in the right valve.

The present specimens of $K$. (K.) glabellata have been compared with paratypes deposited at "Gewerkschaft Brigitta", Hannover.

Distribution. Denmark: Lowest part of the middle subzone of the $O$. danica Zone; Upper Sinemurian (Lias Beta-1b).

Germany: Lias Beta-1b (Klingler \& Neuweiler, 1959).

Kinkelinella (Klinglerella) medioreticulata (Michelsen, 1970)

Pl. 14, figs. 211-215. Text-figs. 32-33.

? 1952: Ostracode 4 Usbeck, p. 404, pl. 18, figs. 61 a-d.

1961: Procytheridea? sp. 17 Oertli - Bizon \& Oertli, pl. VII.

1961: Procytheridea? sp. 17 Oertli - Oertli \& Grosdidier, pl. VI.

1962: Ostracod No. 108 Klingler, p. 79, pl. 12, fig. 3.

1970: Procytheridea medioreticulata Michelsen, p. 39, pl. XII, figs. 1 a-d, 2 a-c; text-fig. 5 .

1971: Klinglerella aff. K. triebeli (Klingler \& Neuweiler) - Lord, p. 655, pl. 123, figs. 1-3.

Material. 277 carapaces, 412 left valves, and 435 right valves in core samples from the Gassum No. 1, Horsens No. 1, Rødby No. 1, Vedsted No. 1 , and Vinding No. 1 borings.

Original diagnosis. "A species of the genus Procytheridea. Surface reticulate in the middle part, with a tendency to a triangular arrangement of the ridges in which one side of the triangle is parallel to and near the ventral margin. The posterodorsal margin of the right valve is distinctly concave" (Michelsen, 1970, p. 40).

Description. See Michelsen, 1970, p. 40.

Measurements and statistics (in $\mathrm{mm}$ ). The specimens in sample No. 4 from Horsens No. 1, samples Nos. 47 and 48 from Gassum No. 1, and samples Nos. 8 and 10 from Rødby No. 1 have been measured. Three of these samples are figured in scattergrams (text-figs. 32 and 33; Michelsen, 1970, text-fig. 5). Statistical calculations of the left valves of the adults from sample No. 4 (Horsens No. 1) and sample No. 47 (Gassum No. 1) are given in the table below: 
Horsens No. 1, sample No. 4:

\begin{tabular}{lcccc}
\hline & \multicolumn{1}{c}{$\mathrm{x}$} & $\mathrm{s}$ & $\mathrm{v}$ & O.R. \\
\hline Females $(\mathrm{N}=31)$ & & & & \\
Length & 0.583 & 0.018 & 3.09 & $0.56-0.64$ \\
Height & 0.349 & 0.012 & 3.44 & $0.33-0.37$ \\
Males $(\mathrm{N}=2)$ & & & & \\
Length & 0.720 & - & - & 0.72 \\
Height & 0.375 & 0.007 & 1.87 & $0.37-0.38$ \\
\hline
\end{tabular}

Gassum No. 1, sample No. 47:

\begin{tabular}{lcccc}
\hline & \multicolumn{1}{c}{$\overline{\mathrm{x}}$} & $\mathrm{s}$ & $\mathrm{v}$ & O.R. \\
\hline Females $(\mathrm{N}=10)$ & & & & \\
Length & 0.570 & 0.027 & 4.74 & $0.53-0.61$ \\
Height & 0.341 & 0.019 & 5.57 & $0.32-0.38$ \\
Males $(\mathrm{N}=1)$ & & & & 0.73 \\
Length & 0.73 & - & - & 0.39 \\
Height & 0.39 & - & - & \\
\hline
\end{tabular}

These two samples agree with each other and show what is considered to be the normal features of $K$. (Klinglerella) medioreticulata. Though the material of sample No. 10 (Rødby No. 1) is limited, this sample too agrees with the two mentioned. The size of the specimens from sample No. 8, which is the uppermost marine deposit of the Rødby section, is a little

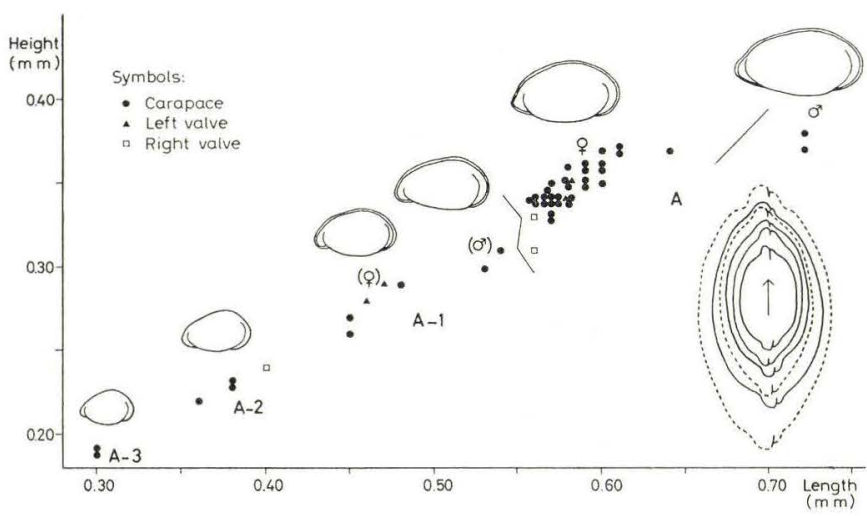

Text-fig. 32. Scattergram showing relations between numbers, lengths and heights for K. (Klinglerella) medioreticulata (Michelsen, 1970). Sample No. 4 from the Horsens No. 1 boring. The outlines in dorsal view are drawn for each of the specimens shown in lateral view. The inferred females are drawn with full lines and the males with dotted lines in dorsal view. 


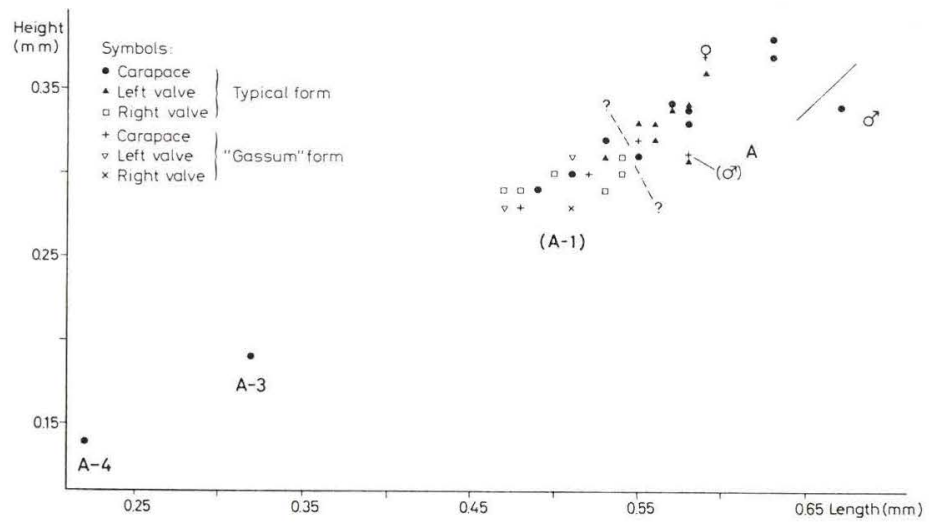

Text-fig. 33. Scattergram showing relations between numbers, lengths and heights for K. (Klinglerella) medioreticulata (Michelsen, 1970). Sample No. 48 from the Gassum No. 1 boring.

reduced (cf. Michelsen, 1970, text-fig. 5). In sample No. 48, Gassum No. 1 (cf. text-fig. 33), it is difficult to separate the instars A and A-1. On the basis of the distribution of the specimens in the instars in relation to the sample above (No. 47) this sample (No. 48) is supposed to be mixed in some way.

Remarks. The present material includes two morphotypes (cf. text-fig. 33): a typical form which is described in Michelsen (1970, p. 39), and the "Gassum" form which differs from the former in its stronger sculpture and less triangular outline in lateral view (cf. pl. 14, fig. 215). The material studied is not good enough to make a conclusive analysis of the relations between the two forms, which cannot be separated by the morphology alone.

The typical form is found in samples from the Rødby No. 1 and Horsens No. 1 borings. Sample No. 47 from Gassum No. 1 includes only the typical form, whilst the other samples from this boring contain a mixture of the two forms. As in the Vedsted No. 1 boring the lower part of the section of Gassum No. 1 seems to be dominated by the "Gassum" form. Both forms also occur in samples from Vinding No. 1.

The measurements (cf. text-fig. 32) show the presence of sexual dimorphism. Dimorphism is also present in the instar A-1. The drawings of the outline in dorsal view make probable the occurrence of sexual dimorphism in this instar. The largest breadth of the female is located more posteriorly than in the male. Sample No. 8 (Rødby No. 1) contain two groups of valves situated between the larval states (cf. Michelsen, 1970, text-fig. 5). This was supposed by the author to be due to "a mixture 
of individuals from two different environments". But in the light of the analysis presented above (text-fig. 32) it can probably be explained by the presence of sexual dimorphism in the larval state.

Studies on material of Procytheridea? sp. 17 Oertli (see Oertli, 1963), during a visit to $\mathrm{H}$. J. Oertli (Pau, France), and on type material of Klinglerella aff. K. triebeli (Klingler \& Neuweiler, 1959), kindly placed at the author's disposal by Alan Lord, have established that these two species and $K$. (Klinglerella) medioreticulata are identical.

Distribution. Denmark: The $O$. aspinata Zone; Hettangian and Lower Sinemurian.

Germany: Ostracod No. 108 is found in Lias Alpha-2 and lower part of Alpha-3 (Klingler, 1962). Ostracode 4 is common in upper part of Lias Alpha-1 and in Alpha-2 (Usbeck, 1952).

France: Procytheridea? sp. 17 is found in the A. bucklandi Zone to the C. turneri Zone; Lower Sinemurian and lowermost Upper Sinemurian (Bizon \& Oertli, 1961).

England: Klinglerella aff. $K$. triebeli is found in the S. angulata Zone to the A. bucklandi Zone; upper Hettangian and lowest Lower Sinemurian (Lord, 1971).

Kinkelinella (Klinglerella) multicostata (Klingler \& Neuweiler, 1959) Pl. 16, figs. 242-244.

1959: Procytheridea multicostata Klingler \& Neuweiler, p. 385, pl. 16, figs. 48-60.

1962: Procytheridea multicostata Klingler \& Neuweiler - Klingler, p. 87, pl. 12, fig. 13.

Material. 7 carapaces, 7 left valves, and 16 right valves in core samples from the Gassum No. 1, Øresund Nos. 9, 14 and 15 borings.

Original diagnosis. "Eine langgestreckte Art der Gattung Procytheridea mit einer vorherrschend mit Längsrippen gekennzeichneten Skulptur; zwischen den Rippen sind feine, niedrigere Quersepten zu erkennen. Die Skulptur ist auf die Mitte der Lateralflächen beschränkt, Vorder- und Hinterende sowie die Dorsalflächen sind glatt" (Klingler \& Neuweiler, 1959, p. 385).

Description. See Klingler \& Neuweiler, 1959, p. 386.

Remarks. The present material is limited and rather badly preserved. The specimens from the Øresund borings are finely reticulated. The specimens from sample No. 38 of Gassum No. 1 agree with the paratypes deposited at "Gewerkschaft Brigitta", Hannover. The two carapaces in sample No. 33 from the same boring are, in spite of their fragmentary condition, with some doubt referred to $K$. (Klinglerella) multicostata.

Distribution. Denmark: The lower part of the $O$. danica Zone; Upper Sinemurian. 
Germany: Lias Beta-1 and lowest part of Beta-2 (Klingler \& Neuweiler, 1959 and Klingler, 1962).

Kinkelinella (Klinglerella) sulcata (Klingler \& Neuweiler, 1959)

Pl. 14, figs. 216-217.

1959: Procytheridea sulcata Klingler \& Neuweiler, p. 393, pl. 18, figs. $82-86$ and $88-90$. 1962: Procytheridea sulcata Klingler \& Neuweiler - Klingler, p. 91, pl. 12, fig. 21.

Material. 2 carapaces and 1 left valve in core samples from the Gassum No. 1 boring.

Original diagnosis. "Eine Art der Gattung Procytheridea mit einer zerfurchten Oberfläche mit unregelmässigen Längsrippen. Die Interkostalfelder sind, wie die gesamte Schalenoberfläche, mit einer Unzahl feiner Grübchen bedeckt" (Klingler \& Neuweiler, 1959, p. 393).

Description. See Klingler \& Neuweiler, 1959, p. 393.

Remarks. These specimens have been compared with paratypes deposited at "Gewerkschaft Brigitta", Hannover.

Distribution. Denmark: In the middle of the O. danica Zone; Upper Sinemurian.

Germany: In the middle of Lias Beta-2 (Klingler \& Neuweiler, 1959).

Kinkelinella (Klinglerella) triebeli (Klingler \& Neuweiler, 1959)

Pl. 15, figs. 218-220; pl. 16, figs. 245-247.

1959: Procytheridea triebeli Klingler \& Neuweiler, p. 381, pl. 13, figs. 11-16; pl. 14, figs. 17-18.

1962: Procytheridea triebeli Klingler \& Neuweiler - Klingler, p. 84, pl. 12, fig. 12.

1968a: Procytheridea vulgaris Klingler \& Neuweiler - Christensen, pl. 23, fig. 19 (non Procytheridea vulgaris Klingler \& Neuweiler, 1959).

Material. 1 carapace in a core sample from the Øresund No. 10 boring, and a few carapaces and valves in cuttings samples from the Nøvling No. 1 and Ørslev No. 1 borings.

Original diagnosis. "Eine Art der Gattung Procytheridea mit retikulierter Oberfläche bei vorherrschenden Längsrippen; zwischen den Längsrippen und den niedrigeren Querrippen sind die Felderböden mit ungezählten Grübchen bedeckt. Im Bereich des vorderen Schlosszahnes ist eine längliche Vertiefung mit nur zarter Skulptur ausgebildet, die schräg nach vorn unten zieht und sich kurz vor der Mittellinie der Klappen verliert. Die Rechten Klappen sind im dorsalen Bereich zwischen der vorderen und hinteren Schlosszahnregion aufgebläht. Eine geringe Ausprägung von Augenknoten ist vorhanden" (Klingler \& Neuweiler, 1959, p. 381).

Description. See Klingler \& Neuweiler, 1959, p. 381. 
Remarks. The above-mentioned specimens agree with $K$. (Klinglerella) triebeli and have been compared with the paratypes deposited at "Gewerkschaft Brigitta" (Hannover). In the opinion of the present author the specimen, referred to Procytheridea vulgaris Klingler \& Neuweiler, 1959, by Christensen (1968a), should be placed in $K$. (K.) triebeli because of the numerous intercostal pits. Furthermore, the characteristic feature of $P$. vulgaris is missing: The "A-förmige Leiste" in the posterior part of the valve.

Distribution. Denmark: The lower part of the $O$. danica Zone; lower part of Upper Sinemurian.

Germany: Lias Beta-1a and lower part of Beta-1b (Klingler \& Neuweiler, 1959 and Klingler, 1962).

Kinkelinella (Klinglerella) cf. triebeli Klingler \& Neuweiler, 1959

P1. 15, figs. 221-224.

cf. 1959: Procytheridea triebeli Klingler \& Neuweiler, p. 381, pl. 13, figs. 11-16; pl. 14, figs. $17-18$.

Material. 2 left valves and 3 right valves in core samples from the Børglum No. 1 boring.

Remarks. The specimens are not very well-preserved, but this morphospecies, which is also found in cuttings samples from Nøvling No. 1 and other borings, shows affinities with $K$. (Klinglerella) triebeli. It is more elongated and the longitudinal ribs are more dominant.

K. (K.) cf. triebeli resembles Ostracoda E Apostolescu (1959, p. 817, pl. III, figs. 54-55). A comparison with type material deposited with H. J. Oertli (Pau, France) has revealed identity with some of the specimens only. The present species is also somewhat like Procytheridea aff. triebeli, figured by Viaud (1963, pl. XI, figs. 326-329), but Viaud's material has not been examined.

The present form is probably new and will be described when more material is available.

Distribution. Denmark: The upper part of the $O$. danica Zone; uppermost Upper Sinemurian and Lower Pliensbachian.

The bipartita-group

Kinkelinella (Klinglerella) bipartita (Klingler \& Neuweiler, 1959) Pl. 20, figs. 324-326; pl. 22, figs. 344-346.

1959: Procytheridea bipartita Klingler \& Neuweiler, p. 387, pl. 16, figs. 61-64. 1962: Procytheridea bipartita Klingler \& Neuweiler - Klingler, p. 88, pl. 12, fig. 14. 
Material. 5 carapaces, 15 left valves, and 19 right valves in core samples from the Gassum No. 1, Øresund Nos. 10, 11, and 14 borings.

Original diagnosis. "Eine Art der Gattung Procytheridea, deren Rippenstruktur durch eine schräg über die Lateralflächen hinziehende Rinne, die von zwei Rippen gesäumt ist, in einen vorderen und hinteren Abschnitt unterteilt wird. Der vorspringende Vorder- und Hinterrand sind frei von Skulpturelementen. Die Interkostalflächen sind mit kleinen, rundlichen Grübchen übersät. Das Gehäuse ist eiförmig, mit sehr wenig nach hinten abfallendem Dorsalrand" (Klingler \& Neuweiler, 1959, p. 387).

Description. See Klingler \& Neuweiler, 1959, p. 387.

Measurements (in $\mathrm{mm}$ ). Only four valves in sample No. 39A from Gassum No. 1 were measurable:

\begin{tabular}{lcc}
\hline & Length & Height \\
\hline Right valve & 0.64 & 0.33 \\
Left valve & 0.63 & 0.37 \\
$-\quad-\quad$ (larva) & 0.65 & 0.38 \\
$-\quad-\quad 0.52$ & 0.29 \\
\hline
\end{tabular}

Remarks. The state of preservation is rather bad. Most of the material mentioned above is more or less broken. The reticulation on some of the specimens (e. g. from Øresund No. 11) is rather weak and with longer ribs posteriorly. Rather large variation in the sculpture is also observed in type material deposited at "Gewerkschaft Brigitta" (Hannover) and with $\mathrm{H}$. Malz (Frankfurt): the ribs may be shorter or longer, more or less curved, and some of the ribs may even be missing.

The specimens of sample No. 39A (Gassum No. 1) have stronger ribs. Both in the latter sample and in sample No. 41A of the same boring a few larvae are found with a slightly differing reticulation. It is supposed that both the adults and the larvae of the two samples also belong to $K$. (K.) bipartita.

Distribution. Denmark: The lower part of the $O$. danica Zone; lowest Upper Sinemurian.

North Germany: Lias Beta-1b (Klingler \& Neuweiler, 1959 and Klingler, 1962).

Kinkelinella (Klinglerella) foveolata n.sp.

P1. 21, figs. 331-335; pl. 22, figs. 347-352. Text-fig. 36.

1968a: Procytheridea aff. P. sulcata Klingler \& Neuweiler - Christensen, pl. 23, fig. 37.

1968a: Ostracod (513) Wicher - Christensen, p1. 23, fig. 48 (non Ostracod (513) Wicher, 1938). 
Derivation of the name. Foveolae $=$ pits, a characteristic feature of the sculpture.

Holotype. A right valve. D.G.U. catalogue No. 1972-OM-10, pl. 22, figs. 347-349.

Type locality. The Øresund No. 12 boring.

Type stratum. Sample No. 1410. Greyish sandstone and siltstone. The G. apostolescui -K. (K.) foveolata Subzone; Lower Pliensbachian.

Material. 18 carapaces, 263 left valves, and 295 right valves in core samples from the Børglum No. 1, Gassum No. 1, Øresund Nos. 12, 14, and 15 borings.

Diagnosis. A species of the subgenus Kinkelinella (Klinglerella), with an oval to subtriangular outline in lateral view. The sculpture on the ventral and posterior sections of the shell consists of rather strong, longitudinal ribs; on the anterodorsal section of wavy and oblique ribs. The area between the ribs is ornamented with numerous pits.

Description. The outline in lateral view is oval to subtriangular, tapering posteriorly, and with the greatest height at the anterior cardinal angle. In dorsal view the carapace is oval, with marked flanges at both ends, and with the greatest breadth posterior to the median. In posterior view it is subtriangular with a concave ventral outline, and with the greatest breadth ventrally.

The dorsal margin is straight in the right valve and slightly convex in the left one. The posterior cardinal angle is obtuse and well-defined, whereas the anterior one is more rounded. The anterior margin is rounded, but slightly extended ventrally. The posterior margin is also rounded, but more sharply, and it is extended dorsally. In the right valve there is a concavity posterior to the posterior cardinal angle. The ventral margin is nearly straight with a concavity in the middle. The right valve is smaller than the left one. The outline of the larvae agrees with this description, but they are more markedly subtriangular. The inferred males are elongated oval with a higher posterior end.

The hinge is straight. In the left valve it consists of two elongated notched sockets separated by a (smooth ?) bar, which is emphasized by a dorsal groove. The hinge of the right valve consists of corresponding terminal dental areas, with seven teeth in the posterior one and six in the anterior one. The two groups of teeth are separated by a groove.

The inner margin and the line of concrescence coincide. The radial pore canals are simple and nearly straight. There are seven pore canals in the anterior margin and three in the posterior one. Normal pore canals can be clearly observed. The muscle scar area consists of a slightly arched vertical row of four spots, and anterodorsal to this are two spots. 
The sculpture can be divided into two sections. Posteriorly and ventrally there are rather strong, longitudinal ribs, whereas dorsally and anteriorly the ribs are wavy and oblique (from the anterior margin to the dorsal one). Along the ventral margin and on the ventral part of the lateral surface the ribs run the whole length of the valve, close to each other ventrally. Behind the muscle scar area there are three ribs, which are often connected by a vertical rib at their anterior end. This is a characteristic feature of the sculpture. Between the muscle scar area and the anterior end there is one rib bent like a question-mark. The ribs dorsally to this are oblique, running from the middle of the anterior margin to the dorsal margin. The area between the ribs is ornamented with numerous pits. The sculpture does not extend to the flanges. A zone along the dorsal margin is also smooth. Small cross-ribs occur in the sculpture of the smallest larvae.

Sexual dimorphism was observed. The inferred males are longer and more oval in outline than the females.

Measurements and statistics (in $\mathrm{mm}$ ). Several specimens have been measured, for example, from Børglum No. 1, sample No. 14; Øresund No. 12 , sample No. 1406; Øresund No. 14, samples Nos. 1686 and 1689; Øresund No. 15, sample No. 1826. The table below demonstrates the statistical calculations for the females and males from Øresund No. 12, sample No. 1406 (see also text-fig. 36).

\begin{tabular}{lcccc}
\hline & $\overline{\mathrm{x}}$ & $\mathrm{s}$ & $\mathrm{v}$ & $\mathrm{O} . \mathrm{R}$. \\
\hline $\begin{array}{l}\text { Males, left valves }(\mathrm{N}=6) \\
\text { Length }\end{array}$ & & & \\
Height & 0.662 & 0.013 & 1.96 & $0.64-0.68$ \\
Males, right valves $(\mathrm{N}=2)$ & 0.322 & 0.012 & 3.73 & $0.30-0.33$ \\
Length & 0.665 & 0.007 & 1.05 & $0.66-0.67$ \\
Height & 0.315 & 0.007 & 2.22 & $0.31-0.32$ \\
$\begin{array}{l}\text { Females, left valves }(\mathrm{N}=20) \\
\text { Length }\end{array}$ & 0.574 & 0.016 & 2.79 & $0.55-0.61$ \\
Height & 0.318 & 0.013 & 4.09 & $0.30-0.34$ \\
Females, right valves $(\mathrm{N}=19)$ & & & \\
Length & 0.561 & 0.020 & 3.57 & $0.54-0.61$ \\
Height & 0.292 & 0.016 & 5.48 & $0.28-0.34$ \\
\hline
\end{tabular}

This sample is the only one with sufficient adults for the calculation. However, compared with other samples the means shown above seem to be too low. Among other things, some well-preserved specimens from two cuttings samples $\left(5240^{\prime}-5270^{\prime}\right.$ and $\left.5570^{\prime}-5600^{\prime}\right)$ of Nøvling No. 1 boring are markedly outside the limits of significance. 


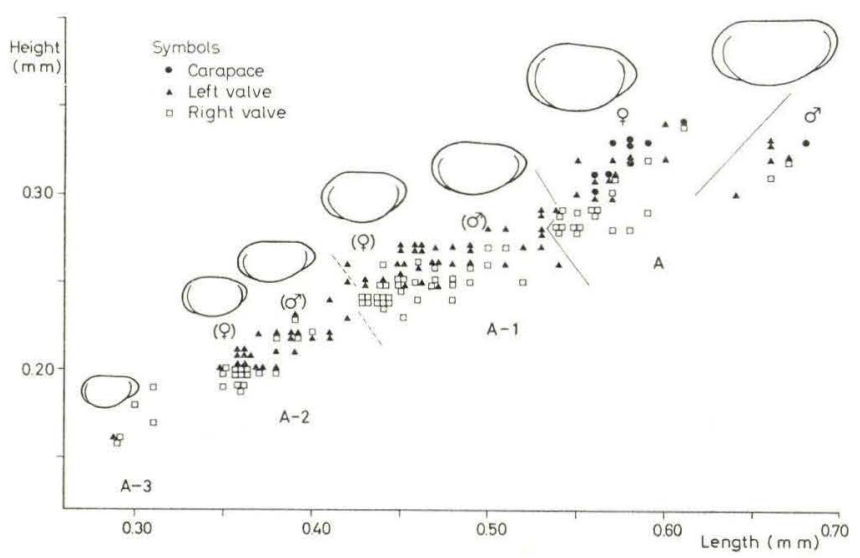

Text-fig. 36. Scattergram showing relations between numbers, lengths and heights for K. (Klinglerella) foveolata n.sp. Sample No. 1406 from the Øresund No. 12 boring.

The figure for each instar is skew, having two morphotypes which have respectively male and female morphology (cf. text-fig. 36). The only explanation for the lack of a clear distinction between the instars and the occurrence of two morphotypes must be (if one accepts the existence of sexual dimorphism in the adults) that sexual dimorphism also occurs in the larvae.

The growth factor is 1.26 with a distribution of instars as proposed in text-fig. 36, which resembles the growth pattern of $K$. (Klinglerella) medioreticulata.

Remarks. K. (Klinglerella) foveolata resembles $K$. (K.) multiforata (Klingler \& Neuweiler, 1959) and $K$. (K.) bipartita (Klingler \& Neuweiler, 1959 ) in some respects. However, the ribs of $K$. (K.) foveolata are rather strong and the pattern is the same in the two valves. The three short longitudinal ribs posterior to the muscle scar area are a characteristic feature.

K. (K.) foveolata seems to have some resemblance to Procytheridea sp. 6 Dreyer (1965, pl. V, figs. 5a-b).

The species named as Procytheridea cf. multiforata in Michelsen, 1971a and 1973a is identical with $K$. (Klinglerella) foveolata $\mathrm{n.sp}$.

Distribution. Denmark: Rare in the middle subzone of the $O$. danica Zone and common in the upper one, the G. apostolescui - K. (K.) foveolata Subzone; Upper Sinemurian and Lower Pliensbachian.

Kinkelinella (Klinglerella) laqueata (Klingler \& Neuweiler, 1959) Pl. 20, figs. 327-330; pl. 22, figs. 353-357.

1959: Procytheridea laqueata Klingler \& Neuweiler, p. 382, pl. 15, figs. 37-47. 
1962: Procytheridea laqueata Klingler \& Neuweiler - Klingler, p. 85, pl. 12, fig. 11. 1965: Procytheridea laqueata Klingler \& Neuweiler - Dreyer, pl. VI, fig. 1.

Material. 7 carapaces, 2 left valves, and 3 right valves in core samples from the Gassum No. 1 boring.

Original diagnosis. "Eine Art der Gattung Procytheridea mit deutlicher Ventralrippe, im vorderen Schalenabschnitt mit einer schlingenartig gebogenen Rippe und zwei Längsrippen auf der hinteren Schalenhälfte, deren vordere Enden manchmal durch eine feine Leiste untereinander verbunden sind. Vorder- und Hinterrand sind deutlich abgesetzt" (Klingler \& Neuweiler, 1959, p. 382).

Description. See Klingler \& Neuweiler, 1959, p. 382.

Measurements (in $\mathrm{mm}$ ). The specimens from sample No. 42 of Gassum No. 1 have been measured:

\begin{tabular}{lcc}
\hline & Length & Height \\
\hline Left valve & 0.53 & 0.31 \\
Carapace & 0.64 & 0.32 \\
Carapace & 0.64 & 0.32 \\
Carapace & 0.53 & 0.29 \\
Carapace & 0.55 & 0.32 \\
\hline
\end{tabular}

Remarks. The present specimens have been compared with the paratypes deposited at "Gewerkschaft Brigitta", Hannover, and are regarded as identical with those.

Some specimens, including the specimens measured, are badly preserved with low and indistinct ribs. However, the ribs seem to make up a pattern like that of $K$. (K.) laqueata (cf. pl. 22, fig. 353).

Distribution. Denmark: The lowest part of the $O$. danica Zone; lowest Upper Sinemurian.

Germany: Lias Beta-1b (Klingler \& Neuweiler, 1959).

Kinkelinella (Klinglerella) variabilis (Klingler \& Neuweiler, 1959)

Pl. 21, figs. 336-338; pl. 24, figs. 373-377.

1959: Procytheridea variabilis Klingler \& Neuweiler, p. 388, pl. 17, figs. 65-67, 69.

1962: Procytheridea variabilis Klingler \& Neuweiler - Klingler, p. 89, pl. 12, fig. 18.

Material. 3 carapaces, 3 left valves, and 1 right valve in core samples from the Gassum No. 1 and Øresund No. 15 borings.

Original diagnosis. "Eine kleine Art der Gattung Procytheridea mit ovalen 
Umriss und einer sehr characteristischen gebogenen Längsskulptur, mit einer dem Ventralrand genähert und ihm parallel verlaufenden, gleichmässig kommaförmig geschwungenen Ventralrippe, dann zum Rücken hin mit einer stumpf endenden Halbrippe, die vom hinteren Schalenbereich bis etwa zur Mitte vorstösst und mit der dorsalsten, die treppenförmig abgesetzt von vorn unten nach hinten oben, diagonal aufwärts verläuft. (Die längeren und grösseren Exemplare scheinen auf Grund der relativen Seltenheit die Männchen zu sein). Diese drei Hauptrippen wandeln bei den einzelnen Formen nur wenig $a b$, dagegen bedecken die Schalenoberflächen noch andere kleinere Rippen, die offenbar in ihrer Lage und Länge nicht konstant sind" (Klingler \& Neuweiler, 1959, p. 389).

Description. See Klingler \& Neuweiler, 1959, p. 389.

Remarks. This species is rare, also in the cuttings samples. The specimens mentioned have been compared with the paratypes deposited at "Gewerkschaft Brigitta", Hannover, and are regarded as identical with those.

Distribution. Denmark: The middle subzone of the $O$. danica Zone; Upper Sinemurian.

Northern Germany: Upper part of Lias Beta-1b to upper part of Lias Beta-3 (Klingler \& Neuweiler, 1959 and Klingler, 1962).

Southern Germany: Lias Beta-2 and lower part of Lias Beta-3 (Klingler, 1962).

Kinkelinella (Klinglerella) ? elongata n.sp.

Pl. 15, figs. 225-227; pl. 18, figs. 268-273.

Derivation of the name. Elongatum = elongated, the characteristic outline of the carapace.

Holotype. A left valve. D.G.U. catalogue No. 1972-OM-33, pl. 18, figs. 268-270.

Type locality. The Børglum No. 1 boring.

Type stratum. Sample No. 14. Claystone, with subordinate beds of sand. The G. apostolescui - K. (K.) foveolata Subzone; Lower Pliensbachian.

Material. 2 carapaces, 13 left valves, and 14 right valves in a core sample from the Børglum No. 1 boring.

Diagnosis. A Klinglerella-like species with an elongated outline, posteriorly pointed and anteriorly rounded. The sculpture is composed of irregularly bent, partly longitudinal, ribs which are low and rounded in cross-section. The sculpture is strongest in the middle of the valve where fine cross-ribs connect the longitudinal ribs. Small pits ornament the intercostal areas and the marginal zones.

Description. In lateral view the outline is elongated, posteriorly pointed, 
anteriorly rounded, with the greatest height at the anterior cardinal angle. In dorsal view the outline is elongated oval, with the greatest breadth posteriorly. In the inferred males there are only small differences between the breadth posteriorly and anteriorly. The posterior flanges are rather strong, whilst the anterior ones are only slightly marked. In posterior view the outline is subtriangular, concave ventrally, with the greatest breadth ventrally.

The dorsal margin is straight to slightly concave in the left valve, and straight to convex in the right valve. The cardinal angles are only weakly marked. The anterior margin is rounded, but extended ventrally. The posterior margin of the left valve is rounded in a rather sharp curve, and slightly concave dorsally. In the right valve this margin is more pointed with a broader concavity. The posterior end is extended dorsally. The ventral margin has a concavity anterior to the mid-point. The left valve is larger than the right one.

The hinge is nearly straight and rather weak. In the left valve it consists of two elongated notched sockets separated by a narrow bar, emphasized by a dorsal groove. In the right valve it consists of corresponding terminal dental areas, with six to seven (?) teeth in each one. No crenulation of the bar and the groove was observed.

The inner margin and the line of concrescence nearly coincide. The duplicature is broad; seven radial pore canals occur anteriorly (the canals in the posterior end were not observed). The muscle scar area consists of a slightly curved, vertical row of four oval spots, with at least one spot in front.

The sculpture consists of low rounded ribs which are longitudinal and irregularly bent. They are most distinct on the lateral surface and are here connected by finer irregularly occurring cross-ribs. The pattern of the longitudinal ribs is broad in the middle of the valve, becoming narrower towards the ends. The intercostal areas and the marginal zones are ornamented by small pits. Only the flanges and the area around the anterior cardinal angle are smooth. Along the ventral margin there are fine longitudinal ribs.

The larvae are not known.

Sexual dimorphism is considered to occur. The inferred males are more elongated and are narrower posteriorly than the females.

Measurements and statistics (in $\mathrm{mm}$ ). The specimens from B $\varnothing$ rglum No. 1 , sample No. 14 have been measured and the statistics of the left valves (and carapaces) are given in the table p. 196.

Remarks. In its elongated outline and irregular sculpture $K$. (K.) ? elongata differs from the known species. Ornamentation agrees partly with that of $K$. (K.) sulcata Klingler \& Neuweiler, 1959, but differs in the stronger and fewer ribs. Furthermore, $K$. (K.) ? elongata is smaller and its pointed posterior end is extended dorsally. 


\begin{tabular}{lcccc}
\hline & \multicolumn{1}{c}{$\overrightarrow{\mathrm{x}}$} & $\mathrm{s}$ & $\mathrm{v}$ & $\mathrm{O}$ \\
\hline $\begin{array}{l}\text { Females }(\mathrm{N}=4) \\
\text { Length }\end{array}$ & 0.523 & 0.006 & 1.15 & $0.52-0.53$ \\
Height & 0.250 & 0.008 & 3.20 & $0.24-0.26$ \\
Males $(\mathrm{N}=3):$ & & & & \\
Length & 0.567 & 0.012 & 2.12 & $0.56-0.58$ \\
Height & 0.270 & 0.012 & 4.44 & $0.26-0.28$ \\
\hline
\end{tabular}

K. (K.) ? elongata is doubtfully referred to Kinkelinella (Klinglerella) because there is only a very narrow flange anteriorly.

Distribution. Denmark: The G. apostolescui $-K$. (K.) foveolata Subzone; Lower Pliensbachian.

Genus Nanacythere Herrig, 1969

Type species. Nanacythere simplex Herrig, 1969.

Original diagnosis. "Eine Gattung der Unterfamilie Progonocytherinae mit folgenden Merkmalen: Schalen klein, langgestreckt; LKl nur wenig höher als RKl; schwach gewölbt, in einem schmalen Streifen entlang dem VoR, VeR und HR seitwärts komprimiert; DR und VeR konvergieren schwach nach hinten; Kl-Oberfläche retikuliert, bestimmte Längs- und Querelemente bisweilen leicht verstärkt; zentroventral mit scharfer lateraler Kante. Schloss merodont, mittlere Elemente glatt; Schlossenden bei LKl durch Vorsprünge der Aussenleiste, bei RK1 durch entsprechende Furchen differenziert. Innere Randzone mässig breit, Innenrand und Verwachsungslinie im VE und HE getrennt, Vestibeln etwa halb so breit wie Innere Randzone; Randständige Porenkanale gerade und unverzweigt, vorn etwa zehn (vorherrschend echte), hinten vier. Vier Schliessmuskelnarben bilden eine schräg zum HE geneigte subzentrale Vertikale. Die terminalen Narben sind dreieckig bis oval, die mittleren länglich" (Herrig, 1969b, p. 1080).

Remarks. The genus Nanacythere must be referred to the subfamily Protocytherinae as the hinge is of the merodont, not of the entomodont, type.

Stratigraphical range. Lower Jurassic (Lower to Middle Lias).

The species described here under the subgenus $N$. (Goniocythere) n.subgen. are found in beds referred to Lower Lias.

Subgenus Nanacythere (Nanacythere) Herrig, 1969

Nanacythere (Nanacythere) simplex Herrig, 1969

Pl. 15, figs. 231-234; pl. 17, figs. 249-252; pl. 18, figs. 276-277. Text-fig. 34. 
1968a: Procytheridea ? cf. P. ? apostulescui Gram. - Christensen, pl. 23, fig. 60.

1969b: Nanacythere (Nanacythere) simplex Herrig, p. 1081, text-figs. 6 and 10; pl. III, figs. 1-4.

Material. 88 carapaces, 154 left valves, and 143 right valves in core samples from the Børglum No. 1, Fjerritslev No. 1, Flyvbjerg No. 1, Gassum No. 1, Haldager No. 1, Vedsted No. 1, and Øresund No. 3 borings.

Original diagnosis. "Eine Art der Gattung Nanacythere mit retikulierter Kl-Oberfläche, wobei Längselemente von der Mitte des VoR ausgehen und zum HE divergieren. Im hinteren Kl-Teil sind die vorspringenden Rippen halbkreisförmig zum DR konvex. Die von Netzleisten umgrenzten Felder enthalten zwei bis vier Grübchen. Die Randständigen Porenkanäle sind dicklumig; anteroventral sind zwei Porenkanal-Paare characteristisch" (Herrig, 1969b, p. 1081).

Description. The outline in lateral view is subrectangular, with the greatest height anteriorly. The outline is elongated oval in dorsal view, with the marginal flanges of both ends extended, and with the greatest breadth just behind the mid-point. The outline in posterior view is oval, with the greatest breadth ventrally.

The dorsal margin is straight; the cardinal angles obtuse. The anterior margin is broadly rounded, and extended ventrally. In the left valve the posterior margin is rounded, but more narrowly than the anterior margin. In the right valve it is sharply rounded and has a concavity dorsally. The ventral margin is concave in the middle and a short distance posteriorly; it passes evenly into the anterior and the posterior margins. The lateral surfaces have a more or less distinct dorsal concavity between the anterior cardinal angle and the middle of the shell. Ventrally the lateral surface is inflated and overhangs the ventral margin; posteroventrally it forms a more or less distinct bulge. The marginal flanges are usually narrow (especially the anterior one). The left valve is only a little larger than the right one.

The larvae have a more triangular outline in lateral view. The lateral surfaces are more evenly arched, and the marginal flanges very narrow.

The hinge is straight and tripartite. In the right valve it consists of two terminal, crenulate teeth. Between these a long groove occurs, emphasized by a dorsal ridge. In the left valve the hinge consists of corresponding sockets separated by a long, straight ridge.

The muscle scar area consists of a vertical row of (four ?) spots.

The duplicature is broad. The vestibule is a third of the inner lamella. The posterior vestibule is elongate and runs into the ventral margin. The radial pore canals were not clearly observed. Normal pore canals are rather numerous and evenly distributed. 


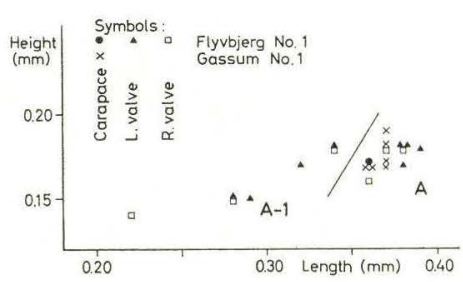

Text-fig. 34. Scattergram showing relations between numbers, lengths and heights for Nanacythere (Nanacythere) simplex Herrig, 1969. Sample No. 18 from the Flyvbjerg No. 1 boring and sample No. 11 from the Gassum No. 1 boring.

The sculpture of the lateral surfaces is an irregular pattern of ribs forming polygons, which may show a dominant longitudinal trend. There are small pits within the polygons. Along the ventral margin there are two to three longitudinal ribs. The flanges seem to be smooth. Some of the present specimens have a very weak and indistinct sculpture, and a few are smooth or with numerous pits.

Measurements (in $\mathrm{mm}$ ). The specimens in sample No. 18 from Flyvbjerg No. 1 and in sample No. 11 from Gassum No. 1 have been measured (cf. text-fig. 34).

The specimens from the Gassum-sample show distinct reticulation, whilst the specimens from the Flyvbjerg-sample are more or less smooth. The specimens of the two populations have the same size, and they also agree in size with those figured by Herrig (1969b, text-fig. 6).

Remarks. Most of the present specimens are brownish coloured and fragmentary. Except for the differences in the sculpture they are identical. The indistinct or missing sculpture may be connected with the colour of the shell. This colour is probably due to a cover of iron or pyrite on the shell, which is often associated with a corrosion of the shell-surface (Herrig, 1969a and 1969b). For this reason the smooth external surface described above can not be regarded as primary.

The relationships between $N$. (N.) simplex and Aphelocythere torosa Plumhoff (1967, p. 556, pl. 4, figs. 42-45) are discussed by Herrig (1969b).

$N$. (N.) simplex shows affinities with Gramannella apostolescui (Gramann, 1962), too. It differs from the latter in its generic characters, whilst the reticulation is closely comparable. For this reason it is difficult to separate small larvae, which (in both species) have a triangular outline (in lateral view) and a fine polygonal reticulation. The difference in the hinge is not very clear in the larvae. In the present material the separation of the larvae is based on occurrence of the adults of the two species. Actually, there have not been big problems as none of the sections studied here include a con- 
tinuous succession from faunas with $G$. apostolescui to faunas with $N$. (N.) simplex.

Distribution. Denmark: The $O$. adenticulata - N. (N.) simplex Zone; Upper Pliensbachian.

Northeast Germany: The P. spinatum Zone; Lias Delta-2 (Herrig, 1969b).

Subgenus Nanacythere (Domeria) Herrig, 1969

Type species. Nanacythere (Domeria) firma Herrig, 1969.

Original diagnosis. "Vertreter der Gattung Nanacythere mit folgende Merkmalen: Schalen klein; VoR und HR breit gerundet; DR und VeR konvergieren deutlich nach hinten. Die Oberflächenretikulation wird von mindestens drei Längsrippen durchzogen. Die Aussenleiste ist am VoR breit. Die Vestibeln im VE und HE sind schmal; unechte Randständige Porenkanäle sind im VE zahlreich. Die Schliessmuskelnarben bilden eine zum HE schwach konvexe Vertikale. Die beiden ventralen Narbenflecke sind kleiner als die dorsalen" (Herrig, 1969b, p. 1085).

Stratigraphical range. Lower Jurassic (Middle Lias).

Nanacythere (Domeria) firma Herrig, 1969

Pl. 17, figs. 253-257; pl. 18, figs. 274-275.

1968a: Cytheropteron? sp. 808 Christensen, pl. 23, fig. 58.

1969b: Nanacythere (Domeria) firma Herrig, p. 1085, text-figs. 7 and 9; pl. III, figs. 7-8; pl. IV, fig. 1.

Material. 25 carapaces, 26 left valves, and 48 right valves in core samples from the Fjerritslev No. 1, Flyvbjerg No. 1, Gassum No. 1, Haldager No. 1, Vedsted No. 1, and Øresund No. 3 borings.

Original diagnosis. "Eine Art der Untergattung Nanacythere (Domeria) sgen.n., deren Schalen durch folgende Längsrippen versteift sind: eine lange Mittelrippe, parallel zu dieser eine kurze und zwei lange Längsrippen jeweils in der dorsalen und ventralen Kl-Hälfte symmetrisch zueinander. Die K1Oberfläche ist zwischen den Längsrippen kräftig retikuliert. Die Vestibeln im VE und HE sind mässig tief"' (Herrig, 1969b, p. 1085).

Description. See Herrig, 1969b, p. 1086.

Remarks. As most of the present specimens are deformed and broken, only the specimens figured on pls. 17-18 have been measured. In addition, the specimens are often badly preserved, since the external surface may be corroded (as mentioned under $N$. (N.) simplex, p. 198).

The two dorsal ribs, beginning at the anterior margin and converging 
along the dorsal margin, are often faintly seen. Sometimes they may be absent or only the anterior sections may be seen. The rib in the middle of the lateral surface and the two ventral ribs are distinct and usually wellpreserved. The rib running along the anterior margin is rarely observed. The intercostal reticulation is more or less distinct, probably owing to the above-mentioned corrosion.

At the posterior end of the two ventral ribs the shell-surface may be more or less raised forming a posteroventral bulge.

The dorsal one of the two short ribs (at the posterior end) may be connected with the long median rib forming an open or closed polygonal figure. This figure resembles variants of the rhomboid figure characteristic of $N$. (D.) fissicosta (see below).

$N$. (D.) firma differs from $N$. (D.) fissicosta in having two dorsal ribs, two ventral ribs extended along the posterior margin, and a strong intercostal reticulation. In $N$. (D.) fissicosta the two ventral ribs are connected at the posterior end. The latter species is furthermore characterized by the rib forming a rhomboid figure (see below).

Badly preserved specimens of $N$. (D.) firma resemble Acrocythere tricostata, but this species has an eye spot.

Distribution. Denmark: The upper part of the $O$. adenticulata $-N$. (N.) simplex Zone; Upper Pliensbachian.

Northeast Germany: The P. spinatum Zone; Lias Delta-2 (Herrig, 1969b).

Nanacythere (Domeria) fissicosta Herrig, 1969

Pl. 17, fig. 258; pl. 18, figs. 278-279.

1938: Ostracode (207) Wicher, pl. 27, figs. 10-11.

1965: Ostracode 207 Wicher - Dreyer, pl. VI, fig. 6.

1969b: Nanacythere (Domeria) fissicosta Herrig, p. 1088, text-fig. 11; pl. III, figs. 5-6.

Material. 17 carapaces, 8 left valves, and 8 right valves in core samples from the Fjerritslev No. 1, Flyvbjerg No. 1, Gassum No. 1, Vedsted No. 1 , and Øresund No. 3 borings.

Original diagnosis. "Eine Art der Untergattung Nanacythere (Domeria) mit breiter Aussenleiste am VoR; die Mittelrippe ist vor ihrem HE aufgespalten, wobei die beiden Äste eine kleine rhombische oder ovale Fläche umgrenzen. Die gewölbten Bereiche der Kl-Oberfläche sind zwischen den Rippen fein retikuliert" (Herrig, 1969b, p. 1088).

Description. See Herrig 1969b, p. 1088.

Remarks. The rhomboid figure at the posterior end of the median rib may be open, because the two parts of the median rib (forming the 
rhomboid figure) do not converge against one another posteriorly. As this variant can be found on one of the valves from an individual, whilst the other valve has the normal rhomboid figure, it must be regarded as the normal range of variation (pl. 18, figs. 278-279).

The resemblance with $N$. (D.) firma is discussed p. 200.

Distribution. Denmark: The upper part of the $O$. adenticulata $-N$. (N.) simplex Zone; Upper Pliensbachian.

Northeast Germany: The P. spinatum Zone; Lias Delta-2 (Herrig, 1969b). Lower Domerian (Dreyer, 1965).

Subgenus Nanacythere (Goniocythere) n.subgen.

Type species. Nanacythere (Goniocythere) circumcostata n.sp.

Derivation of the name. From gonia $=$ angle + cythere, referring to the angled position of the ribs.

Diagnosis. Representatives of the genus Nanacythere characterized by a sculpture consisting of rather strong, diagonal or vertical ribs and fine, intercostal cross-ribs. The ventral and dorsal margins converge posteriorly. The merodont hinge is rather weak with small, finely dentate teeth. The vestibule is narrow.

Remarks. The present subgenus includes five species which are described below: circumcostata, elegans, elongata, minor, and paracostata. They must be included in one taxonomic group as their main characters (hinge, marginal zone, muscle scars) show a high degree of similarity. The sculpture is characterized by diagonal or vertical ribs, which are rather strong and supported by finer cross-ribs. The pattern of the sculpture is characteristic for each of the species.

Sexual dimorphism is not known.

Based on the characters of the hinge, the marginal zone, and the muscle scars these five species can naturally be referred to the genus Nanacythere. As the characteristic sculpture differs pronouncedly from the sculpture of the previously known species ( $N$. (Nanacythere) simplex, N. (Domeria) firma, $N$. (D.) fissicosta) within this genus, the five species mentioned above are included in a new subgenus: Nanacythere (Goniocythere) n.subgen.

Stratigraphical range. Lower Jurassic; Hettangian to Lower Pliensbachian.

Nanacythere (Goniocythere) circumcostata n.sp.

Pl. 17, figs. 259-267; pl. 18, figs. 280-283. Text-fig. 35.

1968a: Lophocythere sp. 860 Christensen, pl. 23, fig. 10.

1970: Lophocythere sp. (4076) Michelsen, p. 38, pl. XII, figs. 4a-b. 


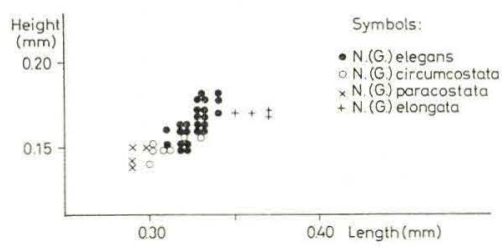

Text-fig. 35. Scattergram showing relations between numbers, lengths and heights for carapaces (adults) of Nanacythere (Goniocythere) elegans (Drexler, 1958), N. (G.) elongata n.sp., $N$. (G.) circumcostata n.sp. and $N$. (G.) paracostata n.sp. from sample No. 48 (Gassum), sample No. 49A (Gassum), sample No. 3 (Horsens) and sample No. 52 (Gassum) respectively.

Derivation of the name. From circum $=$ circle or circular and costae $=$ ribs, referring to the circular rib on the lateral surface.

Holotype. A carapace. D.G.U. catalogue No. 1973-OM-161. Pl. 17, fig. 267.

Type locality. The Horsens No. 1 boring.

Type stratum. Sample No. 5. Dark grey and greyish black shale. The O. aspinata Zone; Lower Sinemurian.

Material. 128 carapaces, 66 left valves, and 55 right valves in core samples from the Gassum No. 1, Horsens No. 1, Rødby No. 1, Vedsted No. 1, Øresund Nos. 8, 9, 10, and 14 borings.

Diagnosis. A species of the subgenus Nanacythere (Goniocythere) characterized by a sculpture of strong ribs. On the posterior third of the valve the ribs are more or less vertical and parallel. On the anterior third they are oblique, from the dorsal margin to the anteroventral part of the valve. Between these two groups of ribs is found one rib forming a closed, roughly oval form. Some of the anterior and posterior ribs are connected to ribs parallel with the ventral margin. Distinct intercostal cross-ribs occur.

Description. The carapace is small. The outline in lateral view is elongated subtriangular, with the greatest height at the anterior cardinal angle. The outline in dorsal view is elongated oval, with the greatest breadth posterior to the mid-point. In posterior view it is subtriangular, with the greatest breadth ventrally.

The dorsal margin in the left valve is straight to slightly concave, in the right valve slightly convex. The cardinal angles are rather distinct. The ventral margin is nearly straight, posteriorly convex, and anterior to the midpoint slightly concave. The anterior margin is broadly rounded. Posterior margin in left valve rounded, but less high than the anterior one. The posterior margin in the right valve is more pointed and with a dorsal concavity. The lateral surface is slightly concave at the middle of the dorsal margin; inflated ventrally and overlapping the ventral margin. The flanges 
are narrow. The right valve is a little smaller than the left, but overlapping the latter along the dorsal margin.

The larvae have features as described above.

The hinge is of the Nanacythere-type. It is straight; in the right valve with small terminal, dentate teeth separated by a long, straight furrow, which is emphasized by a dorsal ridge.

The muscle scars are difficult to observe, but they appear to form a vertical row of spots.

The duplicature is rather broad; the inner margin and the line of concrescence do not coincide. The vestibule is rather narrow; apparently forming less than one third of the width of the duplicature. The radial pore canals have not been observed.

The sculpture on the lateral surface consists of rather strong ribs and is tripartite. The posterior third of the valve with parallel and vertical (or slightly oblique) ribs; the anterior third with ribs of varying obliquity, extending from the dorsal margin to the anteroventral part of the valve; the centre of the valve with one rib forming a closed, roughly oval form extending across the middle of the valve from the posterior group to the anterior one, and turning ventrally anteriorly and returning obliquely upwards to the posterior group. There are no ribs dorsally to the circular one. Fine intercostal cross-ribs are present. The posterior and anterior ribs may be more or less reduced. Along the ventral margin there are two-three fine ribs which are connected to ribs on the lateral surface. The dorsal margin is emphasized by a rib which is most strongly developed in the right valve.

Sexual dimorphism was not observed.

Measurements and statistics (in $\mathrm{mm}$ ). Specimens of sample No. 48 from Gassum No. 1 and sample No. 3 from Horsens No. 1 (see text-fig. 35) have been measured. In the table below are given the calculations for the carapaces from the latter sample:

\begin{tabular}{lccccc}
\hline & $\overline{\mathrm{x}}$ & $\mathrm{s}$ & $\mathrm{v}$ & O.R. & $\mathrm{N}$ \\
\hline Length & 0.310 & 0.012 & 3.87 & $0.30-0.33$ & 7 \\
Height & 0.151 & 0.007 & 4.64 & $0.14-0.16$ & 7 \\
\hline
\end{tabular}

Remarks. The larvae are represented by a few specimens only.

The above-mentioned variation of the sculpture, which is observed in rather few specimens, may be due to corrosion of the external surface, which looks a little less intact in such specimens. It has not been possible to distinguish two different morphogroups. 
$N$. (Goniocythere) circumcostata resembles $N$. (Goniocythere) elegans and $N$. (Goniocythere) paracostata, and is congeneric with them.

The distinction between $N$. (Goniocythere) circumcostata and N. (Goniocythere) paracostata is discussed p. 211.

$N$. (Goniocythere) elegans is a little larger, and in particular it is a little higher, than $N$. (Goniocythere) circumcostata. The circular rib in the latter species and the ribs forming the diamond-pattern in $N$. (Goniocythere) elegans can not be confused. A short longitudinal rib as found in the centre of the diamond-pattern does not occur in N. (Goniocythere) circumcostata.

The more or less vertical ribs in $N$. (Goniocythere) circumcostata are characteristic of this species, but show affinity with $N$. (Goniocythere) paracostata. However, the ribs on $N$. (Goniocythere) paracostata are finer and more regular (see the remarks p. 211).

Concerning the relationships between $N$. (Goniocythere) circumcostata and N. (Goniocythere) elongata, see p. 207.

Some of the specimens from the Øresund borings recorded as L. elegans by Christensen (1968a) must be referred to $N$. (Goniocythere) circumcostata (see p. 211).

Distribution. Denmark: The $O$. aspinata Zone to the $P$. reticulata Subzone; Hettangian (rare), Lower Sinemurian (common) and lowest Upper Sinemurian.

Nanacythere (Goniocythere) elegans (Drexler, 1958)

Pl. 18, figs. 290-291; pl. 19, figs. 292-297. Text-fig. 35.

1952: Ostracode 7 Usbeck, p. 405, pl. 18, figs. 64a-b.

1958: Lophocythere elegans Drexler, p. 523, pl. 24, figs. 5a-e; pl. 27, figs. 10-11.

1970: Lophocythere elegans Drexler - Michelsen, p. 37, pl. XII, figs. 3a-b.

Material. 81 carapaces, 20 left valves, and 36 right valves in core samples from the Gassum No. 1, Horsens No. 1, Rødby No. 1, and Vedsted No. 1 borings.

Original diagnosis. "Eine Art der Gattung Lophocythere mit den folgende Besonderheiten: nur eine durchlaufende Längsrippe auf der Ventralfläche, dichotome Verzweigung von feineren Rippen, in deren Zwischenfeldern eine feine Netzleistenskulptur eingesenkt ist" (Drexler, 1958, p. 524).

Emended diagnosis. A species of the subgenus Nanacythere (Goniocythere) characterized by a sculpture of strong diagonal ribs forming a diamond-pattern with a very short, longitudinal rib in the centre. Between these main-ribs there are fine cross-ribs. Along the ventral margin there are two to three longitudinal ribs.

Supplementary description. Referring to the description given by Drexler (1958) only some features need to be described and emphasized. 
The left valve is larger than the right, but is overlapped by the right valve along the dorsal margin.

The sculpture of the lateral surface consists of strong ribs forming a diamond-pattern with a very short, longitudinal rib in the centre. Dorsally to this centre another short rib (or knob) occurs. Between the ribs forming the diamond-pattern there are fine cross-ribs. Along the ventral margin there are two to three longitudinal ribs which bend towards the lateral surface at the posterior end. Along the dorsal margin of the right valve and the posterior part of the dorsal margin of the left valve there is a sharp rib. This sculpture-pattern can also be observed in the figures given by Drexler (1958, pl. 24, figs. 5a-e).

The hinge is built as in the genus Nanacythere. The teeth (in the right valve) are connected with the contact-ridge of the posterior and anterior end, but in the present material they are more or less smooth, which is probably due to corrosion of the surface.

The inner margin and the line of concrescence do not coincide. The vestibule is very narrow.

The muscle scars were not observed in the present material.

Measurements and statistics (in $\mathrm{mm}$ ). The specimens in sample No. 8 from Rødby No. 1 (cf. Michelsen 1970, p. 38) and in sample No. 48 from Gassum No. 1 (see text-fig. 35) have been measured.

In the table below are shown the calculations on the carapaces from the Gassum sample:

\begin{tabular}{lccccc}
\hline & $\overline{\mathrm{x}}$ & $\mathrm{s}$ & $\mathrm{v}$ & $\mathrm{O} . \mathrm{R}$. & $\mathrm{N}$ \\
\hline Length & 0.326 & 0.008 & 2.45 & $0.31-0.34$ & 24 \\
Height & 0.164 & 0.011 & 6.71 & $0.15-0.18$ & 24 \\
\hline
\end{tabular}

Remarks. The genus Lophocythere Sylvester-Bradley, 1948a is, among other things, characterized by a distinct eye node. Drexler (1958, p. 524) mentioned an "Augenschwiele", which cannot be seen in the figures given by her. Even with examination in the scanning electron microscope it has not been possible to discover an eye node on the present specimens. In all main features (the size and the shape of the shell, the sculpture, and the hinge) these specimens agree with L. elegans Drexler, 1958, so there cannot be any doubt about the identification.

Here, it is proposed that this species be referred to the genus Nanacythere on the basis of the hinge structure (the right valve with terminal teeth separated by a straight furrow, which is emphasized by a dorsal ridge), the broad duplicature, and the size and the shape of the shell. 
Some of the specimens called $L$. elegans by Christensen (1968a) are identical with $N$. (Goniocythere) paracostata. Discussion of the differences between these two species can be found under the latter species. The present author mentioned erroneously in Michelsen (1970) that N. (Goniocythere) elegans "is present in the Döshult beds". Here it must be stressed that this species does not occur in any of the samples studied from the Øresund borings. The relationship between $N$. (Goniocythere) elegans and $N$. (Goniocythere) circumcostata n.sp. is discussed under N. (Goniocythere) circumcostata.

Distribution. Denmark: The $O$. aspinata Zone (and possibly the $C$. betzi - C. crassireticulata Zone); Hettangian and Lower Sinemurian.

Southern Germany: Lias Alpha-2 and lower part of Alpha-3 (Usbeck, 1952 and Drexler, 1958).

Nanacythere (Goniocythere) elongata n.sp.

Pl. 18, figs. 286-287; pl. 19, figs. 298-302. Text-fig. 35.

Derivation of the name. From elongatum = elongated, referring to the characteristic outline.

Holotype. A carapace. D.G.U. catalogue No. 1972-OM-88; pl. 18, figs. 286-287.

Type locality. The Gassum No. 1 boring.

Type stratum. Sample No. 49A. Dark grey shale. The O. aspinata Zone; Lower Sinemurian.

Material. 5 carapaces, 3 left valves, and 1 right valve in core samples from the Gassum No. 1 boring. - More than ten carapaces have been found in cuttings samples from the Nøvling No. 1 boring.

Diagnosis. A species of the subgenus Nanacythere (Goniocythere) characterized by a relatively long carapace. The sculpture consists of rather fine, low ribs, which form a circular figure conforming to the outline of the valve. Crossing these ribs there is an irregular pattern of short and often very fine ribs.

Description. The outline in lateral view is elongated oval, with the greatest height at the anterior cardinal angle. In dorsal view it is elongated oval, with the greatest breadth posteromedianly. It is subtriangular in posterior view, with the greatest breadth ventrally.

In the left valve the dorsal margin is straight, in the right valve slightly convex. The ventral margin is nearly straight with a weak concavity in the middle. The anterior margin is broadly rounded and extended ventrally. The anterior cardinal angle is distinct. The posterior margin is more narrowly 
rounded, and in the right valve it is slightly concave dorsally. The lateral surface is evenly inflated, with a weak concavity in the middle of the dorsal margin. The right valve is a little smaller than the left one, but overlaps the latter along the dorsal margin. The posterior flange is narrow; the anterior flange is broader.

The hinge is of the Nanacythere-type, and the teeth (on the right valve) seem to be finely dentate.

The muscle scar area was observed as a vertical row of four elongated spots.

The duplicature is rather broad; the vestibule is narrow.

The sculpture consists of rather fine low ribs forming elongated oval figures conforming to the outline of the valve in lateral view. Only the central ribs form closed oval figures, whilst the more marginal ribs converge with the anterior margin. This pattern is rather regular and is combined with rather short ribs crossing the above-mentioned ribs in irregular figures. Very fine, closely spaced intercostal cross-ribs occur. The dorsal margin of the right valve is emphasized by a strong rib.

Sexual dimorphism was not observed.

Measurements (in $\mathrm{mm}$ ). Four carapaces from sample No. 49A of Gassum No. 1 have been measured (see text-fig. 35):

\begin{tabular}{|c|c|c|}
\hline $\begin{array}{l}\text { Length: } \\
\text { Height: }\end{array}$ & $\begin{array}{l}0.37 \\
0.17\end{array}$ & $\begin{array}{l}0.37 \\
0.17\end{array}$ \\
\hline
\end{tabular}

Remarks. Unfortunately the present species is known from only a few specimens, of which only three are valves. It is without doubt a new species, which is congeneric with $N$. (Goniocythere) elegans, N. (Goniocythere) circumcostata, N. (Goniocythere) paracostata, and N. (Goniocythere) minor.

$N$. (Goniocythere) elongata is longer than the other species mentioned (cf. text-fig. 35) and can only be mistaken for $N$. (Goniocythere) circumcostata, which is characterized by the rib forming a circular figure in the middle of the lateral face. N. (Goniocythere) circumcostata has stronger ribs, most of which do not form circular figures, but extend more or less vertically from margin to margin.

Distribution. Denmark: The O. aspinata Zone; Hettangian and Lower Sinemurian.

Nanacythere (Goniocythere) minor n.sp.

Pl. 18, figs. 284-285; pl. 19, figs. 303-307.

1968a: Monoceratina sp. 885 Christensen, pl. 23, fig. 34. 
Derivation of the name. From minor = smaller, referring to the small dimensions of the species.

Holotype. A right valve. D.G.U. catalogue No. 1973-OM-14, pl. 18, figs. 284-285.

Type locality. The Øresund No. 12 boring.

Type stratum. Sample No. 1418. Greyish sandstone and siltstone. The G. apostolescui - K. (K.) foveolata Subzone; Lower Pliensbachian.

Material. 1 carapace, 22 left valves, and 29 right valves in core samples from the Gassum No. 1, Øresund Nos. 12 and 15 borings.

Diagnosis. A small species of the subgenus Nanacythere (Goniocythere). The lateral surface is strongly inflated ventrally, forming a horizontal ridgelike edge. The sculpture consists of vertical ribs in the dorsal part of the lateral surface; below, in a zone above the ridge-like edge, the ribs form a polygonal pattern. Between the edge and the ventral margin there are three to four fine longitudinal ribs.

Description. The outline in lateral view is suboval with the dorsal and ventral margins converging posteriorly; the greatest height is near the anterior cardinal angle. In dorsal view it is oval with the greatest breadth posterior to the mid-point. Subtriangular in posterior view with the greatest breadth ventrally.

The dorsal margin of the left valve is nearly straight; in the right valve it is convex. The cardinal angles are weakly marked. The ventral margin is nearly straight with an anteromedian concavity. The anterior margin is sharply rounded ventrally, and from there to the anterior cardinal angle it is formed as a flat arch. The posterior margin is acuminate (or sharply rounded); with a concavity in the dorsal part in the right valve. The lateral surface is strongly inflated ventrally, forming a ridge-like edge between the ventral and lateral surfaces. Between this edge and the dorsal margin the lateral surface is moderately convex. It overhangs the ventral margin at the edge. The marginal flanges are narrow.

The hinge is tripartite, with terminal dentate ridges separated by a crenulate groove in the right valve; dorsally to the groove there is a ridge. In the left valve a corresponding ridge occurs together with terminal socket-like bulges of the margin.

The muscle scars are a vertical row of four elongated spots.

The duplicature is rather broad with a narrow vestibule anteriorly. Posteroventrally there also appears to be a narrow vestibule. Radial pore canals have not been observed.

On the dorsal section of the lateral surface there are rather strong, vertical ribs. In a zone between these and the ridge-like edge the ribs form 
an irregular, often polygonal, pattern. Between the edge and the ventral margin three to four fine, longitudinal ribs are found.

Measurements (in $\mathrm{mm}$ ). The specimens (adults) in sample No. 1432 from the Øresund No. 12 boring have been measured:

\begin{tabular}{lcc}
\hline & Length & Height \\
\hline Right valve & 0.26 & 0.13 \\
Right valve & 0.26 & 0.13 \\
Right valve & 0.26 & 0.14 \\
Right valve & 0.27 & 0.14 \\
Right valve & 0.27 & 0.14 \\
Left valve & 0.26 & 0.13 \\
Left valve & 0.27 & 0.13 \\
Left valve & 0.27 & 0.14 \\
\hline
\end{tabular}

Remarks. N. (Goniocythere) minor resembles N. (G.) circumcostata and $N$. (G.) paracostata. The latter species is characterized by a sculpture of distinct, vertical ribs, without the polygonal pattern found on the present species. $N$. (G.) circumcostata has stronger and more oblique vertical ribs, and a roughly oval rib medianly on the lateral surface.

Distribution. Denmark: The middle and upper subzones of the $O$. danica Zone, Upper Sinemurian and Lower Pliensbachian; one specimen (questionably determined) in the $O$. adenticulata - N. (N.) simplex Zone, Upper Pliensbachian.

Nanacythere (Goniocythere) paracostata n.sp.

P1. 18, figs. 288-289; pl. 19, figs. 308-314. Text-fig. 35.

1968a: Lophocythere elegans Drexler - Christensen, pl. 23, fig. 12 (non L. elegans Drexler, 1958).

1968a: Lophocythere sp. 507 b Christensen, pl. 23, fig. 22.

Derivation of the name. From par $=$ equal and costae $=$ ribs, referring to the equal and parallel ribs.

Holotype. A carapace. D.G.U. catalogue No. 1973-OM-176; pl. 19, figs. 310-311.

Type locality. The Horsens No. 1 boring.

Type stratum. Sample No. 3. Dark grey and greyish black shale. The $O$. aspinata Zone; Lower Sinemurian. 
Material. 29 carapaces and 1 right valve in core samples from the Gassum No. 1, Horsens No. 1, Øresund Nos. 10, 11, and 14 borings.

Diagnosis. A small species of the subgenus Nanacythere (Goniocythere) characterized by an ornamentation of fine, distinct vertical ribs, situated close and parallel to each other. A small area in the centre of the valve has a different sculpture. Very fine, intercostal cross-ribs occur.

Description. The shell is small; subtriangular in lateral view, with the greatest height at the anterior cardinal angle. In dorsal view it is elongated oval, with the greatest breadth just posterior to the mid-point. In posterior view it is subtriangular, with the greatest breadth ventrally.

The dorsal margin is straight in the left valve, but slightly convex in the right valve. The ventral margin is slightly concave at the mid-point. The posterior margin is evenly rounded, whilst the anterior margin is broadly rounded passing into the dorsal and ventral margins with sharp arcs. The lateral surfaces have a weak concavity behind the anterior cardinal angle. Ventrally the lateral surface is inflated; it overhangs the ventral margin. The flanges at both ends are narrow. The right valve is a little smaller than the left valve, but it overlaps the latter along the dorsal margin.

The sculpture is characterized by fine, rather sharp, vertical ribs. In the middle of the lateral surface there are one or two very short longitudinal ribs where the vertical ones diverge into two groups. Along the ventral margin there are three longitudinal ribs which bend on to the lateral surface and ally themselves with vertical ribs. Along the dorsal margin of the right valve and along the posterior part of the dorsal margin of the left valve there is a distinct rib. On the lateral surface very fine cross-ribs occur between the vertical ribs. Posteroventrally, where the longitudinal ribs bend on to the lateral face, the shell-surface may be extended in a bulge.

The internal characters cannot be observed in the present material.

Sexual dimorphism is not known.

Measurements and statistics (in $\mathrm{mm}$ ). The carapaces (including adults only) in sample No. 3 from Horsens No. 1 have been measured:

\begin{tabular}{lcccll}
\hline & $\overline{\mathrm{x}}$ & $\mathrm{s}$ & $\mathrm{v}$ & \multicolumn{1}{c}{ O.R. } & $\mathrm{N}$ \\
\hline Length & 0.266 & 0.005 & 1.88 & $0.26-0.27$ & 5 \\
Height & 0.130 & - & - & 0.13 & 5 \\
\hline
\end{tabular}

The specimens from other borings are larger (e.g. Gassum No. 1, sample No. 52 (cf. text-fig. 35) and sample No. 53). This is probably due to the environment since $N$. (Goniocythere) elegans is also smaller in the Horsens sample than in the Gassum samples. 
Remarks. Nanacythere (Goniocythere) paracostata resembles $N$. (Goniocythere) elegans and $N$. (Goniocythere) circumcostata in the shape of the carapace and in the relative shape and size of the two valves. For these reasons it is referred to the subgenus Nanacythere (Goniocythere), even the internal characters are unknown.

$N$. (Goniocythere) paracostata differs from the two species mentioned in being smaller and in having a quite different sculpture. The ribs on the lateral surface are thinner, parallel to each other, and without pronounced bends in the middle. The number of ribs is greater, and the intercostal cross-ribs are very fine.

Concerning the difference between $N$. (Geniocythere) paracostata and N. (Goniocythere) minor see p. 209.

The specimen figured by Christensen (1968a, pl. 23, fig. 12) under the name $L$. elegans shows a sculpture identical with that of $N$. (Goniocythere) paracostata. Christensen recorded the specimens from the Øresund Nos. 8, 10, and 14 borings as L. elegans. After comparing his material, which has been placed at the present author's disposal, with more well-preserved material from other borings his specimens must be referred partly to $N$. (Goniocythere) paracostata and partly to $N$. (Goniocythere) circumcostata.

$N$. (Goniocythere) paracostata is identical with Lophocythere sp. 4037 mentioned in Michelsen (1973a).

Distribution. Denmark: The upper part of the O. aspinata Zone and the lower part of the $O$. danica Zone; Lower Sinemurian and lowest Upper Sinemurian.

Nanacythere? bachi (Gramann, 1962)

Pl. 20, figs. 315-319.

1962: Lophodentina ? bachi Gramann, p. 194, text-fig. 2; pl. 2, figs. 5a-c. 1968a: Lophodentina ? bachi Gramann - Christensen, pl. 23, fig. 43.

Material. 19 carapaces, 6 left valves, and 3 right valves in core samples from the Børglum No. 1, Øresund Nos. 12 and 15 borings.

Original diagnosis. "Kleine, annähernd trapezförmige Ostracoden mit Merkmalen der Gattung Lophodentina Apostulescu 1959, deren RippenSkulptur bogigen Verlauf zeigt und die Wölbung der Gehäuse stark überragt" (Gramann, 1962, p. 194).

Description. See Gramann, 1962, p. 194.

Measurements (in $\mathrm{mm}$ ). The specimens in sample No. 14 from Børglum No. 1 have been measured. The calculations for the carapaces of the adults are given below: 


\begin{tabular}{lccccc}
\hline & $\overline{\mathrm{x}}$ & $\mathrm{s}$ & $\mathrm{v}$ & O.R. & $\mathrm{N}$ \\
\hline Length & 0.289 & 0.006 & 2.08 & $0.28-0.30$ & 9 \\
Height & 0.156 & 0.008 & 5.13 & $0.14-0.17$ & 9 \\
\hline
\end{tabular}

One larva from the same sample has a length of $0.23 \mathrm{~mm}$ and a height of $0.13 \mathrm{~mm}$. As the measurements of the holotype (see Gramann, 1962, p. 195) are very near to those of the larva the holotype may possibly be a larva.

Remarks. One specimen has features diverging from those of the holotype (see pl. 20, fig. 319). It differs in having several irregular intercostal crossribs. As it is the only specimen found with such features it is (questionably) referred to this species.

All the other specimens accord with the description and figures given by Gramann (1962). As mentioned above, these are larger than the holotype, but the holotype may be a larval form.

Gramann (1962) referred his species to the genus Lophodentina Apostolescu, 1959 with some uncertainty, since it is smaller than the other species referred to this genus.

$N$. ? bachi has several characters congeneric with $N$. (G.) elegans, N. (G.) circumcostata and $N$. (G.) paracostata. The size, the shape and the main character of the sculpture are very similar. The features of the dorsal margins on $N$. ? bachi are as in the other three species. The inner lamella is broad and not narrow as shown for Lophodentina lacunosa Apostolescu (1959, text-figs. c-d). The muscle scar area seems to consist of a vertical row of spots. The hinge is like that of $N$. elegans, but the teeth seem to be smooth, so it may be classified as lophodont. However, in the three species mentioned above the teeth often seem smooth, probably due to corrosion of the surface. For these reasons the present species is with some doubt referred to the genus Nanacythere.

Distribution. Denmark: The G. apostolescui - K. (K.) foveolata Subzone; Lower Pliensbachian.

Germany: The $U$. jamesoni Zone to the $T$. ibex Zone; Lower Pliensbachian (Gramann, 1962).

Nanacythere? sp. 4061 (Michelsen, 1970)

Pl. 20, figs. 320-322; pl. 22, figs. 342-343.

1970: Lophocythere? No. 4061 Michelsen, p. 39, p1. XII, figs. 5a-b.

Material. 3 left valves and 4 right valves in core samples from the Rødby No. 1 boring. 
Description. See Michelsen, 1970, p. 39.

Remarks. Studies by means of the scanning electron microscope have shown a sculpture consisting of very low, fine ribs forming a pattern of polygons (often hexagons). The polygons are arranged in circular figures conforming to the outline of the valve.

The flanges are very narrow.

The hinge is not entomodont (see Michelsen, 1970, p. 39), but lophodont or merodont. It resembles the hinge of the genus Nanacythere, but the teeth appear not to be dentate.

The muscle scars have not been observed.

This species is probably a new one, but as only few specimens, without distinct features, are known it is described with open nomenclature. It is tentatively referred to the genus Nanacythere.

Distribution. Denmark: The $O$. aspinata Zone; uppermost Hettangian.

Nanacythere sp. 4177

Pl. 20, fig. 323 .

Material. 7 carapaces and 1 left valve in a core sample from the Vedsted No. 1 boring.

Description. The carapace is subtriangular in lateral view. The nearly straight dorsal and ventral margins converge pronouncedly posteriorly. The anterior margin is broadly rounded and asymmetrically extended ventrally. The posterior end is acuminate. The lateral surface is most inflated in the ventral-posteroventral part. The external surface is smooth.

Of the internal features only the hinge of the left valve is known. This is of the Nanacythere-type.

Remarks. All the specimens are more or less deformed, but they seem to belong to a new species which cannot be mistaken for any known species.

Although the surface is smooth this species may probably be classed with the subgenus $N$. (Nanacythere).

Distribution. Denmark: The upper part of the $O$. adenticulata $-N$. (N.) simplex Zone; Upper Pliensbachian (upper part).

Nanacythere? spp. 4069 and 4322

P1. 6, figs. 83 and 85 .

Remarks. Three specimens are the only representatives found of the two species.

Nanacythere? sp. 4069 may be closely related to the subgenus Nanacythere (Nanacythere) based on the sculpture and the outline in lateral view. 
(Identical with Cytheropteron sp. 871 Christensen, 1968a, pl. 23, fig. 16).

Nanacythere? sp. 4322 differs more from the genus. The valve is larger and the lateroventral part of the lateral surface is strongly inflated. The sculpture shows affinities to that of the subgenus Nanacythere (Goniocythere).

Distribution. Denmark: Nanacythere? sp. 4069 is found in the P. reticulata Subzone; Upper Sinemurian (Lias Beta-1a). - Nanacythere? $s p$. 4322 in the G. apostolescui - K. (K.) foveolata Subzone and the O. adenticulata $-N$. (N.) simplex Zone; Lower and Upper Pliensbachian.

\section{Genus Pleurifera Gramann, 1962}

Type species. Procytheridea harpa Klingler \& Neuweiler, 1959.

Original diagnosis. "Langgestreckte Vertreter der Gattung Procytheridea, die durch geringere Gehäusewölbung vom Typus abweichen und sich im Bau von Schloss und Randzone der Gattung Pleurocythere Triebel 1951 besonders nähern" (Gramann, 1962, p. 189).

Remarks. Gramann (1962) referred the species Procytheridea harpa (= type species) and the subspecies $P$. harpa harpoidea Gramann, 1962 to this genus. The present author suggests that Procytheridea perplexa Klingler \& Neuweiler, 1959 also be included in this genus.

These species differ from other Liassic "Procytheridea"-species and Irom the genus Procytheridea in being elongated and less inflated, so that the lateral surfaces are only slightly convex in dorsal view. The sculpture is rather simple, consisting of longitudinal ribs without pronounced intercostal reticulation.

Gramann (1962) describes the radial pore canals in $P$. harpa as straight with a lateral widening. In the material described below only two valves were transparent enough for examination of the radial pore canals. In none of these valves did the pore canals have a terminal widening. Even when clarified by means of silicone oil and studied at a magnification of $\times 1000$ the radial pore canals have been observed as simple and nearly straight.

Stratigraphical range. Lower Jurassic (Lias Beta-2 to Lias Gamma-2).

Pleurifera harpa (Klingler \& Neuweiler, 1959)

Pl. 21, figs. 339-341; pl. 24, figs. 378-380.

1959: Procytheridea harpa Klingler \& Neuweiler, p. 396, pl. 18, figs. 87, 91-92 and 95-96.

1962: Procytheridea harpa Klingler \& Neuweiler - Klingler, p. 92, pl. 12, fig. 20.

1962: Procytheridea (Pleurifera) harpa (Klingler \& Neuweiler) - Gramann, p. 189, pl. 1, fig. 6 ; text-fig. 1 .

1968a: Procytheridea harpa Klingler \& Neuweiler - Christensen, p1. 23, fig. 36. 
Material. 3 carapaces, 25 left valves, and 24 right valves in core samples from the Børglum No. 1, Øresund Nos. 12 and 15 borings.

Original diagnosis. "Eine Art der Gattung Procytheridea mit drei die Art characterisierenden Längsrippen, die von vorn unten schräg nach hinten oben ziehen. Gehäuse schmal, niedrig und lang gestreckt. Grösste Höhe im vorderen Viertel, Dorsalrand schwach nach hinten abfallend" (Klingler \& Neuweiler, 1959, p. 396).

Description. See Klingler \& Neuweiler, 1959, p. 396.

Measurements and statistics (in $\mathrm{mm}$ ). The specimens in sample No. 1406 from Øresund No. 12 are measured and show a division into three instars: A, A-1, and A-2. The statistical calculations for instar A (adults) are shown in the table below.

\begin{tabular}{lcccc}
\hline & $\overline{\mathrm{x}}$ & $\mathrm{s}$ & $\mathrm{v}$ & O.R. \\
\hline Left valves $(\mathrm{N}=5)$ & & & & \\
Length & 0.570 & 0.019 & 3.33 & $0.55-0.60$ \\
Height & 0.306 & 0.013 & 4.25 & $0.29-0.32$ \\
Right valves $(\mathrm{N}=2)$ & & & & \\
Length & 0.585 & 0.021 & 3.59 & $0.57-0.60$ \\
Height & 0.275 & 0.007 & 2.55 & $0.27-0.28$ \\
\hline
\end{tabular}

Remarks. The specimens studied are identical with Pleurifera harpa (Klingler \& Neuweiler, 1959). They have been compared with the paratype deposited at "Gewerkschaft Brigitta", Hannover. The sizes of the present material are in accordance with the sizes of the specimens figured by Klingler \& Neuweiler (1959), but not with the greatest length and height given by them.

In 1962 Gramann erected a new subspecies, $P$. harpa harpoidea, which differs by its "unregelmässigere, knotige Rippen". Christensen (1968a, p. 58) mentioned an occurrence of this subspecies in the Øresund No. 12 boring without pointing out the sample where the occurrence was found and without figuring the subspecies. The present author does not find that any of the recorded specimens should be referred to this subspecies. In sample No. 1826 of the Øresund No. 15 boring one valve was found which in size and also partly in sculpture showed some resemblance to the subspecies, $P$. harpa harpoidea, but this valve is here regarded as lying within the variation of the instar A-2 of P. harpa.

Distribution. Denmark: The lower and middle part of the G. apostolescui - K. (K.) foveolata Subzone; Lower Pliensbachian. 
Northern Germany: The upper part of Lias Beta and the main part of Lias Gamma (Klingler \& Neuweiler, 1959 and Klingler, 1962).

Southern Germany: The $U$. jamesoni Zone and the lower part of the T. ibex Zone; Lias Gamma-1 and 2 (Klingler, 1962).

France: The $U$. jamesoni Zone; lowermost Pliensbachian (Viaud, 1963).

Genus Progonoidea Gramann, 1962

Type species. Procytheridea acuticostata Klingler \& Neuweiler, 1959.

Original diagnosis. "Arten mit den Merkmalen der Gattung Procytheridea hinsichtlich des Schlossbaus, die jedoch im Habitus Vertretern der Gattung Progonocythere Sylvester-Bradley 1948 ähneln" (Gramann, 1962, p. 191).

Remarks. Gramann (1962) referred two species to this genus: the type species and Procytheridea (Progonoidea) auleata. In the present paper Procytheridea reticulata Klingler \& Neuweiler, 1959 is also incorporated, as it has a sculpture like $P$. auleata. At the time being these three species are the only known species belonging to this genus.

Gramann (1962) placed Progonoidea as a subgenus under the genus Procytheridea. However, the species included in Progonoidea differ so much from other Liassic "Procytheridea"-species that it is reasonable to give this group the status of an independent genus (cf. pp. 160-162).

Stratigraphical range. Lower Jurassic (Lias Beta).

Progonoidea acuticostata (Klingler \& Neuweiler, 1959)

P1. 23, fig. 358 .

1959: Procytheridea acuticostata Klingler \& Neuweiler, p. 391, pl. 17, figs. 75 and 79-81.

Material. 2 carapaces in cuttings samples from the Dansk Nords $\varnothing$ F-1 and $\mathrm{K}-1$ borings.

Original diagnosis and description. See Klingler \& Neuweiler, 1959, p. 391.

Remarks. The only specimens found of this species are laterally compressed, but well-preserved enough for identification.

Distribution. Denmark: Uppermost (?) in the middle subzone of the O. danica Zone; Upper Sinemurian.

Northern Germany: Lias Beta-2 (Klingler \& Neuweiler, 1959).

Southern Germany: Lias Beta-2 and lowest part of Lias Beta-3 (Klingler \& Neuweiler, 1959). 
Progonoidea auleata (Gramann, 1962)

Pl. 24, figs. 381-382.

1962: Procytheridea (Progonoidea) auleata Gramann, p. 191, pl. 2, figs. 2-4.

Material. 1 left valve in a cuttings sample from the Nøvling No. 1 boring.

Original diagnosis. "Eine Art mit den Merkmalen von Procytheridea (Progonoidea) n.subgen., deren bogige Rippenskulptur gegen den Dorsalrand geöffnet ist" (Gramann, 1962, p. 191).

Description. See Gramann, 1962, p. 191.

Measurements. Length $(0.58) \mathrm{mm}$ and height $0.33 \mathrm{~mm}$.

Remarks. In the outline of the valve and in the character of the sculpture the present specimen agrees with the specimens figured by Gramann (1962). However, the size of the valve differs considerably. The measurements of the holotype are: length $0.39 \mathrm{~mm}$ and height $0.23 \mathrm{~mm}$ (Gramann, 1962, p. 192). In spite of this difference it is decided to refer the specimen to $P$. auleata.

Distribution. Denmark: Recorded from a cuttings sample within the sequence referred to the C. betzi $-C$. crassireticulata Zone (Lower Sinemurian).

Germany: The A. obtusum Zone and the O. oxynotum Zone; Lias Beta$1 \mathrm{~b}$ and 2 (Gramann, 1962).

Progonoidea reticulata (Klingler \& Neuweiler, 1959)

Pl. 23, figs. 359-363; pl. 24, figs. 383-385.

1959: Procytheridea reticulata Klingler \& Neuweiler, p. 378, pl. 14, figs. 19-21 and 23-25.

1962: Procytheridea reticulata Klingler \& Neuweiler - Klingler, p. 82, pl. 12, fig. 7.

1965: Procytheridea reticulata Klingler \& Neuweiler - Dreyer, p. 503, pl. V, figs. 2a-d.

1968a: Procytheridea reticulata Klinger \& Neuweiler - Christensen, pl. 23, fig. 14.

Material. 21 carapaces, 19 left valves, and 27 right valves in core samples from the Fjerritslev No. 1, Gassum No. 1, and Øresund Nos. 9, 10 , and 14 borings.

Original diagnosis. "Eine Art der Gattung Procytheridea mit einer weitmaschigen groben Netzskulptur. Die groben Maschen sind auf der hinteren Schalenhälfte der rechten Klappen sechseckig, im vorderen mannigfaltig geformt mit einem nach hinten oben offenen, V-förmig gebogenen Feld, in dessen Mitte eine von einer Rippe umgebene Vertiefung liegt" (Klingler \& Neuweiler, 1959, p. 378).

Description. See Klingler \& Neuweiler, 1959, p. 378. 
Supplementary description. The lateral surface of the males is dorsally distinctly concave while that of the females is slightly convex. The cardinal angles are only weakly marked.

As written in the original description (Klingler \& Neuweiler, 1959, p. 379) the sculpture mainly consists of a strong hexagonal pattern. In the present material a few well-preserved specimens show an intercostal ornamentation of fine pits. Only the flanges and a narrow zone at the dorsal margin are smooth. In a few samples (e.g. sample No. 42 from Gassum No. 1) the ribs making up the hexagonal pattern are less strong and the hollows formed by them seem more narrow.

The outlines of the larvae agree with the description of the adults. The dorsal part of the lateral surface is flat to slightly concave. The reticulation is less distinct but of the same configuration.

Measurements (in $\mathrm{mm}$ ). Only from sample No. 42 of Gassum No. 1 has material been obtained sufficiently well-preserved for measuring. Below are shown the statistical calculations for the left valves (and carapaces) of the females. None of the valves of the males are entire.

Females, left valve $(\mathrm{N}=8)$

\begin{tabular}{lcccc}
\hline & $\bar{x}$ & $s$ & $v$ & O.R. \\
\hline Length & 0.578 & 0.017 & 2.94 & $0.56-0.60$ \\
Height & 0.348 & 0.020 & 5.75 & $0.32-0.38$ \\
\hline
\end{tabular}

Remarks. The present specimens are like the holotype; also the specimens differing in sculpture (Gassum No. 1, sample No. 42) have been compared and agree with the paratypes deposited at "Gewerkschaft Brigitta", Hannover.

The measurements given above show that the present specimens are smaller than those of Klingler \& Neuweiler (1959); however, specimens found in cuttings samples from Ørslev No. 1 are larger (cf. pl. 23, figs. 361-362, and pl. 24, figs. 383-385).

A few specimens recorded from the Øresund borings show a differing sculpture (see the larva on pl. 23, fig. 360). These are tentatively referred to $P$. reticulata on the basis of the main features of the sculpture and on their contemporaneity with the typical specimens.

The present author supposes this species is identical with Ostracode (153) Wicher (1938, p. 27, figs. 6-8). Unfortunately, Wicher gives no description, so that the two cannot be regarded as definitely synonymous.

Distribution. Denmark: The P. reticulata Subzone; lowermost Upper Sinemurian (Lias Beta-1a). 
North Germany: Lias Beta-1a (Klingler \& Neuweiler, 1959 and Dreyer, 1965).

Indet. gen. sp. 4353

Pl. 23, figs. 364-365a-b.

Material. 1 left valve and 6 right valves in core samples from the Øresund No. 11 boring.

Description. The dorsal margin is slightly convex in the right valve and concave in the left. Both cardinal angles are distinct. The anterior margin is broadly rounded and nearly symmetrical. The posterior margin of the right valve is more narrowly rounded, but not acuminate. The ventral margin is unknown. Of the marginal flanges the anterior one is moderately broad. The lateral surface appears to be evenly inflated.

The hinge is merodont, with small, finely dentate terminal elevations and a straight, crenulate median groove, emphasized by a dorsal ridge, in the right valve.

The muscle scar area has a vertical row of four spots.

The marginal zone is only poorly known. The duplicature is moderately broad. The inner margin and the line of concrescence coincide. Radial pore canals were not clearly observed.

The sculpture consists of a few high sharp ribs. Conforming to the anterior margin and the ventral one there is a strong, high rib. Another rib occurs dorsally to the ventral part of this rib. From the area opposite to the muscle scars to the area at the posterior cardinal angle there is a short rib, which at its posterior end bends dorsally to the dorsal margin and follows this a short distance. All these ribs are connected at the posterior end by an irregular system of finer ribs. Short cross-ribs and small tubercles may occur.

Remarks. Except for three small fragments all the valves found are from larvae, and all are more or less fragmentary. Therefore it has not been possible to describe the entire shell in a satisfactory way.

These valves represent a new species, but as they are poorly preserved (broken) and as they cannot even be referred to any known genus they are here left under open nomenclature.

Indet. gen. sp. 4353 resembles in some respects the genus Wicherella Lord, $1972 \mathrm{a}$, but the only species known from this genus, W. semiora Lord, 1972, has a broader inner lamella, narrower flange, and more rounded ribs.

Indet. gen. sp. 4353 is here regarded as belonging to the subfamily Protocytherinae.

Distribution. Denmark: The lower part of the middle subzone of the $O$. danica Zone; Upper Sinemurian. 
Family Trachyleberididae Sylvester-Bradley, 1948

Genus Trachycythere Triebel \& Klingler, 1959

Type species. Trachycythere tubulosa Triebel \& Klingler, 1959.

Original diagnosis. "Gehäuse mittelgross, unregelmässig vierseitig. Linke Klappe wenig grösser als die rechte, nur an den Enden des Dorsalrandes überstehend. Vorderrand breit gerundet, Hinterrand schmaler gerundet oder stumpf gewinkelt. Linke Klappe mit einer \pm deutlicher Aufwölbung über den vorderen Schlossende; grösste Höhe nahe dem Vorderende. Ventralrand leicht konvex.

Beide Klappen tragen aussen eine deutliche Augenschwiele, innen eine schlüsselförmige, flache Augengrube. Oberfläche des Gehäuses mit auffälligen, hohlen, röhren- bis warzenförmigen Ausstülpungen, die im Gipfel von je einem siebartigen Porenkanal durchsetzt werden. Sie bilden drei z. T. etwas unregelmässige Reihen. Die obere Reihe beginnt unterhalb der Augenschwiele und nähert sich hinter der Schalenmitte dem Dorsalrand. Die zweite, subventrale Reihe liegt unterhalb der Mittellinie, die dritte an der Grenze von Lateral- und Ventralfläche. Der grössere Teil der Lateralfläche bleibt frei von solchen auffälligen Ausstülpungen der Schalenwand, kann aber - wie auch die Ventralfläche - kleinere, gleichfalls porentragende Warzen tragen.

Verschmelzungszone mässig breit, Innenrand und Verschmelzungslinie fallen zusammen und laufen dem Aussenrand annähernd parallel. Marginale Porenkanäle nicht zahlreich, gerade, unverzweigt. Sie münden sämtlich in kleinen Warzen, die auf der äusseren Schalenfläche in der Nähe des Randes stehen. Am oberen Vorderrand kann ein verkürzter, submarginaler Kanal auftreten. Beide Klappen tragen eine blattartige dünne Aussenleiste.

Schloss dreiteilig, rechts mit endständigen, gekerbten Zahnplatten und einer schmalen, fein gekerbten Mittelfurch" (Triebel \& Klingler, 1959, p. 343).

Stratigraphical range. Lower Jurassic (and Upper Triassic ?).

Trachycythere angusta Herrig, 1969

Pl. 23, figs. 366-367.

1969b: Trachycythere angusta Herrig, p. 1078, pl. II, figs. 5-9; text-figs. 4-5.

Material. 1 left valve and 3 right valves in a core sample from the Øresund No. 3 boring.

Original diagnosis. "Eine Trachycythere, bei der DR und VeR nahezu parallel sind. Die Kl-Oberfläche ist mit grossen, halbkugelförmigen, dicht bestachelten Warzen in der dorsalen und ventralen Kl-Hälfte besetzt, 
dazwischen retikuliert. In der hinteren Kl-Hälfte ist das Netzwerk kraftiger als in der vorderen. In den Kreuzungspunkten der Netzleisten erheben sich kleine Warzen (Mündungen von Flächenständigen Porenkanälen). Die Randstacheln stehen am VoR spärlich und sind schwach" (Herrig, 1969b, p. 1078).

Description. See Herrig, 1969b, p. 1078.

Remarks. On the basis of the drawing, the present author believes that the specimen figured as T. tubulosa seratina by Christensen (1968a, pl. 23, fig. 63) belongs to $T$. angusta. Only this species and T. tubulosa tubulosa are found in the samples from Øresund No. 3 treated in the present paper (cf. pl. 23, figs. 366-367 and 370).

Distribution. Denmark: The middle part of the $O$. adenticulata $-N$. (N.) simplex Zone; Upper Pliensbachian.

Northeast Germany: Lias Delta-2 (Herrig, 1969b).

Trachycythere horrida Triebel \& Klingler, 1959

P1. 23, fig. 372 .

1959: Trachycythere horrida Triebel \& Klingler, p. 347, pl. 9, figs. 34a-c.

1962: Trachycythere horrida Triebel \& Klingler - Klingler, pl. 13, fig. 24.

Material. 1 left valve and 1 right valve (both as fragments) in core samples from the Børglum No. 1 and Øresund No. 12 borings.

Original diagnosis. "Eine Trachycythere mit retikulierter Oberfläche und röhrenförmigen Fortsätzen, die etwa doppelt so lang wie breit sind" (Triebel \& Klinger, 1959 p. 347).

Description. See Triebel \& Klingler, 1959, p. 347.

Distribution. Denmark: The G. apostolescui - K. (K.) foveolata Subzone; Lower Pliensbachian.

North Germany: Lower part of Lias Gamma (Triebel \& Klingler, 1959).

Trachycythere tubulosa tubulosa Triebel \& Klingler, 1959

Pl. 23, figs. 368-371; pl. 25, figs. 386-387.

1937: Cythere n.sp. 1 Bartenstein \& Brand, pl. 7, fig. 6.

1938: Ostracode (543) Wicher, pl. 22, fig. 9.

1959: Trachycythere tubulosa tubulosa Triebel \& Klingler, p. 344, pl. 7, figs. 22-26; pl. 8, figs. 27-29; pl. 12, fig. 62.

1962: Trachycythere tubulosa tubulosa Triebel \& Klingler - Klingler, p. 98, pl. 13, fig. 36.

Material. 12 left valves and 13 right valves from core samples of the Fjerritslev No. 1, Flyvbjerg No. 1, and Øresund No. 3 borings. 
Original diagnosis. (Of T. tubulosa) "Eine Trachycythere mit röhrenförmigen seitlichen Fortsätzen, die etwa so lang wie breit sind". - (Of T. tubulosa tubulosa) "Eine Unterart von T. tubulosa mit deutlich retikulierten, nicht bestachelten Lateralflächen" (Triebel \& Klingler, 1959, p. 344).

Description. See Triebel \& Klingler, 1959, p. 344.

Remarks. Christensen mentioned T. tubulosa seratina (cf. Larsen et al. 1968 , p. 58, pls. 4 and 23) as the only species of Trachycythere in Øresund No. 3. According to the present investigation the specimens from Øresund No. 3 must be referred to T. angusta and T. tubulosa tubulosa (cf. pl. 23, figs. $366-367$ and 370).

Distribution. Denmark: Upper part of the O. adenticulata - N. (N.) simplex Zone; Upper Pliensbachian.

Germany: Lias Delta-1a (Triebel \& Klingler, 1959 and Klingler, 1962).

France: The $U$. jamesoni Zone to $A$. margaritatus Zone; Pliensbachian and lower part of Domerian (Oertli \& Grosdidier, 1961 and Viaud, 1963).

Trachycythere tubulosa seratina Triebel \& Klingler, 1959

Pl. 25, figs. 388-390.

1959: Trachycythere tubulosa seratina Triebel \& Klingler, p. 346, pl. 9, figs. 30-33.

1962: Trachycythere tubulosa seratina Triebel \& Klingler - Klingler, pl. 14, fig. 40.

1969b: Trachycythere tubulosa seratina Triebel \& Klingler - Herrig, pl. II, figs. 2-4.

Material. 5 left valves and 3 right valves in core samples from the Fjerritslev No. 1 and Vedsted No. 1 borings.

Original diagnosis. "Eine Unterart von T. tubulosa mit folgenden Besonderheiten: Lateralflächen zwischen den Tubenreihen nicht deutlich retikuliert, aber mit zerstreut stehenden, porentragenden Wärzchen besetzt, die von feinen Stacheln umgeben sind" (Triebel \& Klingler, 1959, p. 346).

Description. See Triebel \& Klingler, 1959, p. 346.

Remarks. Concerning the Trachycythere-species recorded from Øresund No. 3 see pp. 221 and 222.

Distribution. Denmark: Upper part of the O. adenticulata - N. (N.) simplex Zone; Upper Pliensbachian.

Germany: Upper part of the A. margaritatus Zone and the P. spinatum Zone; Lias Delta-1b and 2 (Triebel \& Klingler, 1959 and Klingler, 1962).

Suborder Metacopina Sylvester-Bradley, 1961

Superfamily Healdiacea Harlton, 1933

Family Healdiidae Harlton, 1933

Genus Ogmoconcha Triebel, 1941

Type species. Ogmoconcha contractula Triebel, 1941 
Original diagnosis. "Eine Gattung der Healdiidae mit folgenden Besonderheiten: Gehäuse dickschalig, eiförmig, in der Regel mit Randzähnchen besetzt; ohne auffällige Abdachung am hinteren Teil des Rüchenrandes und ohne Vertikalkante am hinteren Teil des Gehäuses. Die linke Klappe überragt die rechte ringsum. Schlossfurche der linken und Schlossrand der rechten Klappe fein quergerieft. Freier Schalenrand links mit einer Rinne, in die sich der scharfe Rand der rechten Klappe legt" (Triebel, 1941, p. 478).

Remarks. The genus Ogmoconcha was erected in 1941 by Triebel who described it very carefully. Since then, from time to time it has been regarded as a junior synonym of the genus Hungarella Méhes, 1911 (type species: Bairdia? problematica Méhes, 1911). This latter genus is poorly described, so a comparison and possible identification with Ogmoconcha cannot be made on a satisfactory basis. Furthermore, the genotype of Hungarella is now lost (cf. Kozur, 1970). Many authors have discussed the problem concerning this genus. Pietrzenuk (1961), Bizon \& Oertli (1961), Oertli \& Grosdidier (1961), and Gründel (1970) have used the name Hungarella. Lord (1972b) treated the problem very thoroughly and concludes "that until the possible synonymy between Ogmoconcha and Hungarella is proved or disproved it is preferable to use the name Ogmoconcha for Liassic species congeneric with Ogmoconcha contractula Triebel, 1941, the type species of that genus". In his treatment of the same subject Malz (1971) used the same argument. The present author follows this practice so as not to increase the confusion.

The pattern of the muscle scars has been used as a generic character (cf. Gründel, 1964a), but later on he showed the occurrence of infraspecific variation (Gründel, 1968b and 1970). Kozur (1970) also used the features of the muscle scars as an argument in referring the genus Ogmoconchella to Hungarella.

In his treatment and separation of the genera Ogmoconcha Triebel, 1941, Ogmoconchella Gründel, 1964, Pseudohealdia Gründel, 1964 and Ledahia Gründel, 1964, Malz (1971) also took into account the character of the hinge (see also p. 232). In accordance with this, in the present paper the genus Ogmoconcha is regarded as characterized by a muscle scar area consisting of six or more large spots surrounded by twelve or more smaller spots. The area and the size of the spots can be less differentiated (cf. Gründel, 1970). The pattern is intermediate between that of Healdia Roundy, 1926 and Ogmoconchella Gründel, 1964. In the larvae of Ogmoconcha the muscle scar area and the number of spots are reduced (cf. Gründel, 1968b). In the smallest larvae the pattern is very much like the muscle scars of Pseudohealdia. The hinge is finely crenulate with distinct terminal widenings. The greatest height of the shell occurs medianly or anteriorly. 
The external surface of the shell is smooth; small spines may occur on the posterior and anterior margins.

Sexual dimorphism is questionably observed (see O. amalthei amalthei, text-fig. 37).

The growth factor in a few species is calculated as 1.19-1.21. A weak positive allometry seems to occur (see text-fig. 37).

Stratigraphical range. Upper Triassic and Lower Jurassic (Hettangian to Domerian, or lowest Toarcian).

\section{The amalthei/contractula-group}

This group of Ogmoconcha-species is characterized by a subtriangular outline in lateral view and by having the greatest height anteriorly to the mid-point. The genotype $O$. contractula Triebel, 1941 has an oval outline in posterior view, and the posterior and anterior ends are nearly equal in height. In $O$. amalthei (Quenstedt, 1858), redescribed by Triebel (1950b), the outline in posterior view is triangular and the height of the anterior end is greater than the height of the posterior one.

Dreyer (1965) describes four subspecies of $O$. amalthei. O. amalthei rotunda has rounded outlines and differs from $O$. contractula in the convex lateral faces. $O$. a. circumvallata is characterized by a cushion-like inflation along the margin. $O$. a intercedens is an intermediate form between $O$. $a$. amalthei and $O$. a. circumvallata.

The present material includes representatives of this group. Typical specimens of $O$. contractula, $O$. a. amalthei, and $O$. a. circumvallata, O. a. intercedens, and $O$. a. rotunda are found. Intermediate forms between the two first-named species have added complexities to determinations based on the literature and on type material kindly placed at the disposal of the author by Heinz Malz (Frankfurt a.M.). The material from the Danish Embayment includes specimens with characters specific to both $O$. a. amalthei and $O$. contractula. Here all specimens with a triangular or subtriangular outline in posterior view have been judged as belonging to $\mathrm{O}$. a. amalthei, though no edge was observed and the height of both ends was equal. Dreyer (1965, pl. I, fig. 20) also refers to this species specimens with a nearly oval cross-section and with only weakly marked edges. Only specimens having the specific characters of the original description are determined as $O$. contractula in this paper.

Rather few specimens are determined with certainty as $O$. a. circumvallata or as $O$. a. intercedens. Representatives of the closely related species $O$. dentata (Issler, 1908), and O. klingleri Malz, 1971 are not found either. 
Ogmoconcha amalthei amalthei (Quenstedt, 1858)

Pl. 25, figs. 391-394; pl. 26, figs. 397-399. Text-fig. 37.

1950b: Ogmoconcha amalthei (Quenstedt) - Triebel, p. 118, pl. 1, figs. 1-5; pl. 2, figs. $13-17$.

1959: "Ogmoconcha" amalthei (Quenstedt) - Apostolescu, p. 805, pl. I, figs. 12-13.

1965: Ogmoconcha amalthei amalthei (Qunstedt) - Dreyer, p. 497, pl. I, figs. 2a-e.

1967: Ogmoconcha amalhei (Quenstedt) - Donze, p. 74, pl. I, figs. 9-12.

?1968a: Ogmoconcha contractula Triebel - Christensen, pl. 23, fig. 50 (non O. contractula Triebel, 1941).

Material. 290 carapaces, 329 left valves, and 396 right valves in core samples from the Børglum No. 1, Fjerritslev No. 1, Flyvbjerg No. 1, Gassum No. 1, Haldager No. 1, and Øresund Nos. 3, 12, and 15 borings.

Original diagnosis. "Eine Art mit den Merkmalen der Gattung Ogmoconcha und folgenden Besonderheiten: Gehäuse gerundet dreiseitig. Dorsalrand stark und schief gewölbt, grösste Höhe vor der Mitte. Zwischen Lateralund Ventralfläche eine abgestumpfte Kante. Seiten-Umriss in Rücken- und Bauchansicht im mittleren Drittel abgeflacht oder leicht eingezogen" (Triebel, 1950b, p. 118).

Description. See Triebel, 1950b, p. 118.

Measurements (in $\mathrm{mm}$ ). The specimens in samples Nos. 18 and 19 from Flyvbjerg No. 1 have been measured. Text-fig. 37 shows relations between lengths and heights of the specimens from sample No. 19. Unfortunately the numbers of adults (A) and of specimens in the instar A-1 are small. The scattergram shows a weak positive allometry for the left valve, as in O. aspinata (cf. Michelsen, 1970, p. 45, text-fig. 6). In the smallest instars (A-5, A-4, A-3, and A-2) the group of points seems to be distributed in two sections in each instar. A dimorphism such as that of O. aspinata (cf. Michelsen, 1970, p. 45) may occur in O. a. amalthei, too.

The growth factor is calculated as 1.19-1.21.

Remarks. Triebel (1950b) reexamined and redescribed this species very carefully and in much detail.

Issler (1908, pl. VII, fig. 338) erroneously figured a specimen under the name Bairdia amalthei Quenstedt. His specimen has a drop-shaped outline in dorsal view and probably belongs to $O$. aspinata. The specimen figured by Gründel (1970, pl. I, figs. 1-2) has an outline in lateral view resembling $O$. contractula. Christensen (1968a, pl. 23, figs. 44 and 50) gives drawings of $O$. contractula (fig. 44) and $O$. amalthei (fig. 50). The outlines figured in his drawings and the present author's knowledge of the fauna in the Øresund borings suggest that the specimen in fig. 50 is an $O$. contractula and fig. 44 an $O$. a amalthei. 


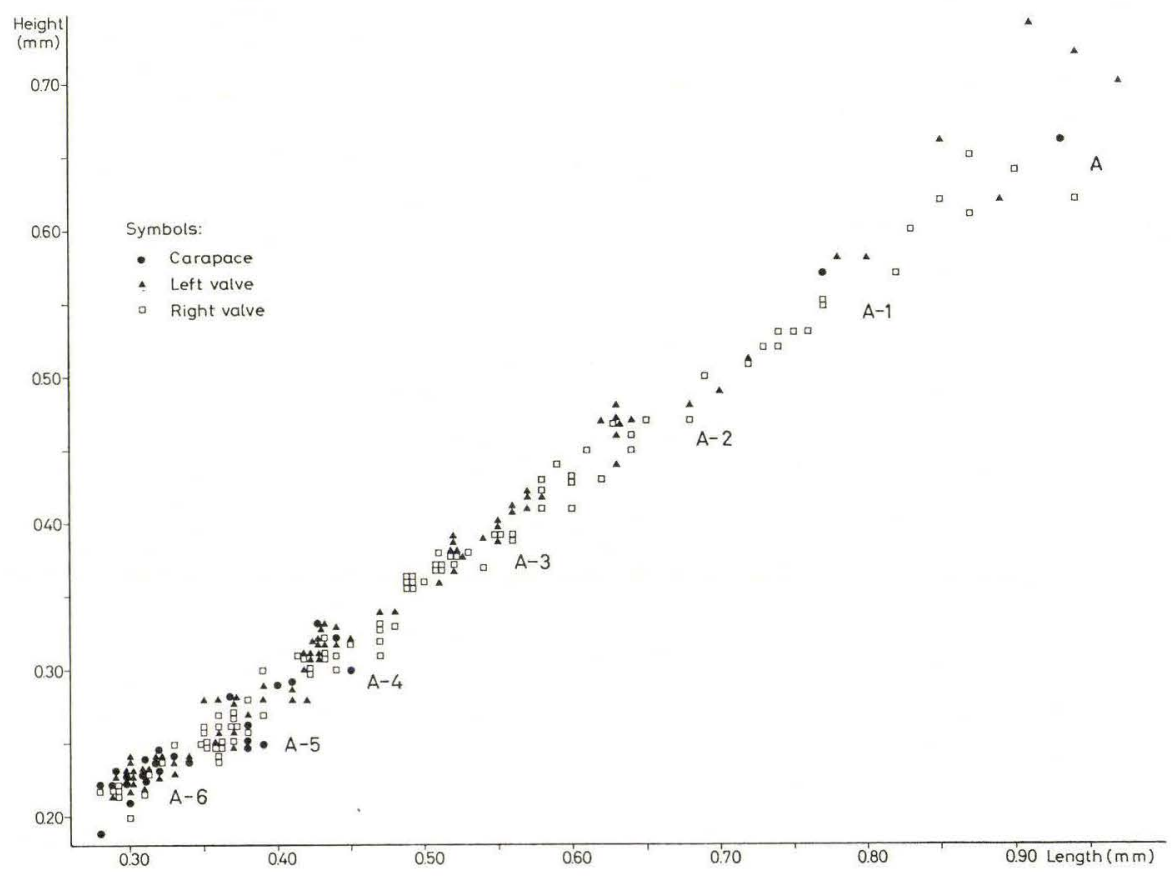

Text-fig. 37. Scattergram showing relations between numbers, lengths and heights for Ogmoconcha amalthei amalthei (Quenstedt, 1858). Sample No. 19 from the Flyvbjerg No. 1 boring.

The specimen figured as $O$. contractula by Klingler (1962, pl. 13, fig. 28 ) is probably an $O$. amalthei, and for this reason the stratigraphical range given by him will not be used here.

The present material includes a few specimens which some other authors perhaps would refer to either O. contractula or O. a rotunda Dreyer, 1965. The very extensive fauna of the Flyvbjerg No. 1 boring includes a few specimens with a high posterior end and a very weakly marked or nonexistent edge between the lateral surface and the ventral surface. Such specimens also occur in the fauna of Gassum No. 1. Because of the occurrence of transitional forms in these borings all of these specimens have been referred to $O$. a amalthei. On the other hand the material of the Øresund No. 3 boring has been rather easy to distribute into the two species.

Distribution. Denmark: Common in the G. apostolescui $-K$. (K.) foveolata Subzone and the $O$. adenticulata $-N$. (N.) simplex Zone; Lower and Upper Pliensbachian.

Southern Germany: Lias Delta (Triebel, 1950b).

Northern Germany: Domerian (Dreyer, 1965). 
France: The $E$. raricostatum Zone to the $P$. spinatum Zone; Upper Lotharingian, Pliensbachian and Domerian (Apostolescu, 1959, Bizon \& Oertli, 1961, Oertli \& Grosdidier, 1961, Viaud, 1963, and Donze, 1967).

Ogmoconcha amalthei circumvallata Dreyer, 1965

P1. 25, fig. 396; pl. 26, figs. 400-402.

? 1962: Ostracod Nr. 13 Klingler, p. 99, pl. 13, fig. 33.

1965: Ogmoconcha amalthei circumvallata Dreyer, p. 499, pl. I, fig. 4; pl. II, figs. 1-5.

1968a: Ostracod Nr. 1 Klingler - Christensen, pl. 23, fig. 55 (non Ostracod Nr. 1 Klingler, 1962).

Material. 4 carapaces, 4 left valves, and 4 right valves in core samples from the Flyvbjerg No. 1, Gassum No. 1, and Øresund No. 3 borings.

Original diagnosis. "Eine Unterart von Ogmoconcha amalthei mit folgenden Besonderheiten: Die Ventralkante wird durch einen Wulst verstärkt und ist dadurch besonders markant. Entlang dem Vorder-, Dorsal- und Hinterrand zieht sich ebenfalls ein mehr oder weniger breiter Wulst. Die Lateralflächen sind meist mit regellos verteilten Grübchen bedeckt" (Dreyer, 1965, p. 499).

Description. See Dreyer, 1965, p. 499.

Remarks. All specimens have a strong cushion-like inflation ventrally. Along the dorsal, posterior and anterior margins more or less continuous inflations are also found. Although there is no distinct separation between $O$. a. intercedens and $O$. a. circumvallata (cf. Dreyer, 1965) the present material is considered to belong to the latter.

Hungarella circumtexta Viaud (1963, pl. IV, figs. 108-111) is probably identical with this species. As his paper has never been published the name given by him is a nomen nudum.

Distribution. Denmark: Upper part of the O. adenticulata - N. (N.) simplex Zone; Upper Pliensbachian.

Northern Germany: Lower Domerian (Dreyer, 1965).

Southern Germany: Uppermost Lias Gamma and Lias Delta (Klingler, 1962).

Ogmoconcha amalthei intercedens Dreyer, 1965

P1. 26, figs. 403-405.

1965: Ogmoconcha amalthei intercedens Dreyer, p. 498, pl. I, fig. 3; pl. III, figs. 1-2. 1971: Ogmoconcha intercedens Dreyer - Malz, pl. 4, fig. 16.

Material. 3 carapaces in cuttings samples from the Dansk Nords $\varnothing$ J-1 and Rønde No. 1 borings.

15* D.G.U. II. rk. nr. 104 
Original diagnosis. "Eine Unterart von Ogmoconcha amalthei mit folgenden Besonderheiten: Die zwischen Lateral- und Ventralfläche ausgebildete Kante ist scharf, nicht abgestumpft. Der Dorsalrand der L ist im Bereich seiner stärksten Wölbung wulstartig verdickt" (Dreyer, 1965, p. 498).

Description. See Dreyer, 1965, p. 498.

Remarks. O. amalthei intercedens is supposedly identical with Ostracod Nr. 1 Klingler (1962, p. 103) as stated by Dreyer (1965, p. 498). However, Malz (1971, p. 440) regards Ostracod Nr. 1 Klingler as synonymous with Ogmoconcha klingleri Malz (1971, p. 440), as he has studied material "das aus dem gleichen stratigraphischen Bereich stammt wie die Klingler'schen Stücke von "Ostr. Nr. 1"'". The latter species is smaller than O. $a$. intercedens, but does not seem to differ clearly from that species. Malz (1971) describes the contact groove in the middle hinge of $O$. klingleri as having twice the breadth of that in $O$. a. intercedens. Unfortunately this character cannot be used on the present carapaces.

The present specimens are for these reasons referred to $O$. a. intercedens.

Distribution. Denmark: In the middle (?) of the $O$. adenticulata $-N$. (N.) simplex Zone; Upper Pliensbachian.

Northern Germany: Lower Domerian (Dreyer, 1965).

Ogmoconcha amalthei rotunda Dreyer, 1965

P1. 27, figs. 406-408.

1965: Ogmoconcha amalthei rotunda Dreyer, p. 500, pl. I, figs. 1a-e.

Material. 2 carapaces in cuttings samples from the Dansk Nords $\varnothing$ J-1 boring.

Original diagnosis. "Eine Unterart von Ogmoconcha amalthei mit folgenden Besonderheiten: Die bei der Nominatart ausgebildete Kante zwischen Lateral- und Ventralfläche fehlt oder ist nur an der R leicht angedeutet" (Dreyer, 1965, p. 500).

Description. See Dreyer, 1965, p. 500.

Distribution. Denmark: Uppermost (?) in the G. apostolescui $-K$. (K.) foveolata Subzone; Lower Pliensbachian.

Northern Germany: Upper Lotharingian to Domerian (Dreyer, 1965).

Omoconcha amalthei form $A$

Pl. 27, figs. 409-413; pl. 28, figs. 417-418.

Material. 20 carapaces in cuttings samples from the Dansk Nords $\varnothing$ F-1, $\mathrm{J}-1$, and $\mathrm{K}-1$ borings. 
Description. The outline in lateral view is subtriangular with the greatest height just anterior to the mid-point. In dorsal view the outline is oval with tapering ends and distinctly swollen margins. A concavity in the middle of the lateral surface is characteristic in dorsal view. In posterior view the outline is rounded triangular, with a sharp bend between the ventral and lateral surfaces, but without a swollen rim. The greatest breadth is found ventrally.

The ventral margin in the right valve is straight, and convex in the left valve. The dorsal margin is convex with a distinct bend anterior to the mid-point. The anterior and posterior margins in the left valve are acuminate, with the maximum extension a little below the mid-point. In the right valve these margins are rounded. In both valves the middle section of the anterior and posterior margins is swollen. None of the other marginal zones are swollen.

The internal features are unknown.

The external surface is smooth.

Remarks. This form, which may be a new subspecies, is close to O. amalthei amalthei. It has the characteristic triangular outline in lateral view and the concavity on the lateral surface. It differs from $O$. a. amalthei mainly in the acuminate extension of the anterior and posterior margins and by the swollen marginal zones. A few specimens of a transitional form occur (cf. pl. 27, figs. 412-413 and pl. 28, fig. 417). A thorough study of the morphological variation and a statistical treatment cannot be made on the present material.

The characteristic outline in lateral view of $O$. amalthei form $A$ is like that of $O$. hagenowi, but the latter species does not have concavities on the lateral surfaces and swollen marginal zones posteriorly and anteriorly.

Distribution. Denmark: The G. apostolescui - K. (K.) foveolata Subzone; Lower Pliensbachian.

\section{Ogmoconcha contractula Triebel, 1941}

Pl. 25, fig. 395 ; pl. 28, figs. 414-416; pl. 29, figs. 426-427.

1941: Ogmoconcha contractula Triebel, p. 378, pl. 14, figs. 156-160.

1959: "Ogmoconcha" contractula Triebel - Apostolescu, p. 804, pl. I, fig. 14.

1967: Ogmoconcha contractula Triebel - Donze, p. 75, pl. I, figs. 13-15.

? 1968a: Ogmoconcha amalthei (Quenstedt) - Christensen, pl. 23, fig. 44 (non $O$. amalthei (Quenstedt, 1858)).

? 1969a: Ogmoconcha contractula Triebel - Herrig, pl. I, fig. 5.

1969b: Ogmoconcha contractula Triebel - Herrig, p. 1073, pl. I, figs. 1-2.

1971: Ogmoconcha contractula Triebel - Malz, pl. 1, fig. 2; pl. 2, figs. 7-8; pl. 3, fig. 9. 
Material. 19 carapaces, 28 left valves and 15 right valves in core samples from the Børglum No. 1, Haldager No. 1, and Øresund No. 3 borings.

Original diagnosis. "Eine Art der Gattung Ogmoconcha mit folgenden Besonderheiten: Klappen mit sehr feinen Randzähnchen besetzt; Lateralflächen über den Schliessmuskel-Ansätzen schwach eingezogen, so dass in Rückenansicht die seitliche Umrisslinie des Gehäuses etwas konkav erscheint" (Triebel, 1941, p. 379).

Description. See Triebel, 1941, p. 379.

Remarks. The problems regarding the determination of this species are mentioned above (pp. 224 and 226) where remarks are also made regarding the figures given by Christensen (1968a, pl. 23, figs. 44 and 50) and by Klingler (1962, pl. 13, fig. 28).

Distribution. Denmark: The $O$. adenticulata - N. (N.) simplex Zone; Upper Pliensbachian.

Germany: Lias Delta (Triebel, 1941).

France: The $T$. ibex Zone to the $P$. spinatum Zone; Pliensbachian and Domerian (Viaud, 1963 and Donze, 1967).

Ogmoconcha hagenowi Drexler, 1958

P1. 28, figs. 419-425; pl. 29, figs. 428-430.

1952: Bairdia sp. (9) Usbeck, p. 406, pl. 19, fig. 68.

1958: Ogmoconcha hagenowi Drexler, p. 508, pl. 21, figs. 8a-f; pl. 26, figs. 1-2.

1959: Ostracoda A Apostolescu, p. 816, p1. I, figs. 9-11.

1962: Ogmoconcha hagenowi Drexler - Klingler, p. 80, pl. 12, fig. 4.

1967: Ogmoconcha hagenowi Drexler - Donze, p. 75, pl. I, fig. 20.

1970: Hungarella hagenowi (Drexler) - Gründel, p. 53, pl. I, figs. 3-4; text-figs. 16-17.

1971: Ogmoconcha hagenowi Drexler - Malz, pl. 4, figs. 17a-b.

1971: Ogmoconcha hagenowi Drexler - Lord, p. 661, pl. 123, figs. 14-16.

1972: Ogmoconcha hagenowi Drexler - Urlichs, p. 690, pl. 4, fig. 1.

Material. 212 carapaces, 16 left valves, and 15 right valves in core samples from the Gassum No. 1, Horsens No. 1, and Vinding No. 1 borings.

Original diagnosis. "Eine Art der Gattung Ogmoconcha mit folgende Besonderheiten: Gehäuse dreiseitig gerundet, dickschalig, grösste Höhe vor der Mitte. Ohne eingezogene Lateralflächen und ohne abgestumpfte Kante zwischen Lateral- und Ventralfläche" (Drexler, 1958, p. 509).

Description. See Drexler, 1958, p. 509.

Measurements and statistics (in $\mathrm{mm}$ ). The specimens from sample No. 3 (Horsens No. 1) and sample No. 42 (Vinding No. 1) have been measured. Statistical calculations for the carapaces of the adults from sample No. 3 (Horsens No. 1) are given in the table below: 


\begin{tabular}{lccccc}
\hline & $\overline{\mathrm{x}}$ & $\mathrm{s}$ & $\mathrm{v}$ & $\mathrm{O} . \mathrm{R}$. & $\mathrm{N}$ \\
\hline Length & 0.625 & 0.016 & 2.56 & $0.61-0.66$ & 11 \\
Height & 0.465 & 0.014 & 3.01 & $0.44-0.50$ & 11 \\
\hline
\end{tabular}

Drexler (1958, pp. 527-533) gives a very thorough statistical treatment of $O$. hagenowi. Her treatment shows a large variation in the size of the shell. The present material falls within this variation, but the means are smaller than those of the German material.

The growth factor is estimated to about 1.20.

Remarks. The present specimens show variation from a form with rounded posterior and anterior ends to a form with acute ends (cf. pl. 28). The latter form is represented by three specimens only (Horsens No. 1, sample No. 3), whilst the rounded form is the dominant one (see also Donze, 1967, pl. I, fig. 20).

The larvae are more elongated than the adult and the point of greatest height occurs more anteriorly.

A comparison with the type material deposited with H. J. Oertli (Pau) has demonstrated that Ostracod A Apostolescu, 1959 is identical with the present $O$. hagenowi.

Distribution. Denmark: The $O$. aspinata Zone and the $C$. betzi $-C$. crassireticulata Zone; upper part of Hettangian and Lower Sinemurian.

Germany: Lias Alpha to Beta-2 (Drexler, 1958 and Klingler, 1962).

France: Uppermost Hettangian to lower Upper Sinemurian (Apostolescu, 1959 and Donze, 1967).

England: The $S$. angulata Zone to the $A$. bucklandi Zone; uppermost Hettangian and lowest Lower Sinemurian (Lord, 1971).

Austria: The specimens determined by Urlichs (1972) are recorded from the "Kössener Schichten"; Norian-Rhaetian.

Genus Ogmoconchella Gründel, 1964

Type species. Healdia aspinata Drexler, 1958.

Original diagnosis. Not given by Gründel (1964a), who refers to the type species: Healdia aspinata Drexler, 1958.

Diagnosis (emend.). A genus of the family Healdiidae characterized by: A rather solid shell with the greatest height and the greatest breadth posteriorly or rarely medianly. The hinge is a crenulate, rather narrow groove in the left valve and a corresponding ridge in the right one. The hinge is with- 
out distinct terminal widenings. The muscle scar area consists of six to seven large spots surrounded by twelve to fifteen smaller ones, situated in a circular area. The external surface may be smooth or ornamented by fine furrows. A posteroventral spine may occur, and a thin external lamella on the anterior margin may occur.

Remarks. The genus Ogmoconchella was established by Gründel (1964a, p. 469) and based on the type species: Healdia aspinata Drexler, 1958.

In 1970 Gründel regarded Ogmoconchella as synonymous with the genus Ogmoconcha and referred $H$. aspinata to this genus. Other species, which in the present paper are referred to Ogmoconchella, were regarded by Gründel (1970) as belonging to the genus Healdia Roundy, 1926. In previous papers (Gründel, 1964b, fig. 5; 1968a, fig. 5) he has clearly shown the differences in the muscle scars of the genera Healdia (Healdia sp.), Ogmoconcha ( $O$. contractula), Ogmoconchella (O. aspinata), and Pseudohealdia (P. pseudohealdiae). This succession may figure a possible phylogenetic reduction in the muscle scars. Because of the infraspecific and transspecific variation in the muscle scars, Gründel (1970) reduced the number of genera to three: Healdia, Ogmoconcha, and Pseudohealdia.

Malz (1971) revived the two genera Ogmoconchella and Ledahia Gründel (1964a) since, in spite of the above mentioned variation, it is possible to distinguish characters of the muscle scars from all the five genera. In his opinion, this, together with the feature of the hinge and the morphology of the shell, forms the basis for the genera.

The present author agrees with Malz (1971) except in the case of the genus Ledahia, which in his opinion must be synonymous with Ogmoconchella. Malz (1971) separated these two genera mainly because of the narrow hinge in Ledahia, which has more or less conical, small teeth. This is not a reasonable basis for separation as species of Ogmoconchella also may have corresponding features (cf. O. gruendeli Malz, pl. 3, fig. 11b). Type material of the two genera (deposited with H. Malz, Frankfurt) have been studied and the difference is considered as due to shell-size.

Here, it is concluded that there are three genera of Healdiidae within the Lower Jurassic section: Ogmoconcha, Ogmoconchella, and Pseudohealdia. (Healdia is not a Lower Jurassic genus).

The characteristic features of the genus Ogmoconchella are given in the diagnosis. The muscle scar area resembles that of Ogmoconcha, but in Ogmoconchella it is simpler, more regular, and usually with fewer spots. In the larvae the muscle scar area is reduced, and in the smallest larvae only the central spots are found. On the external surface of some of the species (e.g. O. adenticulata) there is a reticulation of very fine furrows (often like a finger-print). Some species (e.g. O. bispinosa) have a poster- 
oventral spine on both of the valves. Another species, $O$. aspinata, has a spine on the right valve only, but only in the larval stages. The greatest breadth of the carapace is often near the posterior end, and in some species connected with a more or less distinct, vertical bend on the lateral surface. More rarely is found a vertical swelling (a rib), which may be connected with a posteroventral spine (e.g. O. septenaria).

Sexual dimorphism seems to occur, and even in some of the larval stages.

The growth factor is calculated at about 1.17. Positive allometry is demonstrated.

Stratigraphical range. Triassic (?), Lower Jurassic (Hettangian to Domerian, and lowermost Toarcian).

Ogmoconchella adenticulata (Pietrzenuk, 1961)

Pl. 29, figs. 431-434; pl. 30, figs. 435-440. Text-figs. 38-39.

1961: Hungarella adenticulata Pietrzenuk, p. 89, fig. 18.2.

1965: Ogmoconcha adenticulata (Pietrzenuk) - Dreyer, p. 501, pl. IV, figs. 1-4.

1968a: Ogmoconcha ? cf. Ostracod Nr. 7 Klingler - Christensen, pl. 23, fig. 59 (non Ostracod Nr. 7 Klingler, 1962).

1969a: Ogmoconcha adenticulata (Pietrzenuk) - Herrig, pl. I, figs. 6-7.

1969b: Ogmoconcha adenticulata (Pietrzenuk) - Herrig, p. 1074, pl. I, figs. 3-7; textfig. 2.

Material. 55 carapaces, 64 left valves and 50 right valves in core samples from the Fjerritslev No. 1, Flyvbjerg No. 1, Gassum No. 1, and Øresund No. 3 borings.

Original diagnosis. "Eine Art der Gattung Hungarella mit folgende Besonderheiten: Klappe ohne Randzähnchen. Gehäuseoberfläche mit feiner Riefung in der Art eines Fingerabdrucks. Seitenwände über den Schliessmuskelansätzen nicht eingezogen" (Pietrzenuk, 1961, p. 89).

Description. The carapace is rather large. In lateral view it is nearly oviform. The greatest height in the left valve is located posterior to the mid-point, at a point where the dorsal margin makes a distinct bend. From this point forward the dorsal margin forms an even arch down toward the low and well-rounded anterior end, and posteriorly the dorsal margin is convex to the slightly rounded and oblique posterior end. The transitions between the dorsal and posterior margins, and between the ventral and posterior margins are marked by sharp curves. The greatest height of the right valve is located at the mid-point or a little behind. The right valve is a little more rounded than the left one; the posterior margin is not oblique, and the transitions from it to the dorsal and ventral margins are more even. The ventral margin is straight or slightly concave. The left valve is larger than the right one and overlaps it. The anterior margin of both valves has 
a narrow lamella. The lamella of the left valve is long, whilst that of the right valve is short and a little broader. The lateral view of the larvae is more subtriangular; the greatest height is near the mid-point, and the lamellae are relatively larger.

In dorsal view the carapace is oviform with a rounded posterior end and a more pointed anterior end. In a very few cases both ends are evenly rounded and rather plump. The lateral surfaces are evenly inflated. The greatest breadth is located posterior to the mid-point. The vertical crosssection is oval with the greatest breadth at the middle.

The inner margin is well-rounded in both valves in the anterior end as well as in the posterior end. It is slightly concave ventrally, but distinctly convex dorsally. The surrounding contact groove in the left valve is whole. Ventrally, posteriorly, and anteriorly it is very narrow, and often indistinct. Dorsally the hinge is rather broad and distinct, especially in the anterior part. The contact groove is ornamented with fine cross-ribs. In the right valve the entire free margin likewise has fine cross-ribs.

The area and number of adductor muscle scars seem to be identical with that described by Gründel (1970, p. 49, figs. 4-6). It is most often composed of six large muscle scars which are arranged in pairs along a nearly vertical axis, and surrounded by a number of smaller scars (often 12-14). In front of this area there is a single muscle scar. The dorsal scars are not clearly shown in the material studied. In small larvae the muscle scar area is reduced. In the smallest ones it seems to be composed of the central scars only.

The external surface has fine furrows in well-preserved specimens, arranged like a finger-print.

Measurements and statistics (in $\mathrm{mm}$ ). The specimens from three samples have been measured: sample No. 19 from Flyvbjerg No. 1, and sample Nos. 8 and 15 from Gassum No. 1 (cf. text-figs. 38 and 39). The two figures show the possible presence of positive allometry. The statistical calculations for left valves (and carapaces) from the Flyvbjerg sample are shown in the table:

\begin{tabular}{lccccc}
\hline & $\overline{\mathrm{x}}$ & $\mathrm{s}$ & $\mathrm{v}$ & $\mathrm{O} . \mathrm{R}$. & $\mathrm{N}$ \\
\hline Adult, length & 0.698 & 0.027 & 3.87 & $0.67-0.73$ & 6 \\
A-1, length & 0.589 & 0.015 & 2.55 & $0.57-0.61$ & 7 \\
Adult, height & 0.493 & 0.028 & 5.68 & $0.46-0.53$ & 6 \\
A-1, height & 0.394 & 0.010 & 2.54 & $0.38-0.41$ & 7 \\
Growth factor of the length between A-1 and A: 1.19. & & \\
Growth factor of the height between A-1 and A: 1.25. \\
\end{tabular}




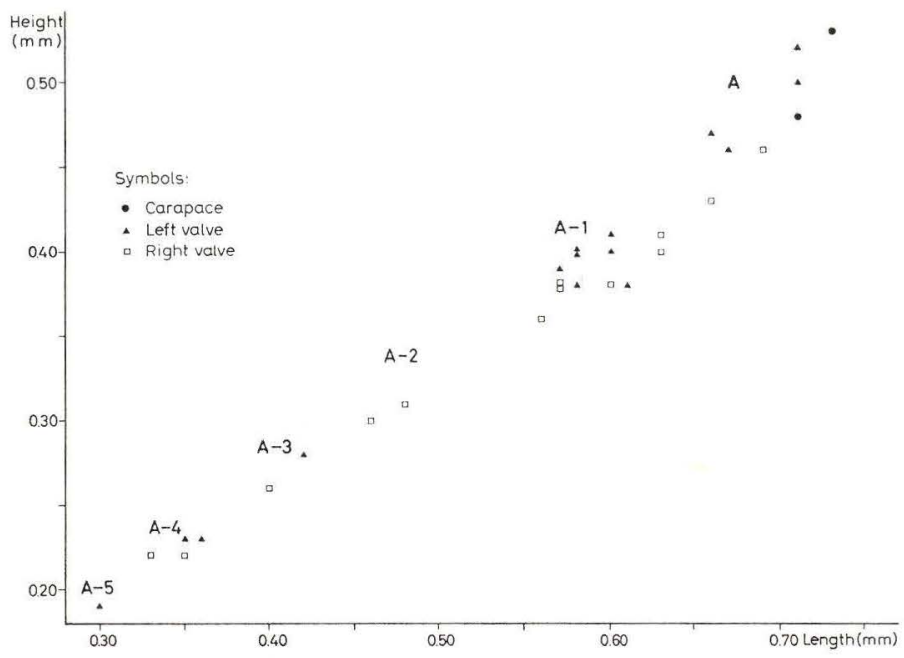

Text-fig. 38. Scattergram showing relations between numbers, lengths and heights for Ogmoconchella adenticulata (Pietzrenuk, 1961). Sample No. 19 from the Flyvbjerg No. 1 boring.

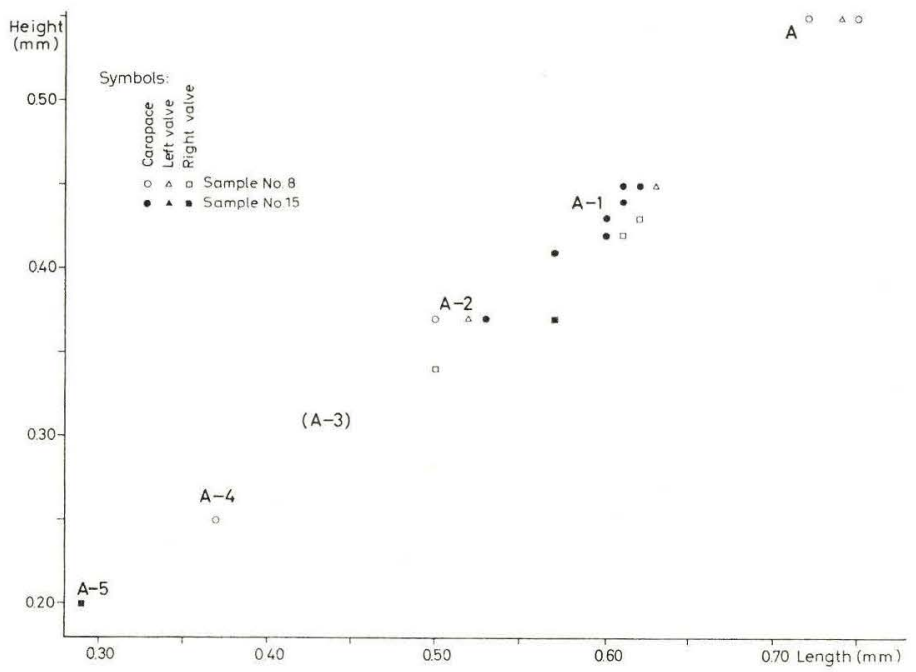

Text-fig. 39. Scattergram showing relations between numbers, lengths and heights for Ogmoconchella adenticulata (Pietzrenuk, 1961). Sample Nos. 8 and 15 from the Gassum No. 1 boring. 
The specimens in the samples from Flyvbjerg No. 1 are relatively a little smaller than the specimens from Gassum No. 1. This difference is expressed in a calculation of the height/length ratio of the left valve:

\begin{tabular}{lcc}
\hline & $\begin{array}{c}\text { Gassum No. 1 } \\
\text { sample No. 15 }\end{array}$ & $\begin{array}{c}\text { Flyvbjerg No. 1 } \\
\text { sample No. 19 }\end{array}$ \\
\hline $\mathrm{N}$ & 7 & 7 \\
$\overline{\mathrm{x}}$ & 0.719 & 0.669 \\
$\mathrm{~S}$ & 0.015 & 0.025 \\
O. R. & $0.70-0.74$ & $0.62-0.69$ \\
\hline
\end{tabular}

Remarks. The specimens described agree with those of Dreyer (1965) and Herrig (1969a \& b). Pietrzenuk (1961) figures the internal side of a left valve and gives a somewhat inaccurate diagnosis. But compared with that description and the topotype figured in Dreyer (1965, pl. IV, fig. 3) the specimens from the Danish Embayment must be $O$. adenticulata.

As also mentioned by Herrig (1969b, pp. 1074-1075) there are a few specimens with a small height/length ratio, which he considers to be an indication of the presence of sexual dimorphism.

$O$. adenticulata has some similarities to $O$. aspinata (Drexler, 1959), $O$. aequalis Herrig, 1969 and $O$. danica n.sp.; these are discussed under these species (concerning $O$. aequalis see Herrig, 1969a, p. 463).

Oertli (1963) figures Ostracoda B Apostolescu from several sections of the Sinemurian and Pliensbachian in France. It has not been possible for the present author to determine whether his specimens are identical with $O$. adenticulata or not. Type material of Ostracoda B Apostolescu deposited with H. J. Oertli (Pau, France) has been studied by the present author, who can establish that those specimens do not belong to $O$. adenticulata.

Distribution. Denmark: Common in the O. adenticulata - N. (N.) simplex Zone; Upper Pliensbachian.

Northern Germany: The P. spinatum Zone; Lias Delta-2 (Pietrzenuk, 1961, Herrig, 1969b and Dreyer, 1965).

Ogmoconchella aequalis (Herrig, 1969)

Pl. 30, figs. 441-445; pl. 31, figs. 446-449. Text-fig. 40.

1965: Ogmoconcha adenticulata (Pietrzenuk) - Dreyer, pl. IV, fig. 5 (non O. adenticulata Pietrzenuk, 1961).

1969a: Ogmoconcha aequalis Herrig, p. 460, text-figs. 11-15; pl. I, figs. 1-4; pl. III, figs. 3-6. 
Material. 33 carapaces, 38 left valves, and 38 right valves in core samples from the Fjerritslev No. 1, Flyvbjerg No. 1, Vedsted No. 1, and Øresund No. 3 borings.

Original diagnosis. "Eine Ogmoconcha, bei der VE und HE in Lateralansicht gleich sind, die $\mathrm{H}$ in halber Kl-Länge, die $\mathrm{Br}$ hinter dem Zentrum liegend. Die Kl-Oberfläche ist fein retikuliert; die Netzleisten sind länglich und dem Kl-Rand parallel" (Herrig, 1969a, p. 460).

Description. See Herrig, 1969a, p. 460.

Measurements (in $\mathrm{mm}$ ). All specimens in the sample Nos. 18 and 19 from Flyvbjerg No. 1, and the sample No. 367 from Øresund No. 3 have been measured. Furthermore the size of the shells sporadically occurring in a large number of samples from both Øresund No. 3 and Gassum No. 1 have been checked.

Text-fig. 40 shows the sizes of the specimens from sample No. 19 of Flyvbjerg No. 1. Both of the samples from this boring show the same distribution. In no other samples from the Danish Embayment have such large shells as the adults (A) been observed. In Øresund No. 3 the largest specimens agree with the larval stage A-2. Sample No. 367 from this boring contains five measurable carapaces with length $0.60-0.61 \mathrm{~mm}$ (mean: $0.606 \mathrm{~mm}$ ) and height $0.40-0.42 \mathrm{~mm}$ (mean: $0.410 \mathrm{~mm}$ ). In Gassum No. 1 the instar A-1 is also represented.

Compared with the material published by Herrig (1969a) the specimens from Flyvbjerg No. 1 are very large. To the discussion below concerning the identification of the present material it must be added that the height/length ratios of the nine adults (in sample No. 19 from Flyvbjerg No. 1) are $0.678-0.722 \mathrm{~mm}$, and the mean $0.706 \mathrm{~mm}$. This is very near the figure published by Herrig (1969a, text-fig. 15).

The growth factor in this material is calculated at about 1.18 .

Remarks. The present material raises some problems of identification. Most of the specimens occur scattered with one to three specimens per sample. However, the two samples from Flyvbjerg No. 1 contain a larger number. The above-mentioned difference in size between the largest specimens from this boring and those from others, such as Gassum No. 1 and Øresund No. 3, may be explained by the occurrence of larvae in the latter borings. The hinge of the specimens from Gassum No. 1 and $\varnothing$ resund No. 3 is narrower and also the muscle scars are simpler than in the adults from Flyvbjerg. It is natural to conclude from the shell-morphology and the measurements (see above) that the distribution represents the occurrence of different instars.

Most of the shells from Øresund No. 3 have a weak lateral concavity. In all other respects they are identical with the holotype. This feature may 


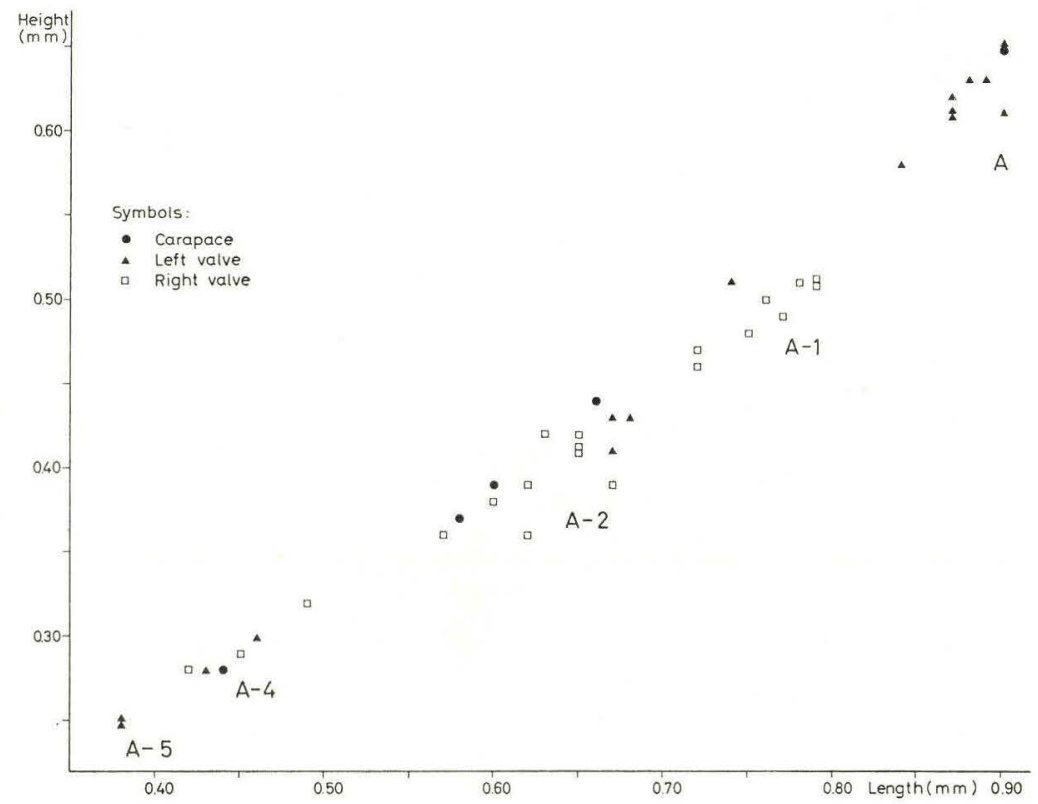

Text-fig. 40. Scattergram showing relations between numbers, lengths and heights for Ogmoconchella aequalis (Herrig, 1969). Sample No. 19 from the Flyvbjerg No. 1 boring.

possibly be due to local ecological circumstances. The present author does not find it reasonable to separate these specimens as a new species.

In all features, except for the size of the shell, the specimens from Flyvbjerg are identical with $O$. aequalis. The difference in size is probably because the adults are missing in the material published by Herrig (1969a). It is difficult to distinguish the adults and the larvae $\mathrm{A}-1$ or $\mathrm{A}-2$ on morphological features, so the present author cannot decide to which instar the muscle scars figured by Herrig (1969a, text-fig. 12b) belong.

Distribution. Denmark: The $G$. apostolescui - K. (K.) foveolata Subzone and the $O$. adenticulata - N. (N.) simplex Zone; Lower and Upper Pliensbachian.

Northern Germany: Lias Delta-2 (Herrig, 1969a).

Ogmoconchella aspinata (Drexler, 1958)

Pl. 31, fig. 450; pl. 33, figs. 470-471.

? 1872: Bairdia (?) ellipsoidea Jones, p. 146.

? 1876: Bairdia liassica Blake, p. 430, pl. XVII, fig. 1.

1938: Ostracoda (521) Wicher, pl. 27, fig. 1. 
1952: Ogmoconchasp. (1) Usbeck, p. 404; pl. 18, figs. 59a-b.

? 1954: Cytheridea ellipsoidea Jones - Conti, p. 229, pl. XII, figs. 6-8.

? 1954: Cytheridea ellipsoidea Brady var. reducta Conti, p. 228, pl. XII, figs. 1-5.

1958: Healdia aspinata Drexler, p. 505; pl. 21, figs. 5a-e; pl. 25, figs. 1-4.

1961: Healdia aspinata Drexler - Pietrzenuk, pl. 15, fig. A-4.

1962: Healdia aspinata Drexler - Klingler, p. 79; pl. 12, figs. 1-2.

1964a: Ogmoconchella aspinata (Drexler) - Gründel, p. 470, figs. 5-7.

1967: Ogmoconchella aspinata (Drexler) - Donze, p. 76, pl. I, figs. 21-24.

1970: Ogmoconchella aspinata (Drexler) - Michelsen, p. 42; pl. XIV, figs. 1-3; p1. XV, figs. 1-7; pl. XVI, figs. 1-6; text-figs. 6-9.

1970: Hungarella aspinata (Drexler) - Gründel, p. 52; pl. I, figs. 9-10; text-fig. 14.

1971: Ogmoconcha ellipsoidea (Jones) - Lord, p. 658, pl. 123, figs. 9-13.

1971: Ogmoconchella aspinata (Drexler) - Malz, p1. 5, figs. 21-22.

Material. 2101 carapaces, 1065 left valves and 1145 right valves in core samples from the Gassum No. 1, Horsens No. 1, Rødby No. 1, Vedsted No. 1, and Vinding No. 1 borings.

Original diagnosis. "Eine Art der Gattung Healdia ohne rückwärts gerichtete Sporne und ohne Vertikalkante am hinteren Teil des G. Die Kontaktfurche trägt am Schlossrand und an den beiden übergängen der Lateralränder zum Ventralrand fine Querriffeln" (Drexler, 1958, p. 505).

Diagnosis (emend.). A Healdia-like species with an asymmetrical, subtriangular outline in lateral view; with the greatest height posteromedianly. Outline in dorsal view is ovoid; the greatest breadth occurs posteromedianly. The muscle scar area consists of six large spots surrounded by about twelve smaller ones. The hinge-furrow of the left valve and the hinge-ridge of the right one are finely crenulate, without or with only weak terminal widenings. The contact-furrow, too, is finely crenulate. The right valve of the larvae has a posteroventral spine.

Description. See Drexler (1958, pp. 505-506) and Michelsen (1970, pp. 42-44).

Measurements and statistics (in $\mathrm{mm}$ ). The specimens of six samples are measured and three of the samples are figured: one in text-fig. 41, and two in Michelsen (1970, text-figs. 6 and 9).

The measurements and the statistical calculations for the material from Gassum No. 1, sample No. 47, are shown in the table below. These measurements show a weak positive allometry, as shown in the sample No. 21 from Rødby No. 1 (Michelsen, 1970, text-fig. 6 and table 1). In the material from Gassum No. 1 the turning point is clearly marked, located at the instar A-1, while in sample No. 21 from Rødby No. 1, the turning point is located at the instar A-5; the curve is also more even here. From this point of view the population from the Gassum No. 1 sample agrees better with the population in the sample No. II from Rødby No. 1 (Michelsen 1970, text-fig. 9). 


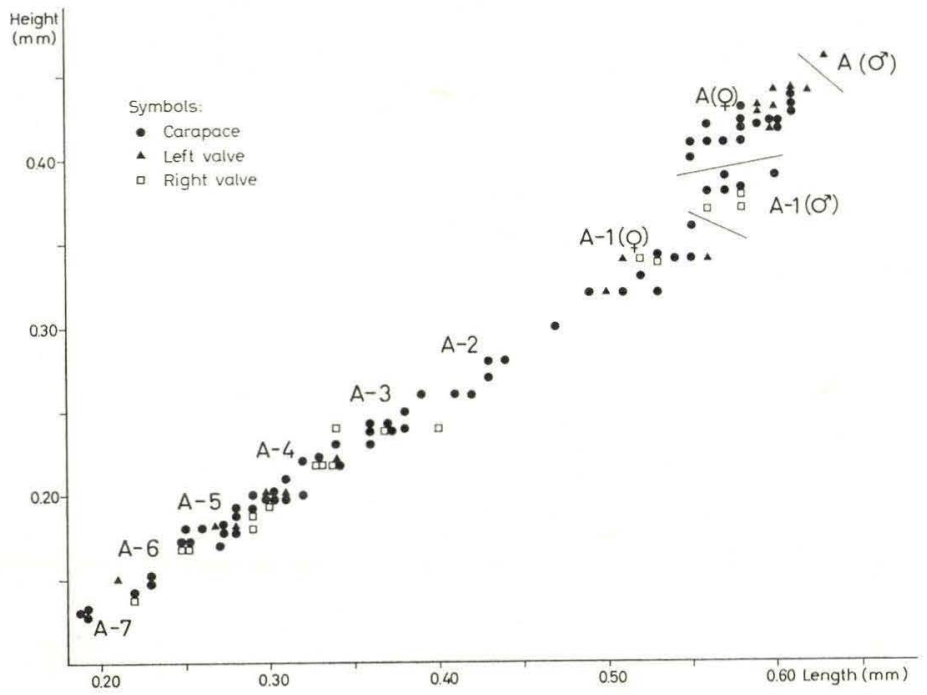

Text-fig. 41. Scattergram showing relations between numbers, lengths and heights for Ogmoconchella aspinata (Drexler, 1958). Sample No. 47 from the Gassum No. 1 boring.

Measurements (in mm). Left valves and carapaces. Gassum No. 1, sample No. 47:

$\begin{array}{llllll}\overline{\mathrm{x}} & \mathrm{S} & \mathrm{V} & \text { O.R. } & \mathrm{N}\end{array}$

Length:

$\begin{array}{lllllr}\text { A, males } & 0.63 & 0.000 & 0.00 & 0.63 & 1 \\ \text { A, females } & 0.589 & 0.020 & 3.40 & 0.55-0.62 & 23 \\ \text { A-1, males (?) } & 0.576 & 0.015 & 2.60 & 0.56-0.60 & 5 \\ \text { A-1, females (?) } & 0.522 & 0.027 & 5.17 & 0.47-0.56 & 12\end{array}$

Height:

$\begin{array}{lllllr}\text { A, males } & 0.46 & 0.000 & 0.00 & 0.46 & 1 \\ \text { A, females } & 0.423 & 0.011 & 2.60 & 0.40-0.44 & 23 \\ \text { A-1, males (?) } & 0.384 & 0.005 & 1.30 & 0.38-0.39 & 5 \\ \text { A-1, females (?) } & 0.331 & 0.016 & 4.73 & 0.30-0.36 & 12\end{array}$

Growth factor:

\begin{tabular}{lccccccc}
\hline & A/A-1 & A-1/A-2 & A-2/A-3 & A-3/A-4 & A-4/A-5 & A-5/A-6 & A-6/A-7 \\
\hline Length & 1.13 & 1.23 & 1.15 & 1.18 & 1.17 & 1.21 & 1.17 \\
Height & 1.28 & 1.23 & 1.11 & 1.16 & 1.16 & 1.22 & 1.14 \\
\hline
\end{tabular}

Remarks. The original diagnosis comprises some characters of the adult of this species, but the larval stages which differ in having a postero- 
ventral spine cannot be included. Because of this difference between the adult and the larvae both the name and the original diagnosis are misleading.

As mentioned above and in Michelsen (1970, p. 49) there seem to be two diverging patterns of development in the growth of this species. In the middle part of the Rødby No. 1 boring (the deltaic series) the positive allometry expressed in the height/length ratio shows an even curved line, and the number of specimens in each instar is about the same. In the lower part of the Rødby No. 1 boring (the lower marine series) and in the other borings there is a distinct jump in the height/length ratio between the instars A-1 and A (cf. text-fig. 41), and the numbers of specimens per instar decrease from A to A-7. The smallest larval stages are often not represented in the samples. This difference must indicate the presence of two different environments. The latter type occurs in an environment with normal marine conditions in contrast to the former (cf. Michelsen, 1973b).

A few specimens are found to have a more rounded outline and they may also be a little more elongated. Whether they belong to another species or whether they are morphological variants of $O$. aspinata has not been determined. Since they never are found in samples without typical $O$. aspinata and since other species of Ogmoconchella often occur together with corresponding "variants", the rounded and elongated "variants" are here counted together with $O$. aspinata.

The present specimens are identical with $O$. aspinata (Drexler, 1958). Lord (1971) describes some Liassic species and refers one of them to O. ellipsoidea (Jones, 1872), = Bairdia (?) ellipsoidea. Of the species described by Lord he kindly sent me some specimens which without doubt are identical with the species described here as O. aspinata. Lord (1971) discusses the relationships between his specimens, Bairdia (?) ellipsoidea Jones, 1872, and Bairdia liassica Blake, 1876, and concludes that they must be referred to the same species: O. ellipsoidea. He mentions only two collections of the two species: Brodie Collection and Blake Collection, and notes that the species in question stored in these two collections are unlike each other. Jones (1872) only describes his species very shortly and does not give any figures. Blake (1876) figures his species by a drawing which may well be of a species identical with $O$. aspinata as well as of another species with features like those of $O$. aspinata. The only reliable basis for the diagnosis of the species described by Lord (1971) is that it is found in the same beds as Jones found his species.

Before Lord (1971) used the name ellipsoidea it seems only to have been used by Conti (1954), who described and figured Cytheridea ellipsoidea Jones and Cytheridea ellipsoidea Brady var. reducta Conti. As the only distinction between the two subspecies he mentions the difference in size. 
Neither his description nor his figures give a satisfactory basis for concluding an identity between his species (subspecies) and $O$. aspinata. On the contrary his species seem to be more rounded posteriorly.

As no figures and no type material give a reliable and satisfactory basis for referring the present material (and O. aspinata Drexler, 1958) to Bairdia (?) ellipsoidea Jones, 1872, and as $O$. aspinata is a well-described and well-known species from other North European localities, the present material is referred to this latter species. For final conclusions as to the identity of or difference between the species mentioned we need: 1) a presentation of the type specimen of $O$. ellipsoidea (or a neotype), 2) a comparison of the type specimens of $O$. aspinata, $O$. ellipsoidea, and the two subspecies of Conti. A comparison of the type material may possibly show the presence of one, two or more species. Until such a comparison has been made the present author suggests the use of the name $O$. aspinata when dealing with a species identical with the species described by Drexler (1958).

$O$. aspinata is very much like $O$. adenticulata, but it is smaller in size and the right valve is more rounded in lateral view, so that the difference between the height of the right valve and the left valve is larger in O. aspinata. Furthermore, the reticulation of this species is very weak in relation to that of $O$. adenticulata. The larvae of $O$. aspinata are also distinguishable by the posteroventral spine on the right valve. The affinity with $O$. danica n.sp. is discussed under that species. $O$. aspinata differs from Hungarella owthorpensis Anderson (1964, p. 147, pl. XIV, figs. 96-101) in being a little more elongated. Furthermore, the posterior end of $H$. owthorpensis is higher and the hinge has rather distinct terminal widenings.

Hungarella? sp. 17 figured by Bizon \& Oertli (1961, pl. VII) and Oertli \& Grosdidier (1961, pl. VI) seems to resemble $O$. aspinata. Studies of French faunas deposited with H. J. Oertli (Pau) have shown that $O$. aspinata occurs in Hettangian and Lower Sinemurian (= Sinemurian s. str.) in France (se also Donze, 1967). However, Hungarella? sp. 17 includes more than one species, amongst others a species occurring in Upper Sinemurian. This latter species has affinities with both $O$. aspinata and $O$. danica.

Distribution. Denmark: Common in the O. aspinata Zone; Hettangian and lower part of Lower Sinemurian.

Southern Germany: Lias Alpha-1 to 3, only scattered in upper part of Alpha-3 (Drexler, 1958).

Northern Germany: Common in Lias Alpha-2, and occurs in Alpha-1 and 3 (Klingler, 1962).

England: The $P$. planorbis Zone to the A. bucklandi Zone, Hettangian and lower part of Lower Sinemurian (Lord, 1971).

France: Hettangian and lowermost Lower Sinemurian (Donze, 1967). 


\section{Ogmoconchella bispinosa (Gründel, 1964)}

Pl. 31, fig. 455 ; pl. 33, figs. 472-475.

? 1962: Ostracod Nr. 5 Klingler, p. 83, pl. 12, fig. 8.

1964a: Pseudohealdia? bispinosa Gründel, p. 472, figs. 13-15.

1967: Pseudohealdia ? bispinosa Gründel - Donze, p. 77, pl. II, figs. 34-35.

1968a: Ostracod Nr. 5 Klingler - Christensen, pl. 23, fig. 42.

1969a: Ogmoconcha bispinosa (Gründel) - Herrig, p. 457, text-figs. 3-4, 7-10; pl. II, figs. 4-8; pl. III, figs. 1-2.

1970: Healdia bispinosa (Gründel) - Gründel, p. 47, text-fig. 1; pl. I, figs. 11-13.

Material. 18 carapaces, 9 left valves, and 16 right valves in core samples from the Flyvbjerg No. 1, Gassum No. 1, Haldager No. 1, Øresund Nos. 3,12 , and 15 borings.

Original diagnosis. "Gehäuseform Healdia-ähnlich mit in der Mitte winklig geknicktem Dorsalrand. Eine hintere vertikale Rippe fehlt. Posteroventral ist an jeder Klappe ein kleiner, aber deutlicher Dorn entwickelt" (Gründel, 1964a, p. 472).

Description. See Gründel, 1964a, p. 472 and Herrig, 1969a, p. 457.

Remarks. The present specimens, which represent larval stages only, occur scattered (one to five in number per sample). The internal characters of the valves cannot be studied in this material. - One adult is recorded in a cuttings sample from the Dansk Nords $\varnothing \mathrm{J}-1$ boring (cf. pl. 31, fig. 455).

Gründel (1964a) did not refer this species to either of the two subgenera of Pseudohealdia, as he could not examine the hinge and the muscle scars. $O$. bispinosa is here referred to the genus Ogmoconchella because of the conformity between its muscle scars (cf. Herrig, 1969a, text-fig. 9b and Gründel, 1970, text-fig. 1) and the muscle scars of $O$. aspinata. From the present material the hinge also seems to be of the Ogmoconchella-type.

On the basis of the outline of the shell, Ostracod Nr. 5 Klingler is supposed to be identical with $O$. bispinosa.

Distribution: Denmark: The G. apostolescui - K. (K.) foveolata Subzone and the $O$. adenticulata $-N$. (N.) simplex Zone; Lower and Upper Pliensbachian.

Northern Germany: Lias Gamma (Gründel, 1964a and 1970, and Herrig, 1969a), and Lias Delta-2 (Herrig, 1969a). - Ostracod Nr. 5 Klingler is recorded from Lias Beta to Lias Delta (Klingler, 1962).

France: Upper Sinemurian to Lower Domerian (Donze, 1967).

\section{Ogmoconchella danica n.sp.}

Pl. 31, figs. 451-454; pl. 32, figs. 456-462; pl. 33, figs. 476-484; pl. 34, figs. $485-489$; pl. 41, figs. 574-577. Text-figs. 42-43. 
Derivation of the name. The type locality is Danish.

Holotype. A left valve. D.G.U. catalogue No. 1972-OM-83; pl. 33, figs. 476-477.

Type locality. The Gassum No. 1 boring.

Type stratum. Sample No. 42. Dark greenish grey shale. The $P$. reticulata Subzone; lowermost Upper Sinemurian.

Material. 714 carapaces, 216 left valves, and 286 right valves in core samples from the Børglum No. 1, Fjerritslev No. 2, Gassum No. 1, Øresund Nos. 10, 12, and 14 borings.

Diagnosis. A species of the genus Ogmoconchella with an evenly rounded outline. The posterior end is well-rounded, only slightly extended ventrally. The external surface is smooth or faintly furrowed; there is no external lamella on the anterior margin.

Description. In lateral view the outline is oval with the greatest height just posterior to the mid-point. The outline in dorsal view is elongated oval, more rounded posteriorly than anteriorly, and with the greatest breadth at the mid-point or rarely just behind. In posterior view the shell is oval with the greatest breadth at the mid-point.

The dorsal margin is evenly arched, only rarely with a weak bend just posterior to the mid-point. The anterior margin is symmetrically rounded, and it passes evenly into the arched dorsal margin and into the almost straight ventral margin. The posterior margin is more broadly and asymmetrically rounded, slightly extended ventrally. It passes evenly into the ventral and dorsal margins. The lateral surface is evenly convex, most strongly arched posteroventrally. The left valve is larger than the right, having the largest overlap along the ventral margin. The external surface of the Danish specimens is without any regular ornamentation; whereas German specimens show a faintly furrowed shell-surface. There is no external lamella on the anterior margin.

In the present material a few specimens have a relatively smaller height. The larvae also tend to be more elongated. The posterior margin of the larvae is more pronouncedly extended posteroventrally.

The hinge is of the Ogmoconchella-type; it is rather narrow without terminal widening and finely crenulate. The contact groove is narrow along the terminal margins of the left valve, but broader along the ventral margin.

The muscle scars consists of six large spots arranged in two subvertical rows and surrounded by fourteen to fifteen smaller spots. Single spots occur dorsally and anteriorly. The number of spots is clearly reduced in the larvae (cf. pl. 32).

Sexual dimorphism was not observed.

Measurements and statistics (in $\mathrm{mm}$ ). The specimens from several 
samples have been measured; sample Nos. 32, 39A, and 42 of Gassum No. 1; sample Nos. 1397 and 1410 of Øresund No. 12; sample No. 14 of Børglum No. 1. Text-fig. 42 shows the relative distribution of the instars in sample No. 1410 (Øresund No. 12), and in the table below the statistical calculations for the left valves (and carapaces) from sample No. 42 (Gassum No. 1) are given.

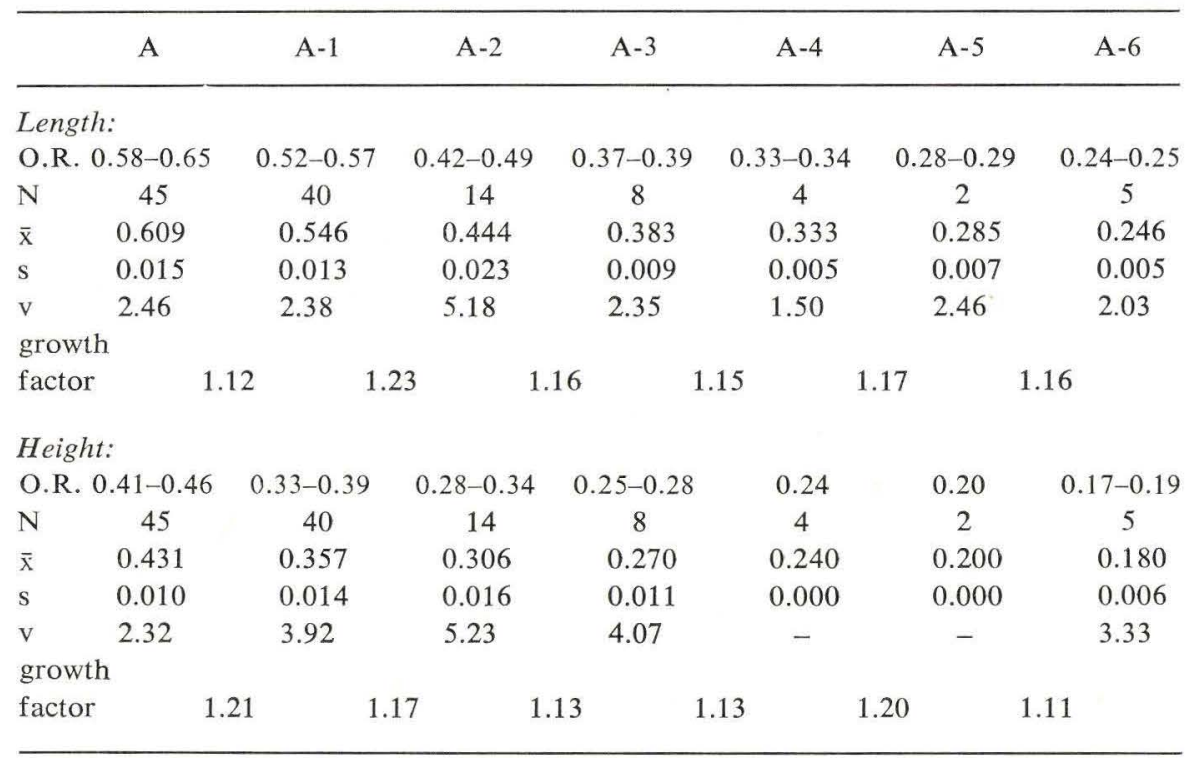

The above seems to show a weak positive allometry; and the average value of the growth factor is 1.17 (cf. O. aspinata in Michelsen, 1970, pp. 45 and 49).

Remarks. In each of the stratigraphical levels $O$. danica is a well-defined species, but it varies from level to level. In text-fig. 43 the size of the specimens of the largest instar from five samples is given. The largest instar from each of these five samples is presumed to be the adult stage, as no characters in the morphology show ontogenetical differences. The two samples from Gassum No. 1 belong to the section referred to the Upper Sinemurian, whereas the three other samples belong to Lower Pliensbachian. The specimens from the latter stratigraphical level are generally larger than the specimens from Upper Sinemurian. In the group with the largest dimensions some of the specimens are a little more rounded posteriorly in dorsal view, and the anterior end may be thicker, but otherwise it is impossible to divide them into two species on the features of the shell. For this reason the specimens described above are regarded as one species with a rather large varia- 


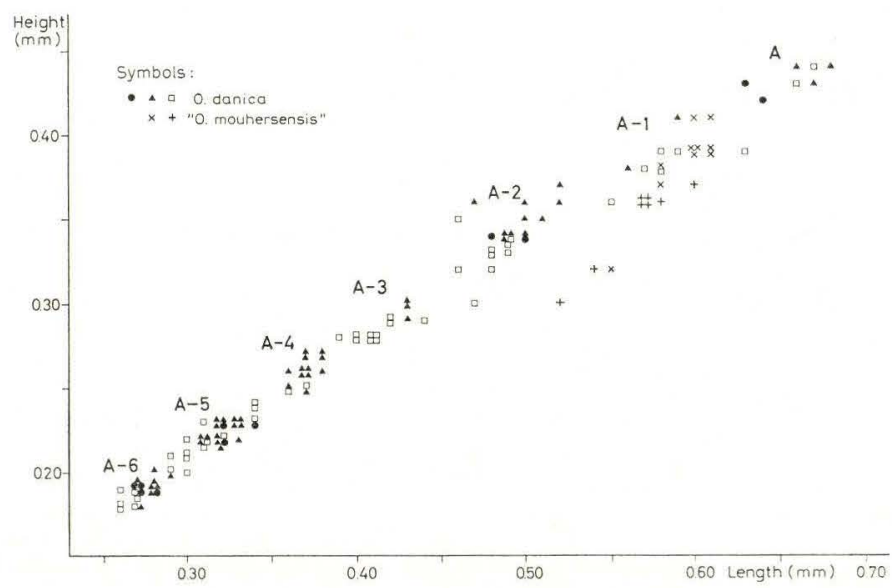

Text-fig. 42. Scattergram showing relations between numbers, lengths and heights for Ogmoconchella danica n. sp. and "O. mouhersensis" (Apostolescu, 1959). Sample No. 1410 from the Øresund No. 12 boring.

tion in size. This variation seems to be connected with the stratigraphical level. The size of specimens measured in additional samples follows the same pattern.

O. danica shows affinities to O. propinqua Malz (1971, p. 442, pl. 2, figs. 23-26), but differs from the latter in its smooth external surface and its broadly rounded posterior end. However, specimens deposited with $\mathrm{H}$. Malz (Frankfurt) and which he kindly lent me show a very faint reticulation (cf. pl. 41, figs. 574-577). The reticulation is of the same character as that seen in $O$. adenticulata, but more weakly developed. The difference between the German specimens and the Danish type material may be due to the condition of preservation. A few specimens found in the G. apostolescui-

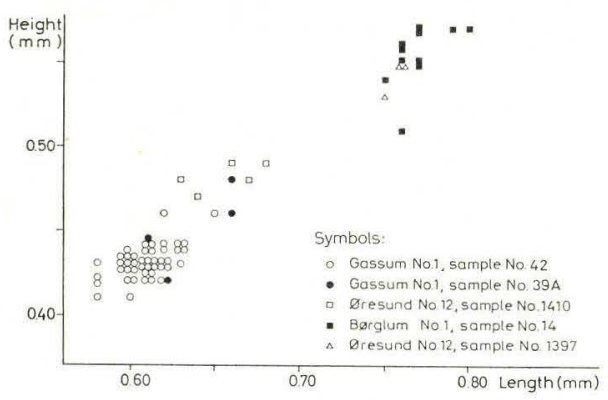

Text-fig. 43. Scattergram showing relations between numbers, lengths and heights for Ogmoconchella danica n. sp. Sample Nos. 39A and 42 from the Gassum No. 1 boring, sample Nos. 1397 and 1410 from the Øresund No. 12 boring, and sample No. 14 from the Børglum No. 1 boring. 
K. (K.) foveolata Subzone in the Gassum section resemble O. propinqua (see pl. 31, figs. 451-452). O. propinqua, found in the German Lias Delta, is larger than $O$. danica, but this feature may be a result of a phylogenetic development.

$O$. danica also shows affinities with species such as $O$. aspinata, O. mouhersensis and $O$. adenticulata, but it differs from these mainly in its more rounded outline, especially its broadly rounded posterior end.

Ostracod Nr. 14 Klingler (1962, p. 83, pl. 12, fig. 9) may be identical with $O$. danica. Concerning the external surface Klingler mentioned that it "ist glatt, jedoch bei sehr guter Erhaltung lassen sich sehr feine Runzeln erkennen".

Ostracoda B Apostolescu (1959, p. 817, pl. II, figs. 20-23) shows affinities with $O$. danica. One of the carapaces studied by the present author in type material deposited with H. J. Oertli (Pau, France) is very near to the present material. Specimens with affinity to $O$. danica also occur in other French material, studied in Pau (cf. Oertli, 1963, pl. X). Occurrences of $O$. danica in French deposits have not been shown with certainty, but at least specimens with affinity with $O$. danica are found (see also Hungarella communis Viaud, 1963, p. 80, pl. II, figs. 39-48; and Donze 1967, p. 77).

Distribution. Denmark: The $O$. danica Zone, Upper Sinemurian and Lower Pliensbachian; and rarely in lower part of the $O$. adenticulata $-N$. (N.) simplex Zone, lower part of Upper Pliensbachian.

Ogmoconchella gruendeli Malz, 1971

P1. 32, figs. 463-464; pl. 34, figs. 490-493. Text-fig. 44.

1971: Ogmoconchella gruendeli Malz, p. 441, text-fig. 4; pl. 3, fig. 11.

Material. 7 carapaces, 12 left valves, and 27 right valves in core samples from the Flyvbjerg No. 1 and Gassum No. 1 borings.

Original diagnosis. "Eine mittelgrosse, glattschalige Ogmoconchella-Art mit breit abgestutztem Hinterende, ohne Ventralsporn. Umriss in Dorsalansicht gestreckt elliptisch" (Malz, 1971, p. 441).

Description. See Malz, 1971, p. 441.

Measurements. The specimens in sample Nos. 18 and 19 from Flyvbjerg No. 1 have been measured (see text-fig. 44).

Remarks. The present material is scarce and consists mainly of larvae. Malz (1971) does not figure the relative features of the external morphology, but from his description these specimens must be referred to his species.

The relations between $O$. gruendeli and $O$. pseudospina are described under the latter. $O$. gruendeli also shows some affinities with $O$. transversa, 
but differs from this in being larger and in having different outlines of the right and left valves. The right valve of $O$. transversa does not overlap the left valve posteroventrally.

Distribution. Denmark: Rare in the middle subzone of the $O$. danica Zone, Upper Sinemurian; occurs in the lower part of the $O$. adenticulata $N$. (N.) simplex Zone, Upper Pliensbachian.

Germany: The A. margaritatus Zone; Lias Delta (Malz, 1971).

"Ogmoconchella mouhersensis" (Apostolescu, 1959)

Pl. 32, figs. 465-466; pl. 34, figs. 494-496; pl. 35, figs. 497-502. Textfig. 42.

? 1959: "Ogmoconcha" mouhersensis Apostolescu, p. 805, pl. II, figs. 18-19.

Material. 132 carapaces, 51 left valves, and 87 right valves in core samples from the Børglum No. 1, Gassum No. 1, Øresund Nos. 12 and 15 borings.

Original diagnosis of $O$. mouhersensis. "Carapace subovoïde en vue latérale, caractérisée dans le tiers postérieur par un sinus bien marqué" (Apostolescu, 1959, p. 805).

Remarks. This material shows great variation, and may possibly contain more than one species. True $O$. mouhersensis with the characteristic vertical swelling posteromedianly on the lateral surface is found in a few samples (e.g. sample No. 39A, Gassum No. 1). Most of the specimens in the samples from the Børglum and Øresund borings do not have a swelling, but only a more or less distinct vertical bend on the lateral surface. The features of these last-named specimens are intermediate between $O$. adenticulata and $O$. mouhersensis. They differ from $O$. gruendeli in having the greatest height and the greatest breadth more posteriorly. Furthermore, the dorsal margin of the right valve between the bend of the margin and the posterior end is straight to slightly concave. The larvae are more rounded and uncharacteristic, and may be mistaken for larvae of $O$. danica (which occurs in the same fauna). However, they differ from the latter in having an external lamella on the anterior margin.

The typical $O$. mouhersensis (found in sample No. 39A of Gassum No. 1) differs from $O$. aspinata by its characteristic swelling on the lateral surfaces. The other variants of the present morphospecies have a more rounded posterior end than $O$. aspinata and have a more or less distinct vertical bend on the lateral surface.

The specimens of several samples have been measured (cf. text-fig. 42), without showing any usable features for a subdivision into more species.

Until supplementary studies can be made this group is regarded as a 
rather heterogeneous morphospecies with only minor stratigraphical value, and possibly, comprising more than one species.

Discussion concerning identity between $O$. telata and $O$. mouhersensis, initiated by Gründel (1970, p. 48), cannot be resolved on the present material.

Distribution. Denmark: The O. danica Zone; Upper Sinemurian and Lower Pliensbachian.

Ogmoconchella pseudospina (Herrig, 1969)

Pl. 32, figs. 467-469; pl. 35, figs. 503-507, 508-509(?). Text-fig. 44.

1961: Hungarella sp. Pietrzenuk, p. 91, fig. 18/1.

1964a: Ogmoconcha sp. Gründel, p. 469, figs. 11-12.

1965: Ogmoconcha sp. Dreyer, pl. III, figs. 3a-b.

1968a: Ostracod Nr. 4 Klingler - Christensen, pl. 23, fig. 51 (non Ostracod Nr. 4 Klingler, 1962).

1968a: Pseudohealdia? sp. 817 Christensen, pl. 23, fig. 66.

1969a: Ogmoconcha pseudospina Herrig, p. 452, text-figs. 4-8; pl. II, figs. 1-3.

1970: Hungarella pseudospina (Herrig) - Gründel, p. 53, text-fig. 15; pl. I, figs. 5-6.

Material. 32 carapaces, 29 left valves, and 26 right valves in core samples from the Flyvbjerg No. 1, Gassum No. 1, Vedsted No. 1, and Øresund No. 3 borings.

Original diagnosis. "Eine Ogmoconcha mit länglich-elliptischen K1; Wölbung und Kl-Breite sind vom Zentrum bis fast zum HR gleich. Vor dem HR fällt die Wölbung in einer abgerundeten Kante ab, die posteroventral stumpf zugespitzt ist und leicht den Kl-Rand überragt. Die Kl-Oberfläche ist glatt" (Herrig, 1969a, p. 453).

Description. See Herrig, 1969a, p. 453.

Measurements and statistics (in $\mathrm{mm}$ ). All specimens recorded from the three samples (Nos. 18, 19 and 21) of the Flyvbjerg No. 1 boring have been measured. Furthermore, the size of nearly all other specimens has been checked. The table below shows the statistical calculations for the adults in sample No. 21 from Flyvbjerg No. 1:

\begin{tabular}{lcccc}
\hline & $\overline{\mathrm{x}}$ & $\mathrm{s}$ & $\mathrm{v}$ & $\mathrm{O} . \mathrm{R}$. \\
\hline $\begin{array}{l}\text { Left valves }(\mathrm{N}=9): \\
\text { Length }\end{array}$ & 0.708 & 0.015 & 2.12 & $0.69-0.73$ \\
Height & 0.443 & 0.007 & 1.58 & $0.44-0.46$ \\
Right valves $(\mathrm{N}=6):$ & & & & \\
Length & 0.685 & 0.013 & 1.90 & $0.67-0.71$ \\
Height & 0.410 & 0.013 & 3.17 & $0.39-0.42$ \\
\hline
\end{tabular}




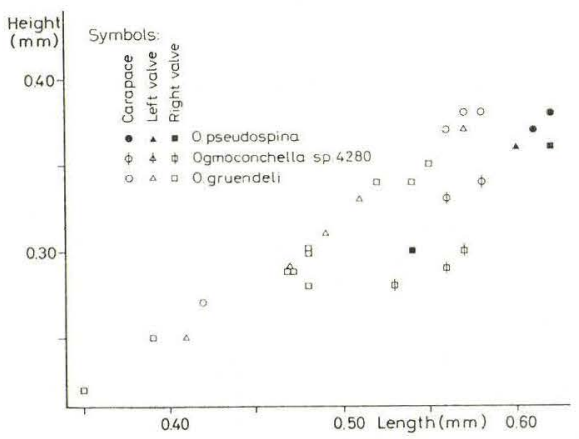

Text-fig. 44. Scattergram showing relations between numbers, lengths and heights for Ogmoconchella pseudospina (Herrig, 1969), O. sp. 4280 and O. gruendeli Malz, 1971. Sample No. 18 from the Flyvbjerg No. 1 boring.

The present specimens are a little smaller than those described by Herrig (1969a) and by Dreyer (1965). On the other hand, the size of the specimens figured by the other authors mentioned above is near to the size given here. One specimen which is referred with some doubt to this species is larger (pl. 35, figs. 508-509).

Text-fig. 44 shows the dimensions of the specimens of $O$. pseudospina, O. gruendeli, and Ogmoconchella sp. 4280 found in sample No. 18 from Flyvbjerg No. 1. From these measurements it is possible to distinguish between the two first-named species.

Remarks. The samples from Øresund No. 3 contain only larvae, which have morphological features very close to the definition given by Herrig (1969a). The specimens from Flyvbjerg No. 1 and Gassum No. 1 show more variation. In dorsal view some of these specimens are rounded posteriorly and have their greatest breadth just posterior to the mid-point (see also Gründel, 1970, pl. I, fig. 6). Malz (1971, p. 441) suggests this form is a separate species from $O$. pseudospina. However, in the present material there is no other basis to make such a division into two species.

The adults, which are rare in the material studied, are a little smaller than those described by Herrig, 1969a (see above). However, the size of the larvae A-1 is within the range he gives for this instar.

Because of the characters of the hinge (narrow, without a terminal thickening, and with fine crenulation) and of the muscle scars this species must be classed within the genus Ogmoconchella.

The affinities between $O$. pseudospina and $O$. bispinosa are described by Herrig, 1969a. As mentioned by Malz (1971) O. gruendeli also shows affinities with the present species. $O$. gruendeli differs in being relatively 
higher (cf. text-fig. 44) and in having a more convex dorsal margin. Its greatest height is near the middle of the shell. In $O$. pseudospina the greatest height is more posteriorly, and in the larvae it is near the posterior end. Furthermore, the posterior margin of the left valve of $O$. gruendeli is oblique and extended dorsally.

"Ogmoconcha" etaulensis Apostolescu, 1959 (p. 805, pl. II, figs. 2930 ) is possibly identical with $O$. pseudospina. Type material (1 carapace and 1 valve) deposited with H. J. Oertli (Pau, France) has been studied by the present author. The two specimens belong to O. pseudospina, which has also been recognized in other French material studied in Pau (see also Oertli, 1963, pl. XVII). However, the specimen figured by Apostolescu differs from the holotype of $O$. pseudospina and seems to be more closely related to the above-mentioned specimen published by Gründel (1970). Final conclusions concerning the affinities (or identity) of the two species should be based on comparison of the holotypes and on studies of the morphological variation. In the present paper the species is named $O$. pseudospina, since most of the studied specimens resemble the holotype of this species.

Distribution. Denmark: Upper part of the G. apostolescui $-K$. (K.) foveolata Subzone and the $O$. adenticulata - N. (N.) simplex Zone; Lower and Upper Pliensbachian.

Northern Germany: Lias Gamma and Delta (Herrig, 1969a, Pietrzenuk, 1961 and Gründel, 1964a and 1970).

Ogmoconchella septenaria (Gründel, 1964)

Pl. 37, figs. 525-527.

1962: Ostracod Nr. 9 Klingler, p. 98, pl. 13, fig. 34.

1964a: Pseudohealdia (Ledahia) septenaria Gründel, p. 471, figs. 1-4.

1965: Pseudohealdia septenaria Gründel - Dreyer, p. 513, pl. VI, fig. 10.

1968a: Pseudohealdia (Ledahia) septenaria Gram. - Christensen, pl. 23, fig. 67.

1970: Healdia septenaria (Gründel) - Gründel, p. 48, text-fig. 3, pl. I, figs. 16-17.

1970: Healdia aff. septenaria (Gründel) - Gründel, p. 48, pl. I, figs. 14-15.

1971: Ledahia septenaria (Gründel) - Malz, p. 443, pl. 1, fig. 4; pl. 2, fig. 5 .

Material. 1 left valve and 1 right valve in core samples from the Øresund No. 3 boring.

Original diagnosis. "Hintere Vertikalrippe sehr deutlich. In der Dorsalansicht Schale im hinteren Drittel nur wenig breitere als im vorderen Drittel, seitliche Begrenzungslinien konvex. Schliessmuskelfeld aus 7 cytherelloid angeordneten Narben bestehend" (Gründel, 1964a, p. 471).

Description. See Gründel, 1964a, p. 471.

Remarks. Malz (1971, p. 444) has studied larger material of this species 
and found a variation which includes the two types: Ostracod Nr. 9 Klingler, 1962 and Pseudohealdia (Ledahia) septenaria Gründel, 1964. In his treatment of the genera Malz (1971) revives Ledahia Gründel, 1964. In the opinion of the present author the genera Ledahia and Ogmoconchella are identical (see p. 232).

O. septenaria is probably identical with the French species Healdia sp. 101 Oertli \& Grosdidier, 1961 and Healdia? bernardi Viaud, 1963 (see also Donze, 1967, p. 76).

Distribution. Denmark: Middle part of the $O$. adenticulata $-N$. (N.) simplex Zone; Upper Pliensbachian.

Northern Germany: Lias Delta (Gründel, 1964a, Klingler, 1962 and Dreyer, 1965), or only in the A. margaritatus Zone (Malz, 1971).

Southern Germany: Lias Gamma to Delta-2 (Klingler, 1962).

France: Healdia sp. 101 and H.? bernardi occur in the T. ibex Zone to the A. margaritatus Zone; Pliensbachian and Domerian (Oertli \& Grosdidier, 1961 and Viaud, 1963).

Ogmoconchella transversa (Gründel, 1970)

Pl. 36, figs. 510-514; pl. 37, figs. 521-524. Text-fig. 45.

1967: Pseudohealdia ? grosdidieri (Viaud) - Donze, p. 78, pl. II, fig. 39-44.

1970: Hungarella transversa Gründel, p. 54, text-fig. 18, pl. I, figs. 18-19.

Material. 28 carapaces, 19 left valves, and 17 right valves in core samples from the Børglum No. 1, Flyvbjerg No. 1, Gassum No. 1, and Øresund No. 12 borings.

Original diagnosis. "HE deutlich von hinten oben nach vorn unten abgeschrägt. Klappen ohne Skulptur. In Dorsalansicht liegt die grösste Breite hinter der Mitte" (Gründel, 1970, p. 54).

Description. The outline in lateral view is oval with ends of nearly the same height; a rounded anterior end and an obliquely angulate posterior end. The greatest height is at the mid-point. The carapace is elliptical in dorsal view, more rounded posteriorly than anteriorly, and with the greatest breadth a little posterior to the mid-point. It has an oval outline in posterior view, with the greatest breadth at the mid-point.

The dorsal margin is convex, with a distinct bend at the mid-point, and flattened against both of the ends. The ventral margin is straight to slightly convex. The anterior margin is well-rounded and symmetrical. The posterior margin is obliquely angulated, extending dorsally, and slightly convex. Both of the valves have these features but the posterior end of the right valve is a little more rounded. 
The hinge is narrow and without a terminal widening; it is finely crenulate. The contact groove of the left valve is very narrow anteriorly and posteriorly, but broader ventrally.

The muscle scars are of the Ogmoconchella-type with six large spots arranged in two subvertical rows and surrounded by smaller spots. Both dorsally and anteriorly to this are seen a few scattered spots.

The external surface is smooth.

Sexual dimorphism was not observed.

Measurements (in $\mathrm{mm}$ ). All specimens have been measured. As sample No. 21 from Flyvbjerg No. 1 is the most representative one with regard to the occurrence of the different instars the measurements from it are given in text-fig. 45. The adults from this sample are rather small as the length of the left valves from other samples (Børglum No. 1, Gassum No. 1, and Øresund No. 12) ranges from $0.64 \mathrm{~mm}$ to $0.69 \mathrm{~mm}$ and the height from $0.42 \mathrm{~mm}$ to $0.46 \mathrm{~mm}$. This difference in size is probably due to environmental conditions; it must be noted that also the specimens of $O$. pseudospina from sample No. 21 from Flyvbjerg No. 1 are rather small.

The size of specimens from the Danish Embayment agrees with the measurements of three specimens given by Gründel, 1970.

Remarks. Gründel (1970) regards Ostracod Nr. 7 Klingler (1962, p. 96, pl. 13, fig. 26) as synonymous with $O$. transversa. As the specimen figured by Klingler seems to have a lamella on the anterior margin of the right valve, it is doubtful whether the two morphospecies are identical.

Hungarella grosdidieri Viaud (1963, p. 89, pl. III, figs. 70-79) is

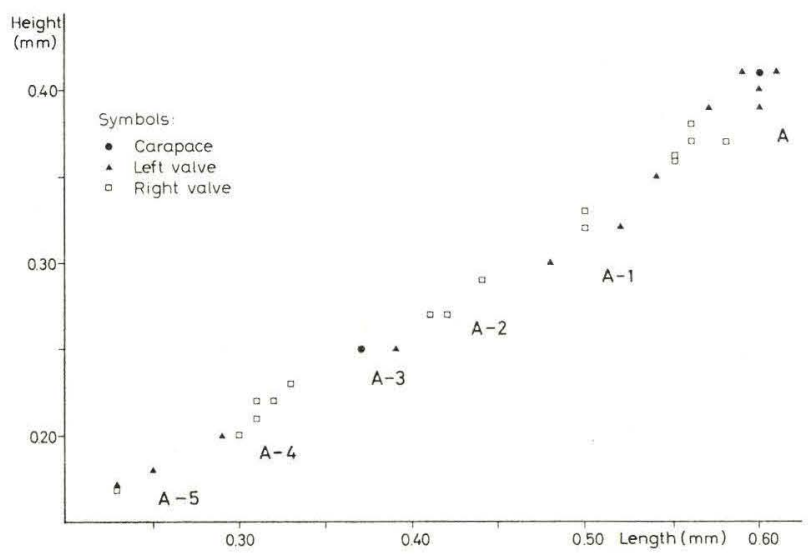

Text-fig. 45. Scattergram showing relations between numbers, lengths and heights for Ogmoconchella transversa (Gründel, 1970). Sample No. 21 from the Flyvbjerg No. 1 boring. 
without doubt identical with $O$. transversa, but unfortunately the name given by Viaud is a nomen nudum, as it has never been published.

O. transversa is identical with the species named Ogmoconcha sp. 4039 in Michelsen, 1971a and 1973a.

Distribution. Denmark: Upper part of the $G$. apostolescui $-K$. $(K$.) foveolata Subzone and lower part of the $O$. adenticulata $-N$. (N.) simplex Zone; Lower and Upper Pliensbachian.

Germany: Uppermost Carixian and lowermost Domerian (Gründel, 1970).

France: The A. bucklandi Zone to the A. margaritatus Zone; Lower Sinemurian to Lower Domerian (Viaud, 1963).

Ogmoconchella Nr. 2 (Klingler, 1962)

P1. 37, figs. 528-530.

1962: Ostracod Nr. 2 Klingler, p. 103, pl. 14, fig. 41.

Material. 1 carapace and 1 right valve in a core sample from the Gassum No. 1 boring.

Description. See Klingler, 1962, p. 103.

Remarks. Neither the hinge nor the muscle scars are included in the description given by Klingler (1962), who mentioned that the external surface has a fine reticulation. Unfortunately the present right valve is filled with sediment, so only the hinge can be observed. It is of the Ogmoconchella-type. Specimens determined by W. Klingler and deposited with H. Malz (Frankfurt) have been studied and are considered to belong to the genus Ogmoconchella.

Distribution. Denmark: Upper part of the O. adenticulata - N. (N.) simplex Zone; Upper Pliensbachian.

Northern Germany: Lias Delta-1b to Delta-2b (Klingler, 1962).

Southern Germany: Lias Delta-1b (Klingler, 1962).

Ogmoconchella? Nr. 15 (Klingler, 1962)

Pl. 37, figs. 531-533.

1962: Ostracod Nr. 15 Klingler, p. 102, pl. 13, fig. 37.

Material. 2 carapaces in cuttings samples from the Rønde No. 1 boring.

Description. See Klingler, 1962, p. 102.

Remarks. This species is tentatively referred to the genus Ogmoconchella on the basis of the external features (described by Klingler, 1962). Neither the hinge nor the muscle scars are known. 
Distribution. Denmark: Lower part (?) of the O. adenticulata $-N$. (N.) simplex Zone; Upper Pliensbachian.

Northern Germany: Lower part of Lias Delta (Klingler, 1962).

Ogmoconchella sp. 4015

Pl. 36, figs. 515-517; pl. 38, figs. 534-538.

1968a: Pseudohealdia? sp. 813 Christensen, pl. 23, fig. 52.

Material. 13 carapaces, 8 left valves, and 4 right valves in core samples from the Fjerritslev No. 1, Gassum No. 1, and Øresund No. 3 borings.

Description. This species is oval in dorsal view, with the greatest breadth at the mid-point or a little behind. The outline in lateral view is asymmetrically oval. The anterior end is broadly rounded and high, whereas the posterior end is more narrowly rounded and lower. The dorsal margin is obliquely curved with a rather distinct bend in the middle. The ventral margin is nearly straight. The greatest height is at the mid-point. The external surface is smooth. The outlines of both valves conform to each other. Both the hinge and the muscle scars are of the Ogmoconchella-type.

Measurements. Seven left valves and carapaces from Øresund No. 3 and Gassum No. 1 have been measured. Five of the specimens have the length $0.55-0.60 \mathrm{~mm}$ and the others $0.70 \mathrm{~mm}$ and $0.75 \mathrm{~mm}$. The corresponding heights are $0.34-0.38 \mathrm{~mm}, 0.42 \mathrm{~mm}$ and $0.50 \mathrm{~mm}$.

Remarks. The outline of the present species is identical with Ogmoconchella conversa Malz (1971, p. 443, pl. 5, fig. 27), but O. sp. 4015 differs from this species in being smaller and in having a smooth external surface.

Ogmoconchella sp. 4015 is perhaps identical with Cytheridea moorei Jones (1894, p. 165, pl. IX, figs. $7 \mathrm{a}-\mathrm{c}$ and $8 \mathrm{a}-\mathrm{b})$. These two morphospecies seem to have identical outlines and are of equal size. As the internal features of $C$. moorei are not very well known, a possible identity between the two species cannot be concluded. Ogmoconchella sp. 4015 and Cytheridea moorei may possibly be larvae of Ogmoconchella conversa, but the larvae of the last species are not described. Future studies on larger and better preserved material may elucidate the relations between these three morphospecies.

Distribution. Denmark: Upper part of the $O$. adenticulata $-N$. (N.) simplex Zone; Upper Pliensbachian. 
Material. 3 carapaces, 2 left valves, and 6 right valves in core samples from the Flyvbjerg No. 1 boring.

Description. These specimens, which belong to one instar, are small, elongated oval with a pointed posterior end, and with the greatest height posterior to the mid-point. In dorsal view the outline is elongated oval, with the greatest breadth posterior to the mid-point. Posteriorly both of the valves form extensions between which there is a marginal concavity, since the extensions cover the margin in lateral view.

The dorsal margin is convex. The posterior margin and the anterior one are well-rounded and of equal height. The ventral margin is straight with a concavity at the mid-point. The anterior margin of both the left valve and the right valve has an external lamella, which in the right valve is large.

The hinge is narrow without a terminal widening, and it is finely crenulate. In the left valve the contact groove along the margins is of nearly the same breadth.

The muscle scars are of the Ogmoconchella-type with six large spots surrounded by smaller spots.

The surface of the shell is smooth.

Measurements. All measurable specimens have been measured (see textfig. 44). The length of the left valve is $0.56-0.58 \mathrm{~mm}$ and the height is $0.32-0.34 \mathrm{~mm}$. For the right valve the corresponding measurements are $0.53-0.57 \mathrm{~mm}$ and $0.28-0.31 \mathrm{~mm}$.

Remarks. Ogmoconchella sp. 4280 shows some affinities with Pseudohealdia pseudohealdiae Gründel (1964a), but differs from the latter in having muscle scars of the Ogmoconchella-type and a relatively lower posterior end.

Ogmoconchella sp. 4280 may be a new species, but it is here described with open nomenclature because of the scarce material, which only includes one instar (adults or larvae?).

Distribution. Denmark: Upper part of the $O$. adenticulata $-N$. (N.) simplex Zone; Upper Pliensbachian.

Genus Pseudohealdia Gründel, 1964

Type species. Pseudohealdia pseudohealdiae Gründel, 1964.

Original diagnosis. "Äussere Gestalt Healdia-ähnlich. Eine hintere vertikale Rippe oder hintere Dornen können auftreten oder fehlen. Schliess- 
muskelfeld aus 5-7 cytherelloid oder darwinuloid angeordneten Narben bestehend" (Gründel, 1964a, p. 470).

Remarks. This genus is distinguished from Ogmoconcha, Ogmoconchella, and Healdia mainly by its simple muscle scar area (consisting of 5-7 spots only).

Stratigraphical range. Lower Jurassic (Hettangian to Upper Pliensbachian).

? Pseudohealdia nasuta (Drexler, 1958)

Pl. 38, fig. 545 .

? 1958: Healdia nasuta Drexler, p. 506, pl. 21, figs. 7a-c; pl. 25, figs. 9-13.

Material. 10 carapaces in core samples from the Gassum No. 1 boring.

Original diagnosis. "Eine Art der Gattung Healdia mit einer dünnen, vorspringenden Kalklamelle am Vorderrand der RKl und LKl" (Drexler, 1958, p. 507).

Description. See Drexler, 1958, p. 507.

Remarks. The ten carapaces are representatives of small larval states, which probably belong to the species $O$. nasuta, as they are found in a fauna with $O$. aspinata. In reality it is very difficult to distinguish these from small larvae of $O$. bispinosa. However, the latter are a little more elongated.

Gründel (1964a, p. 470 and 1964b, text-fig. 5) refers this species to the genus Pseudohealdia.

Distribution. Denmark: The upper part of the $O$. aspinata Zone; Lower Sinemurian.

Southern Germany: Lias Alpha-2 and 3 (Drexler, 1958).

Pseudohealdia truncata Malz, 1971

Pl. 38, figs. 542-544.

1962: Ostracod Nr. 4 Klingler, p. 102, pl. 13, fig. 38.

1971: Pseudohealdia truncata Malz, p. 444, pl. 1, fig. 3; pl. 4, figs. 18-20.

Material. About ten carapaces and valves in cuttings samples from the Rønde No. 1 boring.

Original diagnosis. "Eine grosse Pseudohealdia-Art mit annähernd parallelen Längsrändern in Dorsalansicht und mit fast rechtwinklig abgestutztem Hinterende. Hinterrand in Seitenansicht nicht verdeckt (wie bei Ps. pseudohealdiae) und in der L komma-förmig zum Ventralrand abgeschrägt" (Malz, 1971, p. 444). 
Description. See Klingler, 1962, p. 102.

Distribution. Denmark: The upper part (?) of the $O$. adenticulata $-N$. (N.) simplex Zone; Upper Pliensbachian.

Northern Germany: Lias Delta (Klingler, 1962 and Malz, 1971).

Order Myodocopida Sars, 1866

Suborder Cladocopina Sars, 1866

Family Polycopidae Sars, 1866

Genus Polycope Sars, 1866

Type species. Polycope orbicularis Sars, 1866.

Diagnosis. "Schale annähernd kreisförmig oder kurz oval, meist nur mit flacher Einbuchtung an Stelle einer Rostralincisur oder ohne Andeutung einer solchen. Der Innenast verläuft in geringer Entfernung vom Schalenrand, demselben annährend parallel, die Verwachsungslinie sehr nahe dem Rand" (Müller, 1894, p. 231).

Remarks. This diagnosis was given by Müller (1894) for the family Polycopidae, but was referred by Fischer (1961b, p. 497) and Plumhoff (1963, p. 17) for the genus Polycope. To distinguish this genus from the other one (Polycopsis Müller, 1894) by shell-morphology Polycope was characterized as having a "Schale stets sculpturirt" (Müller, 1894, p. 233).

Stratigraphical range. Devonian ?, Lower Jurassic - Recent.

Polycope cerasia Blake, 1876

Pl. 39, figs. 550-554.

1876: Polycope cerasia Blake, p. 434, pl. 17, fig. 16.

1938: Ostracode (151) Wicher, pl. 27, fig. 9.

1952: Polycope sp. (10) Usbeck, p. 406, pl. 18, fig. 66.

1958: Polycope cerasia Tate \& Blake - Drexler, p. 501, pl. 21, fig. 1.

1959: Polycope pumicosa Apostolescu, p. 801, pl. I, fig. 1.

1961b: Polycope cerasia Tate \& Blake - Fischer, p. 500, fig. 1.

1967: Polycope aff. pumicosa Apostolescu - Donze, p. 73, pl. I, figs. 2-5.

1968a: Polycope (Ostracod (151) Wicher) - Christensen, pl. 23, fig. 31.

1968a: Polycope sp. 807 Christensen, pl. 23, fig. 56.

1971: Polycope cerasia Blake - Lord, p. 645, pl. 122, figs. 1-2.

Material. 8 carapaces and 7 valves in core samples from the Flyvbjerg No. 1, Gassum No. 1, Øresund Nos. 3, 8, 9, 12, and 15 borings.

Original diagnosis. "Carapace, circular, compressed, small, hinge-area small, ventral side with a produced lip; ornamentation, a series of fine ridges and pits running from back to front, bowing out in the centre; when 
seen transversely, it appears only irregularly pitted. The hinge-line is straighter than in P. orbicularis (Sars)" (Blake, 1876, p. 434).

Description. See Lord, 1971, p. 645.

Remarks. The sculpture is a reticulation of rather sharp ribs forming a polygonal (often hexagonal) pattern. In the marginal area the reticulation may be arranged concentrically. In well-preserved specimens the ribs are rather sharp, though centrally on the valve broader and more rounded. In other specimens the main part of the external surface is covered by similar broad ribs, giving an impression of a pitted surface. There is a narrow marginal rim which may be smooth or have weak, radial ribs.

The hinge seems simple: In the right valve a ridge, in the left valve a corresponding groove and short, terminal ridges (?). The muscle scar area is an oval rosette of 6 (?) spots. The marginal zone has not been observed.

Studies on type material of Polycope pumicosa Apostolescu (deposited with H. J. Oertli, Pau, France) and of Polycope cerasia (kindly placed at the author's disposal by A. Lord) have demonstrated identity between the two species. However, Apostolescu (1959, p. 801) describes the ventral margin as having feebly developed spines, which are not visible on his figure. These spines are probably the ends of the radial, marginal ribs, which may be observed on well-preserved specimens.

Concerning the affinities with $P$. cf. cerasia, $P$. decorata and $P$. sp. 4181 see pp. 260, 261 and 264.

Distribution. Denmark: The $C$. betzi $-C$. crassireticulata Zone to the $O$. adenticulata - N. (N.) simplex Zone; Lower Sinemurian to Upper Pliensbachian.

Germany: Lias Alpha to Epsilon (Fischer, 1961b).

England: The $S$. angulata Zone and the A. bucklandi Zone; upper Hettangian and lower Lower Sinemurian (Lord, 1971).

France: The $E$. raricostatum Zone to the $P$. davoei Zone; upper Lotharingian to Pliensbachian (Viaud, 1963). - Upper Carixian to Lower Domerian (Donze, 1967).

Polycope cf. cerasia Blake, 1876

Pl. 40, fig. 565 .

Material. 18 carapaces and 2 valves in core samples from the Gassum No. 1 boring.

Remarks. Although rather many specimens have been recorded, only a few are sufficiently well-preserved to form a basis for a description. The internal features are not observed.

It is a thin-shelled form with a reticulation of fine ribs forming a poly- 
gonal pattern. On the central and the dorsal part of the valve the reticulation is without any direction. On the anterior, posterior and ventral parts it has a vertical direction and consists of elongated polygons.

$P$. cf. cerasia differs from $P$. cerasia in this reticulation, but resembles the latter species in other respects.

Polycope aff. cerasia Tate \& Blake sensu Dreyer (1965, pl. VI, fig. 9) has a more uniform and regular sculpture with stronger ribs.

Distribution. Denmark: The $O$. danica Zone and the O. adenticulata $N$. (N.) simplex Zone; Upper Sinemurian and Upper Pliensbachian.

Polycope cincinnata Apostolescu, 1959

Pl. 40, fig. 563.

1959: Polycope cincinnata Apostolescu, p. 801, pl. I, fig. 2.

1967: Polycope cincinnata Apostolescu - Donze, p. 73, pl. I, figs. 7-8.

Material. 6 carapaces in core samples from the Gassum No. 1 and Øresund No. 9 borings.

Original diagnosis. "Contour de la carapace subcirculaire. Surface des valves fortement costulée" (Apostolescu, 1959, p. 801).

Description. See Apostolescu, 1959, p. 801.

Remarks. The present specimens have been compared with type material deposited with $\mathrm{H}$. J. Oertli (Pau, France). They are smaller than the specimens described by Apostolescu, but resemble them in every other respect.

Distribution. Denmark: The $C$. betzi $-C$. crassireticulata Zone to the $G$. apostolescui $-K$. (K.) foveolata Subzone; Lower Sinemurian to Lower Pliensbachian.

France: The $E$. raricostatum Zone to the $P$. davoei Zone; upper Lotharingian to Pliensbachian (Viaud, 1963). - Upper Carixian to Lower Domerian (Donze, 1967).

Austria: Upper Triassic (Urlichs, 1972).

Polycope cf. cincinnata Apostolescu, 1959

Pl. 40, fig. 566.

Material. 9 carapaces and 1 valve in core samples from the Fjerritslev No. 1, Gassum No. 1, Øresund Nos. 3 and 15 borings.

Remarks. None of these specimens are entire, but from the sculpture they seem to belong to one morphospecies with some affinities with $P$. cincinnata.

The sculpture consists of fine, rather distinct ribs which are subcon- 
centrically arranged. Centrally on the valve they form a vertical, elongated oval figure. Between the ribs there are fine cross-ribs and numerous pits. The shape of the carapace and the internal features can not be described from the present material. The specimen figured on pl. 40 (fig. 566) is the largest one found and the one with the most distinct sculpture.

Polycope cf. cincinnata differs from $P$. cincinnata in having more numerous and less coarse ribs.

Small specimens of $P$. cf. cincinnata, which resembles $P$. minor n.sp., may be distinguished from the latter by the numerous intercostal pits.

Distribution. Denmark: Upper part of the $O$. danica Zone and the $O$. adenticulata - N. (N.) simplex Zone; uppermost Upper Sinemurian to Upper Pliensbachian.

Polycope decorata Apostolescu, 1959

Pl. 40, fig. 569.

1959: Polycope decorata Apostolescu, p. 802, pl. I, fig. 3.

1968a: Polycope sp. 880 Christensen, pl. 23, fig. 32.

Material. 1 carapace in a core sample from the Øresund No. 12 boring.

Original diagnosis. "Contour de la carapace subcirculaire. Surface des valves couverte de fortes réticulations triangulaires" (Apostolescu, 1959, p. 802).

Description. See Apostolescu, 1959, p. 802.

Remarks. The reticulation is strong, especially in the central part of the lateral surface. The ribs form a more or less regular pattern of polygons, which are large centrally and smaller marginally. The polygons may be subdivided into triangles by finer ribs.

The rather coarse and strong reticulation distinguish this species from $P$. cerasia.

Distribution. Denmark: The G. apostolescui - K. (K.) foveolata Subzone; Lower Pliensbachian.

France: The E. raricostatum Zone to the $P$. davoei Zone; upper Lotharingian to Pliensbachian (Viaud, 1963).

Polycope minor n.sp.

Pl. 38, figs. 546-547; pl. 39, figs. 555-562.

1968a: Polycope sp. 851 Christensen, pl. 23, fig. 6.

1970: Polycope No. 4065 Michelsen, p. 49, pl. XII, figs. 6a-b.

Derivation of the name. From minor = smaller, referring to the small size of this species. 
Holotype. A carapace. D.G.U. catalogue No. 1973-OM-266. P1. 39, figs. $555-556$.

Type locality. The Rødby No. 1 boring.

Type stratum. Sample No. 20. Dark grey clay interbedded with silt. The $O$. aspinata Zone; Hettangian.

Material. 74 carapaces and 8 valves in core samples from the Gassum No. 1, Horsens No. 1, Rødby No. 1, Vinding No. 1, Øresund Nos. 8 and 9 borings.

Diagnosis. A small species of the genus Polycope with a subcircular outline; the anteroventral part slightly protuberant. The sculpture consists of fine, subconcentric ribs, which converge towards the ventral margin. The sculpture is distinct marginally and very faint centrally.

Description. See Michelsen, 1970, p. 49.

Measurements. For the majority of the specimens the state of preservation is so bad that they are not measurable. Measurements of eight specimens from Rødby No. 1 are given in Michelsen (1970, p. 50).

Remarks. Unfortunately the internal features of this species are only partly known. Although no observations have been made of the marginal zone most of the specimens mentioned above are considered to be adults of a new species, which cannot be confused with any known species. The small size and the very fine sculpture separate $P$. minor from other Polycope-species.

It must be emphasized that the sculpture, which in Michelsen (1970) is described as consisting of furrows, has later on been shown by means of the scanning electron microscope to consist of fine ribs (cf. pl. 39, fig. 556).

A few specimens recorded from Vinding No. 1 differ slightly from the holotype. They are a little larger and the sculpture is more irregular. Furthermore, very fine ribs occur in the intercostal areas (cf. pl. 39, fig. 560). These specimens may possibly belong to another species, but the mentioned differences may also be due to the state of preservation or the environmental conditions. Until more material is available they are referred to $P$. minor.

Distribution. Denmark: Upper part of the $O$. aspinata Zone to the $P$. reticulata Subzone; Hettangian to lower Upper Sinemurian.

Polycope pelta Fischer, 1961

Pl. 40, figs. 570-573.

1938: Ostracode (227) Wicher, pl. 27, fig. 4.

1961b: Polycope pelta Fischer, p. 499, fig. 1 (Mitte). 
Material. 2 deformed carapaces in a core sample from the Fjerritslev No. 1 boring. -4 well-preserved carapaces in cuttings samples from the Dansk Nords $\varnothing$ J-1 and Rønde No. 1 borings.

Original diagnosis. "Eine Art der Gattung Polycope mit folgenden Besonderheiten: Rostralincisur fehlt, die Skulptur ist auf einen Randstreifen beschränkt und mit zarten, radiären Leistchen versehen. Randzähne fehlen" (Fischer, 1961b, p. 499).

Description. See Fischer, 1961b, p. 499.

Remarks. The present specimens have a sculpture similar to Ostracode (227) Wicher, 1938. The photograph of Polycope pelta given by Fischer (1961b) does not clearly illustrate the sculptural features of the holotype; nor is his description unambiguous. As his specimens are synonymous with the specimen figured by Wicher, the sculpture of the holotype ( $P$. pelta) is supposed to consist of obliquely radial ribs, which do not cover the central part of the valve.

Plumhoff (1963) published two species of the genus Polycope: P. pelta Fischer and $P$. cf. maculata G. W. Müller. His description of $P$. pelta shows a sculpture as on Ostracode (227) Wicher and as on the present specimens. On his photograph Plumhoff (1963, pl. 1, figs. 1-2) shows specimens with a stronger and coarser sculpture although they are smaller than Ostracode (227) Wicher (and P. pelta). The other species published by Plumhoff (Polycope cf. maculata) has a sculpture and size similar to Ostracode (227) Wicher, but it differs in having a net-like sculpture anteriorly (cf. Plumhoff, 1963, p. 18). It is uncertain whether either of these species is identical with $P$. pelta Fischer, 1961.

Polycope pelta may be accepted as clearly defined by the description of Fischer (1961b, p. 499) and the photograph of Wicher (1938, pl. 27, fig. 4).

Distribution. Denmark: The middle subzone of the $O$. danica Zone and the $O$. adenticulata $-N$. (N.) simplex Zone; Upper Sinemurian and Upper Pliensbachian.

Southern Germany: "Lias Delta an bis zur Lias/Dogger-Grenze" (Fischer, 1961b, p. 500).

Polycope sp. 4044

Pl. 40, fig. 564.

Material. 1 carapace in a core sample from the Gassum No. 1 boring.

Remarks. This specimen is characterized by an oval outline in lateral view, with the anterior margin strongly extended ventrally. The lateral surface has $10-15$ branching ribs, parallel to the long axis of the oval. 
This specimen does not resemble any known species and may possibly be a new species.

Distribution. Denmark: Uppermost in the O. aspinata Zone; Lower Sinemurian.

Polycope sp. 4181

Pl. 40, fig. 567.

Material. 4 carapaces and 1 valve in core samples from the Børglum No. 1, Gassum No. 1, and Haldager No. 1 borings.

Remarks. This species has the same shape of carapace as Polycope cerasia, but it is smaller than the latter and it has a different reticulation.

The reticulation consists of numerous pits, more or less regularly concentrically arranged. The marginal area does not have a thickened rim with a different sculpture as on $P$. cerasia.

As only two of the specimens are sufficiently well-preserved to form a basis for defining an independent species, this form is here given with open nomenclature.

Distribution. Denmark: The G. apostolescui - K. (K.) foveolata Subzone (and the $O$. adenticulata $-N$. (N.) simplex Zone ?); Lower Pliensbachian (and Upper Pliensbachian?).

Polycope sp. 4197

Pl. 40, fig. 568.

1968a: Polycope sp. 816 Christensen, pl. 23, fig. 54.

Material. 2 carapaces in core samples from the Gassum No. 1 and Øresund No. 3 borings.

Remarks. Polycope sp. 4197 is characterized by an oval outline in lateral view. The sculpture consists of a few very strong ribs parallel to the long axis of the oval. Between the ribs there are fine cross-ribs.

Polycope sp. 4197 has less ribs than Polycope discus Fischer (1961b, p. 497). The present species also has a well-defined rib conforming to the margin.

P. sp. 4197 is possibly identical with Polycope cf. cincinnata Apostolescu sensu Viaud (1963, pl. I, fig. 2).

As Polycope sp. 4197 is not a well-defined species it is here given with open nomenclature.

Distribution. Denmark: The O. adenticulata - N. (N.) simplex Zone; Upper Pliensbachian. 
Unknown genus and family

Ostracod Nr. 103 Klingler, 1962

Pl. 38, fig. 548.

1962: Ostracod Nr. 103 Klingler, p. 96, pl. 13, fig. 29.

Material. 1 fragment in a core sample from the Øresund No. 14 boring, - and 2 carapaces in cuttings samples from the Rønde No. 1 boring.

Description. See Klingler 1962, p. 96.

Remarks. The specimens figured by Viaud (1963, pl. V, fig. 121 as Krausella? sp. 101) and by Oertli \& Grosdidier (1961, pl. VI as Krausella ? sp. 101 ("Ostracoda K" Apostolescu, 1959)) have a posteroventral spine on the right valve and may be identical with Ostracod Nr. 103 Klingler and not with Ostracod sp. K Apostolescu.

The external features are very much like those of the genus Krausella Urlich, 1894, but as the internal characters are unknown this species cannot be referred to any genus with certainty.

Distribution. Denmark: The middle subzone of the $O$. danica Zone (?); Upper Sinemurian.

Germany: Lias Gamma and lower part of Lias Delta (Klingler, 1962).

France: The $A$. semicostatum Zone to the $P$. spinatum Zone; Sinemurian to Domerian (Oertli \& Grosdidier, 1961 and Viaud, 1963).

Ostracod sp. K Apostolescu, 1959

Pl. 38, fig. 549.

1959: Ostracoda K Apostolescu, p. 817, pl. IV, figs. 75-76.

1968a: Ostracod sp. 893b Christensen, pl. 23, fig. 46.

Material. 5 carapaces and 1(?) left valve in core samples from the Fjerritslev No. 2 and $\emptyset$ resund No. 12 borings.

Remarks. Only three (carapaces) of the specimens are well-preserved and only one is a possible adult. They have been compared with type material of Ostracod K Apostolescu deposited with H. J. Oertli (Pau, France).

Ostracod K Apostolescu resembles Ostracod Nr. 103 Klingler, but differs from the latter in lacking the posteroventral spine. As the two species are of the same size, they must be regarded as separate species and not be combined as in Oertli \& Grosdidier (1961, pl. VI).

This species cannot with certainty be referred to any genus as the internal features not are known. It might belong to Krausella Urlich, $1894-$ see also Ostracod Nr. 103. 
Distribution. Denmark: The G. apostolescui - K. (K.) foveolata Subzone and the $O$. adenticulata $-N$. (N.) simplex Zone; Lower and Upper Pliensbachian.

France: The $U$. jamesoni Zone and the $T$. ibex Zone; Pliensbachian (Apostolescu, 1959). 


\section{Acknowledgements}

The work forming the basis for this paper was carried out (with a few interruptions) in the period 1966-1973, as part of my work for the Department of Subsurface Geology at the Geological Survey of Denmark. I am very grateful to the director, dr.phil. Ole Berthelsen, and chief geologist, dr.phil. Leif Banke Rasmussen for the favourable working conditions I have had there. I should like to thank chief geologist, dr.phil. Leif Banke Rasmussen for encouragement and energetic support for the carrying out of the project, and mag.scient. Ole Bruun Christensen for good help and advice. I thank director, dr.phil. Ole Berthelsen for permission to use this work as a doctoral thesis.

The friendly helpfulness of Dr. H. J. Oertli (Pau, France) and Dr. H. Malz (Frankfurt a.M., Germany) enabled me to make study visits in order to compare Danish material with type material and ostracod faunas from the French Lower Jurassic, and with type material preserved in the "Forschungsinstitut Senckenberg" respectively. The "Gewerkschaften Brigitta und Elwerath Betriebsführunggesellschaft mbH" (Hannover, Germany) kindly placed a number of paratypes of "Procytheridea" species at my disposal for comparative studies. French type material sent by Dr. $H . J$. Oertli and English type material sent by Dr. Alan Lord has also been of great value. My heartiest thanks go to these colleagues who in this way have helped to increase the certainty of identification of the individual species.

I should also like to thank my Danish colleagues for similarly placing material at my disposal. Cand.mag. Inger Bang and mag.scient. Arne Buch have provided material collected in England, and cand.scient. Finn Bertelsen, mag.scient. Ole Bruun Christensen and cand.mag. Erik Stenestad have provided material from Skåne and Bornholm.

Much painstaking assistance has been given me by a large number of co-workers: Thomas Eriksen, Alice Hendriksen and Inger Lise Nielsen resuspended many of the samples; Yvonne Husfeldt, Katalin Jessen and Margrethe Poulsen assisted in sorting and collecting fossils from the samples; Kirsten Andersen, Helle Christensen, Inge Martin-Legéne and Evy Michelsen produced the drawings; Vibeke Hermansen typed the fair copy of the manuscript; Ove Neergaard Rasmussen did the photography and, together 
with Irma Christiansen, the dark-room work; a number of the scanning electron micrographs were taken by $J$. Fuglsang Nielsen and $A$. Nфrgård Jensen (Institute of Historical Geology and Palaeontology, University of Copenhagen); and cand.scient. Mike Robson corrected my English manuscript.

My heartiest thanks go to all those mentioned above, together with all those not mentioned here, who assisted me with discussion, information, and comments.

The English manuscript was completed in December 1973.

Geological Survey of Denmark

Thoravej 31

DK-2400 København NV

Denmark. 


\title{
Dansk sammendrag
}

\author{
Nedre jura biostratigrafi og ostracoder \\ i det Danske Sænkningsområde
}

For mindre end et halvt århundrede siden var nedre jurassiske aflejringer $\mathrm{i}$ Danmark kun kendt fra Bornholm. Boringer udført i forbindelse med eftersøgningen af olie i Danmarks undergrund har i mellemtiden fremskaffet en lang række oplysninger om opbygningen af den prækvartære lagserie. 27 af disse boringer, samt 9 boringer udført i Øresund i geoteknisk фjemed, er ført ned i eller igennem den nedre jurassiske lagserie og udg $\varnothing \mathrm{r}$ et fyldigt materiale vedrørende dens opbygning, mægtighed og geografiske udbredelse. Det er således kendt at aflejringerne er begrænset til det Danske Sænkningsområde. Dette bassin er mod sydvest strukturelt begrænset af Ringk $\varnothing$ bingFyn Højderyggen og mod nordøst af den Fennoscandiske Randzone; i sydøst står bassinet i forbindelse med det Polske Bassin og i vestnordvest med det Norsk-Danske Bassin (cf. text-fig. 1, p. 7).

Forekomsten af nedre jurassiske aflejringer i det Danske Sænkningsområde er første gang nævnt af Nørvang (1946). En beskrivelse af lagserien i flere boringer, inklusiv en stratigrafisk inddeling baseret på analyser af henholdsvis megafossiler og foraminiferer, er publiceret af Gregersen \& Sorgenfrei (1951) og Nørvang (1957). Alle boringer udført af Danish American Prospecting Company er beskrevet og lagserien er kronostratigrafisk inddelt af Sorgenfrei \& Buch (1964); de mesozoiske sedimenter er analyseret af Larsen (1966). Boringerne fra det sidste tiår er udført af Dansk Undergrunds Consortium og findes beskrevet hos Rasmussen (1972) og Rasmussen et al. (1971 og 1973). Endelig skal det fremhæves at ovennævnte geotekniske boringer udført i Øresund er beskrevet i Larsen et al. (1968).

Den foreliggende afhandling omfatter en beskrivelse af de nedre jurassiske ostracoder og ostracodfaunaer i det Danske Sænkningsområde, samt en biostratigrafisk inddeling af lagserien. Det har været hensigten at definere en biostratigrafisk zonering baseret på en mikrofossilgruppe (ostracoder), der forekommer i tilstrækkelige mængder i de relativt små prøver, der fås fra boringer. Den definerede zonering er anvendelig indenfor hele det Danske Sænkningsområde og danner grundlaget ved en korrelation med aflejringer 
andre steder i Nordeuropa. Undersøgelsen er baseret på materiale fra de ovennævnte boringer og på materiale fra tre ikke tidligere publicerede Nordsø boringer. Den geografiske placering af boringerne er vist på fig. 1 (p. 7).

\section{Lithostratigrafi}

Larsen (1966) har lithostratigrafisk inddelt den overvejende del af den mesozoiske lagserie i formationer. Af disse er Fjerritslev Formationen den vigtigste $\mathrm{i}$ forbindelse med nærværende arbejde. Den er defineret som bestående af overvejende mørkfarvede, marine lersten eller skifre; den mest fuldstændige udvikling af formationen findes i bassinets centrale og nordlige del. Den meget ensartede lerstensserie indeholder mindre interkalationer af sandsten og siltsten i dens $\phi$ verste og nederste del, og den $\emptyset$ vre del af formationen kan yderligere udskilles som værende mere finkornet end den underliggende og oftest af grønlig farve.

Under Fjerritslev Formationen findes i Nord- og Midtjylland deltaiske aflejringer defineret som Gassum Formationen, medens der mod sydvest findes marine lag defineret som Vinding Formationen. I den sydligste del af bassinet underlejres Fjerritslev Formationen af deltaiske aflejringer benævnt Ullerslev Formationen. De marine aflejringer i Fjerritslev Formationen afløses og overlejres af deltaiske aflejringer defineret som Haldager Formationen.

På grundlag af tidligere undersøgelser af megafossiler og foraminiferer er den overvejende del af Fjerritslev Formationen henført til lias, medens Gassum Formationen, Vinding Formationen og Ullerslev Formationen er henført til rhaet; den $\varnothing v$ re del af den grønlige serie i Fjerritslev Formationen er sammen med Haldager Formationen bestemt til dogger (se Sorgenfrei \& Buch, 1964 og Larsen, 1966).

De foreliggende unders $\emptyset$ gelser af ostracodfaunaerne har vist at den nedre grænse for nedre jura i den sydlige, sydvestlige og centrale del af bassinet er sammenfaldende med Fjerritslev Formationens nedre grænse (hvilket er i overensstemmelse med tidligere unders $\emptyset$ gelser). I den nordlige del af bassinet er det derimod påvist at også dele af eller hele Gassum Formationen skal henføres til nedre jura. Nye fund af reducerede ostracodfaunaer i den $\varnothing$ verste del af Fjerritslev Formationen og i den nederste del af Haldager Formationen har sandsynliggjort, at grænsen mellem nedre og mellem jura skal placeres ved eller over formationsgrænsen.

Aflejringerne i Øresund området er lithologisk afvigende fra de ovenfor beskrevne. G. Larsen har i Larsen et al. (1968) på dansk givet en grundig beskrivelse af sedimenterne og en lithostratigrafisk inddeling $\mathrm{i}$ overensstemmelse med inddelingen af de tilsvarende aflejringer i Skåne. Der er i fore- 
liggende afhandling ingen afvigelse fra Larsen's lithostratigrafiske inddeling, bortset fra at lagserien i boringen Øresund nr. 2 her henføres til Rydebäck Lagene i overensstemmelse med Norling (1972).

\section{Biostratigrafi}

Det prøvemateriale, der danner grundlaget for den biostratigrafiske inddeling af nedre jura i det Danske Sænkningsområde, omfatter tre kategorier af prøver. De enkelte ostracodarters relative repræsentation, samt faunaernes relative størrelse, er beskrevet ved kvantitativt behandlede kærnepr $\varnothing$ ver (cf. tabellerne 1-13). Som grundlag for vurdering af de enkelte arters vertikale udbredelse og for beskrivelse af faunaernes totale sammensætning (se text-fig. 2, p. 44) er yderligere benyttet et større antal kvalitativt behandlede kærneprøver. Som den tredie kategori er skylleprøver benyttet, og først og fremmest i de boringer hvor kærnemateriale ikke har været til rådighed ved analysen. Skylleprøverne er grundet prøvetagningsteknikken at betragte som kvalitative, til trods for at de præparationsteknisk behandles kvantitativt.

Den stratigrafiske inddeling af lagserien er i nærværende afhandling baseret på definitionen af nedennævnte ostracodzoner og -subzoner. En sammenstilling af denne biostratigrafiske inddeling med den lithostratigrafiske og den kronostratigrafiske er for de enkelte profiler vist i text-fig. 3-21.

Ogmoconchella aspinata Zonen. Denne zone er defineret i boringen R $\varnothing \mathrm{dby}$ nr. 1 (se Michelsen, 1970), og er yderligere fundet i kærner fra boringerne Gassum nr. 1, Horsens nr. 1, Vedsted nr. 1 og Vinding nr. 1.

Den kvantitative fremstilling af $O$. aspinata faunaen findes i tabellerne $1-4,8$ og 13. Aflejringerne tilh $\varnothing$ rende denne zone er gennemgående fossilrige, og ostracodfaunaen er meget veldefineret. Faunasuccessionen giver mulighed for en opdeling af zonen i en nedre og en $\varnothing$ vre del, samt for en korrelation af lagserien til hettangien og nedre del af nedre sinemurien. Denne stratigrafiske bestemmelse støttes af forekomsten af ammonitterne Psiloceras sp., $S$. angulata og $O$. sinemuriensis i Gassum serien.

Cristacythere betzi - Cristacythere crassireticulata Zonen. Den er defineret i boringen Gassum nr. 1 og er yderligere fundet i kærnemateriale fra boringerne Øresund nr. 8, 9 og 14.

Tabellerne 3 og 5 indeholder den kvantitative fremstilling af faunaen, der skarpt adskiller sig fra den underliggende $O$. aspinata fauna og den overliggende $P$. reticulata fauna. Den stratigrafiske korrelation af zonen til $\phi v r e$ del af nedre sinemurien er baseret på tilstedeværelsen af ostracodarten 
$C$. betzi og underbygget af faunaens forekomst mellem $O$. aspinata faunaen og $P$. reticulata faunaen.

Ogmoconchella danica Zonen. Også denne zone er defineret i boringen Gassum nr. 1, og den er yderligere registreret i kærneborede afsnit i boringerne Børglum nr. 1, Fjerritslev nr. 2, Frederikshavn City nr. 2 og Øresund nr. $9,10,11,12,14$ og 15. Zonen er opdelt i tre subzoner, hvoraf den nedre og den $\varnothing v r e$ er oprettet som formelle subzoner, medens faunaen i den midterste subzone er for dårligt kendt til at det på nuværende tidspunkt er anset for forsvarligt at definere denne.

Progonoidea reticulata Subzonen, der er den nederste indenfor O. danica Zonen, er defineret i Gassum nr. 1 og forekommer yderligere i Fjerritslev nr. 2 og Øresund nr. 9, 10 og 14 (cf. tabellerne 5-8). Den veldefinerede ostracodfauna danner basis for en korrelation til nederste $\varnothing$ vre sinemurien (lias beta-1a).

Den mellemste subzone er i sin helhed kun fundet i Gassum profilet (cf. tabel 7). I enkelte intervaller udgøres ostracodfaunaen kun af få arter og forefindes i vekslende bevaringstilstand. Den successive forekomst af en række arter, der er typiske for dele af det tyske lias beta, danner grundlaget for en korrelation til $\emptyset$ vre sinemurien og en inddeling af Gassum serien $\mathrm{i}$ lias beta-1b, 2 og 3. Bestemmelsen af lagseriens nederste del til lias beta-1b støttes af forekomsten af ammonitten $P$. planicosta.

Gramannella apostolescui - Kinkelinella (Klinglerella) foveolata Subzonen omfatter den $\emptyset$ verste del af $O$. danica Zonen. Den meget velbevarede og omfattende fauna, der forekommer i boringen Øresund nr. 12, danner basis for definitionen af $G$. apostolescui $-K$. $(K$.) foveolata faunaen (se tabellerne 7, 9 og 10). Tiltrods for at der ikke er beskrevet en tilsvarende fauna fra Nordvesteuropa kan denne subzone korreleres med nedre pliensbachien på grundlag af de enkelte arters kendte stratigrafiske range. Denne bestemmelse støttes af forekomsten af ammonitten $A$. capricornus i Gassum profilet.

Ogmoconchella adenticulata - N. (Nanacythere) simplex Zonen. Denne zone er ligeledes defineret i boringen Gassum nr. 1, og den $\emptyset$ vre del af zonen er yderligere registreret i kærneborede afsnit i boringerne Børglum nr. 1, Fjerritslev nr. 1 og 2, Flyvbjerg nr. 1, Frederikshavn City nr. 2, Haldager nr. 1, Vedsted nr. 1 og Øresund nr. 3.

Den meget veldefinerede ostracodfauna danner grundlaget for korrelation med $\emptyset v r e$ pliensbachien (cf. tabellerne 4, 8 og 10-13). Denne stratigrafiske bestemmelse st $\emptyset$ ttes af forekomsten af indexfossilerne A. margaritatus og P. spinatum i Gassum profilet. Parallelt med den successive fore- 
komst af disse to ammonitter indicerer ostracodfaunaen i samme boring en mulig opdeling i to subzoner.

I boringen $\emptyset$ resund nr. 2 er der fundet en arts- og individfattig ostracodfauna, der indicerer aflejringer af aalenien alder. Enkelte elementer af denne fauna er yderligere fundet $\emptyset$ verst i Fjerritslev Formationen i boringen Vedsted nr. 1 og nederst i Haldager Formationen i boringerne Haldager nr. 1 og Rønde nr. 1. Den grønlige lersten $\emptyset$ verst i Fjerritslev Formationen, hvorfra der ikke hidtil med sikkerhed er fundet fossiler, har hermed vist sig beliggende mellem lag med en veldefineret pliensbachien fauna og lag med en mulig aalenien fauna. Denne fossilfrie lerstensserie er derfor her foreslået henført til toarcien-aalenien og sidestillet med den tyske Posidonienschifer.

\section{Bassinudviklingen}

På baggrund af tidligere beskrivelser af sedimenter, foraminiferer og megafossiler, samt den detaljerede inddeling af den nedre jurassiske lagserie der er opnået gennem nærværende unders $\emptyset$ gelse, kan sedimentationsforl $\varnothing$ bet og bassinudviklingen kortfattet beskrives.

En oversigt over faciesfordelingen er givet på kortet (text-fig. 24, p. 105), der er sammenstillet på grundlag af kort publiceret af Sorgenfrei (1963, tvl. II, fig. 2) og Larsen (1966, fig. 46). Søjlerne repræsenterer faunaudviklingen $\mathrm{i}$ de enkelte boreprofiler, idet det relative antal af arter i de enkelte ostracodzoner eller -subzoner er fremstillet ved den horisontale akse. Den vertikale akse er uafhængig af lagseriens mægtighed, der derimod er udtrykt i tal under søjlerne. Som generelle træk kan det fremhæves at størstedelen af området dækkes af lerede, marine sedimenter; kun langs den nord$\emptyset$ stlige og $\varnothing$ stlige margin af bassinet findes sandede, ofte deltaiske aflejringer. Centralt i bassinet findes lagmægtigheder op til $980 \mathrm{~m}$ (i Fjerritslev området) og i Øresund området mere end $500 \mathrm{~m}$, medens mægtigheden i de marginale områder er mindre end $300 \mathrm{~m}$.

En regional zone langs Ringk фbing-Fyn Højderyggen (inkl. lokaliteterne Vinding, Slagelse (?) og Rødby) må antages at have været dækket af havet ved overgangen til nedre jura. $O$. aspinata Zonens tykkelse og faunaens karakter viser, at de centrale dele af bassinet dækkedes af havet tidligt i hettangien. Der aflejredes både her og mod sydvest ensartede, marine lersten, medens de marine aflejringer mod syd (i Rødby og Ørslev områderne) veksler med sandede, deltaiske aflejringer. På Bornholm indeholder den Nedre Kulførende Serie kun mindre marine interkalationer (Gry, 1969 og Sellwood, 1972). I Øresund området viser Hälsingborg Formationen og Döshult Formationen en udvikling fra deltaisk til littoral facies (Larsen, 
1968). Forekomsten af $O$. aspinata faunaen i Gassum Formationen i Flyvbjerg serien indicerer marine indslag i denne ellers deltaiske lagserie. I dele af Nordjylland er denne deltaiske serie således samtidig med de marine, lerede aflejringer centralt og sydvestligt i bassinet og må, ligesom de deltaiske og littorale aflejringer i Øresund området og på Bornholm, henføres til hettangien og nedre sinemurien.

$C$. betzi $-C$. crassireticulata Zonen er den ældste ostracodzone der er konstateret i Øresund området, medens den midterste del af $O$. danica Zonen tilsvarende er den ældste i det nordligste Jylland. Disse biostratigrafiske indikationer er sammenfaldende med overgangen fra de overvejende sandede til de lerede aflejringer. I begge områder indicerer fund af megafossiler dog marint nedre sinemurien i dele af de underliggende sandede aflejringer. I $\varnothing v$ re del af nedre sinemurien er der således aflejret mørkfarvede lersten i Øresund området og i størstedelen af bassinet. Der findes ingen aflejringer af denne alder i Rødby, men derimod i den nærliggende boring Ørslev nr. 1. Samtidig med den udstrakte aflejring af disse marine lersten er der på Bornholm og i det nordligste Jylland afsat kystnære sandede sedimenter.

Aflejringen af marine lersten i $\emptyset v$ re sinemurien er udbredt i hele bassinet. I den nordligste del af Jylland er disse de ældst forekommende, medens de ved enkelte lokaliteter langs Ringkøbing-Fyn Højderyggen er de yngst kendte aflejringer fra nedre jura. Lagserien i Øresund området viser forekomsten af facielle ændringer, idet non-marine lag forekommer indlejret enkelte steder i serien. Også faunaen, svarende til nedre del af $O$. danica Zone, indicerer svingninger i de $\emptyset$ kologiske betingelser, såvel vertikalt som horisontalt i lagserien. Det bør således nævnes at en omfattende del af Øresund serien er fossilfri og antageligt aflejret i et miljø med ugunstige kår for den benthoniske fauna.

Ved overgangen til nedre pliensbachien bliver sedimenterne mere siltholdige, især i Øresund området og i Nordjylland, og ostracodfaunaen ( $G$. apostolescui - K. (K.) foveolata faunaen) er meget individ- og artsrig sammenlignet med faunaen i den underliggende del af $O$. danica Zonen. Sammenholdt med forekomsten af de udprægede marine aflejringer på Bornholm anses disse ændringer i såvel de lithologiske som de faunistiske forhold at være influeret af en omfattende transgression i denne periode. Aflejringerne er udbredt i hele bassinet, bortset fra enkelte lokaliteter nær Ringkøbing-Fyn Højderyggen (se text-fig. 24, p. 105).

Ved overgangen til $\emptyset$ vre pliensbachien er der ikke konstateret regionale forskydninger indenfor det Danske Sænkningsområde. Sedimenterne bliver gennemgående mere finkornede, og faunaen $(O$. adenticulata $-N$. (N.) simplex faunaen) er både arts- og individrig. Sammenlignet med den under- 
liggende subzone indicerer både de lithologiske og de faunistiske forhold et miljø med et lavere energiniveau. Aflejringerne i $O$. adenticulata $-N$. (N.) simplex Zonen er udbredt i hele bassinet ligesom G. apostolescui $-K$. (K.) foveolata Subzonens.

Marine aflejringer af aalenien alder er påvist ved en arts- og individfattig fauna i boringen Øresund nr. 2 i overensstemmelse med tidligere unders $\varnothing$ gelser fra Sydsverige. Stærkt reducerede faunaer, af formodentlig samme alder, er fundet på grænsen mellem Fjerritslev Formationen og Haldager Formationen i tre boringer i Nord- og Midtjylland. Det afsnit af Fjerritslev Formationen der ligger mellem pliensbachien aflejringerne og aflejringerne af en mulig aalenien alder er her foreslået henført til toarcien-aalenien og sideordnet med Rydebäck Lagene og Posidonienschifer. Disse grønlige, ret fede lersten er formodet aflejret $\mathrm{i}$ et marint miljø med ugunstige kår for den benthoniske fauna. De findes i Nordjylland og i Midtjylland (Rønde nr. 1). I Øresund området viser de tilsvarende aflejringer en større vekslen i facies og afbrydelser af sedimentationen. I området langs Ringk $\emptyset$ bing-Fyn Højderyggen er tilsvarende aflejringer ikke konstateret.

\section{Palceontologi}

I dette kapitel er de fundne 124 ostracodarter beskrevet. Af disse er 71 tidligere blevet beskrevet, medens 23 er beskrevet som nye arter. De resterende 30 kan ikke henføres til kendte arter og er beskrevet med åben nomenklatur grundet et begrænset eller dårligt bevaret materiale.

Arterne fordeler sig på 27 slægter og underslægter, af hvilke 2 slægter og 1 underslægt er beskrevet som nye i nærværende arbejde.

Karakteristiske eksemplarer af de enkelte arter er afbildet på tavlerne 1-40 sidst $\mathrm{i}$ afhandlingen. Ved fotograferingen er der dels benyttet et lysmikroskop og dels et scanning elektron mikroskop. Det førstnævnte er velegnet til gengivelse af skallernes form og omrids, idet det er muligt at fotografere objektet fra flere sider. Ved scanning elektron mikroskopet fås derimod præcise gengivelser af skulptur, overfladerelief, interne strukturelementer og især af meget små detaljer. De to former for fotograferingsteknik er derfor anset for lige værdifulde og som supplerende hinanden. 


\section{Index of species, subgenera and genera}

The names of the species, subgenera and genera described in the present paper are printed in Italics; all synonyms in Roman types.

\begin{tabular}{|c|c|c|}
\hline there & 2 & chi, Lopho \\
\hline acuticostata, Procytheridea... & 216 & bachi, Nanacythere? .......... \\
\hline acuticostata, Progonoidea .. & 216 & Bairdia \\
\hline adenticulata, Hungarella & 233 & betzi, Cristacythere. \\
\hline adenticulata, Ogmoconcha & 233 & betzi, Procytheridea \\
\hline adenticulata, Ogmoconcha & 236 & bipartita, Kinkelinella (Klinglerella) \\
\hline adenticulata, Ogmoconchella ..... & 233 & bipartita, Procytheridea ....... \\
\hline adunca, Kinkelinella (Kinkelinella) & & bispinosa, Healdia \\
\hline aff. & 179 & bispinosa, Ogmoconcha $\ldots \ldots \ldots$ \\
\hline adunca, Procytheridea & 179 & bispinosa, Ogmoconchella ........ \\
\hline $\begin{array}{l}\text { aequabilis, Macrocypris (Macro- } \\
\text { cypris) } \quad ? \ldots \ldots \ldots \ldots \ldots \ldots \ldots\end{array}$ & 131 & bispinosa, Pseudohealdia? \\
\hline aequalis, Ogmoconcha & 236 & Camptocythere \\
\hline requalis, Ogmoconchella ......... & 236 & carinata, Bairdia cf. .......... \\
\hline amalthei amalthei, Ogmoconcha .. & 225 & cavatum, Cytheropteron? ........ \\
\hline (amalthei, Bairdia) & 225 & cerasia, Polycope ........... \\
\hline amalthei circumvallata, Ogmo- & & cerasia, Polyc \\
\hline concha ........... & 227 & cincinnata, Polycope \\
\hline amalthei form A, Ogmoconcha .... & 228 & cincinnata, Polycope ct. ......... \\
\hline amalthei intercedens, Ogmoconcha. & 227 & circumcostata, Nanacythere (Gonio- \\
\hline amalthei, Ogmoconcha & 225 & \\
\hline amalthei, Ogmoconcha $\ldots . . \ldots \ldots$ & 229 & contractula, Ogmoconcha \\
\hline amalthei rotunda, Ogmoconcha ... & 228 & contractula, Ogmoconcha \\
\hline amlingstadtensis, Monoceratina ... & 138 & costata, Cristacythere .......... \\
\hline angusta, Trachycythere ......... & 220 & crassireticulata, Cristacythere ..... \\
\hline apostolescui, Gramannella ....... & 172 & 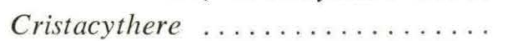 \\
\hline apostulescui, Procytheridea ? & 172 & Cytheropteron \\
\hline apostulescui, Procytheridea? aff. & & Cytherura .... \\
\hline & 172 & \\
\hline apostulescui, Procytheridea ? cf. P. ? & 197 & danica, Ogmoconchella \\
\hline aspinata, Healdia & 238 & decorata, Polycope .............. \\
\hline aspinata, Hungarella & 238 & (Domeria), Nanacythere ......... \\
\hline aspinata, Ogmoc & 238 & \\
\hline (Progonoidea) & 217 & ere \\
\hline auleata, Progonoi & 217 & elegans, Lophocythere \\
\hline
\end{tabular}


elegans, Nanacythere (Goniocythere) 204

ellipsoidea, Bairdia (?) . . . . . 238

ellipsoidea, Cytheridea ......... 238

ellipsoidea, Ogmoconcha ....... 238

ellipsoidea var, reducta, Cytheridea 238

elongata, Bairdia ............ 124

elongata, Bythocypris cf. ....... 126

elongata, Isobythocypris aff. ..... 125

elongata, Isobythocypris cf....... 124

elongata, Isobythocypris cf. ...... 126

elongata, ? Isobythocypris ....... 124

elongata, ? Isobythocypris ....... 126

elongata, Kinkelinella (Klingerella) ? 194

elongata, Nanacythere (Gonio-

cythere) .............. 206

elongata, Pontocyprella ......... 124

firma, Nanacythere (Domeria) ... 199

fissicosta, Nanacythere (Domeria). 200

foveolata, Kinkelinella (Klinglerella) 189

foveolatum, Cytheropteron ? ..... 145

Fuhrbergiella ............... 152

fusiformis, Monoceratina ? ...... 139

fusiformis, Paradoxostoma ? ..... 139

fusiformis, Paradoxostoma ? cf. P. ? 150

gassumensis, Acrocythere ........ 153

glabellata, Kinkelinella(Klinglerella) 182

glabellata, Procytheridea ........ 182

(Goniocythere), Nanacythere ..... 201

Gramannella ................ 172

grosdidieri, Pseudohealdia ? ..... 252

gruendeli, Ogmoconchella ....... 247

hagenowi, Hungarella ........ 230

hagenowi, Ogmoconcha ......... 230

harpa, Pleurifera ............. 214

harpa, Procytheridea (Pleurifera) .. 214

harpa, Procytheridea (Pleurifera) .. 214

horrida, Trachycythere ........ 221

indet. gen. sp. 4353 .......... 219

intercedens, Ogmoconcha ....... 227

Isobythocypris ............... 124

(Kinkelinella), Kinkelinella ...... 178

Kinkelinella ............... 178

(Klinglerella), Kinkelinella....... 181 laevigata, Gramannella ......... 175

lanceolata, ? Krausella ......... 136

lanceolata, ? Liasina .......... 136

laqueata, Kinkelinella (Klinglerella) 192

laqueata, Procytheridea ........ 192

Liasina . . . . . . . . . . . . . . . 135

liassica, Bairdia ........... 238

medioreticulata, Kinkelinella

(Klinglerella) ............ 183

medioreticulata, Procytheridea .... 183

minor, Nanacythere (Goniocythere) 207

minor, Polycope .............. 261

molesta, Bairdia ............. 121

Monoceratina .............. 138

mouhersensis, "Ogmoconcha" .... 248

"mouhersensis, Ogmoconchella" .. 248

multicostata, Kinkelinella (Klingle-

rella) .................... 186

multicostata, Procytheridea ...... 186

multistriata, Monoceratina ? . .... 140

Nanacythere .............. 196

(Nanacythere), Nanacythere ..... 196

nasuta, Healdia ............ 257

nasuta, ? Pseudohealdia ......... 257

oblonga, Kinkelinella (Kinkelinella) 179

oblonga, Procytheridea ........ 179

oeresundensis, Acrocythere ...... 155

Ogmoconcha ............................. 222

Ogmoconchella ............. 231

Ostracod Nr. $103 \ldots \ldots \ldots \ldots \ldots .265$

Ostracod sp. K. .......... 265

paracostata, Nanacythere (Gonio-

cythere) ................. 209

Paracypris ................ 134

Paradoxostoma ............... 149

pelta, Polycope ............. 262

Pleurifera ................. 214

Polycope .................. 258

praecox, Camptocythere ........ 137

Procytheridea ............. 160

Progonoidea ................. 216

Pseudohealdia .............. 256

Pseudomacrocypris ............ 129

pseudospina, Hungarella ....... 249 
pseudospina, Ogmoconcha ....... 249

pseudospina, Ogmoconchella ...... 249

pumicosa, Polycope .......... 258

pumicosa, Polycope aff......... 258

pusillum, Paradoxostoma ?....... 149

rectangula, Acrocythere ........ 156

redcarensis, Bairdia .......... 134

redcarensis, Paracypris ? ....... 134

redcarensis, ? Paracypris ....... 134

reticulata, Procytheridea ....... 217

reticulata, Progonoidea ......... 217

reticulatum, Cytheropteron ....... 147

roedbyensis, Stenestroemia ? ..... 149

scrobiculata, Monoceratina cf. .... 141

septenaria, Healdia .......... 251

septenaria, Healdia aff. ........ 251

septenaria, Ledahia .......... 251

septenaria, Ogmoconchella ...... 251

septenaria, Pseudohealdia (Ledahia) 251

simplex, Nanacythere (Nanacythere) 196

Stenestroemia ............... 149

subaequabilis, Pseudomacrocypris . 131

subtriangularis, Pseudomacrocypris. 132 subtriangularis, Pseudomacrocypris

aff. .................. 134

sulcata, Kinkelinella (Klinglerella). 187

sulcata, Procytheridea ........ 187

sulcata, Procytheridea aff. P. ... 189

tatei, Gramannella cf. ......... 176

Trachycythere .............. 220

transversa, Hungarella ......... 252

transversa, Ogmoconchella ...... 252

tricostata, Acrocythere ......... 158

triebeli, Kinkelinella (Klinglerella).. 187

triebeli, Kinkelinella (Klinglerella)

cf. ................. 188

triebeli, Klinglerella aff. K. ..... 183

triebeli, Procytheridea .......... 187

truncata, Pseudohealdia ......... 257

tubulosa seratina, Trachycythere .. 222

tubulosa tubulosa, Trachycythere. 221

unispinata, Isobythocypris . .... 127

variabilis, Kinkelinella (Klinglerella) 193

variabilis, Procytheridea ........ 193

vestibulifera, Liasina .......... 136

vulgaris, Procytheridea ....... 187 


\section{References}

Alexander, C. I. 1933: Shell structure of the Ostracode genus Cytheropteron, and fossil species from the Cretaceous of Texas. - J. Paleont., 7 (2), pp. 181-214.

Anderson, F. W. 1964: Rhaetic Ostracoda. - Bull. geol. Surv. Gt Br., 21, pp. 133-174. Apostolescu, V. 1959: Ostracodes du Lias du Bassin de Paris. - Rev. Inst. fr. Pétrole, 14 (6), pp. $795-826$.

Bang, I. 1968: Biostratigrafisk analyse af kerneprøver fra Øresundsboringerne sommeren 1964 på grundlag af foraminiferer. (English summary). - In: Larsen et al. 1968, pp. 63-71 and 86-88.

Bang, I. 1971: Jura aflejringerne i Rønde nr. 1 (2103-2614 m). Biostratigrafi på grundlag af foraminiferer. (English summary). - In: Rasmussen et al. 1971, pp. 74-80.

Bang, I. 1973: Jura-biostratigrafi i Nøvling nr. 1 på grundlag af foraminiferer. (English summary). - In: Rasmussen et al. 1973, pp. 119-123.

Bartenstein, H. \& Brand, E. 1937: Mikro-paläontologische Untersuchungen zur Stratigraphie des nordwest-deutschen Lias und Dogger. - Abh. senckenb. naturforsch. Ges., 439, pp. 1-224.

Bate, R. H. 1963: Middle Jurassic Ostracoda from North Lincolnshire. - Bull. Br. Mus. nat. Hist., Geol., 8 (4), pp. 175-219.

Bertelsen, F. 1970: - In: Bertelsen \& Michelsen 1970.

Bertelsen, F. \& Michelsen, O. 1970: Megaspores and Ostracods from the Rhaeto-Liassic Section in the boring Rødby No. 1, Southern Denmark. - Danm. geol. Unders., II række, 94, $60 \mathrm{p}$.

Bizon, G. \& Oertli, H. 1961: Contributions a l'Étude micropaléontologique du Lias du bassin de Paris. - Colloque sur le Lias francais. Mém. Bur. Rech. géol. minièr., 4, pp. 107-119.

Bizon, J. J. 1960: Sur quelques Ostracodes du Lias du Bassin parisien. - Revue Micropaléont., 2 (4), pp. 203-211.

Blake, M. A. 1876: Crustacea - Foraminifera. - In: Tate \& Blake: The Yorkshire Lias. Pp. 429-435 and 449-473.

Bölau, E. 1954: Rote Tone im Rhät-Lias Schonens. - Geol. För. Stockh. Förh., 76, pp. 215-233.

Bölau, E. 1959: Der Südwest- und Südostrand des Baltischen Schildes (Schonen und Ostbaltikum). - Geol. För. Stockh. Förh., 81, pp. 167-230.

Brady, G. S. 1867: A synopsis of the Recent British Ostracoda. - Intellect. Obs., 12.

Brand, E. \& Fahrion, H. 1962: Dogger NW-Deutschlands. - In: Simon, W. \& Bartenstein, H. (ed.) 1962: Leitfossilien der Mikropaläontologie. Pp. 123-158. - Berlin.

Brand, E. \& Malz, H. 1962: Ostracoden-Studien im Dogger, 4: Fuhrbergiella n.g. Senckenberg. leth., 43 (1), pp. 1-39.

Catt, J. A., Gad, M. A., Le Riche, H. H. \& Lord, A. R. 1971: Geochemistry, micropalaeontology and origin of the Middle Lias ironstones in northeast Yorkshire. Chem. Geol., 8, pp. 61-76. 
Christensen, O. B. 1968a: Biostratigrafisk unders $\varnothing$ gelse af $\phi$ resundsboringerne - overvejende på grundlag af ostracoder. (English summary). - In: Larsen et al., 1968, pp. 53-62 and 81-85.

Christensen, O. B. 1968b: Some Deposits and Microfaunas from the Upper Jurassic in Scania. - Sver. geol. Unders. Afh., Ser. C, 632, 46 p.

Christensen, O. B. 1971a: De yngre jurassiske aflejringer og grænsen jura-kridt i Rønde nr. 1. (English summary). - In: Rasmussen et al. 1971, pp. 68-73.

Christensen, O. B. 1971b: Biostratigrafisk unders $\varnothing$ gelse af trias i R $\varnothing$ nde nr. 1 og triasjura grænseområdet. (English summary). - In: Rasmussen et al. 1971, pp. 89-93.

Christensen, O. B. 1971c: Den stratigrafiske inddeling af præ-zechstein aflejringer i Rønde nr. 1. (English summary). - In: Rasmussen et al., 1971, pp. 119-123.

Christensen, O. B. 1973a: De nedre kretaciske og $\varnothing v$ re jurassiske formationer og ostracodfaunaer i Nøvling nr. 1 (1329-1509 m). (English summary). - In: Rasmussen et al. 1973 , pp. $113-118$.

Christensen, O. B. 1973b: Vinding formationen ( $\varnothing$ vre trias) i Nøvling nr. 1. (English summary). - In: Rasmussen et al. 1973, pp. 132-135.

Code of stratigraphic nomenclature. 1961. - Bull. Am. Ass. Petrol. Geol., 45 (5), pp. $645-665$.

Colloque du Jurassique a Luxembourg, 1962. 1964. - Int. geol. Congr., 948 p.

Colloque sur le Lias francais. 1961. - Mém. Bur. Rech. géol. minièr., 4, 862 p.

Conti, S. 1954: Stratigrafia e paleontologia della Val Solda. - Memorie descr. Carta geol. Ital., 30, pp. 1-248.

Cousin, N. \& Apostolescu, V. 1961: Ostracodes. - In: Cousin, N., Espitalier, J., Sigal, J. \& Apostolescu, V. 1961: Ardennes, région de Mézières (Département des Ardennes). - Colloque sur le Lias francais. Mém. Bur. Rech. géol. minièr., 4, pp. 423 431.

Dean, W. T., Donovan, D. T. \& Howarth, M. K. 1961: The Liassic Ammonite zones and subzones of the north-west European province. - Bull. Br. Mus. nat. Hist., Geol., 4 (10), pp. 438-505.

Dinesen, A. 1960: Dybdeboringer på Sjælland, Lavø nr. 1. - Meddr dansk geol. Foren., 14 , p. 280.

Dinesen, A. 1971: Skyllepr $\varnothing$ vernes dybdeangivelse i Rønde nr. 1. (English summary). - In: Rasmussen et al. 1971, pp. 33-34.

Donze, P. 1966: Ostracodes de 1'Hettangien entre Aubenas et Privas (Ardeche). Trav. Lab. Géol. Univ. Lyon, N. S., 13, pp. 121-139.

Donze, P. 1967: Les ostracodes du sondage de Laneuveville-Devant-Nancy (Lotharingien de la région type). - Sciences Terre, XII, pp. 71-92.

Drexler, E. 1958: Foraminiferen und Ostracoden aus dem Lias a von Siebeldingen/ Pfalz. - Geol. Jb., 75, pp. 475-554.

Dreyer, E. 1965: Mikrofossilien des Rät und Lias von SW-Brandenburg. - Jb. Geol., 1, pp. 491-531. - Berlin, 1965 (1967).

Eleventh Micropalaeontological Colloquium. England 1969.

Ellis, B. F. \& Messina, A. R. 1940 ff: Catalogue of ostracoda. - Am. Mus. Nat. Hist., Spec. Publ.

Fischer, S. 1855: Beitrag zur Kenntniss der Ostracoden. - K. Bayer. Akad. Wiss., München, Math.-Physik. Cl., Abh., 7 (3).

Fischer, W. 1961a: Über die Lias/Dogger-Grenze in Süddeutschland. - Neues Jb. Geol. Paläont. Mh., Jg. 1961, pp. 394-399.

Fischer, W. 1961b: Neue Arten der Ostracoden-Gattung Polycope Sars 1865 aus dem 
oberen Lias (Württemberg). - Neues Jb. Geol. Paläont. Mh., Jg. 1961, pp. 497-501.

Fischer, W. 1963: Neue Arten der Ostracoden-Gattung Procytheridea Peterson 1954 aus dem Oberen Lias Schwabens. - Neues Jb. Geol. Paläont. Mh., Jg. 1963, pp. 295300 .

Geyer, O. F. 1964: Die Typuslokalität des Pliensbachium in Württemberg (Südwestdeutschland). - Colloque du Jurassique a Luxembourg, 1962. Int. geol. Congr., pp. 161-167.

Gramann, F. 1962: Skulptierte Ostracoden aus dem niederrheinischen Lias. - Fortschr. Geol. Rheinld. Westf., 6, pp. 185-198.

Gramann, F. 1963: Liasina n.gen. (Ostracoda) aus dem deutschen Lias. - Geol. Jb., 82, pp. $65-74$.

Gramm, M. N. 1970: Ostracodes of the family Healdiidae from Triassic deposits of Southern Primorye. - In: Triassic invertebrates and plants of East of the USSR. - Acad. Scienc. U.S.S.R., Komorov far East scient. Cent. far East geol. Inst., pp. 37-92. - Vladivostok.

Gregersen, A. \& Sorgenfrei, T. 1951: Efterforskningsarbejdet i Danmarks dybere undergrund. - Meddr dansk geol. Foren., 12, p. 141.

Gründel, J. 1964a: Zur Gattung Healdia (Ostracoda) und zu einigen verwandten Formen aus dem unteren Jura. - Geologie, Jg. 13 (4), pp. 456-474.

Gründel, J. 1964b: Zur Ausbildung und taxionomischen Bedeutung der Narben der zentralen Muskelgruppe in der Unterklasse Ostracoda. - Neues Jb. Geol. Paläont. Mh., Jg. 1964, pp. 577-597.

Gründel, J. 1968a: Zur Gliederung der Familie Healdiidae (Ostracoda) und zu ihrer Stellung innerhalb der Ordnung Podocopida. - Ber. dt. Ges. geol. Wiss. A. Geol. Paläont., 13 (2), pp. 225-232.

Gründel, J. 1968b: Zur Variation der Schliessmuskelnarben bei Ostracoden (demonstriert an jurassischen Vertretern der Healdiidae). - 1968 Proceed. IPU, XXIII Int. geol. Congr., pp. 149-158.

Gründel, J. 1970: Die Ausbildung der Muskelnarben an liassischen vertretern der Healdiidae (Ostrac.). - Freiberger ForschHft., C 256, Paläont., pp. 47-63.

Gründel, J. \& Kozur, H. 1971: Zur Taxonomie der Bythocytheridae und Tricorninidae (Podocopida, Ostracoda). - Monatsber. deutsch. Akad. Wiss. Berlin, 13, pp. 907937.

Gry, H. 1969: Megaspores from the Jurassic of the island of Bornholm, Denmark. Meddr dansk geol. Foren., 19, pp. 69-89.

Hallam, A. 1961: Cyclothems, transgressions and faunal change in the Lias of northwest Europe. - Trans. Edinb. geol. Soc., 18, pp. 125-174.

Hallam, A. 1964: Liassic sedimentary cycles in western Europe and their relationships to changes in sea level. - In: van Straaten, L. M. J. U. (ed.) 1964: Deltaic and shallow marine deposits. - Devs Sedimentol., 1, pp. 157-164.

Herrig, E. 1969a: Ostracoden aus dem Ober-Domérien von Grimmen westlich Greifswald (Teil I). - Geologie, Jg. 18 (4), pp. 446-472.

Herrig, E. 1969b: Ostracoden aus dem Ober-Domérien von Grimmen westlich von Greifswald. Teil II. - Geologie. Jg. 18 (9), pp. 1072-1102.

Hoffmann, K. 1949: Zur Paläogeographie des nordwestdeutschen Lias und Dogger. In: Erdöl und Tektonik in Nordwestdeutschland. Pp. 113-129. - Hannover-Celle.

Hoffmann, K. 1960: Lias - Dogger. - In: Boick, H., Dietz, C., Grahle, H.-O., Hoffmann, K., Hollstein, W., Kühne, F., Richter, W., Schneekloth, H. \& Wager, R. 1960: Zur Geologie des Emslandes. - Beih. geol. Jb., 37, pp. 49-87. 
Hoffmann, K. 1962: Lias und Dogger im Untergrund der Niederrheinischen Bucht. Fortschr. Geol. Rheinld. Westf., 6, pp. 105-184.

Hoffmann, K. 1964: Die Stufe des Lotharingien (Lotharingium) im Unterlias Deutschlands und allgemeine Betrachtungen über das "Lotharingien". - Colloque du Jurassique a Luxembourg, 1962. Int. geol. Congr., pp. 135-160.

Hoffmann, K. \& Martin, G. P. R. 1960: Die Zone des Dactylioceras tenuicostatum (Toarcien, Lias) in NW- und SW-Deutschland. - Paläont. Z., 34, pp. 103-149.

Hornibrook, N. de B. 1952: Tertiary and Recent marine Ostracoda of New Zealand. New Zealand Geol. Survey, Pal. Bull., 18.

Issler, A. 1908: Beiträge zur stratigraphie und Mikrofauna des Lias in Schwaben. Palaeontographica, 55 (1), pp. 1-104.

Jones, T. R. 1872: On some Bivalve Entomostraca from the Lias ("Infralias") of Yorkshire. - Q. J1 geol. Soc. Lond., 28, pp. 146-147.

Jones, T. R. 1884: Notes on the Foraminifera and Ostracoda from the Deep Boring at Richmond. - Q. Jl geol. Soc. Lond., 40, pp. 765-777.

Jones, T. R. 1894: On some Rhaetic and some Liassic Ostracoda of Britain. - Q. J1 geol. Soc. Lond., 50, pp. 156-169.

Jones, T. R. \& Sherborn, C. D. 1888: On some Ostracoda from the Fullers-earth oolite and Bradford clay. - Bath Nat. Hist. and Antiquarian Field Club, Proc., 6 (3).

Kaye, P. 1965: Further Ostracoda from the British Lower Cretaceous. - Senckenberg. leth., 46 (1), pp. 73-81.

Kilenyi, T. I. 1969: The problems of ostracod ecology in the Thames estuary. - In: Neale, J. W. (ed.) 1969: The taxonomy, morphology and ecology of recent ostracoda. Pp. 251-267. - Edinburgh.

Kilenyi, T. I. 1971: Some basic questions in the palaeoecology of Ostracods. - In: Oertli, H. J. (ed.) 1971: Paléoécologie des Ostracodes. - Bull. Cent. Rech. Pau, 5 suppl., pp. 31-44.

Klingler, W. 1962: Lias Deutschlands. - In: Simon, W. \& Bartenstein, H. (ed.) 1962: Leitfossilien der Mikropaläontologie. Pp. 73-122. - Berlin.

Klingler, W. \& Neuweiler, F. 1959: Leitende Ostracoden aus dem deutschen Lias $\beta$. Geol. Jb., 76, pp. 373-410.

Kozur, H. 1970: Neue Ostracoden-Arten aus dem Obersten Anis des Bakonyhochlandes (Ungarn). - Ber. Nat-Med. Ver. Innsbruck, 58, pp. 1-40.

Kristan-Tollmann, E. 1971: Torohealdia n. gen., eine charakteristische OstracodenGattung der obersten alpinen Trias. - Erdö1-Erdgas-Z./Marit. Rohstoffgewinnung, 87 Jg. (2), pp. 50-54.

Larsen, G. 1964: Rhaetic - Jurassic - Lower Cretaceous Sediments from deep wells in North Jylland, Denmark. - In: van Straaten, L. M. J. U. (ed.) 1964: Deltaic and shallow marine deposits. - Devs Sedimentol., pp. 227-235.

Larsen, G. 1966: Rhaetic - Jurassic - Lower Cretaceous Sediments in the Danish Embayment. (A Heavy-Mineral Study). - Danm. geol. Unders., II række, 91, 127 p.

Larsen, G. 1968: Almen geologi. (English summary). - In: Larsen et al. 1968, pp. 7-52 and 74-80.

Larsen, G. \& Buch, A. 1960: Dybdeboringer på Sjælland, Slagelse nr. 1. - Meddr dansk geol. Foren., 14, p. 281.

Larsen, G., Christensen, O. B., Bang, I. \& Buch, A. 1968: Øresund. Helsingør-Hälsingborg Linien. Geologisk rapport. (English summary). - Danm. geol. Unders., Rapport nr. $1,90 \mathrm{p}$. 
Lord, A. 1971: Revision of some Lower Lias Ostracoda from Yorkshire. - Palaeontology, 14 (4), pp. 642-665.

Lord, A. 1972a: Wicherella and Gramannella, two new genera of Lower Jurassic Ostracoda from England. - Palaeontology, 15 (2), pp. 187-196.

Lord, A. 1972b: The ostracod genera Ogmoconcha and Procytheridea in the Lower Jurassic. - Bull. geol. soc. Denmark, 21, pp. 319-336.

Malling, C. 1914: De Jespersenske Buelag i Lias på Bornholm. - Meddr dansk geol. Foren., 4, pp. 265-270.

Malling, C. 1920: De marine Lias og Wealden-Aflejringer på Bornholm. - Meddr dansk geol. Foren., 5, pp. 55-57.

Malz, H. 1966: Zur Kenntnis einiger Ostracoden-Arten der Gattungen Kinkelinella und Praeschuleridea. - Senckenberg. leth., 47, pp. 385-404.

Malz, H. 1971: Zur Taxonomie "glattschaliger" Lias-Ostracoden. - Senckenberg. leth., 52, pp. 433-455.

Martin, G. P. R. 1960: - In: Hoffmann \& Martin 1960.

McCoy, F. 1844: A synopsis of the characters of the Carboniferous Limestone fossils of Ireland. - Dublin.

Méhes, G. 1911: Úber Trias-Ostrakoden aus dem Bakony. - Resultate Wiss. Erforsch. Balatonsees, 1, 1, Anh. 3, pp. 1-39.

Meinhold, R., Unger, E. \& Wienholz, R. 1960: Neue Erkenntnisse über den prätertiären Untergrund des Flachlandgebietes der Deutschen Demokratischen Republik. - Int. Geol. Congr., 21st session, Norden, XI, pp. 87-100.

Michelsen, O. 1970: - In: Bertelsen \& Michelsen 1970.

Michelsen, O. 1971a: Nedre jura og nederste mellem jura i Rønde nr. 1. Biostratigrafisk undersøgelse på grundlag af ostracoder. (English summary). - In: Rasmussen et al. 1971, pp. 81-88.

Michelsen, O. 1971b: Lower Carboniferous Foraminiferal Faunas of the Boring Ørslev No. 1, Island of Falster, Denmark. - Danm. geol. Unders., II række, 98, 86 p.

Michelsen, O. 1973a: Nedre jura i Nøvling nr. 1 (1509-1847 m). Biostratigrafi baseret på ostracoder. (English summary). - In: Rasmussen et al. 1973, pp. 124-131.

Michelsen, O. 1973b: On Liassic holothurian and ostracod assemblages from the Danish Embayment. - Danm. geol. Unders., Årbog 1972, pp. 49-68.

Moore, R. C. (ed.) 1961: Treatise on Invertebrate Paleontology. Part Q, Arthropoda 3, Crustacea, Ostracoda. 442 p. - Kansas.

Müller, G. W. 1894: Die Ostracoden des Golfes von Neapel und der Angrenzenden Meeres-Abschnitte. - Fauna Flora Golf. Neapel. 21. Monographie, 404 p.

Murray, J. W. 1968: Living foraminifers of lagoons and estuaries. - Micropaleontology. 14 (4), pp. 435-455.

Neale, J. W. 1960: Marine Lower Cretaceous Ostracoda from Yorkshire, England. Micropaleontology, 6 (2), pp. 203-224.

Neale, J. W. 1971: Microfaunas and some aspects of the Speeton Clay environment. In: Oertli, H. J. (ed.) 1971: Paléoécologie des Ostracodes. - Buli. Cent. Rech. Pau, 5 suppl., pp. 663-681.

Norling, E. 1972: Jurassic Stratigraphy and Foraminifera of Western Scania, Southern Sweden. - Sver. geol. Unders. Afh., Ser. Ca, 47, 120 p.

Nørvang, A. 1946: Marine Lias in Jutland. - Meddr dansk geol. Foren., 11, p. 139.

Nørvang, A. 1957: The Foraminifera of the Lias Series in Jutland, Denmark. - Meddr dansk geol. Foren., 13, pp. 275-414. 
Oertli, H. J. 1957: Ostracodes du Jurassique supérieur du Bassin de Paris (sondage Vernon 1). - Revue Inst. fr. Pétrole, 12 (6), pp. 647-695.

Oertli, H. J. 1959: Malm-Ostrakoden aus dem schweizerischen Juragebirge. - Schweiz. Ges. Naturw., Denkschr. (Soc. Helv. Sci. Nat., Mém.), 83 (1).

Oertli, H. J. 1963: Mesozoic ostracod faunas of France. - Leiden.

Oertli, H. J. 1971: The aspect of ostracode faunas. - A possible new tool in petroleum sedimentology. - In: Oertli, H. J. (ed.) 1971: Paléoécologie des Ostracodes. - Bull. Cent. Rech. Pau, 5 suppl., pp. 137-151.

Oertli, H. J. \& Grosdidier, E. 1961: Ostracodes de quelques sondages du Lias du bassin de Paris. - Colloque sur le Lias francais. Mém. Bur. Rech. géol. minièr., 4, pp. 459461.

Peterson, J. A. 1954: Jurassic Ostracoda from the "Lower Sundance" and Rierdon formations, western Interior United States. - J. Paleont., 28, pp. 153-176.

Pietrzenuk, E. 1961: Zur Mikrofauna einiger Liasvorkommen in der Deutschen Demokratischen Republik. - Freiberger ForschHft., C 113, 129 p.

Plumhoff, F. 1963: Die Ostracoden des Oberaalenium und tiefen Unterbajocium (Jura) des Gifhorner Troges, Nordwestdeutschland. - Abh. senckenb. naturforsch. Ges., 503, $100 \mathrm{p}$.

Plumhoff, F. 1967: Die Gattung Aphelocythere (Ostracoda) im NW-europäischen Jura und zur Entwicklung der Mikrofauna am Übergang Domerium/Toarcium. - Senckenberg. leth., 48 (6), pp. 549-577.

Pokorný, V. 1971: The diversity of fossil ostracode communities as an indicator of palaeogeographic conditions. - In: Oertli, H. J. (ed.) 1971: Paléoécologie des Ostracodes. - Bull. Cent. Rech. Pau, 5 suppl., pp. 45-61.

Rasmussen, L. B. 1971: Oversigt over boringens historie og geologiske resultater. (English summary). - In: Rasmussen et al. 1971, pp. 9-32.

Rasmussen, L. B. 1972: Oversigt over dybdeboringer på dansk landområde 1965-68. Meddr dansk geol. Foren., Arskrift for 1971, pp. 41-48.

Rasmussen, L. B., Dinesen, A., Henriksen, S. E., Bang, I., Stenestad, E., Buch, A., Christensen, O. B., Michelsen, O. \& Jacobsen, F. L. 1971: Dybdeboringen Rønde nr. 1 på Djursland. (English summaries). - Danm. geol. Unders., III række, 39, 123 p.

Rasmussen, L. B., Baartman, J. C., Henriksen, S. E., Kristoffersen, F. N., Dinesen, A., Bang, I., Stenestad, E., Buch, A., Christensen, O. B., Michelsen, O., Hansen, T. J. \& Jacobsen, F. L. 1973: Dybdeboringen N $\varnothing$ vling nr. 1 i Midtjylland. (English summaries). - Danm. geol. Unders., III række, 40, 164 p.

Reyment, R. A. 1959: On Liassic ammonites from Skåne, Southern Sweden. - Stockh. Contr. Geol., 2 (6), pp. 103-157.

Reyment, R. A. 1969: Upper Sinemurian (Lias) at Gantofta Skåne. - Geol. För. Stockh. Förh., 91, pp. 208-216.

Reyment, R. A. 1972: An erratic Amaltheus from drift at Møens Klint, Denmark. Geol. För. Stockh. Förh., 94, pp. 464-466.

Rosenkrantz, A. 1939: Bidrag til de danske Juraaflejringers Stratigrafi. - Meddr dansk geol. Foren., 9, pp. 526-528.

Roth, R. 1928: Monoceratina: A new genus of Ostracoda from the Pennsylvanian of Oklahoma. - J. Paleont., 2.

Rusbült, J. \& Petzka, M. 1964: Zur Stratigraphie des Lias in NE-Mecklenburg. - Ber. geol. Ges. D. D. R., 9 (6), pp. 625-634.

Sars, G. O. 1866: Oversigt af Norges marine Ostracoder. - Vidensk. Selsk. i Christiania, Forh. 
Sellwood, B. W. 1972: Tidal-flat sedimentation in the Lower Jurassic of Bornholm, Denmark. - Palaeogeogr. Palaeoclimat. Palaeoecol., 11 (2), pp. 93-106.

Sorgenfrei, T. 1963: Jura und Unterkreide in Dänemark. - Z. dt. geol. Ges., Jg. 1962, 114 , pp. $446-451$.

Sorgenfrei, T. 1969a: A Review of Petroleum Development in Scandinavia. - In: Hepple, P. (ed.) 1969: The Exploration in Europe and North Afrika. Pp. 191-208. Dorking.

Sorgenfrei, T. 1969b: Geological perspectives in the North Sea area. - Bull. geol. Soc. Denmark, 19, pp. 160-196.

Sorgenfrei, T. \& Buch, A. 1964: Deep Tests in Denmark 1935-1959. - Danm. geol. Unders., III række, 36, 146 p.

Spath, L. F. 1942: The ammonite zones of the Lias. - Geol. Mag., 79, pp. 264-268.

Stoermer, N. 1965: - In: Stoermer \& Wienholz 1965.

Stoermer, N. \& Wienholz, E. 1965: Mikrobiostratigraphie an der Lias/Dogger-Grenze in Bohrungen nördlich der Mitteldeutschen Hauptscholle. - Jb. Geol., 1, pp. 533591. Berlin 1965 (1967).

Surlyk, F. 1972: Morphological adaptations and population structures of the Danish chalk brachiopods (Maastrichtian, Upper Cretaceous). - K. dansk. Vidensk. Selsk. Biol. Skr., 19 (2), 57 p.

Sylvester-Bradley, P. C. 1948a: Bathonian Ostracods from the Boueti Bed of Langton Herring, Dorset. - Geol. Mag., 85, pp. 185-204.

Sylvester-Bradley, P. C. 1948b: The shell of the Ostracod genus Macrocypris. - Ann. Mag. Nat. Hist., 12 (1), pp. 65-71.

Sylvester-Bradley, P. C. 1950: The shell of the Ostracod genus Bairdia. - Ann. Mag. Nat. Hist., 12 (3), pp. 751-756.

Tralau, H. \& Artursson, K. 1972: New Middle Jurassic pollen and spore floras from southern Sweden and the Øresund. - Grana, 12, pp. 57-63.

Triebel, E. 1941: Zur Morphologie und Ökologie der fossilen Ostracoden. - Mit Beschreibung einiger neuer Gattungen und Arten. - Senckenbergiana, 23, pp. 294-400.

Triebel, E. 1950a: Camptocythere, eine neue Ostracoden-Gattung aus dem Dogger Norddeutschlands. - Senckenbergiana, 31, pp. 197-208.

Triebel, E. 1950b: Die taxonomische Stellung der Ostracoden-Gattung Ogmoconcha und Lectotypus von $O$ amalthei. - Senckenbergiana, 31, pp. 113-120.

Triebel, E. \& Bartenstein, H. 1938: Die Ostracoden des deutschen Juras. 1. Monoceratina-Arten aus dem Lias und Dogger. - Senckenbergiana, 20, pp. 502-518.

Triebel, E. \& Klingler, W. 1959: Neue Ostracoden-Gattungen aus dem deutschen Lias. Geol. Jb., 76, pp. 373-410.

Troedsson, G. 1951: On the Höganäs Series of Sweden (Rhaeto-Lias). - Acta Univ. lund., 47 (1), pp. 1-268.

Ulrich, E. O. 1894: The Lower Silurian Ostracoda of Minnesota. - Minn., Geol. Nat. Hist. Surv., Final Rept., 3.

Urlichs, M. 1972: Ostracoden aus den Kössener Schichten und ihre Abhängigkeit von der Ökologie. - Mitt. Ges. Geol. Bergbaust., 21, pp. 661-710.

Usbeck, I. 1952: Zur Kenntnis von Mikrofauna und Stratigraphie im unteren Lias alpha Schwabens. - Neues Jb. Geol. Paläont. Abh., 95, pp. 371-476.

Viaud, J. 1963: Les Ostracodes des principaux bassins liasiques francais. - Unpubl. thesis. - Paris.

Wicher, C. A. 1938: Mikrofaunen aus Jura und Kreide, insbesondere Nordwestdeutschlands. 1. Teil: Lias $\alpha-\varepsilon$. - Abh. preuss. geol. Landesanst., N. F., 193. 
Plates 
Figs. 1-2. Bairdia molesta Apostolescu, 1959 . . . . . . . . . . . . 121

Fig. 1. Carapace, broken posteriorly. Right side. $\times 70$. B $\phi r g-$

lum No. 1, sample No. $14 \ldots \ldots \ldots \ldots \ldots \ldots$. . . . . . . . . . . .

Fig. 2. Carapace, larva, length $0.36 \mathrm{~mm}$, height $0.22 \mathrm{~mm}$.

Right side. $\times 70$. Øresund No. 3, sample No. $348 \ldots \ldots$ 1973-OM-30

Fig. 3. Bairdia cf. carinata Drexler, 1958 . . . . . . . . . . . . . 122

Carapace, length $0.90 \mathrm{~mm}$, height $0.47 \mathrm{~mm}$. Right side. $\times 70$.

N $\varnothing$ vling No. 1, sample $6020^{\prime}-6050^{\prime} \ldots \ldots \ldots \ldots \ldots \ldots$ 1973-OM-31

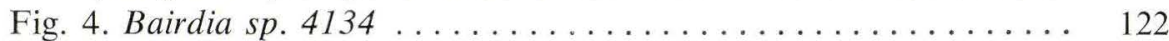

Carapace, length $0.34 \mathrm{~mm}$, height $0.17 \mathrm{~mm}$. Right side.

$\times 100$. Nøvling No. 1 , sample $5180^{\prime}-5210^{\prime} \ldots \ldots \ldots \ldots$ 1973-OM-32

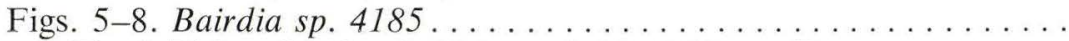

Fig. 5. Right valve, length $1.04 \mathrm{~mm}$, height $0.54 \mathrm{~mm}$. Exter-

nal view. $\times 70$ Fjerritslev No. 1, sample No. 4 . . . . . . 1973-OM-33

Fig. 6. Left valve, broken. Internal view. $\times 70$. Øresund No.

3, sample No. 293

1973-OM-34

Figs. 7-8. Right valve, length $0.89 \mathrm{~mm}$, height $0.48 \mathrm{~mm}$. Internal views. Øresund No. 3, sample No. 293. - Fig. 7: $\times$ 70. - Fig. 8: Detail with the muscle scars, $\times 300 \ldots \ldots$ 1973-OM-35

Fig. 9. Isobythocypris cf. elongata (Blake, 1876) . . . . . . . . 126 Right valve, length $0.79 \mathrm{~mm}$, height $0.40 \mathrm{~mm}$. Internal view. $\times$ 70. Øresund No. 3, sample No. $341 \ldots \ldots \ldots \ldots \ldots$. 1973-OM-36

Figs. 10-11. ? Isobythocypris elongata (Blake, 1876) . . . . . . . . . 124 Fig. 10. Carapace, length $0.84 \mathrm{~mm}$, height $0.41 \mathrm{~mm}$. Right side. $\times$ 70. Øresund No. 3, sample No. $329 \ldots \ldots \ldots$. . . Fig. 11. Pyrite-cast. Right side with muscle scars. $\times 90 . \emptyset$ resund No. 3, sample No. $288 \ldots \ldots \ldots \ldots \ldots \ldots \ldots$. . . . . . . . . . . . Scanning electron micrographs. 


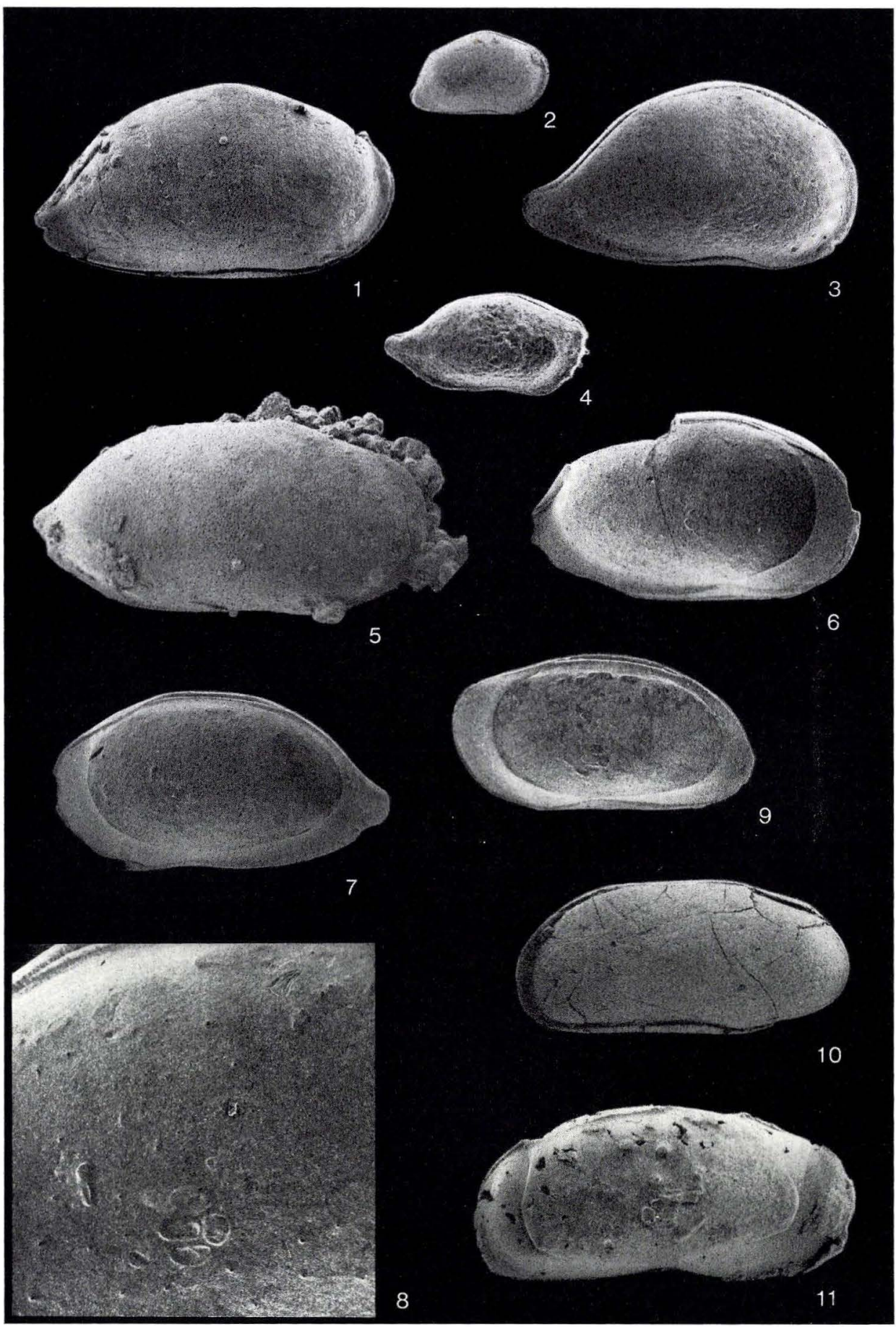


Plate 2

D. G. U. Text catalogue No. page

Fig. 12. Isobythocypris aff. elongata (Blake, 1876) . . . . . . . . 125

Right valve, length $0.69 \mathrm{~mm}$, height $0.39 \mathrm{~mm}$. Internal view.

$\times$ 100. Gassum No. 1, sample 4750'-4756' ......... 1973-OM-39

Fig. 13. Isobythocypris unispinata Apostolescu, 1959 . . . . . . . . . . 127

Carapace, length $0.80 \mathrm{~mm}$, height $0.38 \mathrm{~mm}$. Right side. $\times 70$.

Øresund No. 12, sample No. 1408 ................ 1973-OM-40

Figs. 14-16. Isobythocypris ? sp. $4020 \ldots \ldots \ldots \ldots \ldots \ldots$

Fig. 14. Carapace, broken anteriorly. Right side. $\times$ 70. Gas-

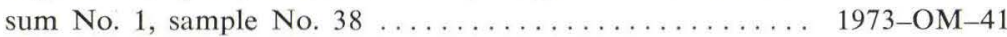

Fig. 15. Carapace, length $0.49 \mathrm{~mm}$, height $0.28 \mathrm{~mm}$. Right side.

$\times$ 70. Gassum No. 1, sample No. $38 \ldots \ldots \ldots \ldots$. . . 1973-OM-42

Fig. 16. Carapace, broken. Right side. $\times$ 70. Gassum No. 1 ,

sample No. $38 \ldots \ldots \ldots \ldots \ldots \ldots \ldots \ldots \ldots \ldots$. . . . . . . . . . . . . .

Figs. 17-19. Isobythocypris sp. $4329 \ldots \ldots \ldots \ldots \ldots \ldots \ldots \ldots$

Fig. 17. Carapace, length $0.24 \mathrm{~mm}$, height $0.16 \mathrm{~mm}$. Right

side. $\times$ 135. Øresund No. 12, sample No. $1408 \ldots \ldots \ldots$. 1973-OM-44

Fig. 18. Carapace, length $0.25 \mathrm{~mm}$, height $0.16 \mathrm{~mm}$. Right

side. $\times 135$. Børglum No. 1, sample No. $14 \ldots \ldots \ldots$. . . 1973-OM-45

Fig. 19. Right valve, broken. Detail with the hinge. $\times 200$.

Øresund No. 3, sample No. $346 \ldots \ldots \ldots \ldots \ldots \ldots \ldots$. . . . . . . . . . . .

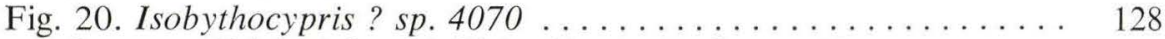

Carapace, slightly deformed. Right side. $\times 70$. Gassum No.

1, sample No. 43 A.......................... 1973-OM-47

Fig. 21. Pseudomacrocypris subaequabilis n. sp. . . . . . . . . . .

Pyrite-cast. Detail with the muscle scars of the left valve.

$\times$ 670. Øresund No. 2, sample No. 204 ........... 1973-OM-48

Figs. 22-28. Pseudomacrocypris subtriangularis n. sp. .............

Figs. 22, 26-28. Right valve, adult, length $0.49 \mathrm{~mm}$, height $0.25 \mathrm{~mm}$. Holotype. Internal views. Rødby No. 1, sample No. 21. - Fig. 22: $\times$ 100. - Fig. 26: Anterior hinge region, $\times$ 270. - Fig. 27: Median hinge region, $\times$ 670. - Fig. 28: Posterior hinge region, $\times 270 \ldots \ldots \ldots \ldots \ldots \ldots \ldots \ldots$

Figs. 23-24. Left valve, broken anteriorly. Internal views. Rødby No. 1, sample No. 21. - Fig. 23: × 100. - Fig. 24:

Posterior hinge region, $\times 670 \ldots \ldots \ldots \ldots \ldots \ldots \ldots$ 1973-OM-49

Fig. 25. Left valve, length $0.37 \mathrm{~mm}$, height $0.18 \mathrm{~mm}$. Internal view. $\times 100$. Rødby No. 1, sample No. $21 \ldots \ldots \ldots \ldots$ 1973-OM-50

Scanning electron micrographs. 


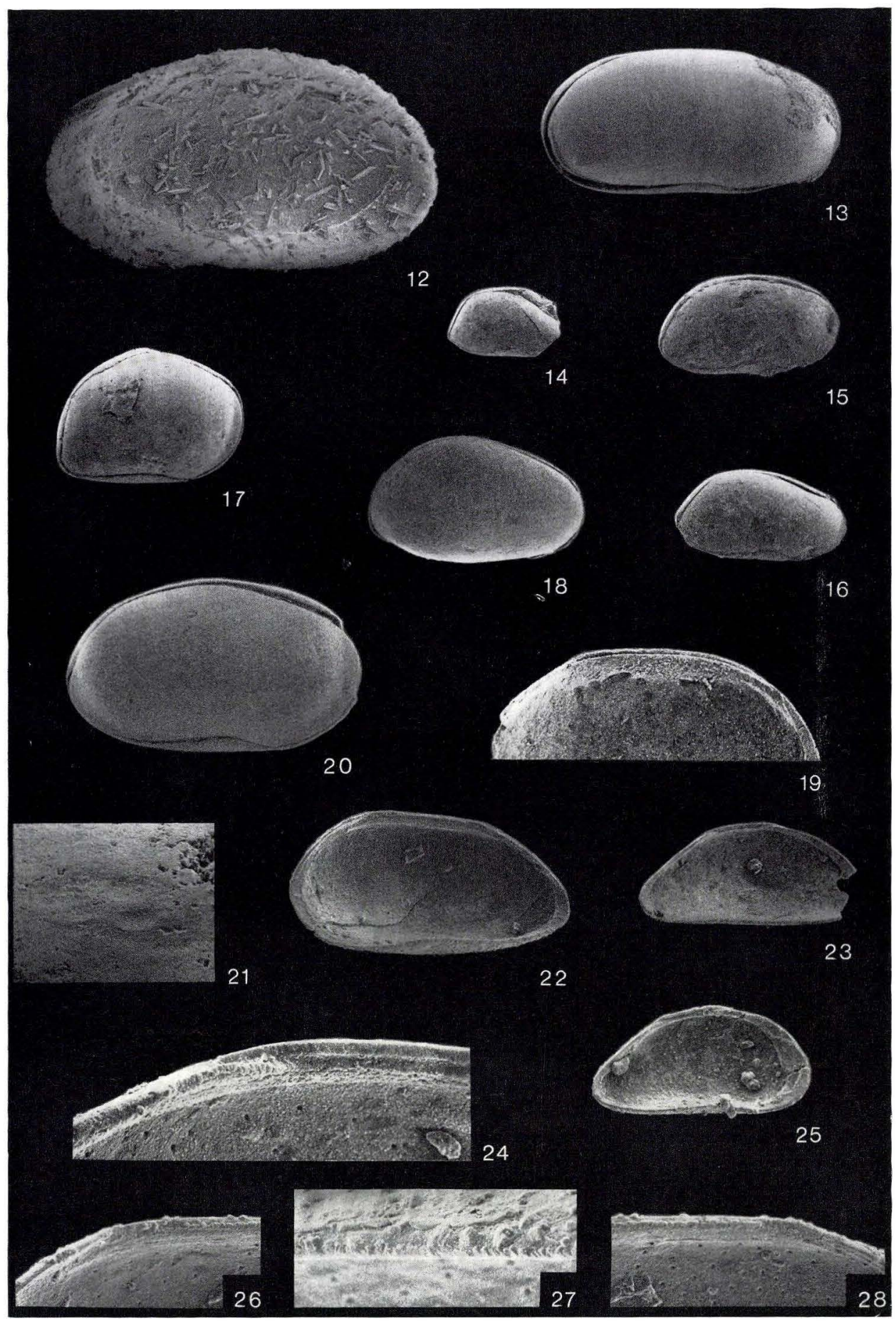


Plate 3

D. G. U. Text

$\times 60$

catalogue No. page

Figs. 29-30. Isobythocypris cf. elongata (Blake, 1876) . . . . . . . 126

Carapace, deformed and broken anteriorly. Fjerritslev No. 2,

sample No. 2. - Fig. 29: Right side. - Fig. 30: Dorsal view. . 1973-OM-17

Figs. 31-32. ? Isobythocypris elongata (Blake, 1876) . . . . . . . . . . .

Carapace, length $0.81 \mathrm{~mm}$, height $0.37 \mathrm{~mm}$. Øresund No. 9,

sample No. 1076. - Fig. 31: Right side. - Fig. 32: Dorsal

view ........................... 1973-OM-16

Figs. 33-36. Isobythocypris aff. elongata (Blake, 1876) . . . . . . 125

Figs. 33-34. Carapace, length $0.69 \mathrm{~mm}$, height $0.43 \mathrm{~mm}$. Gas-

sum No. 1, sample 4750'-4756'. - Fig. 33: Right side. - Fig.

34: Dorsal view . . . . . . . . . . . . . . . . 1973-OM-23

Figs. 35-36. Carapace, length $0.66 \mathrm{~mm}$, height $0.38 \mathrm{~mm}$.

Gassum No. 1, sample 4750'-4756'. - Fig. 35: Right side. -

Fig. 36: Dorsal view .................... 1973-OM-22

Figs. 37-38. Isobythocypris ? sp. $4070 \ldots \ldots \ldots \ldots \ldots \ldots \ldots \ldots$

Carapace, length $0.90 \mathrm{~mm}$, height $0.52 \mathrm{~mm}$. Børglum No. 1 , sample No. 14. - Fig. 37: Dorsal view. - Fig. 38: Right side 1973-OM-18

Phot:: O. Neergaard Rasmussen. 


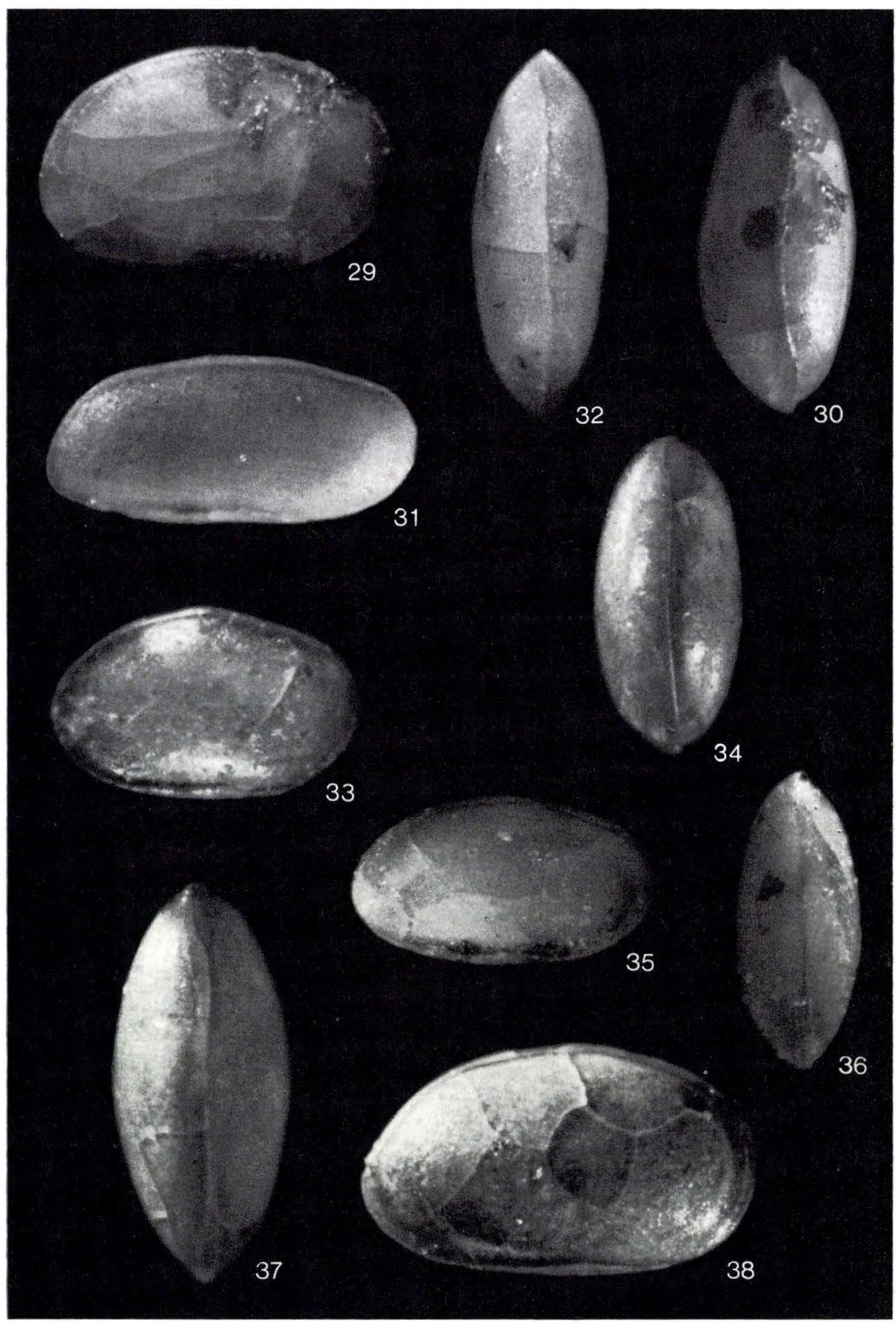


Fig. 39. Pseudomacrocypris subaequabilis n. sp. . . . . . . . . . . 131

Carapace, length $0.41 \mathrm{~mm}$, height $0.20 \mathrm{~mm}$. Holotype. Left

side. Øresund No. 2, sample No. 205 . . . . . . . . . . . . 1972-OM-97

Figs. 40-41, 44-45. Pseudomacrocypris subtriangularis n. sp. ......

Figs. 40-41. Right valve, adult, length $0.49 \mathrm{~mm}$, height 0.25

mm. Holotype. Rødby No. 1, sample No. 21. - Fig. 40: Dor-

sal view. - Fig. 41: External view . . . . . . . . . . 1969_OM-4

Figs. 44-45. Carapace, larva (A-1), lenght $0.41 \mathrm{~mm}$, height $0.20 \mathrm{~mm}$. Gassum No. 1, sample No. 48. - Fig. 44: Dorsal view. - Fig. 45: Left side .................... 1972-OM-99

Figs. 42-43. Pseudomacrocypris aff. subtriangularis n. sp. . . . . . . 134 Carapace, length $0.17 \mathrm{~mm}$, height $0.33 \mathrm{~mm}$. Øresund No. 14, sample No. 1779. - Fig. 42: Left side. - Fig. 43: Dorsal view 1972-OM-100

Figs. 46-47. Paracypris ? sp. $4091 \ldots \ldots \ldots \ldots \ldots \ldots \ldots \ldots$

Carapace, length $0.71 \mathrm{~mm}$, height $0.27 \mathrm{~mm}$. Vinding No. 1, sample No. 42. - Fig. 46: Right side. - Fig. 47: Dorsal view 1973-OM-1

Figs. 48-49. Paracypris ? redcarensis (Blake, 1876) . . . . . . . . . Carapace, broken posteriorly. Øresund No. 12, sample No. 1432. - Fig. 48: Right side. - Fig. 49: Dorsal view ... . . . 1972-OM-98

Fig. 50. ? Liasina lanceolata (Apostolescu, 1959) . . . . . . . . . . . . . Carapace, deformed. Right side. Gassum No. 1, sample No. 38

Figs. 51-52. Liasina vestibulifera Gramann, $1963 \ldots \ldots \ldots \ldots \ldots$

Carapace, adult, length $0.56 \mathrm{~mm}$, height $0.26 \mathrm{~mm}$. Øresund No. 3, sample No. 346. - Fig. 51: Dorsal view. - Fig. 52:

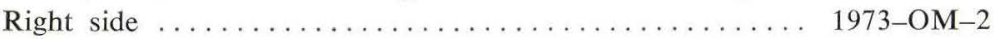

Figs. 53-55. Monoceratina? fusiformis (Drexler, 1958) . . . . . . . . Figs. 53-54. Carapace, length $0.42 \mathrm{~mm}$, height $0.19 \mathrm{~mm}$. Gassum No. 1, sample No. 48. - Fig. 53: Right side. - Fig. 54: Dorsal view . . . . . . . . . . . . . . . . . . . 1973-OM-7 Fig. 55. Carapace, length $0.39 \mathrm{~mm}$, height $0.18 \mathrm{~mm}$. Right side. Horsens No. 1, sample No. 5............... 1973-OM-8

Phot:: O. Neergaard Rasmussen. 


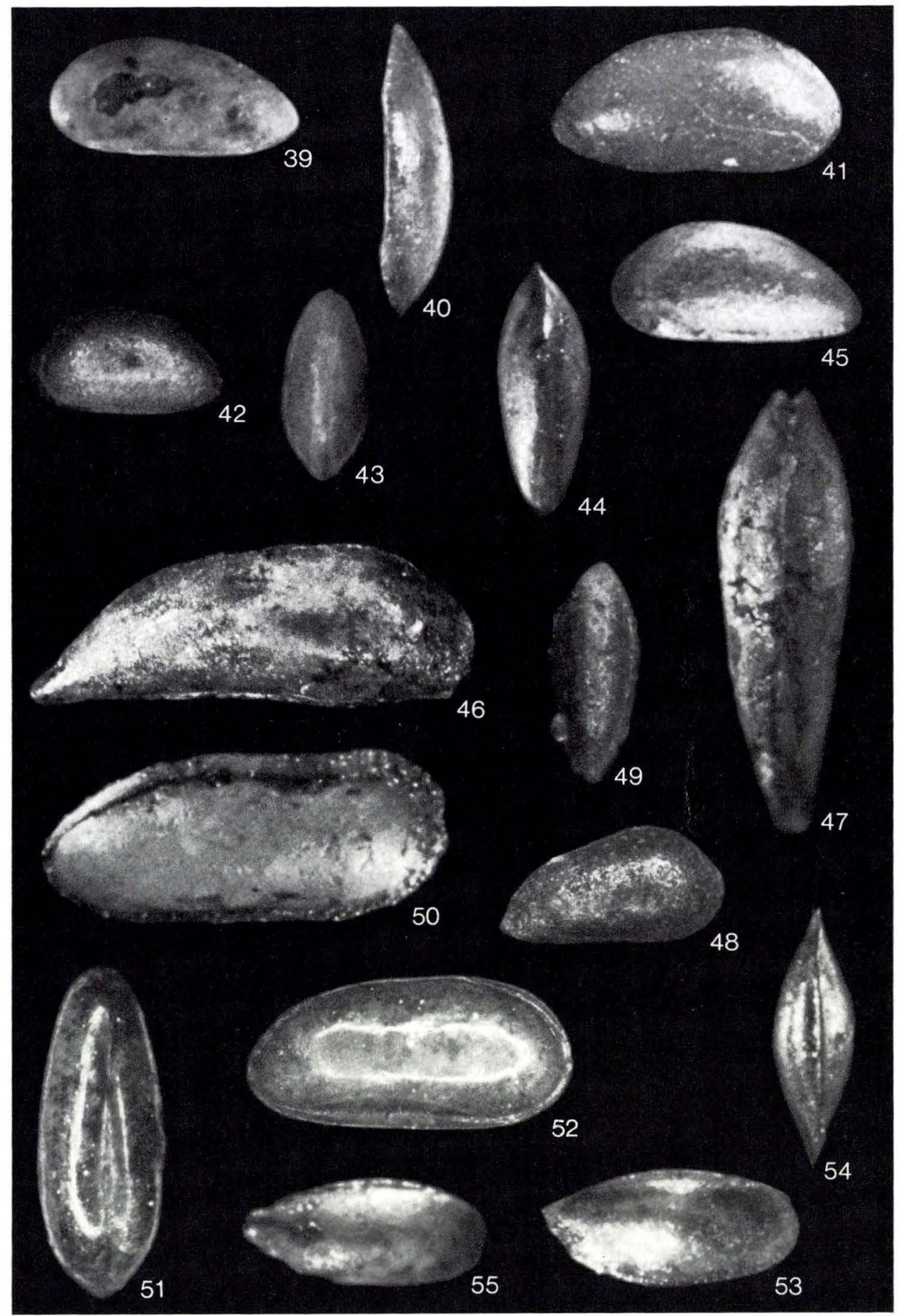


Fig. 56. Camptocythere praecox Triebel, 1950

Right valve, length $0.66 \mathrm{~mm}$, height $0.43 \mathrm{~mm}$. External view.

$\times$ 70. Øresund No. 2, sample No. $208 \ldots \ldots \ldots \ldots \ldots$. 1973-OM-51

Fig. 57. Camptocythere sp. 4190 .....................

Carapace, broken. Left side. $\times$ 70. Øresund No. 2, sample

No. $197 \ldots \ldots \ldots \ldots \ldots \ldots \ldots \ldots \ldots \ldots \ldots$. . . . . . . . . . . . . . . . . .

Figs. 58-60. Monoceratina? fusiformis (Drexler, 1958) . . . . . . . . .

Figs. 58-59. Right valve, length $0.42 \mathrm{~mm}$, height $0.20 \mathrm{~mm}$.

External views. Nøvling No. 1, sample 5300'-5330'. - Fig.

$58: \times 70$. Fig. 59: $\times 200 \ldots \ldots \ldots \ldots \ldots \ldots \ldots \ldots \ldots \ldots$ 1973-OM-53

Fig. 60. Left valve, broken posteriorly. Internal view. $\times 135$.

Horsens No. 1, sample No. 5 . . . . . . . . . . . . . . . 1973-OM-54

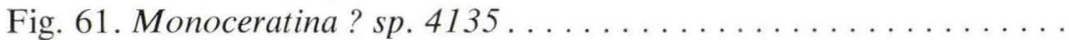

Carapace, length $0.44 \mathrm{~mm}$, height $0.18 \mathrm{~mm}$. Right side.

$\times$ 100. N $\varnothing$ vling No. 1 , sample $5180^{\prime}-5210^{\prime} \ldots \ldots \ldots \ldots$. . . . . .

Figs. 62-63. Monoceratina ? multistriata n. sp. .............

Left valve, length $0.47 \mathrm{~mm}$, height $0.19 \mathrm{~mm}$. External views.

Gassum No. 1, sample No. 47. - Fig. 62: × 100. - Fig. 63:

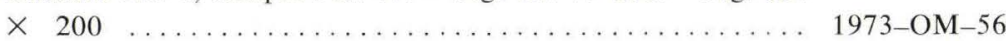

Fig. 64. Monoceratina ? sp. 4325 . . . . . . . . . . . . . . . 142

Carapace, length $0.30 \mathrm{~mm}$, height $0.18 \mathrm{~mm}$. Right side.

$\times 100$. Horsens No. 1, sample No. 4 . . . . . . . . . . 1973-OM-57

Figs. 65-66. Monoceratina cf. scrobiculata Triebel \& Bartenstein, 1938 Carapace, broken. Right side. Gassum No. 1, sample 4265'-

4281'. - Fig. 65: $\times$ 100. - Fig. 66: $\times 335$, anterodorsal part $1973-O M-58$

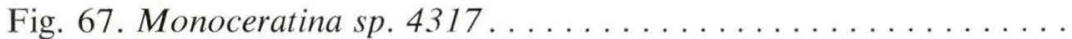

Carapace, length $0.27 \mathrm{~mm}$, height $0.14 \mathrm{~mm}$. Right side.

$\times$ 135. Flyvbjerg No. 1, sample No. 18........... 1973-OM-59

Fig. 68. Monoceratina sp. 4176 . . . . . . . . . . . . . . . . . . 142

Carapace, broken. Right side. $\times 135$. Gassum No. 1, sample No. 53 ............................... 1973-OM-60

Fig. 69. Monoceratina amlingstadtensis Triebel \& Bartenstein, 1938 . 138 Carapace, length $0.45 \mathrm{~mm}$, height $0.23 \mathrm{~mm}$. Right side.

$\times 100$. Nøvling No. 1, sample $5120^{\prime}-5150^{\prime}, \ldots \ldots \ldots \ldots$. $1973-O M-61$

Scanning electron micrographs. 


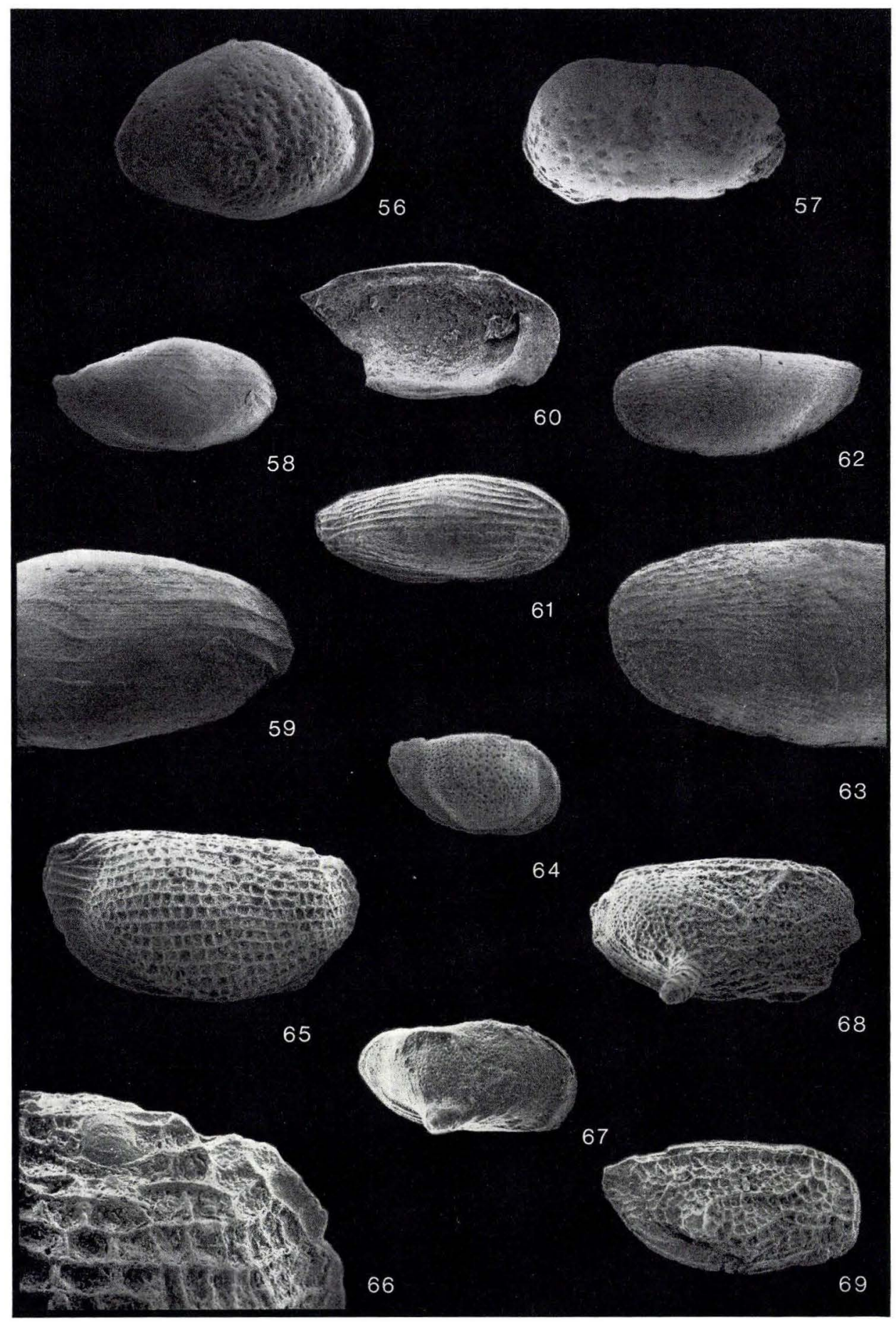


Plate 6

D. G. U. Text catalogue No. page

Figs. 70-71. Cytheropteron ? cavatum n. sp. .............. 144

Fig. 70. Carapace, adult (?), length $0.39 \mathrm{~mm}$, height $0.20 \mathrm{~mm}$.

Holotype. Right side. $\times$ 100. Gassum No. 1, sample No. 38. 1973-OM-62

Fig. 71. Left valve, larva, length $0.34 \mathrm{~mm}$, height $0.17 \mathrm{~mm}$.

Interval view. $\times 100 . \emptyset$ resund No. 14, sample No. 1689... 1973-OM-63

Figs. 72-78. Cytheropteron ? foveolatum n. sp. . . . . . . . . .

Fig. 72. Left valve, adult, broken posteroventrally. External

view. $\times 100$. Fjerritslev No. 1 , sample No. $4 \ldots \ldots \ldots$.

Figs. 73-74. Carapace, broken. Flyvbjerg No. 1, sample No.

19. - Fig. 73: Left side, $\times$ 90. - Fig. 74: Ventral view, $\times 100$ 1973-OM-65

Figs. 75-76. Carapace, length $0.35 \mathrm{~mm}$, height $0.19 \mathrm{~mm}$. Øre-

sund No. 3, sample No. 356. - Fig. 75: Left side, $\times 100$. -

Fig. 76: Ventral view, $\times 100 \ldots \ldots \ldots \ldots \ldots \ldots \ldots \ldots$

Fig. 77. Right valve, adult, deformed. Internal view, $\times 135$.

Fjerritslev No. 1, sample No. $4 \ldots \ldots \ldots \ldots \ldots \ldots \ldots$.

Fig. 78. Left valve, adult, length $0.39 \mathrm{~mm}$, height $0.20 \mathrm{~mm}$.

Internal view. $\times 135$. Fjerritslev No. 1 , sample No. 4 . . . 1973-OM-68

Figs. 79-82. Cytheropteron reticulatum n. sp. . . . . . . . . . .

Figs. 79-80. Carapace, adult, length $0.31 \mathrm{~mm}$, height 0.17

mm. Holotype. Horsens No. 1, sample No. 5. - Fig. 79:

Right side, $\times 100$. - Fig. 80 : Lateroventral view, $\times 100 \ldots$ 1973-OM-69

Fig. 81. Right valve, adult, broken. Internal view. $\times 200$.

Horsens No. 1, sample No. 5 . . . . . . . . . . . . . . . 1973-OM-70

Fig. 82. Left valve, adult, broken. Detail with the muscle

scars. $\times$ 470. Horsens No. 1, sample No. 5 . . . . . . . . 1973-OM-71

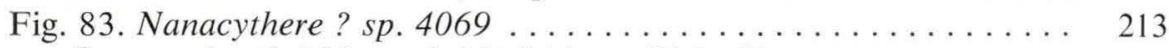

Carapace, length $0.30 \mathrm{~mm}$, height $0.14 \mathrm{~mm}$. Right side.

$\times$ 100. Øresund No. 10, sample No. $1194 \ldots \ldots \ldots \ldots \ldots$ 1973-OM-72

Fig. 84. "Cytheropteron" sp. $4203 \ldots \ldots \ldots \ldots \ldots \ldots \ldots \ldots \ldots \ldots$

Right valve, length $0.27 \mathrm{~mm}$, height $0.14 \mathrm{~mm}$. External

view. $\times$ 100. Øresund No. 12, sample No. 1432 ....... 1973-OM-73

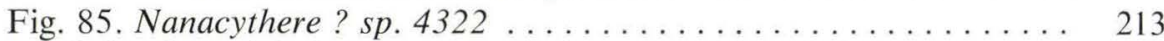

Left valve, adult, broken. External view. $\times 100$. Fjerritslev

No. 2, sample No. $23 \ldots \ldots \ldots \ldots \ldots \ldots \ldots \ldots \ldots \ldots \ldots \ldots$ 1973-OM-74

Fig. 86. Acrocythere ? sp. 4339 .................... 160

Left valve, adult, length $0.36 \mathrm{~mm}$, height $0.18 \mathrm{~mm}$. External

view. $\times 100$. Gassum No. 1, sample $4300^{\prime}-4310^{\prime} \ldots \ldots$. . 1973-OM-75

Fig. 87. Cytherura ? sp. $4340 \ldots \ldots \ldots \ldots \ldots \ldots$

Right valve, adult, length $0.37 \mathrm{~mm}$, height $0.17 \mathrm{~mm}$. External

view. $\times 100$. Gassum No. 1, sample $4300^{\prime}-4310^{\prime} \ldots \ldots \ldots$. 1973-OM-76

Scanning electron micrographs (figs 73-74: A. Nørgaard Jensen). 

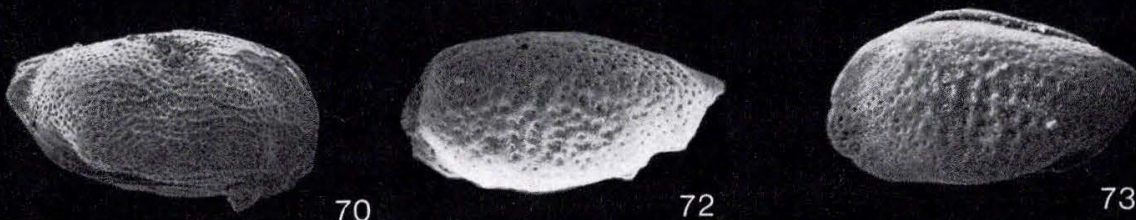

71

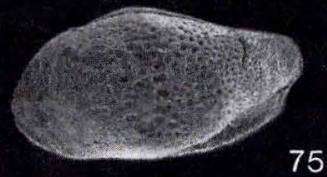

77
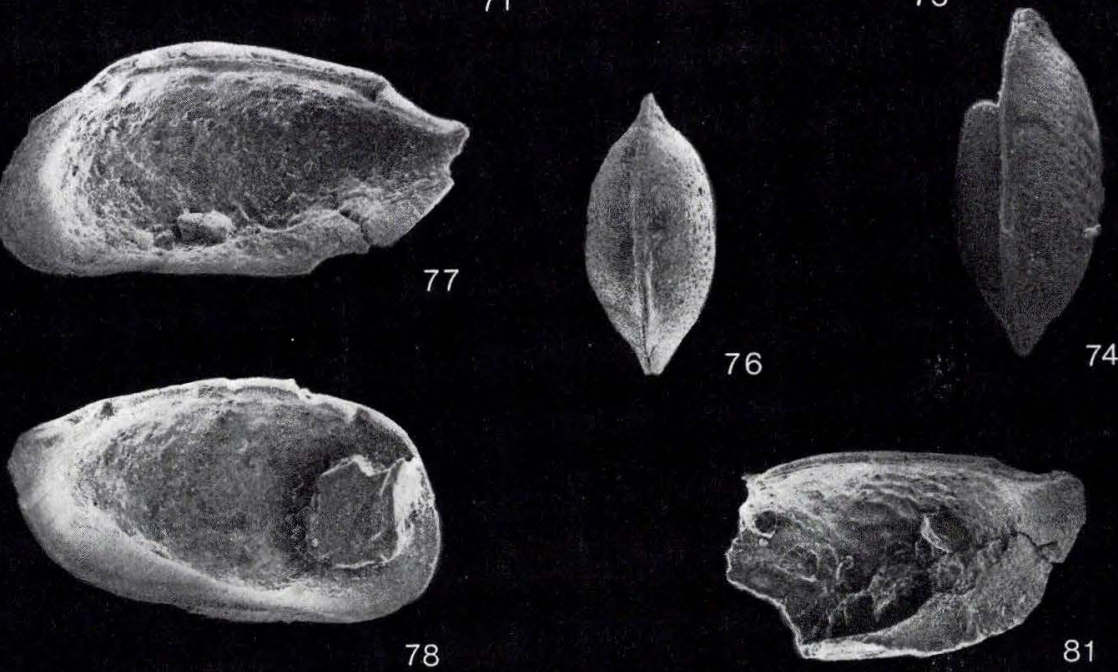

76

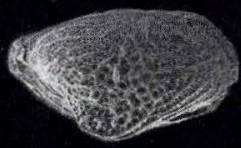

79
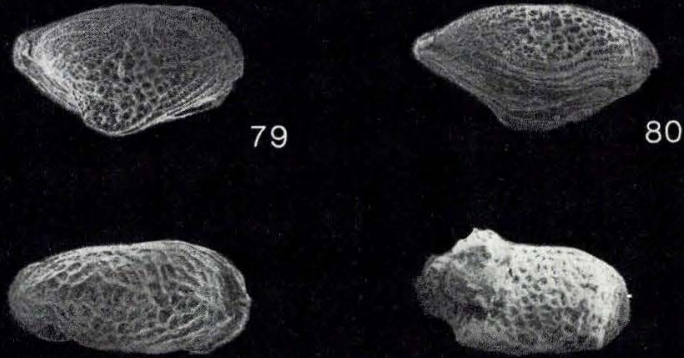

83
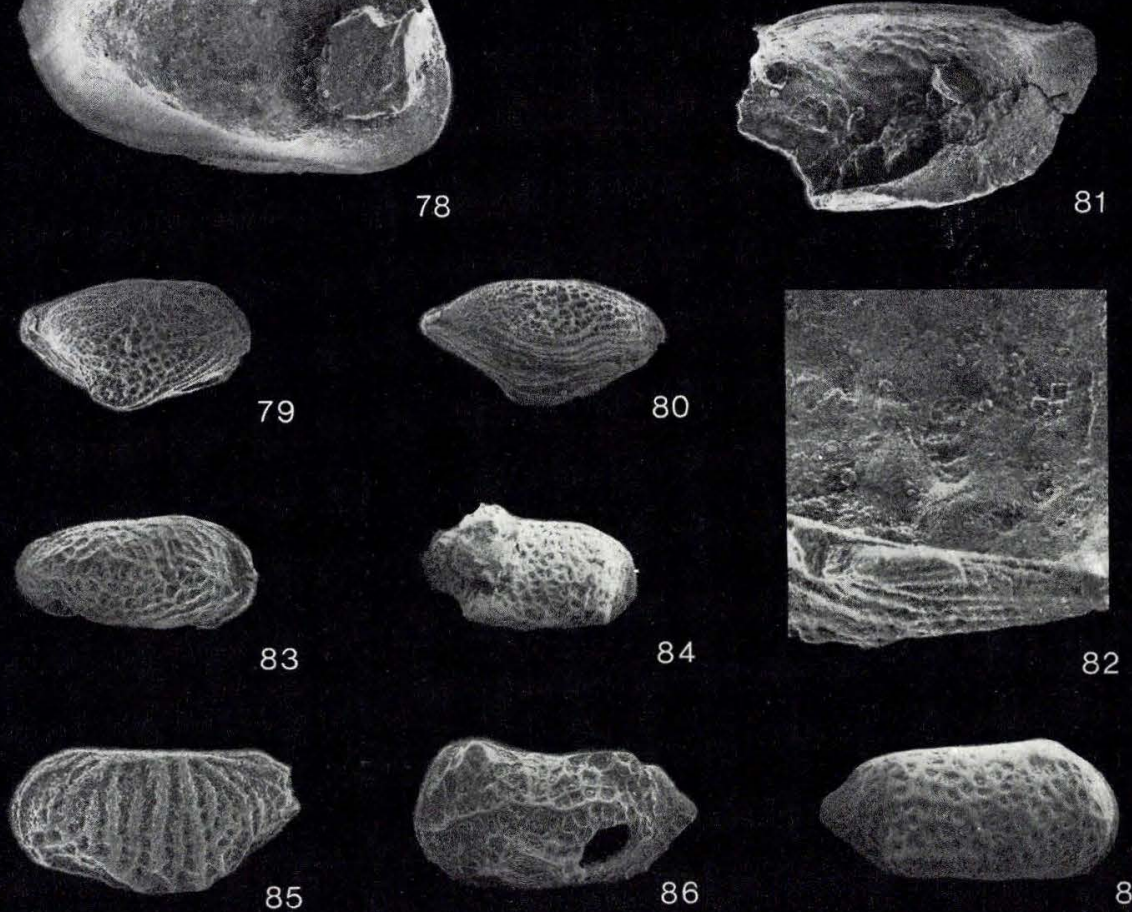
Figs. 88-89. Stenestroemia ? roedbyensis Michelsen, 1970

Right valve, adult, male, length $0.51 \mathrm{~mm}$, height $0.26 \mathrm{~mm}$. Internal views. Rødby No. 1, sample No. 21. - Fig. 88: Detail with the muscle scars, $\times$ 470. - Fig. $89: \times 100 \ldots$ 1973-OM-77

Figs. 90-95. Paradoxostoma ? pusillum n. sp. . . . . . . . . . . . Figs. 90-91. Carapace, length $0.33 \mathrm{~mm}$, height $0.16 \mathrm{~mm}$. Holotype. Øresund No. 8, sample No. 917. - Fig. 90: Dorsal view, $\times 100 .-$ Fig. 91: Left side, $\times 100 \ldots \ldots \ldots \ldots$ Fig. 92. Carapace, length $0.31 \mathrm{~mm}$, height $0.14 \mathrm{~mm}$. Right side. $\times 150$. Gassum No. 1 , sample No. $56 \ldots \ldots \ldots \ldots$ Figs. 93-94. Left valve, length $0.31 \mathrm{~mm}$, height $0.15 \mathrm{~mm}$. Internal views. Rødby No. 1, sample No. 21. - Fig. 93: $\times 135$. - Fig. 94: Detail with the muscle scars, $\times 470 \ldots$ 1973-OM-80 Fig. 95. Right valve, length $0.29 \mathrm{~mm}$, height $0.13 \mathrm{~mm}$. Internal view. $\times 135$. Rødby No. 1 , sample No. $21 \ldots \ldots \ldots$. 1973-OM-81

Fig. 96. Paradoxostoma ? sp. $4092 \ldots \ldots \ldots \ldots \ldots \ldots . \ldots \ldots$ Carapace, deformed ventrally. Left side. $\times 100$. Gassum No. 1 , sample $4143^{\prime}-4148$

Figs. 97-100. Acrocythere gassumensis n. sp. . . . . . . . . . . . . Fig. 97. Carapace, deformed. Right side. $\times 100$. Gassum No.

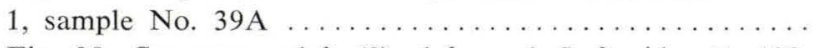
Fig. 98. Carapace, adult (?), deformed. Left side. $\times 100$. $\emptyset$ resund No. 9, sample No. $1062 \ldots \ldots \ldots \ldots \ldots \ldots \ldots$ Fig. 99. Right valve, larva, broken posteriorly. External view. $\times$ 100. Øresund No. 8, sample No. $917 \ldots \ldots \ldots \ldots \ldots \ldots$ Fig. 100. Right valve, larva, broken anterodorsally. Internal view. $\times$ 200. Gassum No. 1, sample No. 39A.......... 1973-OM-86

Figs. 101-104. Acrocythere oeresundensis n. sp. . . . . . . . . . . Figs. 101-103. Right valve, adult, length $0.39 \mathrm{~mm}$, height $0.18 \mathrm{~mm}$. Internal views. Øresund No. 12, sample No. 1405. - Fig. 101: $\times$ 135. - Fig. 102: Detail with the muscle scars, $\times$ 670. - Fig. 103: Detail with the anterior hinge region, $\times 335 \ldots \ldots \ldots \ldots \ldots \ldots \ldots \ldots \ldots \ldots \ldots \ldots \ldots \ldots \ldots \ldots \ldots$
Fig. 104. Left valve, adult, length $0.39 \mathrm{~mm}$, height $0.20 \mathrm{~mm}$. External view. $\times 100$. Øresund No. 12 , sample No. 1406. . 1973-OM-88 Scanning electron micrographs. 

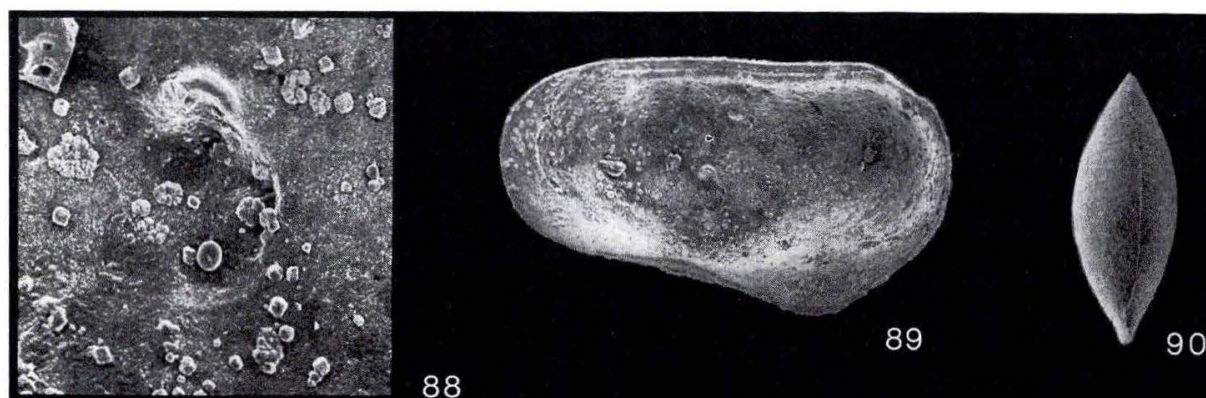

88
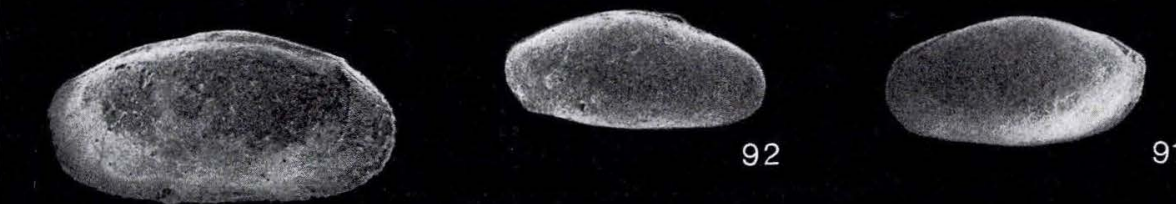

93
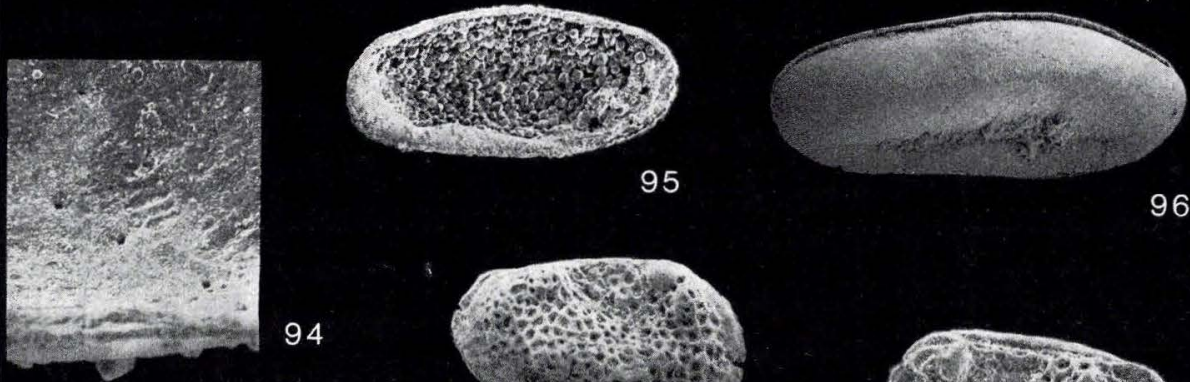

95

96

94
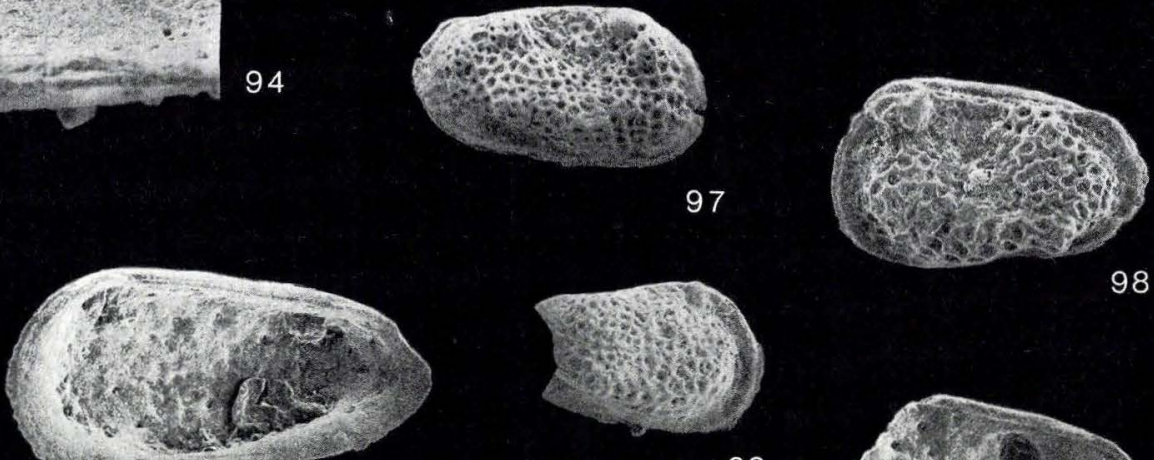

101

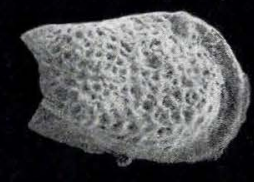

99
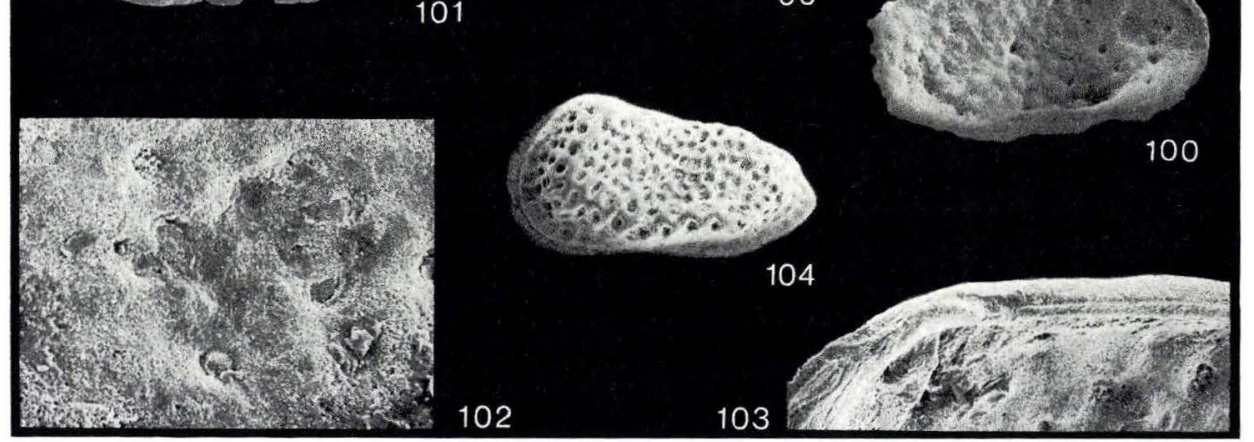

98 
Figs. 105-106. Monoceratina ? multistriata n. sp. . . . . . . . . . 140

Carapace, length $0.58 \mathrm{~mm}$, height $0.23 \mathrm{~mm}$. Holotype. Nøv-

ling No. 1, sample 5930'-5960'. - Fig. 105: Right side. -

Fig. 106: Dorsal view . . . . . . . . . . . . . . 1973-OM-9

Figs. 107-111. Cytheropteron ? foveolatum n. sp............ 145

Figs. 107-109. Right valve, adult, length $0.36 \mathrm{~mm}$, height

$0.21 \mathrm{~mm}$. Holotype. Fjerritslev No. 1, sample No. 4. - Fig.

107: External view. - Fig. 108: Dorsal view. - Fig. 109. In-

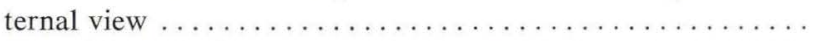

Figs. 110-111. Carapace, adult, length $0.38 \mathrm{~mm}$, height 0.20 mm. Fjerritslev No. 1, sample No. 4. - Fig. 110: Dorsal view.

- Fig. 111: Right side ..................... 1973-OM-13

Fig. 112. Stenestroemia ? roedbyensis Michelsen, 1970 . . . . . . . .

Carapace, adult, female, length $0.48 \mathrm{~mm}$, height $0.24 \mathrm{~mm}$.

Right side. Rødby No. 1, sample No. $21 \ldots \ldots \ldots \ldots$. . . . . 1969-OM-22

Figs. 113-114. Paradoxostoma ? pusillum n. sp...............

Right valve, length $0.30 \mathrm{~mm}$, height $0.14 \mathrm{~mm}$. Rødby No. 1 , sample No. 21. - Fig. 113: External view. - Fig. 114: Internal view . . . . . . . . . . . . . . . . . . . . . . 1969-OM-5

Figs. 115-116. Paradoxostoma ? sp. 4092 . . . . . . . . . . . .

Carapace, deformed. Gassum No. 1, sample 4143'-4148'. -

Fig. 115: Left side. - Fig. 116: Dorsal view ......... 1973-OM-21

Figs. 117-119. Acrocythere gassumensis n. sp.............. 153

Carapace, larva (?), length $0.34 \mathrm{~mm}$, height $0.19 \mathrm{~mm}$. Holotype. Gassum No. 1, sample No. 39A. - Fig. 117: Right side.

- Fig. 118: Posterior view. - Fig. 119: Dorsal view . . . . . . 1973-OM-15

Figs. 120-124. Acrocythere oeresundensis n. sp. . . . . . . . . . . 155

Figs. 120-122. Right valve, adult, length $0.37 \mathrm{~mm}$, height $0.17 \mathrm{~mm}$. Holotype. Øresund No. 12, sample No. 1406. Fig. 120: External view. - Fig. 121: Internal view. - Fig. 122:

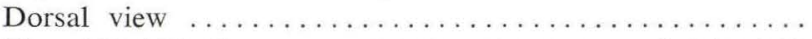

Figs. 123-124. Carapace, adult, length $0.40 \mathrm{~mm}$, height 0.19 mm. Øresund No. 12, sample No. 1406. - Fig. 123: Dorsal view. - Fig. 124: Right side

Phot.: O. Neergaard Rasmussen. 


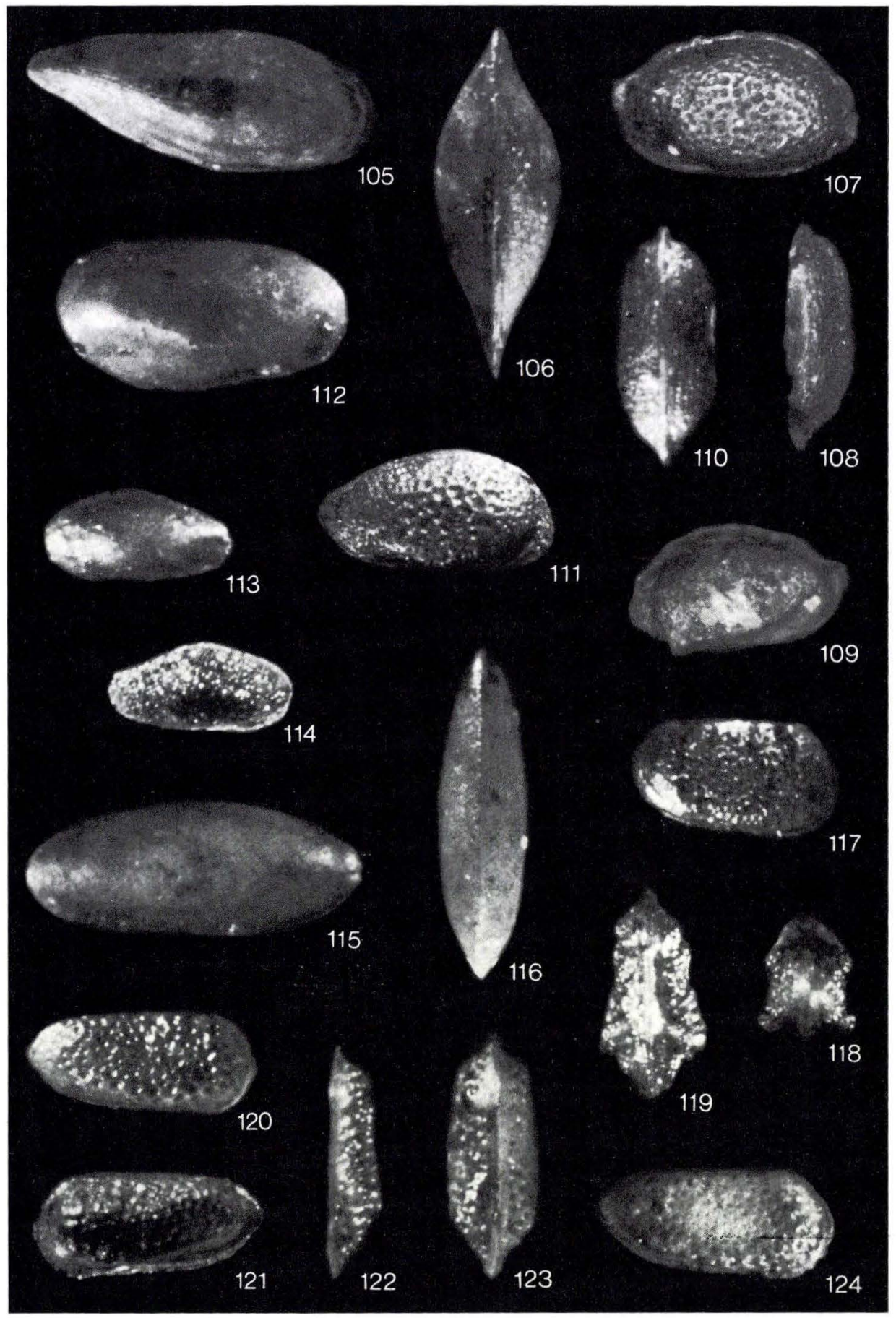




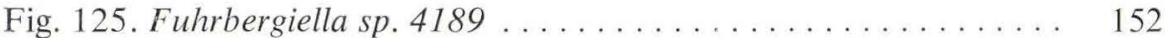

Left valve, broken posterodorsally. External view. $\times 100$.

Øresund No. 2, sample No. 201 ................ 1973-OM-89

Figs. 126-130. Acrocythere rectangula n. sp.............. 157

Fig. 126. Left valve, adult, female, length $0.38 \mathrm{~mm}$, height $0.19 \mathrm{~mm}$. Internal view. $\times 135$. Øresund No. 14 , sample No. 1689 ........................... 1973-OM-90

Figs. 127-128. Left valve, adult, male, length $0.41 \mathrm{~mm}$, height $0.19 \mathrm{~mm}$. Internal views. Øresund No. 14, sample No. 1691. - Fig. 127: $\times$ 135. - Fig. 128: Detail with the muscle scars, $\times 1000$

Fig. 129. Right valve, adult, female, length $0.38 \mathrm{~mm}$, height $0.18 \mathrm{~mm}$. Internal view. $\times 135$. Øresund No. 14 , sample No. 1691

Fig. 130. Carapace, adult, male, length $0.39 \mathrm{~mm}$, height 0.18 mm. Left side. $\times 100$. Øresund No. 10, sample No. 1167 . . 1973-OM-93

Figs. 131-142. Acrocythere tricostata n. sp................ Fig. 131. Left valve, larva, length $0.32 \mathrm{~mm}$, height $0.18 \mathrm{~mm}$. External view. $\times 100 . \emptyset$ resund No. 15 , sample No. $1826 \ldots$ Figs. 132-133. Carapace, adult, length $0.39 \mathrm{~mm}$, height 0.20 mm. Holotype. Gassum No. 1, sample No. 16. - Fig. 132: Dorsal view, $\times 100$. - Fig. 133: Right side, $\times 100$. Figs. 134-135. Left valve, adult. Nøvling No. 1, sample 5270' $-5300^{\prime}$. - Fig. 134: External view, $\times$ 110. - Fig. 135: Internal view, $\times 95 \ldots \ldots \ldots \ldots \ldots \ldots \ldots \ldots \ldots \ldots \ldots \ldots \ldots \ldots \ldots \ldots \ldots$ Figs. 136-138. Right valve, adult. Nøvling No. 1, sample 5150'-5180'. - Fig. 136. Internal view, $\times 100$. - Fig. 137: Ventral view, $\times$ 135. - Fig. 138: External view, $\times 120 \ldots$ Fig. 139. Right valve, larva. Detail with the posterior dental region. $\times 270$. Flyvbjerg No. 1 , sample No. $21 \ldots \ldots \ldots$. Figs. 140-142. Carapace, adult. Nøvling No. 1, sample 5270' $-5300^{\prime}$. - Fig. 140: Right side, $\times$ 120. - Fig. 141: Ventral view, $\times$ 110. - Fig. 142 : Dorsal view, $\times 110 \ldots \ldots \ldots$ 1973-OM-99 Scanning electron micrographs (figs. 134-138, 140-142: A. Nørgaard Jensen). 

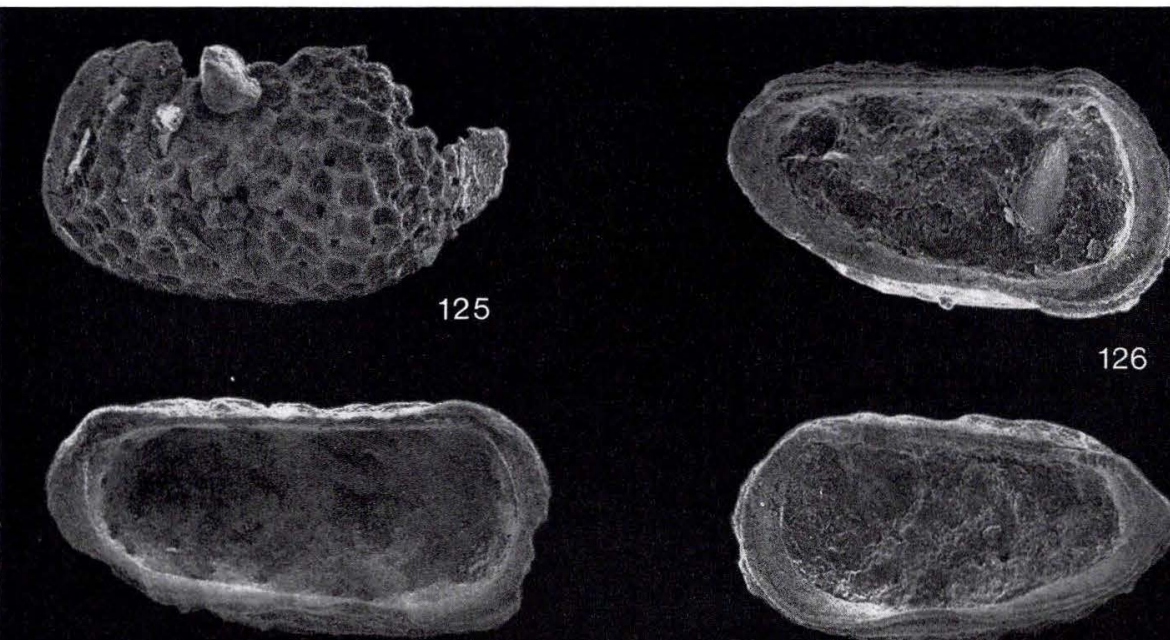

126

127

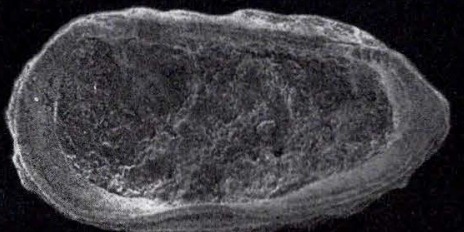

129
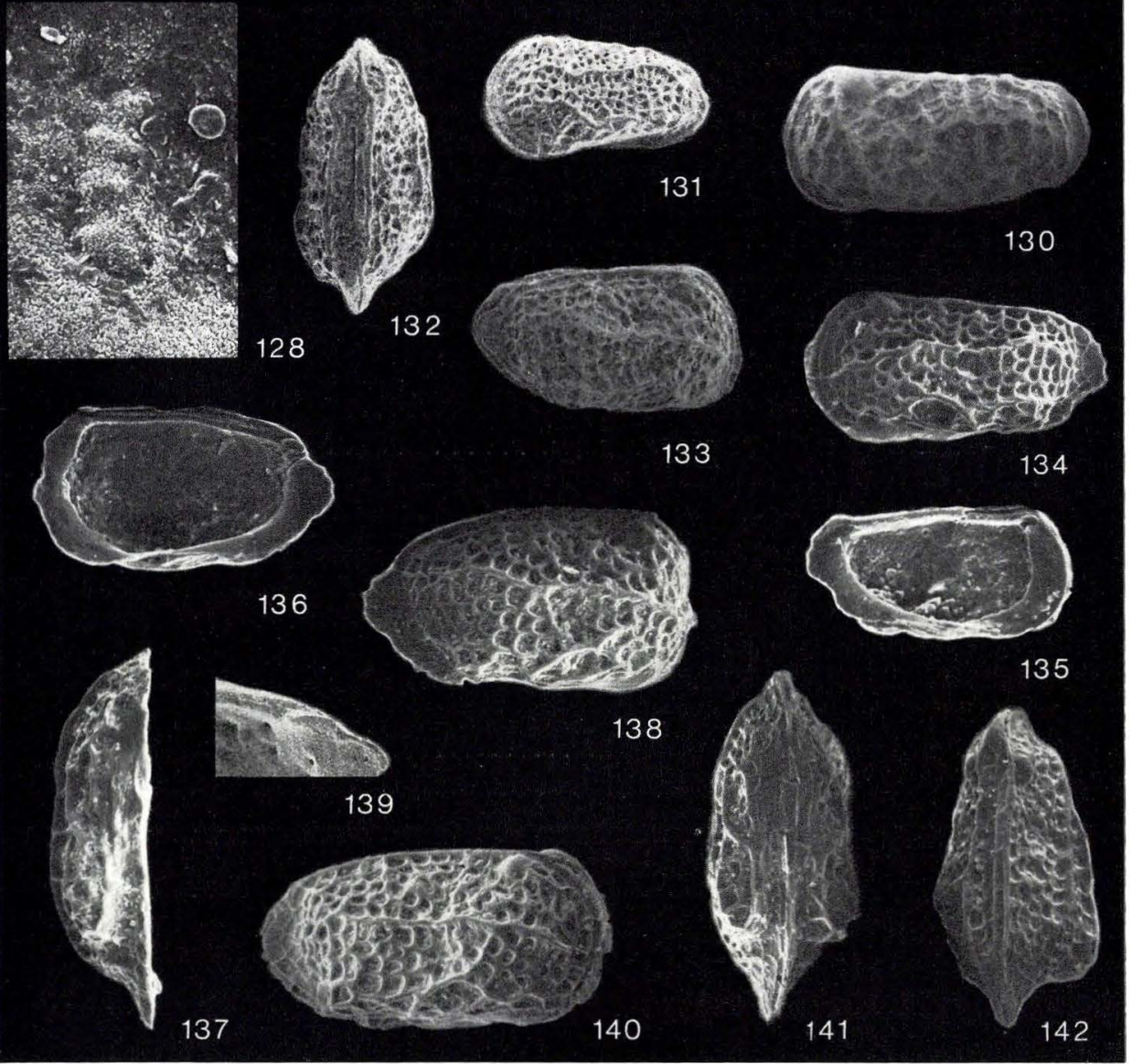
Figs. 143-147. Cristacythere betzi (Klingler \& Neuweiler, 1959) . . . . 163 Fig. 143. Carapace, adult, female (?), length $0.60 \mathrm{~mm}$, height $0.31 \mathrm{~mm}$. Right side. $\times$ 70. Gassum No. 1, sample No. 45D 1973-OM-100 Fig. 144. Right valve, adult, female (?), length $0.58 \mathrm{~mm}$, height $0.29 \mathrm{~mm}$. Internal view. $\times 100$. Gassum No. 1, sample No. $44 \mathrm{D} \ldots \ldots \ldots \ldots \ldots \ldots \ldots \ldots \ldots \ldots \ldots \ldots \ldots \ldots$
Figs. 145,147 . Right valve, length $0.56 \mathrm{~mm}$, height 0.28 mm. Internal views. Øresund No. 8, sample No. 951. - Fig. 145: $\times 70$. - Fig. 147: Detail with the muscle scars, $\times 670$ Fig. 146. Left valve, length $0.56 \mathrm{~mm}$, height $0.30 \mathrm{~mm}$. Internal view. $\times$ 70. Øresund No. 8, sample No. 951 ..... 1973-OM-103

Figs. 148-151. Cristacythere costata n. sp. ............. 165 Fig. 148. Left valve, larva (A-1), male, length $0.46 \mathrm{~mm}$, height $0.25 \mathrm{~mm}$. Internal view. $\times 100$. Flyvbjerg No. 1, sample No. $27 \ldots \ldots \ldots \ldots \ldots \ldots \ldots \ldots \ldots \ldots \ldots$. 1973-OM-104 Fig. 149. Carapace, adult, male, length $0.53 \mathrm{~mm}$, height $0.27 \mathrm{~mm}$. Right side. $\times$ 70. Flyvbjerg No. 1, sample No. 27 1973-OM-105 Fig. 150. Carapace, adult, female, length $0.46 \mathrm{~mm}$, height $0.27 \mathrm{~mm}$. Right side. $\times$ 70. Flyvbjerg No. 1, sample No. 27 1973-OM-106 Fig. 151. Right valve, broken. Detail with the muscle scars. $\times$ 670. Flyvbjerg No. 1, sample No. $27 \ldots \ldots \ldots \ldots \ldots$ 1973-OM-107

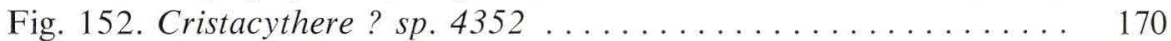
Right valve, length $0.27 \mathrm{~mm}$, height $0.14 \mathrm{~mm}$. External view. $\times$ 100. Øresund No. 10, sample No. 1180 .......... 1973-OM-108

Fig. 153. Cristacythere crassireticulata n. sp............... 168 Carapace, adult, length $0.65 \mathrm{~mm}$, height $0.32 \mathrm{~mm}$. Right side. $\times$ 70. Gassum No. 1 , sample No. 44C . . . . . . . 1973-OM-109 Scanning electron micrographs. 


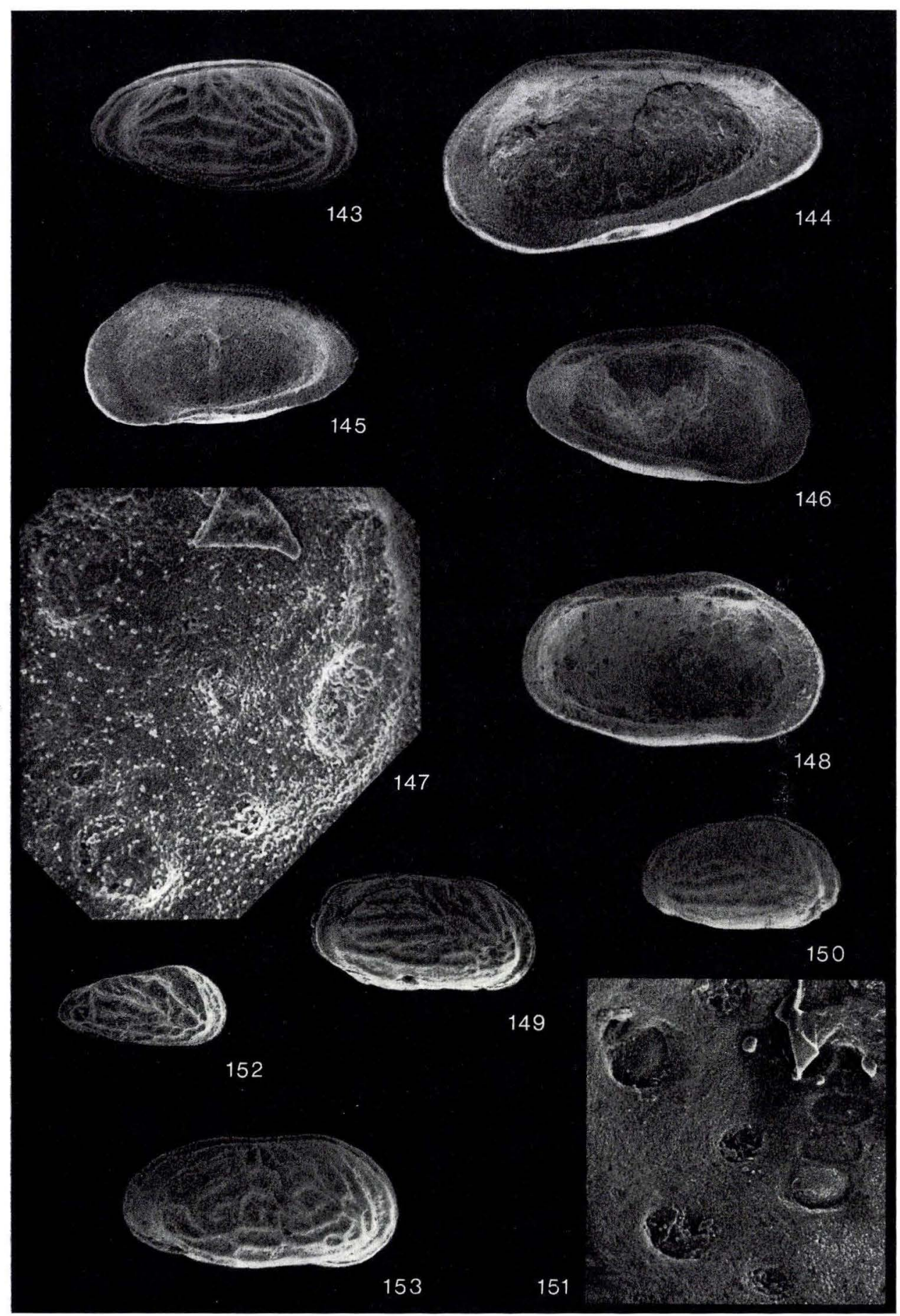


Plate 11

$\times 60$ (figs. 159-171); × 75 (figs. 154-158)

D. G. U. Text catalogue No. page

Figs. 154-156. Acrocythere rectangula n. sp.............. 157

Carapace, adult, female, length $0.37 \mathrm{~mm}$, height $0.18 \mathrm{~mm}$.

Holotype. Øresund No. 14, sample No. 1691. - Fig. 154:

Right side. - Fig. 155: Posterior view. - Fig. 156: Dorsal

view . . . . . . . . . . . . . . . . . . . . . . . . . . . 1972-OM-93

Figs. 157-158. Acrocythere tricostata n. sp. . . . . . . . . . 158

Carapace, adult (?), deformed. Gassum No. 1, sample No.

18. - Fig. 157: Dorsal view. - Fig. 158: Right side . . . . . 1973-OM-6

Figs. 159-171. Cristacythere betzi (Klingler \& Neuweiler, 1959) . . . .

Figs. 159-161. Carapace, adult, length $0.58 \mathrm{~mm}$, height 0.29

mm. Gassum No. 1, sample No. 44D. - Fig. 159: Anterior

view. - Fig. 160: Right side. - Fig. 161: Dorsal view . . . . . 1972-OM-6

Figs. 162-163. Carapace, larva (A-2), length $0.39 \mathrm{~mm}$,

height $0.22 \mathrm{~mm}$. Gassum No. 1, sample No. 44D. - Fig.

162: Dorsal view. - Fig. 163: Right side ............

1972-OM-7

Figs. 164-166. Carapace, adult, length $0.60 \mathrm{~mm}$, height

$0.33 \mathrm{~mm}$. Øresund No. 9, sample No. 1076. - Fig. 164:

Right side. - Fig. 165: Anterior view. - Fig. 166: Dorsal

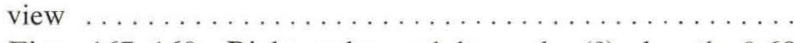

1972-OM-5

Figs. 167-169. Right valve, adult, male (?), length 0.68 $\mathrm{mm}$, height $0.30 \mathrm{~mm}$. Ørslev No. 1, sample $1700^{\prime}-1720^{\prime}$. Fig. 167: Dorsal view. - Fig. 168: Internal view. - Fig. 169:

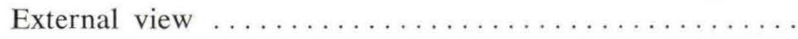

Figs. 170-171. Left valve, adult, male (?), length $0.69 \mathrm{~mm}$, height $0.33 \mathrm{~mm}$. Ørslev No. 1, sample $1700^{\prime}-1720^{\prime}$. - Fig. 170: External view. - Fig. 171: Internal view

1972-OM-3

Phot:: O. Neergaard Rasmussen. 


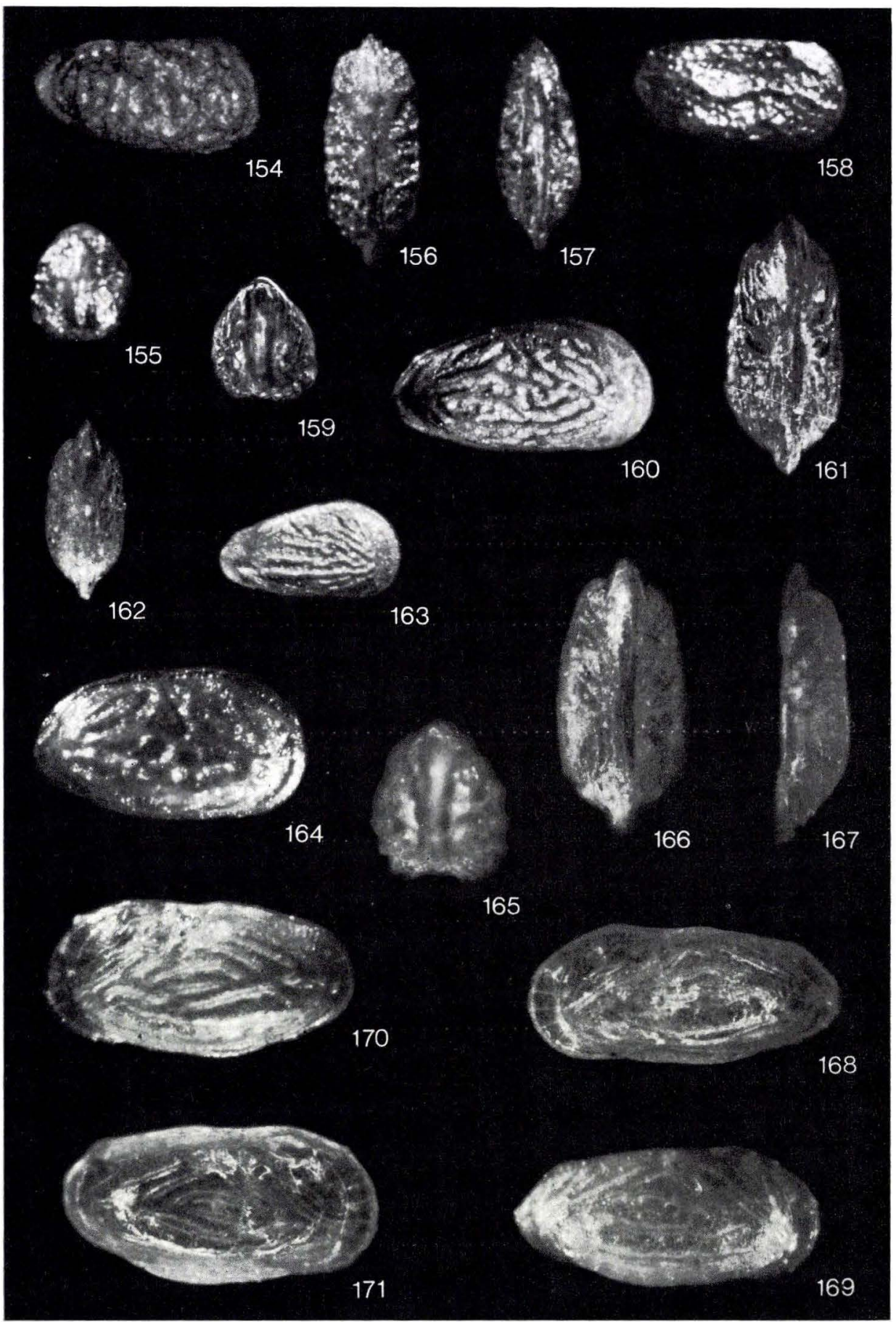


Plate 12

D. G. U.

Text

$\times 60$ (figs. 172-185); $\times 75$ (figs. 186-189)

catalogue No. page

Figs. 172-178. Cristacythere costata n. sp............... 165

Figs. 172-174. Left valve, adult, female, length $0.47 \mathrm{~mm}$, height $0.28 \mathrm{~mm}$. Holotype. Flyvbjerg No. 1, sample No. 27.

- Fig. 172: External view. - Fig. 173: Dorsal view. - Fig.

174: Internal view $\ldots \ldots \ldots \ldots \ldots \ldots \ldots \ldots \ldots \ldots \ldots \ldots \ldots \ldots \ldots$
Fig. 175. Carapace, adult, male, length $0.52 \mathrm{~mm}$, height

$0.26 \mathrm{~mm}$. Showing the radial pore canals. Flyvbjerg No. 1,

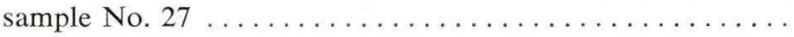

Figs. 176-178. Carapace, adult, female, length $0.45 \mathrm{~mm}$, height $0.27 \mathrm{~mm}$. Flyvbjerg No. 1, sample No. 27. - Fig. 176: Dorsal view. - Fig. 177: Right side. - Fig. 178: Posterior view .......................... 1972-OM-32

Figs. 179-185. Cristacythere crassireticulata n. sp............. Figs. 179-180. Right valve, adult, male (?), length $0.67 \mathrm{~mm}$, height $0.30 \mathrm{~mm}$. Gassum No. 1, sample No. 44A. - Fig. 179: External view. - Fig. 180: Internal view

Figs. 181-182. Carapace, larva, length $0.42 \mathrm{~mm}$, height 0.22 mm. Gassum No. 1, sample No. 44A. - Fig. 181: Right side. - Fig. 182: Dorsal view .................. 1972-OM-23 Figs. 183-185. Carapace, adult, female (?), length $0.61 \mathrm{~mm}$, height $0.30 \mathrm{~mm}$. Holotype. Gassum No. 1, sample No. 44A. - Fig. 183: Right side. - Fig. 184: Dorsal view. - Fig. 185: Anterior view . ..................... 1972-OM-22

Figs. 186-189. Gramannella apostolescui (Gramann, 1962) . . . . . . . Fig. 186. Right valve, larva (A-1), length $0.32 \mathrm{~mm}$, height $0.17 \mathrm{~mm}$. External view. Øresund No. 12, sample No. 1405 Fig. 187. Right valve, adult, female, length $0.38 \mathrm{~mm}$, height $0.20 \mathrm{~mm}$. External view. Øresund No. 12, sample No. 1405 Figs. 188-189. Carapace, adult, male, length $0.42 \mathrm{~mm}$, height $0.19 \mathrm{~mm}$. Børglum No. 1, sample No. 14. - Fig. 188: Dorsal view. - Fig. 189: Right side 1972-OM-14 1972-OM-13 Phot.: O. Neergaard Rasmussen. 


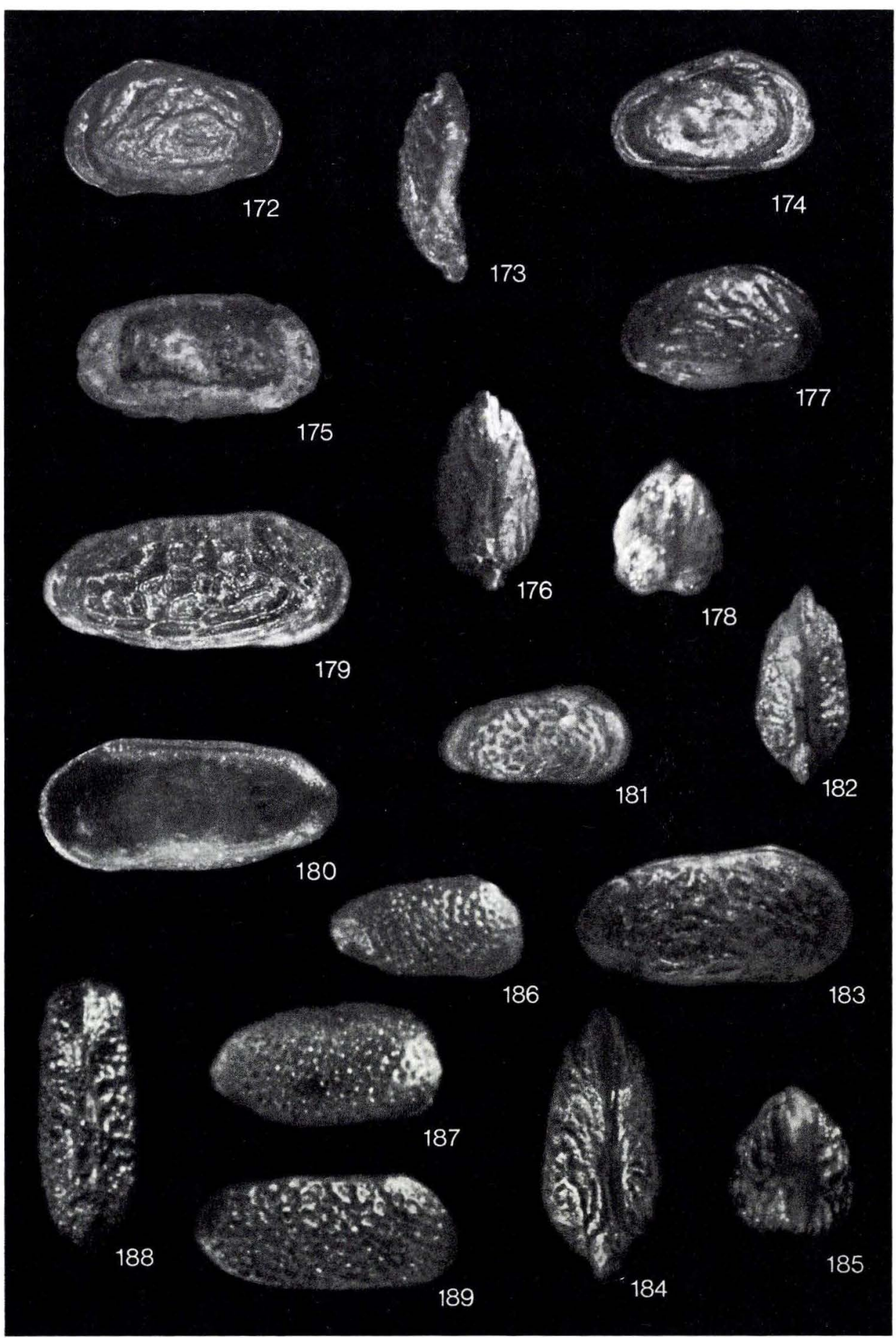


Figs. 190-197. Gramannella apostolescui (Gramann, 1962) . . . . . 172

Fig. 190. Carapace, adult, female, length $0.39 \mathrm{~mm}$, height $0.20 \mathrm{~mm}$. Right side. $\times 70$. Øresund No. 12 , sample No. 1406

Fig. 191. Right valve, adult, female, length $0.36 \mathrm{~mm}$, height $0.19 \mathrm{~mm}$. Internal view. $\times 100$. Øresund No. 12 , sample

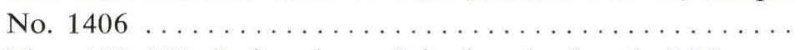

Figs. 192-193. Left valve, adult, female, length $0.38 \mathrm{~mm}$, height $0.20 \mathrm{~mm}$. Internal views. Øresund No. 12, sample No. 1406. - Fig. 192: $\times$ 100. - Fig. 193: Detail with the middle hinge element, $\times 670 \ldots \ldots \ldots \ldots \ldots \ldots \ldots \ldots$ Fig. 194. Left valve, adult, female, length $0.39 \mathrm{~mm}$, height $0.19 \mathrm{~mm}$. Internal view. $\times 135$. Øresund No. 12, sample

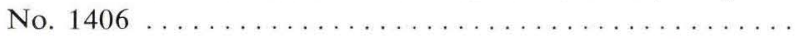
Figs. 195-197. Right valve, adult, female, length $0.40 \mathrm{~mm}$, height $0.20 \mathrm{~mm}$. Internal views. Øresund No. 12, sample No. 1406. - Fig. 195: Detail with the posterior part of the hinge, $\times$ 670. - Fig. 196: Detail with the muscle scars, $\times$ 670. - Fig. 197: $\times 100 \ldots \ldots \ldots \ldots \ldots \ldots \ldots \ldots$

Figs. 198-200, 203. Gramannella laevigata n. sp....... Fig. 198. Right valve, larva, length $0.44 \mathrm{~mm}$, height 0.23 mm. Internal view. $\times 135$. Øresund No. 12 , sample No. 1406

Figs. 199-200. Left valve, larva, length $0.41 \mathrm{~mm}$, height $0.22 \mathrm{~mm}$. Internal views. Øresund No. 12, sample No. 1406. - Fig. 199: $\times$ 100. - Fig. 200: Detail with the muscle scars, $\times 670$

Fig. 203. Right valve, larva, length $0.47 \mathrm{~mm}$, height 0.25 $\mathrm{mm}$. External view. $\times 70$. Øresund No. 12 , sample No. $1406 \ldots \ldots \ldots \ldots \ldots \ldots \ldots \ldots \ldots$ 1973-OM-117

Figs. 201-202. Gramannella cf. tatei (Gramann, 1962) . . . . . . . . 176 Fig. 201. Right valve. Detail with the muscle scars. $\times 670$. Øresund No. 12, sample No. $1399 \ldots \ldots \ldots \ldots \ldots \ldots \ldots$. External view. $\times$ 70. Øresund No. 12, sample No. 1391.. 1973-OM-119 Scanning electron micrographs. 


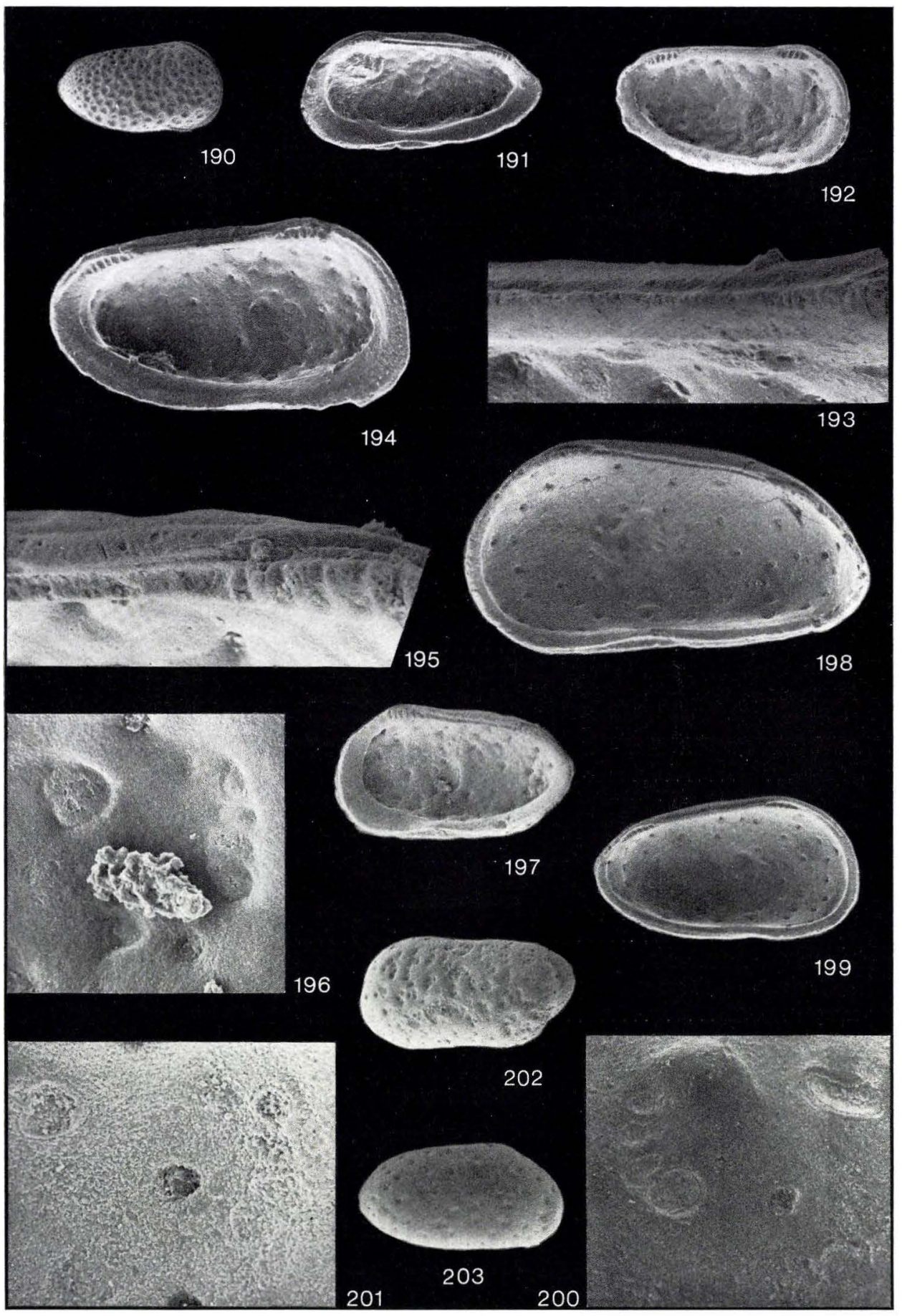


Figs. 204-205. Gramannella cf. tatei (Gramann, 1962) . . . . . . . . 176

Left valve. Internal views. Broken posterodorsally. Øresund No. 12, sample No. 1399. - Fig. 204: Detail with the anterior part of the hinge, $\times$ 670. - Fig. 205: $\times 100 \ldots$ 1973-OM-120

Figs. 206-209. Gramannella ? sp. $4259 \ldots \ldots \ldots \ldots \ldots \ldots \ldots$

Figs. 206-207. Left valve, larva, length $0.47 \mathrm{~mm}$, height $0.24 \mathrm{~mm}$. Internal views. Øresund No. 12, sample No. 1406.

- Fig. 206: Detail with the anterior part of the hinge, $\times 670 .-$ Fig. $207: \times 70 \ldots \ldots \ldots \ldots \ldots \ldots \ldots \ldots \ldots \ldots \ldots \ldots \ldots \ldots \ldots \ldots$ Fig. 208. Right valve, adult, length $0.54 \mathrm{~mm}$, height 0.27 mm. External view. $\times 70$. Øresund No. 12 , sample No. 1406

Fig. 209. Right valve, larva, length $0.32 \mathrm{~mm}$, height 0.17 $\mathrm{mm}$. External view. $\times 100$. Øresund No. 10 , sample No. 1180

Fig. 210. Kinkelinella (Klinglerella) glabellata (Klingler \& Neuweiler, 1959) . . . . . . . . . . . . . . . . . . . . . . . . . Carapace, adult, female, length $0.61 \mathrm{~mm}$, height $0.36 \mathrm{~mm}$.

Right side. $\times$ 70. Gassum No. 1, sample $4500^{\prime}-4516^{\prime}$... . 1973-OM-124 Figs. 211-215. Kinkelinella (Klinglerella) medioreticulata (Michelsen, 1970) . . . . . . . . . . . . . . . . . . . . . Fig. 211. Carapace. Right side in lateroventral view. $\times 110$. Nøvling No. 1, sample 5960'-5990' 1973-OM-125

Fig. 212. Left valve, adult, female, length $0.58 \mathrm{~mm}$, height $0.36 \mathrm{~mm}$. Internal view. $\times 100$. Horsens No. 1 , sample No. $4 \ldots \ldots \ldots \ldots \ldots \ldots \ldots \ldots \ldots \ldots \ldots$. . . . . . . . . . . . . . 1973-OM-126

Fig. 213. Carapace, adult, male, length $0.70 \mathrm{~mm}$, height $0.37 \mathrm{~mm}$. Right side. $\times 70$. N $\varnothing$ vling No. 1 , sample $5960^{\prime}-$ $5990^{\prime}$

Fig. 214. Right valve, adult, female, length $0.58 \mathrm{~mm}$, height $0.34 \mathrm{~mm}$. Internal view. $\times 100$. Nøvling No. 1 , sample $5960^{\prime}-5990^{\prime} \ldots \ldots \ldots \ldots \ldots \ldots \ldots \ldots \ldots \ldots \ldots \ldots \ldots \ldots \ldots \ldots \ldots \ldots$
Fig. 215. "Gassum" form. Carapace, adult, female, length $0.56 \mathrm{~mm}$, height $0.32 \mathrm{~mm}$. Right side. $\times 70$, Gassum No. 1 , sample No. 63 ............................ 1973-OM-129

Figs. 216-217. Kinkelinella (Klinglerella) sulcata (Klingler \& Neuweiler, 1959) ............................. Fig. 216. Carapace, adult, male, length $0.67 \mathrm{~mm}$, height $0.35 \mathrm{~mm}$. Right side. $\times 70$. Gassum No. 1 , sample $4450^{\prime}-$ $4466^{\prime}$ 1973-OM-130

Fig. 217. Left valve, adult, female, length $0.57 \mathrm{~mm}$, height $0.36 \mathrm{~mm}$. Internal view. $\times 100$. Gassum No. 1 , sample $4450^{\prime}-4466^{\prime}$

Scanning electron micrographs (fig. 211: J. Fuglsang Nielsen). 

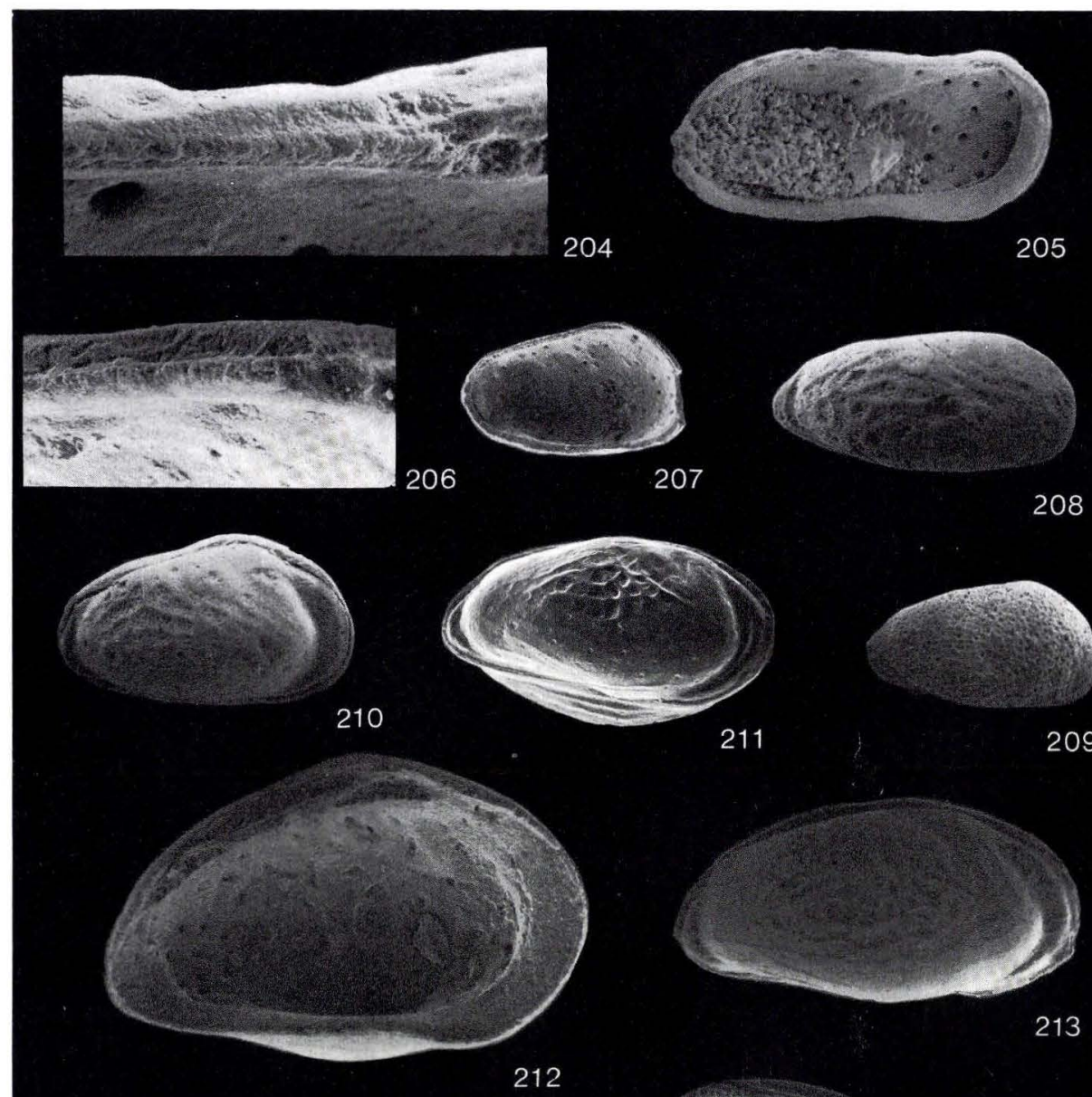

211
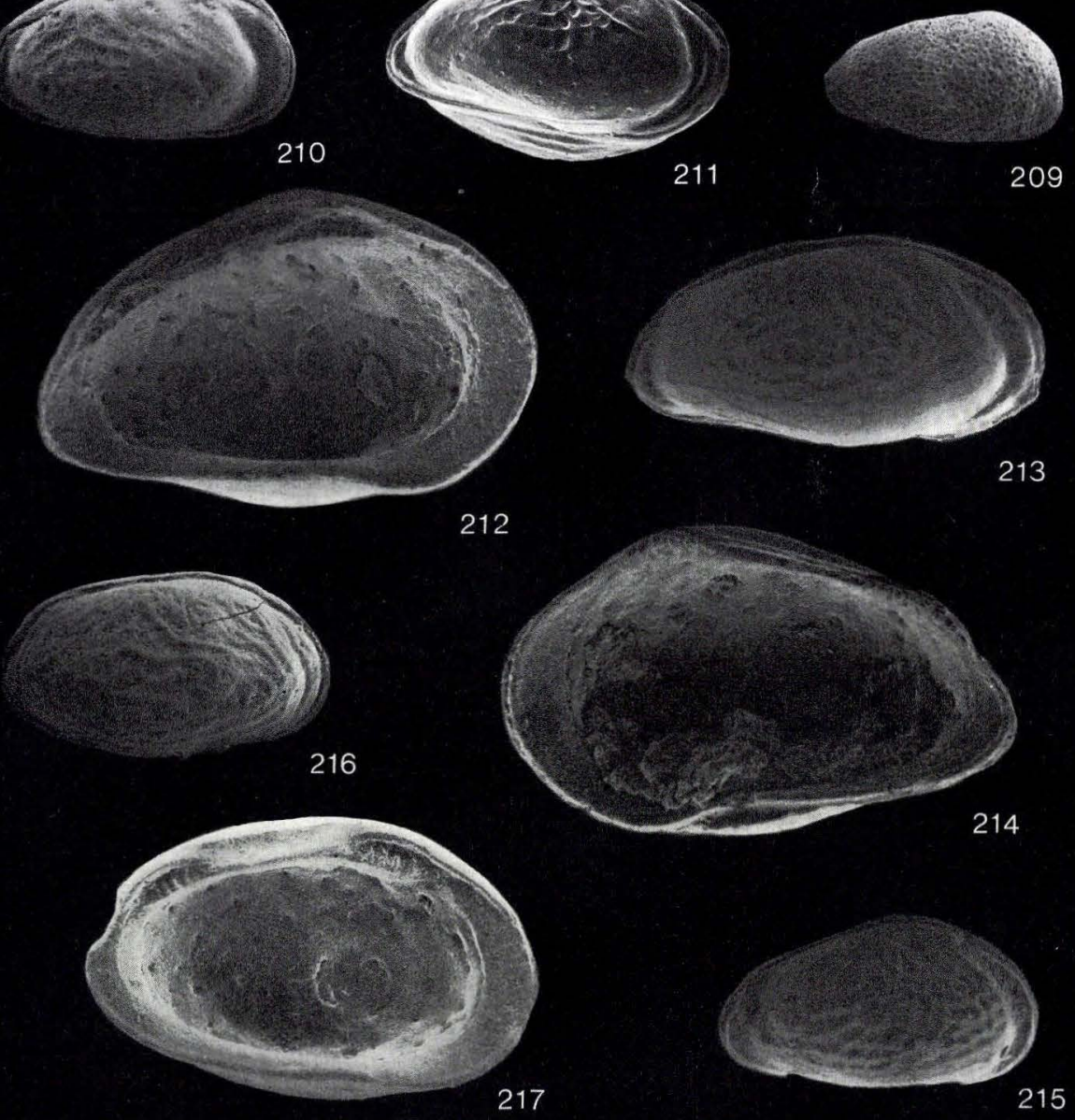

214 
Figs. 218-220. Kinkelinella (Klinglerella) triebeli (Klingler \& Neuweiler, 1959) .......................... Fig. 218. Carapace, adult, length $0.66 \mathrm{~mm}$, height $0.41 \mathrm{~mm}$. Right side. $\times$ 70. Nøvling No. 1, sample $5510^{\prime}-5540^{\prime} \ldots$. . 1973-OM-132 Figs. 219-220. Left valve, broken posteriorly. Internal views. Ørslev No. 1, sample 1600'-1630'. - Fig. 219: $\times 70$. Fig. 220: Detail with the anterior part of the hinge, $\times 470$ 1973-OM-133 Figs. 221-224. Kinkelinella (Klinglerella) cf. triebeli (Klingler \& Neuweiler, 1959)

Fig. 221. Right valve, larva, length $0.59 \mathrm{~mm}$, height 0.30 mm. External view. $\times 70$. Nøvling No. 1 , sample $5240^{\prime}-$ $5270^{\prime}$

Figs. 222-224. Left valve. Nøvling No. 1, sample 5270'5300'. - Fig. 222: Dorsal view, $\times$ 80. - Fig. 223: External view, $\times$ 80. - Fig. 224: Internal view, $\times 80$

Figs. 225-227. Kinkelinella (Klinglerella) ? elongata n. sp. . . . . . . . Fig. 225. Left valve, adult, female, length $0.52 \mathrm{~mm}$, height $0.25 \mathrm{~mm}$. Internal view. $\times 100$. Børglum No. 1 , sample No.

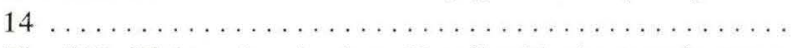
Fig. 226. Right valve, broken. Detail with the muscle scars. $\times$ 335. B $\varnothing$ rglum No. 1, sample No. 14 ........... 1973-OM-137 Fig. 227. Carapace, adult, female, length $0.52 \mathrm{~mm}$, height $0.24 \mathrm{~mm}$. Right side. $\times 70$. Børglum No. 1, sample No. 14 1973-OM-138

Fig. 228. Kinkelinella (Kinkelinella) oblonga (Plumhoff, 1963) . . . . . Carapace, length $0.68 \mathrm{~mm}$, height $0.41 \mathrm{~mm}$. Right side.

$\times$ 70. Øresund No. 2, sample No. 202 ............ 1973-OM-139

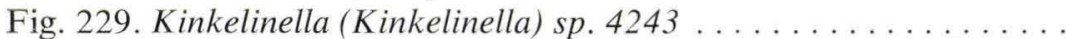
Right valve, broken anteroventrally. External view. $\times 70$. Øresund No. 3, sample No. 336 ................. 1973-OM-140

Fig. 230. Kinkelinella (Kinkelinella) sp. $4336 \ldots \ldots \ldots \ldots \ldots \ldots$. . . . . . Carapace, length $0.64 \mathrm{~mm}$, height $0.37 \mathrm{~mm}$. Right side.

$\times$ 70. Frederikshavn City No. 2, sample 2561'-2566' ... 1973-OM-141

Figs. 231-234. Nanacythere (Nanacythere) simplex Herrig, 1969 . . . . Fig. 231. Left valve, larva, length $0.24 \mathrm{~mm}$, height $0.13 \mathrm{~mm}$. External view. $\times$ 100. Fjerritslev No. 1, sample No. 6... 1973-OM-142 Figs. 232-233. Carapace. Nøvling No. 1, sample 5150'5180'. - Fig. 232: Dorsal view, $\times$ 100. - Fig. 233: Left side, $\times 150 \ldots \ldots \ldots \ldots \ldots \ldots \ldots \ldots \ldots \ldots \ldots \ldots \ldots \ldots$. Fig. 234. Carapace, adult, length $0.36 \mathrm{~mm}$, height $0.17 \mathrm{~mm}$. Right side. $\times$ 100. Fjerritslev No. 1, sample No. 4 . . . 1973-OM-144 Scanning electron micrographs (figs. 222-224, 232-233: A. Nфrgaard Jensen). 


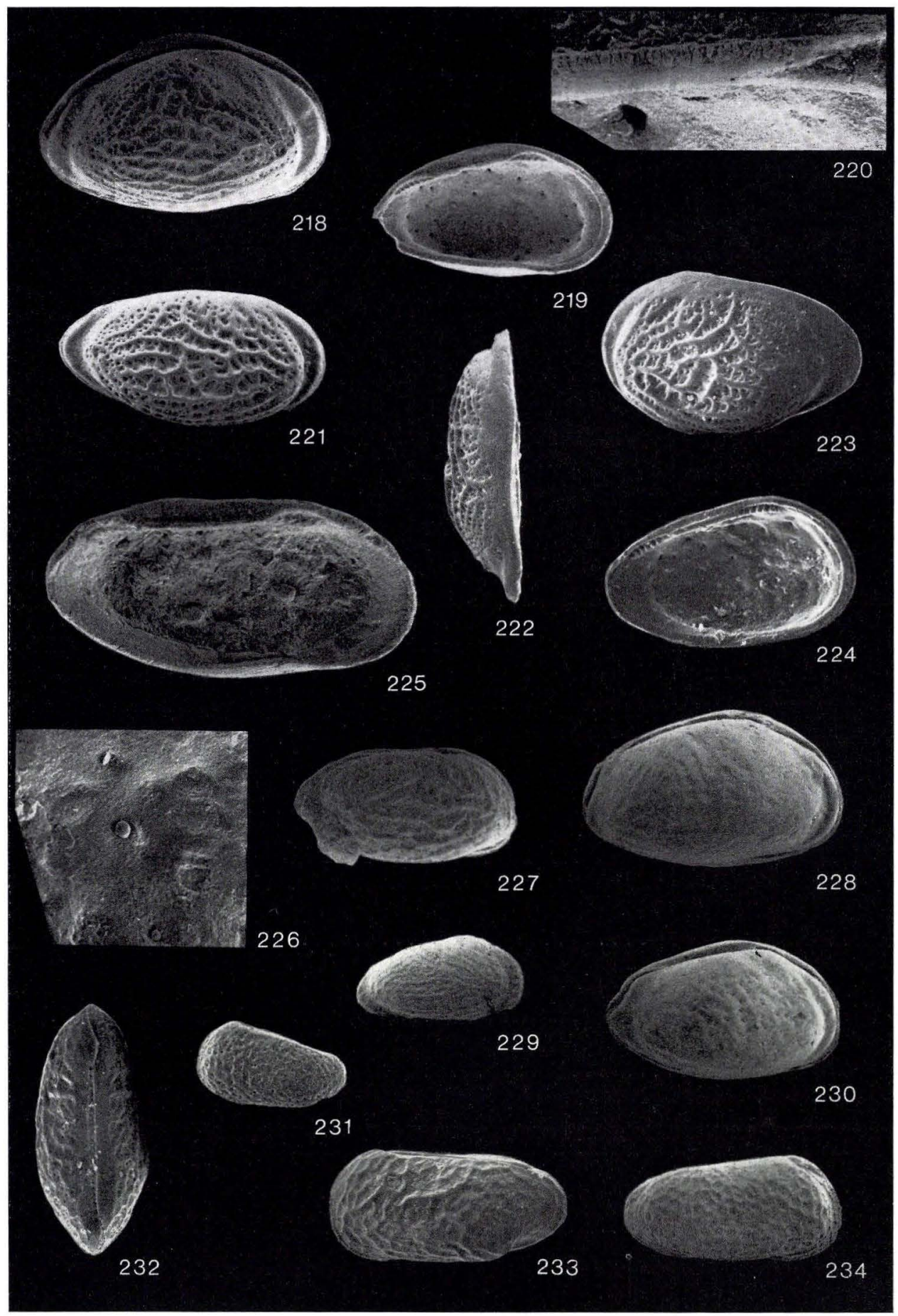


Plate 16

D. G. U. Text

$\times 60$ (figs. 242-248); $\times 75$ (figs. 235-241)

catalogue No. page

Figs. 235-238. Gramannella laevigata n. sp. .............. 175

Fig. 235. Left valve, adult, length $0.56 \mathrm{~mm}$, height $0.25 \mathrm{~mm}$.

Holotype. External view. Øresund No. 12, sample No. 1393 1972-OM-16

Figs. 236-238. Right valve, larva, length $0.43 \mathrm{~mm}$, height

$0.22 \mathrm{~mm}$. Øresund No. 12, sample No. 1405. - Fig. 236:

External view. - Fig. 237: Internal view. - Fig. 238: Dorsal

view ............................. 1972-OM-15

Figs. 239-241. Gramannella sp. 4253 . . . . . . . . . . . . . 176

Left valve, length $0.61 \mathrm{~mm}$, height $0.29 \mathrm{~mm}$. Øresund No.

12, sample No. 1406. - Fig. 239: External view. - Fig. 240:

Internal view. - Fig. 241: Dorsal view. . . . . . . . . . 1972-OM-17

Figs. 242-244. Kinkelinella (Klinglerella) multicostata (Klingler \&

Neuweiler, 1959) ...........................

Carapace, length $0.64 \mathrm{~mm}$, height $0.40 \mathrm{~mm}$. Nøvling No. 1,

sample 5660'-5690'. - Fig. 242: Dorsal view. - Fig. 243:

Right side. - Fig. 244: Posterior view . . . . . . . . . 1972-OM-36

Figs. 245-247. Kinkelinella (Klinglerella) triebeli (Klingler \& Neuwei-

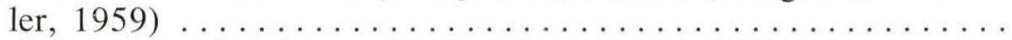
Carapace, length $0.69 \mathrm{~mm}$, height $0.42 \mathrm{~mm}$. Øresund No. 10, sample No. 1183. - Fig. 245: Dorsal view. - Fig. 246:

Posterior view. - Fig. 247: Right side............. 1972-OM-38

ig. 248. Kinkelinella (Kinkelinella) aff. adunca (Plumhoff, 1963). . . .

Left valve, broken posterodorsally. External view. Øresund

No. 2, sample No. 197

1972-OM-1

Phot.: O. Neergaard Rasmussen. 


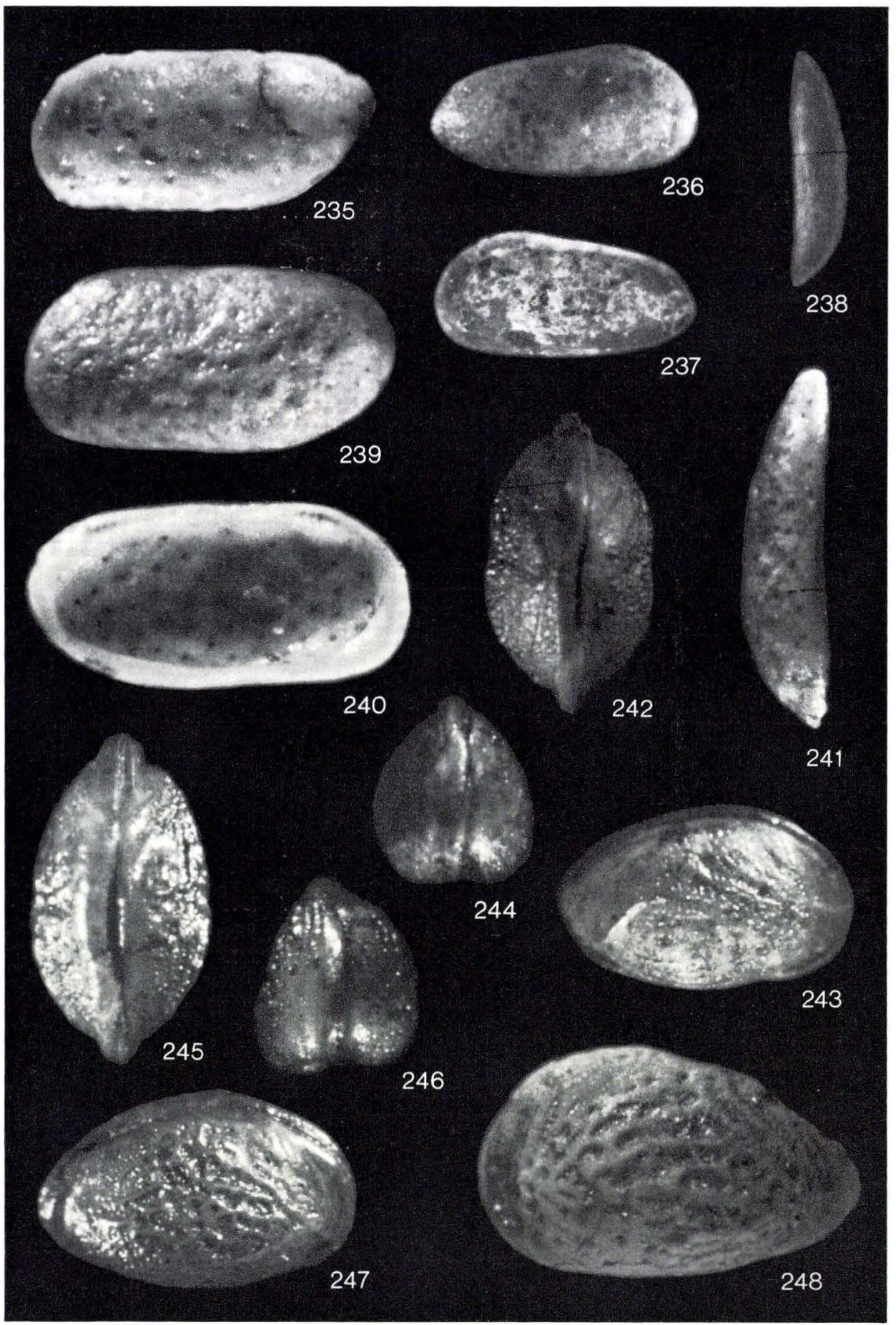


Figs. 249-252. Nanacythere (Nanacythere) simplex Herrig, 1969 . . . 196

Fig. 249. Right valve, adult, length $0.35 \mathrm{~mm}$, height 0.16

mm. Internal view. $\times$ 135. Fjerritslev No. 1, sample No. 4 1973-OM-145

Fig. 250. Left valve, adult, length $0.37 \mathrm{~mm}$, height $0.18 \mathrm{~mm}$.

Internal view. $\times$ 135. Fjerritslev No. 1 , sample No. $4 \ldots$ 1973-OM-146

Figs. 251-252. Left valve, adult, length $0.38 \mathrm{~mm}$, height

$0.18 \mathrm{~mm}$. External views. Flyvbjerg No. 1, sample No. 18. -

Fig. 251: $\times 100$. - Fig. 252: Detail showing the sculpture,

$\times 400 \ldots \ldots \ldots \ldots \ldots \ldots \ldots \ldots \ldots \ldots \ldots \ldots \ldots$ 1973-OM-147

Figs. 253-257. Nanacythere (Domeria) firma Herrig, 1969 . . . . . . .

Fig. 253. Carapace, adult, length $0.32 \mathrm{~mm}$, height $0.15 \mathrm{~mm}$.

Right side. $\times$ 100. Gassum No. 1 , sample No. 10 . . . . 1973-OM-148

Fig. 254. Carapace, adult, length $0.35 \mathrm{~mm}$, deformed ven-

trally. Right side. $\times 100$. Vedsted No. 1 , sample No. $19 \ldots$

Fig. 255. Left valve, adult, length $0.36 \mathrm{~mm}$, height $0.17 \mathrm{~mm}$.

External view. $\times 100$. Øresund No. 3, sample No. $315 \ldots$

Fig. 256. Right valve, adult, length $0.32 \mathrm{~mm}$, height 0.15

mm. Internal view. $\times 135$. Gassum No. 1 , sample No. $10 \ldots$

Fig. 257. Left valve, adult, length $0.33 \mathrm{~mm}$, height $0.16 \mathrm{~mm}$.

Internal view. $\times 135$. Gassum No. 1, sample No. $10 \ldots 1973-O M-152$

Fig. 258. Nanacythere (Domeria) fissicosta Herrig, 1969 Carapace, adult, length $0.36 \mathrm{~mm}$, height $0.17 \mathrm{~mm}$. Right side. $\times 100$. Gassum No. 1, sample No. $10 \ldots \ldots$.... 1973-OM-153

1973-OM-149

$1973-O M-150$

1973-OM-151

200

Figs. 259-267. Nanacythere (Goniocythere) circumcostata n. sp. . . .

Fig. 259. Carapace, adult, length $0.33 \mathrm{~mm}$. Dorsal view.

$\times$ 140. Nøvling No. 1, sample $5930^{\prime}-5960^{\prime} \ldots \ldots \ldots \ldots$

Figs. 260, 266. Carapace, adult, length $0.32 \mathrm{~mm}$. Nøvling

No. 1, sample 5930'-5960'. - Fig. 260: Ventral view,

$\times$ 130. - Fig. 266: Right side, $\times 140 \ldots \ldots \ldots \ldots \ldots$

Fig. 261. Right valve, adult, length $0.32 \mathrm{~mm}$, height 0.15

mm. External view. $\times 100$. Øresund No. 8, sample No. 917

Fig. 262. Carapace, adult, length $0.32 \mathrm{~mm}$, height $0.16 \mathrm{~mm}$.

Left side. $\times 100$. Gassum No. 1 , sample No. $48 \ldots \ldots$.

Fig. 263. Left valve, adult, length $0.32 \mathrm{~mm}$, height $0.15 \mathrm{~mm}$.

Internal view. $\times 100$. Horsens No. 1 , sample No. $3 \ldots \ldots$.

Fig. 264. Right valve, adult, length $0.32 \mathrm{~mm}$, height 0.16

mm. Internal view. $\times 100$. Horsens No. 1 , sample No. 3. .

Fig. 265. Carapace, adult, length $0.32 \mathrm{~mm}$, height $0.14 \mathrm{~mm}$.

Ventral view. $\times 100$. Horsens No. 1 , sample No. $5 \ldots$.

1973-OM-154

201

1973-OM-155

1973-OM-156

1973-OM-157

1973-OM-158

1973-OM-159

Fig. 267. Carapace, adult, length $0.32 \mathrm{~mm}$, height $0.15 \mathrm{~mm}$.

Left side. $\times$ 100. Holotype. Horsens No. 1, sample No. 5 1973-OM-161

Scanning electron micrographs (figs. 259-260, 266: J. Fuglsang Nielsen). 

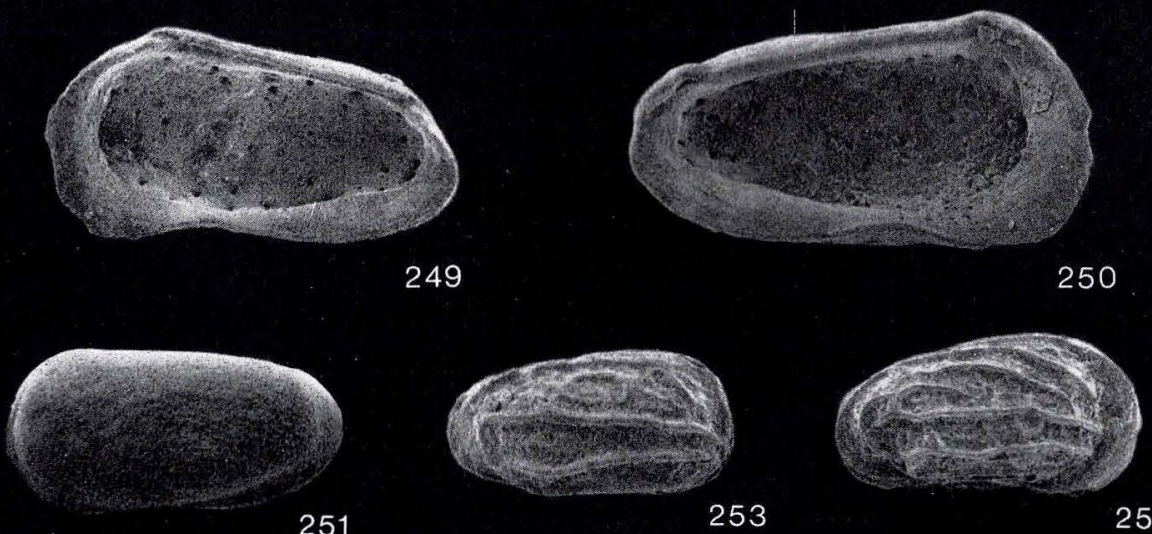

254
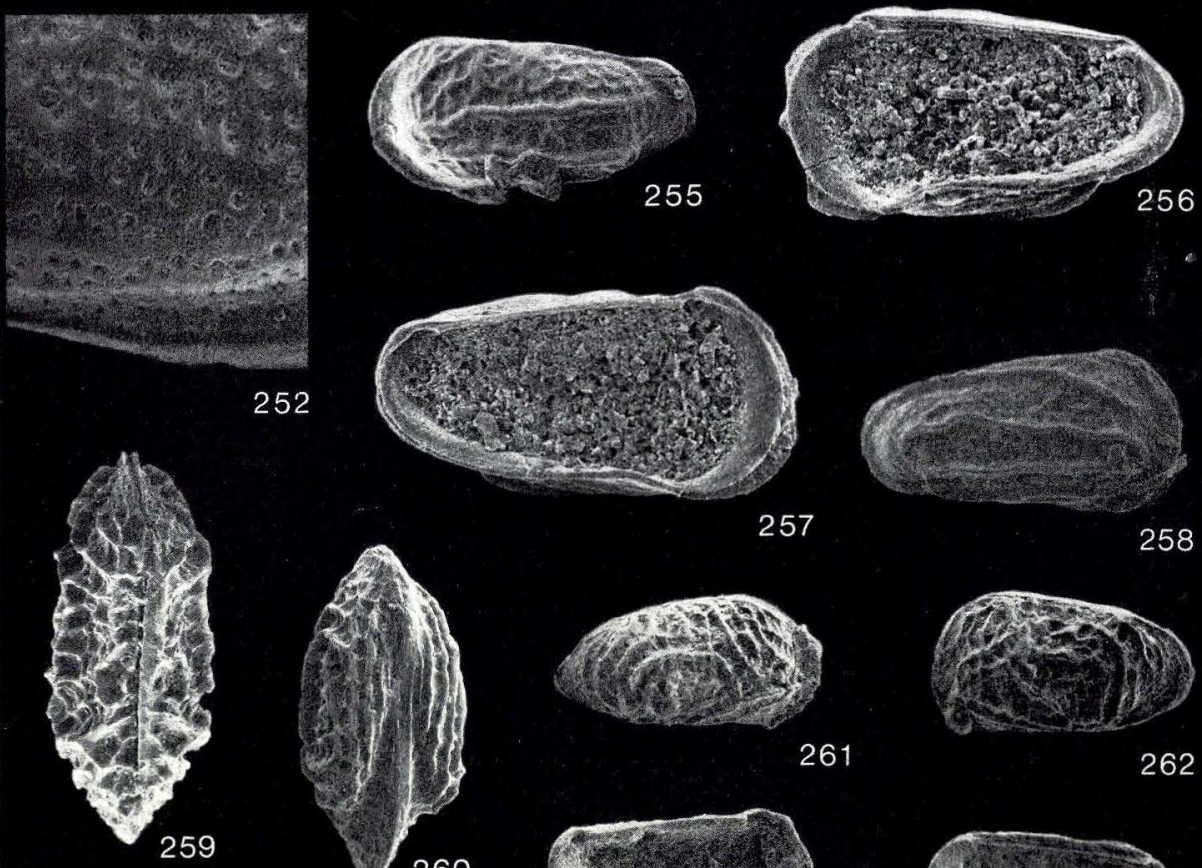

252
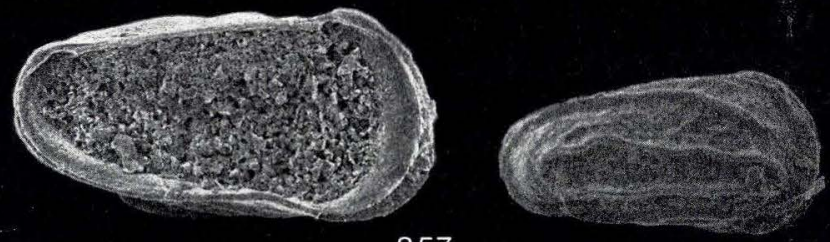

257

258
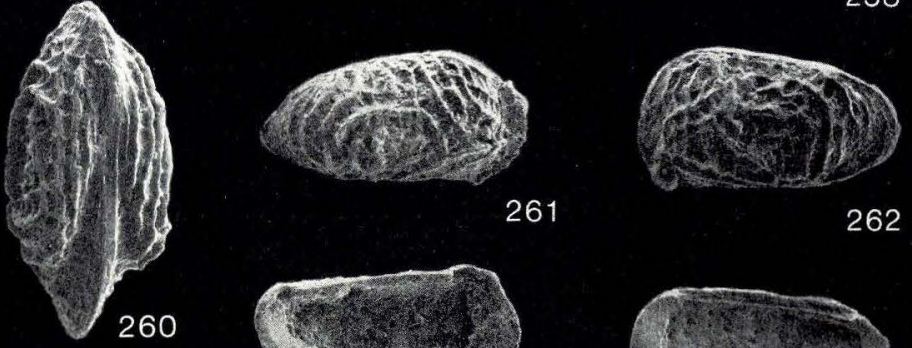

261

262

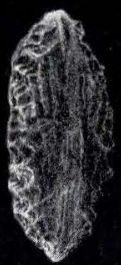

265

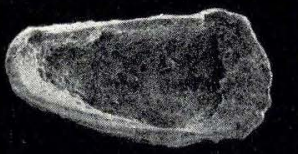

263
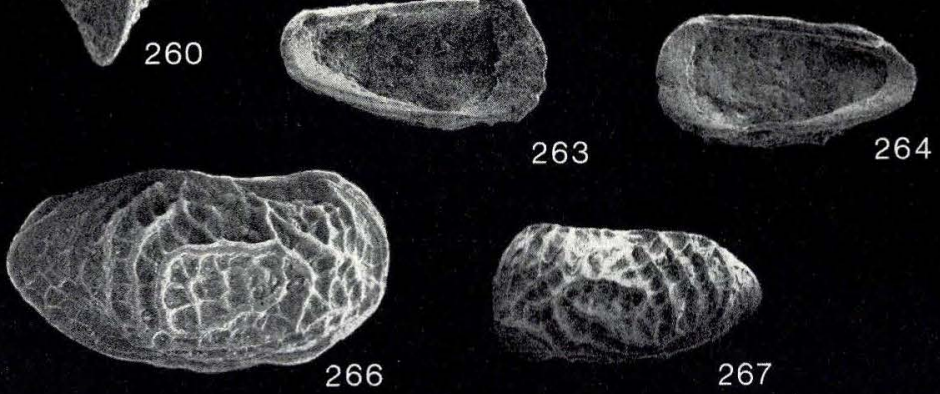
Plate 18

$\times 60$ (figs. 268-273); $\times 75$ (figs. 274-291)

D. G. U. Text catalogue No. page

Figs. 268-273. Kinkelinella (Klinglerella) ? elongata n. sp. . . . . . . . 194

Figs. 268-270. Left valve, adult, female, length $0.52 \mathrm{~mm}$, height $0.25 \mathrm{~mm}$. Holotype. Børglum No. 1, sample No. 14. - Fig. 268: External view. - Fig. 269: Dorsal view. - Fig.

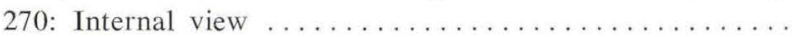
1972-OM-33

Figs. 271-273. Carapace, adult, male, length $0.52 \mathrm{~mm}$, height $0.27 \mathrm{~mm}$. Børglum No. 1, sample No. 14. - Fig. 271: Right side. - Fig. 272: Posterior view. - Fig. 273: Dorsal view ............................ 1972-OM-34

Figs. 274-275. Nanacythere (Domeria) firma Herrig, 1969 . . . . . . Carapace, adult, length $0.36 \mathrm{~mm}$, height $0.16 \mathrm{~mm}$. Rønde No. 1, sample 7645'-7660'. - Fig. 274: Dorsal view. - Fig. 275: Right side ..................... 1972-OM-87

Figs. 276-277. Nanacythere (Nanacythere) simplex Herrig, 1969 . . . . Carapace, adult, length $0.37 \mathrm{~mm}$, height $0.18 \mathrm{~mm}$. Gassum No. 1, sample No. 11. - Fig. 276: Right side. - Fig. 277: Dorsal view ....................... 1972-OM-85

Figs. 278-279. Nanacythere (Domeria) fissicosta Herrig, 1969 . . . . . Carapace, adult, broken and deformed. Gassum No. 1, sample No. 8. - Fig. 278: Right side. - Fig. 279: Left side 1972-OM-86

Figs. 280-283. Nanacythere (Goniocythere) circumcostata n. sp. . . . Figs. 280-281. Right valve, adult, length $0.32 \mathrm{~mm}$, height 0.17 mm. Horsens No. 1, sample No. 3. - Fig. 280: External view. - Fig. 281: Internal view ........... Figs. 282-283. Carapace, aduit, length $0.33 \mathrm{~mm}$, height $0.16 \mathrm{~mm}$. Horsens No. 1, sample No. 3. - Fig. 282: Dorsal view. - Fig. 283: Left side . . . . . . . . . . . . . 1972-OM-90

Figs. 284-285. Nanacythere (Goniocythere) minor n. sp. . . . . . . . . Right valve, adult, length $0.28 \mathrm{~mm}$, height $0.14 \mathrm{~mm}$. Holotype. Øresund No. 12, sample No. 1418.-Fig. 284: External view. - Fig. 285: Internal view .............. 1973-OM-14

gs. 286-287. Nanacythere (Goniocythere) elongata n. sp. . . . . . . Carapace, adult, length $0.37 \mathrm{~mm}$, height $0.17 \mathrm{~mm}$. Holotype. Gassum No. 1, sample No. 49A. - Fig. 286: Right

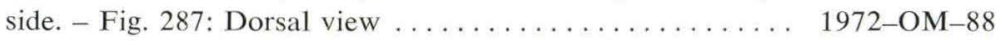

Figs. 288-289. Nanacythere (Goniocythere) paracostata n. sp. . . . . . Carapace, adult, length $0.27 \mathrm{~mm}$, height $0.13 \mathrm{~mm}$. Horsens No. 1, sample No. 3. - Fig. 288: Left side. - Fig. 289: Dorsal view ........................ 1972-OM-91

Figs. 290-291. Nanacythere (Goniocythere) elegans (Drexler, 1958). . Carapace, adult, length $0.33 \mathrm{~mm}$, height $0.17 \mathrm{~mm}$. Gassum No. 1, sample No. 48. - Fig. 290: Left side. - Fig. 291: Dorsal view 1972-OM-92

Phot.: O. Neergaard Rasmussen. 


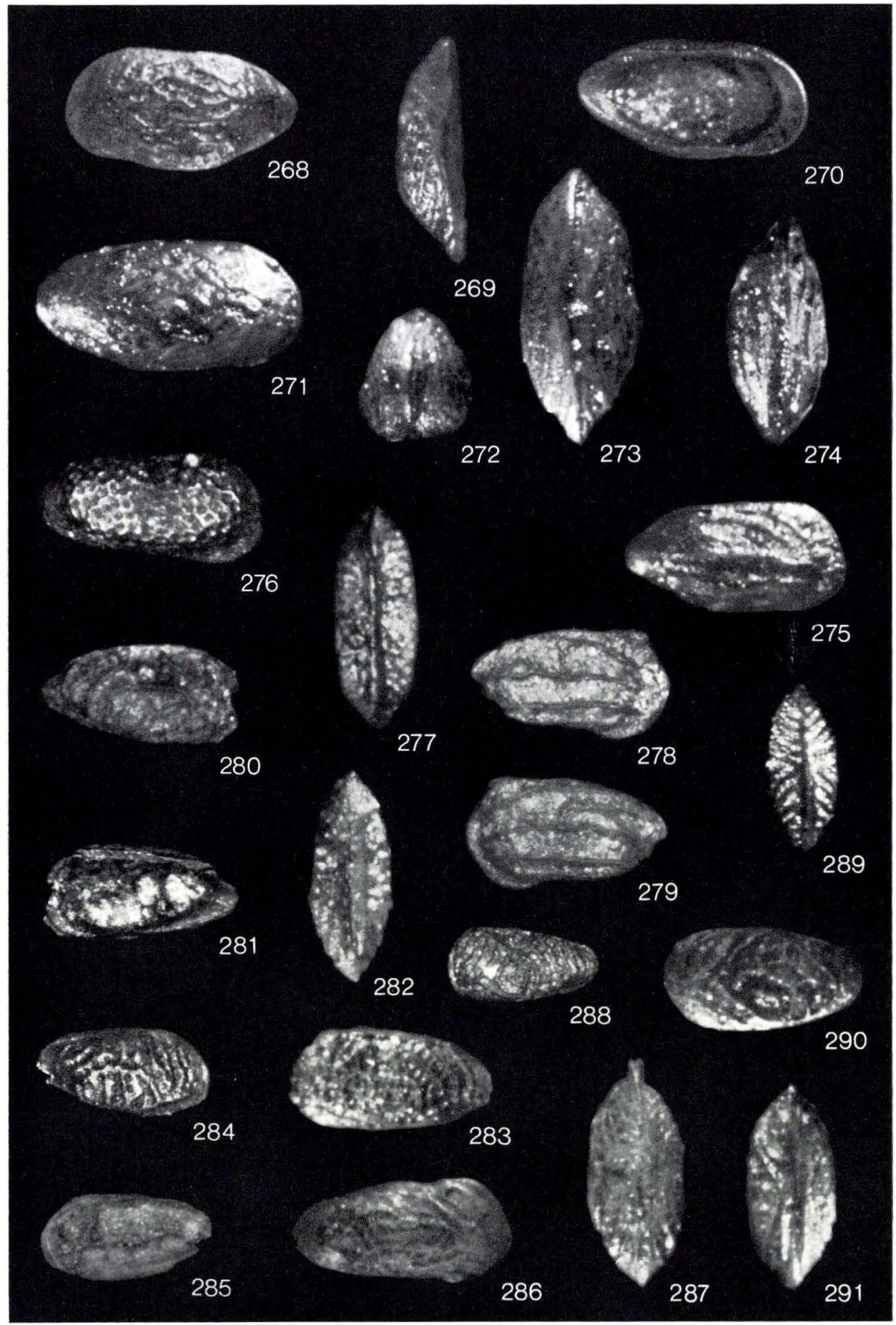


Figs. 292-297. Nanacythere (Goniocythere) elegans (Drexler, 1958) . . 204

Figs. 292-293. Carapace. Nøvling No. 1, sample 5960'5990'. - Fig. 292: Right side, $\times$ 130. - Fig. 293: Lateroventral view, $\times 140$

1973-OM-162

Figs. 294-295. Right valve, adult. Nøvling No. 1, sample 5960'-5990'. - Fig. 294: External view, $\times$ 150. - Fig. 295:

Internal view, $\times 135$

1973-OM-163

Fig. 296. Right valve, adult, length $0.29 \mathrm{~mm}$, height 0.14 mm. Internal view. $\times 135$. Horsens No. 1, sample No. 5 . . Fig. 297. Carapace, adult, length $0.30 \mathrm{~mm}$, height $0.14 \mathrm{~mm}$.

Right side. $\times 100$. Horsens No. 1, sample No. 5 ..... 1973-OM-165

Figs. 298-302. Nanacythere (Goniocythere) elongata n. sp. . . . . . . Fig. 298. Carapace, adult, length $0.37 \mathrm{~mm}$, height $0.17 \mathrm{~mm}$. Right side. $\times 100$. Nøvling No. 1, sample 5990'-6020'.. Fig. 299. Right valve, adult, deformed. Internal view of the anterior part. $\times 270$. Gassum No. 1 , sample No. 49A . Figs. 300-301. Carapace, adult, length $0.36 \mathrm{~mm}$, height $0.17 \mathrm{~mm}$. Gassum No. 1, sample No. 49A. - Fig. 300: Right side, $\times$ 100. - Fig. 301: Dorsal view, $\times 100 \ldots \ldots \ldots$. Fig. 302. Carapace, adult, length $0.37 \mathrm{~mm}$, height $0.17 \mathrm{~mm}$. Ventral view. $\times 100$. Nøvling No. 1, sample 6050'-6080'.

1973-OM-166 1973-OM-167

1973-OM-168

1973-OM-169

Figs. 303-307. Nanacythere (Goniocythere) minor n. sp. . . . . . . . . Fig. 303. Right valve, adult, length $0.27 \mathrm{~mm}$, height 0.14 mm. External view. $\times 100$. Øresund No. 12 , sample No. 1432

Figs. 304-305. Left valve, adult, broken. Øresund No. 12, sample No. 1418. - Fig. 304: External view, $\times$ 100. - Fig. 305: Ventral view, $\times 100$

Fig. 306. Right valve, adult, length $0.26 \mathrm{~mm}$, height 0.13 $\mathrm{mm}$. Laterodorsal view. $\times 100$. Øresund No. 12, sample No. 1432

Fig. 307. Right valve, adult, length $0.26 \mathrm{~mm}$, height 0.14 mm. Internal view. $\times 200$. Øresund No. 12, sample No. 1432 1973-OM-173

Figs. 308-314. Nanacythere (Goniocythere) paracostata n. sp. . . . . . Fig. 308. Carapace, adult, length $0.31 \mathrm{~mm}$, height $0.15 \mathrm{~mm}$. Left side. $\times$ 100. Øresund No. 10, sample No. $1183 \ldots$... Fig. 309. Carapace, adult, length $0.29 \mathrm{~mm}$, height $0.14 \mathrm{~mm}$. Ventral view. $\times 100$. Gassum No. 1, sample No. $52 \ldots$. . Figs. 310-311. Carapace, adult, length $0.26 \mathrm{~mm}$, height $0.13 \mathrm{~mm}$. Holotype. Horsens No. 1, sample No. 3. - Fig. 310: Laterodorsal view, $\times$ 100. - Fig. 311: Left side,

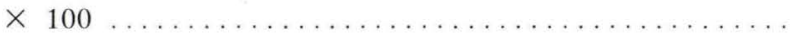

Fig. 312. Right valve, adult, length $0.29 \mathrm{~mm}$, height 0.14 mm. Internal view. $\times 135$. Nøvling No. 1, sample 5990'$6020^{\prime}$ 1973-OM-174 1973-OM-175

Figs. 313-314. Carapace, adult. Nøvling No. 1, sample 5960'-5990'. - Fig. 313: Right side, $\times$ 165. - Fig. 314: Lateroventral view, $\times 160$ 1973-OM-178

Scanning electron micrographs (figs. 292-295, 313-314: J. Fuglsang Nielsen). 


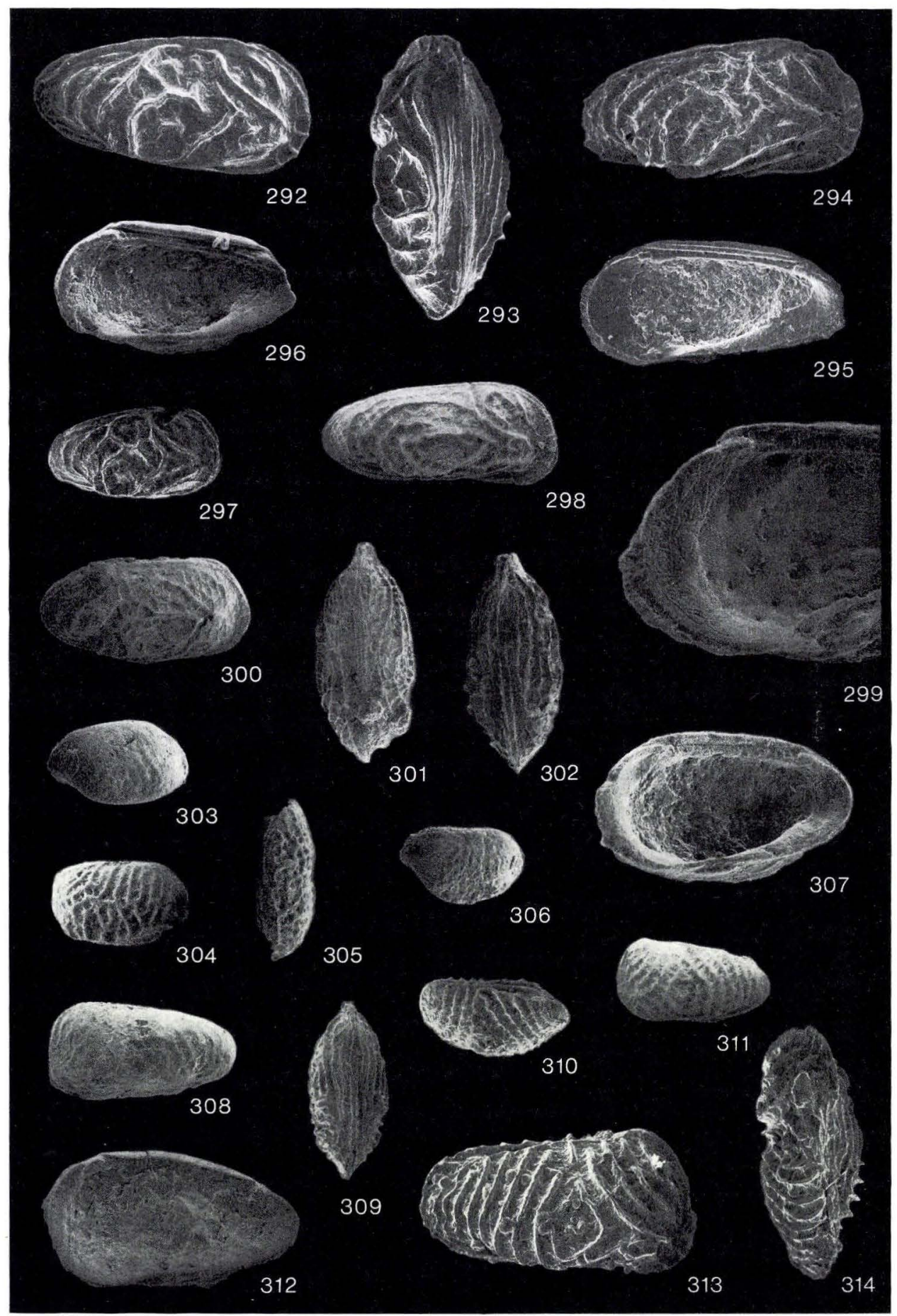


Figs. 315-318. Nanacythere ? bachi (Gramann, 1962) . . . . . . . 211

Fig. 315. Carapace, adult, length $0.29 \mathrm{~mm}$, height $0.15 \mathrm{~mm}$.

Left side. $\times 100$. B $\varnothing$ rglum No. 1 , sample No. $14 \ldots \ldots$.

Fig. 316. Left valve, adult, length $0.29 \mathrm{~mm}$, height $0.14 \mathrm{~mm}$.

Internal view. $\times 135$. B $\varnothing$ rglum No. 1 , sample No. $14 \ldots$.

Fig. 317. Right valve, adult, length $0.29 \mathrm{~mm}$, height 0.16

$\mathrm{mm}$. Internal view. $\times 135$. B $\varnothing$ rglum No. 1 , sample No. 14

Fig. 318. Carapace, adult, length $0.29 \mathrm{~mm}$, height $0.16 \mathrm{~mm}$.

Right side. $\times 100$. Børglum No. 1, sample No. $14 \ldots \ldots$ 1973-OM-182

Fig. 319. ? Nanacythere ? bachi (Gramann, 1962) . . . . . . . . . . . .

Left valve, adult, length $0.30 \mathrm{~mm}$, height $0.16 \mathrm{~mm}$. Exter-

nal view. $\times 100$. Øresund No. 15 , sample No. $1826 \ldots$... 1973-OM-183

Figs. 320-322. Nanacythere? sp. 4061 (Michelsen, 1970) . . . . . . .

Fig. 320. Left valve, length $0.28 \mathrm{~mm}$, height $0.14 \mathrm{~mm}$.

Internal view. $\times 135$. R $\varnothing$ dby No. 1 , sample No. $20 \ldots$ 1973-OM-184

Fig. 321. Left valve, broken posterodorsally. External view.

$\times 100$. R $\varnothing$ dby No. 1, sample No. $21 \ldots \ldots \ldots \ldots \ldots$ 1973-OM-185

Fig. 322. Right valve, broken. Internal view of the anterior

end. $\times$ 135. Rødby No. 1, sample No. 20 ......... 1973-OM-186

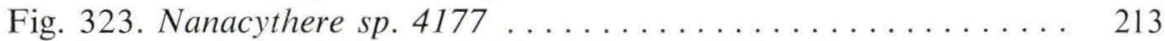

Carapace, length $0.31 \mathrm{~mm}$, height $0.14 \mathrm{~mm}$. Right side.

$\times$ 100. Vedsted No. 1, sample No. $20 \ldots \ldots \ldots \ldots \ldots$ 1973-OM-187

Figs. 324-326. Kinkelinella (Klinglerella) bipartita (Klingler \& Neuweiler, 1959) ........................

Fig. 324. Right valve, adult, length $0.64 \mathrm{~mm}$, height 0.33

mm. Internal view. $\times$ 70. Gassum No. 1, sample No. 39A 1973-OM-188

Figs. 325-326. Left valve, adult, length $0.64 \mathrm{~mm}$, height

$0.36 \mathrm{~mm}$. Internal views. Gassum No. 1, sample No. 39A.

- Fig. 325: $\times$ 70. - Fig. 326: The middle hinge element,

$\times 670 \ldots \ldots \ldots \ldots \ldots \ldots \ldots \ldots \ldots \ldots$ 1973-OM-189

Figs. 327-330. Kinkelinella (Klinglerella) laqueata (Klingler \& Neu-

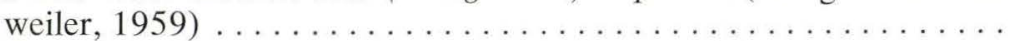

Fig. 327. Left valve, adult, female, length $0.55 \mathrm{~mm}$, height

$0.33 \mathrm{~mm}$. Internal view. $\times 100$. Gassum No. 1 , sample

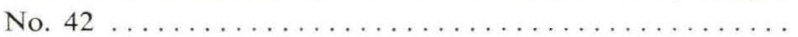

1973-OM-190

Fig. 328. Carapace, adult, female, length $0.57 \mathrm{~mm}$, height

$0.34 \mathrm{~mm}$. Right side. $\times 70$. Nøvling No. 1 , sample $5630^{\prime}-$

$5660^{\prime}$

1973-OM-191

Fig. 329. Carapace, adult, female, length $0.62 \mathrm{~mm}$, height

$0.38 \mathrm{~mm}$. Right side. $\times 70$. Gassum No. 1 , sample $4500^{\prime}-$

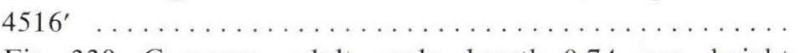

1973-OM-192

Fig. 330. Carapace, adult, male, length $0.74 \mathrm{~mm}$, height

$0.43 \mathrm{~mm}$. Right side. $\times 70$. Gassum No. 1, sample 4500'-

$4516^{\prime}$

1973-OM-193

Scanning electron micrographs. 

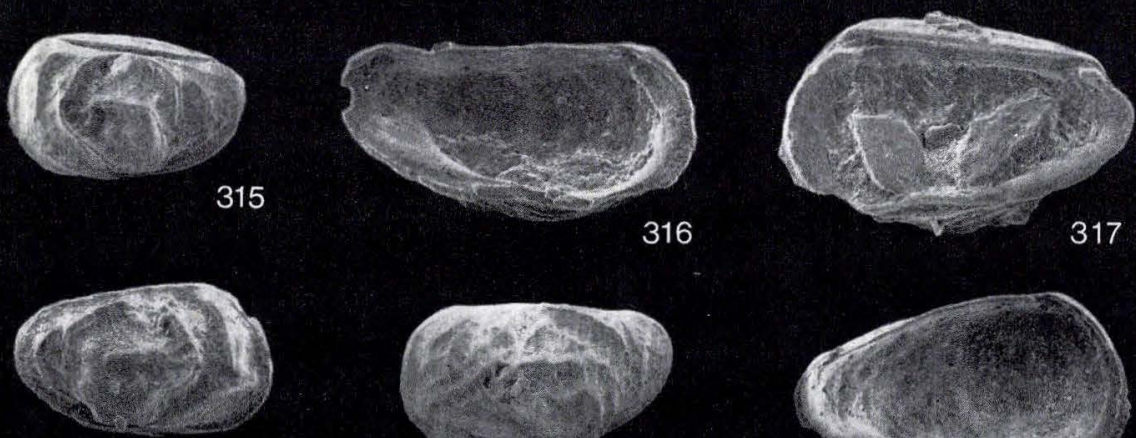

318
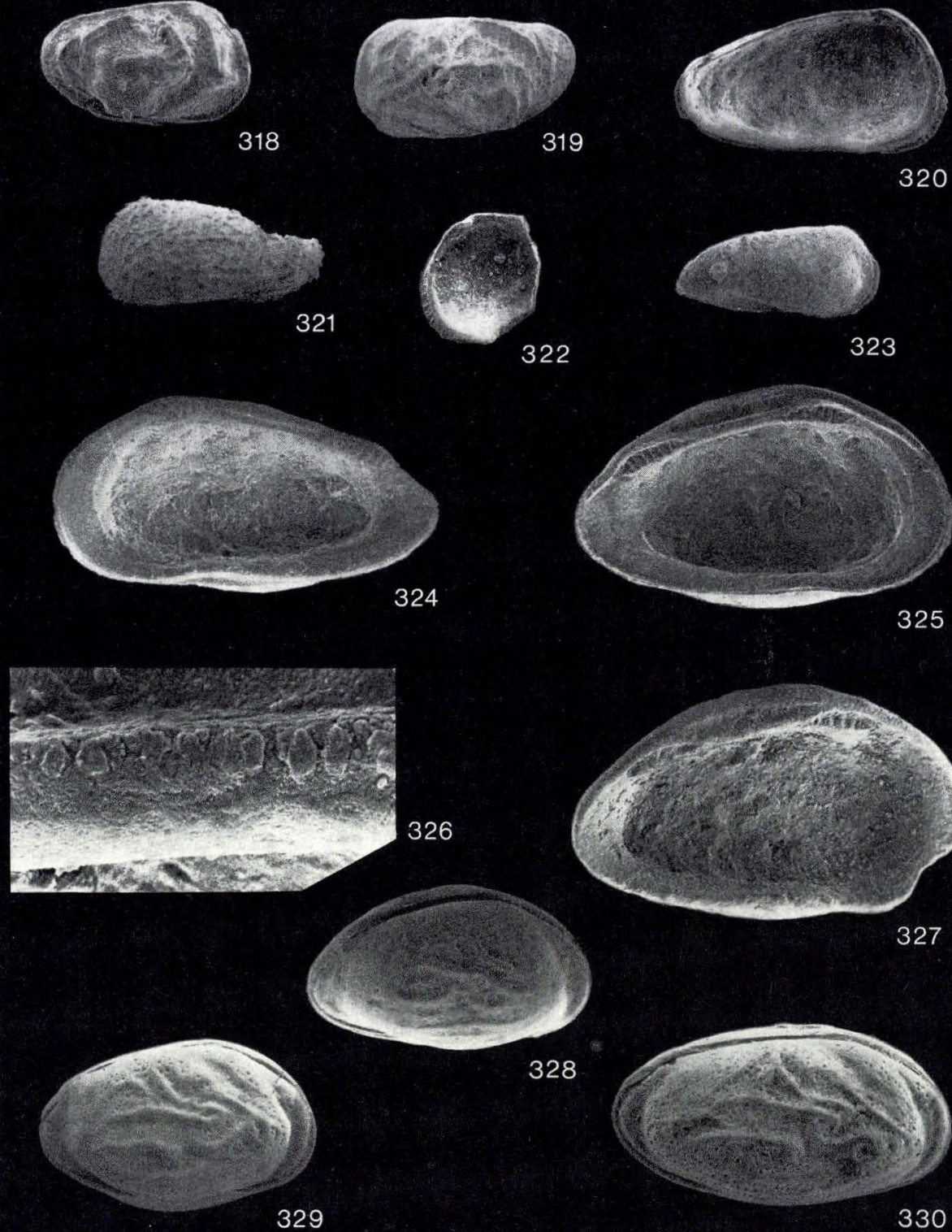

326

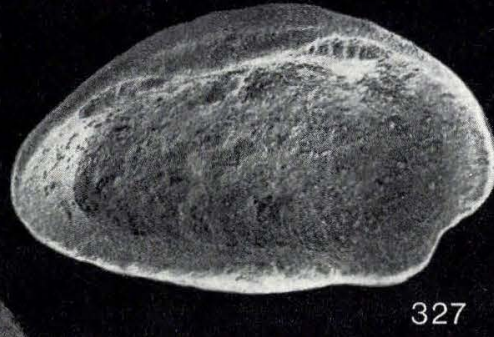

327 
Figs. 331-335. Kinkelinella (Klinglerella) foveolata n.sp. . . . . . . 189

Fig. 331. Carapace, adult, female, length $0.56 \mathrm{~mm}$, height

$0.31 \mathrm{~mm}$. Right side. $\times 100$. Øresund No. 12 , sample No. 1406

Fig. 332. Right valve, adult, male, length $0.67 \mathrm{~mm}$, height $0.32 \mathrm{~mm}$. Internal view. $\times 70$. Øresund No. 12 , sample No. 1406

Fig. 333. Right valve, adult, female, length $0.58 \mathrm{~mm}$, height $0.28 \mathrm{~mm}$. Internal view. $\times 100$. Øresund No. 12, sample No. $1406 \ldots \ldots \ldots \ldots \ldots \ldots \ldots \ldots \ldots \ldots \ldots \ldots \ldots \ldots \ldots \ldots$.

Figs. 334-335. Left valve, adult, female, length $0.60 \mathrm{~mm}$, height $0.34 \mathrm{~mm}$. Internal views. Øresund No. 12, sample No. 1406. - Fig. 334: Detail with the muscle scars, $\times 335$.

- Fig. 335: × $100 \ldots \ldots \ldots \ldots \ldots \ldots \ldots \ldots \ldots$. . . . . . . . . . . . 1973

Figs. 336-338. Kinkelinella (Klinglerella) variabilis (Klingler \& Neuweiler, 1959) ........................... Fig. 336. Carapace, length $0.51 \mathrm{~mm}$, height $0.28 \mathrm{~mm}$. Right side. $\times 70$. Rønde No. 1, sample $8050^{\prime}-8060^{\prime} \ldots \ldots \ldots$. . . Fig. 337. Left valve, larva, length $0.49 \mathrm{~mm}$, height $0.28 \mathrm{~mm}$. Internal view. $\times 100$. Nøvling No. 1 , sample $5300^{\prime}-5330^{\prime}$. Fig. 338. Right valve, broken posteriorly. External view. $\times$ 70. Gassum No. 1 , sample No. 36 Figs. 339, 341. Left valve, adult, length $0.55 \mathrm{~mm}$, height $0.29 \mathrm{~mm}$. Internal views. Øresund No. 12, sample No. 1406. - Fig. 339: Detail with the muscle scars, $\times 335$. - Fig. 341: $\times 100$

Fig. 340. Right valve, adult, length $0.57 \mathrm{~mm}$, height 0.29 $\mathrm{mm}$. Internal view. $\times 100$. N $\varnothing$ vling No. 1 , sample 5300'$5330^{\prime}$

Scanning electron micrographs. 


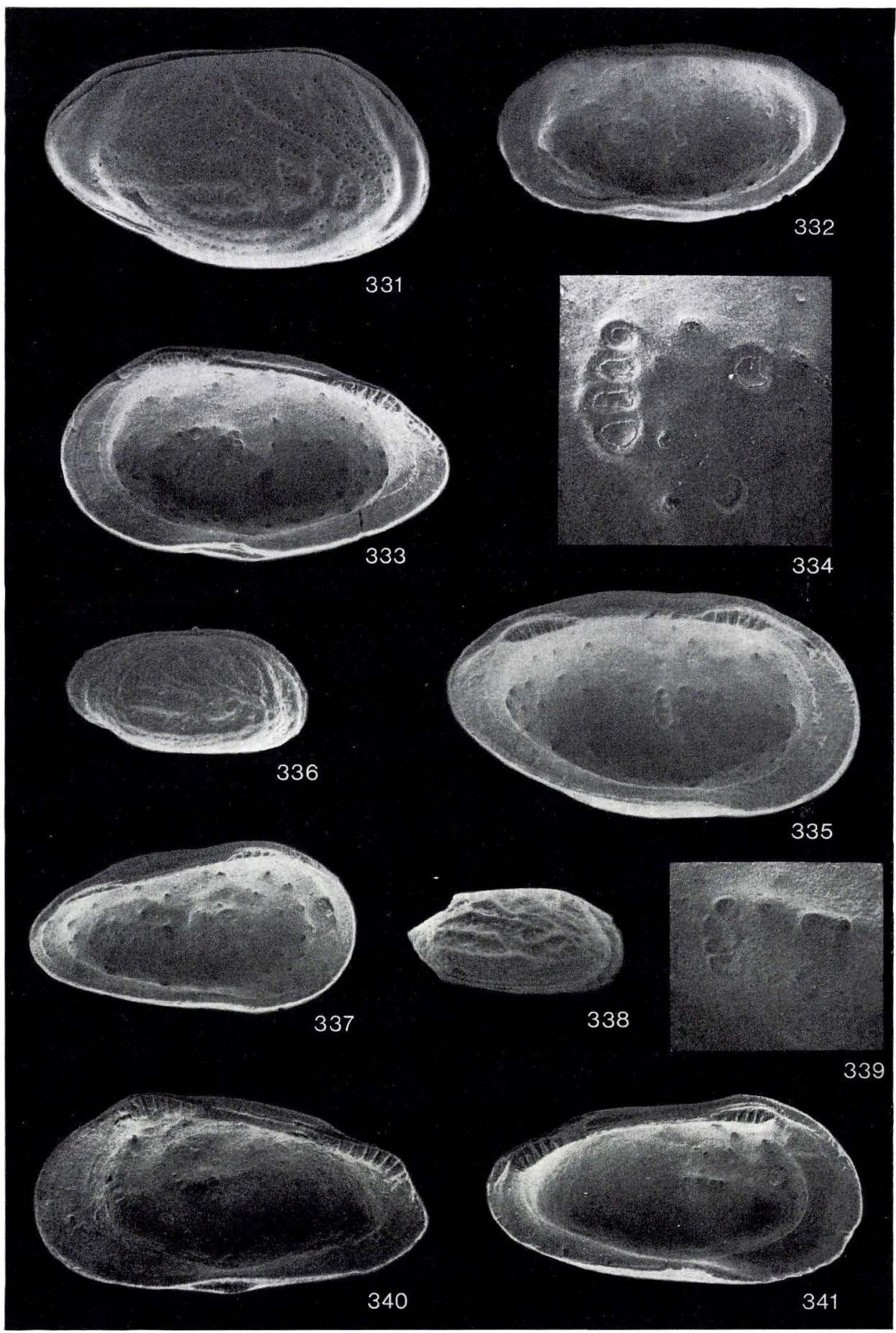


Plate 22

$\times 60$ (figs. 344-357); $\times 75$ (figs. 342-343)

D. G. U. Text catalogue No. page

Figs. 342-343. Nanacythere ? sp. 4061 (Michelsen, 1970) . . . . . 212 Right valve, length $0.29 \mathrm{~mm}$, height $0.14 \mathrm{~mm}$. Rødby No. 1 , sample No. 21. - Fig. 342: External view. - Fig. 343:

Dorsal view . . . . . . . . . . . . . . . . . . . 1969-OM-3

Figs. 344-346. Kinkelinella (Klinglerella) bipartita (Klingler \& Neuweiler, 1959) .............................. Figs. 344-345. Right valve, broken posteriorly. Øresund No. 11, sample No. 1362. - Fig. 344: External view. - Fig. 345:

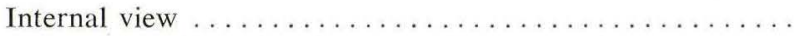
Fig. 346. Left valve, length $0.63 \mathrm{~mm}$, height $0.37 \mathrm{~mm}$. External view. Gassum No. 1, sample No. 39A ....... 1972-OM-9

Figs. 347-352. Kinkelinella (Klinglerella) foveolata n.sp. . . . . . . .

Figs. 347-349. Right valve, adult, female, length $0.58 \mathrm{~mm}$, height $0.29 \mathrm{~mm}$. Holotype. Øresund No. 12, sample No. 1410. - Fig. 347: External view. - Fig. 348: Dorsal view. Fig. 349: Internal view . . . . . . . . . . . . . . 1972-OM-10

Figs. 350-352. Carapace, adult, female, length $0.61 \mathrm{~mm}$, height $0.33 \mathrm{~mm}$. Øresund No. 12, sample No. 1410. - Fig. 350: Right side. - Fig. 351: Dorsal view. - Fig. 352: Anterior view ......................... 1972-OM-11

Figs. 353-357. Kinkelinella (Klinglerella) laqueata (Klingler \& Neuweiler, 1959) . . . . . . . . . . . . . . . . . . . . . Figs. 353-354. Carapace, length $0.65 \mathrm{~mm}$, height $0.26 \mathrm{~mm}$. Gassum No. 1, sample No. 42. - Fig. 353: Right side. Fig. 354: Dorsal view ...................... Figs. 355-357. Carapace, length $0.65 \mathrm{~mm}$, height $0.38 \mathrm{~mm}$. Nøvling No. 1, sample 5510'-5540'. - Fig. 355: Right side. - Fig. 356: Posterior view. - Fig. 357: Dorsal view ...... 1972-OM-26 Phot.: O. Neergaard Rasmussen. 


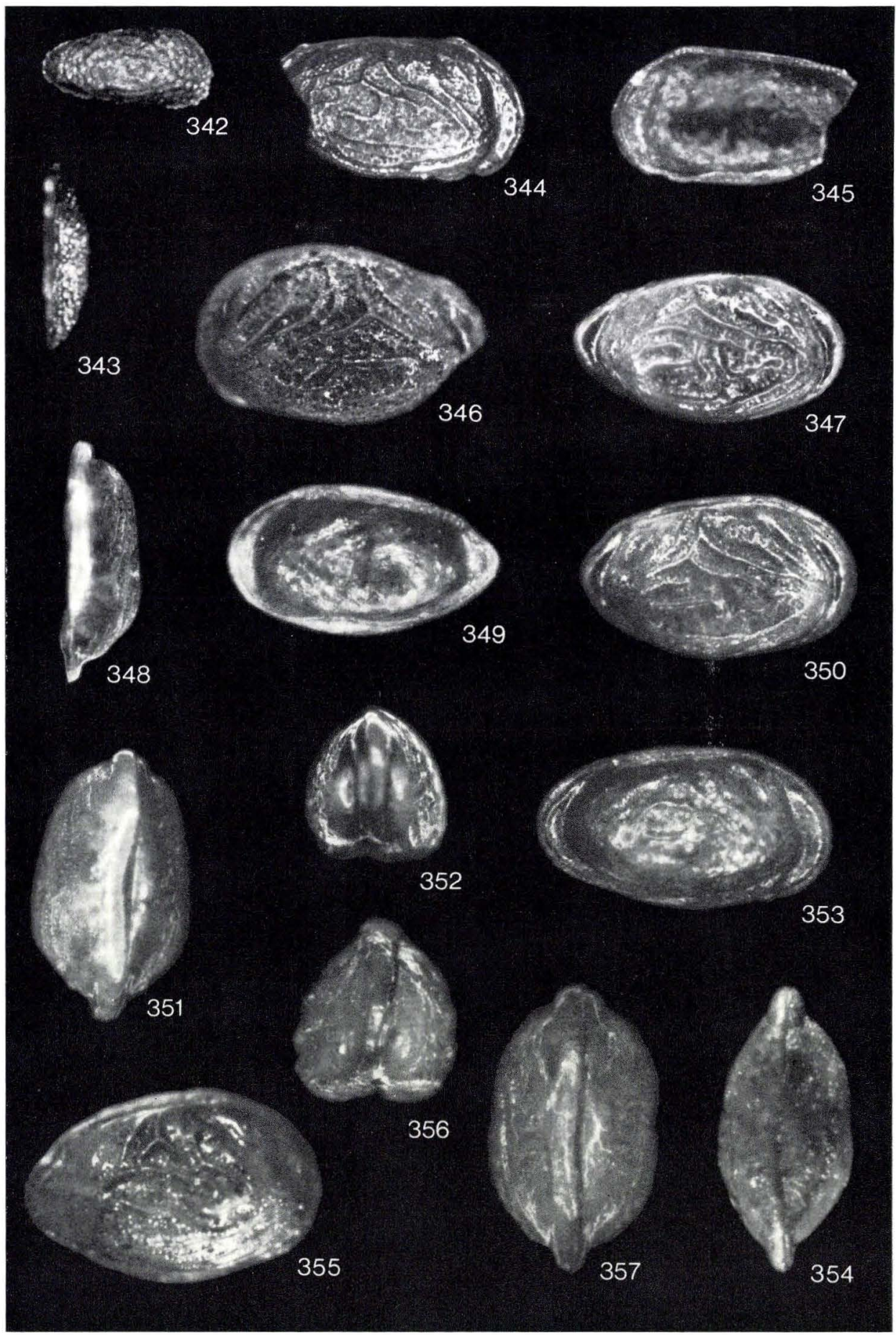


Fig. 358. Progonoidea acuticostata (Klingler \& Neuweiler, 1959) . . . 216 Carapace, deformed. Right side. $\times$ 70. Dansk Nords $\varnothing$ K-1, sample $5510^{\prime}$

Figs. 359-363. Progonoidea reticulata (Klingler \& Neuweiler, 1959). .

Fig. 359. Carapace, adult, female, length $0.58 \mathrm{~mm}$, height

0.37 mm. Right side. × 70. Gassum No. 1, sample No. 42 1973-OM-204

Fig. 360. Carapace, length $0.57 \mathrm{~mm}$, height $0.29 \mathrm{~mm}$. Right

side. $\times$ 70. Øresund No. 9, sample No. $1050 \ldots \ldots \ldots$

Fig. 361. Left valve, adult, female, length $0.62 \mathrm{~mm}$, height $0.36 \mathrm{~mm}$. Internal view. $\times$ 100. Ørslev No. 1, sample $1570^{\prime}-1600^{\prime}$

Fig. 362. Carapace, adult, male, length $0.71 \mathrm{~mm}$, height $0.36 \mathrm{~mm}$. Right side. $\times$ 70. Orslev No. 1, sample 1660'$1690^{\prime}$

Fig. 363. Right valve, adult, female, length $0.60 \mathrm{~mm}$, height $0.34 \mathrm{~mm}$. Internal view. $\times 100$. Gassum No. 1, sample

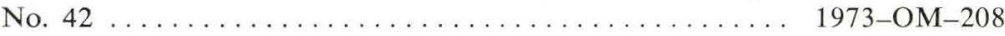

Figs. $364-365$. Indet. gen. sp. $4353 \ldots \ldots \ldots \ldots \ldots \ldots \ldots$ Fig. 364. Left valve, larva (?), broken. Internal view. $\times$ 135. Øresund No. 11, sample No. $1365 \ldots \ldots \ldots \ldots$ Fig. 365a. Right valve, larva (?), broken. External view. $\times$ 100. Øresund No. 11, sample No. $1367 \ldots \ldots \ldots \ldots$ Fig. 365b. Left valve, larva (?), broken; posterior part, broken dorsally. External view. $\times$ 100. Øresund No. 11, sample No. $1369 \ldots \ldots \ldots \ldots \ldots \ldots \ldots \ldots \ldots \ldots \ldots \ldots \ldots$ 1973-OM -210 b

igs. 366-367. Trachycythere angusta Herrig, $1969 \ldots$
Right valve, adult (?), length $0.57 \mathrm{~mm}$, height $0.27 \mathrm{~mm}$. External views. Øresund No. 3, sample No. 343. - Fig. 366: $\times$ 70. - Fig. 367: Detail of the sculpture, $\times 335 \ldots \ldots$. . 1973-OM-211 Figs. 368-371. Trachycythere tubulosa tubulosa Triebel \& Klingler,

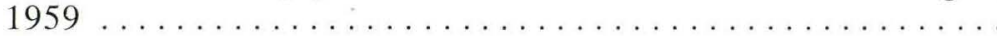
Fig. 368. Left valve, adult (?), length $0.51 \mathrm{~mm}$, height $0.27 \mathrm{~mm}$. External view. $\times 100$. Frederikshavn City No. 2, sample 2560'-2562'

Fig. 369. Right valve. External view. $\times 110$. Flyvbjerg No. 1, sample No. 19

Fig. 370. Left valve, larva, length $0.45 \mathrm{~mm}$, height $0.25 \mathrm{~mm}$. External view. $\times 100 . \emptyset$ resund No. 3, sample No. $366 \ldots$ Fig. 371. Left valve, length $0.50 \mathrm{~mm}$, height $0.25 \mathrm{~mm}$. External view. $\times$ 100. Fjerritslev No. 1, sample No. 4... 1973-OM-215

Fig. 372. Trachycythere horrida Triebel \& Klingler, 1959 . . . . . . . . . Anterior part of right valve. External view. $\times 100$. B $\varnothing$ rglum No. 1, sample No. $14 \ldots \ldots \ldots \ldots \ldots \ldots \ldots$ 1973-OM-216

Scanning electron micrographs (fig. 369: A. Nørgaard Jensen). 


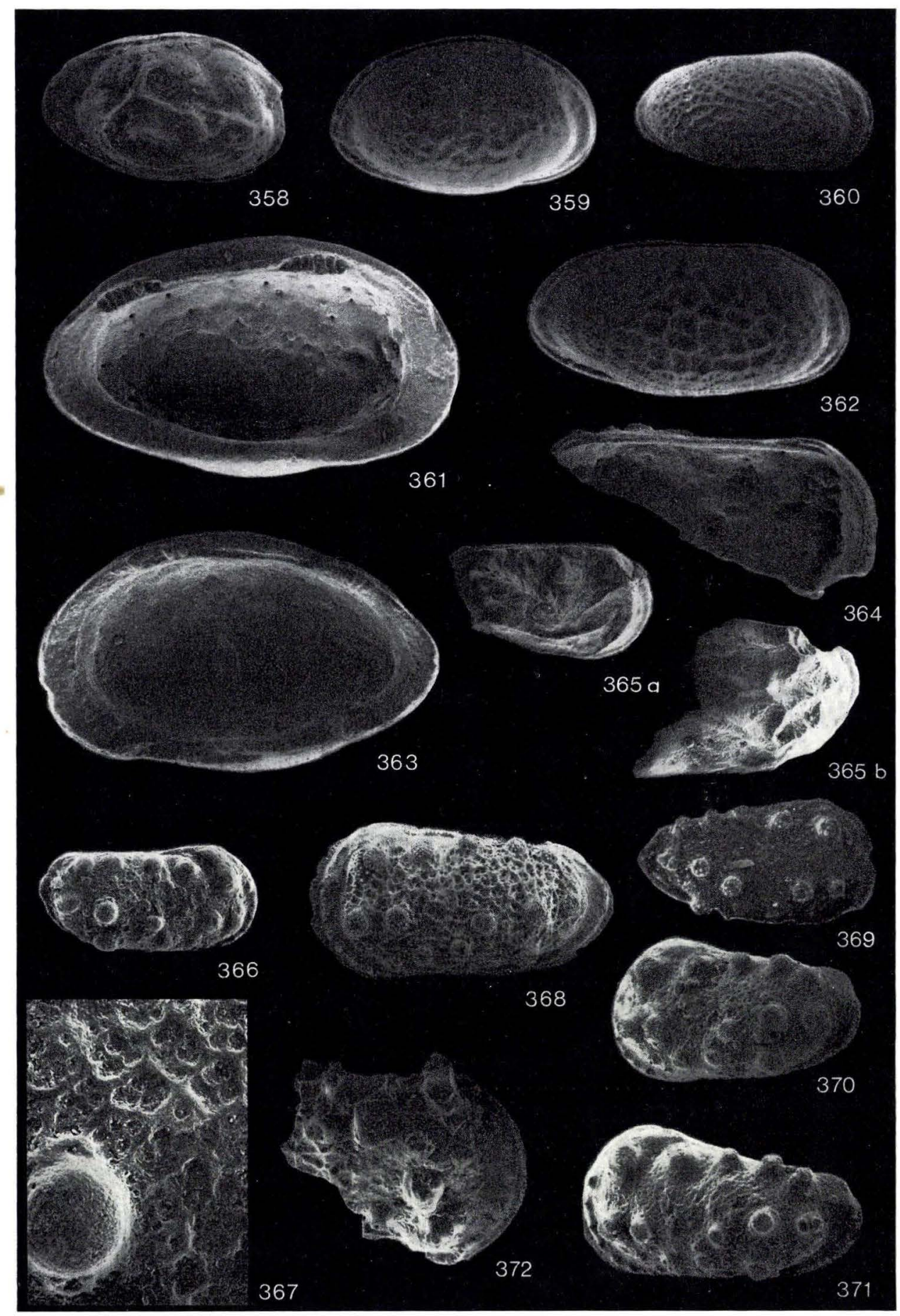


Figs. 373-377. Kinkelinella (Klinglerella) variabilis (Klingler \& Neu-

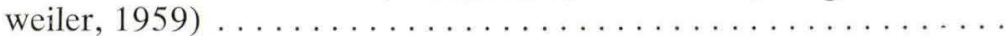

Figs. 373-375. Left valve, broken anteriorly. Øresund No. 15, sample No. 1836. - Fig. 373: External view. - Fig. 374:

Internal view. - Fig. 375: Dorsal view ............

Figs. 376-377. Carapace, length $0.52 \mathrm{~mm}$, height $0.30 \mathrm{~mm}$.

Gassum No. 1, sample 4400'-4410'. - Fig. 376: Dorsal view.

- Fig. 377: Right side ...................... 1973-OM-20

Figs. 378-380. Pleurifera harpa (Klingler \& Neuweiler, 1959) . . . . 214

Figs. 378-379. Carapace, length $0.56 \mathrm{~mm}$, height $0.31 \mathrm{~mm}$.

Øresund No. 12, sample No. 1406. - Fig. 378: Right side.

- Fig. 379: Dorsal view ..................... 1972-OM-25

Fig. 380. Anterior end of left valve. Børglum No. 1, sample

No. 14 .......................... 1972-OM-95

Figs. 381-382. Progonoidea auleata (Gramann, 1962) . . . . . . . .

Left valve, broken posteroventrally. Nøvling No. 1, sample $5630^{\prime}-5660^{\prime}$. - Fig. 381: Internal view. - Fig. 382: External view ............................. 1972-OM-2

Figs. 383-385. Progonoidea reticulata (Klingler \& Neuweiler, 1959) Carapace, adult, female, length $0.62 \mathrm{~mm}$, height $0.36 \mathrm{~mm}$. Ørslev No. 1, sample 1510'-1540'. - Fig. 383: Posterior view. - Fig. 384: Dorsal view. - Fig. 385: Right side ... 1972-OM-37

Phot.: O. Neergaard Rasmussen. 


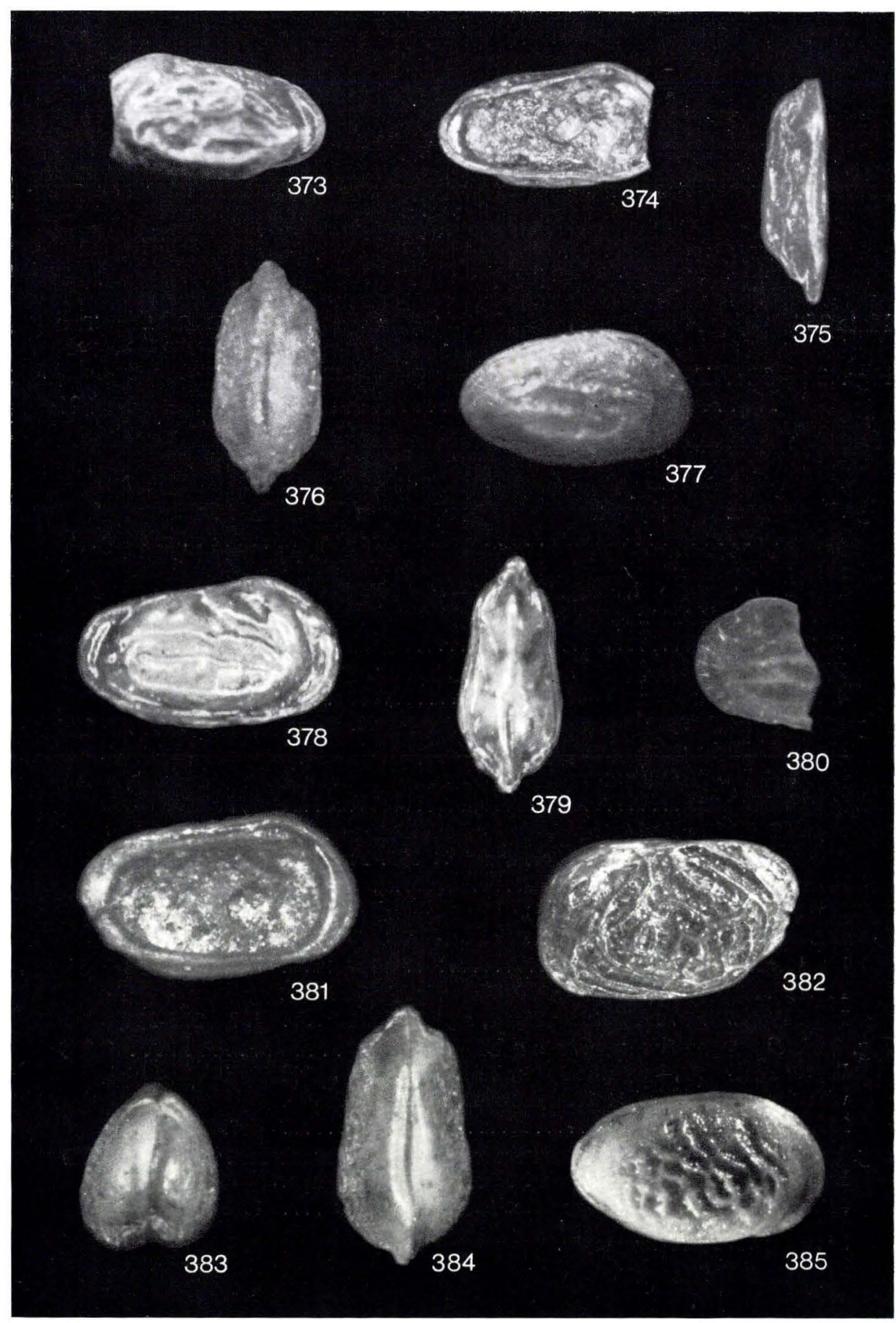


Figs. 386-387. Trachycythere tubulosa tubulosa Triebel \& Klingler,

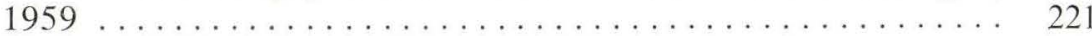

Right valve, larva, length $0.47 \mathrm{~mm}$, height $0.24 \mathrm{~mm}$. External views. "Rønne ny lergrav", Bornholm. - Fig. 386:

$\times 100$. - Fig. 387: Detail of the sculpture, $\times 335 \ldots \ldots$ 1973-OM-217

Figs. 388-390. Trachycythere tubulosa seratina Triebel \& Klingler,

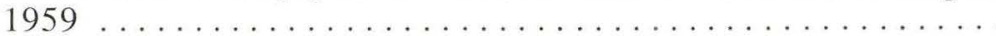
Figs. 388, 390. Right valve, length $0.49 \mathrm{~mm}$, height 0.27 mm. Fjerritslev No. 1, sample No. 4. - Fig. 388: Laterodorsal view, $\times 100$. - Fig. 390: Detail of the sculpture,

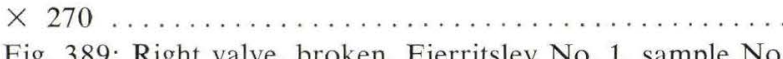

Fig. 389: Right valve, broken. Fjerritslev No. 1, sample No.

4. Detail with the muscle scars, $\times 335 \ldots \ldots \ldots \ldots \ldots$ 1973-OM-219

Figs. 391-394. Ogmoconcha amalthei amalthei (Quenstedt, 1858). . . .

Fig. 391. Right valve, adult, length $0.87 \mathrm{~mm}$, height 0.65 $\mathrm{mm}$. Detail with the muscle scars. $\times 135$. Flyvbjerg No. 1 , sample No. 19 ........................... 1973-OM-220 Fig. 392. Right valve, larva (A-3), length $0.55 \mathrm{~mm}$, height $0.39 \mathrm{~mm}$. Detail with the muscle scars. $\times 335$. Flyvbjerg No 1 , sample No. $19 \ldots \ldots \ldots \ldots \ldots \ldots \ldots \ldots \ldots \ldots \ldots \ldots \ldots$ Fig. 393. Left valve, larva (A-5), length $0.39 \mathrm{~mm}$, height $0.28 \mathrm{~mm}$. Detail with the muscle scars. $\times 535$. Flyvbjerg No. 1, sample No. $19 \ldots \ldots \ldots \ldots \ldots \ldots \ldots \ldots \ldots \ldots$ Fig. 394. Left valve, adult, length $0.97 \mathrm{~mm}$, height $0.70 \mathrm{~mm}$. Internal view. $\times$ 70. Flyvbjerg No. 1, sample No. $19 \ldots$ 1973-OM-223

Fig. 395. Ogmoconcha contractula Triebel, $1941 \ldots \ldots \ldots \ldots \ldots \ldots$ Right valve, adult, length $0.78 \mathrm{~mm}$, height $0.58 \mathrm{~mm}$. Detail with the muscle scars. $\times 200$. Øresund No. 3, sample No. $293 \ldots \ldots \ldots \ldots \ldots \ldots \ldots$. . . . . . . . . . . . . . . . . . . . . 224

Fig. 396. Ogmoconcha amalthei circumvallata Dreyer, 1965 . . . . . . 227 Left valve, larva (A-1) ?, length $0.80 \mathrm{~mm}$, height $0.58 \mathrm{~mm}$. Internal view. $\times 70$. Flyvbjerg No. 1, sample No. $19 \ldots$. 1973-OM-225 Scanning electron micrographs. 


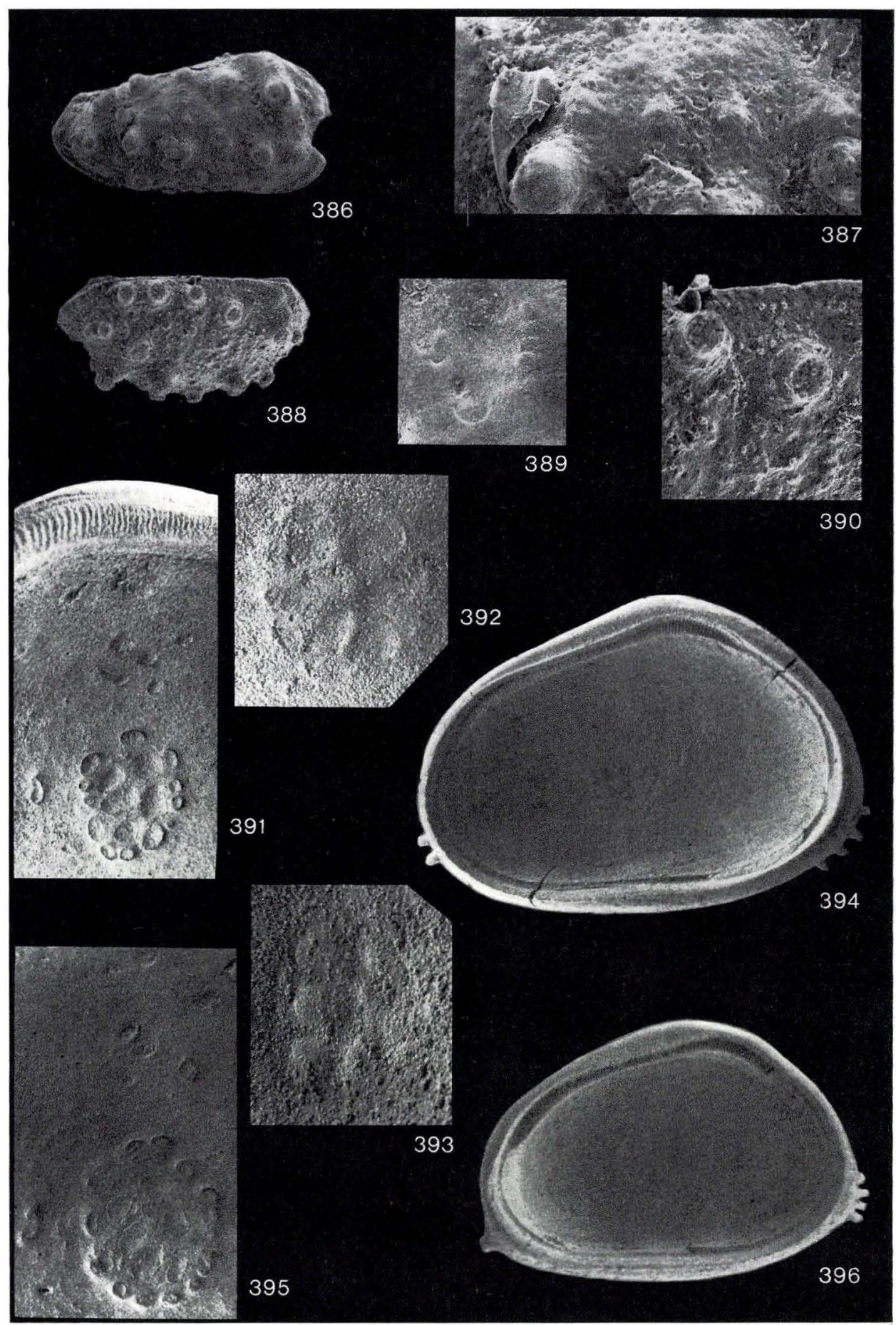


Figs. 397-399. Ogmoconcha amalthei amalthei (Quenstedt, 1858)... 225 Carapace, adult, length $0.91 \mathrm{~mm}$, height $0.70 \mathrm{~mm}$. Øresund No. 3, sample No. 323. - Fig. 397: Right side. - Fig. 398:

Dorsal view. - Fig. 399: Posterior view ........... 1972-OM-42

Figs. 400-402. Ogmoconcha amalthei circumvallata Dreyer, 1965 . . 227 Carapace, larva (A-1) ?, length $0.79 \mathrm{~mm}$, height $0.56 \mathrm{~mm}$.

Flyvbjerg No. 1, sample No. 19. - Fig. 400: Posterior view.

- Fig. 401: Dorsal view. - Fig. 402: Right side ......... 1972-OM-50

Figs. 403-405. Ogmoconcha amalthei intercedens Dreyer, 1965 . . . 227

Carapace, adult (?), length $0.76 \mathrm{~mm}$, height $0.53 \mathrm{~mm}$.

Dansk Nords $\varnothing$ J-1, sample 4320'. - Fig. 403: Right side. -

Fig. 404: Posterior view. - Fig. 405: Dorsal view ...... 1973-OM-24

Phot.: O. Neergaard Rasmussen. 


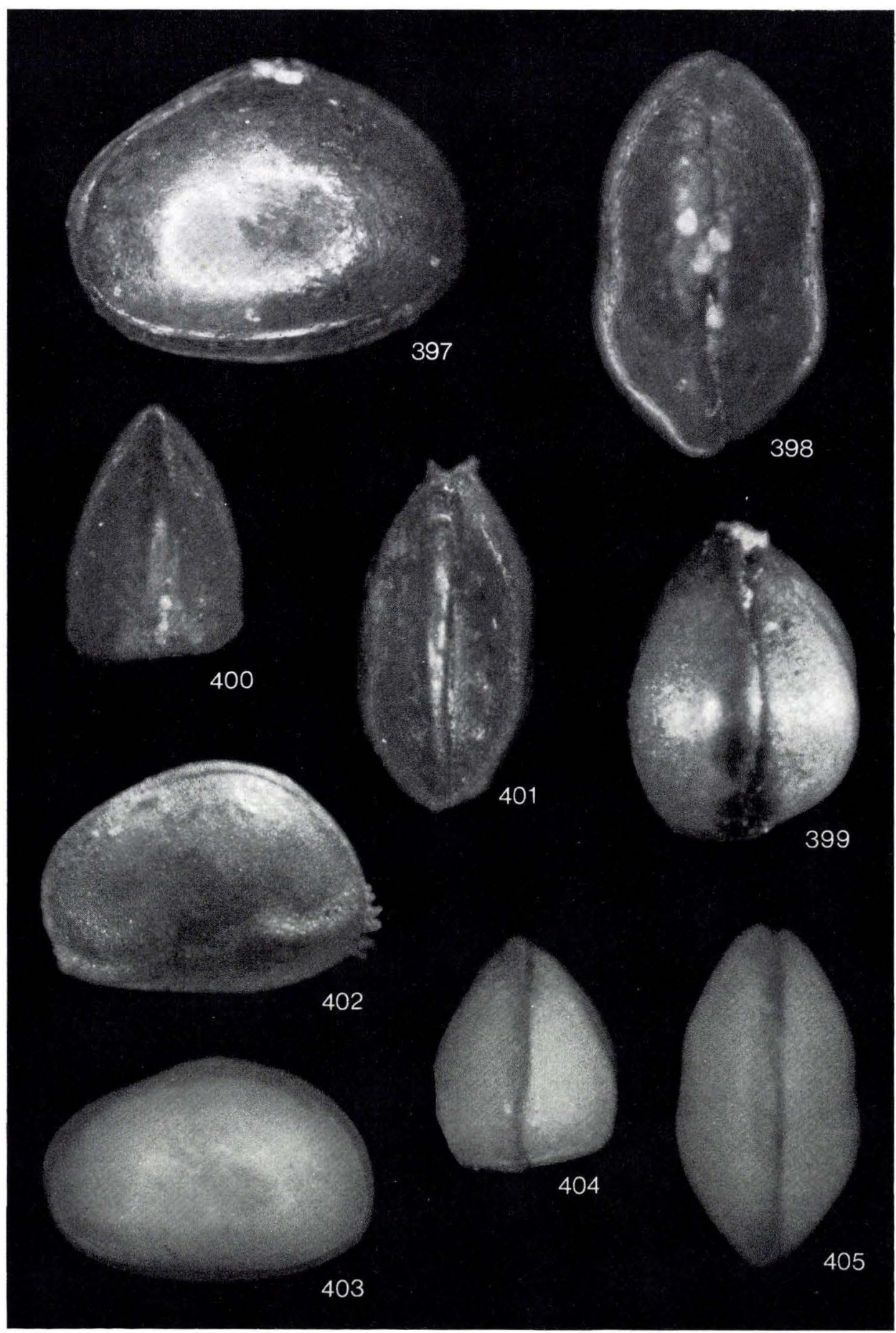


Figs. 406-408. Ogmoconcha amalthei rotunda Dreyer, 1965

Carapace, adult, length $0.80 \mathrm{~mm}$, height $0.62 \mathrm{~mm}$. Dansk

Nords $\varnothing$ J-1, sample 4460'. - Fig. 406: Right side. - Fig.

407: Posterior view. - Fig. 408: Dorsal view .......... 1973-OM-25

Figs. 409-413. Ogmoconcha amalthei form A .......... 228

Figs. 409-411. Carapace, adult (?), length $0.87 \mathrm{~mm}$, height

$0.65 \mathrm{~mm}$. Dansk Nords $\varnothing$ F-1, sample 6100'. - Fig. 409:

Right side. - Fig. 410: Posterior view. - Fig. 411: Dorsal

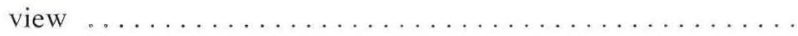

Figs. 412-413. "Transitional form". Carapace, adult (?),

length $0.88 \mathrm{~mm}$, height $0.62 \mathrm{~mm}$. Dansk Nords $\emptyset \mathrm{K}-1$,

cample 5090'. - Fig. 412: Posterior view. - Fig. 413:

Dorsal view . . . . . . . . . . . . . . . . . . . . . . 1973-OM-28

Phot.: O. Neergaard Rasmussen. 


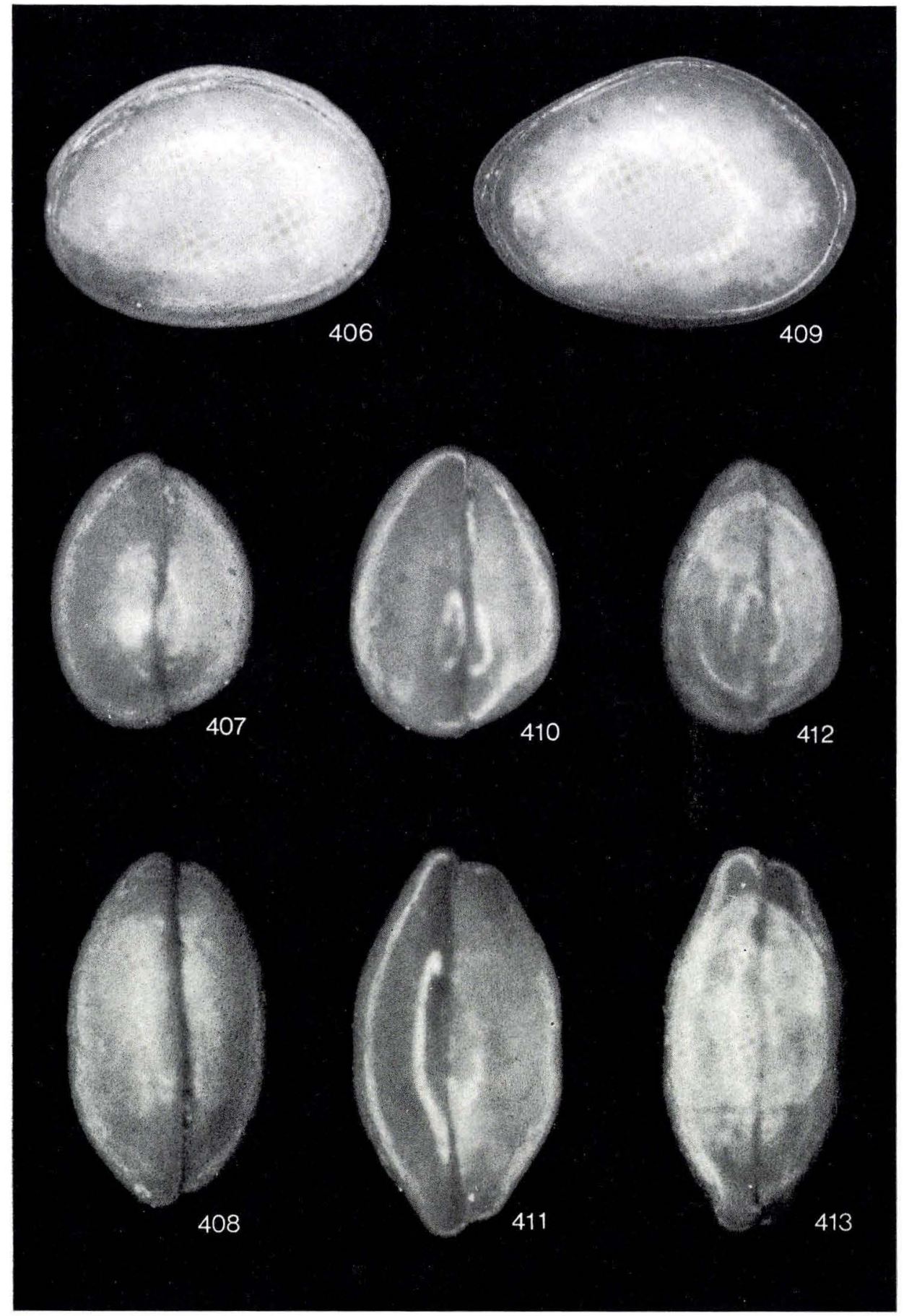


Figs. 414-416. Ogmoconcha contractula Triebel, 1941

Carapace, adult, length $0.84 \mathrm{~mm}$, height $0.67 \mathrm{~mm}$. Øresund No. 3, sample No. 308. - Fig. 414: Right side. - Fig. 415:

Posterior view. - Fig. 416: Dorsal view ........... 1972-OM-51

Figs. 417-418. Ogmoconcha amalthei form A . . . . . . . . . .

Fig. 417. See pl. 27, figs. 412-413. - Right side. . . . . . 1973-OM-28

Fig. 418. Carapace, larva, length $0.74 \mathrm{~mm}$, height $0.52 \mathrm{~mm}$.

Right side. Dansk Nords $\varnothing$ F-1, sample 6480'. . . . . . . . . 1973-OM-27

Figs. 419-425. Ogmoconcha hagenowi Drexler, 1958 . . . . . . . . . .

Figs. 419-420. Carapace, adult, length $0.66 \mathrm{~mm}$, height 0.46 mm. Horsens No. 1, sample No. 3. - Fig. 419: Right side. Fig. 420: Dorsal view . . . . . . . . . . . . . . . .

Figs. 421, 424-425. Carapace, adult, length $0.61 \mathrm{~mm}$, height $0.47 \mathrm{~mm}$. Horsens No. 1, sample No. 3. - Fig. 421: Dorsal view. - Fig. 424: Right side. - Fig. 425: Posterior view.... Fig. 422. Carapace, larva (A-1), length $0.55 \mathrm{~mm}$, height 0.39 $\mathrm{mm}$. Right side. Horsens No. 1, sample No. $3 \ldots \ldots \ldots$. Fig. 423. Carapace, adult, length $0.62 \mathrm{~mm}$, height $0.46 \mathrm{~mm}$. Right side. Horsens No. 1, sample No. 3. 1972-OM-56

Phot.: O. Neergaard Rasmussen. 


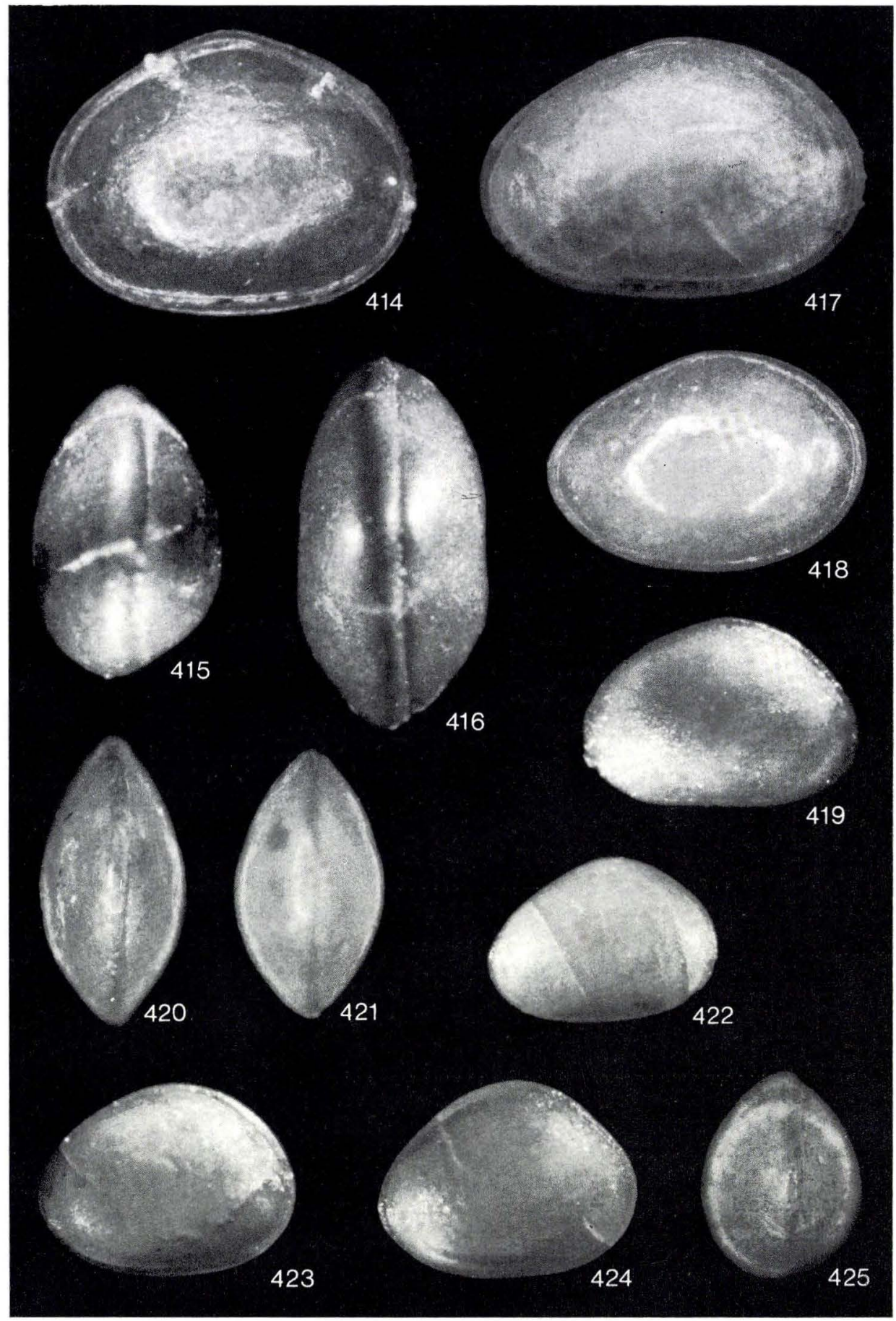


Figs. 426-427. Ogmoconcha contractula Triebel, $1941 \ldots \ldots . \ldots . .229$

Fig. 426. See pl. 25, fig. 395. - Right valve. Internal view.

$\times 70$

Fig. 427. Left valve, adult, length $0.84 \mathrm{~mm}$, height $0.68 \mathrm{~mm}$.

Internal view. $\times 70$. Øresund No. 3, sample No. 293 ... 1973-OM-226

Figs. 428-430. Ogmoconcha hagenowi Drexler, $1958 \ldots \ldots \ldots \ldots . .230$

Fig. 428. Carapace, adult, length $0.67 \mathrm{~mm}$, height $0.48 \mathrm{~mm}$.

Right side. $\times$ 70. Gassum No. 1, sample No. 59 ...... 1973-OM-227

Fig. 429. Right valve, adult, length $0.71 \mathrm{~mm}$, height 0.52

$\mathrm{mm}$. Detail with the hinge. $\times 200$. Nøvling No. 1 , sample

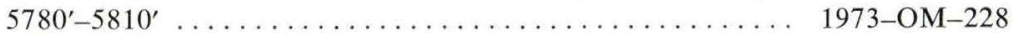

Fig. 430. Left valve. Internal view. $\times 60$. Nøvling No. 1 ,

sample $5960^{\prime}-5990^{\prime} \ldots \ldots \ldots \ldots \ldots \ldots \ldots \ldots \ldots$. . . . . . . . . . . 229

Figs. 431-434. Ogmoconchella adenticulata (Pietrzenuk, 1961) ... 233

Figs. 431, 434. Left valve, adult, length $0.71 \mathrm{~mm}$, height

$0.52 \mathrm{~mm}$. Internal views. Flyvbjerg No. 1, sample No. 19.

- Fig. 431: $\times$ 70. - Fig. 434: Detail with the muscle scars,

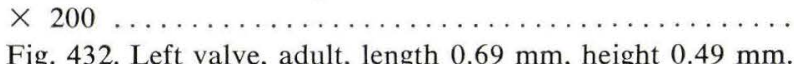

1973-OM-230

Detail of the external surface. $\times 200$. Øresund No. 3, sample No. $337 \ldots \ldots \ldots \ldots \ldots \ldots \ldots \ldots \ldots \ldots \ldots \ldots$.

Fig. 433. Right valve, adult, length $0.69 \mathrm{~mm}$, height 0.46

mm. Internal view. $\times 70$. Flyvbjerg No. 1 , sample No. 19 1973-OM-232

Scanning electron micrographs (fig. 430: J. Fuglsang Nielsen). 


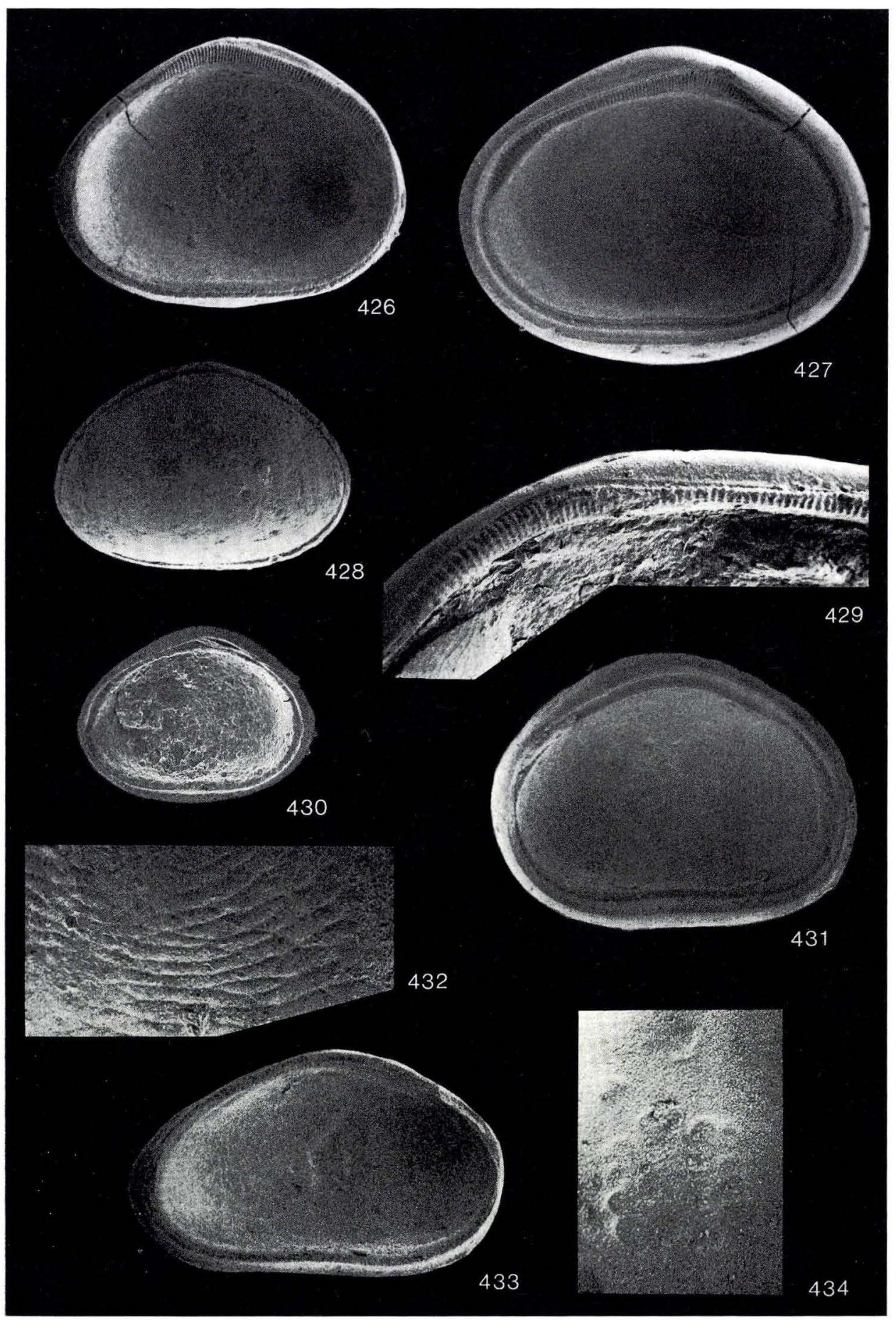


Plate 30

D. G. U. Text

$\times 60$ catalogue No. page

Figs. 435-440. Ogmoconchella adenticulata (Pietrzenuk, 1961) . ...

Figs. 435-436. Carapace, adult, length $0.75 \mathrm{~mm}$, height 0.55

mm. Gassum No. 1, sample No. 8. - Fig. 435: Right side. -

Fig. 436: Dorsal view . . . . . . . . . . . . . . . . . 1972-OM-18

Figs. 437-438. Carapace, larva (A-1), length $0.61 \mathrm{~mm}$, height $0.45 \mathrm{~mm}$. Gassum No. 1, sample No. 15. - Fig. 437:

Dorsal view. - Fig. 438: Right side............. 1972-OM-19

Figs. 439-440. Carapace, larva (A-2), length $0.50 \mathrm{~mm}$,

height $0.37 \mathrm{~mm}$. Gassum No. 1, sample No. 8. - Fig. 439:

Right side. - Fig. 440: Dorsal view. . . . . . . . . . . 1972-OM-20

Figs. 441-445. Ogmoconchella aequalis (Herrig, 1969) . . . . . . . 236

Figs. 441-442, 445. Carapace, adult, length $0.81 \mathrm{~mm}$, height $0.58 \mathrm{~mm}$. Flyvbjerg No. 1, sample No. 18. - Fig. 441: Dorsal view. - Fig. 442: Right side. - Fig. 445: Po-

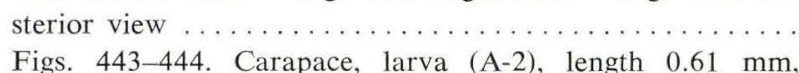
height $0.42 \mathrm{~mm}$. Øresund No. 3, sample No. 314. - Fig. 443: Right side. - Fig. 444: Dorsal view........... 1972-OM-41

Phot.: O. Neergaard Rasmussen. 


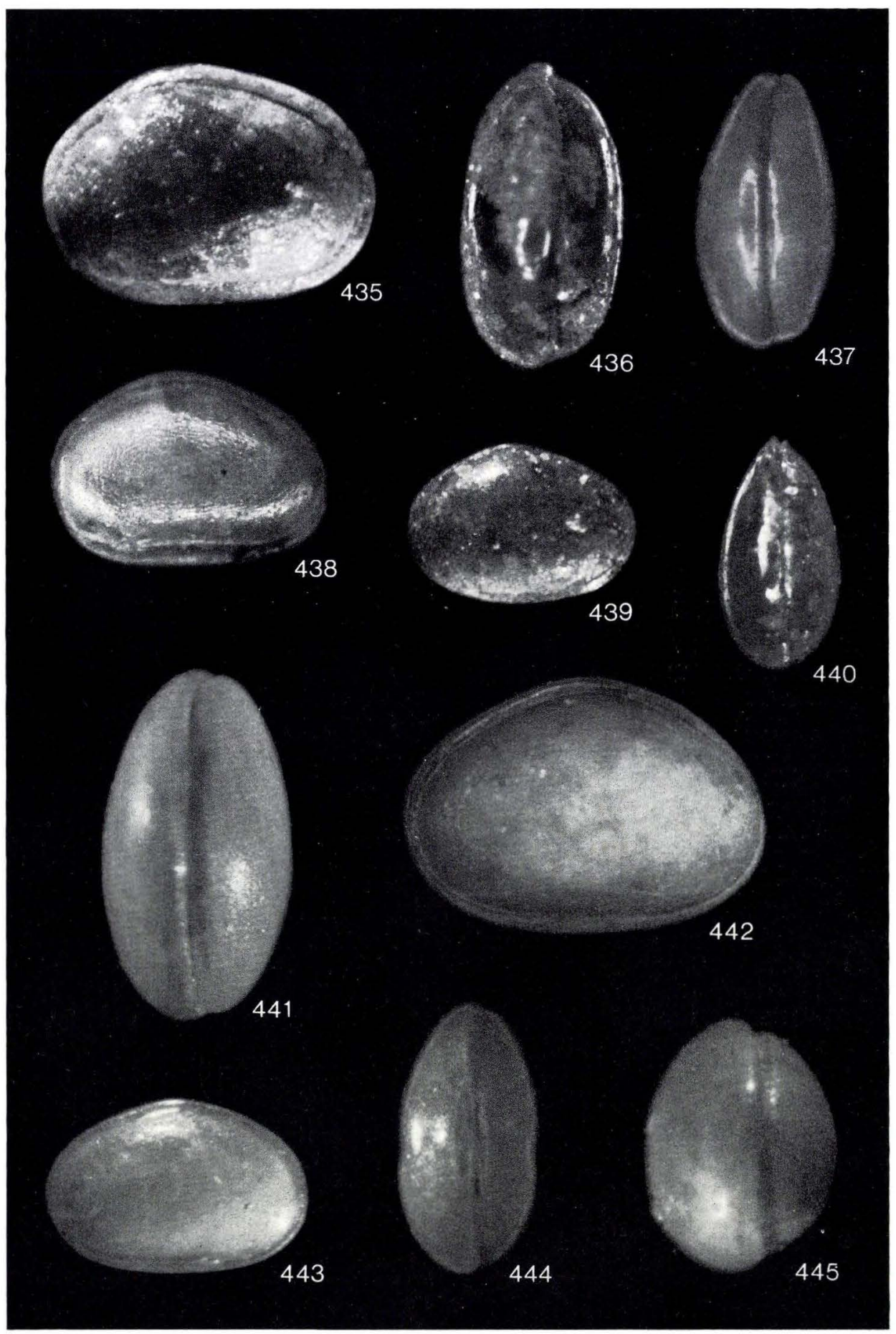


Figs. 446-449. Ogmoconchella aequalis (Herrig, 1969) . . . . . . . 236

Fig. 446. Left valve, adult, length $0.89 \mathrm{~mm}$, height $0.61 \mathrm{~mm}$.

Internal view. $\times 70$. Flyvbjerg No. 1, sample No. $18 \ldots \ldots$ 1973-OM-233

Figs. 447-448. Right valve, adult, length $0.84 \mathrm{~mm}$, height $0.52 \mathrm{~mm}$. Internal views. Flyvbjerg No. 1, sample No. 18. Fig. 447: $\times 70 .-$ Fig. 448: Detail with the muscle scars, $\times 135 \ldots \ldots \ldots \ldots \ldots \ldots \ldots \ldots \ldots \ldots \ldots \ldots \ldots \ldots \ldots \ldots \ldots \ldots$
Fig. 449 . Left valve, larva $(A-2)$, length $0.63 \mathrm{~mm}$, height $0.44 \mathrm{~mm}$. Internal view. $\times 70$. Øresund No. 3, sample No.

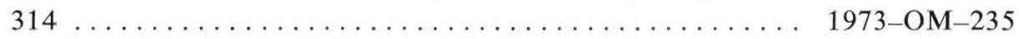

Fig. 450. Ogmoconchella aspinata (Drexler, 1958) . . . . . . . . 238 Carapace, adult, length $0.61 \mathrm{~mm}$, height $0.44 \mathrm{~mm}$. Right side. $\times$ 70. Gassum No. 1, sample No. 47 ......... 1973-OM-236

Figs. 451-454. Ogmoconchella danica n.sp. . . . . . . . . . . . Figs. 451-452. Carapace, adult, length $0.66 \mathrm{~mm}$, height 0.46 mm. Right side. Gassum No. 1, sample 4450'-4466'. - Fig. 451: $\times$ 70. - Fig. 452: Detail with the sculpture, $\times 335 \ldots$ 1973-OM-237 Fig. 453. Right valve, adult, length $0.66 \mathrm{~mm}$, height 0.43 mm. Internal view. $\times 70$. Øresund No. 12 , sample No. 1410 Fig. 454. Left valve, adult, length $0.68 \mathrm{~mm}$, height 0.44 $\mathrm{mm}$. Internal view. $\times 70$. Øresund No. 12, sample No. $1410 \quad 1973-\mathrm{OM}-239$

Fig. 455. Ogmoconchella bispinosa (Gründel, 1964) . . . . . . . . . . Carapace, adult, length $0.80 \mathrm{~mm}$, height $0.43 \mathrm{~mm}$. Right side. $\times$ 70. Dansk Nordsø J-1, sample 4260' 1973-OM-240 Scanning electron micrographs. 


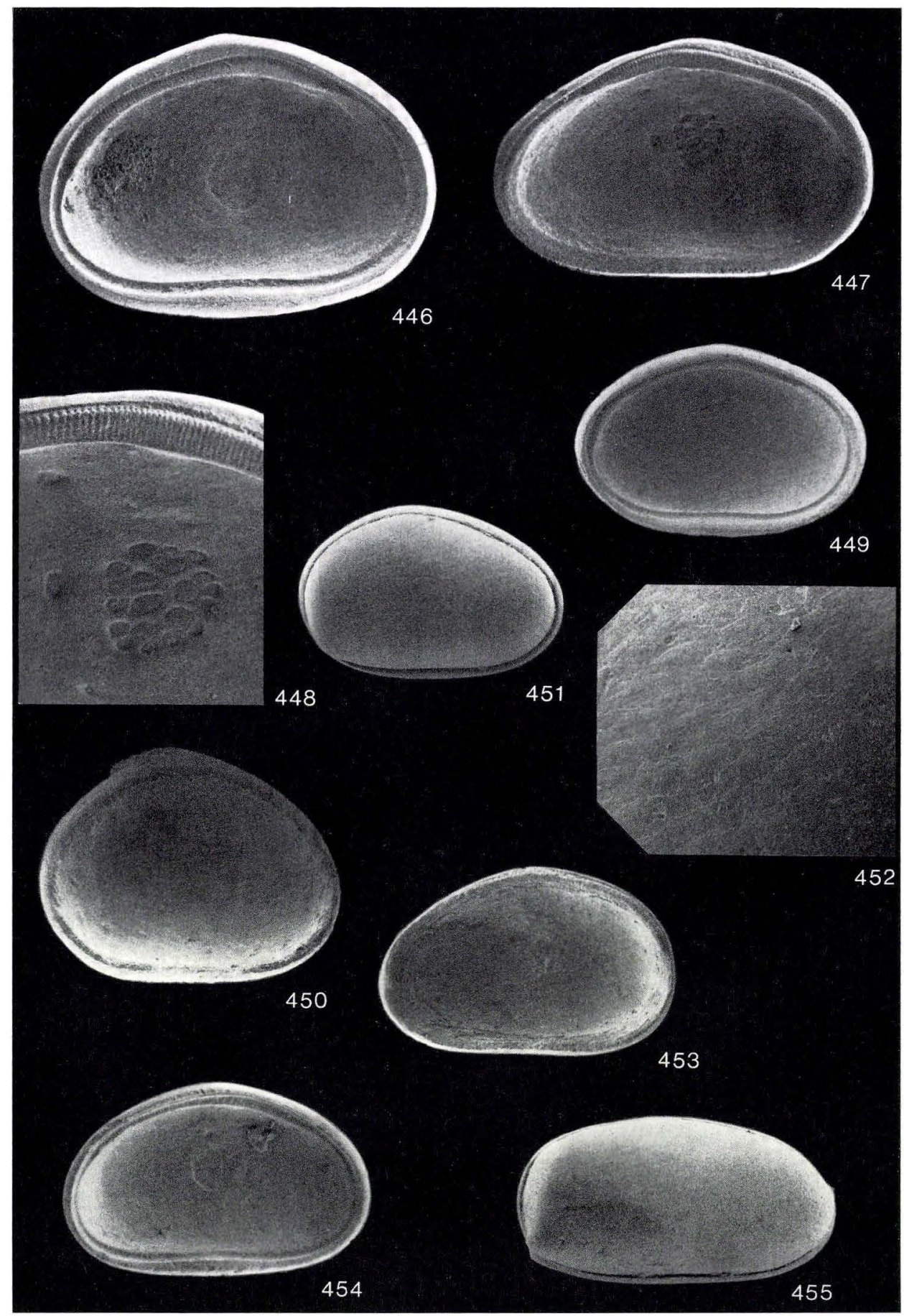


Figs. 456-462. Ogmoconchella danica n.sp. . . . . . . . . . . 243

Details with the muscle scars. Valves from Øresund No. 12, sample No. 1410

Fig. 456. Left valve, adult, length $0.68 \mathrm{~mm}$, height $0.44 \mathrm{~mm}$. $\times 270$

Fig. 457. Left valve, larva (A-1), length $0.56 \mathrm{~mm}$, height $0.38 \mathrm{~mm}$. $\times 400$

Fig. 458. Left valve, larva (A-2), length $0.52 \mathrm{~mm}$, height $0.37 \mathrm{~mm} . \times 400$

Fig. 459. Left valve, larva (A-3), length $0.43 \mathrm{~mm}$, height

$0.30 \mathrm{~mm} . \times 400$

Fig. 460. Left valve, larva (A-4), length $0.37 \mathrm{~mm}$, height $0.26 \mathrm{~mm} . \times 400 \ldots \ldots \ldots \ldots \ldots \ldots \ldots \ldots \ldots \ldots \ldots \ldots \ldots \ldots \ldots \ldots$

Fig. 461. Left valve, larva (A-5), length $0.33 \mathrm{~mm}$, height $0.22 \mathrm{~mm} . \times 400 \ldots \ldots \ldots \ldots \ldots \ldots \ldots \ldots \ldots \ldots \ldots \ldots \ldots \ldots \ldots \ldots \ldots$ Fig. 462. Left valve, larva (A-6), length $0.28 \mathrm{~mm}$, height $0.19 \mathrm{~mm} . \times 670 \ldots \ldots \ldots \ldots \ldots \ldots \ldots \ldots \ldots \ldots \ldots \ldots$ 1973-OM-247

Figs. 463-464. Ogmoconchella gruendeli Malz, 1971 . . . . . . . . Fig. 463. Left valve, larva, length $0.50 \mathrm{~mm}$, height 0.30 $\mathrm{mm}$. Internal view. $\times$ 100. Flyvbjerg No. 1 , sample No. 19 Fig. 464. Right valve, larva, length $0.48 \mathrm{~mm}$. height 0.30 mm. Internal view. $\times$ 100. Flyvbjerg No. 1, sample No. 18 1973-OM-249

Fig. 465-466. "Ogmoconchella mouhersensis” (Apostolescu, 1959). . Left valve, length $0.70 \mathrm{~mm}$, height $0.45 \mathrm{~mm}$. Internal views. Gassum No. 1, sample No. 39A. - Fig. 465: Detail with the muscle scars, $\times$ 335. - Fig. $466: \times 70 \ldots \ldots \ldots \ldots \ldots$ 1973-OM-250

Figs. 467-469. Ogmoconchella pseudospina (Herrig, 1969) . . . . . . . Fig. 467. Left valve, larva (A-1), length $0.66 \mathrm{~mm}$, height $0.37 \mathrm{~mm}$. Detail with the muscle scars, $\times 335$. Flyvbjerg No. 1, sample No. 21..................... Fig. 468. Left valve, adult, length $0.71 \mathrm{~mm}$, height 0.44 mm. Internal view. $\times 70$. Flyvbjerg No. 1 , sample No. $21 \ldots$ Fig. 469. Right valve, adult, length $0.68 \mathrm{~mm}$, height 0.40 mm. Internal view. $\times$ 70. Flyvbjerg No. 1, sample No.21. Scanning electron micrographs. 

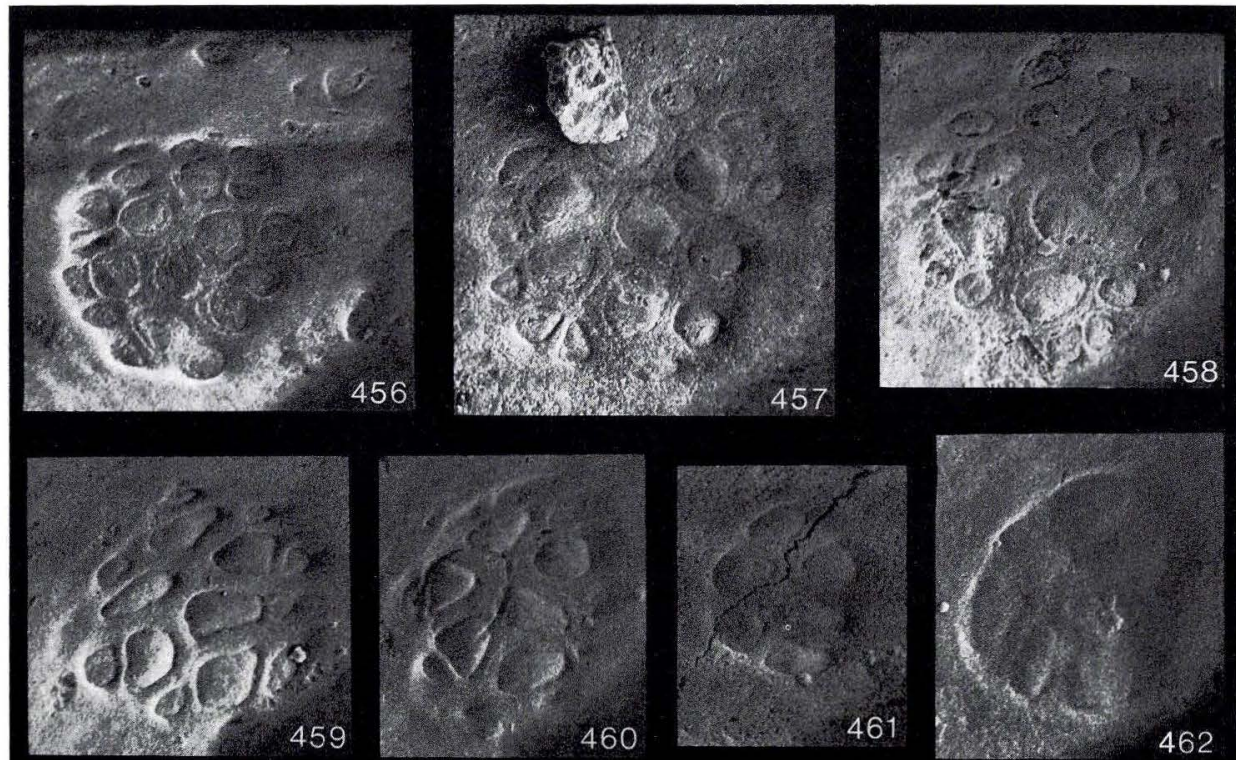

462
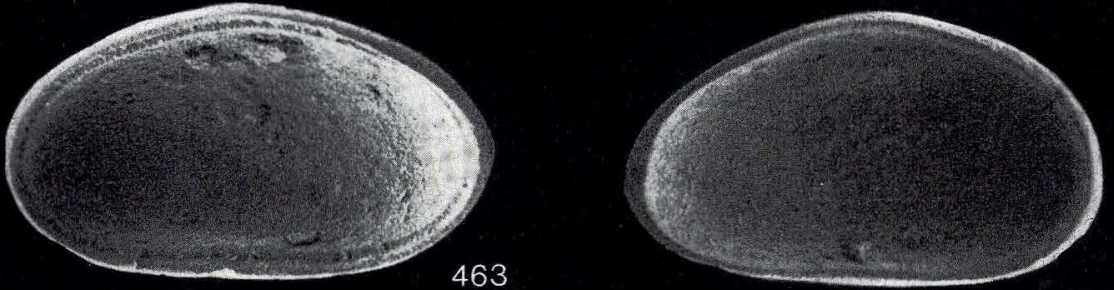

464
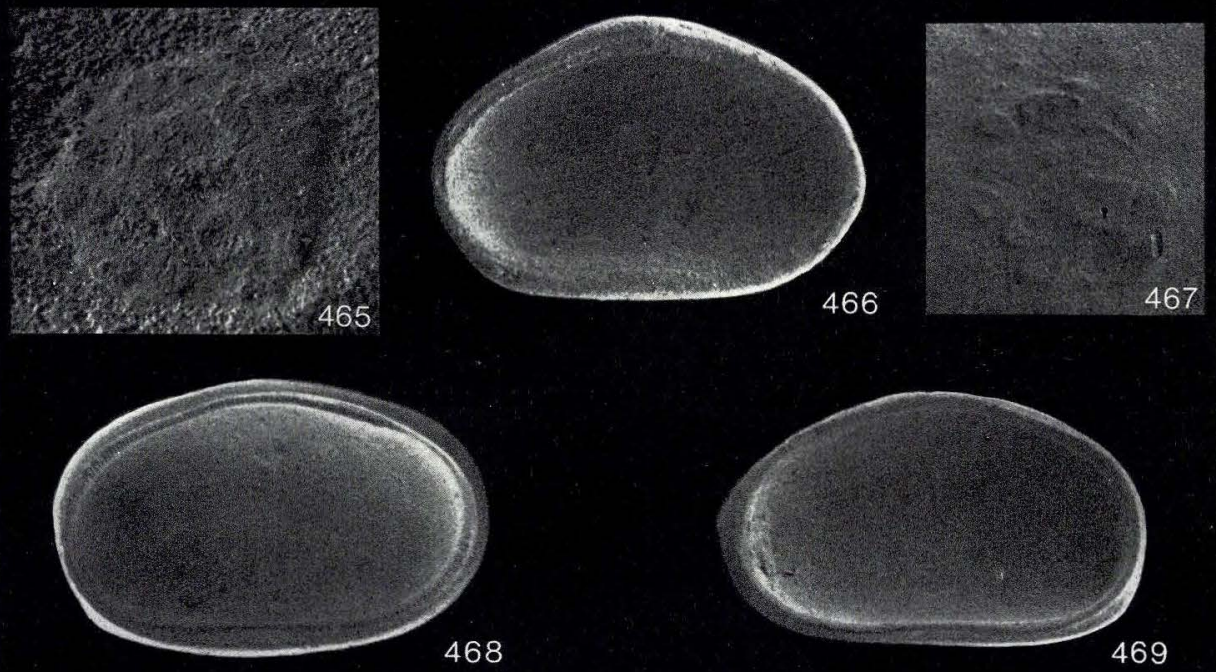
Figs. 470-471. Ogmoconchella aspinata (Drexler, 1958) . . . . . 238

Carapace, adult, length $0.60 \mathrm{~mm}$, height $0.42 \mathrm{~mm}$. Vinding

No. 1, sample No. 43. - Fig. 470: Right side. - Fig. 471.

Dorsal view ........................ 1972-OM-24

Figs. 472-475. Ogmoconchella bispinosa (Gründel, 1964) . . . . . . 243

Fig. 472. Carapace, larva, length $0.48 \mathrm{~mm}$, height $0.27 \mathrm{~mm}$.

Right side. Øresund No. 3, sample No. 314 .......... 1972-OM-53

Figs. 473-475. Carapace, larva, length $0.57 \mathrm{~mm}$, height 0.35

mm. Rønde No. 1, sample 8460'-8470'. - Fig. 473: Dorsal

view. - Fig. 474: Posterior view. - Fig. 475: Right side... . 1972-OM-52

Figs. 476-484. Ogmoconchella danica n.sp. . . . . . . . . . . 243

Figs. 476-477. Left valve, adult, length $0.60 \mathrm{~mm}$, height

$0.43 \mathrm{~mm}$. Holotype. Gassum No. 1, sample No. 42. - Fig.

476: External view. - Fig. 477: Internal view......... 1972-OM-83

Figs. 478-480. Carapace, adult, length $0.61 \mathrm{~mm}$, height

$0.43 \mathrm{~mm}$. Gassum No. 1, sample No. 42. - Fig. 478: Dor-

sal view. - Fig. 479: Right side. - Fig. 480: Posterior view.

Figs. 481-482. Carapace, larva (A-1), length $0.55 \mathrm{~mm}$,

height $0.35 \mathrm{~mm}$. Gassum No. 1, sample No. 42. - Fig. 481:

Dorsal view. - Fig. 482: Right side.............. 1972-OM-79

Fig. 483. Carapace, larva (A-2), length $0.42 \mathrm{~mm}$, height

$0.31 \mathrm{~mm}$. Right side. Gassum No. 1, sample No. 42. . . . 1972-OM-80

Fig. 484. Carapace, larva (A-6), length $0.25 \mathrm{~mm}$, height

0.18 mm. Right side. Gassum No. 1, sample No. 42 . . . . 1972-OM-81

Phot.: O. Neergaard Rasmussen. 


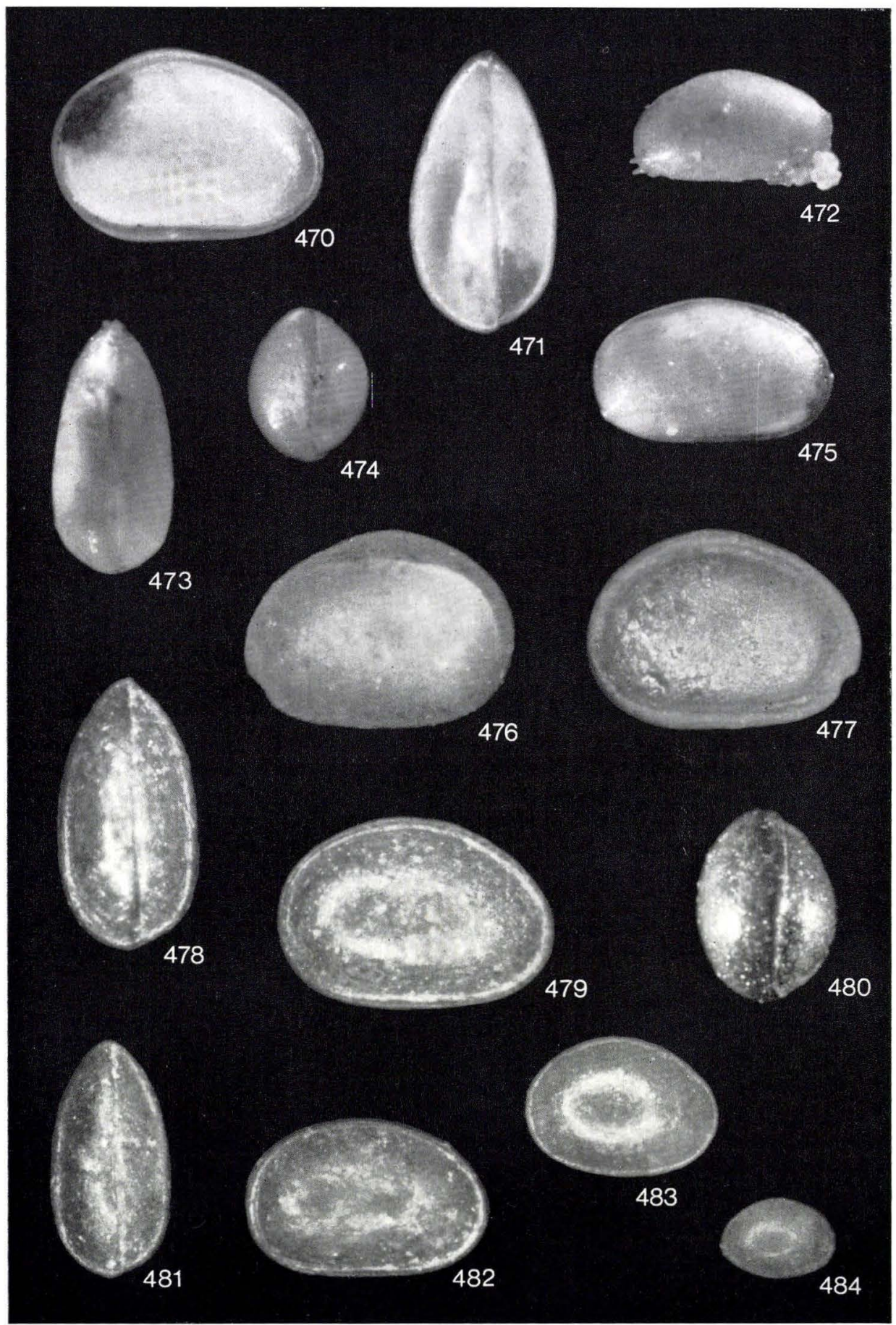


Figs. 485-489. Ogmoconchella danica n. sp. . . . . . . . . . . 243

Figs. 485-487. Carapace, adult, length $0.76 \mathrm{~mm}$, height

$0.55 \mathrm{~mm}$. Børglum No. 1, sample No. 14. - Fig. 485: Right

side. - Fig. 486: Posterior view. - Fig. 487: Dorsal view. . . 1972-OM-82

Figs. 488-489. Carapace, adult, length $0.61 \mathrm{~mm}$, height

$0.44 \mathrm{~mm}$. Øresund No. 12, sample No. 1410. - Fig. 488:

Right side. - Fig. 489: Dorsal view............ 1972-OM-84

Figs. 490-493. Ogmoconchella gruendeli Malz, 1971 . . . . . . . . . 247

Figs. 490-492. Carapace, adult, length $0.80 \mathrm{~mm}$, height

$0.55 \mathrm{~mm}$. Rønde No. 1, sample 7660'-7675'. - Fig. 490:

Right side. - Fig. 491: Posterior view. - Fig. 492: Dorsal

view ............................ 1972-OM-61

Fig. 493. Carapace, larva, length $0.58 \mathrm{~mm}$, height $0.38 \mathrm{~mm}$.

Right side. Flyvbjerg No. 1, sample No. 18 . ........ 1972-OM-60

Figs, 494-496. "Ogmoconchella mouhersensis" (Apostolescu, 1959). . 248

Carapace, length $0.72 \mathrm{~mm}$, height $0.53 \mathrm{~mm}$. Gassum No. 1, sample No. 39A. - Fig. 494: Posterior view. - Fig. 495:

Right side. - Fig. 496: Dorsal view . . . . . . . . . . 1972-OM-74

Phot.: O. Neergaard Rasmussen. 


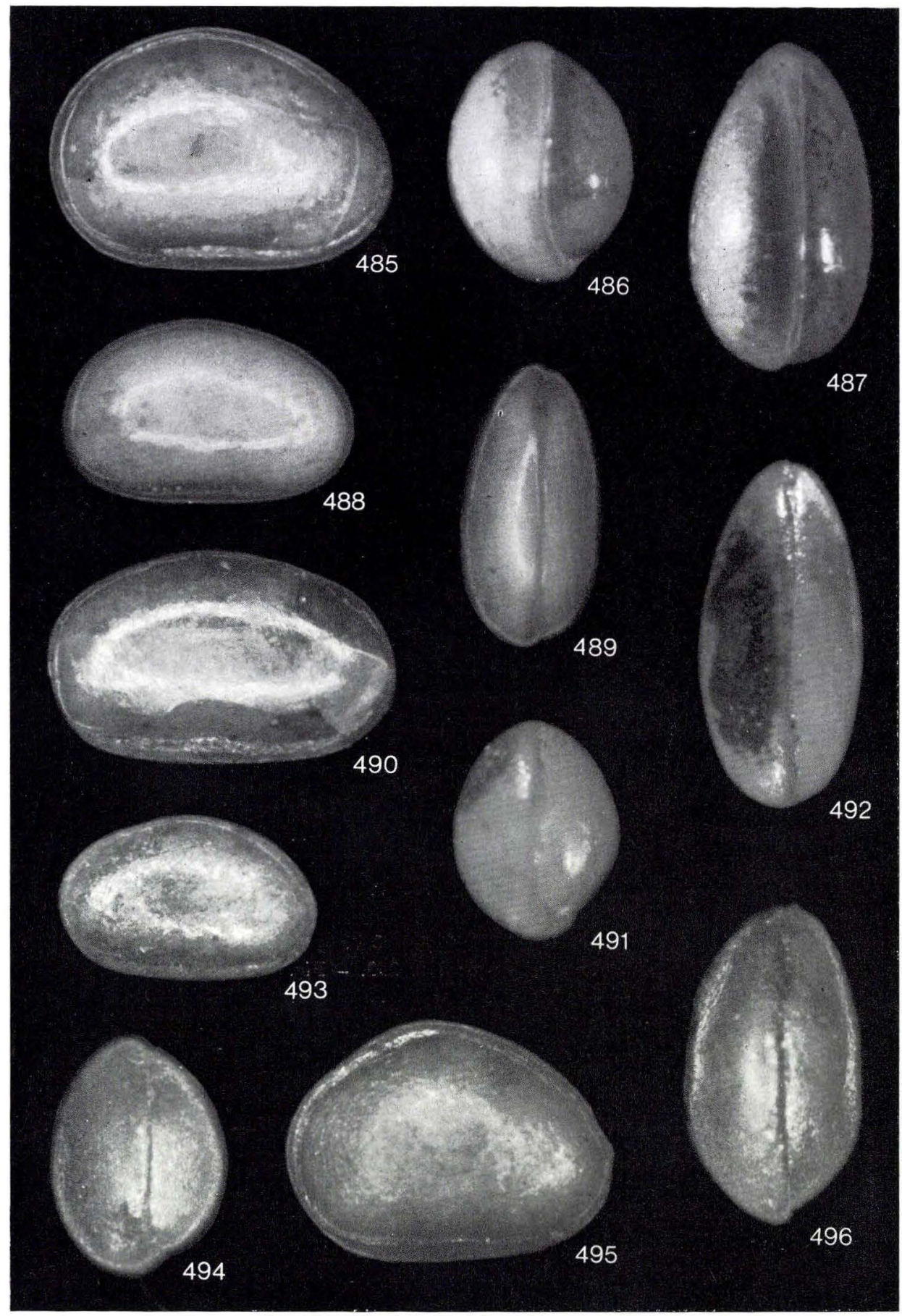


Figs. 497-502. "Ogmoconchella mouhersensis” (Apostolescu, 1959). . 248 Figs. 497-499. Carapace, adult, length $0.71 \mathrm{~mm}$, height 0.49 mm. Børglum No. 1, sample No. 14. - Fig. 497: Right side. - Fig. 498: Posterior view. - Fig. 499: Dorsal view. . . 1972-OM-75 Figs. 500-501. Carapace, larva, length $0.61 \mathrm{~mm}$, height $0.42 \mathrm{~mm}$. Børglum No. 1, sample No. 14. - Fig. 500: Right side. - Fig. 501: Dorsal view. . . . . . . . . . . . . . 1972-OM-76 Fig. 502. Carapace, larva, length $0.42 \mathrm{~mm}$, height $0.28 \mathrm{~mm}$. Right side. Børglum No. 1, sample No. 14 . . . . . . . . . 1972-OM-77 Figs. 503-507. Ogmoconchella pseudospina (Herrig, 1969). . . . . . . Figs. 503-504. Left valve, larva (A-1), length $0.64 \mathrm{~mm}$, height $0.41 \mathrm{~mm}$. Øresund No. 3, sample No. 293. - Fig. 503: Dorsal view. - Fig. 504: Internal view . . . . . . . . 1972-OM-59 Figs. 505-507. Carapace, adult, length $0.69 \mathrm{~mm}$, height $0.44 \mathrm{~mm}$. Flyvbjerg No. 1, sample No. 21. - Fig. 505: Right side. - Fig. 506: Dorsal view. - Fig. 507: Posterior view ......................... 1972-OM-58

Figs. 508-509. ? Ogmoconchella pseudospina (Herrig, 1969) . . . . . . . Right valve, length $0.81 \mathrm{~mm}$, height $0.43 \mathrm{~mm}$. Gassum No. 1, sample No. 9. - Fig. 508: External view. - Fig. 509: Internal view . . . . . . . . . . . . . . . 1972-OM-67 Phot.: O. Neergaard Rasmussen. 


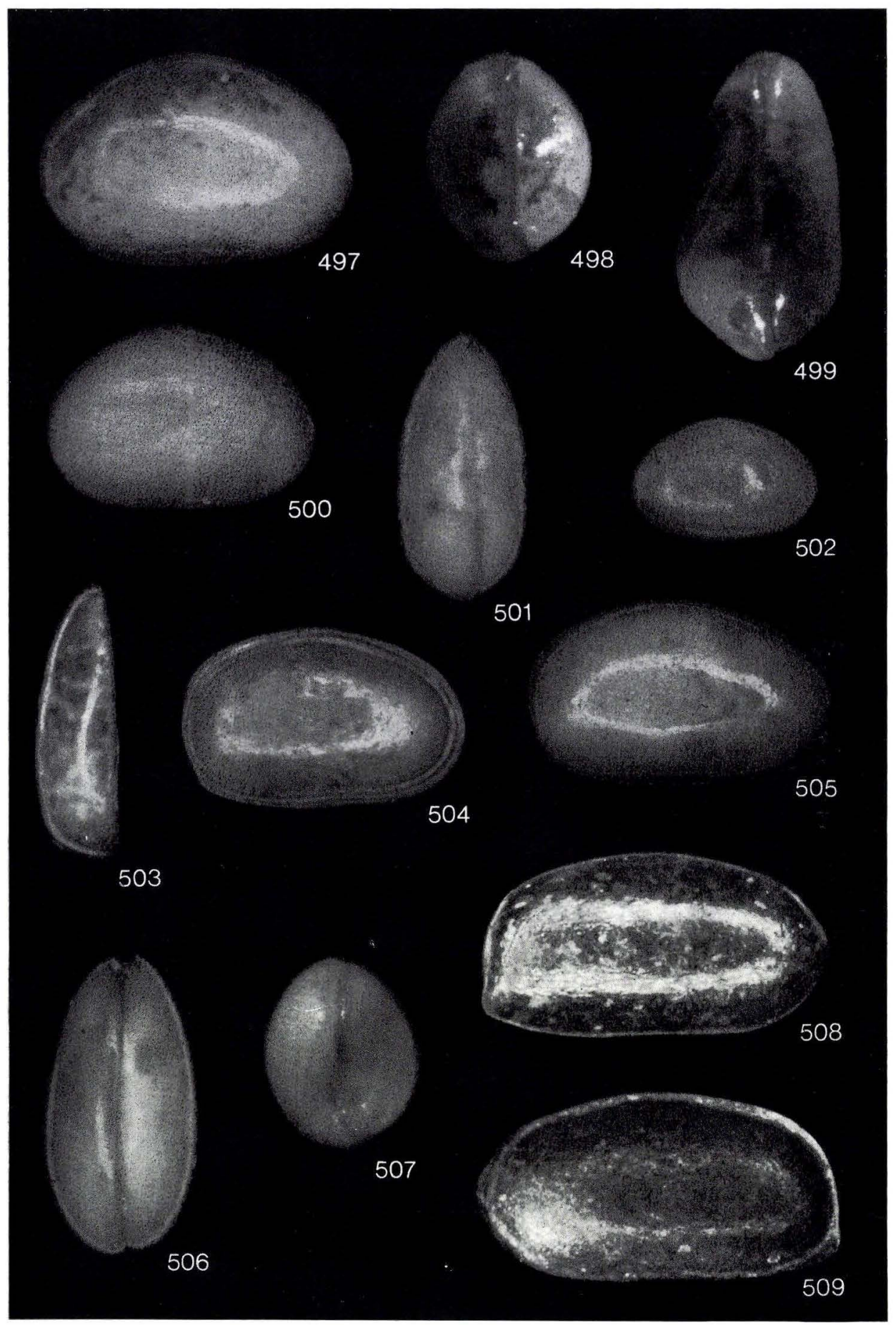


Figs. 510-514. Ogmoconchella transversa (Gründel, 1970) ...... 252

Fig. 510. Right valve, adult, length $0.58 \mathrm{~mm}$, height 0.37

mm. Internal view. $\times$ 70. Flyvbjerg No. 1, sample No. 21. 1973-OM-254

Figs. 511-512. Left valve, adult, length $0.60 \mathrm{~mm}$, height

$0.40 \mathrm{~mm}$. Internal views. Flyvbjerg No. 1, sample No. 21. -

Fig. 511: $\times$ 70. - Fig. 512: Detail with the muscle scars,

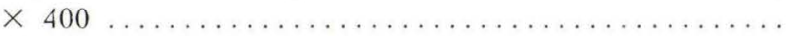

Fig. 513. Left valve, larva (A-1), length $0.52 \mathrm{~mm}$, height $0.32 \mathrm{~mm}$. Detail with the muscle scars. $\times$ 400. Flyvbjerg No. 1, sample No. $21 \ldots \ldots \ldots \ldots \ldots \ldots$

Fig. 514. Left valve, larva (A-3), length $0.39 \mathrm{~mm}$, height $0.25 \mathrm{~mm}$. Detail with the muscle scars. $\times$ 400. Flyvbjerg No. 1, sample No. $21 \ldots \ldots \ldots \ldots \ldots \ldots$. . . . . . . . . . . . . . . . . . 257

Figs. 515-517. Ogmoconchella sp. $4015 \ldots \ldots \ldots \ldots \ldots \ldots$

Figs. 515-516. Left valve, length $0.58 \mathrm{~mm}$, height $0.34 \mathrm{~mm}$. Internal views. Øresund No. 3, sample No. 328. - Fig. 515: Detail with the muscle scars, $\times$ 400. - Fig. 516: $\times 100 \ldots$ 1973-OM-258 Fig. 517. Right valve, length $0.57 \mathrm{~mm}$, height $0.31 \mathrm{~mm}$. Internal view. $\times$ 100. Øresund No. 3, sample No. 343 ... 1973-OM-259 Figs. 518-520. Ogmoconchella sp. 4280

Fig. 518. Left valve, length $0.56 \mathrm{~mm}$, height $0.32 \mathrm{~mm}$. Internal view. $\times 100$. Flyvbjerg No. 1 , sample No. $19 \ldots$ Figs. 519-520. Right valve, length $0.57 \mathrm{~mm}$, height 0.30 mm. Internal views. Flyvbjerg No. 1, sample No. 18. Fig. 519: $\times$ 100. - Fig. 520: Detail with the muscle scars, $\times 270$ 1973-OM-261

Scanning electron micrographs. 

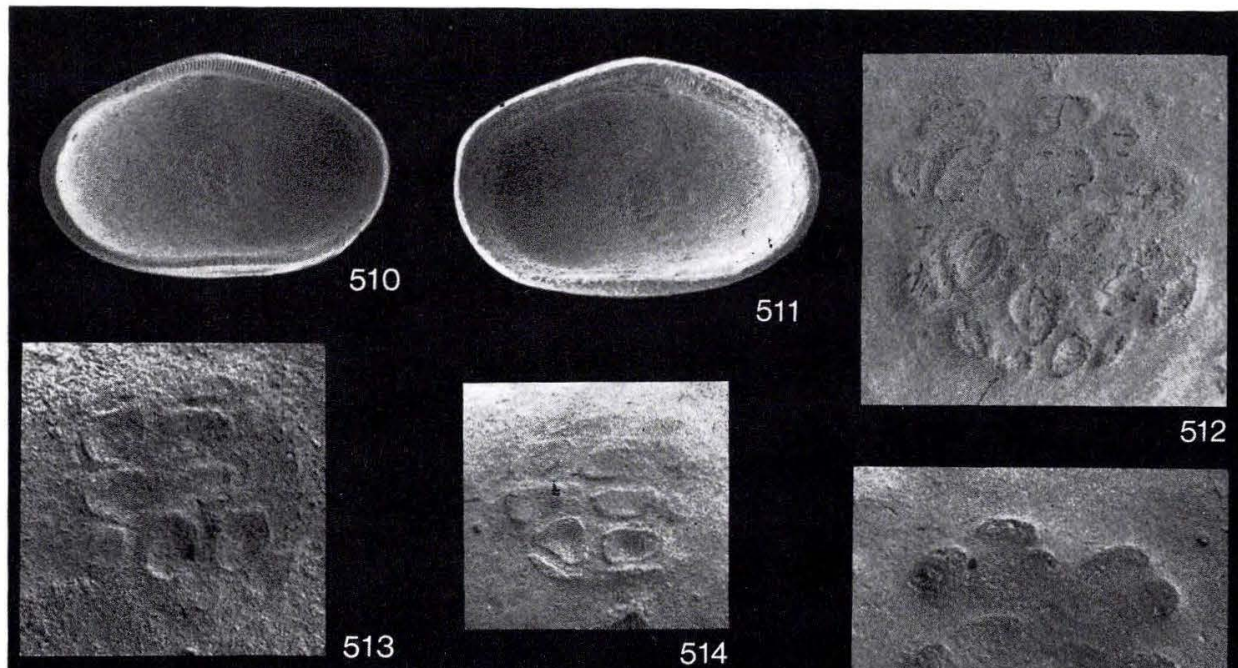

513

514

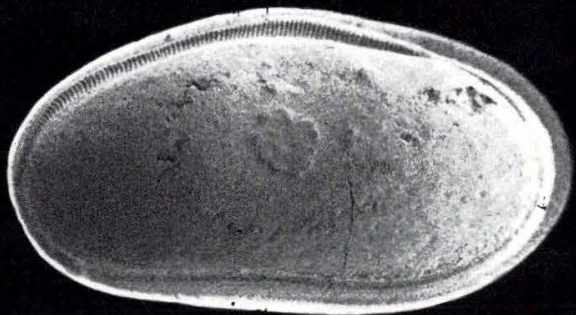

516

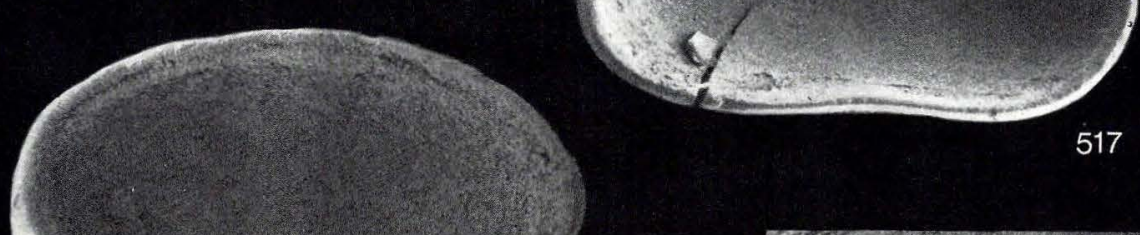

518

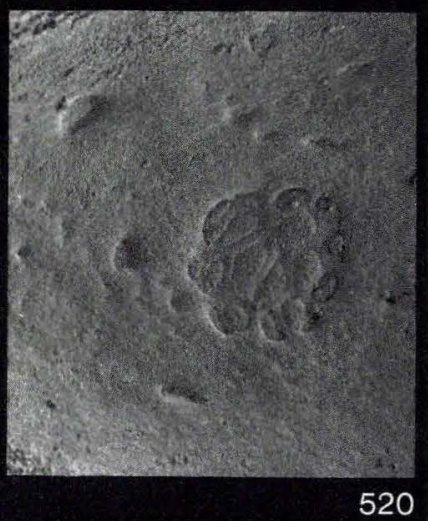


Figs. 521-524. Ogmoconchella transversa (Gründel, 1970) . . . . . 252

Figs. 521-523. Carapace, adult, length $0.67 \mathrm{~mm}$, height $0.42 \mathrm{~mm}$. Gassum No. 1, sample No. 15. - Fig. 521: Right side. - Fig. 522: Posterior view. - Fig. 523: Dorsal view... 1972-OM-63 Fig. 524. Carapace, adult, length $0.60 \mathrm{~mm}$, height $0.42 \mathrm{~mm}$. Right side. Flyvbjerg No. 1, sample No. 21 .......... 1972-OM-64

Figs. 525-527. Ogmoconchella septenaria (Gründel, 1964) . . . . . 251 Figs. 525-526. Left valve, length $0.55 \mathrm{~mm}$, height $0.35 \mathrm{~mm}$. Øresund No. 3, sample No. 317. - Fig. 525: External view. - Fig. 526: Dorsal view.................... 1972-OM-68 Fig. 527. Right valve, broken. External view. Øresund No. 3, sample No. $343 \ldots \ldots \ldots \ldots \ldots \ldots \ldots \ldots \ldots \ldots \ldots \ldots \ldots$ 1972-OM-69

Figs. 528-530. Ogmoconchella Nr. 2 (Klingler, 1962) . . . . . . . 254 Carapace, length $0.86 \mathrm{~mm}$, height $0.55 \mathrm{~mm}$. Gassum No. 1, sample No. 8. - Fig. 528: Posterior view. - Fig. 529: Right side. - Fig. 530: Dorsal view . . . . . . . . . . . . 1972-OM-70

Figs. 531-533. Ogmoconchella ? Nr. 15 (Klingler, 1962) . . . . . . 254 Carapace, length $0.63 \mathrm{~mm}$, height $0.40 \mathrm{~mm}$. Rønde No. 1, sample 7765'-7771'. - Fig. 531: Posterior view. - Fig. 532: Right side. - Fig. 533: Dorsal view 1972-OM-71 Phot.: O. Neergaard Rasmussen. 


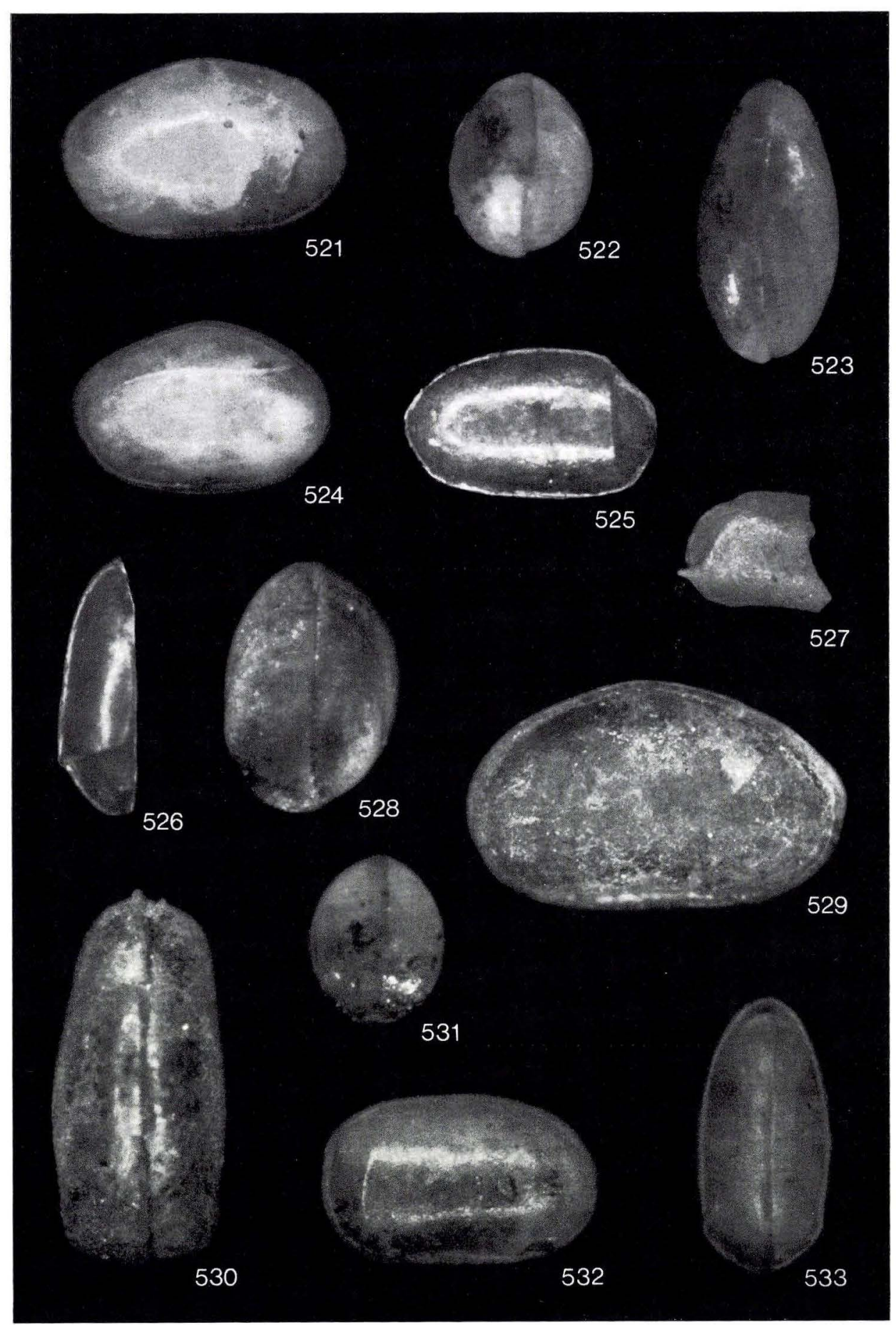


Figs. 534-538. Ogmoconchella sp. 4015 .............. 255

Figs. 534-535. Carapace, length $0.70 \mathrm{~mm}$, height $0.42 \mathrm{~mm}$.

Gassum No. 1, sample No. 5A. - Fig. 534: Right side. -

Fig. 535: Dorsal view . . . . . . . . . . . . . . 1972-OM-66

Figs. 536-538. Carapace, length $0.57 \mathrm{~mm}$, height $0.37 \mathrm{~mm}$. Øresund No. 3, sample No. 343. - Fig. 536: Right side. Fig. 537: Dorsal view. - Fig. 538: Posterior view . . . . . . 1972-OM-65

Figs. 539-541. Ogmoconchella sp. $4280 \ldots \ldots \ldots \ldots \ldots \ldots$ Carapace, length $0.58 \mathrm{~mm}$, height $0.34 \mathrm{~mm}$. Flyvbjerg No. 1, sample No. 18. - Fig. 539: Right side. - Fig. 540: Dorsal view. - Fig. 541: Posterior view ... . . . . . . . . 1972-OM-62

Figs. 542-544. Pseudohealdia truncata Malz, 1971 . . . . . . . . . . 257 Carapace, length $0.74 \mathrm{~mm}$, height $0.53 \mathrm{~mm}$. Rønde No. 1, sample 7735'-7750'. - Fig. 542: Posterior view. - Fig. 543: Dorsal view. - Fig. 544: Right side ............. 1972-OM-72

Fig. 545. ? Pseudohealdia nasuta (Drexler, 1958) . . . . . . . . . . Carapace, length $0.23 \mathrm{~mm}$, height $0.14 \mathrm{~mm}$. Right side. Gassum No. 1, sample No. 60 . . . . . . . . . . . . 1972-OM-73

Figs. 546-547. Polycope minor n. sp. . . . . . . . . . . . . . . Carapace, adult, length $0.17 \mathrm{~mm}$, height $0.17 \mathrm{~mm}$. Rødby No. 1, sample No. 20. - Fig. 546: Left side. - Fig. 547: Dorsal view ............................. 1969-OM-21

Fig. 548. Ostracod $N r .103$ Klingler, $1962 \ldots \ldots \ldots \ldots \ldots \ldots$ Carapace, deformed. Right side. Rønde No. 1, sample 8070 '. $-8087^{\prime}$

Fig. 549. Ostracod sp. K Apostolescu, 1959 . . . . . . . . . . . . . Carapace, length $0.45 \mathrm{~mm}$, height $0.27 \mathrm{~mm}$. Right side. Øresund No. 12, sample No. 1415

Phot.: O. Neergaard Rasmussen. 


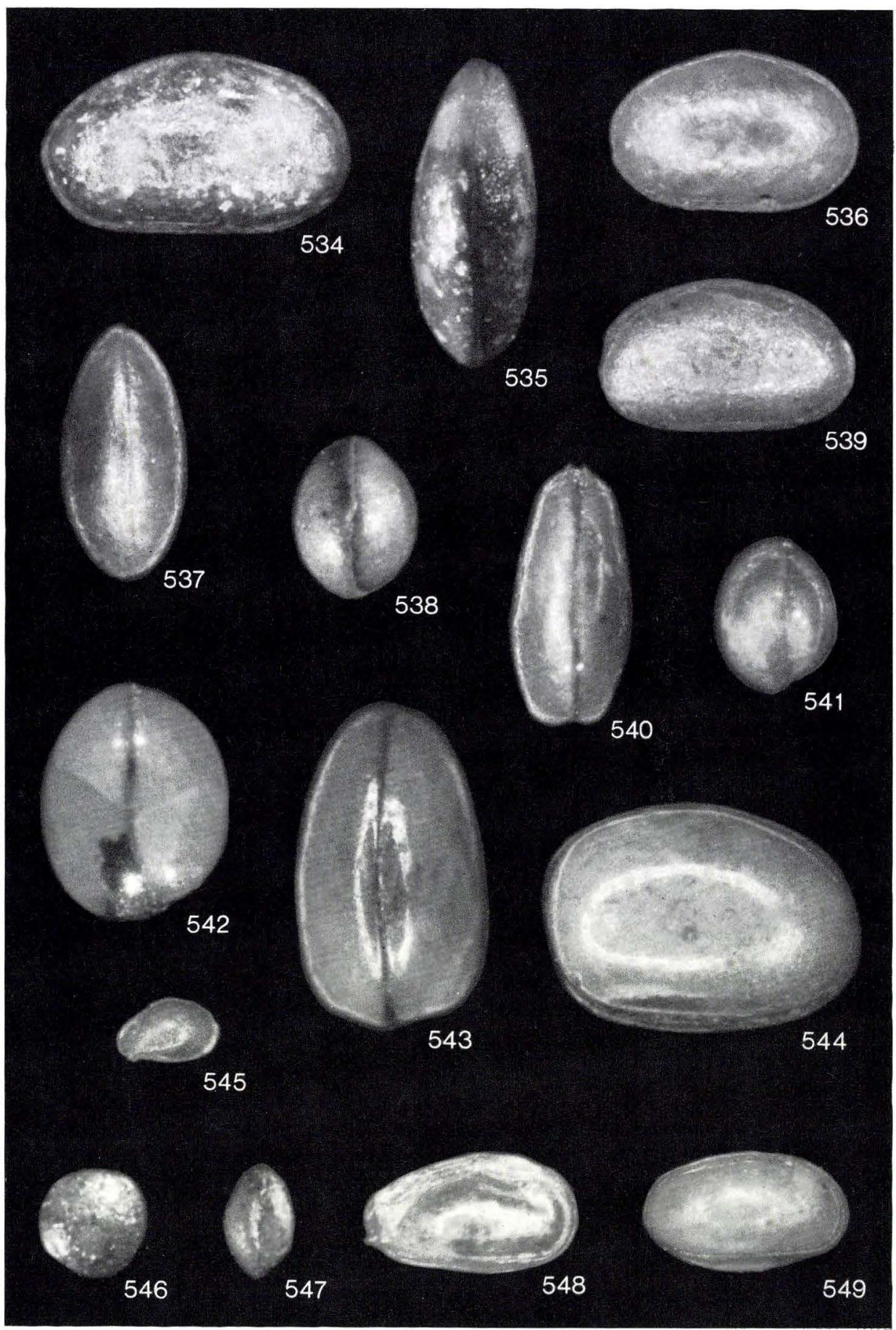


Plate 39

D. G. U. Text

catalogue No. page

Figs. 550-554. Polycope cerasia Blake, $1876 \ldots \ldots \ldots \ldots \ldots . \ldots 258$

Fig. 550 . Carapace, length $0.37 \mathrm{~mm}$, height $0.36 \mathrm{~mm}$. Left

side. $\times 100$. Øresund No. 3, sample No. $342 \ldots \ldots \ldots \ldots$

Fig. 551. Carapace, length $0.33 \mathrm{~mm}$, height $0.31 \mathrm{~mm}$. Right

side. $\times 100$. N $\varnothing$ vling No. 1, sample $5960^{\prime}-5990^{\prime}$. . . . . . .

Fig. 552. Left valve. External view. $\times$ 95. Flyvbjerg No. 1,

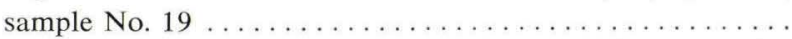

Fig. 553. Left valve, length $0.43 \mathrm{~mm}$, height $0.39 \mathrm{~mm}$. In-

ternal view. $\times 100$. Øresund No. 3 , sample No. $343 \ldots$.

Fig. 554. Right valve, broken. Internal view. $\times 270$. Øre-

sund No. 15, sample No. 1836

1973-OM-262

1973-OM-263

1973-OM-264

1973-OM-265

1973-OM-280

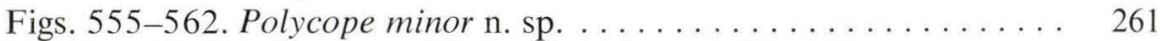

Figs. 555-556. Carapace, adult, length $0.16 \mathrm{~mm}$, height 0.17

mm. Left side. Holotype. Rødby No. 1, sample No. 20. -

Fig. 555: $\times$ 150. - Fig. 556: Detail with the sculpture,

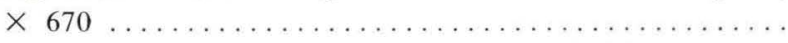

1973-OM-266

Figs. 557-558. Carapace, length $0.14 \mathrm{~mm}$, height $0.15 \mathrm{~mm}$.

$\varnothing$ resund No. 8, sample No. 935. - Fig. 557: Posterior view,

$\times 150$. - Fig. 558: Left side, $\times 150 \ldots \ldots \ldots \ldots \ldots \ldots$

Figs. 559-560. Carapace, length $0.19 \mathrm{~mm}$, height $0.18 \mathrm{~mm}$.

Left side. Vinding No. 1, sample No. 19. - Fig. 559: $\times 200$.

Fig. 560: Detail with the sculpture, $\times 670 \ldots \ldots \ldots \ldots \ldots$

Fig. 561. Right valve, broken. Internal view. $\times 270$. R $\varnothing$ dby

No. 1 , sample No. $21 \ldots \ldots \ldots \ldots \ldots \ldots \ldots \ldots \ldots$

Fig. 562. Left valve, length $0.15 \mathrm{~mm}$, height $0.16 \mathrm{~mm}$. Internal view. $\times 270$. Rødby No. 1 , sample No. $21 \ldots \ldots$ 1973-OM-270

Scanning electron micrographs (fig. 552: A. Nørgaard Jensen). 

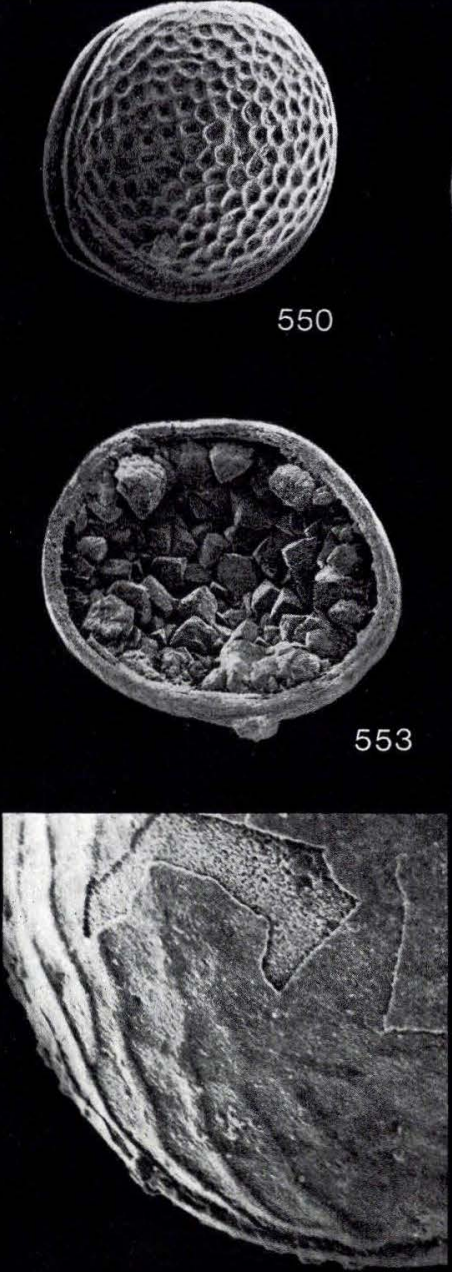

556
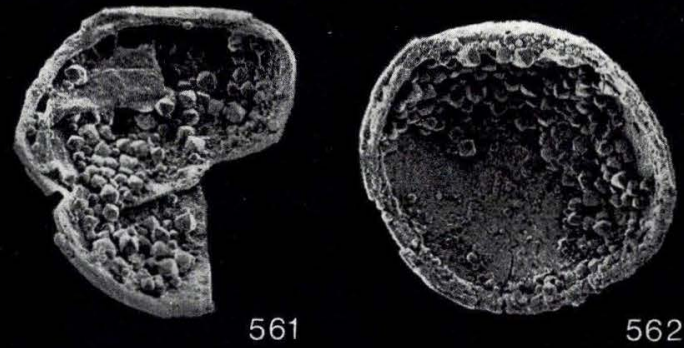

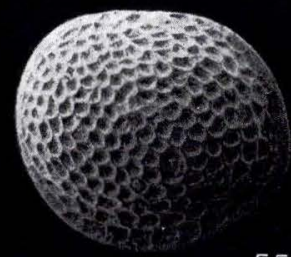

551
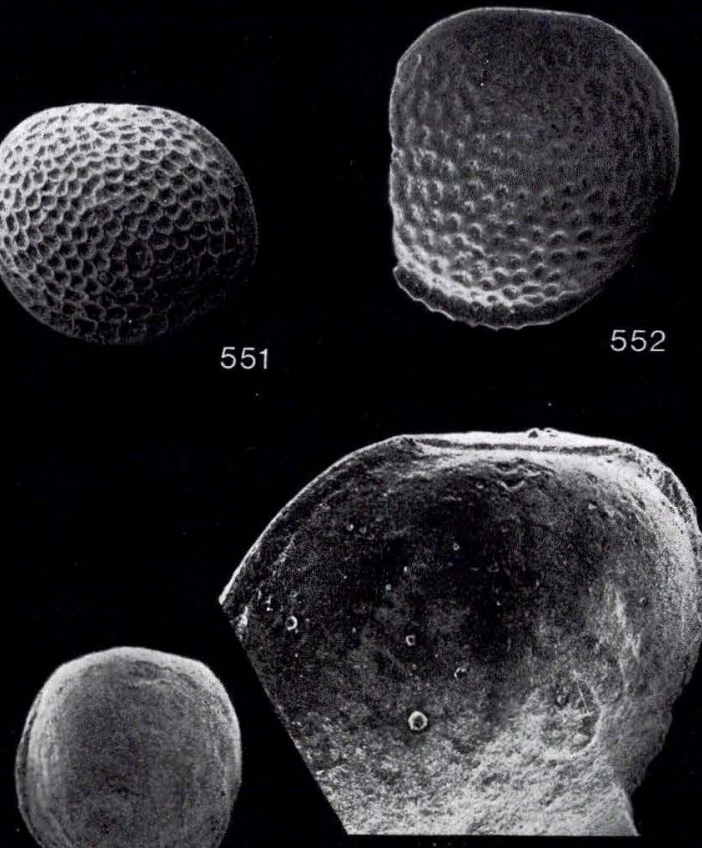

555

554

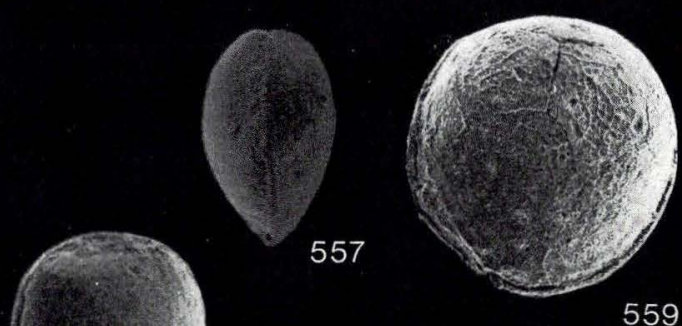

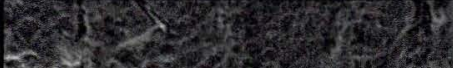

558

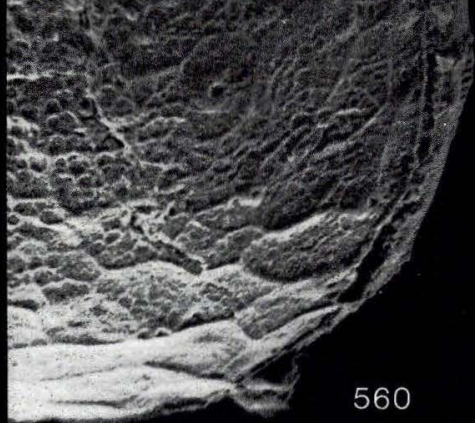


Fig. 563. Polycope cincinnata Apostolescu, 1959 . . . . . . . . . . . . 260

Carapace, length $0.19 \mathrm{~mm}$, height $0.19 \mathrm{~mm}$. Right side.

$\times$ 100. Gassum No. 1, sample No. 39A ........... 1973-OM-271

Fig. 564. Polycope sp. 4044 . . . . . . . . . . . . . . . . . . . . 263

Carapace, broken. Right side. $\times 100$. Gassum No. 1, sample

No. $48 \ldots \ldots \ldots \ldots \ldots \ldots \ldots \ldots \ldots$. . . . . . . . . . . . . . . . . 272

Fig. 565. Polycope cf. cerasia Blake, $1876 \ldots \ldots \ldots . \ldots \ldots 259$

Carapace, length $0.26 \mathrm{~mm}$, height $0.27 \mathrm{~mm}$. Left side.

$\times$ 100. Gassum No. 1, sample No. 39A ............ 1973-OM-273

Fig. 566. Polycope cf. cincinnata Apostolescu, 1959 . . . . . . . . . . . 260

Carapace, broken. Right side. $\times 100$. Nøvling No. 1,

sample $5570^{\prime}-5600^{\prime} \ldots \ldots \ldots \ldots \ldots \ldots \ldots \ldots \ldots \ldots \ldots$ 1973-OM-274

Fig. 567. Polycope sp. $4181 \ldots \ldots \ldots \ldots \ldots \ldots$. . . . . . . . . . . . 264

Carapace, length $0.25 \mathrm{~mm}$, height $0.26 \mathrm{~mm}$. Right side.

$\times$ 100. Børglum No. 1, sample No. $14 \ldots \ldots$. . . . . . 1973-OM-275

Fig. 568. Polycope sp. $4197 \ldots \ldots \ldots \ldots \ldots \ldots \ldots \ldots$. . . . . . . . . 264

Carapace, deformed. $\times$ 100. Øresund No. 3, sample No. 367 1973-OM-276

Fig. 569. Polycope decorata Apostolescu, 1959 . . . . . . . . . . 261

Carapace, length $0.42 \mathrm{~mm}$, height $0.42 \mathrm{~mm}$. Right side.

$\times$ 100. Øresund No. 12, sample No. $1432 \ldots \ldots$. . . . 1973-OM-277

Figs. 570-573. Polycope pelta Fischer, $1961 \ldots \ldots \ldots \ldots 2$

Fig. 570. Carapace, length $0.53 \mathrm{~mm}$, height $0.53 \mathrm{~mm}$. Left

side. $\times$ 100. Rønde No. 1, sample 7885'-7900' . . . . . . 1973-OM-278

Figs. 571-573. Carapace, length $0.54 \mathrm{~mm}$, height $0.56 \mathrm{~mm}$.

Left side. Dansk Nords $\varnothing$ J-1, sample 4540'. - Fig. 571:

$\times$ 100. - Fig. 572: Detail with the marginal sculpture,

$\times$ 670. - Fig. 573: Detail with the central sculpture, $\times 670$ 1973-OM-279

Scanning electron micrographs. 


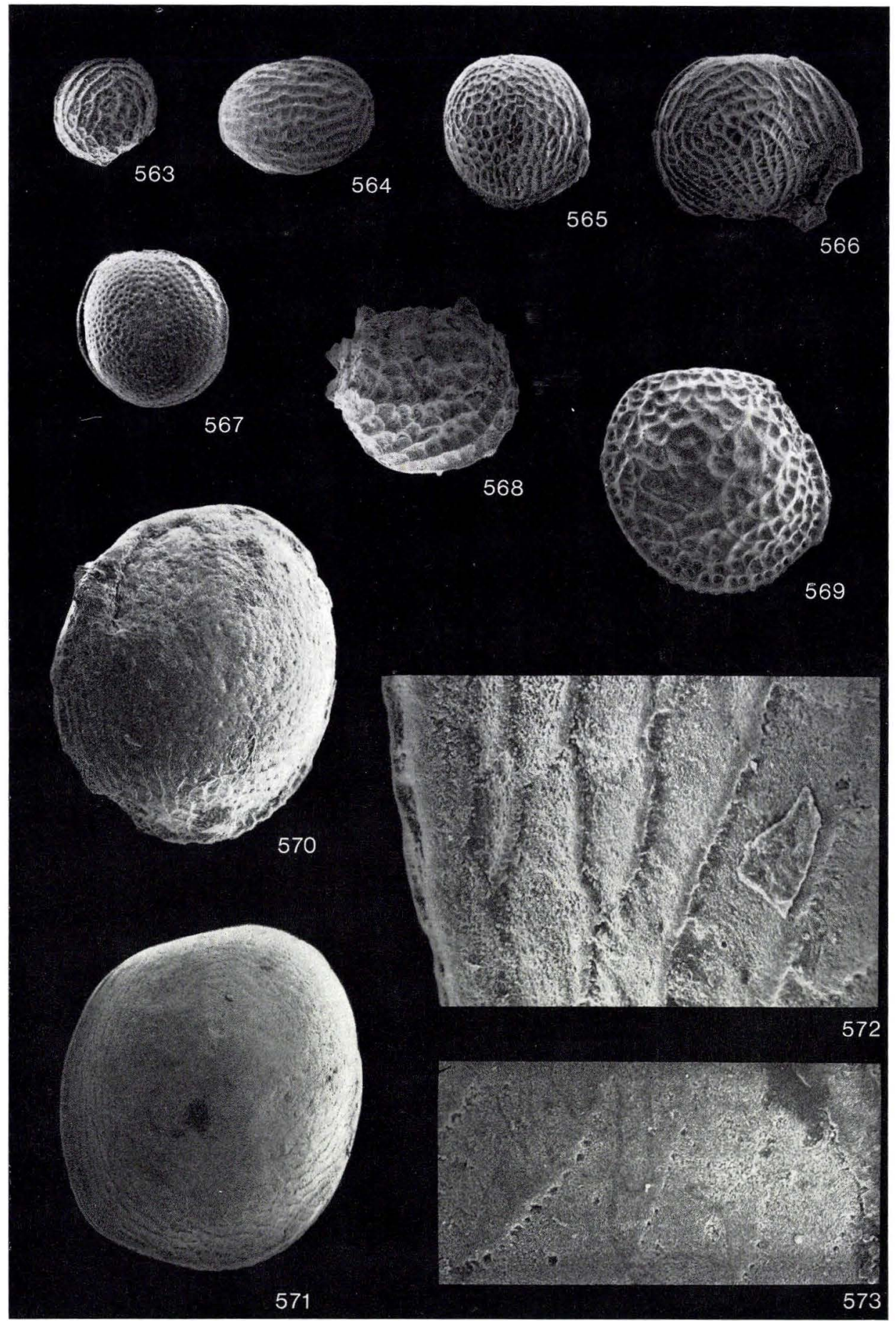


Figs. 574-575. Ogmoconchella danica n. sp. . . . . . . . . . . 243

Carapace, right side, length $0.56 \mathrm{~mm}$, height $0.42 \mathrm{~mm}$, the Hambühren WA2 boring, core sample $725 \mathrm{~m}$ (Lias Beta, Germany). - Fig. 574: $\times$ 110. - Fig. 575: Detail with the

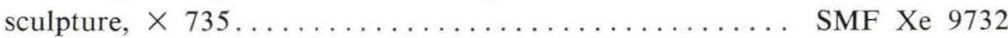

Figs. 576-577. Ogmoconchella danica n. sp. . . . . . . . . . . 243 Left valve, external view, length $0.58 \mathrm{~mm}$, height $0.43 \mathrm{~mm}$, the Hambühren WA2 boring, core sample $725 \mathrm{~m}$ (Lias Beta, Germany). - Fig. 576: $\times 110$. - Fig. 577: Detail with the

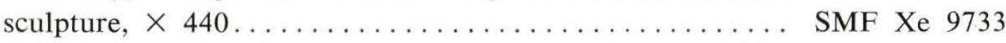

Figs. 578-579. Pseudomacrocypris parva (Kaye, 1965) . . . . . . . 130 Left valve, internal view, length $0.46 \mathrm{~mm}$, height $0.22 \mathrm{~mm}$, Speeton, Yorkshire, England (Lower Barremian). - Fig. 578: $\times$ 145. - Fig. 579: Detail with the muscle scars, $\times 735 \ldots$ SMF Xe 4637 Scanning electron micrographs. The three specimens are deposited in the collections of the Forschungsinstitut Senckenberg (Frankfurt am Main, Germany). 


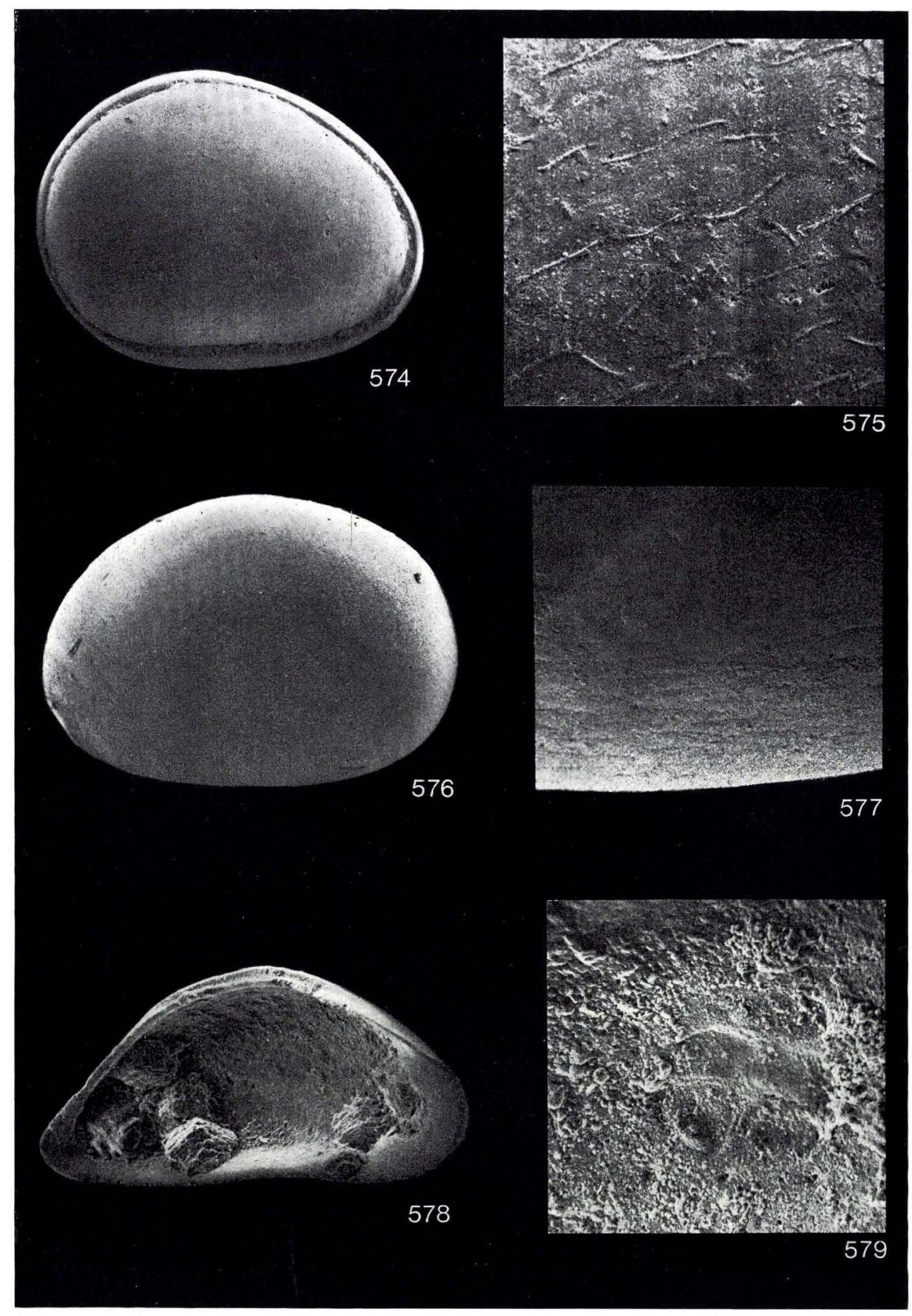



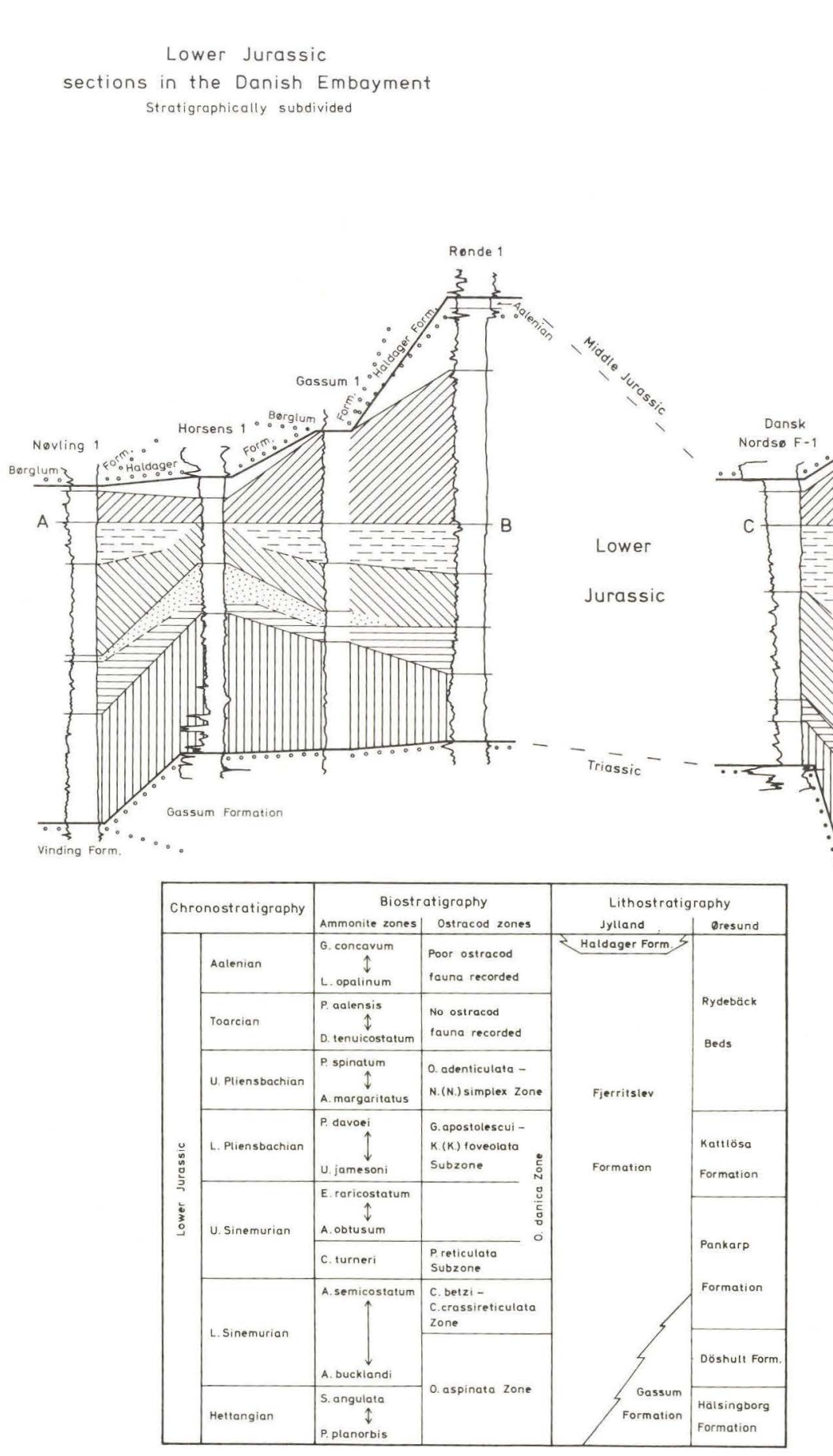

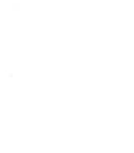
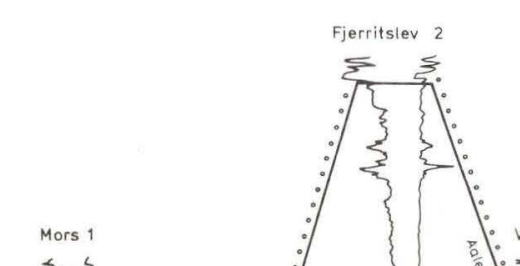

D. G. U.HI. Rk. Nr.104 vinding form. … 